tont $t$

$n$ H

$\rightarrow$

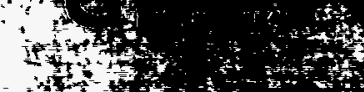

tit

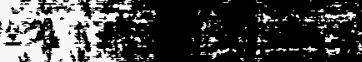

$+4,4$

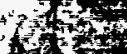

his

76

int

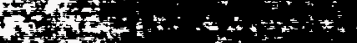

tat 5

ntas.

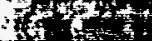

int 1

tist

$+3$

tit

int $x^{2}$

in:

Y

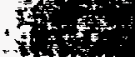

th

tis.

tis

$\frac{1}{2}$

标

$+$

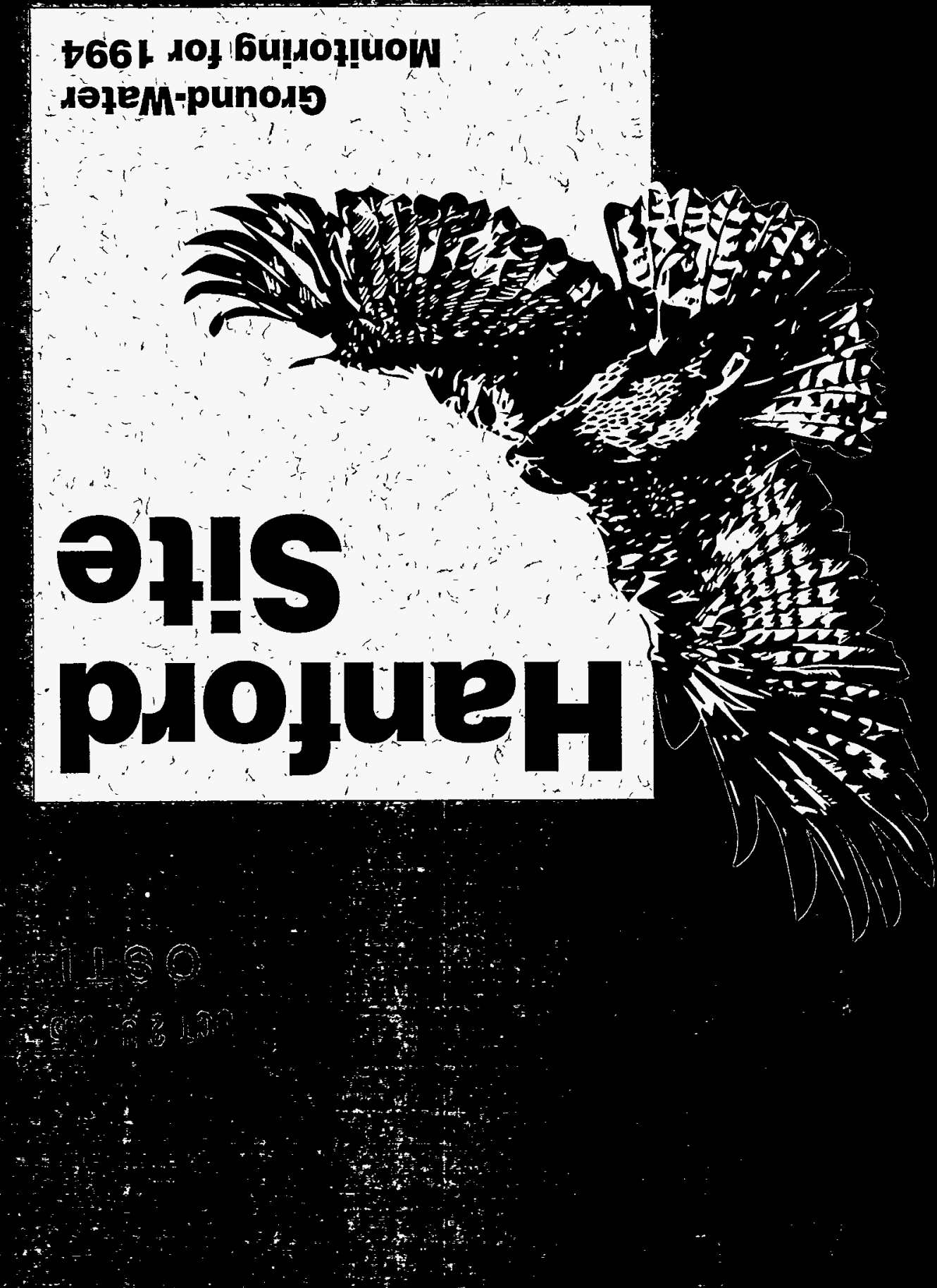

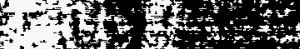

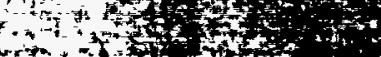

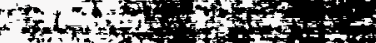

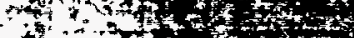

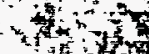

$\log ^{2}$

1.

and

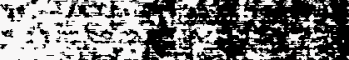

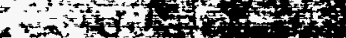




\section{DISCLAIMER}

This report was prepared as an account of work sponsored by an agency of the United States Government. Neither the United States Government nor any agency thereof, nor Battelle Memorial linstitute, nor any of their employees, makes any warranty, expressed or implied, or assumes any legal liability or responsibility for the accuracy, completeness, or usefulness of any information, apparatus, product, or process disclosed, or represents that its use would not infringe privately owned rights. Reference herein to any specific commercial product, process, or service by trade name, trademark, manufacturer, or otherwise does not necessarily constitute or imply its endorsement, recoinmendation, or favoring by the United States Government or any agency thereof, or Battelle Memorial Institute. The views and opinions of authors expressed herein do not necessarily state or reflect those of the United States Government or any agency thereof.

\section{PACIFIC NORTHWEST LABORATORY operated by \\ BATTELLE MEMORIAL INSTITUTE for the UNITED STATES DEPARTMENT OF ENERGY under Contract DE-AC06-76RLO 1830}

Printed in the United States of America

Available to DOE and DOE contractors from the

Office of Scientific and Technical Information, P.O. Box 62, Oak Ridge, TN 37831; prices available from (615) 576-8401. FTS 626-8401.

Available to the public from the National Technical Information Service, U.S. Department of Commerce, 5285 Port Royal Rd., Springfield, VA 22161. 


\section{DISCLAIMER}

Portions of this document may be illegible in electronic image products. Images are produced from the best available original document. 
PNL-10698

UC-402,403

\title{
Hanford Site Ground-Water Monitoring for 1994
}

\author{
P.E. Dresel \\ P.D. Thorne \\ S.P. Luttrell \\ B.M. Gillespie \\ W.D. Webber \\ J.K. Merz \\ J.T. Rieger \\ M.A. Chamness \\ S.K. Wurstner \\ B.E. Opitz
}

August 1995

Prepared for

the U.S. Department of Energy

under Contract DE-AC06-76RLO 1830

Pacific Northwest Laboratory

Richland, Washington 99352 


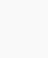




\section{Abstract}

This report presents the results of the Ground-Water Surveillance Project monitoring for calendar year 1994 on the Hanford Site, Washington. Hanford Site operations from 1943 onward produced large quantities of radiologic and chemical waste that have impacted ground-water quality on the Site. Monitoring of water levels and ground-water chemistry is performed to track the extent of contamination and trends in contaminant concentrations. The 1994 monitoring was also designed to identify emerging ground-water quality problems. The information obtained is used to verify compliance with applicable environmental regulations and to evaluate remedial actions. Data from other monitoring and characterization programs were incorporated to provide an integrated assessment of Site ground-water quality. Additional characterization of the Site's geologic setting and hydrology was performed to support the interpretation of contaminant distributions. Numerical modeling of sitewide ground-water flow also supported the overall project goals.

Water-level monitoring was performed to evaluate ground-water flow directions, to track changes in water levels, and to relate such changes to changes in site disposal practices. Water levels over most of the Hanford Site continued to decline between June 1993 and June 1994. The greatest declines occurred in the 200-West Area. These declines are part of the continued response to the cessation of discharge to $U$ Pond and other disposal facilities. The low permeability in this area which enhanced mounding of waste-water discharge has also slowed the response to the reduction of disposal. Water levels near B Pond have remained nearly constant during 1994. However, discharge practices have resulted in declining water levels beneath the western lobe and rising water levels beneath the eastern lobe. Approximately 55 wells are expected to go dry by the year 2005, and approximately 30 wells have already become unsampleable due to declining water levels.

Radiological monitoring results indicated that tritium, cobalt-60, strontium-90, technetium-99, iodine-129, cesium-137, and plutonium were present at levels above the U.S. Environmental Protection Agency or the Washington State maximum contaminant levels (MCL) at the Hanford Site. Concentrations of tritium, plutonium, and strontium- 90 in the 200 Areas were above the derived concentration guide (DCG) specified by DOE Order 5400.5. Strontium-90 concentrations in the 100-N Area were also above the DCG. No constituents had concentrations greater than 10 times the DCG.

Nitrate, fluoride, chromium, carbon tetrachloride, and trichloroethylene were present in 1994 Hanford ground water samples at levels above their MCL. 


\section{Summary}

This report summarizes the results of 1994 ground-water monitoring performed by the GroundWater Surveillance Project at the Hanford Site. The Ground-Water Surveillance Project collected water-level measurements and ground-water samples for chemical and radiological analysis. Data collected by the project were integrated with results from other programs to produce a sitewide assessment of ground-water hydrology and contaminant chemistry. Geologic and hydrologic characterization activities performed to support the monitoring are also summarized in this report.

The uppermost aquifer over most of the Hanford Site is unconfined and is composed of unconsolidated to semiconsolidated sediments deposited on the basalt bedrock. In some areas, deeper parts of the aquifer are locally confined by overlying fine-grained sediments. Confined aquifers occur within the underlying basalt flows and associated sedimentary interbeds. Ground water in the unconfined aquifer generally moves from recharge areas along the western boundary of the site eastward and northward toward the Columbia River, which is the major discharge area. However, this natural flow pattern has been altered by the formation of ground-water mounds created by large amounts of artificial recharge at waste-water disposal facilities.

Continuing hydrogeologic characterization and ground-water modeling activities were performed to improve predictions of the movement of contaminants through ground water. Recent efforts have focused on improving vertical hydrogeologic characterization and developing a threedimensional flow and transport model for the Hanford Site. The basis for this numerical model is a three-dimensional conceptual model, which includes the geometry and hydraulic properties of hydrogeologic layers within the aquifer and the definitions of aquifer boundary conditions. Data from more than 350 wells across the Hanford Site were used to define layers, or units, with relatively consistent textural composition, which are expected to correlate with hydraulic properties. Model boundaries correspond mainly to physical boundaries of the aquifer. These include the underlying basalt, elevated basalt ridges, the water table, and the Columbia and Yakima rivers. A boundary has also been defined for the mouth of the Cold Creek Valley, where recharge enters the Hanford Site aquifer.

In addition to development of the three-dimensional model, the existing two-dimensional model was used to predict declines in water-table elevation caused by decreased waste-water disposal. The predicted water table was compared to monitoring well completion depths to identify wells that are likely to go dry. Approximately 55 wells are expected to go dry by the year 2005. Approximately 30 wells have already become unsampleable because of declining water levels. Pathline modeling was also conducted based on the two-dimensional flow model to determine travel times for contaminants from various locations to the Columbia River. Although a three-dimensional model is needed for accurate mass-transport predictions, the pathline method can provide an estimate of arrival times and peak concentrations.

Water levels were monitored across the Hanford Site and in offsite areas to the north and east across the Columbia River. These measurements were used to determine the water-table configuration for the unconfined aquifer and to monitor changes in water-table elevation resulting from site operational changes. A site water-table map was constructed and used to infer ground-water 
flow direction. Water levels over most of the Hanford Site continued to decline between June 1993 and June 1994. The greatest declines occurred in the 200-West Area because of the continuing dissipation of the ground-water mound beneath the decommissioned $U$ Pond. Another ground-water mound is located beneath B Pond, east of the 200-East Area. The water table near B Pond decreased slightly in the early 1990 s because of reductions in waste-water discharge. However, wells near the eastern lobe of B Pond showed increasing water levels in 1994, due to redirection of discharge to this lobe. Water levels in the area west of the 1100 Area rose between June 1993 and June 1994, possibly because of irrigation activities in this offsite area. Water levels were also measured in wells that tap the upper-basalt confined aquifers. A map of the piezometric surface for this aquifer was prepared in 1993. No significant changes were observed in 1994.

Sampling of radiological and chemical constituents in ground water was conducted in 1994 to monitor the extent of contamination at the Hanford Site and to identify any emerging ground-water quality problems. Analytical results from approximately 800 wells were used in the interpretation.

Radiological monitoring results indicated that tritium, cobalt-60, strontium-90, technetium-99, iodine-129, cesium-137, and plutonium were present at levels above the U.S. Environmental Protection Agency (EPA) or the Washington State drinking water maximum contaminant level (MCL) standards. Uranium was present at levels above the EPA proposed MCL. Concentrations of tritium in the 200 Areas were above the DC.G as specified in.DOE Order 5400.5. Plutonium was detected at levels above the DCG in one well in the 200-East Area. Strontium-90 concentrations in wells in the 100-N Area and the 200-East Area were above the DCG. No constituents were found at concentrations greater than 10 times the DCG. The extent of radiological constituents at levels above the MCL is shown in Figure S.1. Results for individual constituents are summarized below.

Nitrate, fluoride, chromium, carbon tetrachloride, and trichloroethylene were present in 1994 Hanford ground-water samples at levels above their MCL. The extent of chemical constituents at levels above the MCL is shown in Figure S.2. Results for individual constituents are summarized below.

The total volume of ground water impacted by Hanford Site activities is estimated to be $1,400,000,000 \mathrm{~m}^{3}$. However, this estimate is highly uncertain due to a lack of knowledge of the thickness of contaminant plumes in the aquifer.

\section{Tritium}

Tritium is the most widely distributed radiological contaminant onsite. Tritium was present in many waste streams discharged to the soil column and is the most mobile radionuclide on the Site. As a result, tritium reflects the maximum extent of contamination from Site operations in the ground water and is the radionuclide most frequently monitored at the Hanford Site.

Tritium concentrations greater than the $20,000 \mathrm{pCi} / \mathrm{L} \mathrm{MCL}$ were detected in portions of the 100-D, 100-F, 100-K, 100-N, 200-East, 200-West, 400, and 600 Areas. Tritium at concentrations greater than the $2,000,000 \mathrm{pCi} / \mathrm{L}$ DCG were detected in the 200 Areas. Tritium in the 400 and 600 Areas can be related to migration from sources in the other operational areas. In particular, tritium migration from sources near the Plutonium-Uranium Extraction (PUREX) Plant in the 200-East Area has impacted a large part of the 600 Area to the east and southeast, the 400 Area, and the northern 
300 Area. This plume discharges to the Columbia River along a stretch extending from the old Hanford townsite to the 300 Area. A somewhat smaller plume of higher concentration in the region between the 200-East and 200-West Areas has its source in the vicinity of the 200-West Area Reduction Oxidation (REDOX) Plant. This plume is relatively slow moving, as discussed in Section 5.0.

Large portions of the site north of Gable Mountain and Gable Butte have been affected by tritium from site activities. The major sources appear to be the 200-East Area, the 100-K Area, and the $100-\mathrm{N}$ Area.

\section{Cobalt-60}

Cobalt-60 is a neutron activation product typically associated with wastes generated by the processing of irradiated fuel or with reactor effluent water. Cobalt- 60 is normally present as a divalent cation that is strongly adsorbed on sediments onsite and so is rarely observed in ground water. Cobalt-60 is observed onsite in an area north of the 200-East Area 216-BY Cribs and in a small area in the immediate vicinity of the 200-East Area 216-B-5 Injection Well. The cobalt-60 contamination north of the 200-East Area apparently has been mobilized by the presence of cyanide and ferrocyanide. Cobalt- 60 observed in the 100-N Area appears to be related to suspended solids in the samples and is unlikely to be mobile in ground water. The moderately short half-life of cobalt- 60 (5.3 years) means that its concentration onsite has been decreasing rapidly since production operations ended. Thus, cobalt- 60 contamination from most source areas is unlikely to migrate offsite.

\section{Strontium-90}

Strontium-90 is produced as a high-yield fission product and is therefore present in waste streams associated with fuel processing. It may also be released by fuel element failures during reactor operations during 1994. Concentrations of strontium-90 were above the $8 \mathrm{pCi} / \mathrm{L} \mathrm{MCL}$ in wells in the 100-B, 100-D, 100-F, 100-H, 100-K, 100-N, 200-East, 200-West and 600 Areas. Concentrations of strontium-90 were greater than the $1,000 \mathrm{pCi} / \mathrm{L}$ DCG in wells in the $100-\mathrm{N}$ and 200-East Areas. Strontium-90 is of concern due to its moderately long half-life of 28.8 years, its potential for concentrating in bone tissue, and the relatively high energy of the beta decay from the yttrium-90 radioactive decay product.

Strontium-90 distributions have not been completely defined in each of the 100 Areas. The highest concentrations have been found in the 100-N Area. Strontium-90 is discharged from the 100N Area to the Columbia River through seeps, which represent a potential point of public exposure. Data discussed in Section 5.0 indicate that the extent of the 100-N Area strontium-90 plume is not increasing perceptibly at present.

Strontium-90 is detected at concentrations above the MCL in the immediate vicinity of the 216-B-5 Injection Well in the 200-East Area. Strontium-90 was also found at levels above the MCL during previous years in the immediate vicinity of cribs south of the PUREX Plant although none of these wells contained strontium-90 at levels above the MCL in 1994. Strontium-90 near the decommissioned Gable Mountain Pond in the 600 Area is related to disposal of waste from the 200East Area to Gable Mountain Pond. 
Concentrations of strontium-90 above the MCL were detected in two wells in the 200-West Area.

Technetium-99

Technetium-99 is produced as a moderately high-yield fission product and is present in waste streams associated with fuel processing. Some technetium-99 may also be released in reactor areas by fuel element breaches. However, elevated technetium-99 concentrations are rarely observed in the reactor areas. During 1994, concentrations of technetium-99 greater than the $900-\mathrm{pCi} / \mathrm{L} \mathrm{MCL}$ were detected in wells in the 200 Areas. Concentrations greater than the MCL also extended to portions of the 600 Area east of the 200-West Area and. northwest of the 200-East Area. Technetium is transported in ground water as a negatively charged (anionic) species that is highly mobile. Technetium shares some chemical characteristics with uranium and tends to "follow" uranium through the fuel-processing system. Uranium, however, is less mobile in ground water under site conditions.

\section{Antimony-125}

Antimony-125 is a moderately high-yield fission product and, in the past, was found at levels above the MCL in a few wells in the 100-N and 100-K Areas. Concentrations measured in samples from these two areas have been as high as $305 \mathrm{pCi} / \mathrm{L}$ near the $1325-\mathrm{N}$ Land Waste Disposal Facility in 1987. The MCL for antimony-125 is $300 \mathrm{pCi} / \mathrm{L}$, and the $\mathrm{DCG}$ is $60,000 \mathrm{pCi} / \mathrm{L}$. Antimony-125 was not detected at levels above the MCL in any wells on onsite in 1994.

\section{$\underline{\text { lodine-129 }}$}

The presence of iodine-129, a moderately low-yield fission product, in ground water is significant because of its relatively low $\mathrm{MCl}(1 \mathrm{pCi} / \mathrm{L})$, its potential for accumulation in the environment as a result of long-term releases from nuclear fuel reprocessing facilities (Soldat 1976), and its long half-life (16 million years). However, its relatively low fission yield and long half-life have limited its activity in Hanford ground water. At Hanford, the main contributor of iodine-129 to ground water has been liquid discharges to cribs in the 200 Areas. Assay of iodine-129 by high-sensitivity, direct-counting methods requires long counting times with correspondingly low analytical throughput. Extensive plumes of iodine-129 at levels above the MCL are found onsite, with the highest concentrations downgradient from the PUREX and REDOX Plants, in the 200-East and 200-West Areas, respectively. No iodine-129 samples were above the DCG of $500 \mathrm{pCi} / \mathrm{L}$.

Iodine-129 is transported in ground vater as the anionic $\mathrm{I}^{-}$species. Anionic species tend to be. highly mobile in ground water because their adsorption onto organic material or mineral surfaces is limited. Iodine-129 is essentially as mobile as tritium in Hanford Site ground water.

\section{Cesium-137}

Cesium-137 is produced as a high-yield fission product and is present in waste streams associated with fuel processing; it may have also been released in reactor areas by fuel element breaches. Concentrations of cesium- 137 were below the detection limit $(20 \mathrm{pCi} / \mathrm{L})$ except near the 216-B-5 Injection Well where concentrations reached levels over 10 times the MCL of $200 \mathrm{pCi} / \mathrm{L}$. Cesium-137 is restricted to the immediate vicinity of the injection well by its extremely low mobility in ground water. 


\section{Uranium}

There are numerous potential sources of uranium release at Hanford, including fuel fabrication, fuel processing, and uranium recovery from sepăration activities. Uranium may exist in several states, including elemental uranium, uranium oxide, and tetravalent or trivalent ions in aqueous solution. Only the hexavalent form has significant mobility in ground water, and this is largely the result of carbonate complexation. Uranium mobility is thus dependent on both $\mathrm{Eh}$ and $\mathrm{pH}$. Uranium migration at Hanford is retarded relative to that of tritium and technetium-99. .

The EPA has proposed a MCL of $20 \mu \mathrm{g} / \mathrm{L}$ for uranium, in contrast to other radionuclides for which the standards are given in picocuries per liter. This is because there is evidence that uranium ingestion may cause kidney damage, which is better assessed as a chemical hazard than as a radiological hazard. However, uranium may also be analyzed by an alpha-counting method and some risk is associated with its radioactivity, so it is important to be able to convert between ground-water concentrations expressed in micrograms per liter and those expressed in picocuries per liter. Sitespecific data for Hanford indicate that the proportion of the different uranium isotopes in ground water is nearly identical to the average proportion in natural rock. In this case, the total uranium activity in picocuries per liter should be multiplied by 1.49 to convert to the concentration in micrograms per liter, and the proposed $\mathrm{MCL}$ equivalent would be $13.4 \mathrm{pCi} / \mathrm{L}$ (multiply concentration in $\mu \mathrm{g} / \mathrm{L}$ by 0.67 to convert to activity in $\mathrm{pCi} / \mathrm{L}$ ).

Uranium has been detected at concentrations above the proposed MCL in the 100-F, 100- $\mathrm{H}$, 200-East, 200-West, and 300 Areas. The highest concentrations detected onsite in 1994 were in the 200-West Area near the 216-U-1 and 216-U-2 Cribs. This plume extends into the 600 Area to the east. An expedited response action was performed on the 300 Area Process Trenches in mid-1991 to reduce the uranium source in that area. Use of the trenches for disposal of cooling water was resumed following completion of the remedial action, although subsequent discharges to the trenches were much lower. Discharge to the trenches ceased in December 1994. As discussed in Section 5.0, the expedited response action and the reduction in discharge appear to have reduced the uranium concentrations in at least one well monitoring the 300 Area Process Trenches.

\section{Plutonium}

The DCG for plutonium-239 is $30 \mathrm{pCi} / \mathrm{L}$. There is no explicit MCL for plutonium-239; however, the gross alpha MCL of $15 \mathrm{pCi} / \mathrm{L}$ would be applicable. Alternatively, if the DCG (which is based on a 100-mrem dose standard) is converted to the 4-mrem dose equivalent used for the $\mathrm{MCL}$, $1.2 \mathrm{pCi} / \mathrm{L}$ would be the relevant guideline. Plutonium is generally considered to bind strongly to sediments and thus its mobility in the aquifer is limited.

Concentrations of plutonium were below the detection limit in all wells sampled during 1994 except near the 216-B-5 Injection Well in the 200-East Area. As discussed in Section 5.0, concentrations were above the DCG in a sample from one well in this area. Although plutonium has been detected in past years in the 200-West Area, it was not detected in 1994. This is due in part to changing monitoring networks as some wells can no longer be sampled due to declining water levels. 


\section{Nitrate}

Although nitrate is associated primarily with process condensate liquid wastes, other liquids discharged to ground also contained nitrate. Nitrate contamination in the unconfined aquifer reflects the extensive use of nitric acid in decontamination and chemical reprocessing operations. Nitrate, like tritium, can be used to define the extent of contamination because nitrate is present in many waste streams and is mobile in ground water. However, additional sources of nitrate are located offsite to the west and southwest.

Most ground-water samples collected in 1994 were analyzed for nitrate. The nitrate distribution is similar to that from recent years. Nitrate was measured at concentrations greater than the MCL (45 mg/L as $\mathrm{NO}_{3}^{-}$ion) in wells in all operational areas except the 100-B and 400 Areas. Only minor nitrate contamination was detected in the $100-\mathrm{N}$ Area. Although elevated nitrate levels are found throughout the extensive plume emanating from the vicinity of the PUREX plant in the 200East area, only proportionately small areas contain nitrate at levels above the MCL.

\section{Cyanide}

The source of a cyanide plume in and directly north of the 200-East Area is believed to be wastes containing ferrocyanide that were disposed of in the BY Cribs. Wells containing cyanide often contain concentrations of several radionuclides, including cobalt -60 . Although cobalt -60 is normally immobile in the subsurface, it appears to be chemically complexed and mobilized by cyanide or ferrocyanide.

A MCL for cyanide of $200 \mu \mathrm{g} / \mathrm{L}$ has been established by the EPA. All samples collected in 1994 contained cyanide at levels below the MCL. Ferrocyanide is not specifically regulated but is commonly considered with the total cyanide because it is indistinguishable from cyanide in the standard analytical methods. However, ferrocyanide is considered far less toxic than free cyanide.

\section{Fluoride}

Fluoride currently has a primary MCL of $4.0 \mathrm{mg} / \mathrm{L}$ and a secondary standard of $2.0 \mathrm{mg} / \mathrm{L}$. Secondary standards are based primarily on aesthetic considerations and are not federally enforceable, although the state of Washington claims the right to require corrective action from drinking water suppliers if secondary standards are exceeded. Both standards are used in the discussion in Section 5.0; however, only the primary standard is based on health considerations. The MCL is only an indication of the degree of contamination since the area of elevated fluoride concentrations is far from any drinking water supply. Fluoride was detected at levels above the primary MCL in the 200-West Area.

\section{Chromium}

A major source for chromium onsite was the use of sodium dichromate as a corrosion inhibitor in cooling water for the 100 Area reactors. Chromium was also used for decontamination in the 100 , 200, and 300 Areas and for oxidation state control in the REDOX process in the 200-West Area.

Chromium is detectable in ground water from each of the 100 Areas but the major plumes are related 
to operations in the $100-\mathrm{D}, 100-\mathrm{H}$, and $100-\mathrm{K}$ Areas. Surrounding parts of the 600 Area are also affected.

Both filtered and unfiltered samples were collected for chromium and other metals from many of the wells onsite. Unfiltered samples may contain metals present as particulate matter; filtered samples are more representative of the mobile dissolved metals. Comparison of filtered to unfiltered samples provides a better understanding of the transport of chromium onsite. The EPA MCL of 100 $\mu \mathrm{g} / \mathrm{L}$ and the Washington State MCL of $50 \mu \mathrm{g} / \mathrm{L}$ are based on unfiltered concentrations; however, differences in well construction and pumping between monitoring wells and water-supply wells make it difficult to predict potential drinking-water concentrations based on monitoring-well data. The use of stainless steel in recently constructed (after approximately 1984) monitoring wells appears to have added a source of chromium in some well samples, for example, in the 300 Area.

\section{Carbon Tetrachloride}

Carbon tetrachloride contamination was found in the unconfined aquifer above the $5 \mu \mathrm{g} / \mathrm{L}$ MCL. beneath much of the 200-West Area. The plume extends beyond the area boundary and forms the most widespread organic contaminant plume onsite. The contamination is principally from wastedisposal operations associated with the Z Plant, where it was used as a solvent in plutonium processing.

\section{Chloroform}

The 200-West Area chloroform plume appears to be associated but not exactly coincident with the carbon tetrachloride plume. The chloroform may be a degradation product of carbon tetrachloride. The MCL for chloroform is $100 \mu \mathrm{g} / \mathrm{L}$ (total trihalomethanes), which is 20 times higher than that for carbon tetrachloride. No chloroform levels above the MCL were detected in 1994 samples.

\section{Trichloroethylene}

Trichloroethylene (TCE) has a MCL of $5 \mu \mathrm{g} / \mathrm{L}$. TCE was commonly used as a degreasing compound from the late 1950s through the 1970s. TCE has been detected in wells in the 100-BC Area, 100-F Area, 100-K Area, 200-West Area, 300 Area, and near the Solid Waste Landfill in the 600 Area.

During 1994, TCE was detected at levels less than the MCL in 100-BC Area wells and at levels above the MCL in the 100-F Area. In addition, TCE was found at levels above the MCL west of the 100-F Area.

TCE was detected during 1994 at levels above the MCL in the 200-West Area to the west of the T Plant, near the U Plant and extending into the 600 Area to the east, and in one well near the REDOX Plant. Some TCE at levels above the MCL is also associated with the carbon tetrachloride plume in the vicinity of the Plutonium Finishing Plant (PFP).

- TCE and cis-1,2-dichloroethylene were found at levels above the MCL in a well monitoring the lower portion of the unconfined aquifer in the 300 Area near the North Process Pond. Cis-1,2- 
dichloroethylene is a product of TCE biodegradation. TCE is also found at levels above the MCL in a few wells in the southern part of the 300 Area.

Several wells at the Solid Waste Landfill located in the 600 Area contained TCE at levels close to, but slightly below, the MCL. Wells monitoring the Solid Waste Landfill have shown TCE concentrations above the MCL in previous years. TCE is found at levels above the MCL near Siemens Power Corporation and the Horn Fiapids Landfill, which are located in the Richland North Area and the southern 600 Area.

\section{Tetrachloroethylene}

Tetrachloroethylene, also referred to as perchloroethylene, is found at levels below the MCL in a number of areas on the site, including the 200-West Area, the 300 Area, and the southern portion of the 600 Area. A number of samples from wells in the Richland North Area contained low concentrations of tetrachloroethylene. Tetrachloroethylene was not detected at levels above the MCL in wells monitoring the Central Landfill cornplex although levels above the MCL had been detected in previous years. 


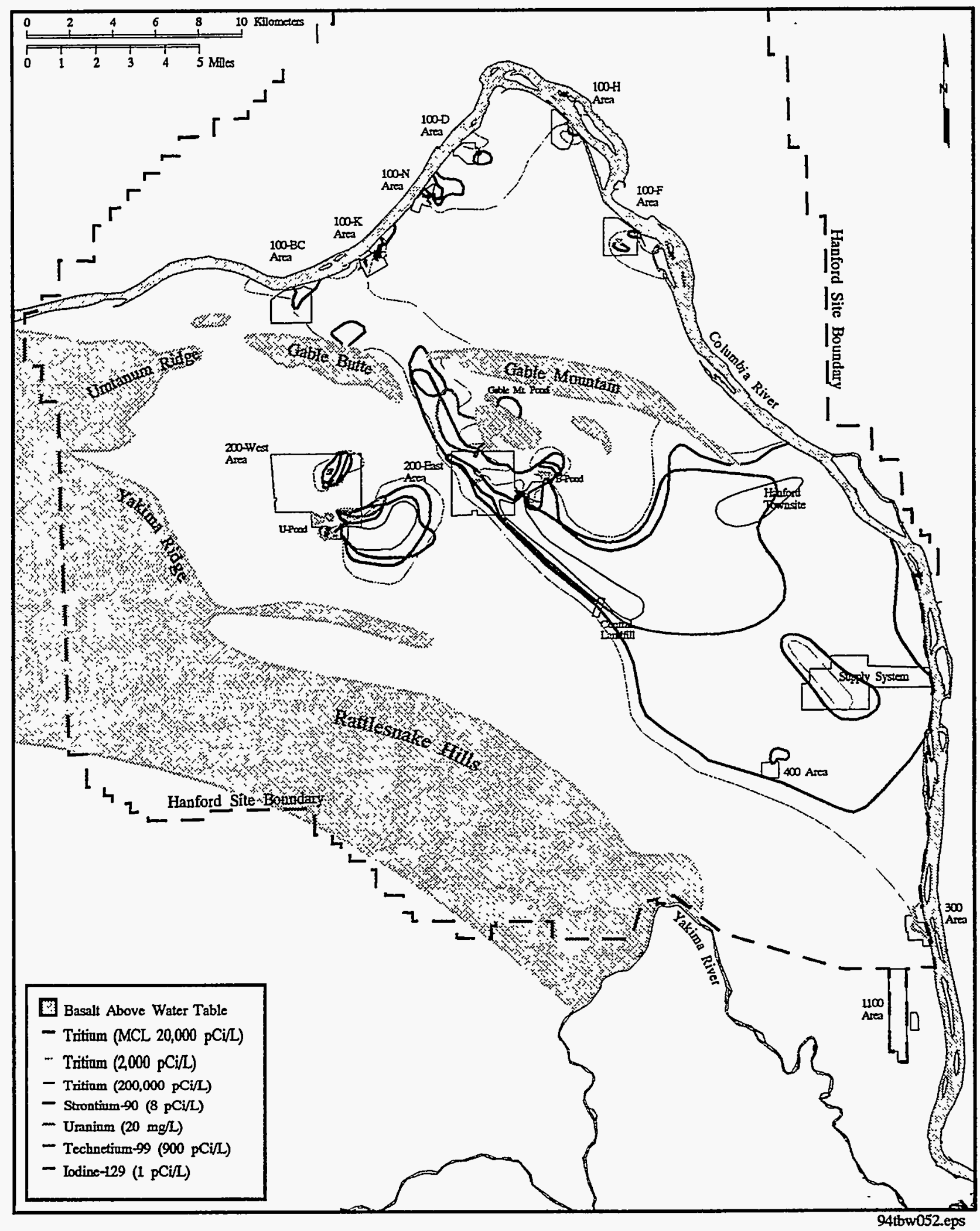

Figure S.1. Distribution of Radionuclides in Ground Water at Concentrations Above the Maximum Contaminant Level 


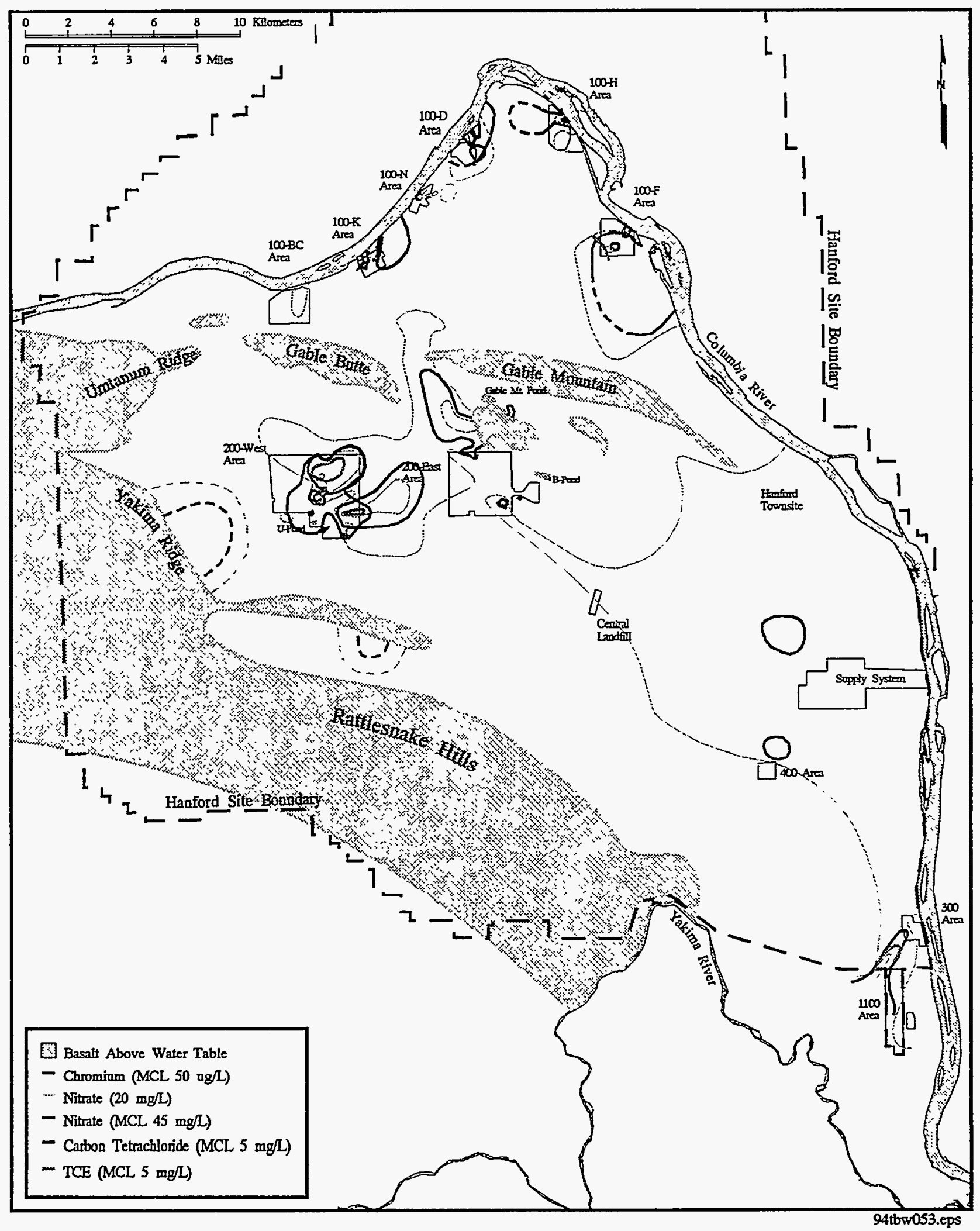

Figure S.2. Distribution of Hazardous Chemicals in Ground Water at Concentrations Above the Maximum Contaminant Level 


\section{Acknowledgments}

Publication of this document is the result of an extensive data collection and evaluation effort. In addition to the authors whose names appear on the cover, a number of people contributed to the Ground-Water Surveillance Project effort. Westinghouse Hanford Company personnel generated much of the ground-water data onsite and authored several of the studies cited here. Collection of samples was scheduled and coordinated by Scott Conley, Paula Henry, Bill Lusty, and Trevor VanArsdale. Sample bottles and documentation were prepared by Janet Julya, and Sylvia Downey. Ground-water samples were collected by Gordon Andersen, Marshall Almarode, Larry Belt, Wade Hankel, John Harrison, Jose Lopez, Dan Mackliet, Alison Marshman, Tomas Moreno, Jr., Dana Mueller, and John Reck. Analytical results were managed with the assistance of Denise Sauer, Wanda Harder, Janet Reilly, Teri Geeting, Kathy Farmer, Bette Jo Westergard, and Shawna Whitten.

Ronald Smith performed a technical review of the document. Rosalind Schrempf provided technical editing advice, and production of the document was coordinated by Denice Carrothers.

Final graphics were produced by Travis Walters, John McDonald, Mark Witkowski, and Janet Reilly. 


\section{Abbreviations}

ASTM American Society for Testing and Materials

CERCLA Comprehensive Environmental Response, Compensation, and Liability Act of 1980

DCE dichloroethylene

DCG derived concentration guide

DOE U.S. Department of Energy

DOE-RL U.S. Department of Energy, Richland Operations Office

DOH Washington State Department of Health

Ecology Washington State Department of Ecology

EPA U.S. Environmental Protection Agency

ERC Environmental Restọration Contract

GC/MS gas chromatography/mass spectrometry

GC gas chromatography

GIS Geographic Information Systems

HEIS Hanford Environmental Information System

ICP inductively coupled plasma (spectroscopy).

IT International Technology Corporation

LERF Liquid Effluent Retention Facility

LWDF Liquid Waste Disposal Facility

MCL maximum contaminant level

MDC minimum detectable concentration

MDL method detection level

NRDWL Non-Radioactive Dangerous Waste Landfill

$$
\text { xix }
$$


PFP Plutonium Finishing Plant

PNL Pacific Northwest Laboratory

PUREX Plutonium-Uranium Extraction (Plant)

RCRA Resource Conservation and Recovery Act

REDOX Reduction Oxidation (Plant)

SARA Superfund Amendments and Reauthorization Act

TCE trichloroethylene.

TEDF Treated Effluent Disposal Facility

Tri-Party

Agreement Hanford Federal Facility Agreement and Consent Order

TRU transuranic

USBR U.S. Bureau of Reclamation

USGS U.S. Geological Survey

VOC volatile organic compounds

WAC Washington Administrative Code

WHC Westinghouse Hanford Company 


\section{Contents}

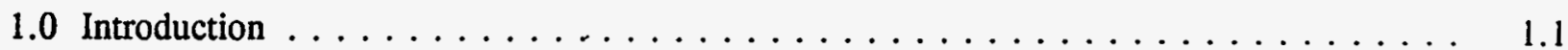

2.0 Hydrogeologic Characterization and Modeling $\ldots \ldots \ldots \ldots \ldots \ldots \ldots \ldots$

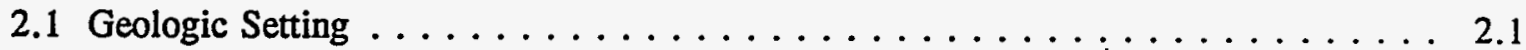

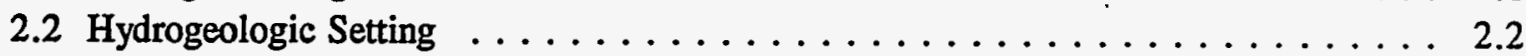

2.3 Three-Dimensional Hydrogeologic Conceptual Model . . . . . . . . . . . . . 2.4

2.3.1 Methodology for Defining the Geologic Framework . . . . . . . . . . . . 2.4

2.3.2 Description of Hydrogeologic Units . . . . . . . . . . . . . . . 2.5

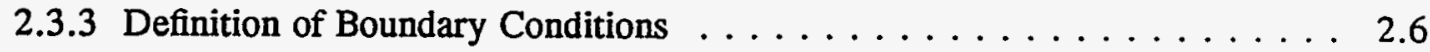

2.4 Sitewide Ground-Water Modeling $\ldots \ldots \ldots \ldots \ldots \ldots \ldots \ldots \ldots$

2.4.1 Two-Dimensional Model Description . . . . . . . . . . . . . 2.9

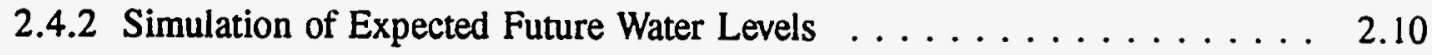

2.4.3 Contaminant Transport . . . . . . . . . . . . . . 2.11

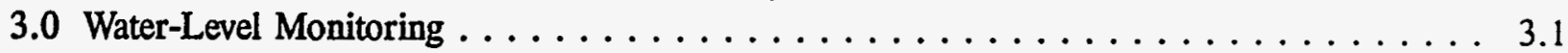

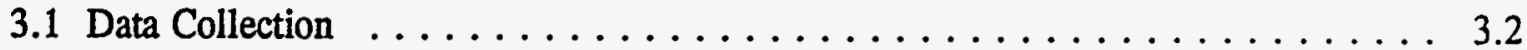

3.2 Results of the 1994 Water-Level Measurements . . . . . . . . . . . . . . . . 3.3

3.2.1 Hanford Site Water-Table Features . . . . . . . . . . . . . . 3.4

3.3 Changes in the Hanford Site Water Table -1993 to $1994 \ldots \ldots \ldots \ldots \ldots \ldots$

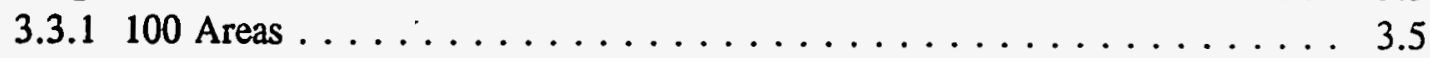

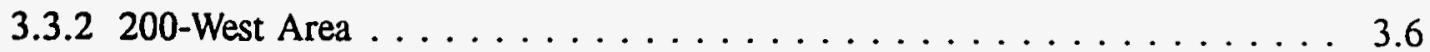

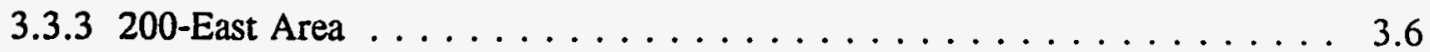

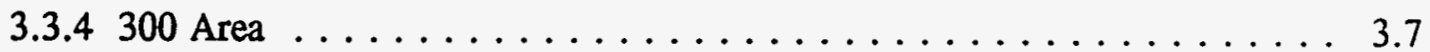

3.3.5 Richland North Area . . . . . . . . . . . . . . . . 3.7

3.3.6 Upper Cold Creek Valley $\ldots \ldots \ldots \ldots \ldots \ldots \ldots \ldots \ldots \ldots$

3.3.7 Response to River Stage . . . . . . . . . . . . . . . . . . . . . . 3.9

3.4 Water-Table Features East and North of the Columbia River . . . . . . . . . . . 3.9

3.5 Confined Aquifer System . . . . . . . . . . . . . . 30

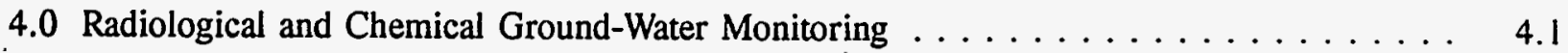

4.1 Data Collection . . . . . . . . . . . . . . . . . . . . 4.1

4.1 .1 RCRA Facility-Specific Monitoring . . . . . . . . . . . . 4.1

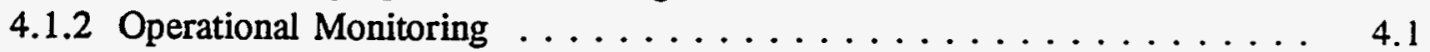

4.1.3 Ground-Water Surveillance Project Monitoring . . . . . . . . . . . 4.2

4.1 .4 Monitoring Network . . . . . . . . . . . . . . . . 4.4

4.1 .5 Sample Collection and Reporting . . . . . . . . . . . . . . 4.4

4.1.6 Monitoring-Well Design and Maintenance . . . . . . . . . . . . 4.6

4.1 .7 Analytical Methods . . . . . . . . . . . . . . . . 4.6 
4.2 Analytical Findings $\ldots \ldots \ldots \ldots \ldots \ldots \ldots \ldots \ldots \ldots \ldots . . \ldots \ldots$

4.2.1 Data Management . . . . . . . . . . . . . . . 4.9

4.2.2 Maximum Contaminant Levels and Derived Concentration Guides . . . 4.11

4.2.3 Assessment of the Monitoring Network . . . . . . . . . . 4.11

4.2.4 Interpretation of Analytical Results $\ldots \ldots \ldots \ldots \ldots \ldots \ldots \ldots .12$

4.3 Quality Assurance/Quality Control $\ldots \ldots \ldots \ldots \ldots \ldots \ldots \ldots \ldots . .14$

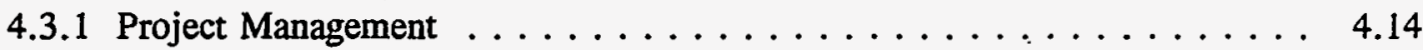

4.3.2 Sample Collection $\ldots \ldots \ldots \ldots \ldots \ldots \ldots \ldots \ldots \ldots . \ldots \ldots .14$

4.3.3 Holding Times $\ldots \ldots \ldots \ldots \ldots \ldots \ldots \ldots \ldots \ldots \ldots \ldots . \ldots \ldots .15$

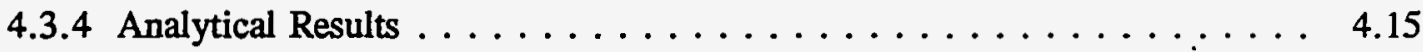

5.0 Extent of Ground-Water Contamination at the Hanford Site $\ldots \ldots \ldots \ldots \ldots . .1$

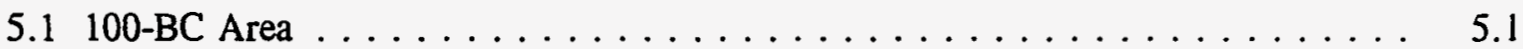

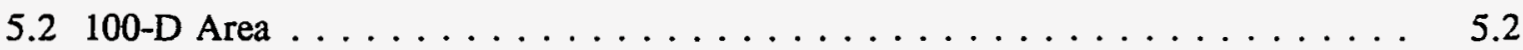

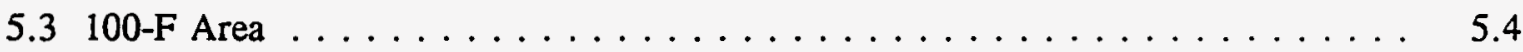

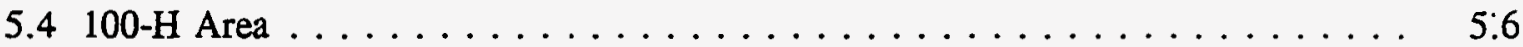

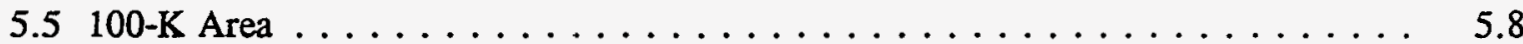

5.5.1 K-East Reactor and Surroundings $\ldots \ldots \ldots \ldots \ldots \ldots \ldots \ldots . \ldots \ldots$

$5.5 .2 \mathrm{~K}$-West Reactor and Surroundings $\ldots \ldots \ldots \ldots \ldots \ldots \ldots \ldots . \ldots \ldots$

5.5 .3 116-K-2 Liquid Waste Disposal Trench . . . . . . . . . . . 5.11

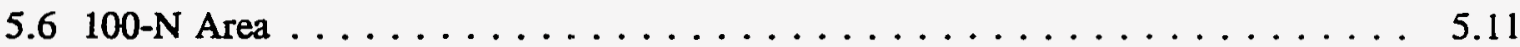

5.6.1 1301-N and 1325-N Liquid Waste Disposal Facilities . . . . . . . . 5.11

5.6.2 1324-N Surface Impoundment and 1324-NA Percolation Pond . . . . . 5.13

5.7 200-West Area . . . . . . . . . . . . . . . . . . . . . . . 5.13

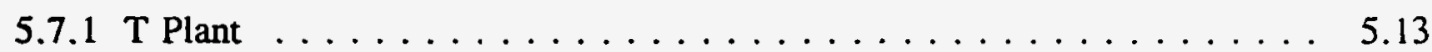

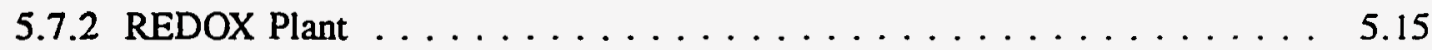

5.7 .3 U Plant $\ldots \ldots \ldots \ldots \ldots \ldots \ldots \ldots \ldots \ldots \ldots \ldots . \ldots \ldots . \ldots \ldots$

5.7.4 Plutonium Finishing Plant (Formerly Z Plant) $\ldots \ldots \ldots \ldots \ldots .5 .18$

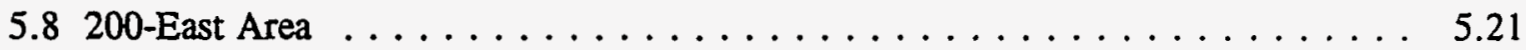

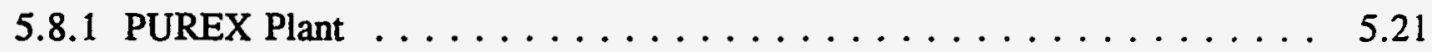

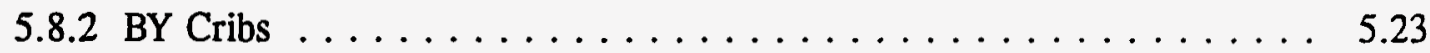

$5.8 .3216-\mathrm{B}-5$ Injection Well $\ldots \ldots \ldots \ldots \ldots \ldots \ldots \ldots \ldots \ldots . \ldots \ldots . \ldots \ldots$

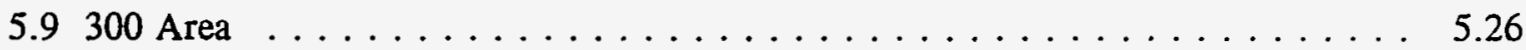

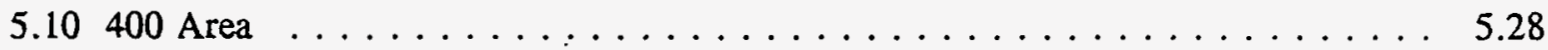

5.11600 Area . . . . . . . . . . . . . . . . . . . . . . . 5.29

5.11 .1 Centrai Landfill Complex . . . . . . . . . . . . . . . . . 5.29

5.11 .2 Gable Mountain Pond $\ldots \ldots \ldots \ldots \ldots \ldots \ldots \ldots \ldots . \ldots \ldots$

5.12 Richland North Area $\ldots \ldots \ldots \ldots \ldots \ldots \ldots \ldots \ldots \ldots \ldots . \ldots \ldots . \ldots \ldots$

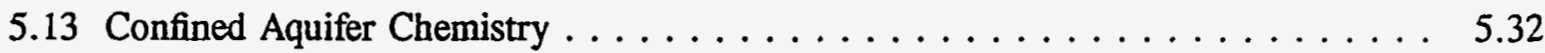

6.0 Conclusions $\ldots \ldots \ldots \ldots \ldots \ldots \ldots \ldots \ldots \ldots \ldots \ldots \ldots \ldots . \ldots \ldots \ldots$

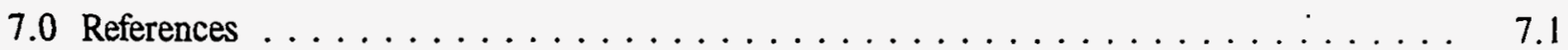


8.0 Historical Bibliography $\ldots \ldots \ldots \ldots \ldots \ldots \ldots \ldots \ldots \ldots \ldots \ldots .1$

Appendix A - Selected Water-Level Measurements from Unconfined Aquifer Wells on the Hanford Site and Outlying Areas, June $1994 \ldots \ldots \ldots \ldots \ldots \ldots \ldots$ A.1

Appendix B - Water-Level Measurements from Unconfined Aquifer Wells on the Hanford Site, December 1994 . . . . . . . . . . . . . . . . . . . . . B. 1

Appendix C - Listing of Chemical and Radiological Data for Calendair Year $1994 \ldots \ldots$. . . C.1

\section{Plate Maps}

(see end of report)

1 Water-Table Elevation Contours for the Unconfined Aquifer, June 1994

2 Locations of Hanford Site Monitoring Wells

3 Tritium Concentrations in Wells and Plume Contours

$4 \quad$ Nitrate Concentrations in Wells and Plume Contours

5 Iodine-129 Concentrations in Wells and Plume Contours 


\section{Figures}

S.1 Distribution of Radionuclides in Ground Water at Concentrations Above the Maximum Contaminant Level $\ldots \ldots \ldots \ldots \ldots \ldots \ldots \ldots \ldots \ldots$

S.2 Distribution of Hazardous Chemicals in Ground Water at Concentrations Above Maximum Contaminant Level $\ldots \ldots \ldots \ldots \ldots \ldots$

1.1 Hanford Site Location Map $\ldots \ldots \ldots \ldots \ldots \ldots \ldots \ldots \ldots \ldots$

2.1 Generalized Geologic Map of the Hanford Site . . . . . . . . . . . . . . 2.13

2.2 Stratigraphic Column for the Hanford Site Showing Nomenclature of Various Authors . . . . . . . . . . . . . . . . . . . . . . 2.14

2.3 Geologic Cross Section of the Hanford Site $\ldots \ldots \ldots \ldots \ldots \ldots \ldots$

2.4 Geologic Units Present at the Water Table, June $1993 \ldots \ldots \ldots \ldots$

2.5 Thickness of the Unconfined Aquifer System $\ldots \ldots \ldots \ldots \ldots \ldots \ldots \ldots$

2.6 Aquifer Transmissivity Distribution for the Unconfined Aquifer System Determined Primarily From the Inverse Calibration of the Numerical Flow Model $\ldots \ldots \ldots \ldots$

2.7 Estimated Recharge at the Hanford Site from Infiltration of Precipitation and Irrigation . . . . . . . . . . . . . . . . . . . . . . 19

2.8 Cut-Away View of Model Layers and Numerical Model Grid . . . . . . . . . . 2.21

2.9 Comparison of Hydraulic Head Data Between the Upper-Basalt Confined Aquifer and

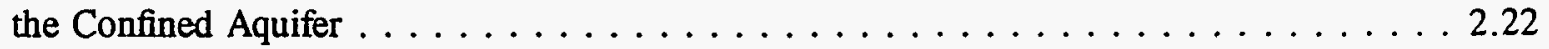

2.10 Modeled Water-Table Changes from December 1993 to December $2005 \ldots$. . . . . . . 2.23

2.11 Model Predicted Water-Table Elevations for the Year $2040 \ldots \ldots \ldots$. . . . . . . . 2.24

2.12 Particle Pathlines from Various Starting Points on the Hanford Site Calculated Using the Two-Dimensional Transient Flow Model . . . . . . . . . . . 2.25 
2.13 Estimated Travel-Time Ranges to the Columbia River from Each Element in the Two-Dimensional Model $\ldots \ldots \ldots \ldots \ldots \ldots \ldots \ldots \ldots \ldots \ldots \ldots \ldots \ldots \ldots \ldots \ldots .26$

2.14 Effects of Dispersion and Radioactive Decay on Break-Through Concentrations from a One-Dimensional Analytical Transport Model . . . . . . . . . . . 2.27

2.15 Tritium Concentrations Along Pathlines from the State Approved Land Disposal Site (C-018H Facility) for Four Different Time Periods $\ldots \ldots \ldots \ldots \ldots 2.28$

3.1 Contour Map of the Changes in the Elevation of the Water Table for the Hanford Site Between June 1993 and June 1994 . . . . . . . . . . . . . . . . . . . 3.12

3.2 Hydrograph of Wells $199-\mathrm{D} 2-5$ and $199-\mathrm{H} 3-1 \ldots \ldots \ldots \ldots \ldots \ldots \ldots \ldots \ldots \ldots \ldots . .13$

3.3 Hydrograph of Wells $199-\mathrm{N}-33$ and $199-\mathrm{N}-67 \ldots \ldots \ldots \ldots \ldots \ldots \ldots \ldots \ldots \ldots \ldots \ldots .13$

3.4 Hydrograph of Wells 299-W 10-13, 299-W11-10, and 299-W 18-21, 299-W23-11, and

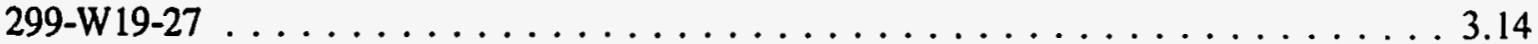

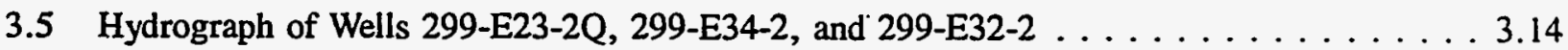

3.6 Hydrograph of Wells $699-60-60$ and $699-20-20 \ldots \ldots \ldots \ldots \ldots \ldots .15$

3.7 Hydrograph of Wells 699-39-39, 699-40-39, and 699-41-40, 699-42-40B,

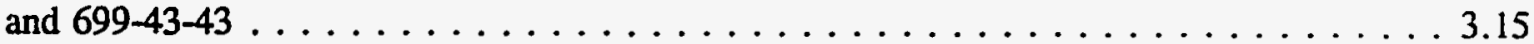

3.8 June 1994 Water-Table Elevation Contours for the 300 Area and Richland North Area . . . . . . . . . . . . . . . . . . . 3.16

3.9 Hydrograph of Well $699-$ S40-E14A $\ldots \ldots \ldots \ldots \ldots \ldots \ldots \ldots \ldots \ldots \ldots \ldots \ldots \ldots .17$

3.10 Hydrograph of Wells 699-S31-1, 699-S42-E8A, and 699-S43-E7A $\ldots \ldots \ldots \ldots .17$

3.11 Hydrograph of Well $699-43-104 \ldots \ldots \ldots \ldots \ldots \ldots \ldots \ldots \ldots \ldots \ldots \ldots \ldots \ldots \ldots \ldots .18$

3.12 Confined Aquifer Monitoring Wells at Hanford $\ldots \ldots \ldots \ldots \ldots \ldots . . \ldots \ldots$

3.13 Potentiometric Map of the Upper-Basalt Confined Aquifer System - March $1993 \ldots \ldots 3.20$

4.1. Ground-Water Monitoring Wells for the Hanford Site Sampled by Various Programs . . . 4.18 
5.1 Tritium Concentration Plume Contours $\ldots \ldots \ldots \ldots \ldots \ldots \ldots \ldots . . \ldots \ldots$

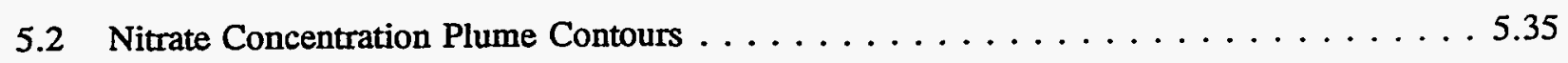

5.3 Iodine-129 Concentration Plume Contours $\ldots \ldots \ldots \ldots \ldots \ldots$

5.41994 Average Strontium-90 in the $100-$ BC Area $\ldots \ldots \ldots \ldots \ldots \ldots . \ldots \ldots$

5.51994 Average Filtered Chromium in the 100-D and 100-H Areas . . . . . . . . . 5.39

5.61994 Average Strontium-90 in the $100-\mathrm{F}$ Area $\ldots \ldots \ldots \ldots \ldots \ldots \ldots . \ldots \ldots$

5.71994 Average Uranium in the $100-\mathrm{F}$ Area $\ldots \ldots \ldots \ldots \ldots \ldots \ldots \ldots \ldots . \ldots \ldots$

5.81994 Average Filtered Chromium in the $100-$ F Area $\ldots \ldots \ldots \ldots \ldots \ldots . \ldots \ldots$

5.91994 Average Trichloroethylene in the $100-\mathrm{F}$ Area $\ldots \ldots \ldots \ldots \ldots \ldots . \ldots . \ldots . . \ldots 44$

5.10 Filtered Chromium Concentration Trend in the $199-\mathrm{H} 4-12$ Well Nest $\ldots \ldots \ldots . \ldots 5.45$

5.111994 Average Technetium-99 in the $100-\mathrm{H}$ Area $\ldots \ldots \ldots \ldots \ldots \ldots \ldots$

5.12 Technetium-99 Concentration Trend in Well $199-\mathrm{H} 4-3 \ldots \ldots \ldots \ldots \ldots 7$

5.13 Technetium-99 Concentration Trend in the $199-\mathrm{H} 4-12$ Well Nest $\ldots \ldots \ldots \ldots . \ldots 57$

5.141994 Average Uranium Concentration in the $100-\mathrm{H}$ Area $\ldots \ldots \ldots \ldots \ldots . \ldots . \ldots$

5.151994 Average Strontium-90 Concentration in the $100-\mathrm{H}$ Area $\ldots \ldots \ldots \ldots . \ldots . \ldots$

5.16 Tritium Concentration Trend for Well $199-\mathrm{K}-30 \ldots \ldots \ldots \ldots \ldots$

5.17 Tritium Concentration Trend for Well $199-\mathrm{K}-27 \ldots \ldots \ldots \ldots \ldots$

5.181994 Average Carbon-14 Concentration in the $100-K$ Area . . . . . . . . . . . . 5.51

5.19 Antimony-125 Concentration Trend for Well $199-\mathrm{K}-27 \ldots \ldots \ldots \ldots \ldots$. . . . . . . 52

5.201994 Average Strontium-90 Concentration in the $100-\mathrm{K}$ Area $\quad \ldots \ldots \ldots . \ldots . \ldots 5$

5.211994 Average Chromium Concentration in the $100-\mathrm{K}$ Area $\ldots \ldots \ldots \ldots \ldots . . \ldots$ 
5.221994 Average Strontium-90 Concentration for the $100-\mathrm{N}$ Area $\ldots \ldots \ldots \ldots \ldots .55$

5.23 Strontium-90 Trend for Well $199-\mathrm{N}-67 \ldots \ldots \ldots \ldots \ldots \ldots \ldots \ldots \ldots \ldots \ldots \ldots \ldots \ldots \ldots$

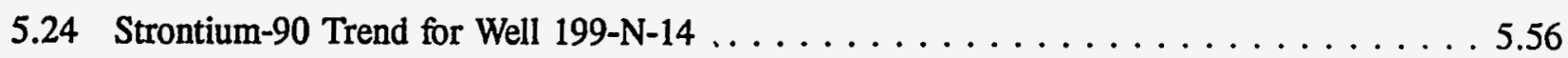

5.251994 Average Sulfate Concentration for the $100-\mathrm{N}$ Area $\ldots \ldots \ldots \ldots \ldots \ldots . \ldots .57$

5.261994 Average Technetium-99 Concentration for the 200-West Area $\ldots \ldots \ldots \ldots .58$

5.27 Nitrate Concentration Trend for Well $299-W 15-4 \ldots \ldots \ldots \ldots \ldots \ldots \ldots . \ldots \ldots$

5.281994 Average Carbon Tetrachloride Concentration in the 200 -West Area . . . . . . . 5.60

5.291994 Average Trichlorethylene Concentration in the 200-West Area . . . . . . . . 5.61

5.30 Tritium Concentration Trend for Well $299-W 22-9 \ldots \ldots \ldots \ldots \ldots \ldots \ldots . \ldots \ldots 2$

5.311994 Average Uranium Concentration in the 200 -West Area . . . . . . . . . . . 5.63

5.32 Nitrate Concentration Trend for Well $299-w 22-20 \ldots \ldots \ldots \ldots \ldots \ldots .6 \ldots$

5.33 Uranium Concentration Trend for Well $299-W 19-3 \ldots \ldots \ldots \ldots \ldots \ldots .6 \ldots$

5.34 Nitrate Concentration Trend for Well $299-W 19-3 \ldots \ldots \ldots \ldots \ldots \ldots \ldots .65$

5.35 Carbon Tetrachloride Concentration Trends in Selected Wells in the

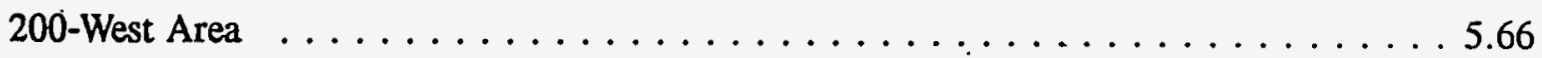

5.361994 Average Chloroform Concentration for the 200-West Area . . . . . . . . . . 5.67

5.371994 Average Fluoride Concentration for the 200-West Area $\ldots \ldots \ldots \ldots \ldots \ldots .68$

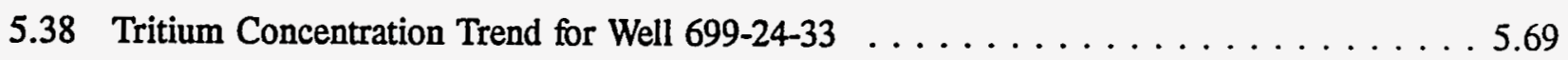

5.39 Tritium Concentration Trend for Well $699-40-1 \ldots \ldots \ldots \ldots \ldots \ldots .70 \ldots \ldots$

5.40 1994 Average Strontium-90 Concentration in the 200-East Area and

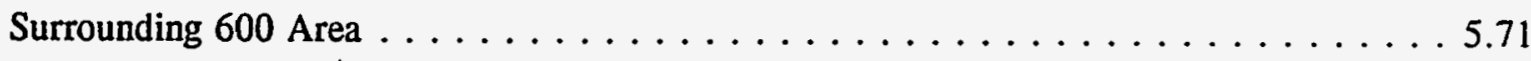

5.41 1994 Average Technetium-99 Concentration in the 200-East Area and Surrounding 600 Area $\ldots \ldots \ldots \ldots \ldots \ldots \ldots \ldots \ldots \ldots \ldots \ldots \ldots \ldots \ldots \ldots \ldots \ldots .72$ 
5.42 Cobalt-60 Concentration Trend for Well $699-50-53 \mathrm{~A} \ldots \ldots \ldots \ldots \ldots . \ldots \ldots$

5.43 Technetium-99 Concentration Trend for Well $699-50-53 \mathrm{~A} \ldots \ldots \ldots \ldots \ldots . \ldots \ldots$

5.44 Technetium-99 Concentration Trend for Well $699-52-54 \ldots \ldots \ldots \ldots \ldots \ldots .74$

5.451994 Average Uranium Concentration in the 200-East Area . . . . . . . . . . . . . 5.75

5.461994 Average Uranium Concentration in the 300 Area . . . . . . . . . . . . 5.76

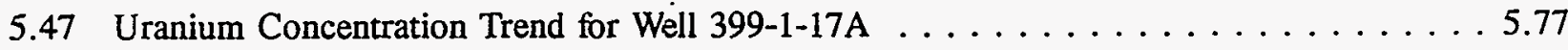

5.481994 Average Trichloroethylene Concentration in the 300 Area . . . . . . . . . 5.78

5.49 Comparison of Tritium.Trends in the 400 Area Drinking Water System . . . . . . . 5.79

5.50 Tritium Concentration Trend for Well $699-\$ 19-E 13 \ldots \ldots \ldots \ldots \ldots$

5.51 1994 Average Tritium Concentrations and June Water Levels for the 300 Area

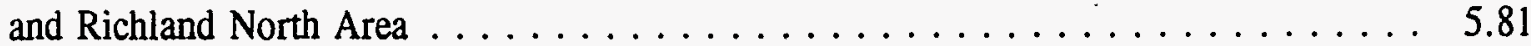

5.52 Trichloroethylene Concentration Trends for Selected Wells in the Richland North Area . . . . . . . . . . . . . . . . . . . . . 5.82

5.53 Tritium Concentration Trend for Well $699-42-40 \mathrm{C} \ldots \ldots \ldots \ldots . \ldots \ldots$

\section{Tables}

4.1 Major Chemical and Radiological Ground-Water Contaminants and Their Link to Site Operations $\ldots \ldots \ldots \ldots \ldots \ldots \ldots \ldots \ldots \ldots \ldots \ldots$

4.2 Methodologies Used to Obtain Routine Data Results for the Ground-Water Surveillance Project Samples . . . . . . . . . . . . . . . . . . 4.20

4.3 Maximum Contaminant Levels $\ldots \ldots \ldots \ldots \ldots \ldots \ldots \ldots \ldots \ldots \ldots \ldots$

4.4 Derived Concentration Guides and 4 mrem Effective Dose Equivalent Concentrations for

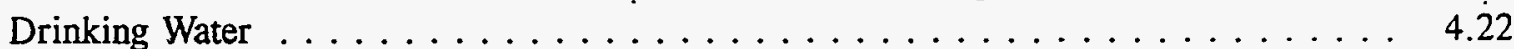


4.6 Summary Results of DataChem Laboratories EPA Water Pollution and Water Supply Performance Evaluation Studies, $1994 \ldots \ldots \ldots \ldots \ldots \ldots \ldots$

4.7 Summary of International Technology Corporation Performance on DOE Quality Assessment Program Samples, 1994

4.8 Summary of International Technology Performance on EPA Intercomparison

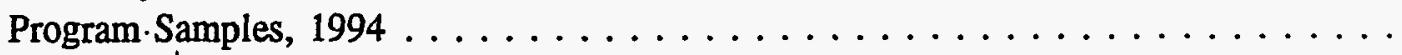

4.9 Summary of Ground-Water Surveillance Project Quarterly Blind Spike Determinations .

4.10 Comparison of Quality Assurance Task Force 1994 Intercomparison Samples.

PNL analyses by IT are compared against grand mean $( \pm$ SEM) of participating laboratories. 


\title{
1.0 Introduction
}

\author{
S.P. Luttrell
}

The Pacific Northwest Laboratory (PNL) $)^{(2)}$. monitors and documents the distribution of . radionuclides and other hazardous materials in ground water at the Hanford Site (Figure 1.1) for the U.S. Department of Energy (DOE) in a program administered by the U.S. Department of Energy, Richland Operations Office (DOE-RL). This work is performed by the Ground-Water Surveillance Project to meet those requirements of DOE Order 5400.1 that apply to environmental surveillance and ground-water monitoring (DOE 1988a). DOE Order 5400.1 was issued November 9, 1988, to establish direction for environmental protection programs at DOE facilities. The environmental surveillance activities are conducted to monitor the effects, if any, of DOE activities at Hanford to the onsite and offsite environment and to the public. The Ground-Water Surveillance Project is part of the Public Safety and Resource Protection Program, which is designed to satisfy the following program objectives, as identified in DOE Order 5400.1:

- verify compliance with other applicable environmental laws and regulations (e.g., RCRA and CERCLA)

- verify compliance with environmental commitments made in environmental impact statements, environmental assessments, safety analysis reports, or other official DOE documents (e.g., Defense Waste Environmental Impact Statement, Tri-Party Agreement)

- characterize and define trends in the physical, chemical, and biological condition of the environment

- establish baselines of environmental quality

- provide a continuing assessment of pollution abatement programs

- identify and quantify new or existing environmental quality problems.

The Ground-Water Surveillance Project monitors contaminant distribution in ground water across the entire site. Other ground-water monitoring activities are being conducted at Hanford by Westinghouse Hanford Company (WHC) and the Environmental Restoration Contract (ERC) team. Ground-water samples are collected by WHC for operational monitoring in and around the 200 Areas, in compliance with DOE orders. Facility-specific monitoring is conducted by WHC for compliance with the Resource Conservation and Recovery Act (RCRA) (40 CFR 264 and 40 CFR 265) and the Washington Administrative Code (WAC 173-303 and -304). The results of some of these other

(a) The Pacific Northwest Laboratory is operated for the U.S. Department of Energy by Battelle Memorial Institute under Contract DE-AC06-76RLO 1830. 
activities are reported in detail elsewhere [e.g., DOE-RL 1995a]. The results of these compliance monitoring activities (primarily for chemical constituents) are valuable in determining the total impact of site operations on ground water and therefore are used by the Ground-Water Surveillance Project to meet its objectives.

Additional ground-water characterization and monitoring activities were conducted by the Hanford Site ERC to support investigations defined in the Hanford Federal Facility Agreement and Consent Order [Washington State Department of Ecology (Ecology) et al. 1992], more commonly called the Tri-Party Agreement. The ERC is a consortium of Bechtel Hanford, Inc. (BHI), CH2MHill Hanford, Incorporated (CHI), International Technology Corporation (IT), and ThermoAnalytical, Incorporated (TMA). Comprehensive Environmental Response, Compensation, and Liability Act of 1980 (CERCLA) as amended by the Superfund Amendments and Reauthorization Act of 1986 (SARA) investigations are under way at a number of areas where known or suspected environmental contamination may have resulted from past site activities. The CERCLA ground-water data, when available, have been integrated into the Ground-Water Surveillance Project interpretations. The use of ground-water data obtained from other programs onsite precludes the need for costly, redundant sampling and enables the Ground-Water Surveillance Project to review activities of other programs in support of DOE's overall environmental objectives.

This annual report discusses the Ground-Water Surveillance Project's ground-water monitoring activities at the Hanford Site during 1994. Section 2.0 describes the site geologic and hydrologic setting; this section includes the unconfined and confined aquifer hydrogeology, and conceptual and numerical modeling of ground-water flow and contaminant transport. Section 3.0 discusses unconfined and confined water-level monitoring and related interpretations. Section 4.0 describes the monitoring programs, with emphasis on the Ground-Water Surveillance Project's activities, including network design, sample collection, sample analysis, quality assurance and quality control, and data management. The results and interpretations of chemical and radiological monitoring are discussed in Section 5.0, organized by Hanford Site Operational Area (e.g., 200-East Area). The monitoring results are generally presented relative to known and probable source areas although potential receptor locations, such as the 400 Area drinking-water supply and the Richland North well field, are discussed separately. Conclusions are presented in Section 6.0. Reference sources referred to in the text are listed in Section 7.0. A more extensive bibliography, which includes a large number of references to historical and current reports related to ground water on or pertaining to the Hanford Site, is included as Section 8.0. Figures and tables appear at the ends of the section in which they are discussed. Pockets at the end of the document include plates of the Hanford Site water table map and the distribution of tritium, nitrate, and iodine-12,9 in ground water, as well as a disk containing chemical and radiological ground-water data for 1994. The ground-water data included in the disk are explained in Appendix C. 


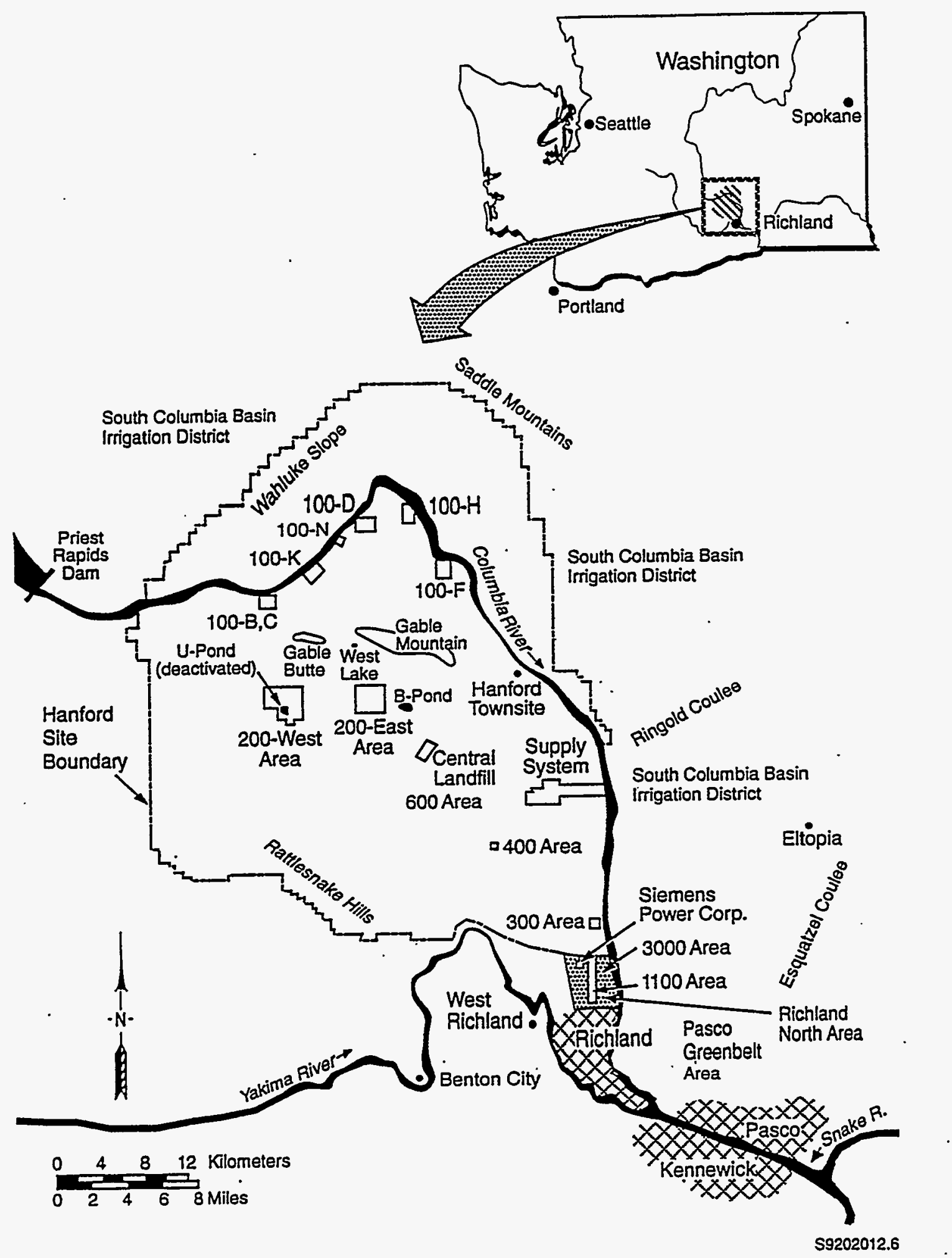

Figure 1.1. Hanford Site Location Map 


\title{
2.0 Hydrogeologic Characterization and Modeling
}

\author{
P.D. Thorne, M.A. Chamness, and S.K. Wurstner
}

Hydrogeologic characterization and ground-water modeling activities are performed by the Ground-Water Surveillance Project to improve the ability to monitor and predict the movement of ground water and associated contaminants. A conceptual understanding of the ground-water flow system is required to determine optimum locations of contaminant monitoring facilities and to assess the impact of remediation activities and proposed land-use scenarios on contaminant plumes. Hydrogeologic characterization also supports numerical modeling of ground-water flow and contaminant transport, which provides a method for predicting the movement of ground water and contaminants under various possible future conditions. For example, a ground-water flow model has been used to determine the effect of decreased waste-water recharge on water levels at existing monitoring wells. Models are also used to predict ground-water flow paths and contaminant travel times under various possible scenarios.

Recent hydrogeologic characterization and modeling efforts have focused on improving vertical hydrogeologic characterization and developing a three-dimensional flow and transport model for the Hanford Site. The existing two-dimensional models do not account for vertical variations in groundwater flow paths or the vertical distribution of contaminants. Therefore, they cannot provide accurate estimates of the contaminant mass transported through ground water. This section provides general information about the geology and hydrogeology of the Hanford Site and summarizes progress on hydrogeologic characterization and modeling activities conducted during 1994.

\subsection{Geologic Setting}

The Hanford Site and adjacent areas north and east of the Columbia River in Grant, Adams, and Franklin counties lie within the Pasco Basin, a structural depression that has accumulated a relatively thick sequence of fluvial, lacustrine, and glaciofluvial sediments. The surface geology and major structural features of the Pasco Basin are shown in Figure 2.1. Figure 2.2 shows the generalized stratigraphy for the Hanford Site and nomenclature used by various authors. The Pasco Basin and nearby anticlines and synclines are formed in the underlying Columbia River Basalt Group, a sequence of continental flood basalts covering more than $160,000 \mathrm{~km}^{2}$. These basalt flows were formed from molten lava during the late Tertiary Period. The most recent laterally extensive basalt flow underlying the Hanford Site is the Elephant Mountain Member of the Saddle Mountains Basalt Formation. Sandwiched between various basalt flows are sedimentary interbeds collectively called the Ellensburg Formation. The Ellensburg Formation includes fluvial and lacustrine sediments consisting of mud, sand, and gravel. The Rattlesnake Ridge Interbed is the uppermost laterally extensive interbed of the Ellensburg Formation.

Figure 2.3 is an east-west cross section illustrating the relationship of geologic formations at the Hanford Site. Overlying the basalt within the Pasco Basin are fluvial and lacustrine sediments of the Ringold Formation. The ancestral Columbia and Salmon-Clearwater River systems flowed into the 
Pasco Basin, depositing coarse-grained sediments in the migrating river channels and fine-grained sediments in the overbank flood deposits. The Plio-Pleistocene unit, consisting of a paleosol/calcrete and/or basaltic sidestream sediments, and the early "Palouse" soil, an eolian sand and silt deposit, are present only in the western portion of the Fasco Basin. As shown in Figure 2.1, the uppermost sedimentary unit covering much of the Hanford Site is the Hanford formation, a complex series of coarse- and fine-grained sediments deposited by cataclysmic floods (called the Missoula floods) during the last ice age. For the most part, the fine-grained sediments are found near the margins of the basin and in areas protected from the main flood currents, which deposited the coarse-grained sediments. Capping the Hanford formation in many areas is a thin veneer of eolian sands and/or recent fluvial deposits.

As the post-basalt sediments were being deposited, the basalt underwent structural deformation. The basin continued to subside, and the ridges continued to rise. This process led to the formation of sedimentary units that are thickest in the center of the basin and become thin or, in places, pinch out along the anticlines. Hanford formation sediments directly overlie the basalt in a few places where the Ringold Formation either was never deposited or was eroded away by ancestral Columbia and/or Salmon-Clearwater rivers before or by the Missoula floods.

More complete descriptions of the geology of the Hanford Site are contained in reports by DOE (1988b), Newcomb et al. (1972), Myers et al. (1979), and Reidel et al. (1992). A more complete geologic description of the areas north and east of the Columbia River is reported by Grolier. and Bingham (1978). Recent reports that provide additional information on the geology of specific areas of the site include those by Connelly et al. (1992a,b) for the 200-East and 200-West aggregate areas, Swanson (1992) for the 300 Area, and Petesson (1992) for the 100 Areas and surroundings.

\subsection{Hydrogeologic Setting}

An unconfined aquifer and a sequence of confined aquifers lie beneath most of the Hanford Site. Perched water-table conditions have been encountered in sediments above the unconfined aquifer in the 200-West Area (Airhart 1990, Last and Rohay 1993) and in irrigated offsite areas east of the Columbia River (Brown 1979). The unconfined aquifer is generally located in unconsolidated to semiconsolidated sediments that overlie the basalt bedrock. In some areas, permeable units within these sediments are locally confined by overlying mud units. However, because the entire aquifer system above the basalt bedrock is interconnected on a sitewide scale, it has commonly been referred to as the "Hanford unconfined aquifer." The confined basalt aquifers are composed of the brecciated tops of basalt flows and sedimentary interbeds located between basalt flows of the Columbia River Basalt Group. The uppermost aquifers located within the Columbia River Basalt are referred to as the "upper-basalt confined aquifer system" (Spane and Raymond 1993), which includes the Rattlesnake Ridge Interbed.

The unconfined aquifer at Hanford occurs mainly within the Ringold and Hanford formations. Because the sand and gravel facies of the Ringold Formation are generally more consolidated, contain more silt, and are less well-sorted, they are about 10 to 100 times less permeable than the sediments of the overlying Hanford formation (DOE 1983b). The Ringold Formation also contains relatively extensive layers of fine-grained sediments such as silt or clay. Before waste-water disposal operations 
began at the Hanford Site, the uppermost aquifer was almost entirely within the Ringold Formation, and the water table extended into the Hanford formation at only a few locations near the Columbia River (Newcomb et al. 1972). However, waste-water discharges have caused the water table elevation to rise into the Hanford formation in the vicinity of the 200-East Area and in a wider area near the Columbia River. Figure 2.4 outlines areas of the Hanford Site where the water table is estimated to lie within the Ringold Formation. This map is based on 1993 water levels.

The unconfined aquifer is bounded below by either the basalt surface or, in places, by relatively impervious clays and silts of the lower mud unit of the Ringold Formation. Laterally, the unconfined aquifer is bounded by the basalt ridges that surround the basin and by the Yakima and Columbia rivers. Where they rise above the water table, the basalt ridges have low permeabilities and act as barriers to lateral flow of ground water (Gephart et al. 1979). On the Hanford Site, the saturated thickness of the unconfined aquifer is greater than $61 \mathrm{~m}(200 \mathrm{ft})$ in some areas but pinches out along the flanks of the basalt ridges. The thickness of the unconfined aquifer, which includes all saturated sediments above the lower mud unit or above the top of basalt where the lower mud is absent, is shown in Figure 2.5. Depth to the water table ranges from less than $0.3 \mathrm{~m}(1 \mathrm{ft})$ near the Columbia River to more than $106 \mathrm{~m}$ (348 ft) near the 200 Areas. In some offsite areas east of the Columbia River, the saturated

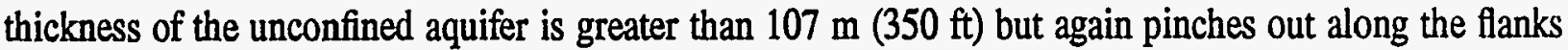
of the basalt ridges. Depth from the ground surface to the water table in this area ranges from $0.3 \mathrm{~m}$ $(1 \mathrm{ft})$ near the Columbia River to approximately $50 \mathrm{~m}$ (165. ft) in the Esquatzel Coulee.

Figure 2.6 shows the transmissivity distribution of the unconfined aquifer determined from a combination of well testing and ground-water flow model calibration. Transmissivity is highest in the central part of the Hanford Site, where the greatest thickness of highly permeable Hanford formation flood channel deposits are found below the water table. These sediments were deposited by catastrophic floods that poured through the gap between Gable Mountain and Gable Butte. Other high transmissivity areas occur intermittently along the Columbia River.

Ground water in the basalt confined aquifers underlying the Hanford Site comes mainly from infiltration of precipitation and streamflow within recharge areas along the periphery of the Pasco Basin (DOE 1988b). The potential for interflow between the upper confined basalt aquifers and the unconfined aquifer system is discussed in Section 2.3.3. Hydraulic-head information indicates that ground water in the confined aquifers flows generally toward the Columbia River and, in some places where vertical flow is enhanced, upward to the unconfined system (Bauer et al. 1985, Spane 1987, DOE 1988b, Spane and Raymond 1993).

Ground water in the unconfined aquifer at Hanford generally flows from recharge areas in the elevated region near the western boundary of the Hanford Site toward the Columbia River. The Columbia River is a discharge zone for the unconfined aquifer on both sides of the Columbia River. The Yakima River lies southwest of the Hanford Site and is generally regarded as a source of recharge to the unconfined aquifer.

Natural areal recharge from precipitation at the Hanford Site is highly variable, ranging from 0 to more than $100 \mathrm{~mm} / \mathrm{yr}$ depending on climate, vegetation, and soil texture (Gee et al. 1992). Areas with. shrubs and fine-textured soils like silt loams tend to have low recharge rates, while areas with little vegetation and coarse-textured soils tend to have high recharge rates. Recharge is also generally higher 
near the basalt ridges because of greater precipitation and runoff. Estimated recharge rates across the Hanford Site are presented by Fayer and Walters (1995) and are shown in Figure 2.7.

Since 1944, the artificial recharge from Hanford waste-water disposal operations has been greater than the natural recharge. As of 1989 , an estimated $1,681,000,000 \mathrm{~m}^{3}$ ( 444 billion gallons) of liquid had been discharged to the ground through disposal ponds, trenches, and cribs (Freshley and Thorne 1992). Additional discharges of $14,000,000 \mathrm{~m}^{3}$ (3,696 million gallons) for $1990,11,000,000 \mathrm{~m}^{3}$ ( 2,904 million gallons) for $1991,8,200,001 \mathrm{~m}^{3}$ (2,165 million gallons) for $1992,6,200,000 \mathrm{~m}^{3}$ (1,637 million gallons) for 1993 , and an estimated $7,650,000 \mathrm{~m}^{3}$ (2,021 million gallons) for 1994 have been reported by WHC (1992a,b, 1993, 1994, and in press). Waste-water discharges to these facilities have resulted in ground-water mounds in some areas that have altered the patterns of flow within the unconfined aquifer system. The volume of artificial recharge resulting from waste-water disposal has decreased during the past few years causing decreases in water-table elevation in some areas, as described in Section 3.0.

\subsection{Three-Dimensional Hydrogeologic Conceptual Model}

A three-dimensional, multilayer numerical ground-water model of the unconfined aquifer system is being developed by the Ground-Water Surveillance Project to assist in the interpretation and prediction of contaminant transport at Hanford (Wurstner and Devary 1993). The basis for this sitewide numerical model is a sitewide three-dimensional conceptual model. The conceptual model consists of the geometry and hydraulic properties of hydrogeologic layers within the aquifer and the definitions of aquifer boundary conditions. This section describes ongoing development of the conceptual model and a description of components of the model.

\subsubsection{Methodology for Defining the Geologic Framework}

Data from more than 350 wells across the Hanford Site have been used to define hydrogeologic layers, or units, with relatively consistent textural composition. The textural composition is expected to correlate with hydraulic properties. Data used in defining hydrogeologic units included well logs, downhole geophysical logs, particle size analyses, calcium carbonate content, and geologic interpretations from other reports. The depth and thickness of units present at each well location were determined. This information was then interpolated on a regular grid spacing using EarthVision software to form three-dimensional layers that together form the framework of the conceptual model. Figure 2.8 shows a stepped cross section and part of the grid used in the numerical ground-water model.

Hydrogeologic units of the sitewide conceptual model have also been defined by the GroundWater Surveillance Project based on an understanding of the depositional environment. Geologic interpretations have been generated for a number of studies on the Hanford Site, but these have been focused mainly on those areas involved in waste disposal practices, such as the 200 Areas. Individual reports on most of the 100 Areas (Peterson 1992, Hartman and Lindsey 1993, Lindberg 1993a and b), the 200 Areas (Connelly et al. 1992a,b), and the 300 and 400 Areas (Swanson 1992, Tyler 1992, respectively) have been released in the past 5 years, but few geologic studies have addressed the regions of the Hanford Site lying between these operational areas. Understanding the lateral extent and 
relationships between the geologic units found in each of the operational areas is crucial to understanding the movement of ground water away from waste disposal sites.

There is a critical distinction between the interpretation of hydrogeologic units in the sitewide conceptual model and the geologic interpretations based on sedimentary facies provided in the reports cited above. Strict geologic interpretations are based on geologic processes that are bounded by time as well as by physical methods of deposition; a river deposits coarse-grained sand and gravel within the channel, while deposition of fine-grained sand and mud occurs primarily from flooding beyond the banks of the river. Deposition is occurring in both environments over the same geologic time interval, but the geologic textures are different, forming different facies within one geologic unit. The geologic interpretations in the above reports use this method to identify and group facies into geologic units. For example, Lindsey (1992) found that in the area north of Gable Mountain, his Unit E of the Ringold Formation is coarse-grained in the west and fine-grained in the east.

In developing the sitewide hydrogeologic conceptual model, the sedimentary facies were grouped differently, with more emphasis on textural composition of the sediments. The movement of ground water is controlled by the hydraulic conductivity, which is closely related to the texture. Texture is a function of the grain-size distribution, sorting, and consolidation. For modeling ground-water flow, it is less important to know that sedimentary facies were deposited by the same river in the same time period than it is to know that there are two texturally distinct sedimentary facies with different hydraulic properties lying adjacent to one another. Consequently, Unit 5 of the conceptual model, which generally correlates to Lindsey's Unit E, is classified as Unit 5 only where Unit E is coarsegrained. Where Unit $\mathrm{E}$ consists of fine-grained overbank deposits, the sediments have been grouped into Unit 6, which is fine-grained.

\subsubsection{Description of Hydrogeologic Units}

Nine sedimentary units were identified for the hydrogeologic model. They are correlated with the geologic units in Lindsey et al. (1992) for clarity (Figure 2.2). Unit 9 lies directly above basalt at the bottom of the unconfined aquifer system. This unit consists of sand and gravel and correlates to Lindsey's Unit A (basal Ringold). This unit is not isolated from the relatively permeable flow top of the underlying basalt, and the two are considered to be a single unit. Unit 9 is often locally confined by overlying mud units. Unit 8 is equivalent to Lindsey's Lower Mud Sequence (the lower Ringold and part of the basal Ringold) and forms an aquitard across much of the site.

Units 6 and 7 have a more complex structure and were more difficult to classify. During this period of deposition, the river channel shifted position, depositing a complex pattern of overbank and mainstream deposits. Unit 7 was defined as the coarse-grained sediments overlying Unit 8. Unit 6 consists of the mostly fine-grained sediments overlying Unit 7, but can include some interbedded coarse-grained sediments. Unit 7 generally corresponds to Lindsey's Units B and D, while Unit 6 corresponds to Unit $\mathrm{C}$ and the unnamed mud layers. An areal distribution of the percent mud within Unit 6 was estimated from well-drilling information and will be used in assigning the distribution of hydraulic conductivities to this layer.

Where the coarse-grained Unit 7 is not present, it was impossible to distinguish between Units 6 and 8. In these cases, the fine-grained sediments were usually grouped into Unit 8. Likewise, where 
the fine-grained Unit 6 is not present, it was impossible to distinguish between Units 5 and 7, and the coarse-grained sediments were grouped into Unit 5. Unit 5 corresponds to the coarse-grained sediments of Lindsey's Unit E (middle Ringold). However, the fine-grained facies of Unit E were generally grouped with Unit 6 . Overlying Unit 5 is Unit 4, a fine-grained layer which corresponds to Lindsey's Upper Ringold Unit. Units 2 and 3 correspond to the early "Palouse" soil and the PlioPleistocene unit, respectively. Unit 3 is generally a coarse-grained sand and gravel unit. Unit 2 is a buried soil horizon containing caliche and generally displaying a low hydraulic conductivity. Unit 1 is the Hanford formation, which is generally a high permeability sand and gravel unit of the Hanford Site.

\subsubsection{Definition of Boundary Conditions}

Nearly all the boundaries of the sitewicle conceptual model represent physical boundaries of the flow system. Perimeter boundaries define the edges of the flow system corresponding to the Columbia River on the north and east and the Yakima River and basalt ridges on the south and west. Boundary conditions are also needed for the top and bottom of the aquifer system. The top boundary consists of the water table and may include both natural areal recharge and local recharge from liquid waste disposal, irrigation, and artificial recharge. The bottom boundary.of the aquifer is the top of basalt or, in some places, the top of Ringold mud units that lie directly on top of the basalt. The lower model boundary is currently defined as no-flow. However, there is a potential for recharge from, or discharge to, the basalt upper-confined aquifer system in some areas.

\section{Columbia River Boundary}

In the vertical dimension, the Columbia River is defined as a prescribed-head boundary from the surface of the river to the riverbed and as a no-flow boundary from the riverbed to the bottom of the aquifer. The water-table configuration (Plate 1) shows that the gradient is towards the Columbia River from both sides. It is unlikely that ground water in the unconfined aquifer system flows across this boundary. However, such flow is possible if a locally confined permeable unit extends beneath the river and is affected by stresses such as pumping. For the sitewide model, daily and seasonal changes in the river stage resulting from releases from upstream dams have been ignored, and a time-averaged river stage elevation was used for the prescribed-head value at the river.

\section{Yakima River Boundary}

In past numerical models, the Yakima River has been represented by a prescribed-head boundary (Jacobson and Freshley 1990). Because the prescribed head values for the river are higher than the heads within the model area, this boundary is a source of recharge. The recharge rate is controlled by the hydraulic conductivity of model elements adjacent to the river and the difference between the head value defined for the river and the head at adjacent nodes. The total model-calculated recharge at this boundary is reasonable in comparison to the flow rate of the Yakima River. However, both the total recharge and the distribution of recharge along the length of the river are uncertain because of a lack of wells and a corresponding lack of information concerning hydraulic properties and water-level elevations near the river.

To help define aquifer behavior in the vicinity of the Yakima River, river-stage monitoring has been conducted at a location just below Horn Rapids Dam. Water levels have been continuously 
monitored at Well 699-S24-19 for both the unconfined aquifer system and the upper-basalt confined aquifer system. Water levels at this well do not show a direct response to changes in river stage. However, the water level of the unconfined aquifer interval does respond to the filling of a canal (the Horn Rapids Ditch) between the well and the river.

The section of the Yakima River below Horn Rapids dam flows through flood plain sediments that consist of moderately permeable stream channel deposits within fine-grained overbank and oxbow lake deposits. In this area, the unconfined aquifer may be somewhat isolated from the river by these finegrained deposits near the river. Examination of drilling logs for private wells near the river shows that there is often fine-grained material near the water table, which sometimes acts as a locally confining unit. The presence of low-permeability sediments near the river may also explain the lack of waterlevel response to the river stage at Well 699-\$24-19. However, because this well responds to filling of the canal, which is closer to the well, it is likely that the low-permeability sediments do not extend to the canal location. The lack of response could also be explained by recent silt deposits in the riverbed.

The Yakima River is still represented as a prescribed-head boundary in the sitewide ground-water flow model. However, reassessment of the hydraulic properties of sediments along the river is expected to change the recharge rate at this boundary.

\section{Cold Creek and Dry Creek Valleys .}

The perimeter boundary of the model region crosses the mouths of Cold Creek Valley and Dry Creek Valley along the western edge of the Hanford Site. These are areas where the model boundary does not coincide with a physical boundary of the unconfined aquifer flow system. The unconfined aquifer sediments extend into the valleys and are a conduit for recharge to the Hanford Site unconfined aquifer system.

The actual recharge rate from Cold Creek and Dry Creek Valleys is not known. However, recharge rates have been estimated from calibration of numerical flow models. Based on this information, Jacobson and Freshley (1990) used prescribed-flux boundaries with assumed recharge of about $9100 \mathrm{~m}^{3} / \mathrm{d}$ for Cold Creek Valley and $1330 \mathrm{~m}^{3} / \mathrm{d}$ for Dry Creek Valley in two of the cases that were run for the inverse calibration model. The result in both cases was unrealistically high head values calculated by the model in the vicinity of Cold Creek Valley. Therefore, either the prescribed recharge at this boundary was too large or transmissivities in the area were set too low. Better results were obtained by Jacobson and Freshley (1990) when a prescribed-head boundary for Cold Creek Valley was used. However, uncertainty remains in the transmissivity distribution determined from the inverse model calibration because it is not known if the recharge calculated by the model at this boundary, which depends on the head difference across the boundary and the transmissivity of the adjacent model elements, is realistic.

A hydraulic test was conducted at Well 699-43-104 during the past year (Thorne et al. 1994). This test resulted in a relatively low transmissivity estimate of $25 \mathrm{~m}^{2} / \mathrm{d}$ and an equivalent hydraulic conductivity of about $2 \mathrm{~m} / \mathrm{d}$. However, these values may not be representative of the bulk of Cold Creek Valley sediments. 


\section{Interflow with the Basalt Confined Aquifer System}

Flow-system boundaries are formed by the contact between the unconfined aquifer system and basalt. At places where basalt rises above the water table, this contact may form either a perimeter boundary or an island of basalt within the model area. The basalt contact also forms the lower boundary of the unconfined aquifer system except in some areas, where a mud unit underlies the aquifer directly over basait.

Some of the perimeter basalt contact boundaries (i.e., Rattlesnake Mountain) probably contribute minor amounts of recharge from the infiltration of precipitation runoff and spring discharge from the upper slopes. For modeling purposes, this recharge has usually been estimated and added into the prescribed flux from Dry Creek.

There is also a potential for interflow (recharge or discharge) between the upper-basalt confined aquifer system and the unconfined aquifer system. Over most of the site, the amount of interflow is thought to be small because of the low hydraulic conductivity of the rock separating the two aquifer systems. However, areas of increased vertical communication have been previously identified in the Gable Mountain and Gable Butte area on the basis of chemistry data (Graham et al. 1984, Jensen 1987). As shown in Figure 2.9, comparison of hydraulic head data from the upper-basalt confined aquifer and the unconfined aquifer indicates the potential for upward flow into the unconfined system in the northern and eastern parts of the Hanford Site, and a potential for downward flow into the confined aquifer system in the western portion of the Hanford Site. In areas where waste-water discharge has resulted in ground-water mounds, such as the decommissioned U Pond in the 200-West Area and B Pond east of the 200-East Area, there is an increased potential for downward flow because of the elevated hydraulic head in the unconfined aquifer (Spane and Raymond 1993). Another potential area of increased vertical communication is in the vicinity of the Yakima River horn, where the river may have incised the upper basalt confining layers.

The rate of ground-water movement between the confined and unconfined aquifer systems is difficult to quantify and therefore has not been included in ground-water flow modeling. It is not known if neglecting this contribution has a significant effect on the accuracy of the ground-water flow model. Differences in ground-water chemistry and temperature offer two possible methods for identifying areas of enhanced intercommunication and possibly quantifying flow rates. The possible use of temperature logs for this purpose has been preliminarily inyestigated (Thorne et al. 1994).

\subsection{Sitewide Ground-Water Modeling}

Numerical ground-water flow models of the Hanford Site were first developed by PNL in the early 1970s (Kipp et al. 1972). Sitewide models have been used to assess the effects of proposed changes in waste-water disposal practices at Hanford and to assess the potential for human exposure to contaminants transported through ground water (Lindberg and Bond 1979, Luttrell et al. 1992, Wurstner and Freshley 1994). Submodels depicting ground-water flow and contaminant transport in smaller areas of the Hanford Site have been developed by WHC to support CERCLA and RCRA investigations (e.g., Connelly et al. 1992a,b; Connelly 1994). 
Past sitewide models have been two-dimensional and assumed that aquifer flow properties and the concentration of contaminants did not vary vertically in the aquifer. However, because the Hanford unconfined aquifer is heterogeneous and anisotropic, and because contaminants were generally introduced at the water table, both hydraulic properties and contaminant concentrations do vary in the vertical direction. Two-dimensional models cannot accurately predict the mass transport of contaminants through the heterogeneous unconfined aquifer system that exists on the Hanford Site. To improve the accuracy of contaminant transport predictions, a three-dimensional sitewide ground-water flow model is being developed based on the conceptual model of the unconfined aquifer flow system described in Section 2.3. In addition to the geometry of the hydrogeologic units, the model must include hydraulic properties, boundary conditions, and initial conditions for such variables as hydraulic head and contaminant concentrations. Work on defining these parameters is currently in progress. Much of the existing two-dimensional model, such as lateral boundary descriptions, is also applicable to the three-dimensional model. Therefore, the two-dimensional model forms the basis for development of the three-dimensional model.

Although a three-dimensional model is needed for accurately determining contaminant mass transport through ground water, two-dimensional models can provide accurate simulations of future hydraulic head distributions and can also give reliable estimates of ground-water flow paths and particle travel times. Therefore, while the three-dimensional model was being developed, the two-dimensional model of the Hanford Site described in Wurstner and Devary (1993) was used for various tasks that required modeling of the unconfined aquifer system.

\subsubsection{Two-Dimensional Model Description}

The two-dimensional ground-water. flow model based on the Coupled Fluid, Energy, and Solute Transport (CFEST) Code is described in Wurstner and Devary (1993) and Wurstner and Freshley (1994). It consists of a finite-element grid containing 997 nodes and 904 elements. The grid information is registered to the Lambert metric coordinate system, and model units are in meters and days. Initial conditions for hydraulic head are based on 1979 flow conditions, which were used by the steady-state inverse calibration as the criteria for generating transmissivities (Jacobson and Freshley 1990). Figure 2.6 shows the aquifer transmissivity distribution used in the two-dimensional model. Aquifer thickness, which includes all saturated sediments above the Ringold lower mud unit or above the top of the basalt when the lower mud is absent, is shown in Figure 2.5. The hydraulic conductivity field is derived from the aquifer thickness and the transmissivity field. An aquifer specific yield value of 0.35 was used because it falls within the range of observed data and provides the best match to measured head values for transient flow simulations.

Boundary conditions consist primarily of prescribed head along the Columbia and Yakima rivers, no-flow boundaries at the bottom of the aquifer and along the basalt outcrops and subcrops, and constant flux along a portion of Rattlesnake Mountain (reflecting discharges from springs) and along the Dry Creek valley. A prescribed head boundary is also used at the entrance of Cold Creek Valley onto the Hanford Site. This boundary is affected by offsite irrigation upgradient from the Hanford Site boundary. A prescribed head elevation of $150 \mathrm{~m}$ is used to reflect recent water-level observations in Well 699-43-104, located near the boundary. No natural recharge from precipitation is included in the two-dimensional model, and no flow between the unconfined aquifer and the deeper basalt aquifers is taken into account. 


\subsubsection{Simulation of Expected Future Water Levels}

The volume of water discharged to the ground has been greatly reduced since Hanford Site operations were curtailed in 1987, and the Site mission changed from the production of nuclear materials to environmental restoration, waste management, and technology development. As a result, the water table has begun to decline, impacting existing monitoring wells used by contractors on the Hanford Site. Since 1985, approximately 30 monitoring wells have become impossible to sample because of the reduced length of the water column. As the water table declines over the next 5 to 10 years, a larger number of wells are expected to be impacted.

The Ground-Water Surveillance Project evaluated the impacts of declining water levels on unconfined aquifer monitoring wells by simulating the expected future water table. Simulation of future ground-water flow conditions was conducted in two stages. The first stage consisted of predicting water levels from 1980 through 1993 and comparing with maps showing the measured water- table elevations. The second stage consisted of continuing the simulations to predict the future water-table response. Monthly effluent discharges from 1980 to 1992 were based on WHC effluent reports and communications with staff members responsible for effluent monitoring. Effluent discharges for 1993 to 2005 were based on projected Hanford Site operations, which assume decreased waste-water discharges. Water levels predicted by the two-dimensional ground-water model at each monitoring well location were compared with well completion intervals to determine which wells may become dry in the future. All Hanford Site wells located within the model boundary for which screen interval information was available were included in the study, which is described in Wurstner and Freshley (1994). The comparison of well completion intervals and water levels was performed using the commercially available Geographic Information Systems (GIS) software package, Arc/Info. The change in predicted water levels from December 1993 to December 2005 is shown in Figure 2.10. The results indicate that the length of the water column will drop to less than $1 \mathrm{~m}$ in an additional 55 wells by the year 2005 , which will make these wells difficult or impossible to sample.

A companion study, conducted by PNL and funded in part by WHC, predicted future water levels at monitoring wells based on a straight-line projection of well hydrographs (Webber and McDonald 1994). Wurstner and Freshley (1994) provide well hydrographs that compare the results of this straight-line prediction method to water-level predictions based on modeling.

The sitewide ground-water model was developed and calibrated assuming that artificial recharge to the unconfined aquifer system from site operations was much greater than natural recharge. However, as the volume of artificial recharge decreases and the flow system approaches pre-Hanford conditions, the assumption that artificial recharge is dominant may no longer be valid. Sources of natural recharge include inflow from Cold Creek and Dry Creek Valleys, runoff and springs in the Rattlesnake Hills, the Yakima River, flow from the upper-confined basalt aquifer system, and infiltration of precipitation. Uncertainty in recharge estimates for these sources have a greater effect on the model results for future periods when small artificial recharge volumes are assumed.

As waste-water discharges cease, the flow system in the unconfined aquifer will approach conditions similar to pre-Hanford conditions. However, present irrigation in the Cold Creek Valley and potential land-use changes on the Hanford Site will probably provide more recharge to the unconfined aquifer than was present before the Hanford Site was established. Zimmerman et al. (1986) 
observed that water-level changes occurred in the unconfined aquifer through 1970 in response to discharges to the ground at the Hanford Site. Similarly, it can be expected that the effects of declining discharges will be observed in the unconfined aquifer for several decades.

\subsubsection{Contaminant Transport}

Although the two-dimensional model does not provide a good tool for predicting contaminant concentrations, it can be used to make certain approximations. The particle tracking method uses the two-dimensional ground-water model to generate particle pathlines and travel times. Dispersion, sorption, and radioactive decay are not taken into account. However, corrections can be applied to the results to account for these effects.

The two-dimensional ground-water flow model was used to predict flow paths and transport of tritium from the proposed State Approved Land Disposal Site (SALDS), also called the C-018H facility, north of the 200-West Area. Water-table elevations from 1980 through 2040 were simulated assuming transient flow conditions. Figure 2.11 shows the predicted water-table elevations for the year 2040. Steady-state flow conditions were assumed after 2040. Earlier pathline transport models had been run assuming steady-state flow conditions after 2005 . This difference in assumptions resulted in significantly different pathlines from the $\mathrm{C}-\mathrm{O} 18 \mathrm{H}$ facility.

\section{Pathlines}

A particle travel pathline shows the path that an average water particle would follow based on the transient flow field predicted by the model. For contaminants that are soluble and nonreactive, and not strongly sorbed onto the sediments, particle travel pathlines can be used to approximate the path that the contaminant will take through the ground-water flow system. This method does not consider dispersion and, therefore, approximates the travel path of the contaminant plume's center of mass. Figure 2.12 shows pathlines started at various locations on the Hanford Site. Pathlines are terminated by the model when they reach a model boundary, such as the Columbia River.

\section{Travel Times}

Particle travel time, defined as the average time it takes a water particle to travel between designated points along a pathline, can be calculated with the existing two-dimensional ground-water flow model. Figure 2.13 shows the calculated range of travel time to the Columbia River for each of the model elements. Each element is assigned a color based on a travel time range from that location. Elements that are colored light yellow indicate that a travel time could not be calculated because of a numerical problem in the pathline determination that sometimes occurs near flow system boundaries. The model generated travel times may not be accurate for all locations because of uncertainties in aquifer hydraulic properties or approximations to actual boundary conditions. For example, basalt is known to extend above the water table in a small area to the southeast of Gable Mountain. This is not reflected in the existing two-dimensional model. Therefore, travel times calculated for elements upgradient of this obstacle are probably shorter than the actual travel times.

Particle travel time can be used to estimate arrival time of the peak contaminant concentration at a specific location. Because the method does not-consider dispersion or sorption, the travel time 
corresponds to the center of mass of a completely nonreactive plume. Radioactive decay is also not considered. As discussed below, for contaminants with a short half-life, the arrival of the peak concentration will actually be sooner than the travel time predicts.

\section{Determining Concentrations Using Pathlines}

A one-dimensional analytical transport code can be used to calculate transport along a specified streamline or pathline. This provides a concentration breakthrough curve at any point on the pathline for a given contaminant source. Dispersion, radioactive decay, and sorption can be accounted for in the analytical transport code and used to correct the travel time of the peak concentration. .Figure 2.14 shows concentration breakthrough curves at a point along a pathline with different assumptions. The baseline curve assumes no dispersion, no sorption and no decay. The additional curves show the effects of longitudinal dispersion and decay, both separately and combined. The source is a constant concentration pulse of tritium lasting for 60 years. Note that for the baseline curve, the arrival time of the pulse is equal to the particle travel time. For the curve that includes dispersion, the peak concentration is also equal to the particle travel time. The concentration peak for the curve that includes both dispersion and decay arrives earlier than the baseline particle travel time. For contaminants with a relatively short half-life (e.g., tritium), the contaminant mass that arrives earliest is affected much less by decay than the later arriving center of mass of the plume. This phenomenon of the peak concentration occurring earlier than the particle travel time occurs for contaminants with relatively short half-lives traveling long flow paths.

Figure 2.15 shows predicted tritium concentrations at a few points along pathlines from the SALDS (C-018H) facility. Each map represents a different time over the next 100 years in approximately 25-year increments (every two half-lives of tritium). 


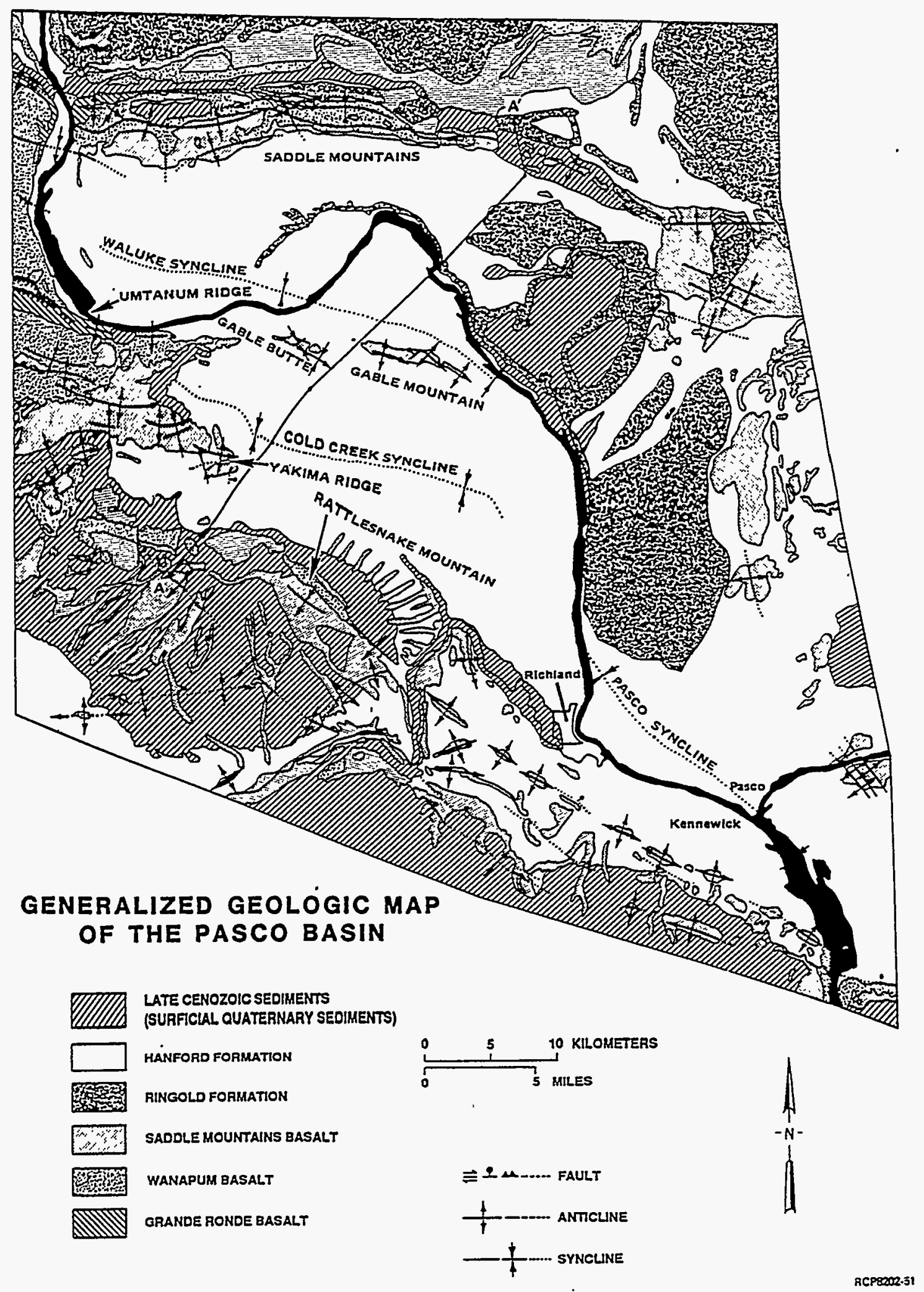

Figure 2.1. Generalized Geologic Map of the Hanford Site (from Reidel et al. 1992) 


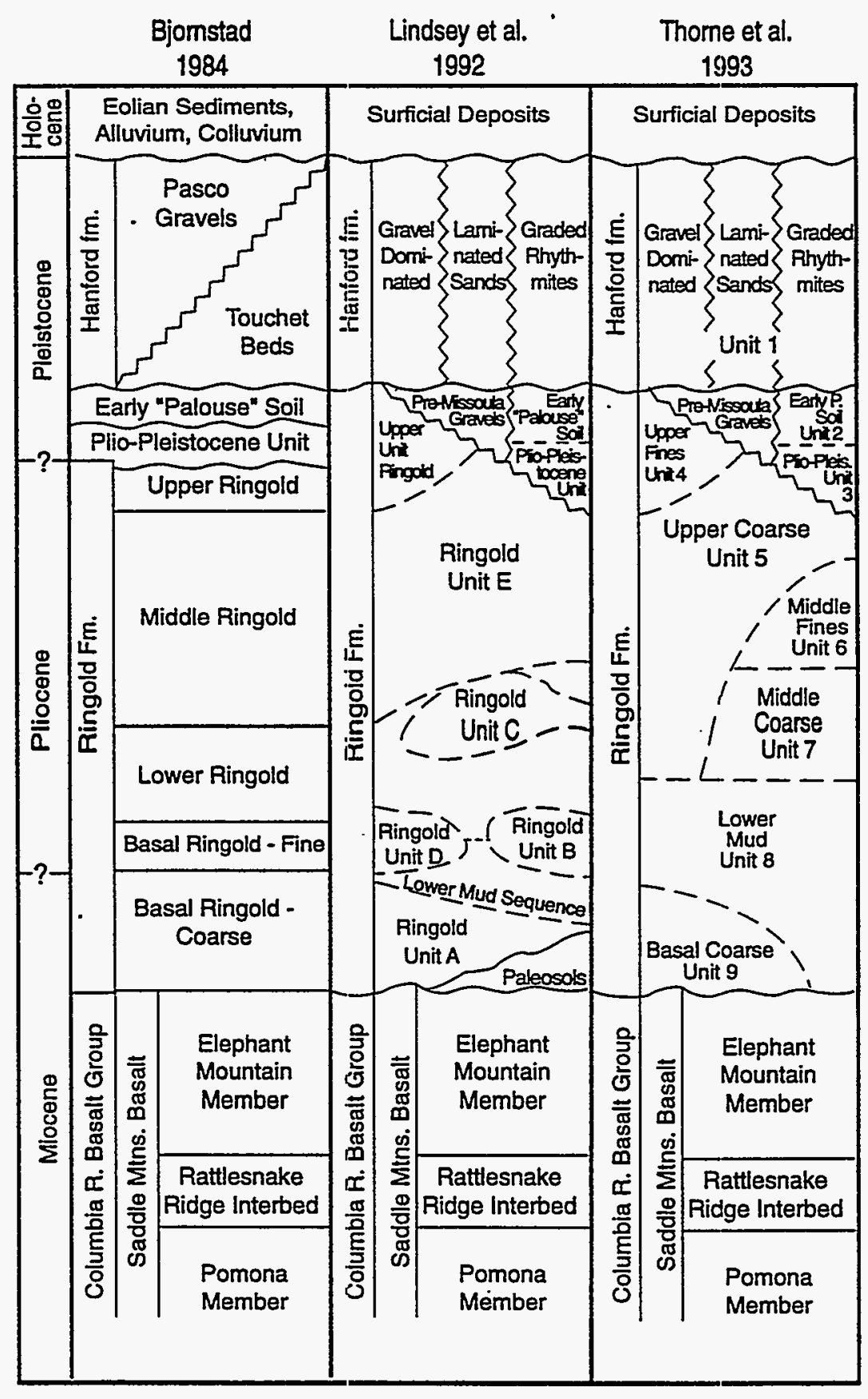

$\$ 9505044.1$

Figure 2.2. Stratigraphic Column for the Hanford Site Showing Nomenclature of Various Authors 
Hanford Formation

Early "Palouse" Soil

- and Plio-Pleistocene Unit

Ringold Formation Fine-grained Units

West

Ringold Formation Coarse-grained Units

I Water Table

$\rightleftharpoons$ Inferred Fault

012345 Kilometers 1,

$\begin{array}{lllllll}0 & 1 & 2 & 3 & 4 & 5 & \text { Miles }\end{array}$

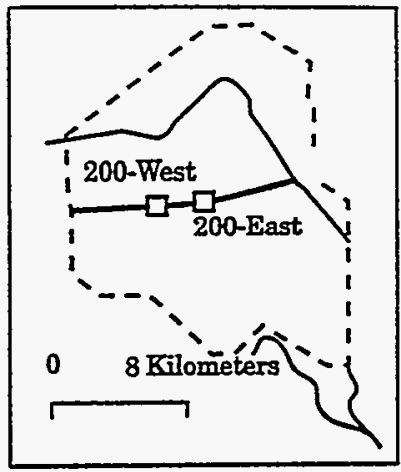

East

White

Bluffs

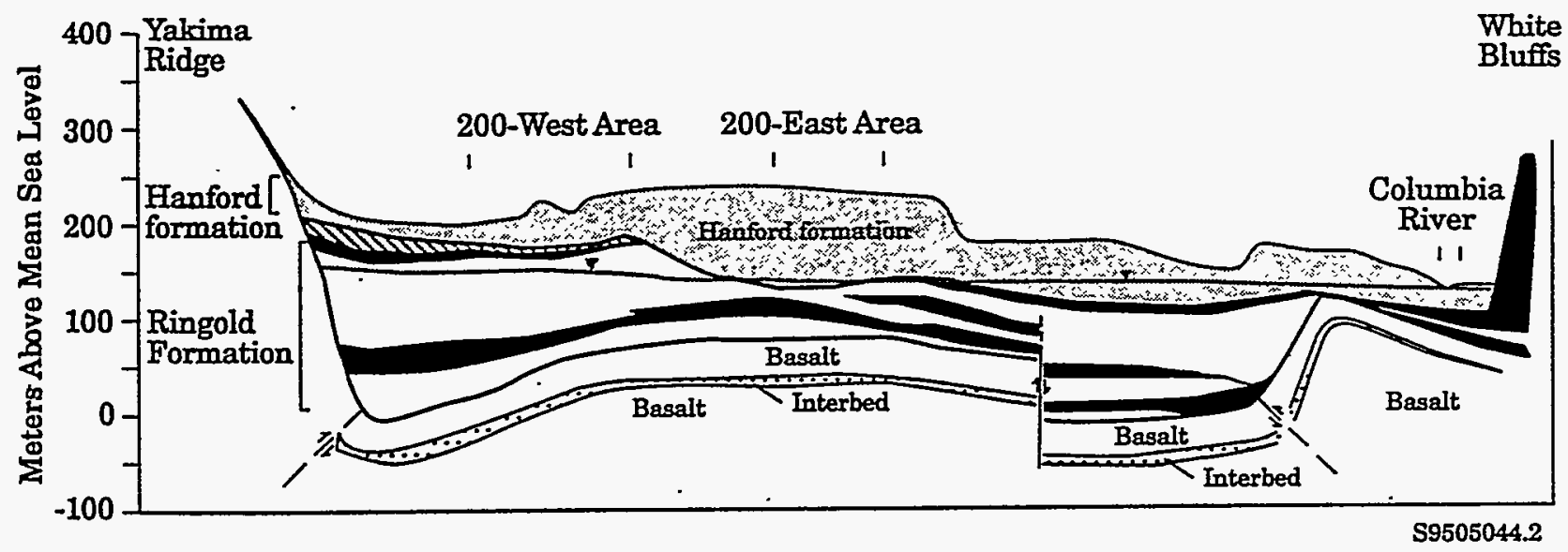

Figure 2.3. Geologic Cross Section of the Hanford Site 


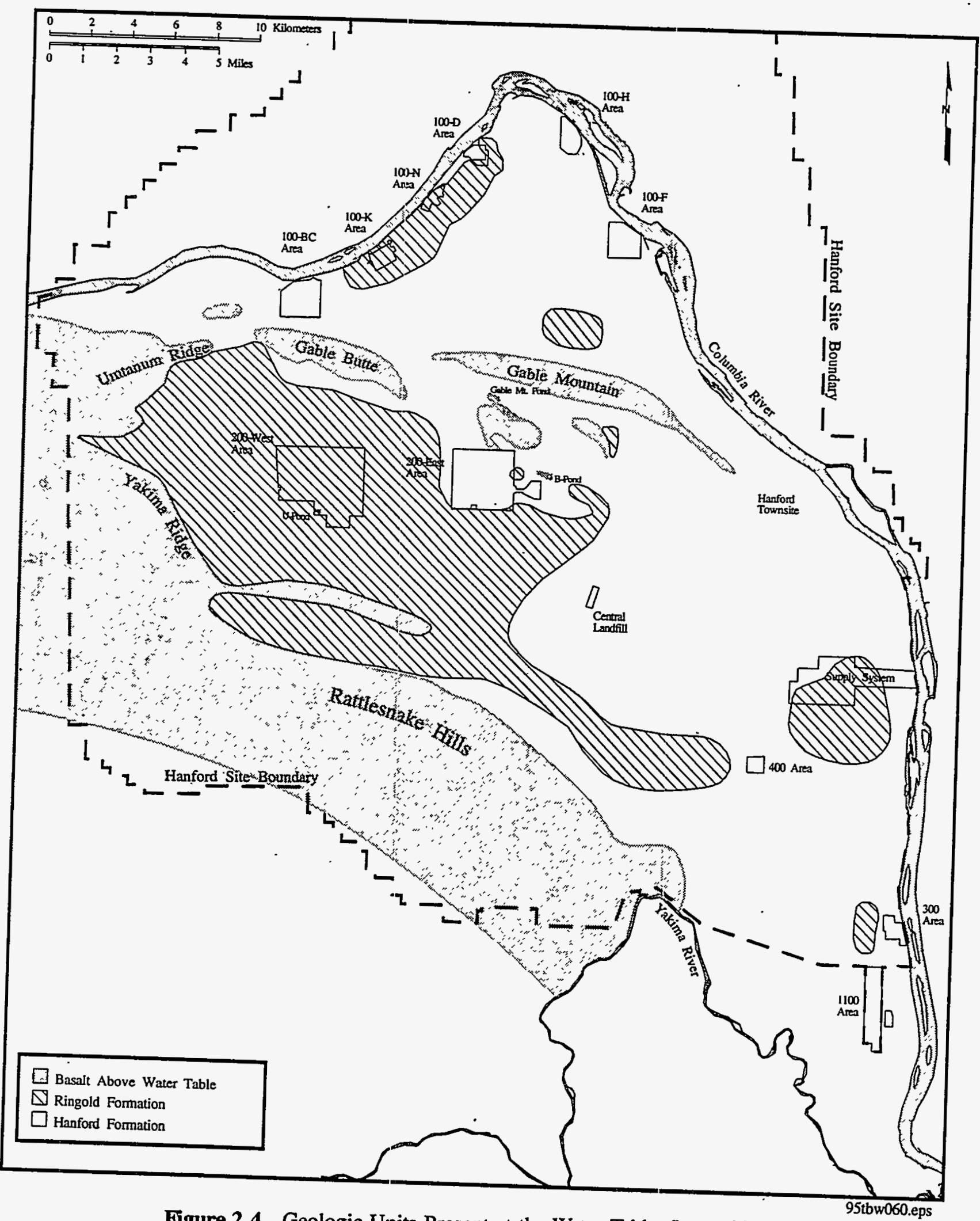

Figure 2.4. Geologic Units Present at the Water Table, June 1993 


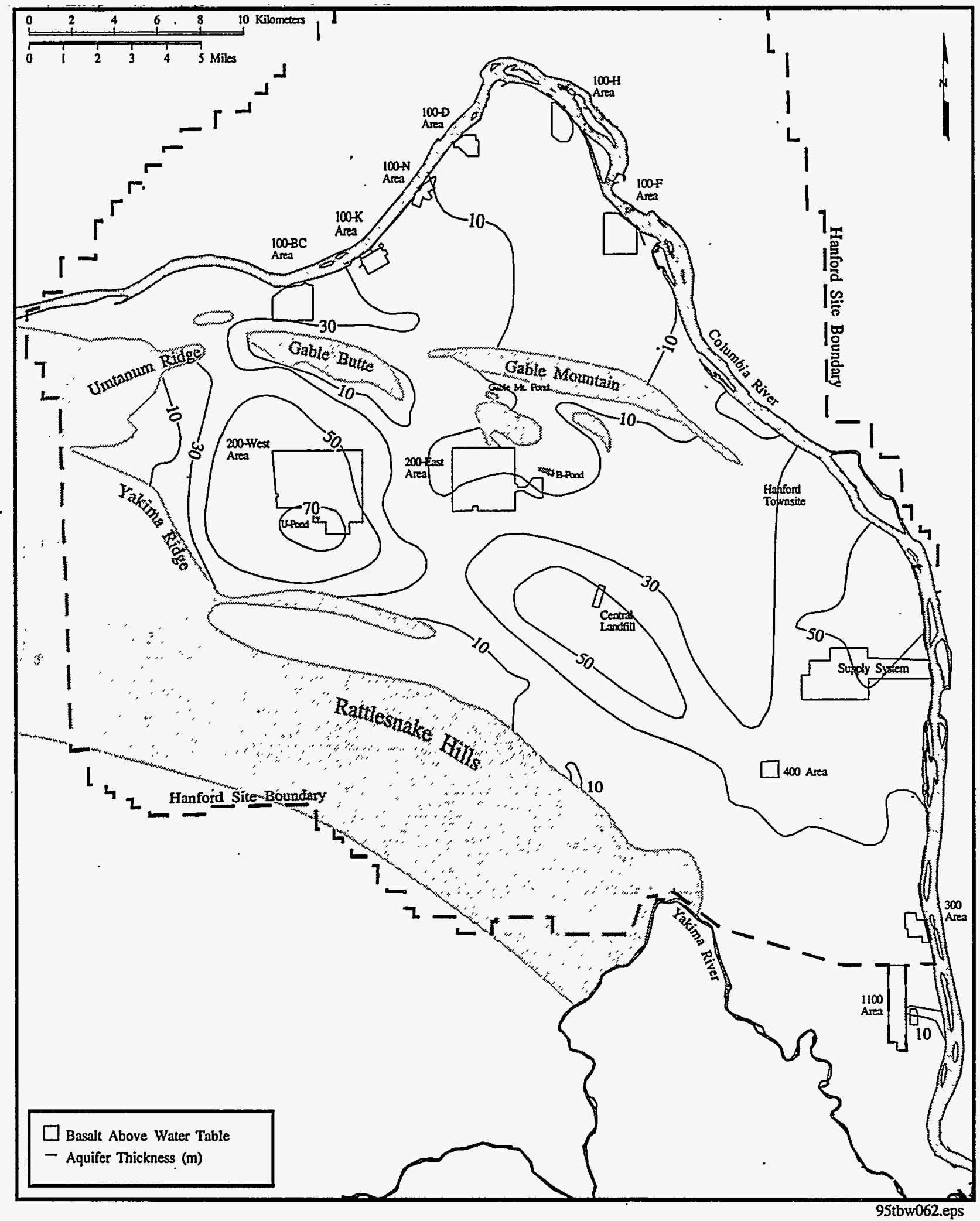

Figure 2.5. Thickness of the Unconfined Aquifer System 


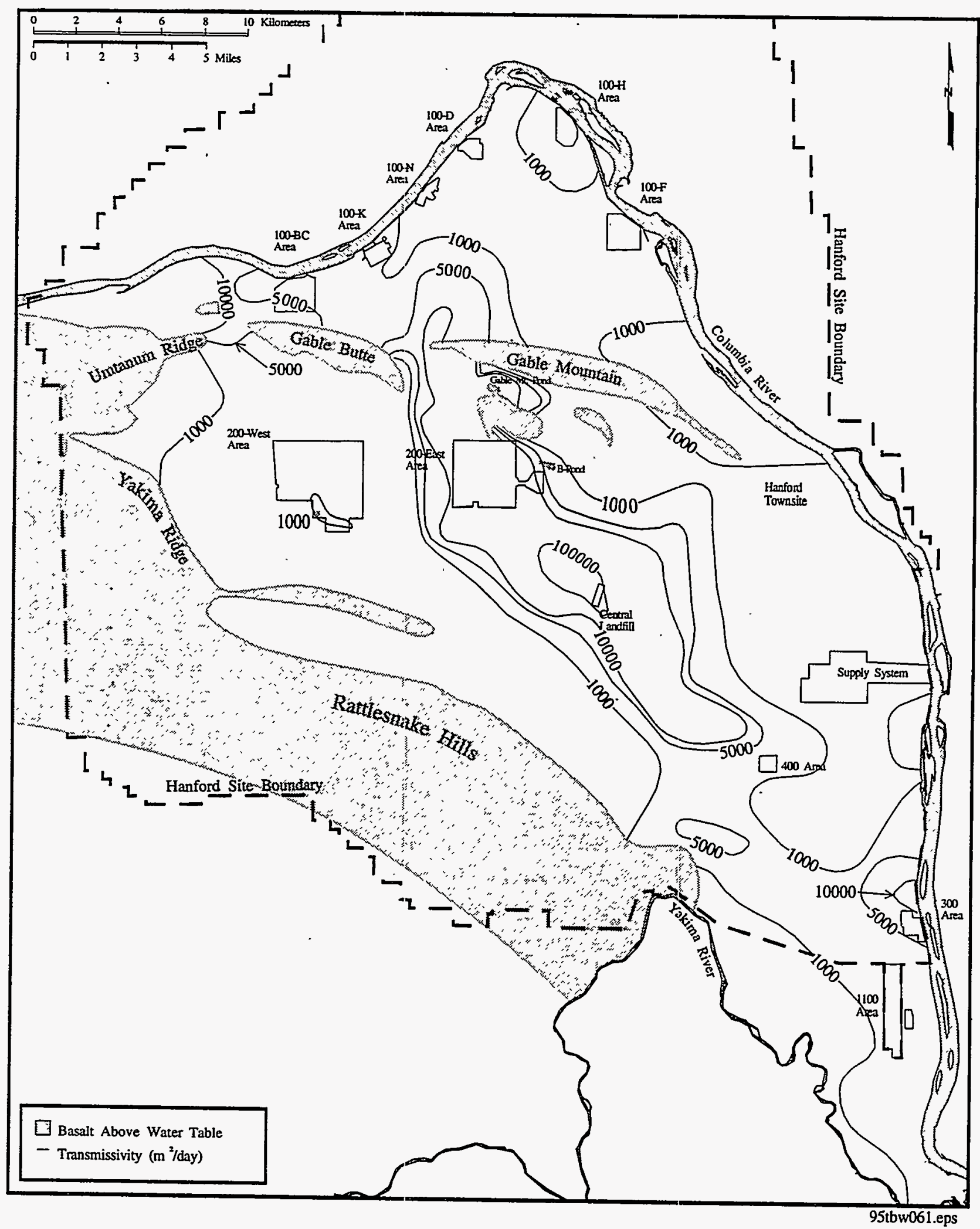

Figure 2.6. Aquifer Transmissivity Distribution for the Unconfined Aquifer System Determined Primarily from the Inverse Calibration of the Numerical Flow Model 


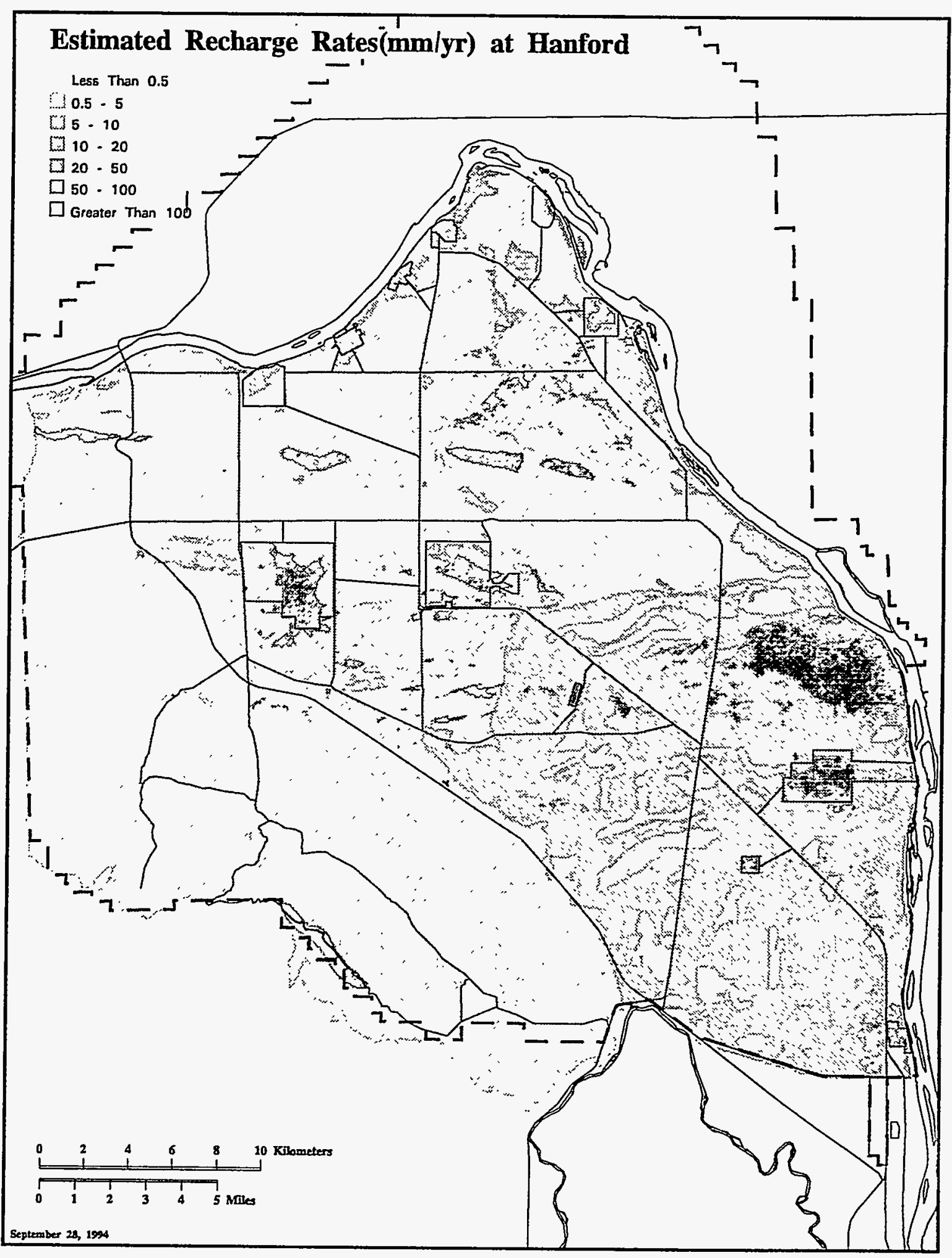

Figure 2.7. Estimated Recharge at the Hanford Site from Infiltration of Precipitation and Irrigation (from Fayer and Walters 1995) 


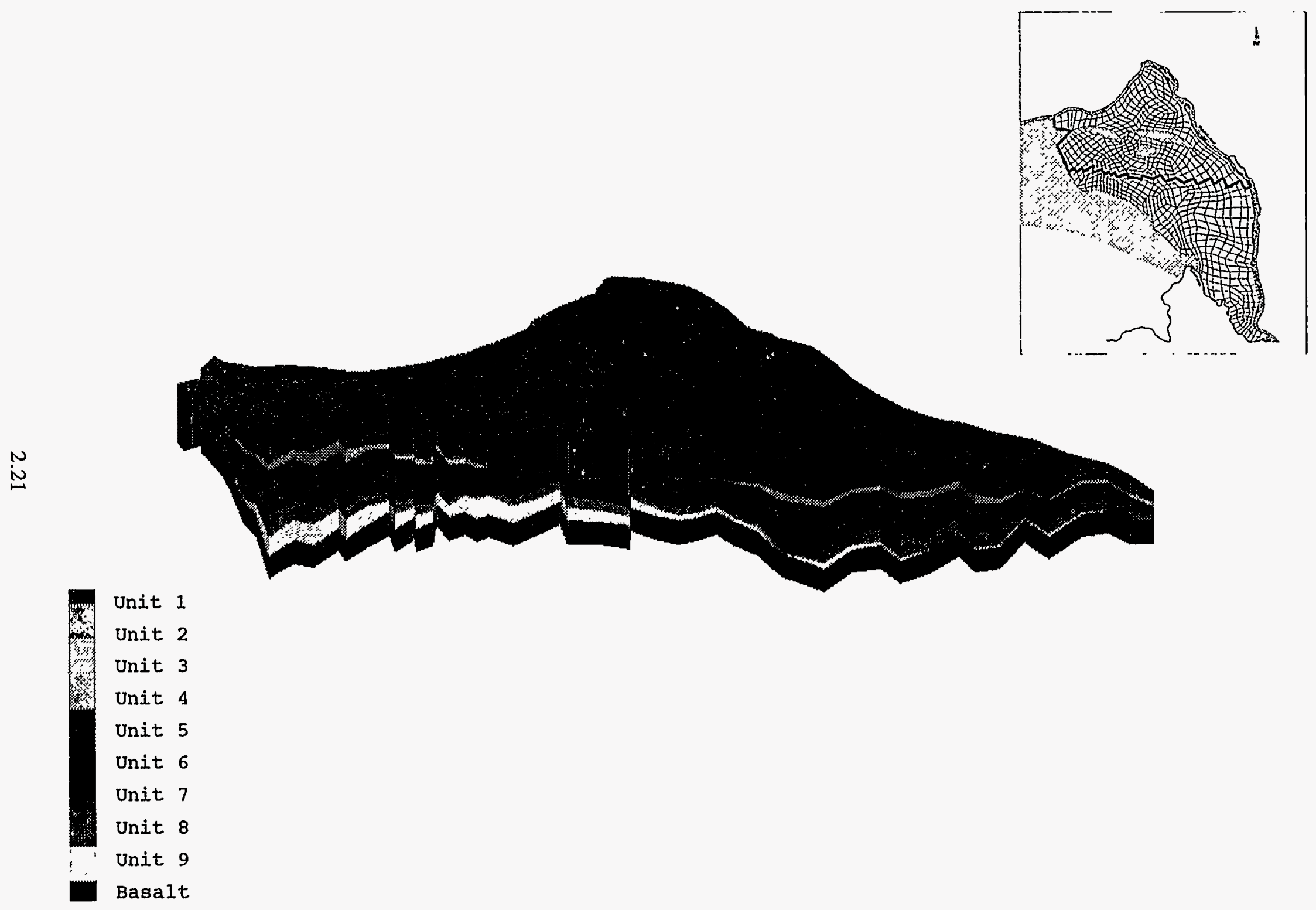

Figure 2.8. Cut-Away View of Model Layers and Numerical Model Grid 


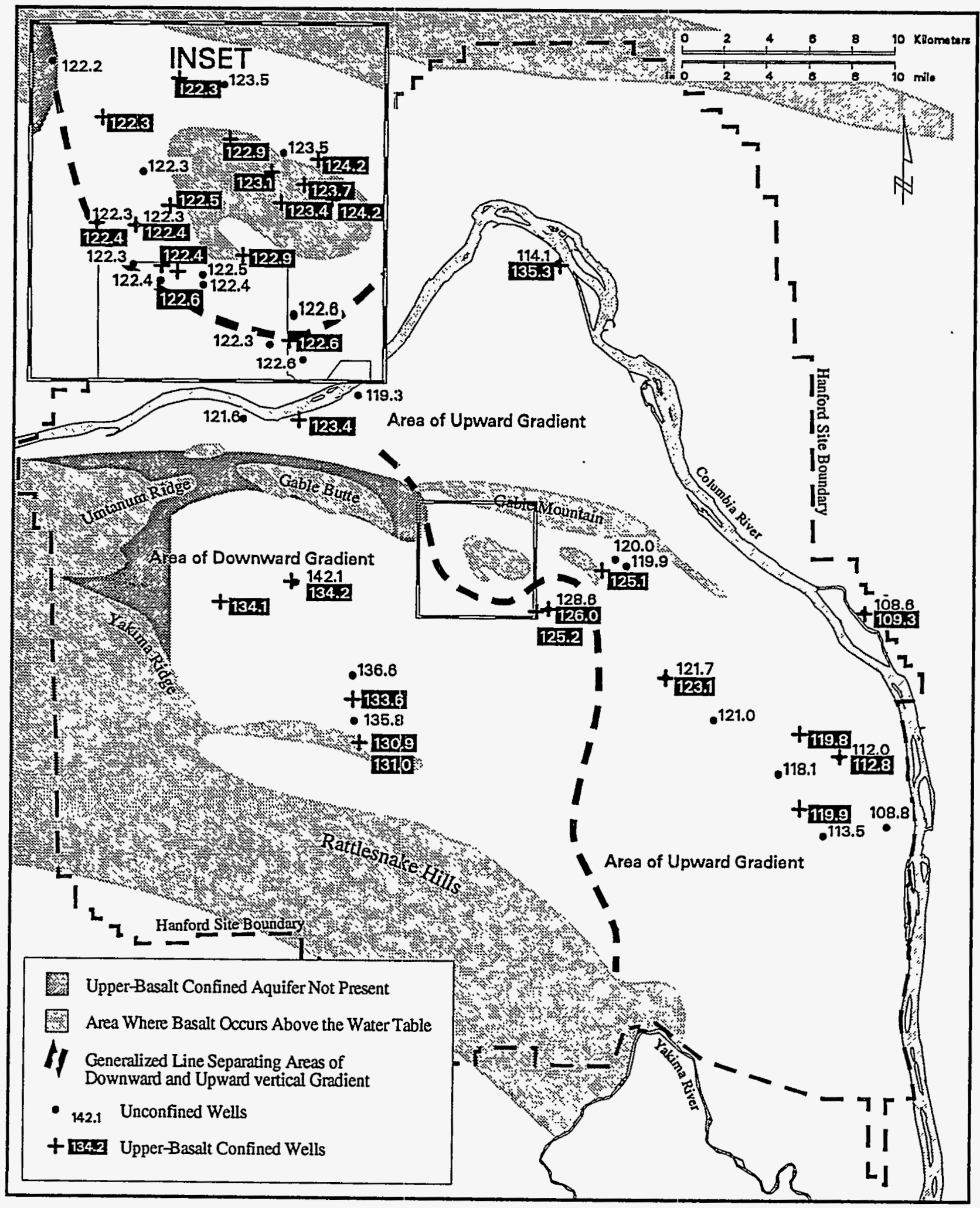

Figure 2.9. Comparison of Hydraulic Head Data Between the Upper-Basalt Confined Aquifer and the Confined Aquifer 


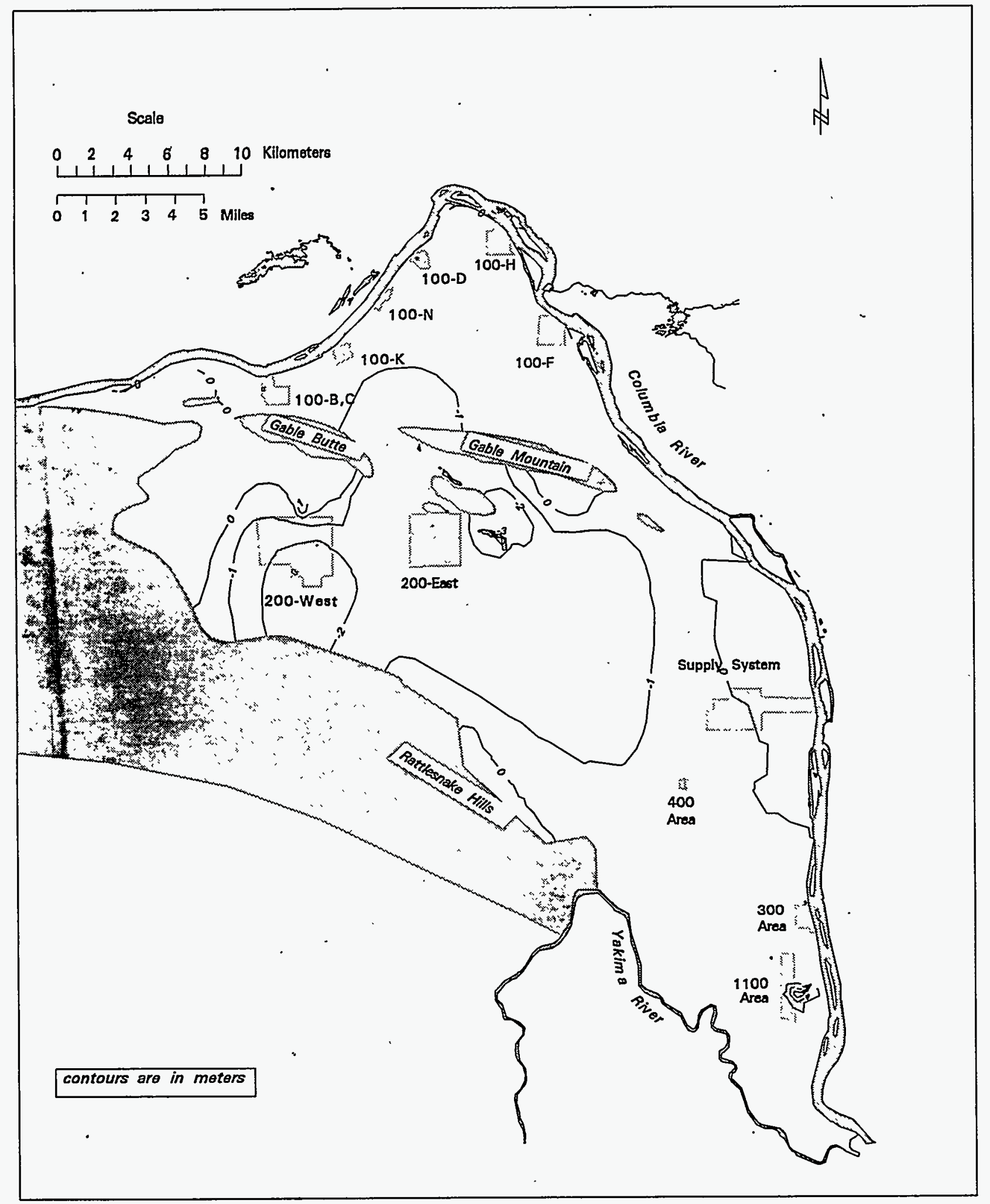

Figure 2.10. Modeled Water-Table Changes from December 1993 to December 2005 


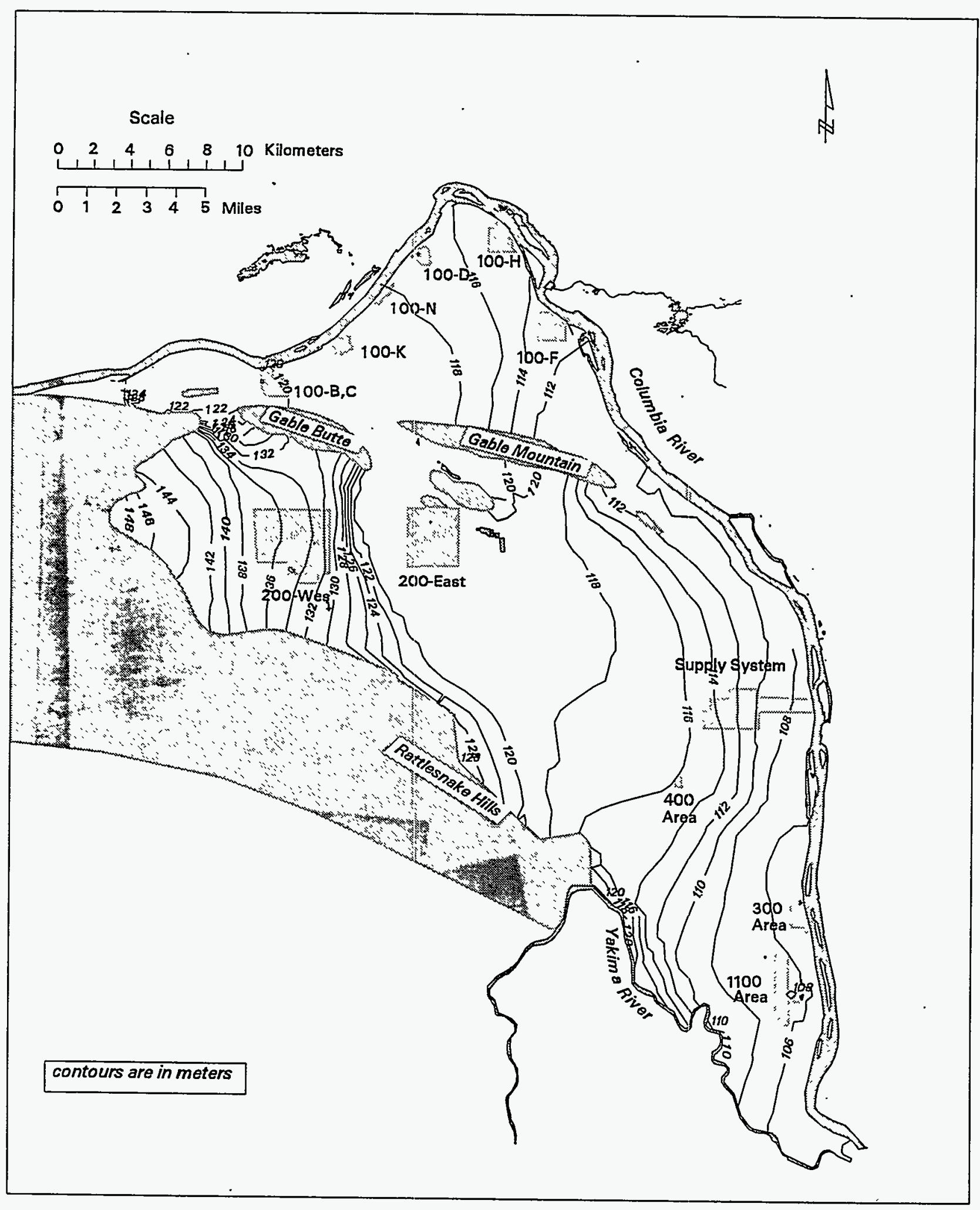

Figure 2.11. Model Predicted Water-Table Elevations for the Year 2040 


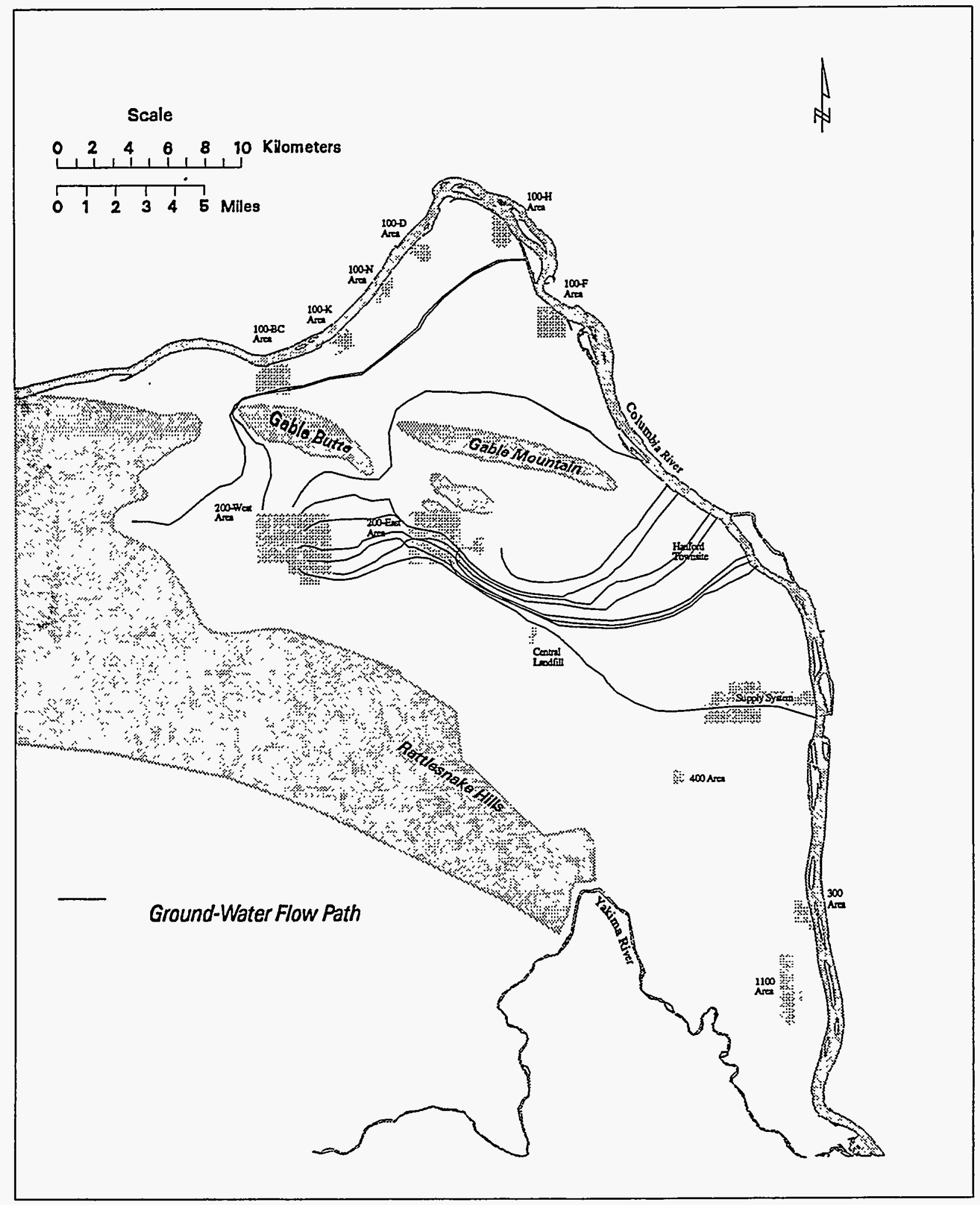

Figure 2.12. Particle Pathlines from Various Starting Points on the Hanford Site Calculated Using the Two-Dimensional Transient Flow Model 


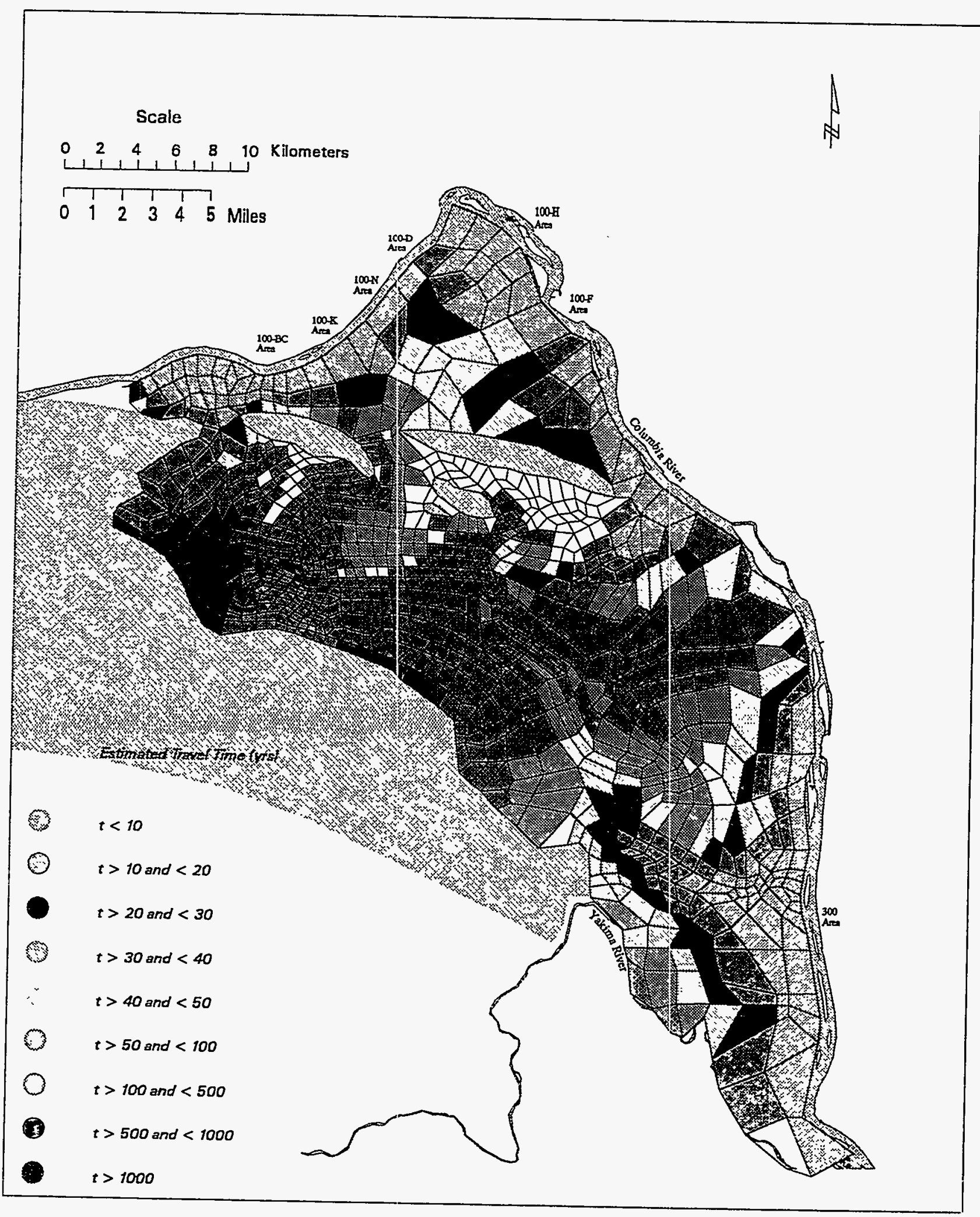

Figure 2.13. Estimated Travel-Time Ranges to The Columbia River From Each Element in the Two-Dimensional Model 

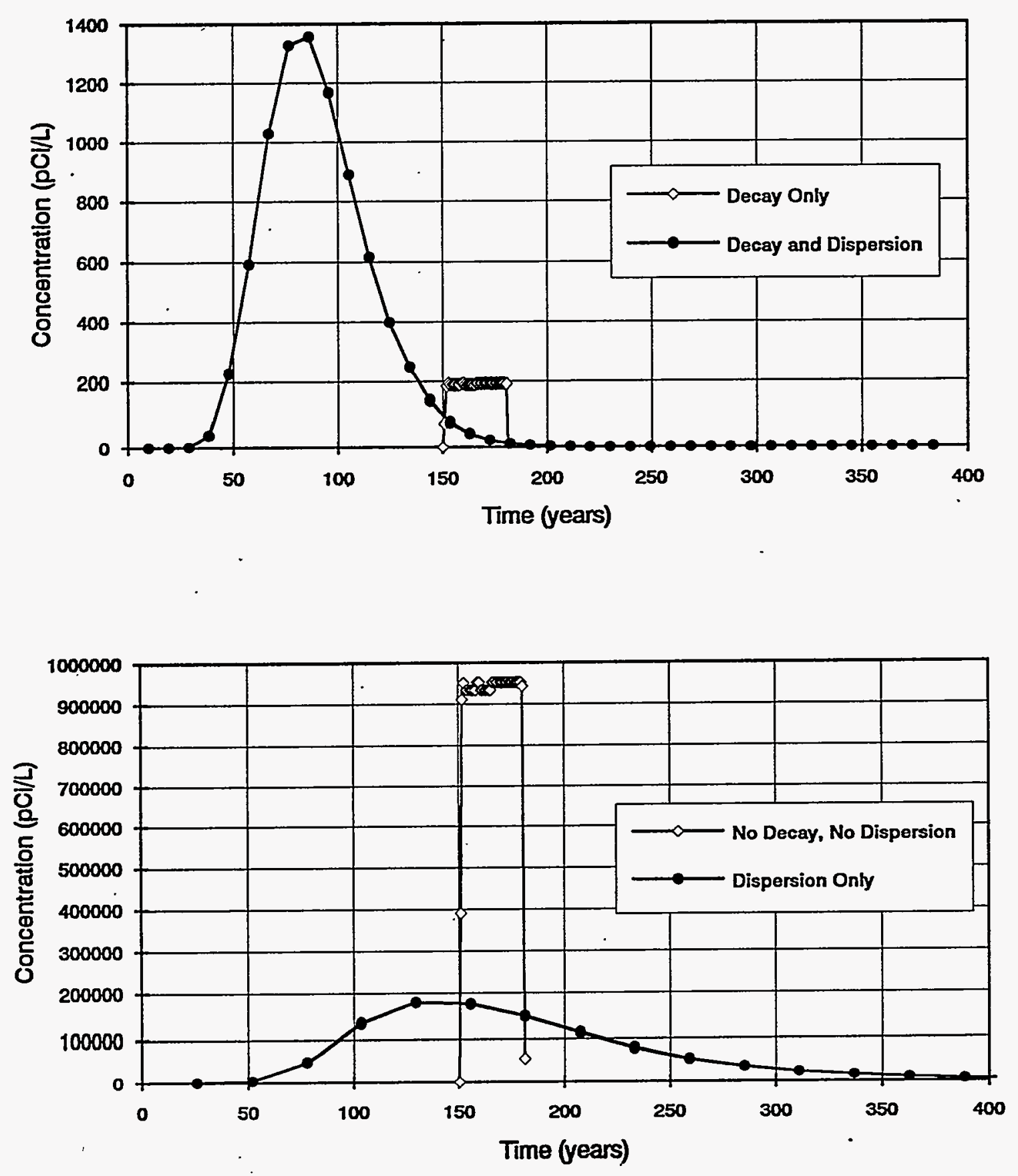

Figure 2.14. Effects of Dispersion and Radioactive Decay on Break-Through Concentrations from a One-Dimensional Analytical Transport Model 

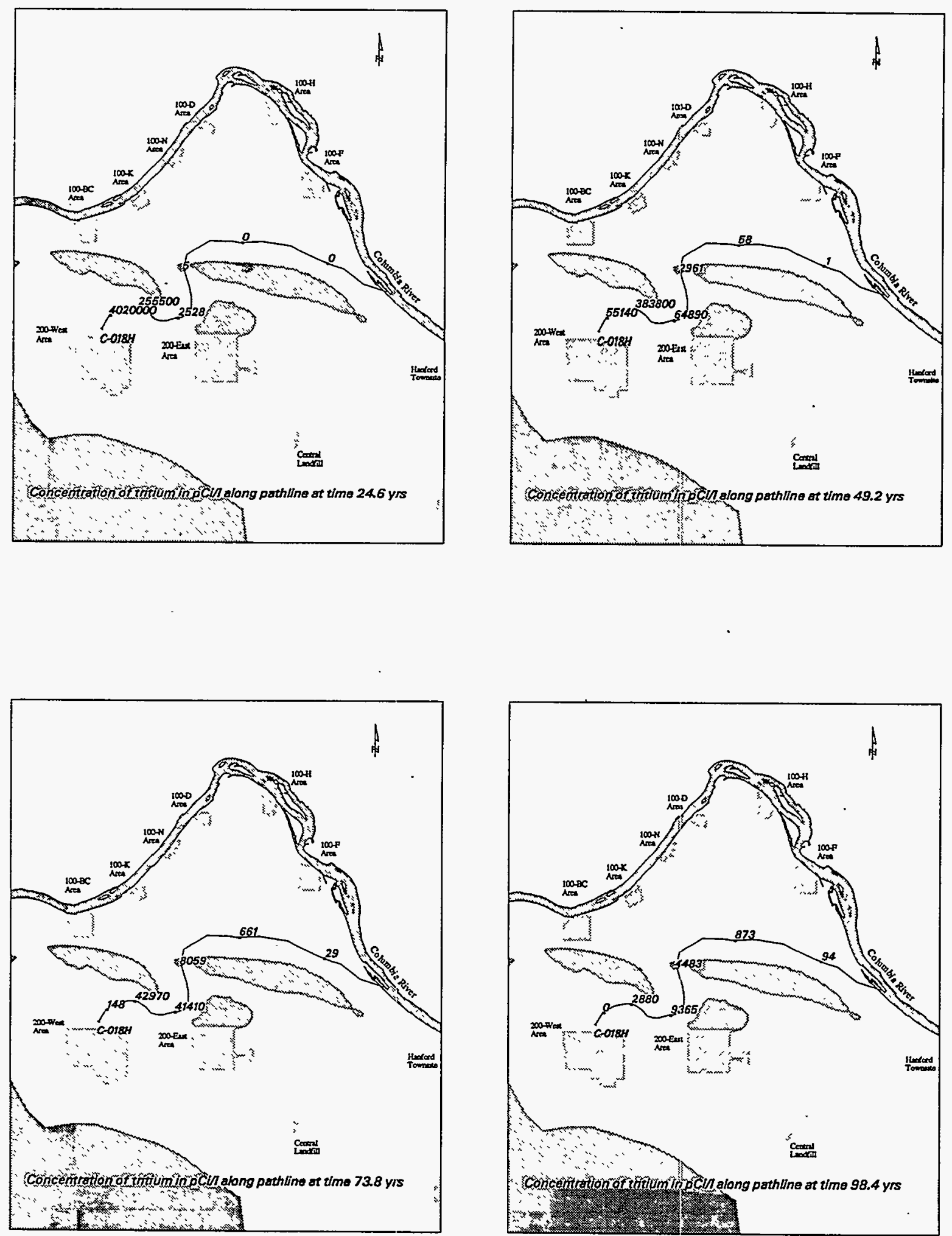

Figure 2.15. Tritium Concentrations Along Pathlines from the State Approved Land Disposal Site (C-018H Facility) for Four Different Time Periods 


\title{
3.0 Water-Level Monitoring
}

\author{
P.D. Thorne and W.D Webber
}

Water levels are measured in selected wells completed in the unconfined aquifer beneath the Hanford Site during June of each year. The purpose of these measurements is to monitor changes in water-table elevation, which affect the flow direction and velocity of ground water and associated contaminants. Measurements are made at a few of the same wells during December to monitor seasonal variations. The Ground-Water Surveillance Project also measures water levels in selected offsite wells north and east of the Columbia River during June. These measurements are primarily made in unconfined aquifer, wells installed by the U.S. Bureau of Reclamation (USBR) to monitor water-level changes and drainage patterns associated with recharge from irrigation practices. Water levels in this area have also been measured by the U.S. Geological Survey (Walters and Grolier 1960, USGS 1977, Drost et al. 1993).

Water-level measurements for the unconfined aquifer were used to construct a map showing the elevation of the water-table surface for June 1994. The measured wells were chosen based on hydrogeologic evidence that they were completed in the unconfined aquifer. The water-table map can be used to determine general directions of ground-water flow, particularly in the upper part of the aquifer. Ground water moves from regions of high potential to regions of low potential. Potential is proportional to hydraulic head, which is equivalent to the water-table elevation for an unconfined aquifer. Therefore, assuming isotropic hydraulic conductivities, the direction of ground-water flow is perpendicular to contours of equal water-table elevation. In addition, water-table maps can be used to

- identify recharge and discharge areas

- evaluate the influence of waste-water discharges on ground-water flow directions

- identify the potential for water movement between adjacent ground-water and surface-water bodies

- determine the hydraulic gradient, which is required to estimate the average linear velocity of ground water and contaminants

- improve the design of the monitoring-well network

- provide information required to calibrate ground-water flow and contaminant transport models

- evaluate ground-water flow for interpreting contaminant fate and transport. 
Before 1991, water-table maps of the Hanford Site were limited to the area bounded by the Columbia River on the north and east; the anticlinal basalt ridges, Umtanum Ridge, Yakima Ridge, and Rattlesnake Hills to the west and southwest; and the Hanford Site boundary between Horn Rapids and the 300 Area to the south. Beginning in 1991, the annual water-table map was extended to include irrigated agricultural areas north and east of the Columbia River (Newcomer et al. 1992). This area is

bounded by the Saddle Mountains to the north and Jackass Mountain to the east. The mapped area was expanded so that the hydrology of the Hanford Site could be presented in the context of the regional ground-water flow system.

In addition to water levels measured in wells scattered across the Hanford Site, water levels were measured at more closely spaced wells in four specific areas within the Hanford Site. These areas are around the decommissioned 216-U-10 Pond (U Pond) in the 200-West Area, around the 216-B-3 Pond (B Pond), at the 100-N Area, and within the Richland North Area, which includes the 300 Area, 1100 Area, and 3000 Area. Artificial recharge to the unconfined aquifer in these areas has resulted in ground-water mounding that appears to influence ground-water flow. The locations of these areas are shown in Figure 1.1.

Water-table maps and water-level data for June 1992 and June 1993 were presented by Dresel et al. (1993, 1994), respectively. Evaluations of past water-table changes resulting from Hanford operations are presented by Zimmerman et al. (1986) and Newcomer (1990). Brown (1979) presented water-table maps of the Pasco Basin for 1979 and characterized the occurrence of unconfined ground water in the eastern part of the Pasco Basin. A regional map of ground-water levels in materials overlying the Columbia River basalt group for spring 1985, including water-level contours of the unconfined aquifer in the Pasco Basin, is presented by Bauer et al. (1985). Semiannual water-level measurements and water-table maps of the Hanford Site and operational areas for June 1993, December 1993, and June 1994 were presented by Kasza et al. (1994a, 1994b) and Serkowski et al. (1994), respectively. Water levels north and east of the Columbia River in Grant and Franklin counties were measured by the USGS for 1986-1989 (Drost et al. 1989), and a water-table map for the area north and east of the Columbia River in Franklin County for March 1986 was prepared by Drost et al. (1993).

\subsection{Data Collection}

During June 1994, WHC and the Ground-Water Surveillance Project measured water levels in more than $\mathbf{5 0 0}$ wells completed in the unconfined aquifer beneath the Hanford Site. The Ground-Water Surveillance Project also measured water levels in about 100 wells completed in the unconfined aquifer north and east of the Columbia River in Grant, Adams, and Franklin counties during June 1994.

Most monitoring wells used for water-level measurement at the Hanford Site are 15 or $20 \mathrm{~cm}$ (6 or 8 in.) in diameter and are constructed of steel casing (Chamness and Merz 1993). Several smalldiameter [5-cm (2-in.)] piezometers and some larger-diameter wells are also used. Wells constructed for RCRA ground-water monitoring are 10 or $15 \mathrm{~cm}$ (4 or 6 in.) in diameter and are constructed of 
stainless steel. Monitoring wells used to measure water levels for the unconfined aquifer are completed with well screens or perforated casing that is generally open to the upper 3 to $6 \mathrm{~m}$ (10 to $20 \mathrm{ft}$ ) of the aquifer. This type of completion allows measurements generally representative of the water-table elevation. Most offsite wells monitored by the Ground-Water Surveillance Project are 4, 8, 10, or $15 \mathrm{~cm}(1.5,3,4$, or $6 \mathrm{in}$.) in diameter and completed with perforated steel casing (Walters and Grolier 1960, personal communication, Tony Gladue, Technician, USBR).

A written procedure developed in accordance with the techniques described by the American Society for Testing and Materials (ASTM 1988), the U.S. Environmental Protection Agency (EPA 1986b), Garber and Koopman (1968), and USGS (1977) was followed to measure water levels in piezometers and wells across the Hanford Site. WHC also used a standard procedure (WHC 1989) to measure water levels at the Hanford Site. Both PNL and WHC used steel tapes that were standardized by comparison to a calibrated steel tape. Only those standardized steel tapes that deviated in length from the calibrated steel tape by less than $\pm 0.03 \mathrm{~m}( \pm 0.10 \mathrm{ft}$ ) were used. PNL also used laminated steel electric sounding tapes that meet standardization requirements similar to those for steel tapes. Water levels are reported as elevation above the National Geodetic Vertical Datum (NGVD29). The water-table elevation values were calculated by subtracting the measured depth to water from the surveyed elevation of a measuring-point datum permanently marked on the top of each well casing.

To reduce the effect of seasonal and other long-term. water-level changes, all water-level measurements were made within a one-month period (June 1994). The most significant short-term water-level changes that occurred within this period were in wells influenced by fluctuations in Columbia River stage. Water-level fluctuations in wells influenced by river-stage fluctuations may introduce errors in representing the water-table surface adjacent to the river. Therefore, the watertable elevation contours adjacent to the river have a greater uncertainty than other contours. Other minor uncertainties in the water-level measurements are caused by short-term external stresses (e.g., barometric pressure and earth tides), deviations from the vertical in wells, errors in the elevation of surveyed measuring points, and limits of the precision of the measuring tapes. However, the magnitude of these uncertainties is insignificant relative to site-wide water-table gradients.

\subsection{Results of the 1994 Water-Level Measurements}

A map showing June 1994 water-table elevation contours for the unconfined aquifer is presented in Plate 1. The locations of measurement points used in preparing the map are also shown. The contour interval is $2 \mathrm{~m}$ in the Hanford Site area, west and south of the Columbia River, and $50 \mathrm{~m}$ in the area north and east of the Columbia River. A larger contour interval was used in this area because the variation in water-table elevations is much greater. Selected 1994 water-level data for the unconfined aquifer are presented in Appendix A. Appendix A also includes the measured depth to water, the measuring-point elevation, and the calculated water-table elevation for each well. Water-level data for December 1994 are listed in Appendix B. 
The locations of Hanford Site wells used to prepare the water-table map are indexed in Plate 2. Wells north and east of the Columbia River are numbered by the USGS well-numbering system, prefixed by township and range. Locations of these wells can be determined from the well number. Wells on the Hanford Site, south and west of the Columbia River, are named with their Hanford coordinates. The locations of basalt above the water table shown in Plate 1 were updated by comparing the top of basalt topographic surface with the 1993 water-table surface.

\subsubsection{Hanford Site Water-Table Features}

Ground-water flow at the Hanford Site is generally from recharge areas on the west to the Columbia River on the north and east. The lowest water-table elevations are found near the Columbia River. This indicates that the river is the major discharge area for the unconfined aquifer. Water-table elevations decrease while approaching the river from either side showing that ground-water flow converges at the river.

Steep gradients in the western region of the Hanford Site result from ground-water recharge at the western edge of the Pasco Basin combined with relatively low hydraulic conductivities. Possible sources of recharge include infiltration of runoff from rain and snow at higher elevations and offsite irrigation of agricultural land in the Cold Creek Valley.

Ground-water mounding from past waste-water disposal at U Pond and from smaller ongoing discharge to other 200-West Area disposal facilities is apparent from the shape of the contours passing through the 200-West Area. These contours curve eastward around the ground-water mound. The steep gradient just east of the 200-West Area results from this ground-water mound and the relatively low transmissivity of the aquifer in this area. The hydraulic gradient decreases abruptly between the 200-West and 200-East Areas. This change in gradient corresponds to an increase in transmissivity caused by the presence of highly permeable Hanford formation sediments below the water table.

A local ground-water high exists immediately north of Gable Mountain. Water levels measured in two wells, which are completed at the top of the unconfined aquifer, are higher than water levels in surrounding wells. Closely spaced water-table elevation contours to the east of the ground-water high indicate an area of low transmissivity. The area of elevated ground-water levels was reported by Jenkins (1922) even before the Hanford Site was established, and it has persisted to the present. Possible explanations include the occurrence of local perched water-table conditions, past leakage from the Hanford Irrigation Ditch, infiltration of runoff from Gable Mountain, or leakage from the underlying basalt aquifer. Because of the low permeability sediments, even a small amount of recharge could result in significant ground-water mounding.

Closed elevation contours northeast of the 200-East Area indicate a ground-water mound around B pond, where process cooling water and other liquid wastes are discharged to the ground. The hydraulic gradient in the area southwest of the 200-East Area is relatively flat. Although this area is in the main flow path through the Hanford Site, the presence of highly permeable sediments results in a 
relatively flat water table. A ground-water mound beneath the Richland North Area, south of the 300 Area, has resulted from recharge at the City of Richland's recharge infiltration basins.

The elevation of the water table in the region between the Yakima River and the Columbia River is

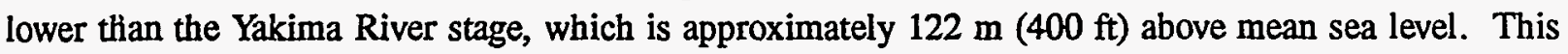
implies that the unconfined aquifer is recharged by the Yakima River in this area. The aquifer may also be recharged by leakage from the Horn Rapids Ditch and the Columbia Canal, which originates at Horn Rapids Dam, and by irrigation in offsite areas east of the Yakima River.

\subsection{Changes in the Hanford Site Water Table - 1993 to 1994}

As shown in Figure 3.1, water levels over most of the Hanford Site decreased slightly from June 1993 to June 1994. This continued a trend that began in the 1980s when discharge to waste-water disposal facilities, particularly U Pond in the 200-West Area and Gable Mountain Pond north of the 200-East Area, was reduced. These two facilities were decommissioned and some of the waste water was diverted to B Pond, located east of the 200-East Area. As a result, water-table elevations in the vicinity of B Pond increased during the 1980s, (Newcomer 1990). Water-table elevations near B Pond decreased slightly in the early 1990 s because of additional reductions in waste-water discharge.

However, wells near the eastern lobe of B Pond showed increasing water levels in 1994 as discussed in Section 3.3.3.

The greatest declines in the water-table elevation between June 1993 and June 1994 occurred in the southern part of the 200-West Area, near the former location of U Pond, and near the City of Richland infiltration basins east of the 1100 Area. The City of Richland pumps river water into these basins to recharge a network of water-supply wells. Water levels in the area west of the 1100 Area rose between June 1993 and June 1994, possibly because of irrigation activities in this offsite area.

\subsubsection{Areas}

The Hanford Site water-table map indicates that ground water flows north through the gaps between Umtanum Ridge, Gable Butte, and Gable Mountain and eventually discharges to the Columbia River. The 100 Areas are located along the river and ground water beneath these sites generally flows towards the river. The ground-water mound created by waste-water disposal in the 200 Areas extends north of the gap between Gable. Mountain and Gable Butte. Water levels in this area are about $3 \mathrm{~m}$ higher than they were in 1950 (Zimmerman et al. 1986). Ground-water flow is predominantly to the northwest at the 100-K and 100-N Areas. Near the 100-D Area the ground-water flow direction divides, flowing northwestward towards the river in the western part of the 100-D Area, and flowing northeastward in the eastern part of the area (DOE 1994). At the 100-H and 100-F Areas, located on the eastern side of the horn, flow is predominantly towards the east. 
As discussed in Section 3.3.7, ground-water elevations in parts of the 100 Areas are strongly influenced by changes in Columbia River stage. Hydrographs of Wells 199-D2-5 and 199-H3-1 are presented in Figure 3.2. Annual fluctuations resulting from changes in river stage are evident in this figure, as is a general decrease in water-table elevation. In the 100-N Area, the volume of waste-water effluent decreased significantly with the shut-down of $\mathrm{N}$ Reactor in 1988. Dissipation of the groundwater mound caused by this effluent is reflected in the steeper downward trend in pre-1993 water levels at Wells 199-N-33 and 199-N-67 (Figure 3.3). A water-table map of the 100 Areas for June 1994 can be found in Groundwater Maps of the Hanford Site, June 1994 (Serkowski et al. 1994).

\subsubsection{0-West Area}

The elevation of the water table beneath most of the 200 Area Plateau declined from June 1993 through June 1994. The largest change occurred in the 200-West Area where the water table dropped

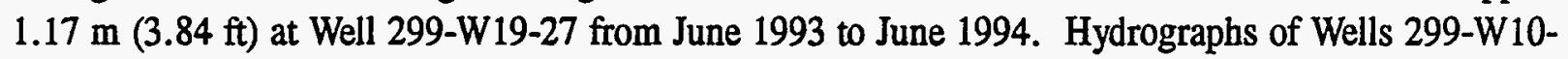
13, 299-W11-10, 299-W18-21, 299-W19-27, and 299-W23-11 (Figure 3.4) show that between June 1993 and June 1994 water levels in these wells declined by about 0.2 to $0.7 \mathrm{~m}(0.6$ to $2.3 \mathrm{ft}$ ), depending on the well location. The declining water table in this area is caused by continuing dissipation of the mound from the decommissioned $U$ Pond. The maximum elevation of this mound, which occurred in 1984, was approximately $148 \mathrm{~m}$ (485 ft) above mean sea level. The residual mound from U Pond appears to have shifted northward because of continuing waste-water disposal to the ZPlant Cribs (Serkowski et al. 1994). However, the total annual discharge of waste water to the ground in the 200-West Area is far less than the volume discharged annually during the operation of $U$ Pond (Newcomer 1990, WHC in press). The water-table map for the Hanford Site and outlying areas (Plate 1) indicates that the ground-water mound beneath the 200-West Area has influenced regional groundwater flow. It contributes to steep hydraulic gradients to the east of the 200-West Area. The groundwater mound from $U$ Pond has also increased the gradient in the gap between Umtanum Ridge and Gable Butte. However, the steep gradient in this area also results from recharge coming from the Cold Creek Valley and from the small width and shallow sediments in the gap.

\subsubsection{0-East Area}

The water table in and around the 200-East Area has been declining during the past 5 years because of reduced volumes of discharge to B Pond and other disposal facilities. However, from June 1993 to June 1994, the water table has risen slightly around the eastern lobe of B Pond because of changes in pond operation.

Hydrographs of Wells 299-E23-2Q, 299-E32-2, and 299-E34-2 indicate that the water table within the 200-East Area declined by approximately 0.2 to $0.3 \mathrm{~m}(0.6$ to $1.0 \mathrm{ft})$ between June 1993 and June 1994 (Figure 3.5). This appears to be a slightly lower rate of decline than has been observed over the previous 5-year period. Wells in downgradient areas near 200-East Area show a similar response. Hydrographs of Well 699-60-60, located in the gap between Gable Butte and Gable Mountain, and 
Well 699-20-20, located southeast of the 200-East Area, also show that water levels declined between 1993 and 1994, but at a slightly slower rate than the 5-year trend (Figure 3.6).

The ground-water mound shown beneath B Pond in Plate 1 indicates radial flow beneath the pond. The mound is shifting to the east because of changes in operation of B Pond. All waste water is now

going into the eastern lobe of the pond, and the western lobe has been decommissioned. As shown in the Figure 3.1 inset, water levels in wells near the western lobe of B Pond have dropped, and water levels in wells near the eastern lobe have risen. Figure 3.7 shows water-level changes at five wells near B Pond over the past 5 years. Wells 699-39-39, 699-40-39, 699-41-40, and 699-42-40B are all located near the eastern lobe of the pond and show that water levels increased by up to $0.5 \mathrm{~m}(1.6 \mathrm{ft})$ from June 1993 to June 1994. This is a reversal of the 5-year declining trend observed at these wells. The water level at Well $699-43-43$, which is located near the western lobe of B Pond, declined by $0.13 \mathrm{~m}(0.42 \mathrm{ft})$ from June 1993 to June 1994.

\subsubsection{Area}

Figure 3.8 shows the June 1994 water-table elevation contours for the 300 Area and the adjacent Richland North Area. The water table in the southern part of the Hanford Site indicates that ground water from the northwest, west, and southwest converges in the vicinity of the 300 Area as it flows toward the Columbia River. This is partly caused by recharge from the Yakima River to the east and from the City of Richland infiltration basins located about $3 \mathrm{~km}$ (1.9 miles) south of the 300 Area. The infiltration ponds create a ground-water mound south of the 300 Area. The presence of highly permeable gravel-filled channels that intersect the Columbia River in the 300 Area (Lindberg and Bond 1979, Swanson 1992) also contributes to the convergence of ground-water flow in this area.

The primary influence on ground-water elevation in the 300 Area is the fluctuation in Columbia River stage. Campbell et al. (1993) shows hydrographs for several 300 Area wells compared to river stage fluctuations. The water table beneath the 300 Area is also influenced by recharge from process effluent. During 1994 the process trenches received the largest volume of waste water in the 300 Area, $291,000 \mathrm{~m}^{3}$ (7.7 million gallons) (WHC in press). However, in December 1994, the 300 Area Treated Effluent Disposal Facility (TEDF) was placed in operation and significantly reduced discharge to the process trenches. Effluent from the TEDF is discharged to the Columbia River. The water table in

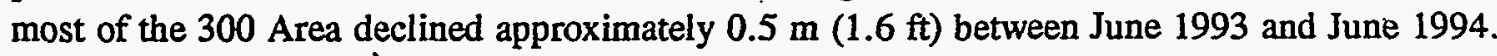

\subsubsection{Richland North Area}

Ground water beneath the Richland North Area generally flows from west to east between the Yakima and Columbia rivers, except for the radial flow away from the ground-water mound at the City of Richland infiltration basins (see Plate 1). Sources of ground-water recharge include infiltration along the Yakima River, infiltration at the City of Richland well field infiltration basins, irrigation in the Richland North Area, and irrigation of agricultural land to the west and southwest. Ground-water extraction by pumping occurs at the Richland North well field and at wells used for irrigation. 
At the Richland North well field, located east of the 1100 Area, water is pumped from the Columbia River into a system of basins (ICF 1987) that recharge the unconfined aquifer. Water is then pumped from the aquifer via the well field to supplement the City of Richland water supply. This system is primarily used when the filtration plant is shut down for annual maintenance between January and March and during the summer months. Because the volume of water pumped into the infiltration basins is much larger than the volume of ground water removed, a water-table mound has formed. around this facility. Figure 3.9 shows that water levels in Well 699-S40-E14A, which is located on the western edge of the infiltration basins, declined about $1.8 \mathrm{~m}(5.9 \mathrm{ft})$ between June 1993 and June 1994. However, this followed an increase of about $3 \mathrm{~m}(9.8 \mathrm{ft})$ in the previous year. The water level at this well in June 1994 was similar to the level measured in 1990. The seasonal usage of the infiltration basins causes the elevation of the ground-water mound to rise and fall each year, as shown in Figure 3.9.

Ground-water levels in the Richland North Area are also influenced by. irrigation practices west of the 1100 Area. Irrigation water is pumped primarily from the Columbia River and, to a lesser extent, from a shallow irrigation well. Increasing water levels in the area west of the 1100 Area are apparent on the water-level change map shown in Figure 3.1 and on the hydrographs for Wells 699-S31-1, 699S42-E8A, and 699-S43-E7A shown in Figure 3.10. Well 699-S31-1 is approximately $3 \mathrm{~km}$ (2 miles) west of the Horn Rapids Landfill along the northern perimeter of the irrigated fields. The water level at this well rose $0.3 \mathrm{~m}(1.0 \mathrm{ft})$ between June 1993 and June 1994, which is consistent with the trend observed since 1991. Wells 699-S42-E8A and 699-S43-E7A are located southeast of the irrigated area and near the location of the irrigation pumping well. Water levels measured at these wells also show an increasing trend, although water levels drop in the summer because of nearby pumping.

\subsubsection{Upper Cold Creek Valley}

Zimmerman et al. (1986) postulated that the water table in the western part of the Hanford Site responded to irrigation practices in the upper Cold Creek Valley. Figure 3.11 shows a hydrograph of Well 699-43-104, which is located downgradient from the irrigated fields in upper Cold Creek Valley (Plate 2). The hydrograph indicates that the water table has declined steadily since at least 1990 . In fact, water levels in this well have declined since about 1988. The water level declined approximately $0.6 \mathrm{~m}(1.9 \mathrm{ft})$ between June 1993 and June 1994. The declining water level in this well may result from decreased recharge of the unconfined aquifer by irrigation water resulting from changes in irrigation practices by Ste. Michelle Vineyards. Between 1982 and 1983, Ste. Michelle Vineyards converted their irrigation system from a sprinkler system to drip irrigation, which reduced consumption by $40 \%$ to $50 \%$ (Newcomer 1990). Declining water levels in the unconfined aquifer may also be associated with decreases in hydraulic heads of the underlying confined aquifers in this area. It is

estimated that hydraulic heads in the confined aquifer system have dropped over $5.5 \mathrm{~m}$ in the Cold Creek Valley since the early 1900s (DOE 1988a). 


\subsubsection{Response to River Stage}

Water levels in many wells near the Columbia River fluctuate in response to changes in river stage. The river stage generally rises and falls daily because of releases from upstream dams and can change by up to $3 \mathrm{~m}$ within a few hours. Seasonal changes of about the same magnitude are also observed. River stage fluctuations measured at the 300 Area are only about half the magnitude of those measured near the 100 Areas because of the effect of the pool behind McNary Dam, located downstream from the Hanford Site (Campbell et al. 1993). Changes in water-table elevation near the river result primarily from pressure waves transmitted through the unconfined aquifer. Some water also moves into the aquifer from the river during high river stage resulting in "bank storage" effects. However, the pressure fluctuation can be seen considerably farther inland than the area affected by bank storage.

Ground-water levels in the 100 and 300 Areas are heavily influenced by river-stage fluctuations. Hydrographs showing the influence of the river stage on the unconfined aquifer at various locations along the Columbia River have been presented by Newcomb and Brown (1961), Jensen (1987), Liikala et al. (1988), Schalla et al. (1988), Fruland and Lundgren (1989), McMahon and Peterson (1992), Campbell et al. (1993), and Campbell (1994).

\subsection{Water-Table Features East and North of the Columbia River}

The dominant pattern of ground-water flow in the unconfined aquifer east and north of the Columbia River is from basalt ridges that form the edge of the Pasco Basin toward the Columbia River. The water-table configuration in the area east of the river is heavily influenced by recharge from irrigation with imported surface water. The irrigated areas are a part of the South Columbia Basin Irrigation District, which is part of the Columbia Basin Irrigation Project. Recharge to the unconfined aquifer in this area is caused by leakage from canals, wasteways, and ponds, and by seepage from irrigated fields (Ebbert et al. 1991). Pumping from wells that tap the unconfined aquifer is mostly for domestic, stock, and irrigation purposes, but yield is commonly low (Bauer et al. 1985). For this reason, pumping from the unconfined aquifer in this area has little influence on water levels.

Irrigation-induced recharge in the areas east and north of the Columbia River has caused the development of extensive perched water bodies (Brown 1979). However, the extent of perched conditions is poorly defined because few wells tap the perched aquifers. Water-table elevations shown in Plate 1 for areas east and north of the Columbia River reflect the level of perched ground water in some areas because water levels were measured primarily in shallow wells.

The water-table map in Plate 1 shows a steep hydraulic gradient along the eastern bank of the Columbia River east of Gable Mountain in the area known as White Bluffs. A similar steep gradient is seen in the area east of the river and north of the 300 Area. Because of the abrupt change in land surface elevation between the Columbia River and the bluffs, the increased elevation of the water table 
from irrigation has caused the formation of a series of springs issuing from the bluffs. A water-table map of Franklin County for March 1986 was presented by Drost et al. (1993).

Increased recharge has also affected water levels in the irrigated Wahluke Slope area northwest of the Hanford Site. This is also part of the South Columbia Basin Irrigation District. Water-table maps by the USGS (Drost et al. 1989) indicate that the elevation of the water table north of the Columbia River, extending southeast to Columbia Flat, is controlled by the topography of the land surface and the underlying basalt. Comparison of water-level data indicates that the water-table elevation in this area did not change significantly between 1989 and 1994. Water-table elevation contours in the nonirrigated portion of the Wahluke Slope north of the Columbia River are inferred because data are limited (i.e., there are few wells for measuring water levels). The sources of information used to infer the contours include the elevation of water in ponds and seeps in the Saddle Mountain National Wildlife Refuge across the Columbia River from the $100-\mathrm{N}$ and $100-\mathrm{K}$ Areas. These data, used in conjunction with topographic elevations, indicate that the $150-\mathrm{m}$ contour extends south and east of the ponds (see Plate 1). Along the northeast border of the Hanford Site, contour flexures are inferred from topographic elevations.

\subsection{Confined Aquifer System}

The term "upper-basalt confined aquifer: system" refers to the flow system which occurs in basalt fractures and joints, interflow contacts, and intercalated sedimentary interbeds within the upper Saddle Mountains basalt formation (see Figure 2.2). Water is confined within this aquifer system by dense, low-permeability interior sections of the basalt flows, and by silt and clay units within the overlying suprabasalt sediments (i.e., Ringold Formation). Wells completed in the upper-basalt confined aquifer are shown in Figure 3.12.

The Ground-Water Surveillance Project prepared a preliminary potentiometric map for the upperbasalt confined aquifer system for March 1993 (Figure 3.13) and evaluated the flow dynamics of the upper-basalt confined aquifer system (Spane and Raymond 1993). The following five measurement sources, consisting of more than $\mathbf{4 0}$ monitoring wells and boreholes, were used to collect hydraulic head information:

- onsite monitoring wells completed primarily within the Rattlesnake Ridge interbed

- onsite monitoring wells completed within other hydrogeologic units of the upper Saddle Mountains Basalt (e.g., Elephant Mountain interfiow contact, Levey interbed) overlying the Rattlesnake Ridge interbed

- onsite boreholes completed in the top of the upper Saddle Mountains Basalt 
- inactive onsite monitoring wells completed within hydrogeologic units of the upper Saddle Mountains Basalt

- offsite private or domestic wells completed within the upper Saddle Mountains Basalt.

The inferred lateral flow pattern shown in Figure 3.13 is believed to be representative of steadystate ground-water flow conditions within the upper-basalt confined aquifer system and is nearly identical with patterns delineated by Spane (1987) and DOE (1988b) for the Mabton interbed, which marks the lower stratigraphic boundary of the Saddle Mountains Basalt. Salient hydrogeologic features shown in Figure 3.13 for the upper-confined aquifer system include

- a broad recharge mound extending northeastward from the Yakima Ridge in the 200-West Area

- a small recharge mound immediately east of the 200-East Area in the vicinity of B Pond

- a hydrogeologic barrier (i.e., an impediment to ground-water flow) near the mouth of Cold Creek Valley.

- the presence of a region of low hydraulic head (potential discharge) in the Umtanum Ridge and Gable Mountain structural area

- a region of high hydraulic head to the north and east of the Columbia River that is associated with recharge attributed to agricultural activities.

Recharge to the upper-basalt confined aquifer is believed to result from natural recharge from precipitation and surface water infiltration, and from artificial recharge associated with offsite irrigation and discharge of waste water from facilities on the Hanford Site. The hydrologic barrier at the mouth of Cold Creek Valley is believed to be related to faulting. The Rattlesnake Ridge interbed and the Elephant Mountain basalt interflow contact are not present west of this feature. Hydraulic intercommunication with overlying and underlying aquifer systems is believed to cause the region of low hydraulic head found in the Umtanum Ridge and Gable Mountain structural area. Spane and Raymond (1993) discuss these features in more detail, and the potential for flow between the upperbasalt confined and unconfined aquifer systems is discussed further in Section 2.3.3. 
†66I aun p pue \&66I әun पәәмวәg

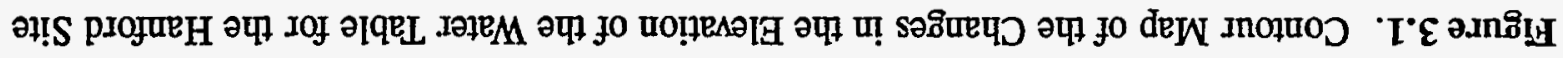

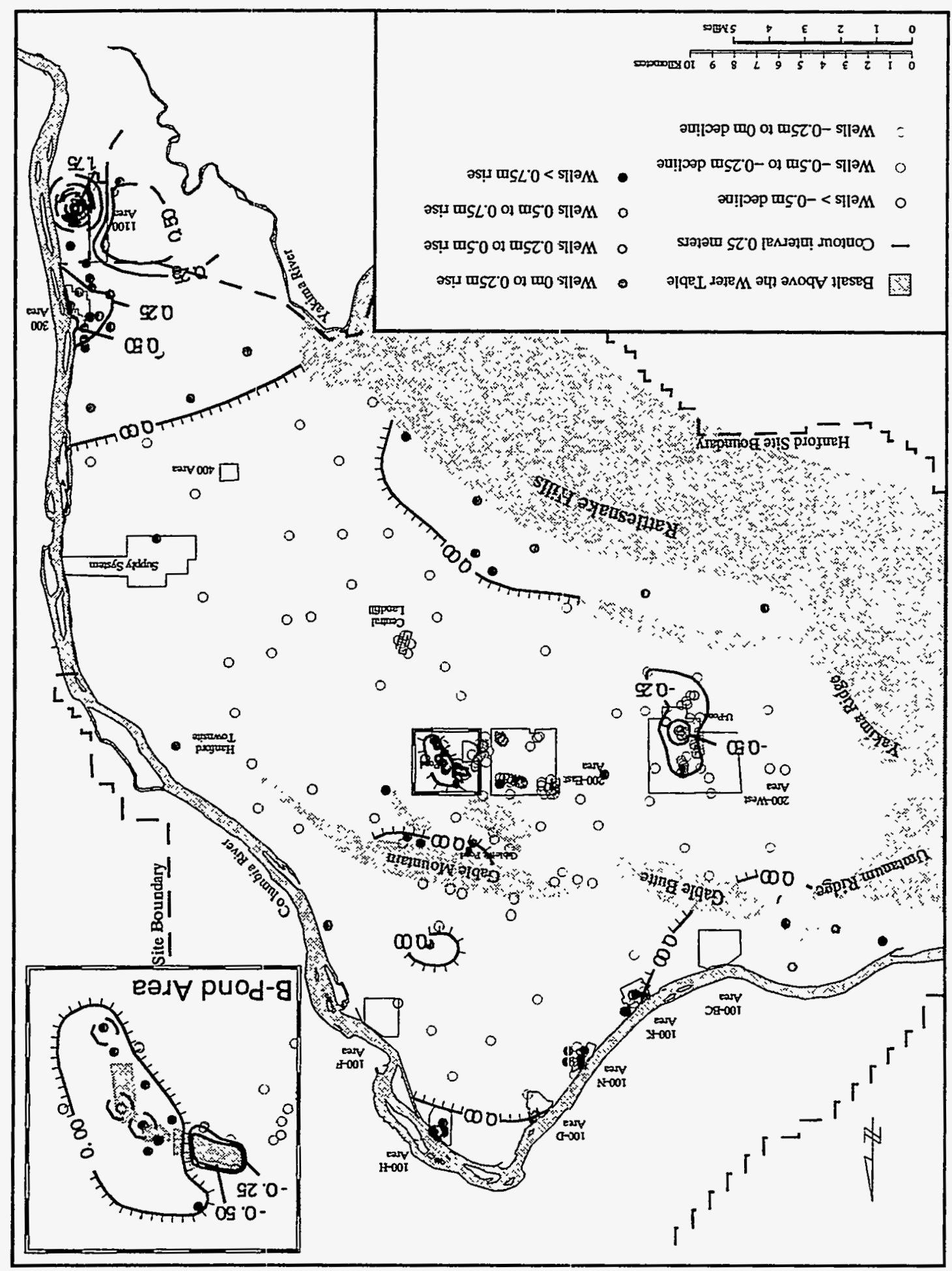




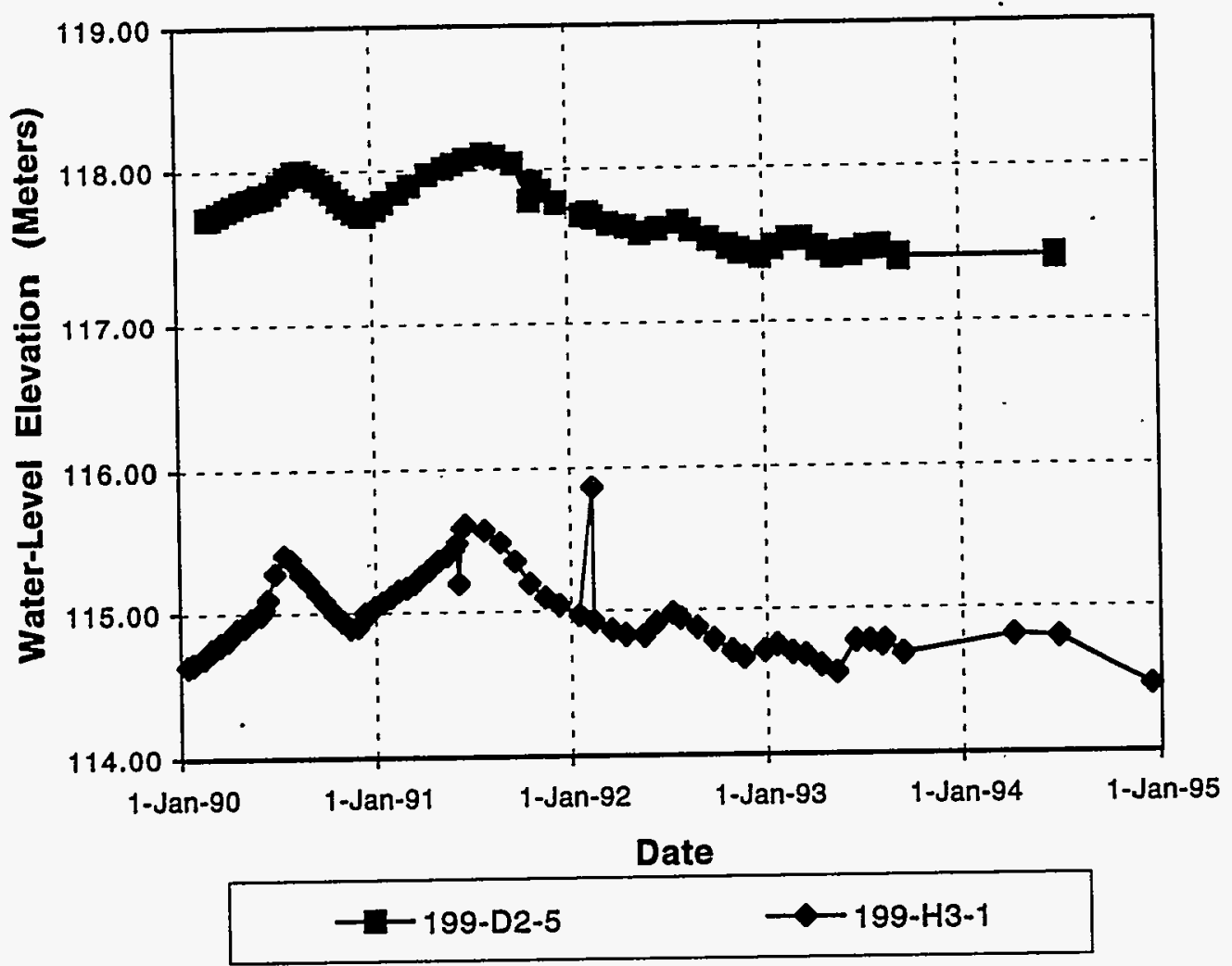

Figure 3.2. Hydrograph of Wells 199-D2-5 and 199-H3-1

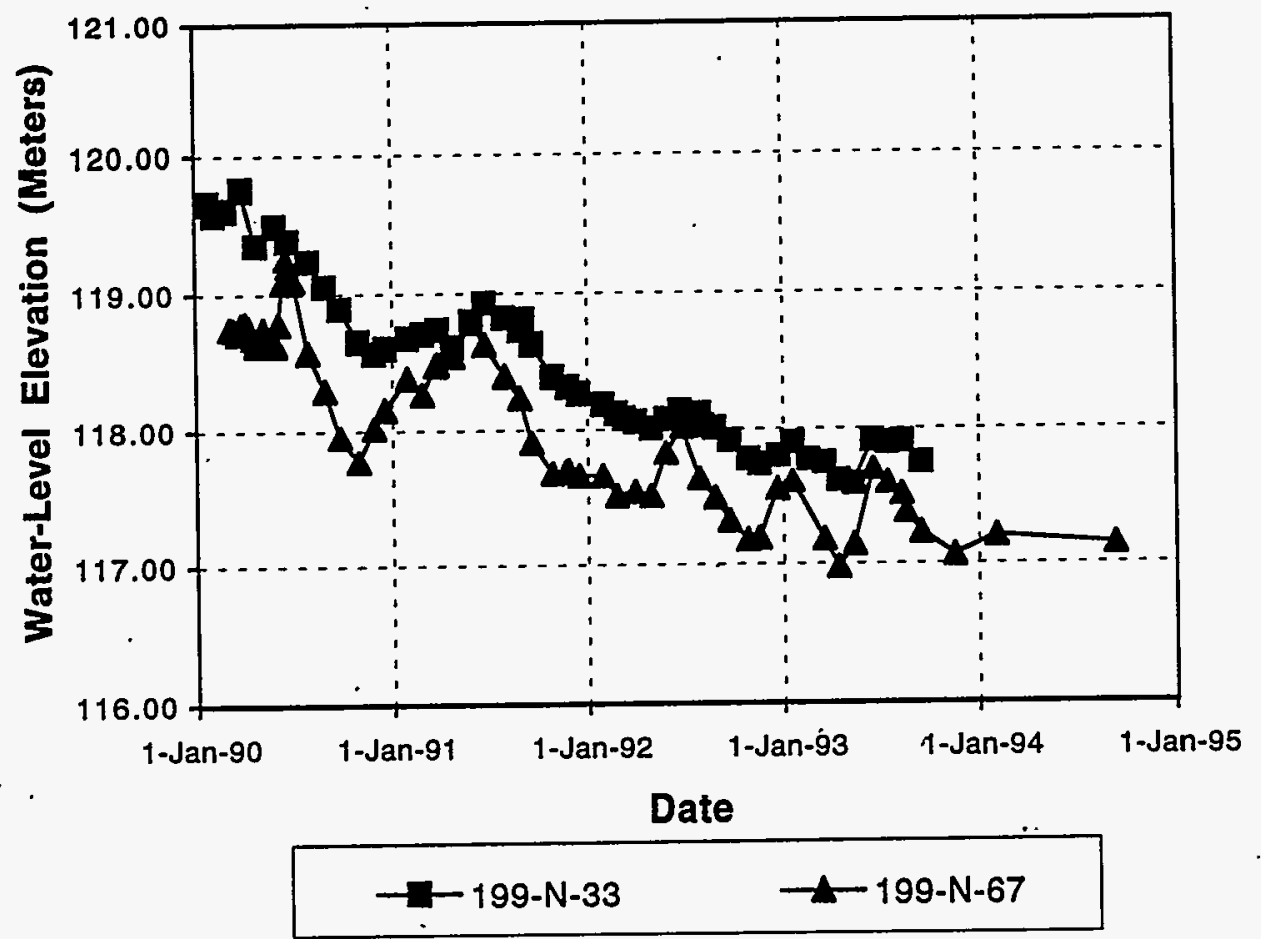

Figure 3.3. Hydrograph of Wells $199-\mathrm{N}-33$ and 199-N-67 


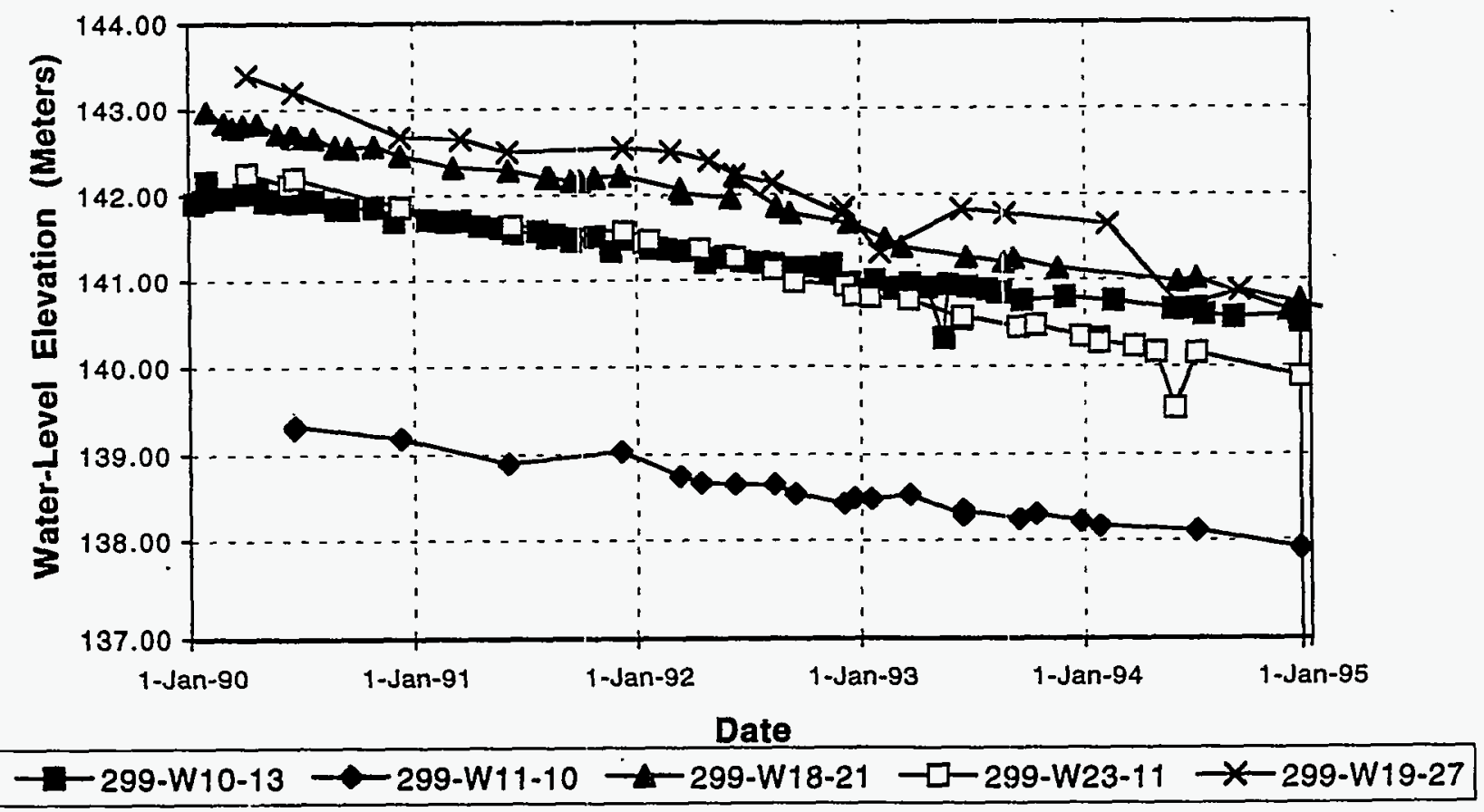

Figure 3.4. Hydrograph of Wells 299-W10-13, 299-W11-10, 299-W18-21, 299-W23-11, and 299-W19-27

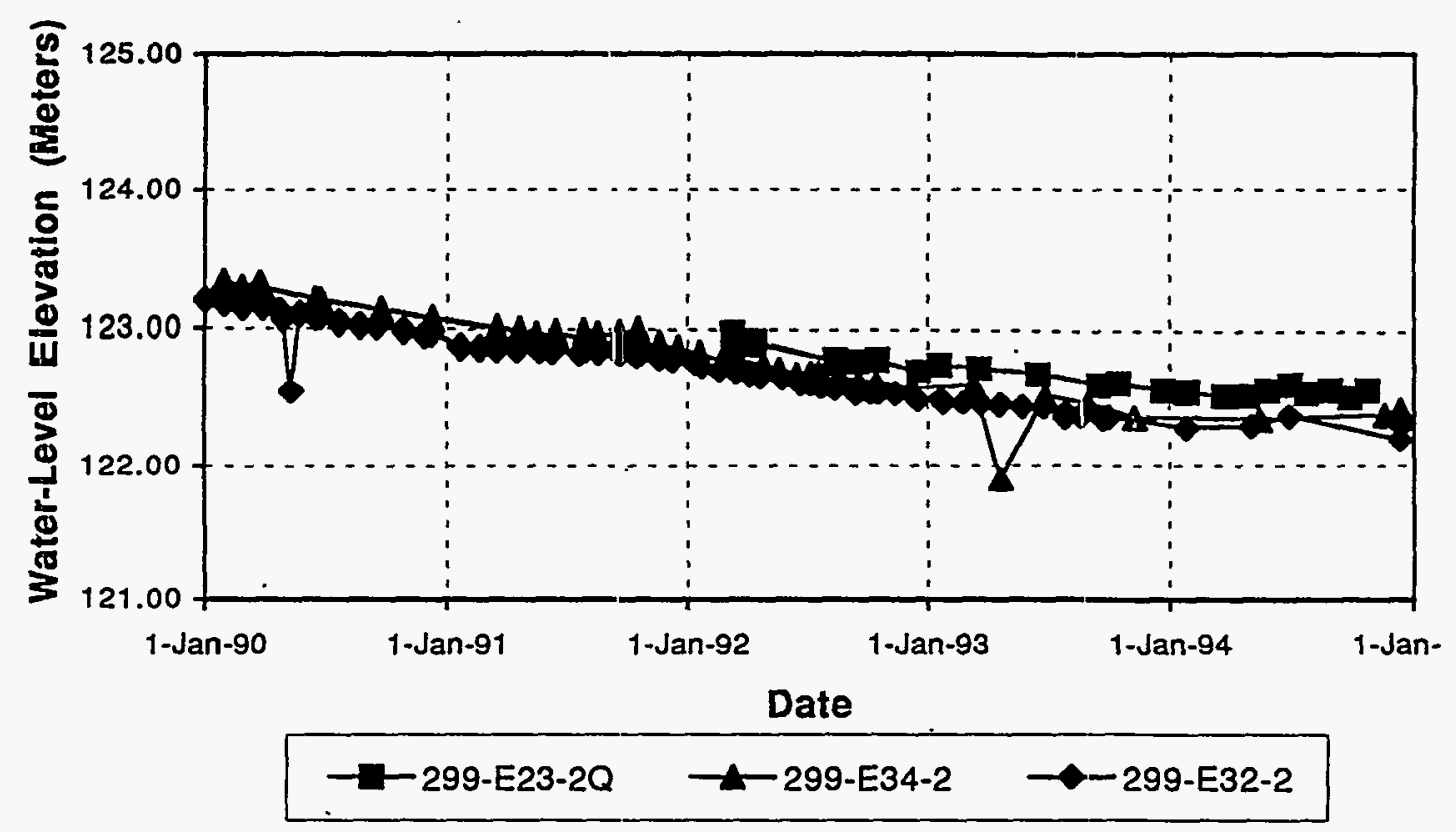

Figure 3.5. Hydrograph of Wells 299-E23-2Q, 299-E34-2, and 299-E32-2 


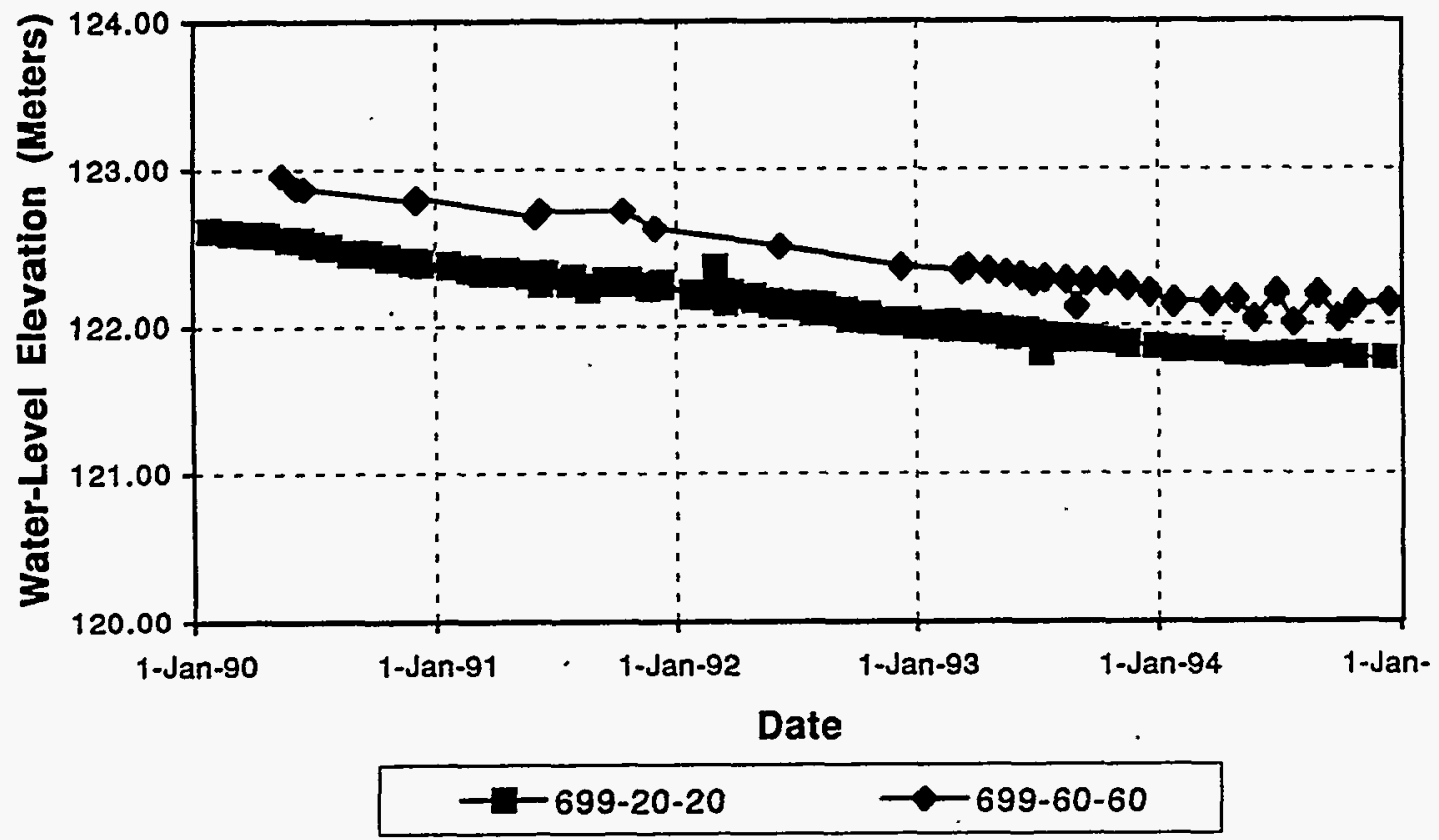

Figure 3.6. Hydrograph of Wells $699-60-60$ and $699-20-20$

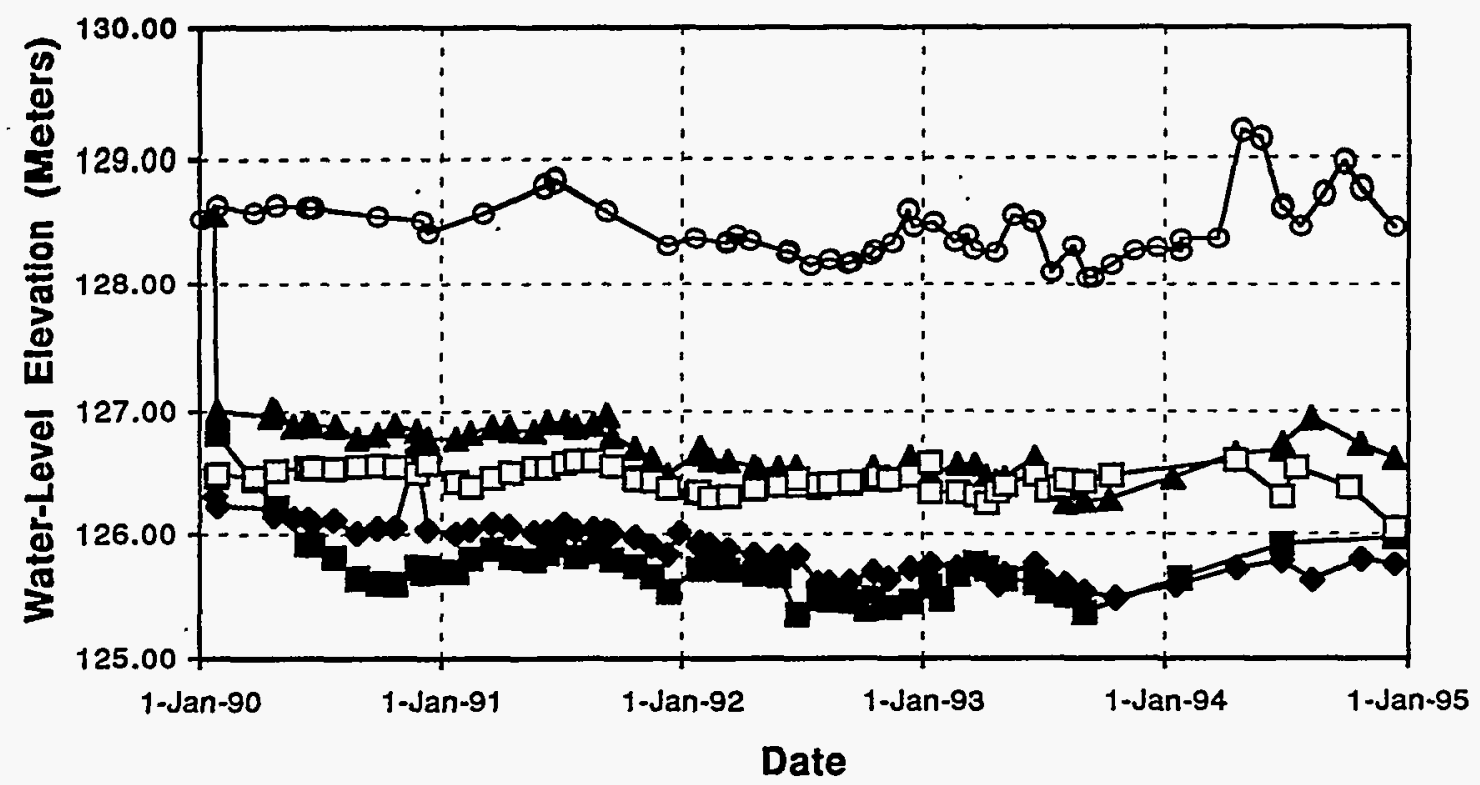

$\neg-699-39-39 \longrightarrow-699-40-39-699-41-40 \rightarrow-699-42-40 \mathrm{~B} \quad \square-699-43-43$

Figure 3.7. Hydrograph of Wells 699-39-39, 699-40-39, and 699-41-40, 699-42-40B, and 699-43-43 


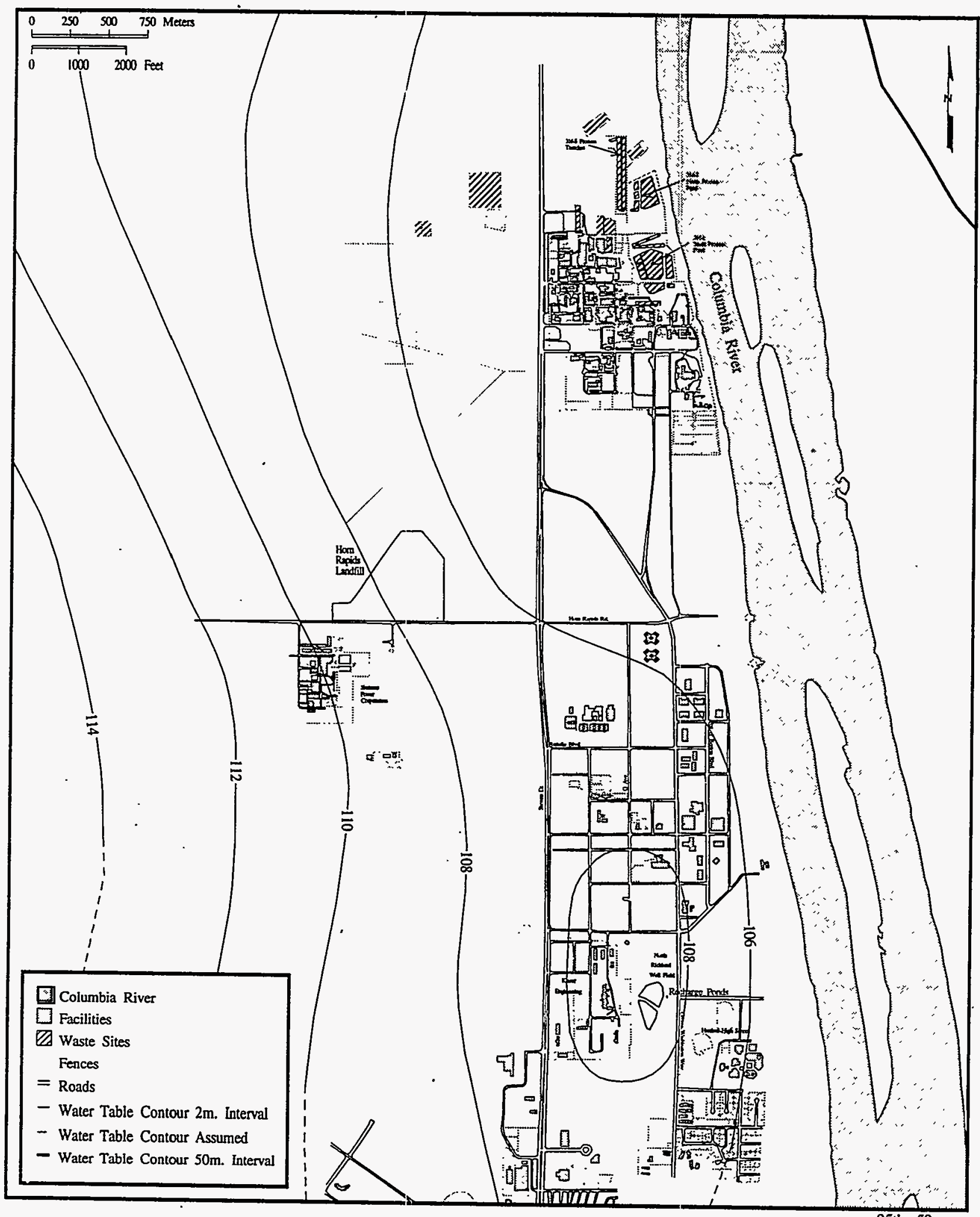

Figure 3.8. June 1994 Water-Table Elevation Contours for the 300 Area and Richland North Area 


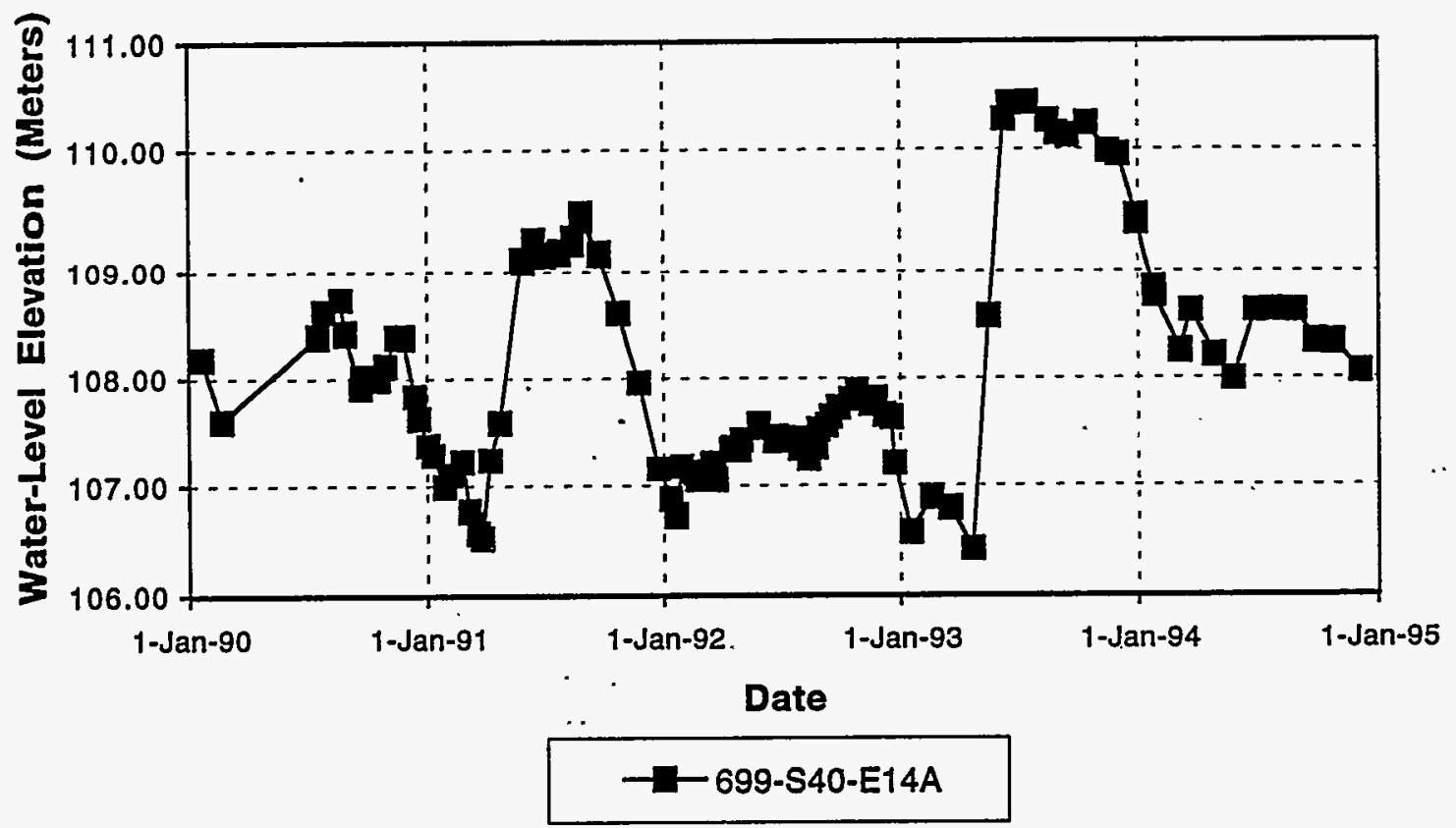

Figure 3.9. Hydrograph of Well 699-S40-E14A

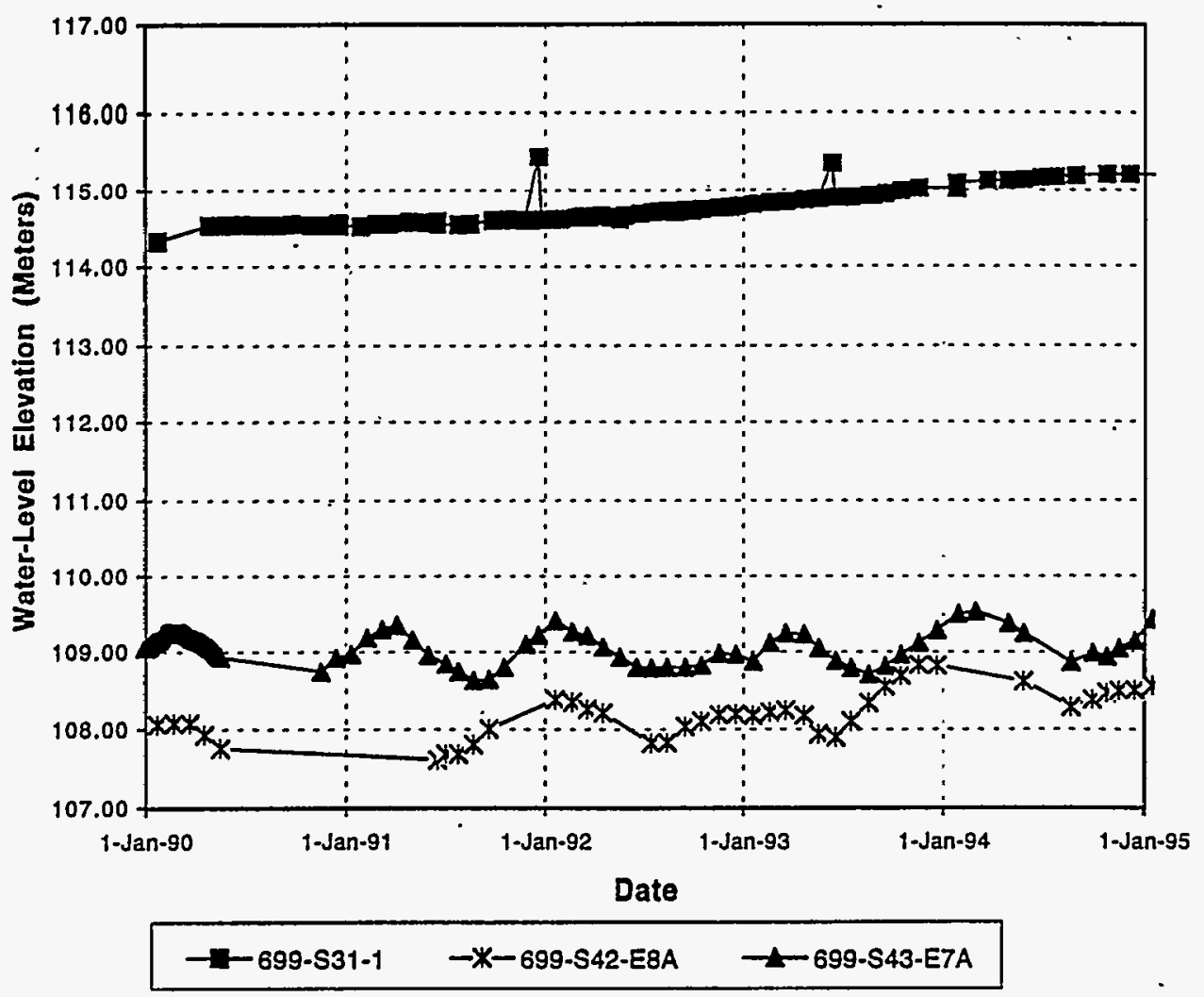

Figure 3.10. Hydrograph of Well 699-S31, 699-S42-E8A, and 699-S43-E7A 


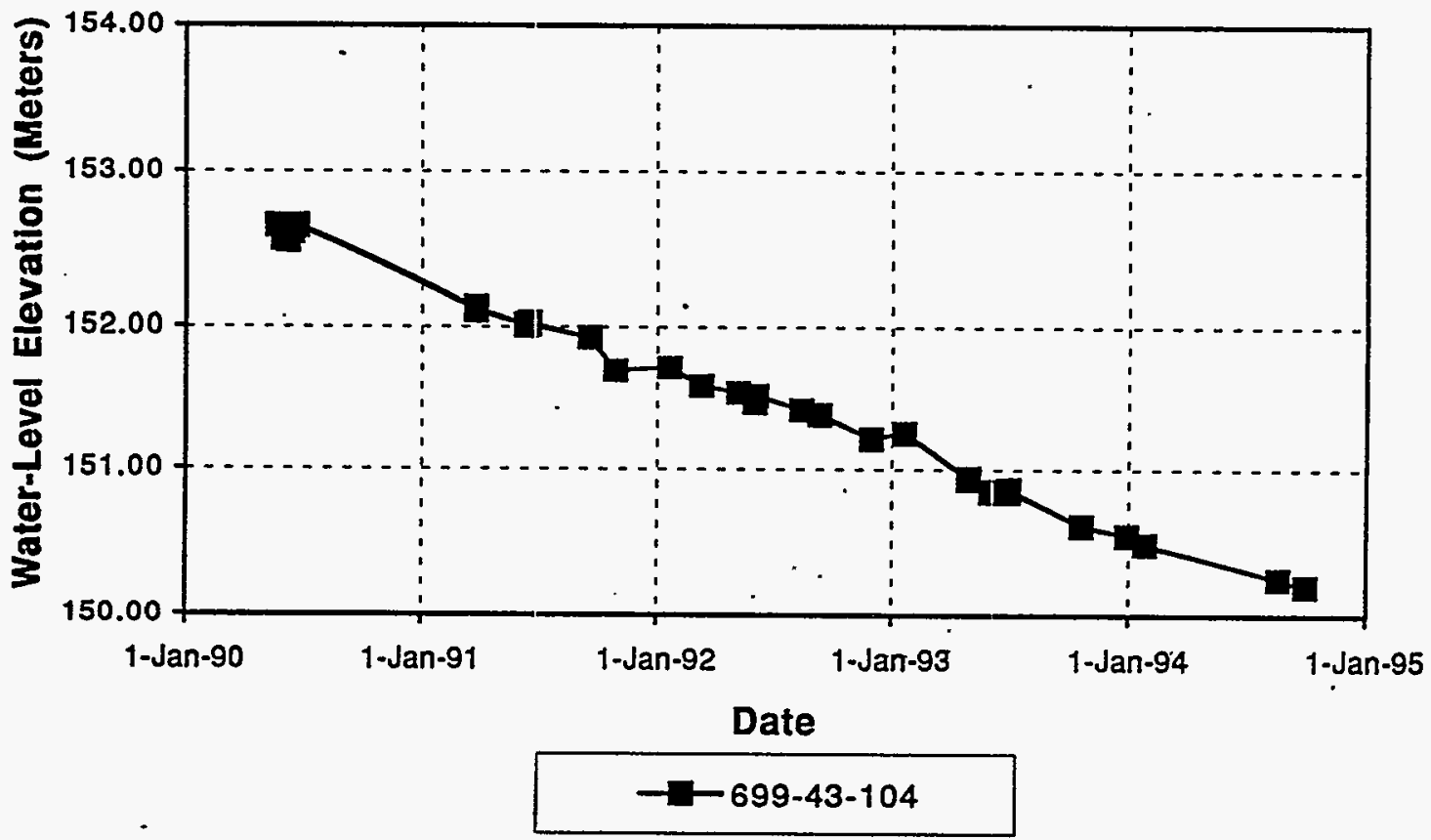

Figure 3.11. Hydrograph of Well 699-43-104 


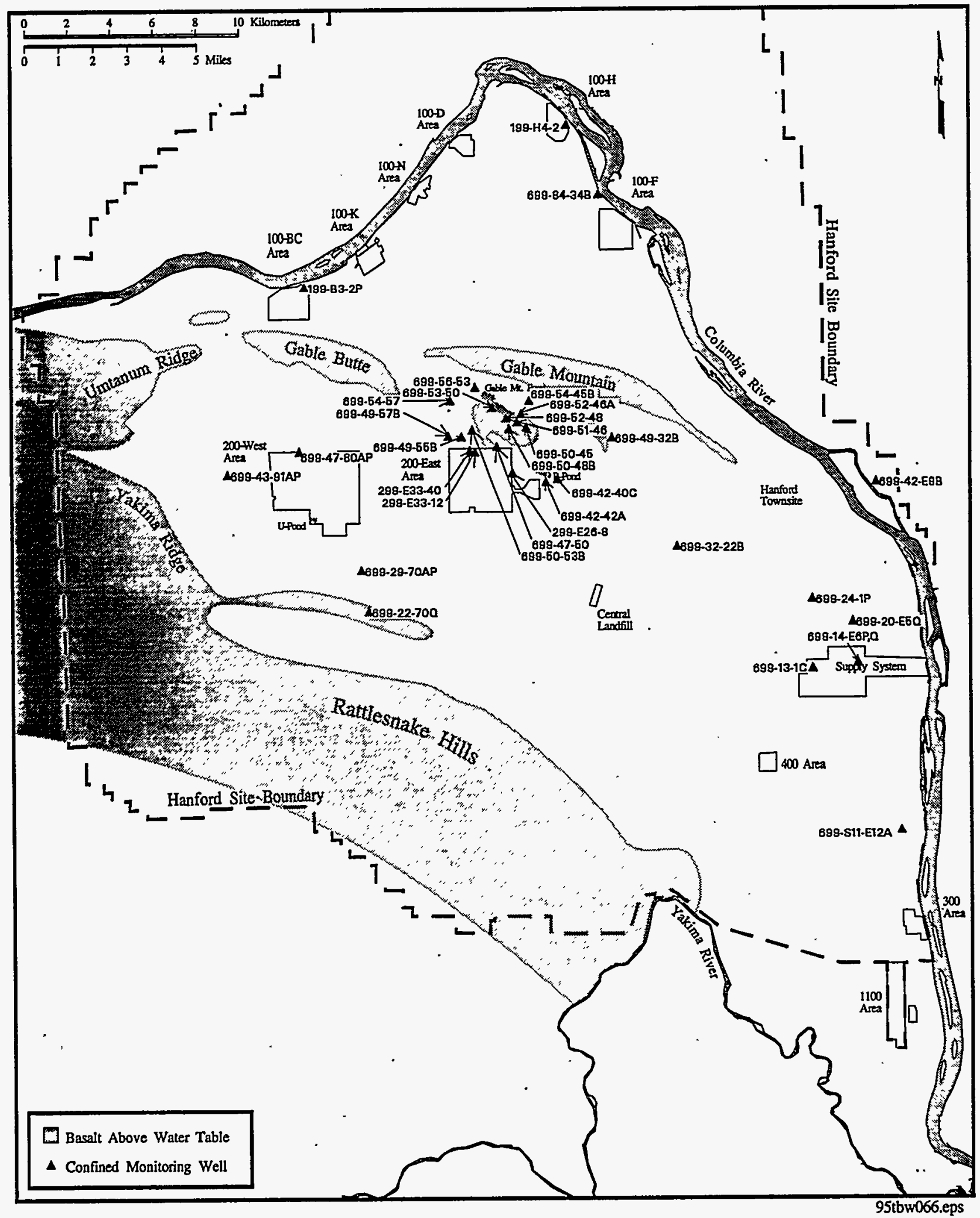

Figure 3.12. Confined Aquifer Monitoring Wells at Hanford 


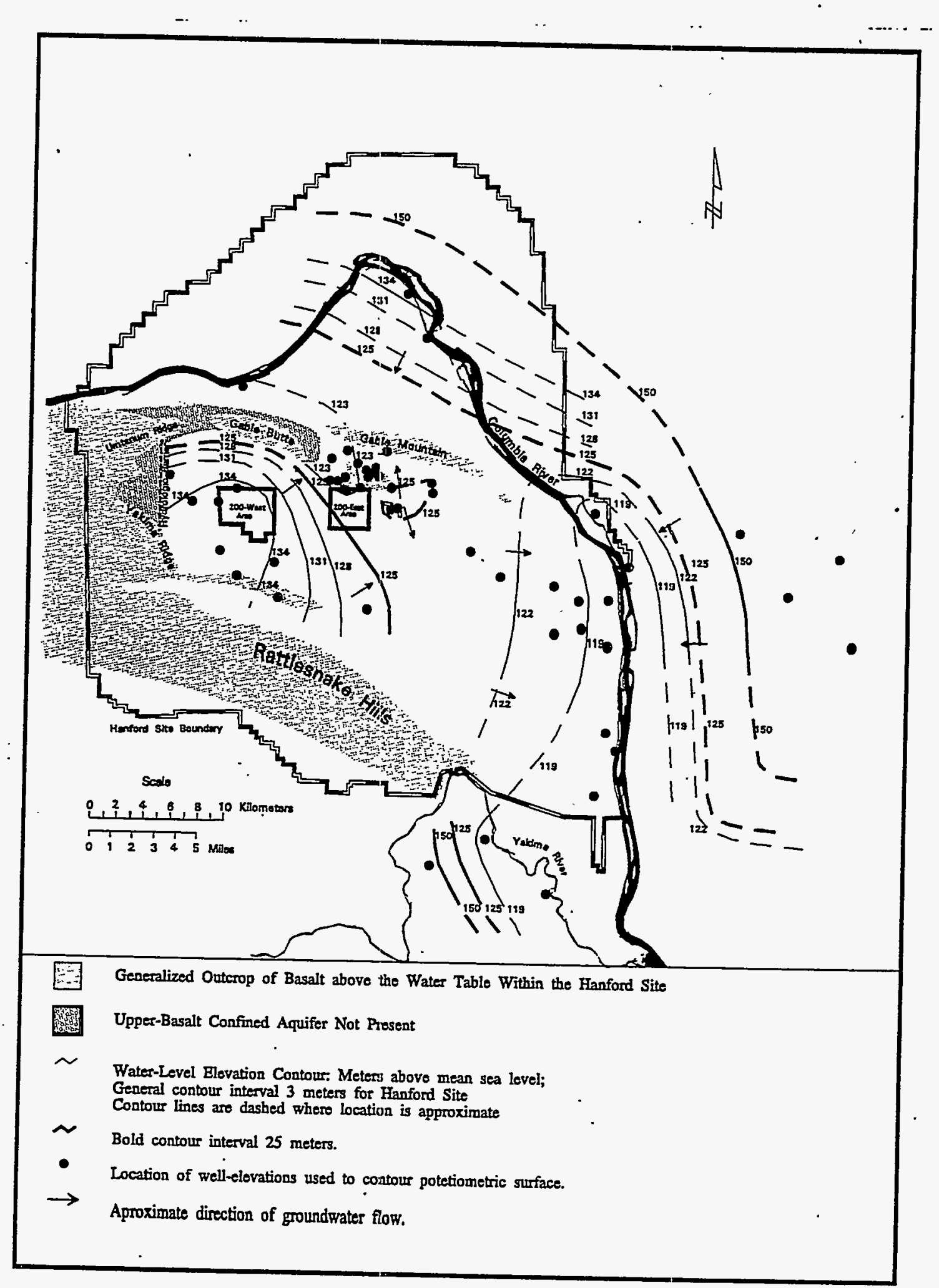

Figure 3.13. Potentiometric Map for the Upper-Basalt Confined Aquifer System - March 1993 


\title{
4.0 Radiological and Chemical Ground-Water Monitoring
}

\author{
P.E. Dresel, B.M. Gillespie, B.E. Opitz, and J.T. Rieger
}

\subsection{Data Collection}

The Ground-Water Surveillance Project meets its goal of monitoring radiological and chemical contamination by incorporating the results of sampling by RCRA-related, Operational, and CERCLArelated projects with results of sampling cónducted specifically to meet project needs. The basis for selecting wells, the sampling frequencies, and the constituents analyzed are different for each of these projects and are determined by individual project objectives, if available. Each year, the sampling schedules for the Operational, RCRA, and CERCLA networks are reviewed and a supplemental monitoring network is developed to meet the objectives of the Ground-Water Surveillance Project.

Analytical results for samples collected for the Ground-Water Surveillance project were obtained from International Technology Corporation's (IT) laboratory in Richland, Washington, and DataChem Laboratories, Incorporated in Salt Lake City, Utah. Most volatile organic compound (VOC) analyses for the Ground-Water Surveillance Project were performed by PNL's internal laboratories. CERCLArelated projects used a variety of analytical laboratories. Until late 1994, samples for RCRA-related and Operational monitoring were collected by PNL, under contract to WHC, under procedures consistent with the Ground-Water Surveillance Project's sample collection. WHC made the transition to independent sample collection in late 1994.

\subsubsection{RCRA Facility-Specific Monitoring}

Well networks have been established around specific waste-disposal facilities to comply with RCRA requirements. The requirements for monitoring-well design and location, constituents to be sampled, and sampling frequency are specified in RCRA regulations (40 CFR 264 and 265) and by WAC 173-303 and -304. Ground-water monitoring systems at each site consist of at least one monitoring well hydraulically upgradient and at least three monitoring wells downgradient of the facility. The RCRA regulations require that ground water be sampled and analyzed for 1) drinkingwater parameters, 2) parameters that establish ground-water quality, and 3) parameters used as indicators of ground-water contamination. Samples are also analyzed for specific contaminants that are known to have been disposed of at the facility being monitored. The frequency of sampling for each parameter is specified in the RCRA regulations, based on the permitting status of the facility (e.g., interim status, permitted status). Annual reports (e.g., DOE-RL 1994a) document the results presented in quarterly reports (DOE-RL 1993a,b, 1994b,c).

\subsubsection{Operational Monitoring}

Operational monitoring near waste facilities in the 200 Areas is conducted by WHC to obtain information for evaluating the performance of radioactive waste-disposal sites. The Operational Monitoring Program also samples wells in the 100-K Area to assess the impacts of operation of the 100-K Fuel Storage Basins. The Operational Monitoring Program sampled approximately 100 wells in 1994. 


\subsubsection{Ground-Water Surveillance Project Monitoring}

The objective of ground-water surveillance monitoring is to delineate the distribution and movement of radionuclides and other potentially hazardous materials in ground water at the Hanford Site. The work is performed to satisfy the environmental surveillance requirements identified in DOE Order 5400.1 as it applies to ground water. The selections of wells, constituents for which samples are collected and analyzed, and sampling frequency are based on knowledge of waste-disposal practices and inventories, regulatory requirements, contaminant mobility, and the site hydrogeology. During 1994, approximately 800 wells were sampled for radiological and chemical constituents as part of the various Hanford ground-water investigations. The Ground-Water Surveillance Project analyzed samples from approximately 454 wells. The Ground-Water Surveillance Project has attempted to coordinate with other programs to cosample wells, avoiding redundant analyses and minimizing investigation-derived waste.

\section{Radiological Monitoring}

The radiological monitoring network was developed to monitor the extent of contamination, identify new instances of contaminant release to the ground water, and sample for selected radionuclides that may contribute to radiation dose. The Ground-Water Surveillance Project reviews and uses sample data available from other onsite monitoring programs as part of its evaluation.

Radionuclide analyses are performed by a variety of alpha-, beta-, and gamma-counting methods and by chemical analyses. Gross alpha and gross beta analyses provide indications of radionuclide distributions but may be difficult to relate to specific constituents. The Ground-Water Surveillance Project therefore seldom samples for gross alpha or gross beta, preferring to perform more specific tests. However, gross alpha and gross beta analyses are performed by other programs onsite, in cosampling with regulatory agencies, and by offsite investigators. Specific analytes are discussed below.

Elevated gross alpha readings in ground water on the Hanford Site generally relate to the presence of uranium and in rare instances to that of plutonium. Widespread monitoring of plutonium in 1990 and 1991 confirmed that plutonium is very immobile in ground water (Evans et al. 1992a,b). Since that study, plutonium has been monitored in only a few wells near facilities suspected of receiving plutonium. These wells are all located within the 200 Areas.

Elevated gross beta concentrations are more difficult to associate with individual radionuclides because a relatively large number of beta-emitting radionuclides have been discharged in Hanford liquid wastes. Of the beta-emitting radionuclides discharged onsite, strontium- 90 and technetium- 99 are common contributors to elevated gross beta concentrations in ground water. Iodine-129 is another relatively mobile beta-emitter of potential concern in the ground water. Radioactive decay products of uranium also contribute to gross beta concentrations in areas with elevated uranium levels. Although cesium-137 is a beta as well as a gamma emitter, it is seldom detected in ground water so does not typically contribute to the gross beta measurements.

Several difficulties occur in using gross beta measurements to monitor for radioactive

contaminants. Technetium-99 is a relatively weak beta emitter and gross beta measurements of ground 
water tend to under-represent the technetium- 99 activity. Although strontium- 90 is a strong beta emitter, its low maximum contaminant level $(\mathrm{MCL})(8 \mathrm{pCi} / \mathrm{L})$ means that the presence of important amounts of strontium- 90 can be masked by other beta emitters the presence of relatively insignificant amounts of technetium-99 (MCL of $900 \mathrm{pCi} / \mathrm{L})$. Iodine- 129 has a very low $\mathrm{MCL}(1 \mathrm{pCi} / \mathrm{L})$ and needs to be monitored using special procedures.

Tritium is the most commonly analyzed radionuclide onsite. Tritium was concentrated in certain large-volume wastes, such as reactor coolant in the 100 Areas and process condensates in the 200 Areas. The maximum extent of radionuclide contamination in ground water beneath the Hanford Site is generally delineated by the tritium plumes because much of the radioactive waste disposed of at Hanford contains tritium. Because tritium exists as part of the water molecule, it moves with the ground water virtually unretarded by chemical and physical interaction with dissolved constituents or aquifer materials.

The EPA has proposed a MCL of $20 \mu \mathrm{g} / \mathrm{L}$ for uranium, in contrast to other radionuclides for which the standards are given in picocuries per liter. This is because there is evidence that uranium ingestion may cause kidney damage, which is better assessed as a chemical hazard than as a radiological hazard. However, uranium may be analyzed by an alpha-counting method and some risk is associated with its radioactivity, so it is important to be able to convert between ground-water concentrations expressed in micrograms per liter and those expressed in picocuries per liter. The relationship between uranium activity and chemical concentration depends on the proportions of uranium-234, uranium-235, and uranium-238 in the sample. Based on a series of ground-water analyses throughout the United States, EPA considers the proposed MCL of $20 \mu \mathrm{g} / \mathrm{L}$ to be equivalent to a standard of $30 \mathrm{pCi} / \mathrm{L}$. However, site-specific data for Hanford indicate that the proportion of the different uranium isotopes in ground water is nearly identical to the average proportion in natural rock. The relationship between uranium activity and chemical concentration depends on the isotopic abundance in the sample. Uranium-234, uranium-235, and uranium-238 isotopic measurements on ground-water samples from the Hanford Site indicate that the relative abundances of the isotopes are similar to those in naturally occurring indigenous rocks. In this case, the total activity in $\mu \mathrm{g} / \mathrm{L}$ should be multiplied by 0.67 to convert to activity in $\mathrm{pCi} / \mathrm{L}$. If activities are determined by alpha spectroscopy, the total uranium concentration can be determined by considering the specific activity of each isotope and adding together the concentrations of each isotope. The relationship based on an isotopic abundance in rocks may be used if only total uranium activity is known (multiply by 1.49 to convert $\mathrm{pCi} / \mathrm{L}$ to $\mu \mathrm{g} / \mathrm{L}$ )

Cobalt-60, antimony-125, and cesium-137, are the main gamma-emitting radionuclides occasionally detected in Hanford ground water. In the past, significant amounts of ruthenium-106 contamination were found, but this isotope has largely. decayed away. A number of other isotopes are identifiable by gamma spectroscopy; they are either reported as below detection levels or simply not reported where not found.

\section{Chemical Monitoring}

Many well samples collected in 1994 were analyzed for potentially hazardous chemical (nonradioactive) constituents. Wells selected for chemical analysis were chosen primarily for their proximity to known active and inactive chemical disposal areas in the 100,200, and 600 Areas, on the basis of the compiled waste inventories (Stenner et al. 1988), and on the basis of knowledge of contaminant 
distributions from prior sampling events. The constituents analyzed by the RCRA and CERCLA programs were selected based on regulatory requirements as well as known contaminants.

Nitrate is monitored in most of the wells sampled. Nitrate, which is mobile in ground water, was present in many of the waste streams disposed of to the ground and, like tritium, can be used to help define the extent of contamination in Hanford aquifers. Extensive historical records for nitrate also exist. Other chemicals and radionuclides related to site operations that are potential ground-water contaminants are listed in Table 4.1. In addition, geochemical indicator parameters such as $\mathrm{pH}$, major cations, and major anions are often also analyzed in the same samples to aid interpretation and for quality control checks on analytical data.

\subsubsection{Monitoring Network}

The ground-water monitoring network for 1994 is shown in Figure 4.1. Monitoring well names and locations are shown on Plate 2.

Each fall, the ground-water monitoring network is developed for the next calendar year's monitoring. Details of the 1994 planned network were published with the sampling plans for other aspects of the Environmental Surveillance Program in a report by Bisping (1994). The network is based on the historical monitoring efforts of this project, as well as any relevant new items. The wells in the monitoring network are chosen to track the concentrations and extent of known ground-water plumes, to monitor concentrations upgradient of source areas and at the perimeter of the site, to identify emerging or inadequately characterized ground-water quality problems, and to address specific questions regarding ground-water contaminant fate and transport. The Ground-Water Surveillance Project's monitoring is coordinated as much as practical with the other ground-water sampling activities onsite. Sampling for RCRA compliance is scheduled on a fiscal-year basis, and results are made available to the GroundWater Surveillance Project. Therefore, the Ground-Water Surveillance Project avoids duplication of sample analysis at wells used by the RCRA program. Coordination with CERCLA-related sampling is accomplished through informal discussions with CERCLA operable unit managers.

Modifications to the monitoring network are made throughout the year as needed. Wells sampled and constituent lists may change in response to changes in other sampling programs. Additional sampling needs identified during the year are incorporated in the schedule. These changes are documented in the project files. Scheduled wells may be found to be unsampleable and are dropped from the schedule. Wells may be resampled when unexpected or suspect results are found.

\subsubsection{Sample Collection and Reporting}

All field sampling and analysis staff receive extensive procedural training consistent with accepted ground-water collection and handling standards and cross training with respect to their area of expertise. The basis for most procedures is EPA SW-846 (EPA 1986a) sample handling, documentation, and analysis protocol. Operational considerations with respect to site-specific area access on the Hanford Site are included in training requirements. Sitewide surveillance procedures are consistent with RCRA sampling protocol. These procedures are documented in PNL's Procedures for GroundWater Investigations (PNL 1993). 
Because of the large number of wells sampled by all programs on the Hanford Site, a proactive purge-water management system is in place for the site contractors, which include PNL, WHC, ICF Kaiser, and ERC. The DOE, EPA, and Ecology jointly developed a purge-water management strategy, which specifies criteria for containment of purge water that contains constituents above an agreed-upon level. PNL actively monitors constituent concentrations from the various wells across the site and, when required, the purge water generated in sampling a well is contained in a special purgewater tank truck. When the truck is filled, it is emptied at the Liquid Effluent Retention Facility (LERF) from which the water is ultimately disposed by WHC. .

The purge-water management strategy entails a review of data by the Ground-Water Surveillance Project to update the list of wells requiring containment and to identify wells that can be removed from the containment list. This review uses the Hanford Environmental Information System (HEIS) database, which is the primary storage system for the data received from the analytical laboratories.

Each-year-the-list-of-wells-in-the-network-to-be-sampled-over-the-coming-year-is_submitted_to_the Sample Scheduling task leader, who integrates the requests with those of other well-sampling programs and develops a yearly sampling schedule and a list of constituents for collection. The schedule and associated environmental tracking documentation, as well as laboratory contractual documentation, are forwarded to the Sample Set Preparation staff, who prepare the field sampling kits.

Field sampling kits include chain-of-custody forms for sample tracking, field record forms for well information, and sample analysis requests for the laboratory. Included with the documentation are the sample containers (with appropriate preservatives, if necessary) for the samples to be collected from each well. Several types of chemical preservatives are used in the field sampling kits. Acids, bases, or other chemical additives are added to specific bottles to preserve chemical components contained in the collected samples. In some instances, preservatives are added to the samples after collection but before shipment to the laboratory.

Once the kits are ready, the environmental field staff goes into the field to collect the samples. requested. The field staff collects ground-water samples from four types of ground-water wells on the Hanford Site: wells that require the use of bailers, wells equipped with pneumatic Hydrostar pumps, wells with electric submersible pumps, and piezometer tubes using the airlift method to obtain samples. Collected samples are packaged in ice chests- for transport to the analytical laboratory. The ice chests contain either wet ice or "blue ice" to cool the samples as soon after collection as posssible, according to recommended preservation protocol contained in the EPA guidance manuals (e.g., EPA 1986b). Samples stored at PNL facilities before they are delivered to the labs are kept at $4 \pm 2{ }^{\circ} \mathrm{C}$.

When transport packaging activities are complete, the environmental field staff submits the samples to the appropriate laboratory; some samples go to technical staff within PNL but the majority are delivered to two contractually arranged analytical laboratories for analysis of chemical constituents and radionuclides. Results from the analytical laboratories are typically returned to PNL within 25 to 30 working days. The data are then reviewed by project staff.

Samples submitted to the offsite and internal analytical laboratories for analysis are tracked for anticipated receipt of data. When the data are received, several contractual compliance evaluations are performed immediately. These include checks for analytical completeness, whether requirements for turnaround and holding times were met, whether the data were provided in the proper format, and 
whether any incident reports were submitted for the samples. Once these checks are complete, the information is forwarded to the project stafi for technical review and use. Data from the PNL internal laboratory are entered into a Paradox database. Electronic copies of the information are forwarded to the project staff for incorporation into the HEIS database.

\subsubsection{Monitoring-Well Design and Maintenance}

Most monitoring wells on the Hanford Site are 10,15 , or $20 \mathrm{~cm}(4,6$, or 8 in.) in diameter and are constructed of steel casing. Several small-diameter [5-cm (2-in.)] piezometers are sampled for radionuclides only. Most monitoring wells for the unconfined aquifer are completed with well screens or perforated casing in the upper 3 to $6 \mathrm{~m}$ (10 to $20 \mathrm{ft})$ of the aquifer. Completion at the water table allows collection of samples near the top of the aquifer, which is where maximum concentrations for contaminants are generally found on the Hanford Site (Eddy et al. 1978). Monitoring wells for the confined aquifer have screens, perforated casing, or an open hole within the monitored horizon.

Maintenance of wells and pumps is essential to the collection of acceptable ground-water samples. Maintenance is scheduled so that the wells used in the Ground-Water Surveillance Project network for ground-water sampling are cleaned and the pumps replaced or cleaned at least once every 5 years. This maintenance is performed by a drilling subcontractor and includes scouring the casing wall and removing sediment from the bottom of the well. Over time, the cost of this maintenance is much less than the cost of repairing or rebuilding a.well that has not been maintained.

The well-construction data stored in HEIS indicates exactly where the screen or perforations are; however, the database does not indicate any modifications that may have been made that shorten the monitored interval. Substantial modifications have been made to many wells on the Hanford Site as monitoring programs evolved, so the Ground-Water Surveillance Project performs careful assessments of well logs, maintenance records, and in many cases, inspection of wells. In 1993 and 1994, a compilation of well screen data was retrieved from the HEIS database and modified to reflect the actual interval from which water can be sampled. These effective screened intervals were then used to predict which wells may eventually go dry as the water table across the Hanford Site drops in response to decreased waste-water discharges to ground (Wurstner and Freshley 1994). This data set is also being used in combination with the hydrogeologic conceptual model to identify which geologic unit is . monitored at each well. This will further enhance the understanding of contaminant movement through the ground-water system.

\subsubsection{Analytical Methods}

The methodology for analysis of chemical constituents conforms to EPA SW-846 Test Methods for Evaluating Solid Wastes, Physical/Chemical Methods (EPA 1986a), the Annual Book of ASTM Standards (ASTM 1986), EPA Methods for Chemical Analysis of Water and Wastes (EPA 1982), or other EPA methods. The methodology used for analysis of radiochemical constituents is developed by the analyzing laboratory and recognized as acceptable procedures within the technical radiochemical industry. The methodologies used to obtain routine data results for the Ground-Water Surveillance Project samples are presented in Table 4.2 and briefly described below. 


\section{Radiological Analyses}

Gross Alpha and Gross Beta. Gross alpha and gross beta are determined by SW-846 Method 9310 (EPA 1986a). An aliquot of water is evaporated onto a stainless steel counting planchet. The residue is dried to constant weight and counted for alpha and beta radioactivity. Activity is determined using a standardized counting efficiency versus sample solids curve for the detector system. Efficiencies are determined by using americium-241 and strontium/yttrium-90 certified standards.

Gamma Spectrometry. Gamma scans provide a quantitative assay for a large number of gammaemitting isotopes with a range of half-lives. Because these assays are performed by high-resolution counting techniques, it is possible to identify isotopes of interest with a high degree of confidence. In addition, a software library search can be used to identify unknowns. Isotopes routinely reported include cesium-137, cobalt-60, ruthenium-106, and antimony-125; numerous other isotopes are reported when detected.

Samples are counted directly using an intrinsic (hyperpure) germanium or lithium-drifted germanium detector. Isotopes with gamma-ray energies from 60 to $2000 \mathrm{KeV}$ are detected. Activity concentrations are determined using a Nuclear Data computer system supplied with a library of isotopes.

Total Uranium. Total uranium analyses are generally performed by fluorophotometry but may also be performed by alpha-counting determinations of individual isotopes for activity. The activity is then converted to mass determinations using a conversion factor of 1.49 .

In the fluorophometry method, the sample is evaporated and fused with sodium and lithium fluoride flux. The yellow-green uranium fluorescence is then measured using a fluorophotometer. A uranium-232 tracer is used to determine recovery from the purification process, and a natural uranium standard addition is used to adjust for interferences and quantify sample reading.

Uranium Isotopes. Uranium is separated from thorium, radium, and lead on a hydrochloric acid anion-exchange resin column; iron is removed by passing the sample through a nitric acid anionexchange resin column. The uranium fraction is eluted and electrodeposited on a disc for alpha spectrometry counting.

Tritium. Sodium hydroxide is added to the sample. The alkaline sample is then distilled and a fraction $(5 \mathrm{ml})$ is mixed with scintillation cocktail, allowed to sit while the chemiluminescence decays, and then counted by liquid-scintillation instrumentation.

Low-Level Tritium. The sample is distilled in the presence of potassium permanganate to eliminate solids and organic material that may cause quenching. The sample is then enriched in a basic medium by electrolysis to a small volume. The enriched volume is transferred to a liquid-scintillation vial with scintillation cocktail and allowed to set for 24 hours while the chemiluminescence decays and temperature equilibrium is reached. It is then counted by liquid-scintillation instrumentation.

Technetium-99. The samples are wet ashed with nitric acid and hydrogen peroxide to destroy organic material in the sample. Actinides, lanthinides, alkaline earths, transition metals, and lead are removed through precipitation as hydroxides and carbonates. Technetium as the pertechnetate ion is adsorbed from a weak nitric acid solution on a strongly basic anion-exchange resin column. The 
technetium is then eluted with a stronger nitric acid solution and counted by liquid-scintillation beta counting.

Strontium-90. Samples are precipitated first as a nitrate and then as a carbonate. Calcium, barium, radium, and lead are removed by co-precipitation on barium chromate. Iron and other fission products are removed through hydroxide scavenging. The gravimetric yield of carrier (or strontium-85 tracer yield) is determined along with the strontium- 89 and strontium- 90 activities by beta-counting following final carbonate precipitation. Yttrium- 90 is then separated from the strontium by hydroxide and oxalate precipitations. The yttrium oxalate is converted to yttrium oxide, weighed for chemical recovery, and counted by beta-proportional counting for activity.

Americium-241. Americium and curium are concentrated in the sample by coprecipitation on ferric hydroxide. Plutonium and thorium are separated from the americium and curium as the sample is passed through an anion-exchange resin column conditioned with dilute nitric acid. The iron is then separated from the americium and curium by coprecipitation of the americium and curium on calcium oxalate. The americium and curium are then extracted into a bidentate organophosphorus solvent (DDCP) from a nitric acid solution and then back-extracted with weak nitric acid. Traces of iron, thorium, and any organic residue are removed by passing the solution through a cation-exchange resin column. The americium and curium are eluted from the cation-exchange resin column with dilute hydrochloric acid, electrodeposited or precipitated on a counting disk, and counted by alpha spectrometry.

Plutonium Isotopes. The sample is acidified with nitric acid, the plutonium oxidation state is adjusted to +4 with sodium nitrite, and the solution is loaded onto an anion-exchange resin column. The plutonium is eluted with hydrochloric acid and ammonium iodide. The sample is electrodeposited or coprecipitated on a counting disc and the activity counted by alpha spectrometry.

Iodine-129. Iodine-129 analyses present a particular challenge because of the need for especially sensitive measurement. The iodine-129 MCL is $1 \mathrm{pCi} / \mathrm{L}$ - the lowest for any radionuclide. The contractual detection limit [referred to as the "minimum detectable concentration" (MDC)] is currently $1 \mathrm{pCi} / \mathrm{L}$ for the most sensitive method used by the primary radiological laboratory.

Iodine isotopes are first separated from interfering radioactive isotopes by oxidation to iodine $\left(\mathrm{I}_{2}\right)$ with sodium nitrite and then extracted into carbon tetrachloride from dilute acid media. The iodine is next reduced to iodide with sodium bisulfite. It is then back-extracted into water, precipitated as silver iodide, and counted on a low-energy photon detector. Chemical yield is determined gravimetrically.

\section{Non-Radiological Analyses}

Volatile Organic Compounds. Volatile Organic Compounds (VOCs) were analyzed by gas chromatography (GC) SW-846 Method 8010/8020, EPA GC Method 502.2 SW-846 gas chromatography/mass spectrometry (GC/MS) Method 8240, or SW-846 GC/MS Method 8260. VOCs are extracted from the water sample through a purge-and-trap system [e.g., SW-846 Method 5030 (EPA 1986a)]. Purged sample components are trapped in a tube containing suitable sorbent materials. When purging is complete, the sorbent tube is heated and backflushed with helium to desorb trapped sample components onto a gas chromatography (GC) column. The column separates the analytes, which are then detected with a photoionization detector and a halogen-specific detector placed in series 
for Methods 8010/8020 and 502.2. For Methods 8240 and 8260, the compounds are identified and quantified using a mass-spectrometer.

Semivolatile Organic Compounds. Semivolatile organic compounds analyzed by SW-846 GC/MS Method 8270 after extraction into methylene chloride, using a fused-silica capillary column. Polynuclear aromatic hydrocarbons, chlorinated hydrocarbons and pesticides, phthalate esters, organophosphate esters, nitrosamines, haloethers, aldehydes, ethers, ketones, anilines, pyridines, quinolines, aromatic nitro compounds, and phenols (including nitrophenols) can be analyzed using this methodology.

Cyanide. Cyanide is analyzed by SW-846 Method 9010 or 9012 (EPA 1986b). The sample is acidified, converting any cyanide to hydrocyanic acid. The sample is then distilled and the hydrocyanic acid is trapped in an absorber-scrubber of sodium hydroxide solution. The cyanide ion is converted to cyanogen chloride with Chloramine-T, and color formation is achieved through the addition of pyridine-barbituric acid. The cyanide concentration is then determined by either colorimetry or automated UV colorimetry.

ICP Metals Analysis. Samples are acid-digested before analysis by SW-846 Method 6010 (EPA 1986b).

Alkalinity. The alkalinity of a sample is determined using the method described in ASTM D1067A, (ASTM 1986), or EPA Method 310.2 (EPA 1982). These are colorimetric titration methods using methyl orange indicator.

Anions. The anions nitrate, nitrite, bromide, chloride, fluoride, phosphate, and sulfate are determined using the methodology described in ASTM D4327-88, (ASTM 1986), or EPA Method 300.0 (O'Dell et al. 1984). The sample is introduced into an ion chromatograph, and the anions of interest are separated and measured with a conductivity detector.

\subsection{Analytical Findings}

\subsubsection{Data Management}

Results of the Ground-Water Surveillance Project's monitoring are discussed in detail in Section 5.0. The HEIS database is the central repository for all ground-water monitoring results obtained onsite, including data collected by other programs. The interpretations presented here are based on the data available in the HEIS database at the time of the interpretation. However, there is some lag time in entering data into the HEIS database and for data verification or validation, so all T994 data may not be represented. The amount of lag time depends on the projects involved and the form in which the data were received. At the time of report preparation, data validation for 1994 was not completed by the CERCLA programs. An addendum to this report will be issued should significant changes to the interpretation be required as the result of issues discovered during data validation. Additional sources of data include the RCRA quarterly reports (DOE-RL 1994b,c; 1995b,c). 
The data management task of the Ground-Water Surveillance Project is responsible for ensuring that data for the project are made accessible in the HEIS database. This database currently resides on a Sequent ${ }^{\odot}$ S27 UNIX-based multiprocessor computer. The database software is ORACLE ${ }^{\oplus}$, and is the user-interface software is Uniface ${ }^{\otimes}$.

Several types of environmental data are stored in the HEIS database. Those stored and maintained by the Ground-Water Surveillance Project include analytical results of ground-water samples collected from wells on the Hanford Site, hydraulic head measurements at the wells, and well information such as surveyed elevations. By far the largest group of data is the ground-water analytical results. In 1994, approximately 12,800 ground-water analytical results and 2,400 hydraulic head measurements were entered_into_HEIS_by_the_Ground-Water_Surveillance_Project.

The majority of the analytical results are received from two laboratories that are under subcontract to PNL. Analytical data are delivered from these two main laboratories on electronic media in a format specified by the contracts. The electronic media are loaded into HEIS using software written and maintained by HEIS personnel. Some analyses are also performed at secondary laboratories both within and some outside PNL. The data from these laboratories are received in hard-copy form and entered into a Paradox spreadsheet. A C program is used to convert the data into the same format as that specified in the major laboratory contracts, and then it is loaded into the database using the programs mentioned above. This process is an improvement over the past procedure of entering the data using Uniface data-entry screens because it is faster and results in fewer data-entry errors. Field measurements such as $\mathrm{pH}$, specific conductance, and temperature are entered using the Uniface dataentry screens. All of these manually entered data values are verified after entry by comparison to the hard copies.

Hydraulic head (water level) is usually measured as part of the sampling procedure. In addition, some wells are measured in June and December for the purpose of producing and verifying water-table maps, and certain tasks within the project collect measurements of water levels at some wells monthly, quarterly, or semiannually. Water-level measurement taken at wells, surveyed well elevations, and other types of well information are currently entered into the HEIS database manually by using Uniface data entry screens.

Based on analytical data in HEIS, the Purge Water Strategy Implementation List is generated, usually twice a year. This list of wells indicates those from which purge water is not allowed to be discharged to the ground. The criteria used to develop this list are those set forth in the Tri-Party Agreement, and this list is distributed to personnel at PNL, WHC, ICF Kaiser, ERC, and DOE.

The HEIS programmers and HEIS data owners ensure database integrity and data consistency through membership in the HEIS Configuration Control Board and other ad hoc groups. The GroundWater Surveillance Project is represented on this board, and project personnel are key in several of the ad hoc groups. The Ground-Water Surveillance Project personnel are responsible for maintaining certain data tables central to the operation of HEIS. 


\subsubsection{Maximum Contaminant Levels and Derived Concentration Guides}

MCLs and DCGs provide useful reference concentrations for comparison with the results of ground-water analyses. The MCLs for constituents of concern at the Hanford Site are presented in Table 4.3. These concentration levels are discussed below.

MCLs are EPA or state-mandated drinking water standards. An MCL is defined as the maximum level of a constituent that can be allowed in drinking water before corrective action must be taken. The MCLs are generally set by considering available data on the risk associated with lifetime (assumed to be 70 years) ingestion of $2.0 \mathrm{~L} /$ day of water, the available treatment technology, and economic factors. As a result, the MCL may not be directly related to the estimated health risk. Secondary MCLs are based on aesthetic rather than health considerations. Monitoring wells are constructed to different standards from those for drinking-water production wells, and monitoring wells are generally purged for only a relatively short time before sampling, which complicates the application of standards. This is mainly a problem for metal analyses because the metals may be sorbed to particulate matter in the well bore. MCLs are defined for samples of water as it would be consumed, so unfiltered samples from wells are generally compared to MCLs. Monitoring wells are likely to produce a greater proportion of particulate matter than production wells, so the samples may not be representative of what would be found for water supplies. Filtered samples are more representative of the dissolved load and are better suited to interpretation of transport geochemistry. Therefore, most Ground-Water Surveillance Project analyses for metals were performed on filtered samples. Samples for radiological analysis were generally unfiltered, because this provides more sensitivity for detecting radionuclides, which may be partially sorbed onto particulate matter. However, this may not always represent the mobile dissolved concentrations.

Specific MCLs have not been set for most anthropogenic radionuclides. The MCLs for beta- and photon-emitters are based on an annual dose of $4 \mathrm{mrem} / \mathrm{yr}$ to the affected organ. The levels of individual radionuclides that are calculated to result in this dose are shown in Table 4.4. The levels are additive for dose calculation when more than one radionuclide is present.

DCGs are calculated only for radionuclides. DCGs are based on an effective dose equivalent to the public from all routine DOE activities as specified in DOE Order 5400.5. The DCG for an individual constituent is that concentration in ground water that would result in a dose of $100 \mathrm{mrem} / \mathrm{yr}$ if consumed at a rate of $2 \mathrm{~L}$ per day. DCGs are presented DOE Order 5400.5 (DOE 1990) and are summarized in Table 4.4. Dose calculations used in determining MCLs are in some instances based on different data from that used in determining DCGs, so the levels are not always in agreement.

\subsubsection{Assessment of the Monitoring Network}

Most major ground-water contaminant plumes on the site are now believed to be identified and reasonably well-characterized; however, some uncertainties remain. The most serious limitation to knowledge comes from the nature of the well network itself, because the wells are irregularly distributed and generally do not provide sufficient spatial density for optimal contouring. Areas where the . well density is insufficient for accurate plume definition include 1) the area north of the BY Cribs in the 200-East Area, 2) the area south of the BC Cribs near the 200-East Area, 3) the area between the 200-East and 200-West Areas, 4) the eastern portion of the plumes originating in the U1/U2. Cribs in 
the 200-West Area, 5) the area of chromium contamination between the 100-D Area and 100-H Area, and 6) the 100-F Area and vicinity.

The ground-water monitoring network is being adversely impacted by declining water levels in the operational areas. The termination of operational activities has resulted in decreasing discharges to disposal facilities in the operational areas, and the water table is declining towards pre-operational levels. Additional decreases in discharge have resulted from pollution-prevention programs which have reduced the volume of remaining releases and improved the water quality. This has resulted in several monitoring wells becoming impossible to sample because water levels have declined below the pump intake or because yield is insufficient. An investigation was conducted by the Ground-Water Surveillance Project in 1994 to assess the impact of the declining water levels on the monitoring network and to predict the loss of monitoring locations (see Section 3.0).

Ground-water monitoring data indicate that the zones of contamination generally are found near the water table in the unconfined aquifer. Certain areas of the site are exceptions, where monitoring data are insufficient for determining the vertical extent of contaminant plumes. Carbon tetrachloride disposal in the 200-West Area may have caused transport of dense nonaqueous phase liquid carbon tetrachloride into the aquifer. The presence or depth of penetration of any nonaqueous phase liquid source is not known, and the depth of ground-water contamination is poorly defined by the present monitoring network. Disposal of high total-dissolved-solid waste in the BY Cribs in the 200-East Area may have produced density-driven flow to significant depths in the aquifer (Smith 1980). Monitoring of the bottom of the unconfined aquifer in the 200-East Area is sparse. The sparseness of threedimensional monitoring data also complicates interpretation of contamination in the other operational areas.

\subsubsection{Interpretation of Analytical Results}

Each analysis of a ground-water sample provides information on the composition of ground water at one time at one location in the aquifer. Uncertainty in the analysis results from a number of sources, some of which are discussed below. Given these uncertainties, several techniques are used in interpreting the sample results, and these are also discussed in this section.

The chemical composition of ground water fluctuates with time because of differences in the contaminant source, recharge, or flow field. The range of this fluctuation can be estimated by taking many samples, but there is a practical limit to the number that can be taken. Comparison of results through time helps in interpreting the natural variability.

Sampling techniques are designed to provide a sample that is reasonably representative of the aquifer concentration when the sample is taken. However, there are limitations to our ability to collect representative samples or even to define precisely the volume of aquifer that is represented in the sample. Proper well construction, well purging, sample preservation, and in some instances filtering are used to help ensure that samples are consistent and representative. Careful sample-labeling protocols, chain-of-custody documentation, and bottle preparation prevent many gross errors in sample results. Duplicate samples and field blanks help in assessing the sampling procedure. 
Uncertainties are also inherent in laboratory analysis of samples. Gross errors can be introduced in the laboratory as well as during sampling. Such errors include transcription errors, calculation errors, mislabeling of results, and other errors that result from failing to follow established procedures. Often these gross errors can be recognized because unreasonably high or unreasonably low values result. Data review procedures are used to identify and correct gross errors.

Random errors are unavoidably introduced in the analytical procedures. Usually there are too few replicate analyses to assess the overall random error. Instruments for analyzing radioactive constituents count the number of radioactive decay products at a detector, and background counts are subtracted out. The nature of radioactive decay and the instrument design result in a random counting error, which is reported with the analytical result. Generally, sample results that are less than the counting error are an indication that the constituent was not detected. The counting methods may also result in the reporting of results.that are less than zero. Although they are physically impossible, the negative values may be of use for some statistical analyses.

Systematic errors may result from inaccurate instrument calibration, improper standard or sample preparation, chemical interferences in analytical techniques, or faulty sampling methodology and sample. handling. Sample and laboratory protocols have therefore been designed to minimize systematic errors. The laboratories used by the Ground-Water Surveillance Project and other monitoring programs participate in interlaboratory comparisons, in which many laboratories analyze blind samples prepared by the EPA. The laboratories used have compared favorably with other laboratories, indicating that the level of systematic error from many sources is small enough to be acceptable.

Overall sample uncertainty may be factored into data evaluation by considering the concentration . trend in a given well over time. This often helps identify gross errors, and long-term trends can be distinguished from short-term variability. The interpretation of concentration trends depends on an understanding of chemical properties as well as site hydrogeology. The trend analysis, in turn, aids in refining the coriceptual model of the chemical transport.

The plume maps presented in this report are diagrams of the interpretation of the ground-water chemistry at the Hanford Site. Although analytical data are available only for specific points where wells were sampled, contours are drawn to join the approximate locations of equal chemical concentration or radionuclide activity. The contour maps are necessarily simplified representations of plume geometry given the map scale, the lack of detailed information, and the fact that plume depth and thickness cannot be fully represented on a two-dimensional map. Nevertheless, plume mapping is a powerful tool, reflecting concentrations in surrounding wells, ground-water flow, site geology, and other available information. This combination of information minimizes the impact of uncertainty or error in any particular sample.

Plume maps in this report were prepared using the averages for 1994 sample analyses from each well. Average values for radionuclides were calculated using reported values, including negative counts. Values for chemical constituents below detection limits were considered to be zero in calculating averages. In a few instances, data believed to represent gross errors in sample collection and analysis were removed from the data set before averaging. Sample data from prior years were used in some cases to provide further information for areas that were not sampled in 1994. The data were contoured using a combination of computerized algorithms and hand contouring. 


\subsection{Quality Assurance/Quality Control}

Quality assurance practices encompass all aspects of the Ground-Water Surveillance Project. A comprehensive quality assurance prograrn, including various quality control practices, is maintained to ensure the quality of data collected through the Ground-Water Surveillance Project. Quality assurance plans are maintained for all surveillance activities and define the appropriate controls and documentation required to meet DOE Orders (DOE Order 5700.6C).

Quality assurance for the Ground-Wate: Surveillance Project also includes procedures and protocols for 1) documenting instrument calibrations, 2) conducting activities in the field and laboratory, 3) maintaining wells to ensure that representative samples are collected, and 4) using dedicated sampling pumps to avoid cross-contamination.

Samples are analyzed according to documented standard analytical procedures (see Section 3.1). The quality of analytical data is verified by a continuing program of internal laboratory quality control, participation in interlaboratory crosschecks, replicate sampling and analysis, analysis of blind standard samples and blanks, and splitting samples with other laboratories: The aspects of the Quality Assurance/Quality Control Programs are discussed below.

\subsubsection{Project Management}

The Ground-Water Site Surveillance Project implements the requirements of DOE Order 5700.6C, "Quality Assurance". The program is defined in PNL's quality assurance manual. The manual provides guidance for implementation by, addressing quality assurance elements such as identifying the organizations, procurement of services and items, control of procedures and documents, control of measuring and test equipment, inspection of services and operations, corrective actions, and records.

The Ground-Water Surveillance Project's current quality assurance plan describes specific quality assurance elements and how they apply to the project. All plans are approved by PNL's independent quality assurance organization, which conducts assessments and audits to verify compliance with QA plans. Work performed under contracts with external groups, such as sample analysis, must meet the same quality assurance requirements. Potential suppliers of equipment and services may be audited before contracts for services are awarded or before the approval of purchase of materials that could have a significant impact on a project's quality.

\subsubsection{Sample Collection}

Samples for ground-water monitoring are collected by trained staff according to approved and documented procedures. Chain-of-custody procedures (EPA 1986a) include the use of evidence tape in sealing sample bottles to maintain the integrity of the samples during shipping. Field quality control samples, consisting of full trip blanks and field duplicates, were submitted periodically during field sampling operations.

All 27 radiochemical constituents reported for the 1994 full trip blank samples were within the control limits. Sample results are considered within in the control limits if they are below the total propagated analytical uncertainty. 
Twenty-three of the 210 chemical constituents analyzed for 1994 full trip blank samples were not within control limits (see Table 4.5). Sample results are considered within control limits if they are less than the MDL. In most cases, the MDL is well below $1 / 2$ the drinking water standards. A project data quality objective is to have the MDL be less than one-half the MCL. In most cases, the MDL was considerably below the MCL so results from trip blanks that were not within control limits do not have a significant impact on the quality of the data.

The 79 duplicate field results were within the control limits. Duplicate sample results are considered within the control limits if (1) they are above five times the MDL and are within $\pm 20 \%$ relative percent difference and/or (2) if the results are between the MDL and five times the MDL the duplicate results agree within \pm the MDL.

\subsubsection{Holding Times}

Chemical constituent concentrations in ground-water samples are required to be determined within a specified time frame or "holding time" from the time of collection to the time of analysis or preparation. Samples must be analyzed within this time frame, or the concentration of the constituents of concern may, in some instances, be compromised by decomposition or chemical change. Samples are also refrigerated to slow the chemical changes within the sample matrix. For EPA SW-846 Methods (EPA 1986b), the holding time is 14 days for volatile organic analysis, 7 days before extraction and 40 days after extraction for semivolatile analysis, 14 days for cyanide analysis, and 6 months for ICP analysis of metals. As required by the American Society of Testing and Materials (ASTM 1986) and O'Dell et al. (1984) methodology, holding times are 48 hours for the determination of nitrate, nitrite, and phosphate and 28 days for the determination of chloride, bromide, fluoride, sulfate, and ammonium. There is no designated holding time for radiochemical constituents because they do not change chemically or decompose under ambient temperatures. Results of radionuclide analysis are corrected for decay between sample and analysis date.

Of the 949 non-radiochemical analysis tests conducted specifically for the Ground-Water Surveillance Project in 1994, only 16 of the 469 anion analysis tests were not performed within the specified holding time. No other holding times were determined to have been violated.

\subsubsection{Analytical Results}

Routine analyses of hazardous and nonhazardous chemicals in Ground-Water Surveillance Project water samples were performed by DataChem Laboratories, Inc. of Salt Lake City, Utah, and by PNL internal laboratories. DataChem participates in the EPA Water Pollution and Water Supply

Performance Evaluation Studies and maintains an internal quality control program that meets the requirements of EPA SW-846 (EPA 1986a) and of which PNL audits and reviews. In addition, PNL submitted quality control blind spiked samples for analysis.

Routine radiochemical analyses of Ground-Water Surveillance Project samples were performed under contract with IT at its laboratory in Richland, Washington. IT's Richland laboratory participates in DOE's quality assessment program and EPA's Laboratory Intercomparison Studies. In addition, a quality control blind spike sample program was conducted. IT's Richland laboratory also maintains an 
internal quality control program, which is audited and reviewed both internally and by PNL. Additional information on these quality control efforts is provided in the following subsections.

U.S. Department of Energy and U.S. Environmental Protection Agency Comparison Studies. DataChem participated in the EPA Water Pollution and Water Supply Performance Evaluation Studies. Standard water samples were distributed as blind samples to participating laboratories. These samples contained specific organic and inorganic analytes at concentrations that were unknown to the analyzing laboratories. After analysis, the results were submitted to EPA for comparison with known values and with those obtained by other participating laboratories. Results during the year are summarized in Table 4.6. Approximately $97 \%$ of the results during the year were within the "3-sigma control limits" ( \pm 3 standard errors of the mean) that are typically used. This reflects excellent performance on the samples analyzed in the study.

IT's Richland laboratory participated in DOE's Quality'Assessment Program and EPA's Laboratory Intercomparison Studies Program. These programs provide standard samples containing specific amounts of one or more radionuclides that are unknown to the participating laboratory. After sample analysis, the results were forwarded to DOE or EPA for comparison with known values and with results from other laboratories. Both EPA and DOE have established criteria for evaluating the accuracy of results by comparing to 3-sigma control limits based on all results reported in the intercomparison study (Jarvis and Siu 1981, Sanderson 1985). Summaries of the 1994 results for water samples for the programs are provided in Tables 4.7 and 4.8 . Approximately $95 \%$ of the results analyzed during the year were within 3-sigma control limits. This reflects good performance on the samples analyzed in the study.

Pacific Northwest Laboratory Evaluation. In addition to DOE. and EPA interlaboratory quality control programs, a quality control program is maintained by PNL to evaluate its analytical contractors' precision and accuracy and to conduct special intercomparisons: This program includes the use of blind spiked samples and replicate samples. Blind spiked quality control samples and blanks were prepared in triplicate and submitted to check the accuracy and precision of analyses at the DataChem and IT laboratories. Overall, 85\% of DataChem's blind spiked determinations were within control limits and $96 \%$ of IT's blind spike cleterminations were within control limits (Table 4.9). Results not within $\pm 30 \%$ of the spiked concentrations are as follows:

- The plutonium isotopic blind spiked samples for the three quarters averaged $30 \%$ low. The referee blind spiked sample was also low. The standard is being reverified for accuracy. The precision of the laboratory's triplicate analyses were good.

- One of the triplicate chromium spiked samples for the third quarter was reported at $84 \%$ high. This value was brought to the attention of the laboratory. The laboratory review showed no problem with analysis. The result was considered a flier.

- The fluoride blind spiked sample results have all been flagged by the analyzing laboratory as having a possible positive interference. This issue is being evaluated with the laboratory.

- One of the triplicate uranium spiked sample results for the third quarter was $35 \%$ high. 
- Two of the triplicate cyanide results for the second quarter spike were biased greater than $30 \%$. The referee laboratory results for this spike concentration was also $30 \%$ low. The known spike concentration seems to be high for this sample.

Laboratory Internal Quality Assurance Programs. Under their contracts with PNL, DataChem and IT are required to maintain internal quality assurance and quality control programs. These programs are periodically reviewed and audited for compliance both internally and by PNL. The quality control program at DataChem meets the quality control criteria of EPA SW-846 (EPA 1986a). This program requires the laboratory to maintain a system for reviewing and analyzing the results of the quality control samples to detect problems arising from contamination, inadequate calibrations, calculations, or procedure performance. MDLs are determined twice a year.

IT's internal quality control program involves routine calibrations of counting instruments, yield determinations of radiochemical procedures, frequent radiation check source and background counts, replicate and spiked sample analyses, use of matrix and reagent blanks, and maintenance of control charts to indicate analytical deficiencies. Available calibration standards traceable to the National Institute of Standards and Technology were used for radiochemical calibrations.

In 1994, one inspection of DataChem and one inspection of IT were conducted under the contracts that supported the Ground-Water Surveillance Project. These inspections documented each analytical facility's conformance with contractual requirements and provided the framework for identifying and resolving potential performance problems. Responses to audit and inspection findings were documented in writing, and corrective actions were verified by follow-up audits and inspections.

The results of the internal laboratory quality control programs are summarized by the laboratories in quarterly reports. The results of the quality control sample summary reports and the observations noted by each laboratory indicated an acceptable functioning quality control program.

Laboratory Comparisons. Additional comparisons are conducted on most of them quarterly individual samples. The Washington State Department of Health (DOH) co-sampled 25 ground-water wells during 1994. The data will be made available in the Washington State Department of Health 1994 annual report.

In addition to DOH co-sampling, PNL participates in a Quality Assurance Task Force conducted by $\mathrm{DOH}$. Public and private organizations from Idaho, Oregon, and Washington participate in analyzing the intercomparison samples. Two Hanford Site well-water samples were analyzed in 1994 as part of this intercomparison. The results are presented in Table 4.10. 


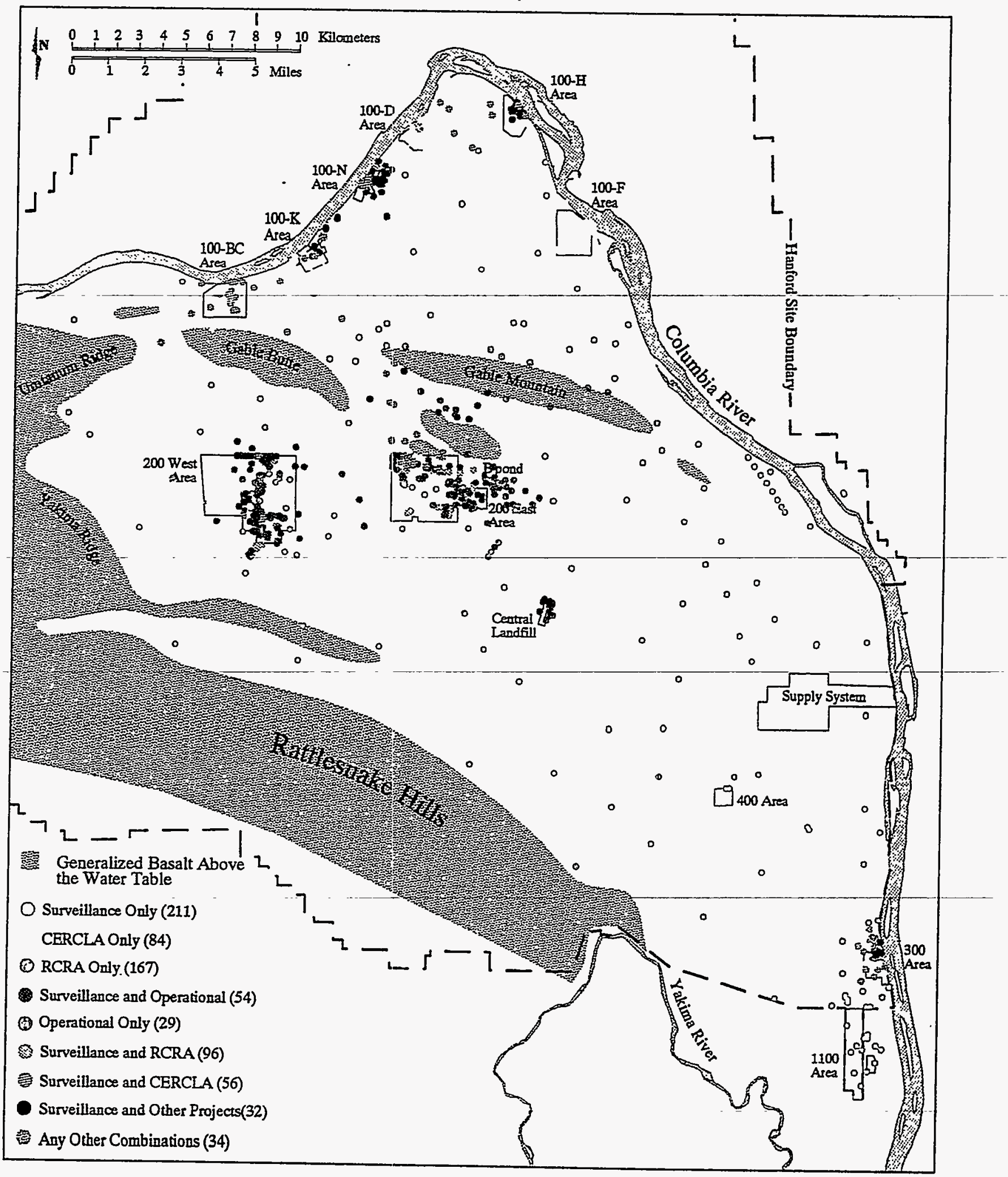

Figure 4.1. Ground-Water Monitoring Wells for the Hanford Site Sampled by Various Programs 
Table-4.1.-Major_Chemical_and_Radiological_Ground-Water Contaminants and Their Link to Site Operations

\begin{tabular}{|c|c|c|}
\hline Facilities Type & Area & Constituents \\
\hline Reactor Operations & 100 & $\begin{array}{l}\text { tritium, cobalt }-60 \text {, strontium- } 90 \text {, } \\
\text { chromium, sulfate }\end{array}$ \\
\hline Irradiated Fuel Processing & $\begin{array}{l}200-W \text { and } \\
200-E\end{array}$ & $\begin{array}{l}\text { tritium, cesium-137, strontium- } 90 \text {, } \\
\text { iodine- } 129 \text {, technetium- } 99 \text {, nitrate, } \\
\text { chromium, cyanide, fluoride, } \\
\text { uranium, plutonium }\end{array}$ \\
\hline Plutonium Purification & $200-W$ & $\begin{array}{l}\text { carbon tetrachloride, chloroform, } \\
\text { plutonium }\end{array}$ \\
\hline Uranium Recovery & $200-W$ & uranium, technetium- -99 , nitrate \\
\hline Fuel Fabrication & 300 & $\begin{array}{l}\text { uranium, technetium-99, } \\
\text { chromium, nitrate, } \\
\text { trichloroethylene }\end{array}$ \\
\hline
\end{tabular}


Table 4.2. Methodologies Used to Obtain Routine Data Results for the Ground-Water Surveillance Project Samples

Analytical Test

VOCs
VOCs
Semivolatile Organic Compounds
Cyanide
ICP Metals
Alkalinity
Anions
Gross Alpha and Gross Beta
Gamma Spectrometry
Total Uranium
Uranium Isotopic

Tritium

Low-Level Tritium

Technetium-99

Strontium-90

Americium-241

Plutonium Isotopic

Iodine-129
Reference

SW-846, Method 8010/8020

SW-846, Method 8260

SW-846, Method 8270

SW-846, Method 9010 or 9012 .

SW-846, Method 6010

ASTM D1067A or EPA Method 310.2

ASTM D4327-88 or EPA Method 300.0

SW-846, Method 9310

Laboratory Specific

Laboratory Specific

Laboratory Specific

Laboratory Specific

Laboratory Specific

Laboratory Specific

Laboratory Specific

Laboraliory Specific

Laboratory Specific

Laboratory Specific
Analytical Methodology

Gas Chromatography

Gas Chromatography/

Mass Spectroscopy

Gas Chromatography/

Mass Spectroscopy

Colorimetry or Automated UV colorimetry

ICP, Stomic Emission Spectroscopy

Colorimetric

Ion Chromatography

Gas-Flow Proportional Counting

Intrinsic Germanium Counting

Fluorophotometry

Anion-exchange Resin Separation with Alpha Energy Analysis

Distillation and Liquid Scintillation Counting

Electrolysis to enriched volume and Liquid Scintillation Counted

Anion-exchange Resin Column Separation with Liquid Scintillation Counting

Nitrate and Carbonate coprecipitation, gravimetric yield and Beta Gas Flow

Proportional Counting

Anion-exchange Resin Column Separation with Alpha Energy Analysis

Anion-exchange Resin Column Separation with Alpha Energy Analysis

Chemical Separation, coprecipitated and counted on Low-Energy Photon Detector 
Table 4.3. Maximum Contaminant Levels

\begin{tabular}{|c|c|c|c|}
\hline Constituent & Primary MCL & Agency & EPA Status \\
\hline Fluoride & $4 \mathrm{mg} / \mathrm{L}$ & $\mathrm{EPA}, \mathrm{DOH}^{(a)}$ & Final/under review \\
\hline Nitrate & $45 \mathrm{mg} / \mathrm{L}$ & $\mathrm{EPA}, \mathrm{DOH}$ & Final \\
\hline \multirow[t]{2}{*}{ Chromium } & $100 \mu \mathrm{g} / \mathrm{L}$ & EPA & Final \\
\hline & $50 \mu \mathrm{g} / \mathrm{L}$ & $\mathrm{DOH}$ & \\
\hline Trichlorethylene & $5 \mu \mathrm{g} / \mathrm{L}$ & $\mathrm{EPA}, \mathrm{DOH}$ & Final \\
\hline Tetrachloroethylene & $5 . \mu \mathrm{g} / \mathrm{L}$ & EPA & Final \\
\hline Carbon Tetrachloride & $5 \mu \mathrm{g} / \mathrm{L}$ & EPA. DOH & Final \\
\hline Chloroform (THM) & $100 \mu \mathrm{g} / \mathrm{L}$ & EPA & \\
\hline Uranium & $20 \mu \mathrm{g} / \mathrm{L}$ & EPA & Proposed \\
\hline $\begin{array}{l}\text { Total alpha } \\
\text { (excluding uranium) }\end{array}$ & $15 \mathrm{pCi} / \mathrm{L}$ & EPA; DOH & Final \\
\hline $\begin{array}{l}\text { Beta particle and photon } \\
\text { activity }\end{array}$ & $4 \mathrm{mrem} / \mathrm{yr}^{(\mathrm{c})}$ & EPA, DOH & Final \\
\hline Tritium & $20,000 \mathrm{pCi} / \mathrm{L}^{(d)}$ & EPA & \\
\hline Carbon-14 & $2,000 \mathrm{pCi} / \mathrm{L}$ & EPA & \\
\hline Cobalt -60 & $100 \mathrm{pCi} / \mathrm{L}^{(\mathrm{d})}$ & EPA & \\
\hline Strontium-90 & $8 \mathrm{pCi} / \mathrm{L}^{(d)}$ & EPA & \\
\hline Technetium-99 & $900 \mathrm{pCi} / \mathrm{L}^{(\mathrm{d})}$ & EPA & \\
\hline Ruthenium-106 & $30 \mathrm{pCi} / \mathrm{L}^{(d)}$ & EPA & \\
\hline Antimony-125 & $300 \mathrm{pCi} / \mathrm{L}^{(d)}$ & EPA & \\
\hline Iodine-129 & $1 \mathrm{pCi} / \mathrm{L}^{(\mathrm{d})}$ & $\mathrm{EPA}$ & \\
\hline Cesium-137 & $200 \mathrm{pCi} / \mathrm{L}^{(d)}$ & EPA & \\
\hline
\end{tabular}

(a) DOH = Washington State Department of Health.

(b) Standard is for total trihalomethanes.

(c) Beta and gamma radioactivity from anthropogenic radionuclides. Annual average concentration shall not produce an annual dose from anthropogenic radionuclides equivalent to the total body or any internal organ dose greater than $4 \mathrm{mrem} / \mathrm{yr}$. If two or more radionuclides are present, the sum of their annual dose equivalents shall not exceed $4 \mathrm{mrem} / \mathrm{yr}$. Compliance may be assumed if annual average concentrations of total beta, tritium, and strontium- 90 are less than $50,20,000$, and $8 \mathrm{pCi} / \mathrm{L}$, respectively.

(d) Concentration assumed to yield an annual dose of $4 \mathrm{mrem} / \mathrm{yr}$. 
Table 4.4. Derived Concentration Guides ${ }^{(a, b, c)}$ and 4 mrem Effective Dose Equivalent Concentrations for Drinking Water ${ }^{(e)}$

\begin{tabular}{|c|c|c|}
\hline Radionuclide & $\begin{array}{l}\text { Water, } \\
\mathrm{pCi} / \mathrm{L}\end{array}$ & $\begin{array}{r}4 \text { mrem effective } \\
\text {.. dose equivalent }\end{array}$ \\
\hline Tritium & $2,000,000$ & 80,000 \\
\hline Carbon-14 & 70,000 & 2,800 \\
\hline Chromium-51 & $1,000,000$ & 40,000 \\
\hline Manganese-54 & 50,000 & 2,000 \\
\hline Cobalt -60 & 5,000 & 200 \\
\hline Zinc-65 & 9,000 & 360 \\
\hline Krypton-85 & $\mathrm{NA}^{(\mathrm{d})}$ & $N A^{(d)}$ \\
\hline Strontium-90 & 1,000 & 40 \\
\hline Technetium-99 & 100,000 & 4,000 \\
\hline Ruthenium-103 & 50,000 & 2,000 \\
\hline Ruthenium-106 & $-6,000$ & -240 \\
\hline Antimony-125 & 60,000 & 2,400 \\
\hline Iodine-129 & 500 & 20 \\
\hline Iodine-131 & 3,000 & 120 \\
\hline Cesium-137 & 3,000 & 120 \\
\hline Cerium-144 & 7,000 & 280 \\
\hline Uranium-234 & 500 & 20 \\
\hline Uranium-235 & 600 & 24 \\
\hline Uranium-238 & 600 & 24 \\
\hline Plutonium-238 & 40 & 1.6 \\
\hline Plutonium-239 & 30 & 1.2 \\
\hline Plutonium-240 & 30 & 1.2 \\
\hline
\end{tabular}

(a) Concentration of a specific radionuclide in water that could be continuously consumed at average annual rates and not exceed an effective dose equivalent of $100 \mathrm{mrem} / \mathrm{yr}$.

(b) Values in this table represent the lowest, most conservative DCGs considered potentially applicable to Hanford operations, and may be adjusted upward (larger) if accurate solubility information is available.

(c) From DOE Order 5400.5.

(d) $\mathrm{NA}=$ No standard.

(e) Concentration of a specific radionuclide in water that would produce an effective dose equivalent of $4 \mathrm{mrem} / \mathrm{yr}$ of consumed at average annual rates. 
Table 4.5. Chemical Constituents Not Within Control Limits ${ }^{(2)}$

\begin{tabular}{|c|c|c|c|}
\hline Constituent $t^{(\mathfrak{b})}$ & Result $(\mu \mathrm{g} / \mathrm{L})$ & $\mathrm{MDL}(\mu \mathrm{g} / \mathrm{L})$ & $\begin{array}{l}1 / 2 \mathrm{MCL} \\
(\mu \mathrm{g} / \mathrm{L})^{(c)}\end{array}$ \\
\hline Aluminum & 60 & 26 & 25 \\
\hline Magnesium & 27 & 23 & Not Applicable \\
\hline Calcium & 16 & 14.5 & Not Applicable \\
\hline Zinc & 1.9 & 0.11 & $2500^{(c)}$ \\
\hline Zinc & 0.66 & 0.11 & $2500^{(c)}$ \\
\hline Zinc & 55 & 6.3 & $2500^{(c)}$ \\
\hline Iron & 8.2 & 5.2 & $150^{(c)}$ \\
\hline Iron . & 10 & 5.2 & $150^{(\mathrm{c})}$ \\
\hline Iron & 8.6 & 5.2 & $150^{(\mathrm{c})}$ \\
\hline Fluoride & 200 & 51 & $1000^{(c)}$ \\
\hline Chloride & 900 & 71 & $125,000^{(\mathrm{c})}$ \\
\hline Chloride & 30 & 14 & $125,000^{(c)}$ \\
\hline Nitrate & 60 & 44.4 & 22,500 \\
\hline Nitrate & 300 & 96 & 22,500 \\
\hline Nitrate & 40 & 11 & 22,500 \\
\hline Nitrate & 40 & 11 & 22,500 \\
\hline Nitrate & 20 & 11 & $22,500^{\circ}$ \\
\hline Chloroform & 3.1 & 2 & 50 \\
\hline
\end{tabular}


Table 4.6. Summary Results of DataChem Laboratories EPA Water Pollution and Water Supply Performance Evaluation Studies, 1994

\begin{tabular}{|c|c|c|}
\hline Analytes & $\begin{array}{l}\text { Number of Results } \\
\text { Reported }\end{array}$ & $\begin{array}{l}\text { Number Within } \\
\text { Control Limits }^{(a)}\end{array}$ \\
\hline $\begin{array}{l}\text { Metals } \\
\text { silver, aluminum, arsenic, } \\
\text { baron, barium, beryllium, } \\
\text { cadmium, cobalt, chromium, } \\
\text { copper, iron, mercury, } \\
\text { manganese, molybdenum, } \\
\text { nickel, lead, antimony, } \\
\text { selenium, strontium, titanium, } \\
\text { thallium, vanadium, zinc }\end{array}$ & 55 & 55 \\
\hline $\begin{array}{l}\text { Other Inorganic tests } \\
\text { pH, conductivity, total } \\
\text { dissolved solids, total hardness, } \\
\text { calcium, potassium, sodium, } \\
\text { alkalinity, chloride, fluoride, } \\
\text { sulfate, ammonia, nitrate, . } \\
\text { nitrite, chemical oxygen } \\
\text { demand, etc. }\end{array}$ & 79 & 78 \\
\hline $\begin{array}{l}\text { Organic tests } \\
\text { total organic carbon, PCBs, } \\
\text { pesticides, herbicides, volatile } \\
\text { organic constituents, other }\end{array}$ & 113 & 108 \\
\hline
\end{tabular}


Table 4.7. Summary of International Technology Corporation Performance on DOE Quality Assessment Program Samples, 1994

\begin{tabular}{lll} 
Radionuclides & $\begin{array}{l}\text { Number of } \\
\text { Results Reported } \\
\text { for Each }\end{array}$ & $\begin{array}{l}\text { Number } \\
\text { Within Control } \\
\text { Limits }\end{array}$ \\
\cline { 2 - 2 } $\begin{array}{l}\text { tritium, manganese-54, } \\
\text { cobalt-60, cesium-134, } \\
\text { cesium-137, cerium-144, }\end{array}$ & 2 & 2 \\
$\begin{array}{l}\text { americium-241, total } \\
\text { uranium }\end{array}$ & 2 & \\
$\begin{array}{l}\text { strontium-90 } \\
\begin{array}{l}\text { uranium-234, } \\
\text { plutonium-238, } \\
\text { uranium-238, } \\
\text { plutonium-239, curium-244 }\end{array}\end{array}$ & 1 & 1 \\
\hline
\end{tabular}

(a) Control limits are from Sanderson (1985) and Sanderson et al. (1995).

Table 4.8. Summary of International Technology Performance on EPA Intercomparison Program Samples, 1994

\begin{tabular}{|c|c|c|}
\hline Radionuclides & $\begin{array}{l}\text { Number of Results } \\
\text { Reported for Each }\end{array}$ & $\begin{array}{l}\text { Number Within } \\
\text { Control Limits }^{(a)}\end{array}$ \\
\hline plutonium-239 & 1 & 1 \\
\hline ruthenium-106 & 1 & 0 \\
\hline $\begin{array}{l}\text { barium-133, tritium, } \\
\text { zinc- } 65\end{array}$ & 2 & 2 \\
\hline $\begin{array}{l}\text { cobalt-60, strontium-89, } \\
\text { strontium-90, } \\
\text { cesium-134, cesium-137 }\end{array}$ & 4 & 4 \\
\hline $\begin{array}{l}\text { Total alpha, radium-226, } \\
\text { radium-228 }\end{array}$ & 5 & 5 \\
\hline Total beta, total uranium & 5 & 4 \\
\hline
\end{tabular}


Table 4.9. Summary of Ground-Water Surveillance Project Quarterly Blind Spike Determinations

\begin{tabular}{|c|c|c|}
\hline Radionuclide & $\begin{array}{l}\text { Number of Results } \\
\text { Reported }^{(a)}\end{array}$ & $\begin{array}{c}\text { Number Within } \\
\pm 30 \% \text { RPD }^{(b)}\end{array}$ \\
\hline Cobalt -60 & 9 & 9 \\
\hline Cesium-137 & 9 & 9 \\
\hline Iodine-129 & 9 & 9 \\
\hline Strontium-90 & 9 & 9 \\
\hline Technetium-99 & 9 & 9 \\
\hline Plutonium-239 & 9 & 7 \\
\hline Total uranium & 9 & 8 \\
\hline Tritium & 9 & 9 \\
\hline Cyanide & 9 & 7 \\
\hline Chromium & 9 & 6 \\
\hline Nitrate & 9 & 9 \\
\hline Fluoride & 9 & 4 \\
\hline Carbon tetrachloride & 3 & 3 \\
\hline Chloroform & 3 & 3 \\
\hline Trichloroethylene & 3 & 3 \\
\hline
\end{tabular}

(a) Blind samples were submitted in triplicate each quarter and compared to actual spike values.

(b) RPD $=$ Relative Percent Difference 
Table 4.10. Comparison of Quality Assurance Task Force 1994 Intercomparison Samples. PNL analyses by IT are compared against grand mean ( \pm SEM) of participating laboratories.

\begin{tabular}{|c|c|c|c|c|}
\hline Radionuclide & $\begin{array}{l}\text { No. of } \\
\text { Samples }\end{array}$ & $\begin{array}{l}\text { Ground-water well 399-1-16A, } \\
\qquad \mathrm{pCi} / \mathrm{L}\end{array}$ & $\begin{array}{l}\text { No. of } \\
\text { Samples }\end{array}$ & $\begin{array}{c}\text { Ground-water } \\
\text { well } 199-\mathrm{N}-56 \text {, } \\
\mathrm{pCi} / \mathrm{L}\end{array}$ \\
\hline $\begin{array}{l}\text { Tritium } \\
\text { PNL (IT) } \\
\text { Grand Mean }\end{array}$ & $\begin{array}{l}3 \\
19\end{array}$ & $\begin{array}{l}10300 \pm 958 \\
10364 \pm 1034\end{array}$ & $\begin{array}{l}3 \\
19\end{array}$ & $\begin{array}{l}11,000 \pm 346 \\
10,903 \pm 2544\end{array}$ \\
\hline $\begin{array}{l}\text { Cobalt-60 } \\
\text { PNL (IT) } \\
\text { Grand Mean }\end{array}$ & & & $\begin{array}{l}3 \\
17\end{array}$ & $\begin{array}{l}\mathrm{ND}^{(x)} \\
3.3 \pm 3.6\end{array}$ \\
\hline $\begin{array}{l}\text { Strontium-90 } \\
\text { PNL (IT) } \\
\text { Grand Mean }\end{array}$ & & & $\begin{array}{l}3 \\
16\end{array}$ & $\begin{array}{l}272 \pm 50 \\
232 \pm 31\end{array}$ \\
\hline $\begin{array}{l}\text { Uranium-234 } \\
\text { PNL (IT) } \\
\text { Grand Mean }\end{array}$ & $\begin{array}{l}3 \\
13\end{array}$ & $\begin{array}{l}73.4 \pm 9.1 \\
65.9 \pm 11.5\end{array}$ & & \\
\hline $\begin{array}{l}\text { Uranium-235 } \\
\text { PNL (IT) } \\
\text { Grand Mean }\end{array}$ & $\begin{array}{l}3 \\
13\end{array}$ & $\begin{array}{l}2.48 \pm 3.0 \\
3.0 \pm 1.5\end{array}$ & . & . \\
\hline $\begin{array}{l}\text { Uranium-238 } \\
\text { PNL (IT) } \\
\text { Grand Mean }\end{array}$ & $\begin{array}{l}3 \\
13\end{array}$ & $\begin{array}{l}57.8 \pm 1.9 \\
53.9 \pm 7.5\end{array}$ & & \\
\hline $\begin{array}{l}\text { Total Uranium } \\
\text { PNL (IT) } \\
\text { Grand Mean }\end{array}$ & $\begin{array}{l}3 \\
16\end{array}$ & $\begin{array}{l}94.4 \pm 5.9 \\
125.9 \pm 55.4\end{array}$ & & - \\
\hline
\end{tabular}

(a) Below MDC. 


\title{
5.0 Extent of Ground-Water Contamination at the Hanford Site
}

\author{
- P.E. Dresel
}

Ground-water contamination at the Hanford Site has been related to a number of sources within the operational areas. In some cases, several potential sources such as cribs, trenches, or other disposal facilities may contribute to a particular ground-water plume, and their contributions cannot be readily distinguished. In these cases, the sources are discussed together. The sources discussed are grouped by operational area. Additional discussions are included for the potential receptor areas in the Richland North Area and 400 Area and for the uppermost basalt confined aquifer system. Wells discussed in this section are located on Plate 2. Tritium, nitrate, and iodine $=129$ concentrations in wells and plume contours are shown in Plates 3,4, and 5, respectively. The distributions of tritium, nitrate, and iodine129 are generalized in Figures 5.1, 5.2, and 5.3. Figures for other constituent distributions are presented for specific areas as discussed below.

The volume of ground water impacted by Hanford Site activities can be estimated based on the contaminant distributions presented in this report. However, the estimate is subject to considerable uncertainty due to a lack of knowledge of the thickness of contaminant plumes throughout the site. In addition, the porosity of the aquifer is not well-characterized for the purpose of this calculation, the porosity is assumed to be 30 percent. Based on liquid data, the plume thickness is estimated to be $20 \mathrm{~m}$ except in the 100,300, and 1100 Areas, where it is estimated to be $5 \mathrm{~m}$. Therefore, the total volume of contaminated ground water is approximately $1,400,000,000 \mathrm{~m}^{3}$.

\subsection{0-BC Area}

The 100-BC Area is farthest upstream of the reactor areas along the Columbia River. The B Reactor was the world's first production nuclear reactor. It was placed in service in 1944 and operated until 1968. The C Reactor operated from 1952 to 1969 . The B and C reactors, like all other production reactors onsite except the $\mathrm{N}$ Reactor, used a single-pass system for cooling water. After passing through the reactor, the cooling water was discharged to the Columbia River. A considerable amount of disposal of liquid to the ground in the past is indicated by historical water-table maps showing ground-water mounding in the 1950s. Currently, strontium-90 is the only constituent detected at levels above the MCL in the 100-BC Area. However, past data show tritium levels greater than the MCL. In addition, technetium-99, which is found at levels well below the MCL, is possibly related to disposal activities in the 100-BC Area.

The 100-BC Area ground water is addressed as part of the 100-BC-5 Operable Unit and was the subject of a CERCLA-related Limited Field Investigation (DOE-RL 1993a). The report of this activity summarized the known disposal facilities that may have affected the ground water; the results of sampling were screened based on regulatory and risk-based criteria. The report recommended that no expedited response action or interim remedial measures be undertaken. 


\section{Tritium}

Tritium levels in the 100-BC Area are currently below the MCL (Plate 3). The maximum tritium concentration detected in 1994 was $14,800 \mathrm{pCi} / \mathrm{L}$ in Well 199-B2-13. Tritium levels from Well 699-65-72, which is located approximately $2 \mathrm{~km}$ southeast of the 100-BC Area, are higher, reaching a maximum of $26,200 \mathrm{pCi} / \mathrm{L}$ in the April 1994 sample. It is possible that ground-water mounding from past disposal practices at the 100-BC Area resulted in some flow to the southwest. Hydraulic gradients are fairly small in this part of the site, and there is some suggestion that the Columbia River recharges the upper unconfined aquifer upstream from the 100-BC Area. A more probable source of tritium at Well 699-65-72 is the plume in the gap between Gable Mountain and Gable Butte. This plume originated in the 200 Areas. The network of wells available to monitor the ground water in this vicinity is inadequate to determine the source of tritium in Well 699-65-72.

\section{Strontium-90}

Strontium-90 was detected in the majority of 100-BC Area wells monitored in 1994. The distribution of strontium-90 is shown in Figure 5.4. The highest levels of strontium- 90 are found downgradient of the 116-B-1 and 116-C-1 liquid overflow trenches. These trenches received cooling water contaminated with relatively high concentrations of radionuclides after fuel cladding failures. The 116-B-11 and 116-C-5 Retention Basins may have also contributed strontium to ground water in this area. The maximum concentrations were above the $8 \mathrm{pCi} / \mathrm{L} \mathrm{MCL}$, ranging up to $56.7 \mathrm{pCi} / \mathrm{L}$ in Well 199-B3-46. In 1994, strontium-90 concentrations in this well ranged up to $150 \mathrm{pCi} / \mathrm{L}$. Strontium-90 at concentrations above the MCL is also found in wells near the B Reactor Building. . Liquid waste disposal sites in this area received contaminated water from the B Reactor Fuel Storage Basin, contaminated cooling water, and water from decontamination activities. Figure 5.4 indicates that ground water containing strontium-90 at levels above the MCL is discharging to the Columbia River in the 100-BC Area. The extent of strontium-90 in ground water to the east of the 100-BC Area cannot be defined by the current monitoring network.

\section{Technetium-99}

Technetium-99 is detectable at levels well below the $900 \mathrm{pCi} / \mathrm{L}$ MCL in the $100-\mathrm{BC}$ Area. The maximum technetium-99 detected in this area was $98.9 \mathrm{pCi} / \mathrm{L}$ in well $199-\mathrm{B3}-46$. It appears that there may be a technetium-99 source from liquid waste disposal sites near the B Reactor. Concentrations of technetium-99 are generally remaining stable or decreasing slightly from previous years. The technetium- 99 is detected a considerable distance to the east of the 100-BC Area, toward the 100-K Area and Gable Mountain. The distribution indicates that there is probably an additional source from the 200 Areas.

\subsection{0-D Area}

Tritium, strontium-90, nitrate, and chromium are found at levels greater than the MCL in the 100-D Area. The D Reactor operated from 1944 to 1967 . The DR Reactor, also located in the 
100-D Area, operated from 1950 to 1965. The chromium plume from the 100-D Area has highest concentrations near the D-Reactor building and extends east into the 600 Area and possibly as far as the 100-H Area.

A small part of the 100-D Area in the vicinity of the 100-D Ponds is the subject of RCRA monitoring (Hartman 1995a). The 100-D Ponds were used for the discharge of effluent from the 183-D Filter Plant and 189-D Building engineering testing laboratories. Discharge to the 100-D Ponds was terminated in 1994. Potential impacts on ground water from the 100-D Ponds was assessed by Alexander (1993). Sampling for this project began in 1992.

The ground-water impacts of 100-D Area past practices are being investigated under the 100-HR-3 CERCLA project. A limited field investigation was undertaken for this CERCLA operable unit (DOE-RL 1993a). This investigation summarized the known disposal facilities that may have impacted ground water and screened the results of sampling based on regulatory and risk-based criteria.

The water-level contours shown in Plate 1 indicate that ground-water flow in the 100-D Area is approximately to the northeast, nearly parallel to the Columbia River. However, on a local scale, ground-water flow in the western part of the 100-D Area is directly toward the Columbia River. Discharge to the river in the 100-D Area is strongly infiuenced by the river stage. As the ground water approaches the river, changes in river stage affect its flow rate and direction. Ground water mounds from past disposal also affect flow directions and apparently produced flow generally to the east from parts of the 100-D Area.

\section{Tritium}

Tritium in the 100-D Area is found at concentrations greater than the MCL in several wells in the vicinity of the 100-DR Reactor (Plate 3). The maximum value for tritium reported in 1994 was $69,000 \mathrm{pCi} / \mathrm{L}$ in Well 199-D5-17. Many of the wells with tritium above the MCL were installed in 1992, so long-term trend data are unavailable. Tritium detected at levels less than the MCL in . 600 Area wells northeast of the 100-D Area may also be related to 100-D Area disposal activities.

The zone of low tritium concentrations found adjacent to the Columbia River in the 100-D Area suggests that disposal of non-radioactive waste to the 100-D Ponds has reduced ground-water concentrations in the immediate area of the ponds (Hartman 1995a). The dilution effect of the ponds appears to extend away from the river to some distance past Well 199-D5-13, which is the "upgradient" well for the 100-D Ponds RCRA unit. Concentrations of nitrate are currently increasing in Well 199-D5-13 in response to the termination of discharge at the ponds (Hartman 1995a) indicates the zone around the 100-D Ponds is starting to become impacted by contamination from other parts of the Area.

\section{Strontium-90}

Strontium-90 was found in the 100-D Area at levels greater than the MCL only in Well 199-D5-12, where the maximum concentration measured in 1994 was $44 \mathrm{pCi} / \mathrm{L}$. This well is located adjacent to the D Reactor Building and has had fairly constant strontium-90 levels since the earliest measurement 
recorded in the HEIS database in 1987. Strontium-90 was also detected near the 116-D-7 and * 116-DR-9 Retention Basins. The maximum levels reported near the retention basins were just under the MCL.

\section{Nitrate}

Nitrate was found at concentrations greater than the MCL over parts of the 100-D Area (Plate 4). Many of the nitrate data in this area were collected for CERCLA characterization activities, and the analytical method used combined nitrate plus nitrite as nitrogen concentration. Past data from this area indicate that nitrate will dominate the resulting value because of the highly oxidizing nature of the ground water. For the purposes of this report, all nitrate plus nitrite nitrogen was assumed to be present as nitrate, and the results were converted to milligrams per liter as nitrate by multiplying by 4.5. The nitrate plume is found in the vicinity of the reactor buildings. Another small plume appears to originate in the vicinity of the 116-D-7 and 116-DR-9 Retention Basins and 116-DR-1 and 116-DR-2 Disposal Trenches near the river.

\section{Chromium}

The highest chromium concentrations in the 100-D Area were found in the vicinity of the D-Reactor Building, with values up to a maximum of $1,760 \mu \mathrm{g} / \mathrm{L}$ of chromium in filtered samples from Well 199-D5-15 in 1994. Chromium levels were similar in filtered and unfiltered samples from the 100-D Area, indicating that the bulk of the chromium is in solution and probably mobile. The chromium plume exterids northeast into the 600 Area (Figure 5.5). A possible source of the chromium is the disposal of large inventories of chromium waste to the 116-D-1A and 116-D-1B Trenches in the 1950s and 1960s (Stenner et al. 1988). Alternatively, the source may have been leakage from the sodium dichromate distribution system (DOE-RL 1993a). Sodium dichromate was used for corrosion control in the single-pass-cooling reactors.

The extent of chromium from the 100-D Area reaching into the 600 Area is not well defined. The ground-water flow in the eastern part of the 100-D Area is not directly towards the river but to the northeast as discussed in Section 3.3. Past discharges in the 100-D area would have increased flow to the east and northeast from that seen today. There are few wells in the 600 Area to the east of the 100-D Area. Although concentrations of chromium in Well 699-96-49 are less than the MCL, Wells 699-96-43 and 699-97-43 further east contain chromium at levels greater than the MCL. Wells 699-96-43 and 699-97-43 are located upgradient of the 100-H Area under present flow conditions. The extent of the 100-D Area chromium plume to the southwest is also uncertain. Well 699-87-55 to the southwest of the 100-D Area contained $60 \mu \mathrm{g} / \mathrm{L}$ of chromium in a 1994 sample. Chromium in ground water at this location may be related to $100-\mathrm{D}$ Area disposal.

\section{$5.3100-F$ Area}

The F Reactor operated from 1945 to 1965 . Interpretation of the ground-water chemistry in the $100-F$ Area is limited by the sparse monitoring-well coverage. This is a particular problem for identifying the extent of trichloroethylene (T.CE) and nitrate which may have sources upgradient of the $100-\mathrm{F}$ Area. Other ground-water contamination in the 100-F Area includes strontium-90 in the vicinity 
of the 116-F-14 Retention Basins, uranium near the F-Reactor building, and tritium near the 118-F-1 Burial Ground. Nitrate is found at levels above the MCL over much of the southern part of the 100-F Area and in the 600 Area to the south.

The amount of information on ground-water quality in the 100-F Area has improved due to site characterization of the 100-FR-3 CERCLA operable unit. Thirteen new wells were installed in the 100-F Area for CERCLA-related characterization activities. No RCRA projects are located in the 100-F Area.

\section{Tritium}

Tritium is found in the 100-F Area at concentrations greater than the MCL in Well 199-F8-3 in the vicinity of the 118-F-1 Burial Ground (Plate 3). The maximum value for tritium reported for this well in 1994 was $98,300 \mathrm{pCi} / \mathrm{L}$. This plume extends east toward the Columbia River.

\section{Strontium-90}

Strontium-90 was detected at levels above the MCL in wells in the eastern part of the 100-F Area (Figure 5.6). The maximum concentration detected in 1994 was $20.5 \mathrm{pCi} / \mathrm{L}$ in Well 199-F5-1. The concentration reported for Well $199-\mathrm{F} 5-3$ of $18.4 \mathrm{pCi} / \mathrm{L}$ was approximately ten times lower than concentrations found in previous years and may be in error. The source appears to be waste disposal at or near the 116-F-14 Retention Basins, and the plume extends to the Columbia River.

\section{Uranium}

Total uranium measurements for the 100-F Area were made for samples from selected wells by the Ground-Water Surveillance Project. Uranium analyses for the 100-F Area performed by alpha spectrometry to meet CERCLA requirements were reviewed during this assessment and found to be in agreement with the total uranium values plotted in Figure 5.7 and with values from other years.

Uranium continues to be detected at levels above the proposed $\mathrm{MCL}(20 \mu \mathrm{g} / \mathrm{L})$ in Wells 199-F8-1 and 199-F8-2. The 1994 sample from Well 199-F8-1 contained $133 \mu \mathrm{g} / \mathrm{L}$ total uranium. Well 199-F82 contained $33 \mu \mathrm{g} / \mathrm{L}$ (calculated from uranium isotopic analyses, thus not shown on Figure 5.7). These wells are located near the F-Reactor building.

\section{Chromium}

Chromium levels detected in several wells in the 100-F Area were somewhat erratic, with levels greater than the $50 \mu \mathrm{g} / \mathrm{L}$ State MCL in at least one filtered sample from Wells 199-F5-1, 199-F5-6, and 199-F8-3. Samples from these wells in previous years were all below the MCL. One sample from Well 199-F5-46 was above the federal and the state MCL for chromium in 1994 (366 $\mu \mathrm{g} / \mathrm{L})$; however, chromium concentrations in the other sample were below both standards in the other sample collected in 1994. This well has been sampled since December.1992, and values for filtered chromium in 1992 and 1993 ranged from 70 to $291 \mu \mathrm{g} / \mathrm{L}$. The distribution of chromium in the 100-F Area, based on average concentrations for 1994 samples; is shown in Figure 5.8. 


\section{Trichloroethylene}

TCE has been detected at concentrations above the MCL in the 100-F Area and in surrounding parts of the 600 Area (Figure 5.9). The maximum TCE level detected in 1994 in the 100-F Area was . $25 \mu \mathrm{g} / \mathrm{L}$ in Well 199-F7-1, in the southwestern corner of the area. TCE is also detected at levels generally less than the MCL in other wells in the 100-F Area. The TCE concentration in Well 699-77-36, to the west and upgradient of the 100-F Area, was $25 \mu \mathrm{g} / \mathrm{L}$ in the 1994 sample. TCE levels in Well 699-77-36 have been fairly constant with time. Thus, it is probable that the TCE source is in the 600 Area but has not yet been identified. Efforts related to the CERCLA 100-IU-2 Operable Unit will address potential sources west of the 100-F Area.

\section{Nitrate}

Nitrate is found at levels above the MCL over much of the 100-F Area and the 600 Area to the south (Plate 4). The maximum concentration detected in 1994 was $110 \mathrm{mg} / \mathrm{L}$ in Well 199-F7-3. The source of nitrate found in the 600 Area south of the 100-F Area has not been established. The nitrate plume is defined by relatively few wells so its extent is uncertain. Past disposal in the 100-F Area is one possible source.

\subsection{0-H Area}

The H Reactor operated from 1945 to 1965 . Major ground-water contaminants in the $100-\mathrm{H}$ Area include strontium-90, technetium-99, uranium, nitrate, and chromium. As discussed below, chromium may come from a source upgradient of the $100-\mathrm{H}$ Area as well as from local sources. .

The 183-H Solar Evaporation Basins are monitored by the RCRA program (Hartman 1995b). These Basins were in active use for waste storage from 1973 through 1985. Ground-water characterization of the 100-H Area is being conducted by the 100-HR-3 CERCLA project, which published a limited field investigation report in 1993 (DOE-RL 1993c): The investigation screened ground-water analyses to determine whether interim remedial measures should be initiated.

An increase in concentrations of constituents in a number of wells noted in the 100-H Area in 1993 continued in 1994 (Hartman 1995b). The constituents with increased concentrations include chromium, nitrate and sulfate.

\section{Chromium}

Chromium was detected at levels greater than the MCL over a large part of the 100-H Area. Chromium was usually found at similar concentrations in both filtered and unfiltered samples, indicating that the chromium is mobile. Most wells in the 100-H Area are completed across, or near, the water table. The distribution of chromium for the 100-H Area, shown in Figure 5.5, is the distribution for these shallow wells. The highest concentration of filtered chromium detected in the 100-H Area in 1994 was $300 \mu \mathrm{g} / \mathrm{L}$ in one sample from Well 199-H4-3. Other samples collected from this well in 1994 ranged from 66 to $130 \mu \mathrm{g} / \mathrm{L}$. 
Potential chromium sources in the 100- $\mathrm{H}$ Area include disposal of sodium dichromate to the ground near the reactor building and to the 107-H liquid waste trench, as well as chromium in acid wastes stored in the 183-H Solar Evaporation Basins (Peterson and Connelly 1992). Hall (1989) presented arguments that the contamination from the 183-H Solar Evaporation Basin is superimposed on a larger contaminant plume from disposal of sodium dichromate during reactor operations. Peterson and Connelly also suggest the possibility of an ùgradient source affecting $100-\mathrm{H}$ Area chromium concentrations.

Chromium in the 100-H Area is also detected in Well 199-H4-12C, which is completed in the middle part of the unconfined aquifer. Well 199-H4-12C continues to contain consistently high concentrations of chromium in both filtered and unfiltered samples. The maximum concentration detected in Well 199-H4-12C in 1994 was $290 \mu \mathrm{g} / \mathrm{L}$. Well 199-H3-2C, which is also completed in the middle of the unconfined aquifer and is upgradient of the 183-H solar evaporation basins, contains only low concentrations of chromium. The completion for Well 199-H3-2C is at a somewhat lower elevation than Well 199-H4-12C and may not be monitoring the same zone. Chromium levels have been decreasing in wells in nest 199-H4-12, which monitor the upper part of the unconfined aquifer (Wells 199-H4-12A and 199-H4-12B). Concentration trends for filtered chromium in the 199-H4-12 well nest are shown in Figure 5.10. There are other differences in the chemical signatures for Well 199-H4-12C versus Wells 199-H4-12A and 199-H4-12B. The upper aquifer wells contain technetium99 (discussed below), whereas technetium-99 is not detected in the middle-unconfined Well 199-H412C. The distinct chemistry of Well 199-H4-12C with respect to the shallower wells suggests an upgradient source for the chromium. Peterson (1994), however, suggests that the chromium may result from corrosion of stainless steel in the well completion.

Chromium was also detected in parts of the 600 Area adjacent to the $100-\mathrm{H}$ Area. The 600 Area wells closest to the 100-H Area, Wells 699-96-43 and 699-97-43, contained a maximum of $160 \mu \mathrm{g} / \mathrm{L}$ and $170 \mu \mathrm{g} / \mathrm{L}$, respectively, in 1994. These values are similar to those of previous years and support the possible presence of an upgradient source. The most probable upgradient source is the 100-D Area. Elevated chromium levels in the 100-D Area are discussed above. Flow from the 100-D Area to the 100-H Area would result from the gradient across the "horn" of the Columbia River and possibly from past ground-water mounding caused by disposal practices in the 100-D Area. The sodiumdichromate barrel disposal site in the 100-IU-4 CERCLA Operable Unit is farther south. Chromium is below the MCL in samples from wells immediately downgradient of the disposal site.

\section{Technetium-99}

Elevated technetium-99 activities were found in several wells in the 100-H Area, although only samples from Wells 199-H4-3 and 199-H4-4, downgradient from the 183-H Solar Evaporation Basins, had levels above the MCL (Figure 5.11). The maximum technetium-99 activity detected in the $100-\mathrm{H}$ Area in 1994 was $2,070 \mathrm{pCi} / \mathrm{L}$ in Well 199-H4-3. Technetium-99 concentrations in Well $199-\mathrm{H} 4-4$ in 1994 ranged from 285 to $1,190 \mathrm{pCi} / \mathrm{L}$. The large fluctuations are apparently related to river-stage influences. Well 199-H4-3 is farther from the river but concentrations have fluctuated greatly with time (Figure 5.12). Technetium is transported in ground water as an anionic species, which is not retarded significantly by adsorption onto sediments. The technetium- 99 trend from the 199-H4-12 wells is shown in Figure 5.13. This figure illustrates the trend of decreasing technetium-99 in the upper unconfined aquifer Wells (199-H4-12A and 199-H4-12B). By contrast, technetium-99 was never detected in the middle-unconfined aquifer Well 199-H4-12C. This provides evidence that the 
chromium detected in Well 199-H4-12C is not related to the 183-H Solar Evaporation Basins. If the chromium had a local source, then the other mobile local constituents such as technetium-99 should also be detected. It is possible that a different chromium source within the $100-\mathrm{H}$ Area containing no technetium-99 was present, possibly resulting from disposal near the $\mathrm{H}$ Reactor Building. However, this location is relatively far from Well $199-\mathrm{H} 4-12 \mathrm{C}$, and any plume from the $\mathrm{H}$ Reactor Building would probably have been farther south, flowing toward the river.

\section{Uranium}

Uranium continues to be detected at levels greater than the proposed MCL ( $20 \mu \mathrm{g} / \mathrm{L})$ in Wells 199 H4-3 and 199-H4-4, which are downgradient of the 183-H Solar Evaporation Basins and have historically shown elevated uranium concentrations (Figure 5.14). The maximum uranium concentration detected in 1994 was $93.9 \mu \mathrm{g} / \mathrm{L}$ in Well 199-H4-3. Concentrations of uranium and other constituents in these wells fluctuate, which may be attributable to changes in Columbia River stage.

\section{Strontium-90}

Strontium-90 was detected at levels greater than the MCL in 1994 in samples from Well 199-H4-13 in the 100-H Area (Figure 5.15). The maximum concentration detected in this well in 1994 was 28 $\mathrm{pCi} / \mathrm{L}$. This well is located downgradient of the 107-H Retention Basin. Other wells located near the 107-H Retention Basin and 107-H.Liquid Waste Trench were not sampled for strontium-90 in 1994 but had strontium-90 levels greater than the MCL in 1993. Strontium-90 was not monitored in most 100-H Area wells between 1988 and 1992 . Thus, little is known regarding the history of strontium-90 in 100-H Area ground water.

\section{Nitrate}

Nitrate concentrations lower than the MCL are found through most of the 100-H Area. Concentrations above the MCL were detected in wells between the 183-H Solar Evaporation Basin and the Columbia River (Plate 4). The maximum concentration detected in the 100-H Area in 1994 was $480 \mathrm{mg} / \mathrm{L}$ in Well 199-H4-3. Nitrate concentrations increased greatly in a number of wells in the . 100-H Area in 1993. The cause of this incirease is unclear, but it is correlated with increases in turbidity, chromium, sulfate, and sodium (F'eterson 1994). A number of wells continued to show higher levels of nitrate in 1994 (Hartman 1995a).

\subsection{0-K Area}

The K-East and K-West reactors in the 1.00-K Area were operated from 1945 to 1965 . Tritium in the 100-K Area had reached levels greater than the DCG in 1993 but remained below the DCG for all 1994 samples. Other constituents detected in the 100-K Area include strontium-90, antimony-125, carbon-14, nitrate, and chromium. Potentially important sources in the 100-K Area are the Liquid Waste Disposal Trench, the K-East fuel storage basin, the K-East and $\mathrm{K}$-West french drains, and other . disposal sites near the reactor buildings. The $\mathrm{K}$-West and $\mathrm{K}$-East fuel storage basins have been used for storing irradiated fuel elements from the $100-\mathrm{N}$ reactor since the late 1970 s. Facilities in the $100-\mathrm{K}$ Area are described in Carpenter and Cote (1994). 
In addition to the Ground-Water Surveillance Project's sampling, ground-water sampling for selected constituents is conducted in the 100-K Area by the Operational Monitoring Program. The Operational Monitoring Program mainly addresses the potential impacts of fuel-storage basin leaks. Characterization is also carried out by the 100-KR-4 Operable Unit CERCLA project. A CERCLArelated limited field investigation recommended that interim remedial measures be pursued in this area (DOE-RL 1993d).

\subsubsection{K-East Reactor and Surroundings}

Contamination found in the vicinity of the K-East reactor building includes some of the highest ground-water tritium concentrations found on the site. Carbon-14, strontium-90, antimony-125, and nitrate are also found in this vicinity.

Tritium levels near the K-East Reactor are dramatically higher than the surrounding levels (Plate 3). An unusual occurrence report filed in February 1993 (Occurrence Report Number RL-WHCKBASINS-1993-0007) reported a potential leak in the K-East Fuel Storage Basin. The K-East basins contain unencapsulated irradiated fuel elements from the $\mathrm{N}$ Reactor. In 1993, the tritium concentration in the basin ranged from $2,090,000$ to $3,360,000 \mathrm{pCi} / \mathrm{L}$. Past tritium values in the basin were higher, with values between $4,000,000$ and $6,000,000 \mathrm{pCi} / \mathrm{L}$ common from 1984 to 1989 . Plutonium in the basin ranged from 6,150 to $246,000 \mathrm{pCi} / \mathrm{L}$ in 1993 . Strontium-90 ranged from 348,000 to $4,810,000 \mathrm{pCi} / \mathrm{L}$. Cesium-137 concentrations ranged from 882,000 to $24,900,000 \mathrm{pCi} / \mathrm{L}$.

The maximum tritium concentration detected in 1994 in the $100-\mathrm{K}$ Area was $1,040,000 \mathrm{pCi} / \mathrm{L}$ in Well 199-K-30. The tritium concentration in this well was above the $2,000,000 \mathrm{pCi} / \mathrm{L}$ DCG in April and May 1993. The tritium concentration in Well 199-K-27 was also high, ranging up to $628,000 \mathrm{pCi} / \mathrm{L}$. Wells $199-\mathrm{K}-28$ and 199-K-29, located between Wells 199-K-27 and 199-K-30, show lower tritium concentrations, with 1994 maxima of 4,310 and $25,800 \mathrm{pCi} / \mathrm{L}$, respectively. The distribution of concentrations in wells near the K-East Reactor Building suggest a very narrow plume or plumes. The contours shown in Plate 3 have generalized the tritium distribution in this area, showing one plume encompassing all 4 wells. The narrowness of the plume is also suggested by the variability of the sample values; minor changes in gradient or the amount of pumping during sampling could have a major effect on measured concentrations. However, the extent of tritium to the east of the reactor and downgradient is not well-defined.

The tritium trends in wells near the K-East Reactor also show different patterns, suggesting separate sources for the tritium found in Wells 199-K-27 and 199-K-30. The trend for Well 199-K-30 shown in Figure 5.16 indicates that the levels have been high since at least 1981. However, the trend for Well 199-K-27 (Figure 5.17) shows an increase in concentration in 1989 and again in 1993. This suggests that the tritium in Well 199-K-30 may result from a different, older source. Additional chemical differences between the two wells include carbon-14, antimony-125, and nitrate concentrations, as discussed below.

The 100-KR-4 limited field investigation report indicates that approximately $200 \mathrm{Ci}$ of tritium and of carbon-14 were discharged to the 119-KW-1 and 119-KE-1 french drains during reactor operations (DOE-RL 1993d). Well 199-K-30, located approximately downgradient of the 119-KE-1 french drain, contained a maximum of $20,000 \mathrm{pCi} / \mathrm{L}$ of carbon- 14 in 1994 which is 10 times the MCL of 
$2,000 \mathrm{pCi} / \mathrm{L}$. The drain is thus a potential alternative or addition to the fuel storage basin as a source of tritium in this well. The french drains received condensate from experimental use of inert gases in the reactor operations. Both tritium and carbon- 14 could be produced through irradiation of the inert gas, depending on which gases were used: The distribution of carbon-14. in the 100-K Area is shown in Figure 5.18.

The chemical signature found in Well 199-K-27 is quite different from that in Well 199-K-30. . Well 199-K-27. was the only well in the 100-K Area in which antimony-125 was detected, with a maximum concentration of $55.6 \mathrm{pCi} / \mathrm{L}$. Antimony- 125 is a gamma-emitter with a half-life of 2.76 years. The decreasing concentrations of reported antimony-125 in ground water is largely due to radioactive decay. The antimony-125 trend for Well 199-K-27 shown in Figure 5.19 indicates that antimony-125 was present even before the increase in tritium concentrations measured in 1989.

The maximum nitrate concentration detected in the 100-K Area in 1994 was $110 \mathrm{mg} / \mathrm{L}$ in one sample from Well 199-K-30. The nitrate source probably is not the K-East basin. Nitrate found in wells near the 116-K-1 Crib and 116-K-2 Liquid Waste Disposal Trench may represent the downgradient portion of the nitrate plume impacting Well 199-K-30 (Plate 4).

Strontium-90 is found at levels above the MCL in Well 199-K-109A, which was drilled in 1994. The maximum concentration reported for this well in 1994 was $803 \mathrm{pCi} / \mathrm{L}$. This represents a previously unrecognized strontium-90 plume near the K-East Reactor. This well is located near the 116-KE-3 french drain that received overflow from the K-East fuel storage basin. Another potential source for the strontium-90 is the 116-KE-2. Crib, which received strontium-90 bearing wastes (Stenner et al. 1988). The strontium-90 distribution in the 100-K Area is shown in Figure 5.20.

\subsubsection{K-West Reactor and Surroundings}

Tritium concentrations are considerably lower near the K-West Reactor than near the K-East Reactor (Plate 3) but a broad area around the K-West Reactor contains considerable carbon-14 (Figure 5.18). The maximum carbon-14 detected near the K-West.Reactor in 1994 was $20,600 \mathrm{pCi} / \mathrm{L}$ in Well 199-K-106A. The MCL for carbon-14 is $2,000 \mathrm{pCi} / \mathrm{L}$. Well $199-\mathrm{K}-106 \mathrm{~A}$ was installed to monitor the $116-\mathrm{KW}-1 \mathrm{Crib}$. It thus serves an analogous function to Well 199-K-30 for the 116-KE-1 Crib.

Strontium-90 is also found at levels above the MCL in the vicinity of the K-West Reactor (Figure 5.20). The maximum concentration detected in 1994 samples was $37.4 \mathrm{pCi} / \mathrm{L}$ in Well 199-K-34. This well is near the 116-K.W-2 french drain that served as an overflow weir for the $\mathrm{K}$-West fuel storage basin.

Chromium is found at levels above the MCL in filtered samples from wells near the K-West Reactor (Figure 5.21). The maximum concentration detected in 1994 was $190 \mu \mathrm{g} / \mathrm{L}$ in Well 199-K-107A. Chromium levels detected in unfiltered samples are similar to those in filtered samples. A nitrate plume extends from the K-West Reactor vicinity to the Columbia River (Plate 4). 


\subsubsection{6-K-2 Liquid Waste Disposal Trench.}

The 116-K-2 Liquid Waste Disposal Trench (sometimes called "the mile-long trench") received contaminated cooling water from both the K-East and K-West reactors. Discharge from the reactors was routed through the 116-KE-4 and 116-KW-3 retention basins. During fuel element failures, the water was routed to the 116-K-1 Crib and the 116-K-2 Trench. As shown in Figure 5.19, strontium-90 is found at levels above the MCL near the Liquid Waste Disposal Trench. Chromium is also found at levels above the MCL in this vicinity although, as shown on Figure 5.21, chromium is also found near the K-East filtration plant, which is generally upgradient.

\subsection{0-N Area}

The N Reactor was the last of the production reactors, to be built onsite and operated from 1963 to 1987. The $\mathrm{N}$ Reactor was unique among the Hanford reactors in that it was designed for both plutonium production and steam generation for electric power production. In addition, the $\mathrm{N}$ Reactor recycled cooling water, whereas the other reactors used single-pass cooling. As a result, smaller quantities of water were disposed from the $N$ Reactor but radionuclide concentrations appear to have been higher because of increased residence time in the reactor and reduced dilution. Ground-water contamination in the 100- $\mathrm{N}$ Area is considered in Sections 5.6.1 and 5.6.2. Section 5.6.1 considers the contamination related to the $1301-\mathrm{N}$ and $1325-\mathrm{N}$ Liquid Waste Disposal Facilities (LWDFs). The highest concentrations of strontium- 90 found on the Hanford Site are associated with these disposal areas. Section 5.6.2 considers contamination that appears to be related to the 1324-N/NA Surface Impoundment and Percolation Pond.

The 1301-N LWDF, 1325-N LWDF, and 1324-N/NA site are monitored by the RCRA groundwater program (Hartman 1994). Alexander and Johnson (1993) have published a ground-water impact assessment for the 1325-N LWDF. The 100-N Area ground water is included in the 100-NR-2 CERCLA operable unit. For the purposes of the discussion below, the plumes from the LWDFs will be discussed together, and the reasonably distinct plumes from the 1324 site will be considered separately. Releases from other facilities may have impacted ground water in the 100-N Area but the impacts are considered under the CERCLA program, and present data indicate they are less significant.

Ground-water flow in the 100-N Area is generally toward the Columbia River, with a strong component to the north in the downstream direction of the river. The flow rate and direction in areas near the Columbia River are affected by variation in the river stage. The area of the unconfined aquifer that is subject to recharge from river-stage fluctuations is not completely defined. The hydrogeology of the 100-N Area was recently addressed by Hartman and Lindsey (1993).

\subsubsection{1-N and 1325-N Liquid Waste Disposal Facilities}

Primary disposal locations in the 100-N Area were the 1301-N LWDF and the 1325-N LWDF. The 1301-N LWDF was the primary disposal facility for the N Reactor from 1963 to 1985. Radioactive fission and activation products were received by this facility. The 1325-N LWDF was constructed in 1983 and used until late 1991, replacing the 1301-N LWDF. No wastes are currently discharged to these facilities (Hartman 1995b). 


\section{Strontium-90}

Strontium-90 is the constituent of greatest concern at the $100-\mathrm{N}$ Area. This is the only one of the 100 Areas where strontium- 90 exceeds the $\mathrm{DCG}$ of $1,000 \mathrm{pCi} / \mathrm{L}$. The strontium plume in the 100-N Area is shown in Figure 5.22.

The two LWDFs are apparently the major sources of the strontium-90 plume. The maximum strontium-90 concentration detected in the $100-\mathrm{N}$ Area in 1994 was $4,030 \mathrm{pCi} / \mathrm{L}$ in Well 199-N-67, located between the 1301-N LWDF and the Columbia River. The trend for strontium-90 in Well 199-N-67 is shown in Figure 5.23. Although concentrations have decreased markedly since 1989, the decline has slowed, resulting in continued levels well above the DCG. The spread of the strontium-90 plume northward in the 1980 s is illustrated by the trend data from Well 199-N-14 (Figure 5.24). The strontium- 90 concentrations in this well have fluctuated but generally have remained above the DCG since 1989 except for a period between 1990 and 1992. Wells farther northeast do not show detectable strontium-90. The steady levels indicate that the plume is not spreading or contracting at a discernible rate at this time.

Ground water containing strontium-90 at levels above the MCL is discharging to the Columbia River in the 100-N Area. Strontium-90 discharge through springs along the Columbia River presents a potential route of exposure of the public. Potential doses to the public from this and other routes are discussed in Hanf and Dirkes (1995).

\section{Cobalt-60}

Cobalt -60 has been found in the past in a few wells in the 100-N Area. In 1994, one well had a concentration above the MCL of $100 \mathrm{pCi} / \mathrm{L}$ for cobalt -60 . The cobalt- 60 concentration detected, in Well 199-N-33, was $732 \mathrm{pCi} / \mathrm{L}$. The high concentrations of cobalt-60 in this well appears to be related to high concentrations of suspended solids in the samples. Although turbidity was not reported for the 1994 sample, the sample for 1993 had extremely high measured turbidity. The water level in this well has declined to near the bottom of the screen, which is apparently the reason for the high levels of suspended solids. Well 199-N-49 contained high levels of cobalt-60 (and other radionuclides that are strongly sorbed) in 1993, but was unsampleable in 1994. Samples collected for radionuclide analysis were not filtered before analysis. The analysis from these wells is therefore not considered representative of the concentrations that are mobile in ground water, although they do indicate that cobalt -60 remains present in aquifer sediments. Cobalt -60 has a half-life of 5.3 years. The concentration sorbed onto sediment and in ground water will continue to decrease through radioactive decay.

\section{Tritium}

Tritium was found at concentrations greater than the MCL in the northern part of the $100-\mathrm{N}$ Area and extending into the 600 Area to the north and east (Plate 3). The maximum tritium level detected in the $100-\mathrm{N}$ Area in 1994 was $74,200 \mathrm{pCi} / \mathrm{L}$ in Well $199-\mathrm{N}-75$. Water levels in the $100-\mathrm{N}$ Area are declining because disposal activities have been reduced, and as a result it has become impossible to sample a number of wells that in past sampling had tritium levels above the MCL. It appears that much of the present tritium distribution in the 100-N Area and surrounding areas can be attributed to past water-table mounding that resulted from 100-N Area disposal activities. 


\subsubsection{4-N Surface Impoundment and 1324-NA Percolation Pond}

The unlined 1324-NA Percolation Pond was used from 1977 to 1986 for disposal of treated wastes containing sulfuric acid and sodium hydroxide at variable pH. From 1986 to 1988, the wastes were treated in a lined pond, the 1324-N Surface Impoundment, at essentially the same location. Elevated sulfate levels are detectable downgradient of these facilities (Figure 5.25). The maximum sulfate detected in the 100-N Area in 1994 was $560 \mathrm{mg} / \mathrm{L}$ in one sample from Well 199-N-73, immediately downgradient of the 1324 facilities. Sulfate has a secondary MCL of $250 \mathrm{mg} / \mathrm{L}$.

Two wells downgradient of the 1324 facilities contained nitrate at levels above the MCL in 1994 samples (Plate 4). Well 199-N-26 contained the highest levels of nitrate in the 100-N Area in 1994, with a maximum concentration of $65 \mathrm{mg} / \mathrm{L}$. A few wells in other parts of the $100-\mathrm{N}$ Area have concentrations of nitrate greater than the MCL detected sporadically. Well 199-N-2, downgradient of the 1301-N LWDF, contained $48 \mathrm{mg} / \mathrm{L}$ of nitrate in one sample collected in 1992.

\subsection{0-West Area}

The 200-West Area at Hanford was used historically for chemical separation and purification of plutonium and associated waste management. For reasons of safety and security, the area was established with a significant spatial separation from the 200-East Area and with some redundancy of function. Differences in hydrogeology between the two sites have resulted in significant differences in the degree of the spread of contaminants. Four key source areas in the environs of the 200-West Area will be discussed. These are the T Plant, Reduction Oxidation (REDOX) Plant, U Plant, and Plutonium Finishing Plant (PFP), which was formerly referred to as Z Plant. Operation of the facilities has contributed, or is expected to contribute, to ground-water contamination. Waste-disposal facilities associated with these activities include cribs, trenches, tile fields, surface impoundments, injection wells, tank farms, and landfills.

Because of the complexity of past waste-disposal operations in the 200 Areas, as well as the close spacing of the facilities, it is generally impossible to determine the exact source of contamination. For example, although it is well-known that numerous tank leaks have occurred in the 200-West Area, ground-water impacts from tank leaks have not been established. In most cases, the tanks are located close to cribs or other waste-disposal facilities that also received similar wastes in the same periods. In some cases, wastes from operation at the tank farms was discharged to ground nearby. Thus, it is difficult to identify a distinctive chemical signature for tank leaks that would serve as an indicator of ground-water impacts.

\subsubsection{T Plant}

T Plant was constructed during the Manhattan Project and used for plutonium separation with the bismuth phosphate precipitation process. T Plant operated as a separations facility from April 1945 to Octọber 1952. More recently, $\mathrm{T}$ Plant has been used as an equipment decontamination facility. The waste facilities for $\mathrm{T}$ Plant are generally located southwest of the plant. Major waste-disposal facilities in the area include cribs and tank farms (WMA-T and WMA-TX-TY single-shell tank farms). Of particular interest is the 216-T-26 Crib, which received diverse chemical and radiological waste, and 
the adjacent 216-T-28 Crib, which received large amounts of water as well as some decontamination . wastes. Ground-water plumes originating from this area include tritium, technetium-99, iodine-129, nitrate, and chromium. A fluoride plume is also present in the area. A carbon tetrachloride plume originating near the PFP appears to extend throughout the T Plant area. Aqueous discharges to the 216-T-19 Crib may be responsible for part of the carbon tetrachloride plume in that area (Rohay et al. 1994a).

\section{Tritium}

A tritium plume that covers much of the northern half of the 200-West Area has its highest concentrations near the WMA-TX-TY Single-Shelled Tank Farm and the associated 216-T-26 Crib (Plate 3). The maximum tritium detected in this plume in 1994 was $413,000 \mathrm{pCi} / \mathrm{L}$ in an August 13 sample from Well 299-W13-12. The plume extends northeast past the boundary of the 200-West Area.

\section{Technetium-99}

A technetium-99 plume in the T Plant area has similar dimensions to the tritium plume (Figure 5.26). This contrasts with the U Plant technetium-99 plume, which has lower tritium levels. The area of the plume with technetium-99 levels above the MCL is restricted to the immediate vicinity of the WMA-TX-TY Tank Farm and associated disposal facilities.

\section{Iodine-129}

The extent of iodine-129 at levels above the MCL in the T Plant area coincides with the tritium and technetium-99 plumes (Plate 5). The maximum concentration of iodine-129 detected in this vicinity in 1994 was $39.4 \mathrm{pCi} / \mathrm{L}$ in Well 299-W14-12.

\section{Nitrate}

Much of the northern part of the 200-West Area continued to contain nitrate at concentrations in excess of the MCL (Plate 4). Maximum concentrations in this part of the 200-West Area in 1994 ranged up to $1,100 \mathrm{mg} / \mathrm{L}$ in Well $299-W 10-1$. The nitrate plume is broader than the tritium, technetium-99, or iodine-129 plumes. A trend plot of nitrate concentrations in Well 299-W15-4 is shown in Figure 5.27. The figure clearly shows the dramatic impact of the T Plant operations on the ground water during the late $1950 \mathrm{~s}$, followed by a decrease associated with the shutdown of $T$. Plant and a long period of relatively constant nitrate contamination levels above the MCL over the past twenty years.

\section{Chromium}

Chromium contamination has been found in the T Plant area but the rather erratic distribution of the chromium has made it difficult to define a plume, particularly since concentrations have declined in some of the wells that had shown significant chromium contamination in the past, and the presence of a plume is less obvious. The origin of the contamination is unclear. The 216-T-28 Crib is reported to have received miscellaneous decontamination waste from T Plant. Since hexavalent chromium was frequently used in decontaminating systems containing uranium, that crib is a likely source. The 
highest filtered chromium concentration observed in the vicinity of the $\mathrm{T}$ Plant disposal facilities in 1994 was $500 \mu \mathrm{g} / \mathrm{L}$ in the July 1 sample from Well 299-W10-15, located near the WMA-T Tank Farm.

\section{Chlorinated Hydrocarbons}

Although the bulk of the carbon tetrachloride plume in the 200-West Area is known to have originated from LWDFs in the vicinity of the PFP, a second source may exist in the vicinity of $T$ Plant. According to Rohay et al. (1994a), the source could be carbon tetrachloride that was dissolved in the 242-T evaporator overhead and discharged from 1973 to 1976 to the 216-T-19 Crib. An increase in carbon tetrachloride concentrations west of $\mathrm{T}$ Plant may be related to that disposal. The carbon tetrachloride distribution in the 200-West Area is shown in Figure 5.28. TCE is also found at levels above the MCL in the vicinity of T Plant (Figure 5.29).

\subsubsection{REDOX Plant}

Operation of the REDOX Plant began in 1951 and continued through 1967. Its primary mission was separation of plutonium from uranium and fission products using counter-current solvent extraction, eventually replacing the bismuth phosphate process used in the T Plant and B Plant. The solvent extraction process used an organic solvent (hexone) to separate plutonium from uranium fuel that had been dissolved in nitric acid. Chemical contaminants found in the ground water near the REDOX Plant include nitrate and minor amounts of TCE. The carbon tetrachloride plume prevalent in most of the rest of the 200-West Area is largely absent near the REDOX Plant, apparently as a consequence of the low sediment permeability in that area and the lack of any local discharges of carbon tetrachloride (Figure 5.28). The main radiological contaminants are tritium, iodine-129, technetium-99, and uranium.

\section{Tritium}

The movement of tritium plumes in the 200 -West Area was consistent with previous observations (Plate 3). The plume extending from near the REDOX Plant in the southern part of the 200-West Area continued to expand slowly to the east and north. Tritium is found at levels above the MCL upgradient of the REDOX Plant as far as the 216-S-25 Crib. One well in the vicinity of the REDOX Plant in the 200-West Area (299-W22-9) continued to show tritium levels in excess of the DCG during 1994. The concentrations of tritium detected in this well, 299-W22-9, have decreased steadily since 1977 to the 1994 level of 2,400,000 (Figure 5.30).

The tritium plume from the 200-West Area is approaching the U.S. Ecology Low-Level Radioactive Waste Disposal Facility. The maximum concentrations of tritium detected in ground water at that facility in 1994 were in Well 699-35-59 (U.S. Ecology Well no. 13) in which the concentrations ranged from 3,010 to $3,649 \mathrm{pCi} / \mathrm{L}$. This well is located on the western (upgradient) side of the facility. Well 699-35-57 (U.S. Ecology Well no. 3), which is on the eastern side of the facility, contained concentrations of tritium nearly as high with a maximum of $3,250 \mathrm{pCi} / \mathrm{L}$ in 1994 . Other wells at the U.S. Ecology site contained between 1,538 and $2,091 \mathrm{pCi} / \mathrm{L}$ of tritium in the quarterly samples. Tritium concentrations in ground-water samples from wells at the U.S. Ecology site have generally increased since 1992. In Well 699-35-59 (U.S. Ecology Well no. 13) the concentrations ranged from 2,270 to $2,450 \mathrm{pCi} / \mathrm{L}$ in 1992 . 
Movement of the REDOX Plant tritium plume is expected to be slow due to the low permeability of the sediments in this area and the dissipation of the ground-water mound beneath the 200-West Area since the reduction of waste disposal. Tritium concentrations in individual wells are affected by the original source concentration, radioactive decay during the travel time to the well, and dispersion of the plume.

\section{Iodine-129}

The highest iodine-129 concentration observed in Hanford ground water in 1994 was $86.1 \mathrm{pCi} / \mathrm{L}$, found in Well 299-W22-9. The iodine-129 plume from the 200-West Area (Plate 5) extends into the 600 Area to the east and coincides with the tritium plume originating near the REDOX Plant (Plate 3). This iodine-129 plume and iodine-129 contamination originating farther.north near the U Plant appear to coalesce downgradient and become indistinguishable at the current level of monitoring detail.

\section{Technetium-99}

Technetium-99 is found at levels above the MCL in a plume extending southeast from the vicinity of the WMA-S-SX Single-Shell Tank Farm and 216-S-25 Crib into the 600 Area (Figure 5.26). This plume is not coincident with the highest concentration part of the tritium plume. Although the wells with elevated technetium-99 also contain tritium at levels above the MCL, The wells with the highest tritium values contain only low concentrations of technetium-99. The highest technetium-99 concentrations are over ten times the MCL and are located on the periphery of the WMA-S-SX tank farm. If the technetium source was disposal to the 216-S25 Crib, then the pulse has moved downgradient as the source dissipated. The technetium- 99 at the high-concentration, western end of the plume is not associated with detectable iodine- 129 but is associated with uranium contamination.

\section{Uranium}

Uranium is found at levels above the proposed MCL to the west of the REDOX plant (Figure 5.31). This plume is generally coincident with the technetium-99 plume. The extent of the uranium plume downgradient to the southeast is less than the technetium- 99 plume. This suggests that uranium transport is retarded by sorption.

\section{Nitrate}

In past annual monitoring reports (e.g. Dresel et al., 1994), the major nitrate plume emanating from the southern part of the 200-West Area has been associated predominantly with the REDOX Plant and the U Plant. Assessment of the nitrate distribution shown in Plate 4, however, suggests that only relatively minor nitrate contamination is currently found in the vicinity of REDOX Plant operations and waste disposal. Nitrate is found at levels above the MCL near the 216-S-25 Crib, which routinely received process condensate from REDOX operations. Nitrate is also found at levels above the MCL in Well 299-W22-20, located near the 216-S-20 Crib, which received laboratory waste from the 222-S building. The trend plot for nitrate in Well 299-W22-20 indicates that nitrate contamination has been present for at least 35 years (Figure 5.32). 


\subsubsection{U Plant}

U Plant was originally designed as a plutonium separation facility but was never used for that purpose. The plant was converted for uranium recovery operations in 1952 to recover uranium waste generated by the bismuth phosphate process and stored in tanks up to that time. Wastes generated by processing resulted in subsurface contamination near the plant and in other areas as the wastes were moved to tanks in the 200-East Area. Waste from U Plant operations was also disposed to the BC Cribs south of the 200-East Area. Ground-water contaminants in the U Plant area include uranium, technetium-99, iodine-129, nitrate, and TCE. In contrast to many parts of the fuel processing areas, tritium contamination near the U Plant is only minor.

Remediation of ground water in the vicinity of the U Plant is being addressed by the CERCLA 200-UP-1 Project. Activities in this area include a ground-water pump-and-treat treatability test in the 216-U-17 Crib area that continues to operate and remove contaminants. Treated water is reinjected down former monitoring wells that have been converted to injection wells. These wells are thus no longer available for monitoring; and future interpretations should consider the effects of reinjection of treated water.

\section{Uranium}

The highest uranium levels in Hanford ground water in 1994 occurred near the U Plant in the 200-West Area in wells downgradient from the 216-U-1 and 216-U-2 Cribs and adjacent to the 216-U17 Crib (Figure 5.31). Uranium concentrations in wells near the 216-U-1 and 216-U-2. Cribs have been decreasing over the past 7 to 8 years, since remediation activities associated with these cribs were undertaken. A trend plot of uranium concentrations in samples from Well 299-W19-3, immediately downgradient from the cribs, is shown in Figure 5.33. The uranium levels in this well have decreased considerably since the maximum measured in 1986, but have remained relatively stable at levels greater than the proposed MCL since 1990. The maximum concentration detected in this area in 1994 was $2,720 \mu \mathrm{g} / \mathrm{L}$ in a sample from Well 299-W19-29. Results from the well have been erratic since 1991 , and further data are needed to interpret the trends. However, the 1994 uranium isotope concentrations detected in Well 299-W19-29 were greater than the DCGs. The uranium plume extends into the 600 Area to the east.

\section{Technetium-99}

Technetium- 99 has typically followed uranium throughout much of the fuel cycle. Thus, a sizable technetium-99 plume is associated with the $216-\mathrm{U}-1,216-\mathrm{U}-2$, and $216-\mathrm{U}-17$ Cribs in essentially the same location as the uranium plume (Figure 5.26). The extent of the technetium plume is greater because of the higher mobility of technetium in the aquifer. The maximum technetium- 99 concentration associated with this plume in 1994 was $23,700 \mathrm{pCi} / \mathrm{L}$, found in Well 299-W19-24.

\section{Iodine-129}

Iodine-129 is found at levels above the MCL in the immediate vicinity of the 216-U-1 and $216-\mathrm{U}-2$ Cribs (Plate 5). The highest iodine-129 level associated with U Plant operations was $8.83 \mathrm{pCi} / \mathrm{L}$ in Well 299-W19-2, adjacent to the 216-U-8 Crib that received process condensate and stack drainage 
from U Plant operations. Downgradient; the iodine-129 plume from the U Plant operations becomes indistinguishable from the REDOX Plant plume, as discussed in Section 5.7.1.

\section{Nitrate}

The highest nitrate concentrations on the site in 1994 continued to be found in wells east of U Plant near the 216-U-17 Crib (Plate 4). The maximum concentration detected in 1994 was $1,700 \mathrm{mg} / \mathrm{L}$ in Well 299-W19-23. Nitrate was already observed in wells near this crib before February 1988, when the crib went into operation. The main source of nitrate is believed to be wastes disposed of in the 216-U-1 and 216-U-2 Cribs. These cribs received over 1 million kilograms of nitrate during their operation from 1951 to 1967 (Stenner et al. 1988). Nitrate concentrations in wells located near the 216-U-1 and 216-U-2 Cribs west of the U Plant have continued to decrease, with concentrations in several wells dropping below the MCL. For example, the nitrate concentration in Well 299-W19-3 near the U Plant has decreased to less than the MCL, as shown in Figure 5.34. The distribution of the highest concentrations in the nitrate plume is similar to the technetium- 99 plume, which would indicate a common source. Elevated nitrate concentrations are also observed farther south near the 216-U8 and 216-U-12 Cribs.

\section{Trichloroethylene}

A relatively low-level TCE plume can be seen in ground water near the U Plant (Figure 5.29) The maximum concentration of TCE found in 1994 in this plume was $13 \mu \mathrm{g} / \mathrm{L}$ in Well 299-W19-35. The MCL for TCE is $5 \mu \mathrm{g} / \mathrm{L}$.

\subsubsection{Plutonium Finishing Plant (Formerly Z Plant)}

The Z Plant was constructed in 1949 to purify plutonium and reduce it to a metallic state. In the early 1980s, the plant was modernized and renamed the Plutonium Finishing Plant (PFP). The mission of the plant remained essentially unchanged, but liquid discharges were significantly reduced. Primary wastes associated with the Plant include transuranics (TRUs) (primarily plutonium and americium), nitrate, carbon tetrachloride, tributyl phosphate, dibutyl phosphate, dibutyl phosphonate, aluminum fluoride-nitrate, and lard oil. TRU contaminants typically remain bound in the soil column at relatively shallow depths although there may be minor exceptions. Alkyl phosphates have not been observed in the ground water, and their fate is still relatively obscure. Lard oil is expected to remain at shallow depth in the soil due to its high viscosity. Nitrate and carbon tetrachloride associated with the Z Plant Cribs have produced ground-water plumes. Some minor fluoride contamination near the $T$ Plant area may have originated from the Z Plant Cribs.

\section{Plutonium and Americium}

Plutonium-239,240 and americium-241 were detected at low levels (up to $8.3 \mathrm{pCi} / \mathrm{L}$ plutonium$239 / 240$ and $5.9 \mathrm{pCi} / \mathrm{L}$ americium-241) in 1990 and 1991 in Well 299-W15-8, which monitors the 216Z-9 Trench. The 216-Z-9 Trench received a large burden of TRUs from PFP liquid effluent streams. That well has not been monitored for TRUs since 1991 because the water level has dropped below the well screen. The origin of the TRU contaminants in the well is unclear. The contaminants may be associated with poor quality well completion and thus may be very localized (Rohay et al. 1994b). 
Rohay et al. (1994b) discuss the potential mobilization of plutonium and americium isotopes in the organic liquid phase discharged to ground in the vicinity of the $\mathrm{Z}$ Plant. A liquid phase containing carbon tetrachloride and tributylphosphate was used in the purification process to complex and remove plutonium from the aqueous phase. The distribution of TRU contaminants in the vadose zone suggests that they have an increased mobility due to transport in the nonaqueous phase liquid.

\section{Nitrate}

The 216-Z-9 Trench received an estimated 1.3 million kilograms of nitrate containing chemicals over the course of its operation from 1955 to 1962 . Other LWDFs associated with the Z Plant received smaller but significant amounts of nitrate. There is thus a nitrate plume originating in this area, with nitrate levels ranging up to several hundred $\mathrm{mg} / \mathrm{L}$ (Plate 4).

\section{Chlorinated Hydrocarbons}

Carbon tetrachloride contamination was found in the unconfined aquifer beneath much of the 200-West Area. The presence of this plume was first noted in early 1987, although trend data from two wells extend back to early 1986 . The contamination is believed to be from waste operations associated with the Z Plant before 1973. Three LWDFs near the Z Plant (216-Z-18 Crib, 216-Z-1A Tile Field, and 216-Z-9 Trench) received an estimated 577 to 922 metric tons of carbon tetrachloride during their operational history (Rohay et al. 1994a). The maximum carbon tetrachloride concentration detected in the 200-West Area in 1994 was 5,200 in Well 299-W15-16. The plume covers much of the 200-West Area (Figure 5.28). The MCL for carbon tetrachloride is $5 \mu \mathrm{g} / \mathrm{L}$. The 200-West Area is the only location at Hanford where significant carbon tetrachloride contamination has been detected.

The carbon tetrachloride distribution in the 200-West Area ground water has remained relatively stable since the presence of the contaminant plume was first noted. Figure 5.35 shows the trends over time in carbon tetrachloride concentrations for wells located around the plume. Well 699-39-79 shows a major increase during 1987 and 1988, indicating arrival of the bulk of the plume at that time. Since 1988 , concentrations in Well 699-39-79 have remained relatively constant. Wells 299-W7-4 and 299W6-2 to the north show an increase in concentration in recent years, although the most recent measurement in Well 299-W6-2 is lower. Concentrations in Well 299-W18-21 exhibit a considerable increase in carbon tetrachloride since approximately 1992 , and values continue to climb. Concentrations in Well 299-W19-16 to the southeast of PFP Plant have risen in recent years. Concentrations in Well 699-38-70, located on the eastern edge of the plume, remained relatively stable in 1994.

The extent of carbon tetrachloride contamination is poorly constrained in several directions. The biggest uncertainty lies in the extent of contamination to the west, east, and northeast. The apparent division into two lobes on the eastern side of the 200-West Area may be related to discharge of water from the laundry facilities and steam plant, but the data available in this area are insufficient to determine if this is the case. In addition, there is considerable uncertainty regarding the extent of contamination in deeper parts of the aquifer.

As discussed in Section 3.0, ground-water flow beneath the 200-West Area has been heavily influenced by mounding caused by operation of the $U$ Pond located at the southwest corner of the 200- 
West Area. The U Pond received large amounts of cooling water from the REDOX Plant and other facilities. Although U Pond has been decommissioned, a large residual ground-water mound remains. The spreading of the 200-West Area carbon tetrachloride plume to the west, and now apparently to the south as well, is thus somewhat unexpected, since it is counter to the apparent ground-water flow direction. Changes in ground-water flow since the decommissioning of U Pond and shift in wastewater disposal to newer facilities may influence the plume location and configuration. Another potential influence is continued spreading of the carbon tetrachloride above the water table, in either the liquid or the vapor phase. Free-phase liquid carbon tetrachloride above and possibly below the water table could provide a continuing source of contamination. Subsurface investigations performed in association with the ongoing expedited response action and the VOCs-Arid Integrated Demonstration or the 200-ZP-1 CERCLA investigation have so far failed to conclusively demonstrate the presence of free-phase liquid, though the extremely high soil gas concentrations (tens of thousands of ppm) found at several locations suggest the presence of free-phase liquid. Because of the difficulties and high costs associated with subsurface access, the investigation has been relatively limited in scope, and any conclusions concerning the presence of free-phase liquid will of necessity be based on indirect evidence. The contaminant concentrations and distribution suggests that non-aqueous phase liquid is probably present above and below the water table. It appears likely based on observations to date that the carbon tetrachloride plume will expand slowly until more aggressive remedial measures are implemented.

In addition to carbon tetrachloride, lesser concentrations of TCE and chloroform have been found in the same area. TCE is found at levels slightly above the MCL near the PFP (Figure 5.29). A chloroform concentration of 1,540 $\mu \mathrm{g} / \mathrm{L}$ was measured in Well 299-W15-8 in May 1990. The highest recorded chloroform level in 1994 was $107 \mu \mathrm{g} / \mathrm{L}$ in Well 299-W18-4. Well 299-W18-2, which contained the highest concentration of chloroform in 1993, was not sampled in 1994. The chloroform plume appears to be associated, but not exactly coincident, with the carbon tetrachloride plume (Figure 5.36). The chloroform appears to be associated primarily with the 216-Z-9 Trench area. The origin of the chloroform is unknown, but it is strongly suspected to be a degradation product of carbon tetrachloride. In the past, septic drainage fields operated in the area close to where the chloroform maximum was measured, so anaerobic bacterial degradation processes are strongly indicated. The MCL for chloroform is $100 \mu \mathrm{g} / \mathrm{L}$ (total trihalomethanes), which is 20 times higher than that for carbon tetrachloride.

\section{Fluoride}

A few wells in the 200-West Area near the T Plant showed elevated levels of fluoride during 1994 (Figure 5.37). The maximum concentration in 1994 was $5.1 \mathrm{mg} / \mathrm{L}$ in one sample from Well 299-W1015; this exceeded both the secondary MCL $(2.0 \mathrm{mg} / \mathrm{L})$ and the primary MCL $(4.0 \mathrm{mg} / \mathrm{L})$. Well 299W15-4 had the maximum fluoride onsite in $1993(7.4 \mathrm{mg} / \mathrm{L})$ but was not sampled in 1994 . The source of the small fluoride plume is believed to be several LWDFs associated with the PFP. For example, the $216-Z-9$ Trench received $210 \mathrm{~kg}$ of aluminum fluoride nitrate during its operation from 1955 to 1962 (Stenner et al. 1988). A similar amount of aluminum fluoride nitrate was disposed of to the 216Z-18 Crib during its operation from 1969 to 1973 . However, the fact that the plume is some distance from both of those facilities makes the identification of the source questionable. 


\subsection{0-East Area}

The 200-East Area at Hanford was used historically for chemical separation and purification of plutonium with associated waste management. For reasons of safety and security, the area was established with a significant spatial separation from the 200-West Area and with some redundancy of function. Differences in hydrogeology between the two sites have resulted in significant differences in the spread of contaminants. In the 200-East Area, specific waste-disposal sources include the Plutonium-Uranium Extraction (PUREX) Plant, the BY Cribs, and the 216-B-5 Reverse Injection Well. Waste-disposal facilities associated with operations include cribs, trenches, tile fields, surface impoundments, injection wells, tank farms, and landfills. Because of the complexity of past wastedisposal operations in the 200 Areas, as well as the close spacing of the facilities, it is generally impossible to determine the exact source of contamination. For example, although it is well-known that numerous tank leaks have occurred in the 200-East Area, there is as yet no conclusive evidence for ground-water impacts from tank leaks. In most cases, the tanks are located close to cribs or other waste-disposal facilities that received similar wastes in the same periods. In some instances, tank supernatant or other waste from tank farm operations was discharged to ground in nearby cribs, so the ground-water impacts are essentially from the overall tank farm operations.

The RCRA monitoring program is responsible for monitoring several 200-East Area facilities including the WMA-A-AX and WMA-B-BX-BY Single-shell Tank Farms, the 216-A-29 Ditch, the 216-A-10 Crib, the 216-A36B Crib, the 216-B-63 Trench, the 2101-M Pond, the 200-East Area LERF and 200-East area Low-Level Burial Grounds. In addition, the B Pond in the 600 Area receives waste from the 200 Areas and is monitored under the RCRA Program (DOE-RL 1995a).

The 200-BP-5 CERCLA program is responsible for ground-water characterization and remediation in the northwestern 200-East Area and adjacent 600-Area. This program has performed treatability tests for pump-and-treat at the 216-B-5 Injection Well and north of the BY Cribs.

\subsubsection{PUREX Plant}

The PUREX Plant started operation in 1956. It eventually replaced the REDOX Plant as the Hanford plutonium separations facility. The first PUREX operational campaign extended from 1956 to 1972. Following an 11-year shutdown, the plant began operations again in 1983, which ended in December 1988 when the Hanford weapons production mission ended. A short stabilization run was made starting in December 1989 to stabilize material in the system. Operations at the PUREX Plant are currently focused on diverse waste management needs. Because of the high permeabilities found downgradient of PUREX and the relatively long period of shutdown, separate plumes resulting from the two operations campaigns can be distinguished. Contaminant plumes associated with PUREX operations primarily contain those species associated with process condensates, including tritium, iodine-129, and nitrate. Some strontium- 90 and technetium-99 is also associated with PUREX waste disposal, although technetium-99 is not found at levels above the MCL.

\section{Tritium}

The highest tritium concentrations in the 200-East Area continued to be found in wells near cribs that received effiuent from the PUREX Plant (Figure 5.1 and Plate 3). Concentrations greater than the 
$2,000,000 \mathrm{pCi} / \mathrm{L}$ DCG were detected in only one well in the 200-East Area, Well 299-E17-9 located downgradient of the 216-A36-B Crib. The maximum concentration detected in this well in 1994 was $3,370,000 \mathrm{pCi} / \mathrm{L}$ which was also the maximum tritium concentration detected onsite in 1994 . Tritium concentrations exceeding the MCL continued to be found in many wells affected by cribs near the PUREX Plant.

The movement of the widespread tritium plume (see Plate 3) extending from the southeastern portion of the 200-East Area to the Columbia River was consistent with patterns noted earlier (Dirkes et al. 1994, Dresel et al. 1994). Separate tritium pulses associated with the two episodes of PUREX operations can be distinguished in the plume. The greater-than-200,000-pCi/L lobe east of the 200-East Area near the Columbia River is a result of discharges during the operation of the PUREX Plant from 1956 to 1972 . The area near the Columbia River with tritium concentrations greater than $200,000 \mathrm{pCi} / \mathrm{L}$ continues to shrink from approximately $42 \mathrm{~km}^{2}\left(16 \mathrm{mi}^{2}\right)$ in 1988 (Evans et al. 1989) to approximately $5 \mathrm{~km}^{2}\left(2 \mathrm{mi}^{2}\right)$ in 1994 . Elevated tritium concentrations measured in several wells (for example, Wells 699-32-43 and 699-24-33) downgradient from the 200-East Area represent a second pulse of tritium moving away from PUREX waste-disposal facilities. Large-scale movement of the leading edge of this plume is best observed in Well 699-24-33 (Figure 5.38), located near the central landfill, approximately 4 miles from the source, which clearly shows arrival of the plume in early 1987, well after the passage of the plume from the earlier campaign. The tritium concentrations in this well during passage of the first pulse were at least three times the maximum concentrations in the pulse from the second campaign. A trend plot of the tritium concentrations in Well 699-40-1 (Figure 5.39), located near the shore of the Columbia River, shows the arrival in the early 1970s of the first plume and no discernible effect from the second plume, as yet.

The zone of lower tritium concentrations near the Supply System may be related to an area where the Ringold Formation sediments are present at the water table (Figure 2.4). This suggests a zone of lower permeability material is present in this area, which may be diverting the bulk of the contaminant transport to the north and south.

\section{Iodine-129}

The highest iodine-129 concentrations observed in the 200-East Area in 1994 were in the southeast corner near the PUREX Plant (Plate 5). The maximum detected iodine-129 concentration in 1994 in the 200-East Area was $11.8 \mathrm{pCi} / \mathrm{L}$ in Well 299-E17-9, which monitors the 216-A36B Crib south of the PUREX Plant. The iodine-129 plume extends southeast into the 600 Area and appears to coincide with the tritium and nitrate plumes. The relatively high detection limit, relative to the MCL, for iodine-129 using the standard analytical methods makes it difficult to track the plume at levels less than the 1 $\mathrm{pCi} / \mathrm{L} \mathrm{MCL}$. The historical record for iodine-129 is not as extensive as that for tritium so there is no record of first-arrival of iodine-129 for many wells. Monitoring Well 699-42-12A was reported to have iodine-129 at levels above the MCL for the first time in 1994, although this well had not been sampled for iodine-129 since 1989. Iodine-129 concentrations in monitoring wells farther east, near the river, remained below the MCL in 1994. An area south of the old Hanford townsite has no monitoring wells so the extent of the iodine-129 plume is not well-defined there. In 1987, iodine-129 was reported as being above the MCL in Well 699-27-8, which is approximately $6.5 \mathrm{~km}$ (4 mi) from the Columbia River. This suggests that the plume extends toward the Columbia River in that vicinity. 
Iodine-129 is found at levels above the MCL in a broad band from the northwest to the southeast corner of the 200-East Area and in a lobe extending to the northeast of the PUREX Plant (Plate 5). There are numerous disposal facilities including cribs, trenches, ditches, and tank farms north and east of the PUREX Plant so the exact sources of iodine-129 in this area are difficult to identify.

\section{Strontium-90 and Technetium-99}

Strontium-90 has been found at levels above the MCL in a few wells near cribs that received discharge from the PUREX Plant in past years. No samples for 1994 were above the MCL. (Figure 5.40). The maximum strontium-90 concentration detected in 1993 was $15.6 \mathrm{pCi} / \mathrm{L}$ in Well 299-E17-14, located next to the 216-A-36B Crib this well was not sampled in 1994. Well 299E17-20, adjacent to the 216-A-10 Crib, exhibited concentrations greater than the MCL in 1991 and 1992 but was slightly below the MCL in 1994 (7.32 pCi/L). The impact is very localized due to the lower mobility of strontium- 90 as compared to tritium, iodine-129, and nitrate.

Technetium-99 is found at levels below the MCL near the PUREX Plant and downgradient (Figure 5.41). The presence of technetium-99 in this area inhibits the effectiveness of using gross beta measurements to infer strontium-90 concentrations (see Section 4.1.3).

\section{Nitrate}

The highest nitrate concentrations in the 200-East Area continued to be found near LWDFs that received effluent from PUREX operations. The maximum nitrate concentration detected near PUREX in 1994 was $120 \mathrm{mg} / \mathrm{L}$ in Well 299-E17-15, which is adjacent to the $216-\mathrm{A}-36 \mathrm{~B}$ Crib. Nitrate concentrations in wells near the 216-A-10 and 216-A-36B Cribs have generally tended to decrease in the past few years but remain above the MCL, even though the facilities were removed from service in 1987. The extent of the nitrate plume emanating from the 200-East Area (Figure 5.2 and Plate 4) is nearly identical to that of the tritium plume. However, the area with nitrate above the $45 \mathrm{mg} / \mathrm{L} \mathrm{MCL}$ (as $\mathrm{NO}_{3}$ ) is considerably more restricted than the area with tritium above the MCL (Figure 5.1 and Plate 3).

\subsubsection{BY Cribs}

In 1954 and 1955, scavenged uranium recovery waste supernatant containing large amounts of nickel ferrocyanide and other chemical and radiological components from U Plant operations was discharged to the BY Cribs and to one of the BX Trenches located in the northern part of the 200-East Area (Waite 1991). This practice was soon discontinued because of the appearance of unacceptably high levels of cobalt-60, as well as some cesium-137, in the ground water. With the decommissioning of Gable Mountain Pond in recent years, ground water in that area has begun flowing northward, and a number of ground-water contaminant plumes have reappeared north of the 200-East Area boundary. Chemical contaminants include nitrate, sulfate, and cyanide (as ferrocyanide). Calcium and strontium, which were present in the supernatant as hold-back carrier added to prevent solubilization of strontium-90, also clearly exceed natural background levels. Selenium has also been present in this plume at enhanced levels for several years. Radiological contaminants.include a small tritium plume, minor amounts of cobalt -60 , and substantial levels of technetium- 99 . Elevated gross beta levels in the area are associated primarily with the technetium plume. 
Remediation of the BY Cribs is being managed under the 200-BP-1 CERCLA project. The record of decision for this project calls for capping of the crib area to prevent infiltration of precipitation. A field-scale pump-and-treat treatability test to address contamination by cyanide, technetium-99, and cobalt-60 in the area northwest of the BY Cribs was started in 1994 under the 200-BP-5 CERCLA ground-water Operable Unit project. RCRA monitoring in the northwestern 200-East Area is performed by the 200 Area Low-Level Burial Ground Program and the Single-Shell Tank Program.

\section{Nitrate}

The plume originating from the BY Cribs contains some of the highest ground-water nitrate levels on the site (Plate 4). The maximum concentration detected in 1994 in the 600 Area to the northwest of the BY Cribs was $340 \mathrm{mg} / \mathrm{L}$ in one sample from Well 699-52-54. .

\section{Cyanide}

In past monitoring activities, cyanide was detected in samples collected from wells in and directly north of the 200-East Area. The cyanide source is believed to be wastes containing ferrocyanide disposed of in the BY Cribs. The MCL for cyanide is $200 \mu \mathrm{g} / \mathrm{L}$. Samples taken from the 200-East Area in 1994 had a maximum cyanide concentration of $39.5 \mu \mathrm{g} / \mathrm{L}$ in one sample from well 299-E33-12, just east of the BY Cribs. This sample also contained $36 \mathrm{pCi} / \mathrm{L}$ of cobalt-60. Well 299E33-12 is completed in the basalt, indicating that these contaminants have migrated to considerable depth in the flow system. Migration through the unconsolidated sediments may have been increased by the higher hydraulic head caused by past disposal activities and by the high density of some of the waste streams (Smith 1980, Graham et al. 1984). Characterization of the deeper parts of the unconfined aquifer and the confined aquifer in the vicinity of the BY Cribs is considerably less complete than the characterization of the top of the unconfined aquifer. Well 699-52-54, north of the BY Cribs, contains higher cyanide concentrations than are found within the $200-$ East Area $(160 \mu \mathrm{g} / \mathrm{L}$ in 1994). Wells containing elevated cyanide often contain elevated concentrations of several radionuclides, including cobalt- 60 . Although cobalt -60 is normally immobile in the subsurface, it appears to be chemically complexed and mobilized by cyanide or ferrocyanide.

\section{Selenium}

The presence of significant levels of selenium in ground-water samples from Well 699-50-53A has been noted since 1987, but the origin of the selenium is not known. A maximum selenium level of 61 $\mu \mathrm{g} / \mathrm{L}$ in Well 699-50-53A was found in November 1991. The highest selenium level reported for that well in 1994 was $27 \mu \mathrm{g} / \mathrm{L}$. The MCL for selenium is $50 \mu \mathrm{g} / \mathrm{L}$.

\section{Cobalt-60}

Well 699-50-53A, which is located north of the 200 Areas in an area that has been affected by waste disposed of in the BY Cribs, has consistently shown the presence of detectable cobalt -60 in recent years. In 1994 , cobalt-60 in this well ranged up to $49.2 \mathrm{pCi} / \mathrm{L}$, continuing the general decline from a maximum in 1989-1990, as shown in Figure 5.42. A prior maximum cobalt-60 concentration occurred about 1960 and was considerably higher. The increased cobalt-60 concentration from 1985 through 1992 appears to be the result of changes in the flow field rather than any changes in the contaminant source term. Much of that cobalt- 60 has now decayed away because of its 5.3-year half- 
life. Cobalt- 60 in this area appears to be highly mobile, probably because of the presence of a soluble cobalt-cyanide (or ferrocyanide) complex associated with the plume originating in the BY Cribs. Well 699-52-54 contained the maximum cobalt-60 detected in this vicinity, $74.3 \mathrm{pCi} / \mathrm{L}$, which was also associated with the presence of cyanide. The presence of complexed cobalt-60 in tributylphosphate scavenged wastes was known by 1957 to result in little retention by sediments (Haney 1957).

\section{Technetium-99}

Elevated technetium-99 levels apparently associated with the BY Cribs plume continued to be observed in 1994. Technetium-99 levels in Well 699-50-53A are similar to 1993 levels but have dropped from earlier years (Figure 5.43). The maximum technetium-99 detected in this vicinity in 1994 was $4,250 \mathrm{pCi} / \mathrm{L}$ in Well 699-52-54, which is nearly five times the $900 \mathrm{pCi} / \mathrm{L} \mathrm{MCL}$.

Concentrations of technetium-99 have been increasing in Well 699-52-54 (Figure 5.44), indicating that the plume continues to move to the north. The extent of technetium- 99 in the area to the northwest of the BY Cribs is shown in Figure 5.41. Concentrations of technetium-99 less than the MCL detected north of Gable Mountain indicate that this plume is moving into and through the gap between Gable Mountain and Gable Butte.

\section{Iodine-129}

The distribution of iodine-129 in the northwestern 200-East Area (Plate 5), is distinct from the technetium-99 distribution, suggesting different sources. The iodine-129 plume extends northwest towards the gap between Gable Mountain and Gable Butte. The highest concentration part of this plume is generally located somewhat south and west of the BY Cribs.

\section{Uranium}

Contrary to suggestions from previous years (e.g. Dresel et al. 1994), there appears to be no uranium plume associated with the technetium-99 plume in the 600 Area north of the BY Cribs. However, a few samples in the northwestern part of the 200-East Area show uranium at levels greater than the $20 \mu \mathrm{g} / \mathrm{L}$ proposed MCL (Figure 5.45). The sources of this uranium are not understood.

\subsubsection{6-B-5 Injection Well}

The 216-B-5 Injection Well was operated from April 1945 to September 1946. It received radioactive wastes from B Plant activities, including some hot-cell drainage and supernatant overflow from settling tanks. The waste was pressure-injected below the water table, resulting in radiological contamination that is still apparent 50 years later. Radiological contaminants associated with the facility include strontium-90, cesium-137, and plutonium. These three contaminants are restricted to the immediate vicinity of the injection well by their low mobility in ground water and the extremely low hydraulic gradient in this area. Characterization activities in the vicinity of the 216-B-5 Injection Well were reported by Smith (1980).

Remediation of ground water in the area of the 216-B-5 Injection Well is being investigated under the 200-BP-5 CERCLA project. A field-scale treatability test for a pump-and-treat remediation system 
was initiated in 1994. The low mobility of the contaminants of concern is likely to limit the system's ability to remove them unless a more aggressive treatment strategy is adopted.

\section{Strontium-90}

Concentrations of strontium-90 in 1994 ranged up to $9,740 \mathrm{pCi} / \mathrm{L}$ in Well $299-\mathrm{E} 28-23$ near the 216-B-5 Injection Well (Figure 5.40). Strontium-90 was also found at $69.3 \mathrm{pCi} / \mathrm{L}$ in Well 299-E-28-2, which is approximately $150 \mathrm{~m}$ (490 ft) from the 216-B-5 Injection Well. The 216-B-5 Injection Well received an estimated $27.9 \mathrm{Ci}$ of strontium-90 (decayed through April 1, 1986) during 1945 to 1946, when it was used for waste disposal (Stenner et al. 1988).

\section{Cesium-137}

Concentrations of cesium-137 in 1994 reached 2,310 pCi/L in Well 299-E28-23, located near the 216-B-5 Injection Well. The 216-B-5 Injection Well received an estimated $31.8 \mathrm{Ci}$ of cesium-137 (decayed through April 1, 1986) while it was used for waste disposal from 1945 to 1946 (Stenner et al. 1988). The MCL for cesium-137 is $200 \mathrm{pCi} / \mathrm{L}$, and the $\mathrm{DCG}$ is $3,000 \mathrm{pCi} / \mathrm{L}$.

\section{Plutonium}

The maximum concentration of plutonium-239,240 detected near the 216-B-5 Injection Well in 1994 was 2,670 pCi/L in Well 299-E28-24 (approximately $3 \mathrm{~m}$ from the injection well). Although this concentration is extremely high compared to past values, review of the laboratory results indicate the analysis is acceptable. Plutonium was also detected in Well 299-E28-2 northwest of the 216-B-5 Injection Well. The 216-B-5 Injection Well received an estimated $244 \mathrm{Ci}$ of plutonium-239,240 during its operation from 1945 to 1946 (Stenner et al. 1988). The DCG for plutonium-239 is $30 \mathrm{pCi} / \mathrm{L}$. There is no explicit MCL for plutonium-239; however, the gross alpha MCL of $15 \mathrm{pCi} / \mathrm{L}$ would be applicable at a minimum. Alternatively, if the DCG (which is based on a 100-mrem dose standard) is converted to the 4 -mrem dose equivalent used for the $\mathrm{MCL}, 1.2 \mathrm{pCi} / \mathrm{L}$ would be the relevant guideline. Plutonium is generally considered to bind strongly to sediments and thus has limited mobility in the aquifer.

\subsection{Area}

The major role of the 300 Area in Hanford Site operations was the processing of uranium into fuel elements for the reactors. Fuel fabrication activities ended in 1987. During fuel fabrication, uranium was reportedly disposed of to the process ponds and trenches in dissolved and particulate forms. Facilities known to have received uranium include the 316-1 South Process Pond, the 316-2 North Process Pond, and the 316-5 Process Trenches. Of these, only the 316-5 Process Trenches were active in 1994. Discharge to the 316-5 Trenches ceased in December 1994.

Constituents of concern detected in ground water at the 300 Area include uranium and TCE. Although tritium levels greater than the MCL have not been detected in the 300 Area, the tritium plume from the 200-East Area impacts the northern part of the 300 Area (Figure 5.1 and Plate 3). The regional tritium plume and its effects on the 300 Area have been discussed in relation to its source area 
in the 200-East Area. Chromium detected in unfiltered samples from the 300 Area appears to be related to stainless steel monitoring-well construction. Ground-water flow and contaminant transport in the 300 Area are influenced by fluctuations in the Columbia River stage and associated changes in gradient and bank storage.

The 316-5 Process Trenches are monitored by the RCRA program (Lindberg 1995). Use of the trenches began in 1975. The west trench was used until 1991. Impacts on ground water from past activities in the 300 Area are being addressed by the 300-FF-5 CERCLA project. The Remedial Investigation/Feasibility Study Report for the 300-FF-5 Area Operable Unit has been published (DOERL 1995d).

\section{Uranium}

The uranium distribution in the 300 Area is shown in Figure 5.46. The highest uranium concentrations are located in the northern part of the 300 Area, downgradient from the 316-5 Process Trenches and the 316-1 and 316-2 Process Ponds. The maximum uranium concentration detected in the 300 Area in 1994 was $150 \mu \mathrm{g} / \mathrm{L}$ in Well 399-2-2. Contaminated material was removed from the inflow area of the 316-5 process trenches as part of an expedited response action in 1991. Well 399-1-17A monitors the upper unconfined aquifer near the inflow of the trenches. This well has shown cyclical variations in uranium concentration in the past. Currently concentrations remain low (Figure 5.47) but were above the MCL in most 1994 samples. The lower uranium concentration in Well 399-1-17A may be a function of the expedited response action and/or the reduced discharge to the trenches.

The area of elevated uranium concentration in the southern part of the 300 Area is separated from the area in the northern 300 Area by a zone of somewhat lower concentrations. The zone of lower uranium concentrations between the two highs corresponds approximately to a zone of lowerpermeability sediments. The plume geometry probably reflects the effect of this lower-permeability zone on ground-water flow, although the possibility of other uranium sources in the southern 300 Area cannot be ruled out. Well 399-4-12, which supplies water for ponds used in trout research south of the 331 Building, contained a maximum of $23 \mu \mathrm{g} / \mathrm{L}$ in 1994 sampling and is the southernmost well in the 300 Area where uranium was detected at levels above the proposed MCL.

\section{Trichloroethylene and Dichloroethylene}

Few wells in the 300 Area contain concentrations of TCE greater than the MCL (Figure 5.48), although TCE was used during fuel fabrication, and significant quantities were disposed to the ground (Stenner et al. 1988). The presence of cis-1,2-dichloroethylene (DCE) in some samples indicates that anaerobic biodegradation of TCE has occurred. However, the fact that vinyl chloride has not been detected in the 300 Area indicates that the degree of biodegradation is relatively low (cis-1,2-DCE is degraded to vinyl chloride less readily than TCE is degraded to cis-1,2-DCE). It should be noted that data collected until 1990 by the RCRA programs and the Ground-Water Surveillance Project apparently did not distinguish cis-1,2-DCE, from trans-1,2-DCE; however, the data were reported as trans-1,2DCE. Some past data were reported as total 1,2-DCE. More detailed characterization demonstrates that nearly all of the DCE, is cis-1,2-DCE as would be expected from biodegradation. The maximum detected concentration of cis-1,2-DCE in monitoring Well 399-1-16B in 1994 was $130 \mu \mathrm{g} / \mathrm{L}$, which is more than an order of magnitude greater than the TCE concentration $(5.4 \mu \mathrm{g} / \mathrm{L})$. The MCL for cis1.2-DCE is $70 \mu \mathrm{g} / \mathrm{L}$. 
The highest TCE concentrations detected in the 300 Area in 1994 were $7 \mu \mathrm{g} / \mathrm{L}$ in Well $399-2-2$, which is located near the 316-2 North Process Pond. The TCE concentrations detected in lower unconfined aquifer Well 399-1-16B in 1994 were $5.4 \mu \mathrm{g} / \mathrm{L}$. A maximum of only $1.1 \mu \mathrm{g} / \mathrm{L}$ of TCE was detected in Well 399-1-16A, which is screened across the water table at the same location. Although TCE has been detected in past samples from the upper confined aquifer Well 399-1-16C, these values probably relate to leakage from the unconfined aquifer around the well bores. Shortly after installation of the wells, the water level in 399-1-16C declined to near that of 399-1-16B, suggesting áquifer intercommunication resulting from well installation. Well 399-1-16C was remediated in 1993, and TCE was not detected in 1993 (or later) samples from Well 399-1-16C. Well 399-1-16D, which was still deeper, was abandoned because of suspected well-construction problems.

The reason that TCE concentrations are higher in the lower unconfined aquifer than in the upper unconfined aquifer in the 399-1-16 wells is probably related to greater flushing of the upper unconfined aquifer by relatively cleaner water being disposed of to the 316-5 Process Trenches. Hydraulic gradients in the 300 Area are toward the river and upward, so it is unlikely that TCE is being transported to greater depths by the current flow system. Past disposal practices, however, may have produced sufficient mounding immediately beneath the 316-2 North Process Pond to transport disposal water to significant depths. The presence of dense nonaqueous phase liquid TCE at depth within the aquifer is unlikely. If dense nonaqueous phase liquid were present, it would remain at residual saturation through the upper sediments in the source area and provide a continuing source of high concentration contamination to the shallow flow system. The present distribution of contamination is best explained by flushing of aqueous phase TCE from a source that has now been removed.

TCE is present at low levels in many samples from the southern portion of the 300 Area. In most cases, TCE concentrations were below the $5-\mu \mathrm{g} / \mathrm{L} \mathrm{MCL}$. The only exception was from Well 399-3-12, which contained $6.1 \mu \mathrm{g} / \mathrm{L}$ of TCE. The large area of low-level TCE in ground water in the southern part of the 300 Area suggests a widely distributed source, such as the sewer system, or a source upgradient from the area.

\section{Chromium}

Chromium continues to be detected sporadically in unfiltered samples from the 300 Area. The concentrations in filtered samples remain below the MCL in 1994 for all samples, but those in some unfiltered samples were above the Washington State MCL of $50 \mu \mathrm{g} / \mathrm{L}$. The erratic presence of chromium in only unfiltered samples only suggests that the high chromium concentrations in these monitoring wells represent particulate matter, which is probably related to the stainless steel well construction. The erratic concentrations are caused by minor changes in well-purging procedures, the length of time between samples, or other effects that do not reflect the general ground-water quality.

\subsection{Area}

The 400 Area is the location of the Fast Flux Test Facility, which is a liquid-sodium-cooled reactor facility. This reactor is slated for decommissioning within the next few years. Assessment efforts associated with the 300-FF-2 CERCLA Operable Unit will extend to include ground-water contamination in the 400 Area. 
No sources of ground-water contamination have been identified in the 400 Area. However, elevated levels of tritium and nitrate associated with the ground-water plume from the vicinity of the PUREX Plant in the 200-East Area have been identified in 400 Area wells (Plates 3 and 4). A water supply Well 499-S1-8J, was drilled to the lower unconfined aquifer in 1985 to reduce tritium concentrations to below the MCL. Two water supply wells, 499-S0-7 and 499-S0-8, in the upper unconfined aquifer are also connected to the 400 Area water supply. Well 499-S0-7 is used for backup water supply, and Well 499-S0-8 is maintained for emergency use. The tritium activities in Wells 499S1-8J, 499-S0-7, and 499-S0-8 are compared to those in the 400 Area drinking water supply in Figure 5.49.

Tritium in the 400 Area drinking water supply is monitored by the PNL Surface Environmental - Surveillance Project for the Hanford Environmental Health Foundation. Tritium has remained below the MCL for all but one sampling event since the new supply well (499-S1-8J) went online in 1985. The concentration of tritium in the drinking water supply closely reflects that in the main supply Well 499-S1-8j, in spite of occasional use of the backup well. Tritium in backup Well 499-S0-7 remained above the MCL. Tritium concentrations in Well 499-S0-8 suddenly dropped below the MCL in 1992 and have remained low ever since. The reason for this drop is unclear. Well construction allows water from the 400 Area water supply to flow slowly down the well to lubricate the pump bearings. Since the well is seldom used, this practice may affect the sample quality. However, a change in sampling procedure to pump the 400 Area water supply wells for at least 20 minutes at approximately $760 \mathrm{~L} / \mathrm{min}$ (200 gal/min), purging approximately 3 well volumes before sampling, did not affect the sample results. A zone of lower tritium concentration appears to be present in the general vicinity of the 400 Area. Nitrate remained below the MCL through 1992 in samples from all three supply wells in the 400 Area. It is possible that this zone is related to infiltration of water from surface discharge of 400 Area water north of the Area.

\subsection{Area}

Most ground-water contamination found in the 600 Area is related to sources in the operational areas discussed above. However, several other sources or potential sources of contamination exist. These include the Central Landfill Complex and Gable Mountain Pond.

\subsubsection{Central Landfill Complex}

The Central Landfill Complex includes the Non-Radioactive Dangerous Waste Landfill (NRDWL), which is a RCRA facility, and the Solid Waste Landfill, a non-RCRA facility southeast of the 200-East Area (Figure 1.1). The Central Landfill Complex is included in the 200-IU-3 Operable Unit for the purposes of the Tri-Party Agreement. The 1994 RCRA monitoring of the NRDWL and monitoring of the Solid Waste Landfill has been summarized by Hodges (1995a,b).

The NRDWL received dangerous non-radioactive waste from 1977 to 1985 and continued to receive asbestos waste until 1988. The Solid Waste Landfill has been in operation since 1972 and has received principally paper waste, construction debris, asbestos waste, and lunchroom waste. In addition, some sewage waste and wash water from the Hanford Site bus garage were disposed of at the Solid Waste Landfill between 1985 and 1987 (DOE-RL 1992). 
The chlorinated hydrocarbon compounds, including TCE and tetrachloroethylene, detected at the Solid Waste Landfill are attributed to the bus garage washwater. A soil-gas survey of the Solid Waste Landfill performed in 1989 (Evans et al. 1989) confirmed the presence and documented the distribution of chlorinated hydrocarbons in the landfill. Chlorinated hydrocarbons detected in the soil-gas survey include TCE, tetrachloroethylene, and 1,1,1-trichloroethane (1,1,1-TCA).

More recently, Jacques (1993) performed a soil-gas survey in the NRDWL with similar results. The NRDWL survey included detection of minor carbon tetrachloride contamination not seen in other parts of the landfill but occasionally seen at minor levels in the ground water.

Several wells at the Solid Waste Landfill contained TCE at levels close to but slightly below the $\mathrm{MCL}$; the maximum concentration detected in 1994 was $4.3 \mu \mathrm{g} / \mathrm{L}$ in Well 699-22-35. Wells monitoring the Solid Waste Landfill had TCE concentrations above the MCL in previous years. Tetrachloroethylene concentrations in 1994. reached a maximum of $4.9 \mu \mathrm{g} / \mathrm{L}$, just below the $\mathrm{MCL}$, in Well 699-24-34C. Other VOCs detected at levels less than the MCL in this vicinity in 1994 are carbon tetrachloride, chloroform, and 1,1,1-TCA.

\subsubsection{Gable Mountain Pond}

Gable Mountain Pond is a liquid waste disposal area located south of Gable Mountain. Gable Mountain Pond received liquid wastes from the 200-East Area until it was deactivated in 1987. The pond is currently dry. Concentrations of strontium-90 above the MCL are detected in several wells near Gable Mountain Pond (Figure 5.40). Strontium-90 in that area apparently resulted from the discharge of waste to that pond during its early use. The maximum concentration of strontium-90 detected in the Gable Mountain Pond area in 1994 was $994 \mathrm{pCi} / \mathrm{L}$ in Well 699-53-48B. This is slightly below the DCG of $1000 \mathrm{pCi} / \mathrm{L}$. Strontium -90 was also detected in basalt below the contact with the sediments in Well 699-53-48A, where the concentration was $119 \mathrm{pCi} / \mathrm{L}$. The depth to basalt in this

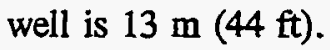

\subsection{Richland North Area}

The Richland North Area including the 1100 and 3000 Areas, that part of the 600 Area south of the 300 Area, and nearby offsite parts of Richland are considered together in this section. Thus, this area includes the CERCLA 1100-EM-1 Operable Unit, the Siemens Power Corporation facilities, the North Richland well field and recharge basins, and a number of other commercial, agricultural, and residential areas. Particular concern in the Richland North Area is related to the potential for future impacts at the North Richland well field, which is used as a supplementary water supply for the City of Richland (see Section 3.3.5).

The Horn Rapids Landfill is part of the 1100-EM-1 Operable Unit. Results of the CERCLA 1100-EM-1 investigations are presented in the Final Remedial Investigation/Feasibility Study (DOE-RL 1992), and the Tri-Party Agreement record of decision for the 1100-EM-1 Operable Unit that was signed in September 1993. The remedy for ground water that was selected was natural attenuation and ground-water monitoring, with institutional controls on drilling of new water supply wells. 
Ground-water constituents of concern in the Richland North Area include gross alpha or uranium, nitrate, technetium-99, and TCE. The potential for transport of tritium from site operational areas into the Richland North Area is also being assessed.

\section{Tritium}

Tritium from the 200-East Area discharge has been transported to the Columbia River as far south as the 300 Area (Figure 5.1 and Plate 3). The levels in monitoring wells north of the 300 Area increased steadily until 1993 and have raised concern regarding possible future impact on the Richland North water supply wells. The increasing trend in tritium activity in Well 699-S19-E13, north of the 300 Area, is shown in Figure 5.50. Tritium concentrations in samples collected from the Richland North wells are approximately the same as Columbia River Water and do not indicate any groundwater transport of contamination to the well field.

Several factors are believed to limit the migration of the 200-East Area tritium plume toward the Richland North Area. The first of these is the eastward flow across the area produced by ground-water recharge from the Yakima River. Elevation of the Yakima River, to the west of the Richland North Area, is approximately $15 \mathrm{~m}$ higher than the Columbia River to the east. The Yakima River therefore is a source of recharge and causes the ground water to flow eastward across the area and discharge to the Columbia River. Additional recharge from irrigation in the western Richland North Area is also believed to contribute to the eastward flow. The ground-water mound at the Richland North well field recharge basins also limits southward flow of ground water from the site. These factors produce converging flow lines and discharge to the Columbia River in the 300 Area (see Figure 5:51).

Nitrate

Nitrate distributions in the Richland North Area provide additional support for the interpretation of ground-water flow presented above. Nitrate concentrations greater than the MCL in ground water are found in the vicinity and downgradient of the Siemens Power Corporation plant (Figure 5.2 and Plate 4). The maximum nitrate concentration detected in sampling on the Hanford Site downgradient of the Siemens Power Corporation plant in 1994 was $220 \mathrm{mg} / \mathrm{L}$ as $\mathrm{NO}_{3}^{-}$in well 699-S30-E10B. Somewhat elevated nitrate concentrations have also been found upgradient of Siemens Power Corporation in the western portion of the Richland North Area. The upgradient sources may be application of agricultural fertilizer and irrigation. Potential nitrate sources from the Siemens Power Corporation operations have been discussed by DOE-RL (1992). Nitrate was not identified as a soil contaminant in the Horn Rapids Landfill.

An area of low nitrate concentration is located around the Richland North well field recharge basins. This pattern is interpreted as representing the effect of infiltrating low-nitrate water from the Columbia River.

\section{Trichloroethylene}

TCE has been detected in ground-water samples from wells in the areas of Siemens Power Corporation and the Horn Rapids Landfill (Figure 5.48). The maximum TCE detected in the vicinity of the Horn Rapids Landfill in 1994 was $36 \mu \mathrm{g} / \mathrm{L}$ in Well 699-S31-10A. 
The only potential TCE source identified in the Richland North Area is the use of TCE in installing and maintaining pond liners at the Siemens Power Corporation facility (DOE-RL 1992). TCE has been detected in ground water at the Siemens Power Corporation facility and downgradient from it. The maximum TCE concentrations detected in ground water on the Siemens Power Corporation site in 1994 were $12 \mu \mathrm{g} / \mathrm{L}$ (Geraghty and Miller 1995). No TCE was detected in soil samplings from the Horn Rapids Landfill. TCE detected in soil-gas sampling at the landfill probably results from volatilization of the ground-water plume.

TCE concentrations in the southernmost wells adjacent to the landfill are decreasing, while in the northernmost wells concentrations are increasing. Wells downgradient to the northeast show increasing TCE concentrations. TCE was first detected in Well 699-S28-E12 in early 1993 and was first detected in late 1993 in Well 399-5-1 (Figure 5.52). Soil-gas monitoring points were installed in 1994 by the Ground-Water Surveillance Project in order to further define and monitor the TCE plume. TCE concentrations in soil gas indicate that the plume extends northeast from the Horn Rapids Landfill area (Figure 5.52). TCE was detected in soil gas to the north of Wells 699-S29-E11 and 699-S28-E12. TCE was not detected in a few soil-gas sample points within the plume boundary. This is possibly attributable to the presence of less permeable lenses inhibiting upward transport of TCE in the vadose zone.

\section{Technetium-99, Uranium and Gross Alpha}

Technetium-99 has been detected at low levels in the vicinity of the Horn Rapids Landfill. The technetium- 99 appears to be related to offsite elevated gross-beta measurements (Gheraghty and Miller 1995). Uranium is not detected at levels significantly above background in this vicinity but elevated gross alpha values are found offsite and are attributable to uranium contamination.

Gross alpha levels up to $153 \mathrm{pCi} / \mathrm{L}$ were detected in 1994 at the Siemens Nuclear Power Corporation plant (Geraghty and Miller 1995). Although the gross alpha MCL of $15 \mathrm{pCi} / \mathrm{L}$ excludes uranium, separate uranium measurements were not reported, and no correction can be made. It is probable that uranium makes a large contribution to the gross alpha measurements at this location since the facility is used to fabricate fuel rods for commercial nuclear power plants. Uranium concentrations greater than the MCL have not been detected in any of the Hanford wells monitoring the Horn Rapids Landfill. Gross alpha measurements indicate that the area of elevated gross alpha contamination extends downgradient at least to the eastern side of the Horn Rapids Landfill. The maximum extent of the plume has not been defined any more precisely because of the lack of wells within the landfill itself. The geometry of the plume indicates that its source is located offsite.

\subsection{Confined Aquifer Chemistry}

The Ground-Water Surveillance Project monitors the ground-water chemistry in the confined aquifer beneath the Hanford Site. Wells completed in the upper-basalt aquifer are shown in Figure 3.11. In the area south of Gable Mountain near B Pond, the Rattlesnake Ridge Interbed of the upper basalt confined aquifer is exposed to suprabasalt sediments (Graham et al., 1984), increasing the potential for intercommunication between the upper basalt confined aquifer and the overlying Hanford unconfined aquifer. Discharge of waste water from Hanford facilities to the ground has resulted in an 
elevated water table across much of the Hanford Site and the mounding of ground water near B Pond in the 200-East Area and around the decommissioned U Pond in the 200-West Area (Plate 1; Figure 3.5). A downward gradient exists beneath much of the 200 Area Plateau, particularly where ground-water mounding occurs, resulting in the potential for ground water from the Hanford unconfined aquifer to mix with ground waters of the upper basalt confined aquifer.

Tritium, nitrate, and iodine-129 are readily transported by ground water and can be used to assess the general extent of contaminants associated with Hanford Site activities in the upper confined aquifer. Tritium levels above the MCL have been reported in past years for four wells completed within the upper basalt confined aquifer. However, any reported concentrations above the MCL are suspect because they are outside the general trend of data and probably do not represent aquifer conditions. No samples from confined aquifer wells in 1994 contained tritium at levels above the MCL: Tritium concentrations in Well 699-42-40C peaked in early 1993 and have been somewhat lower since then (Figure 5.53). The maximum value for tritium observed in this well in 1994 was $7,130 \mathrm{pCi} / \mathrm{L}$. Well $699-42-40 \mathrm{C}$ is located adjacent to B Pond and monitors the Rattlesnake Ridge Interbed.

Nitrate and technetium-99 concentrations near and above the MCL have been reported for Well 299-E33-12 and have remained fairly constant from 1991 through 1994. The 1994 value for nitrate measured in this well was $46 \mathrm{mg} / \mathrm{L}$. The maximum concentration of technetium-99 measured in 1994 was $1,530 \mathrm{pCi} / \mathrm{L}$. In addition, tritium was detected at low levels (up to $770 \mathrm{pCi} / \mathrm{L}$ ) and cobalt -60 was detected at levels up to $36.4 \mathrm{pCi} / \mathrm{L}$. Well 299-E33-12 is located along the northern boundary of the 200-East Area and completed within the Rattlesnake Ridge Interbed.

Contaminants detected in Wells 699-42-40C and 299-E33-12, which are completed within the Rattlesnake Ridge Interbed, apparently result from waste water discharged from Hanford facilities in the 200-East Area. Downward gradients associated with ground-water mounding near B Pond result in areas of enhanced intercommunication where the Rattlesnake Ridge Interbed is exposed to the Hanford formation. These areas likely induce flow from the Hanford unconfined aquifer to the upper basalt confined aquifer (Graham et al. 1984). The gradients in the confined aquifer indicate that the upper basalt confined aquifer beneath the Hanford Site discharges to the unconfined aquifer and ultimately to the Columbia River, although at this time there is no evidence for discharge of contaminated ground water from the confined aquifer to the river.

Strontium-90 and tritium. contamination is found in the upper confined aquifer in the 100-BC Area. Samples collected in 1994 from Well 199-B3-2P contained up to $20.9 \mathrm{pCi} / \mathrm{L}$ of strontium-90 and 504 $\mathrm{pCi} / \mathrm{L}$ of tritium. Although this well is currently completed in the confined aquifer, it was open to both the unconfined and confined aquifers between 1953 and 1970, so it is possible that the well provided a conduit for contamination in the unconfined aquifer to be transported to the confined aquifer. Since this is the only well in the vicinity completed in the confined aquifer, the current extent of contamination is unknown. The potentiometric surface in the upper confined aquifer system presented in Section 3.0 suggests that flow in this aquifer in the 100-BC Area is generally to the south-southwest and upward in the vicinity of Umtanum Ridge and Gable Butte. Thus the contamination is not believed to be migrating offsite within the confined aquifer system. 


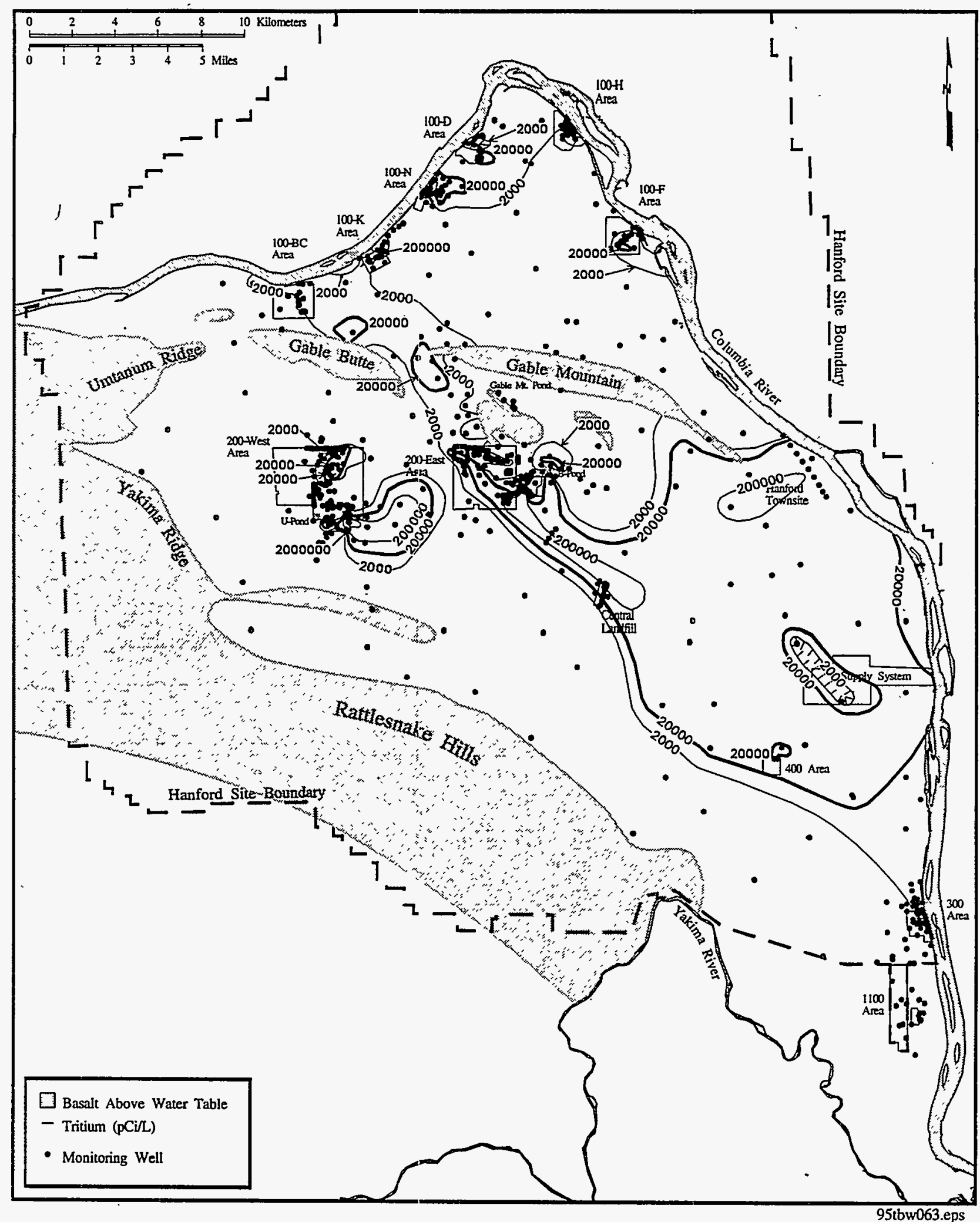

Figure 5.1. Tritium Concentration Plume Contours 


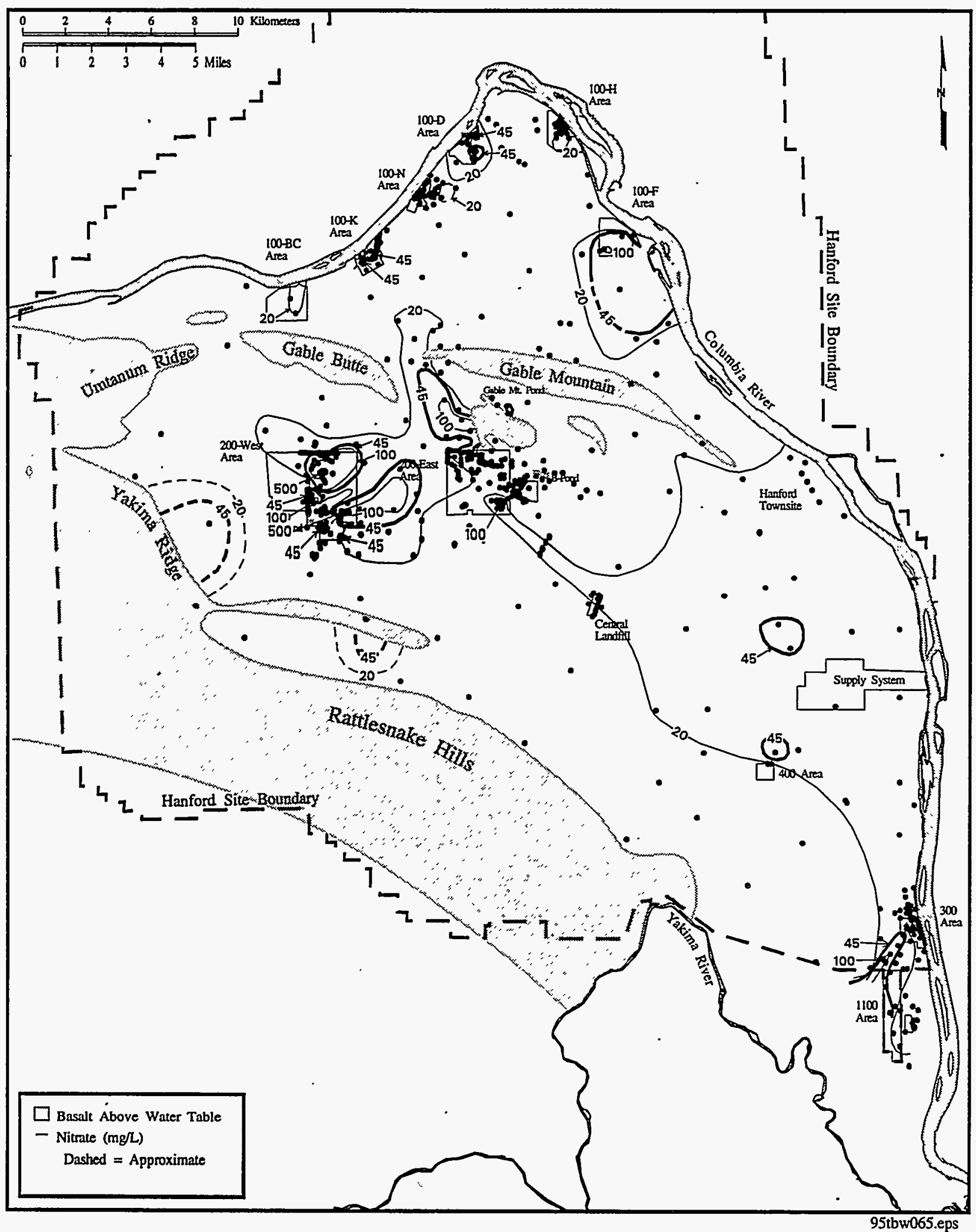

Figure 5.2. Nitrate Concentration Plume Contours 


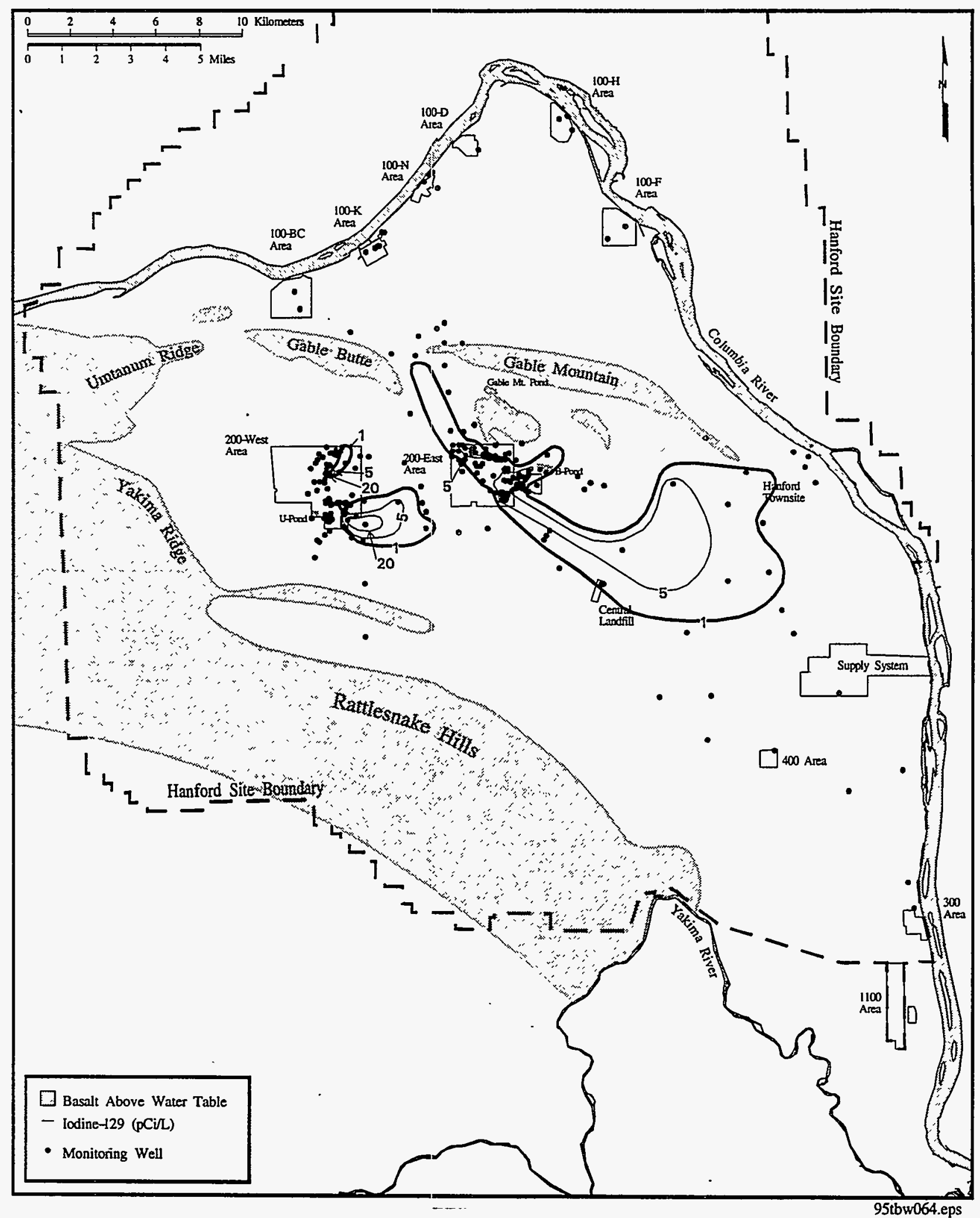

Figure 5.3. Iodine-129 Concentration Plume Contours 


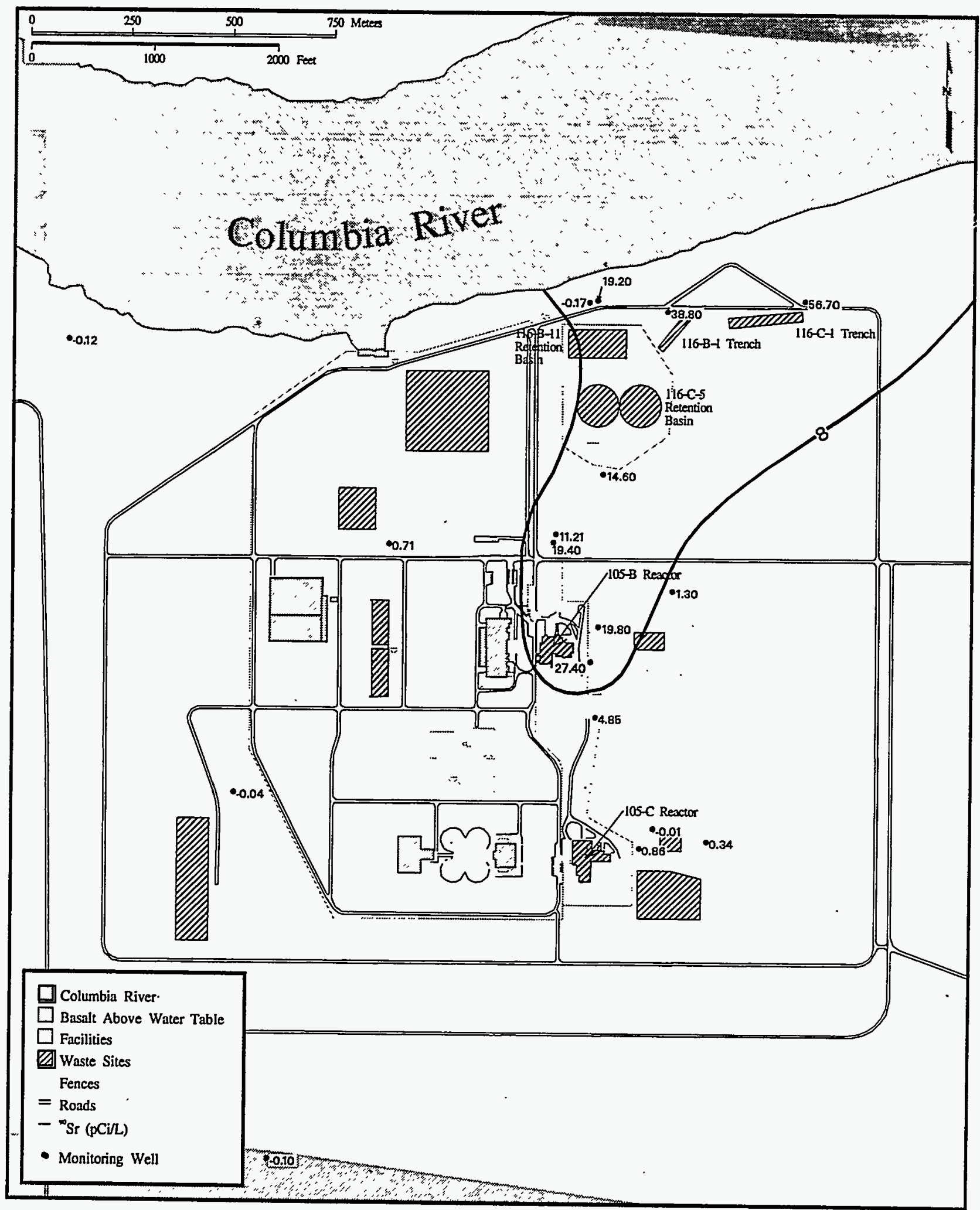

Figure 5.4. 1994 Average of Strontium-90 in the 100-BC Area 


\section{.}




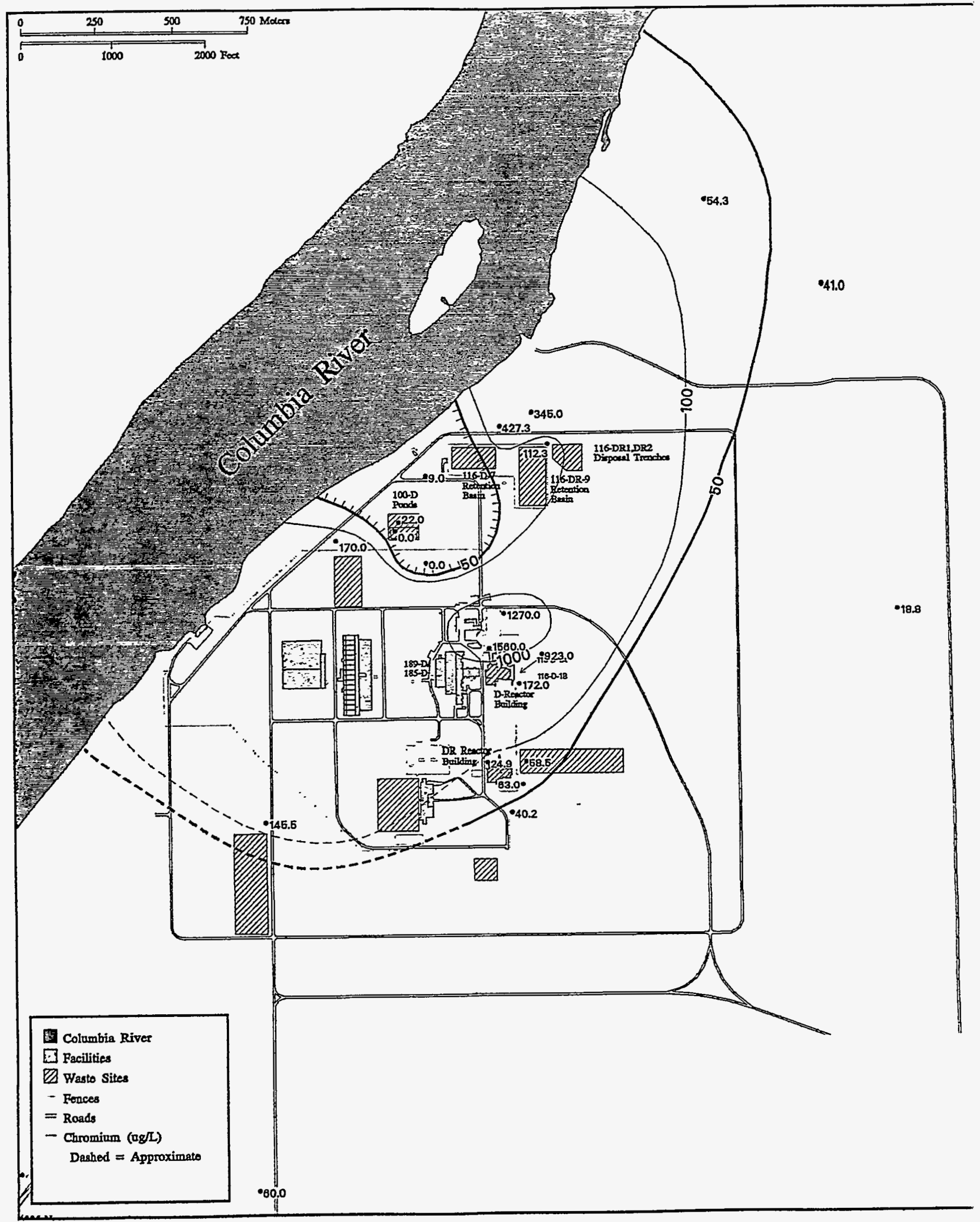




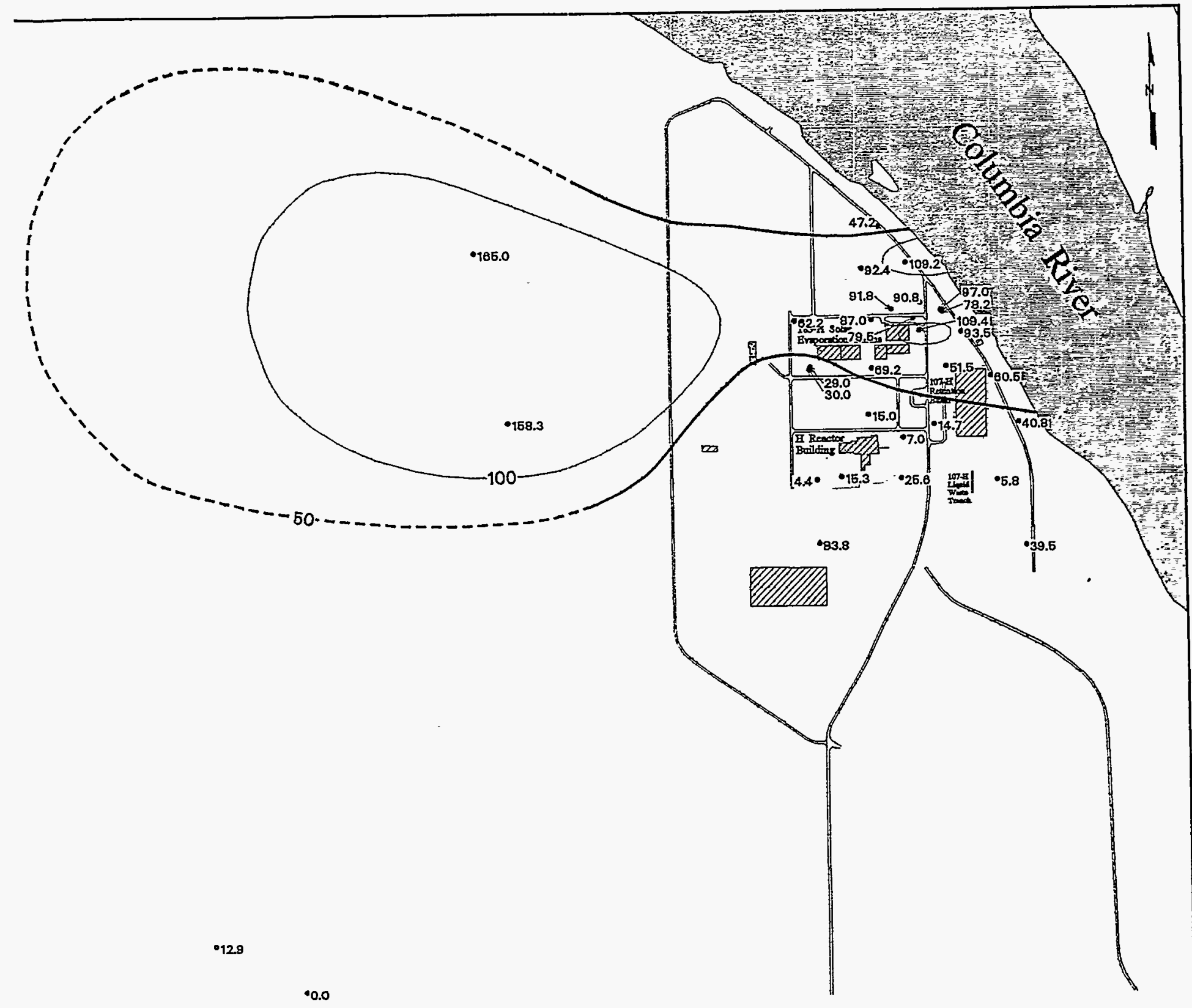




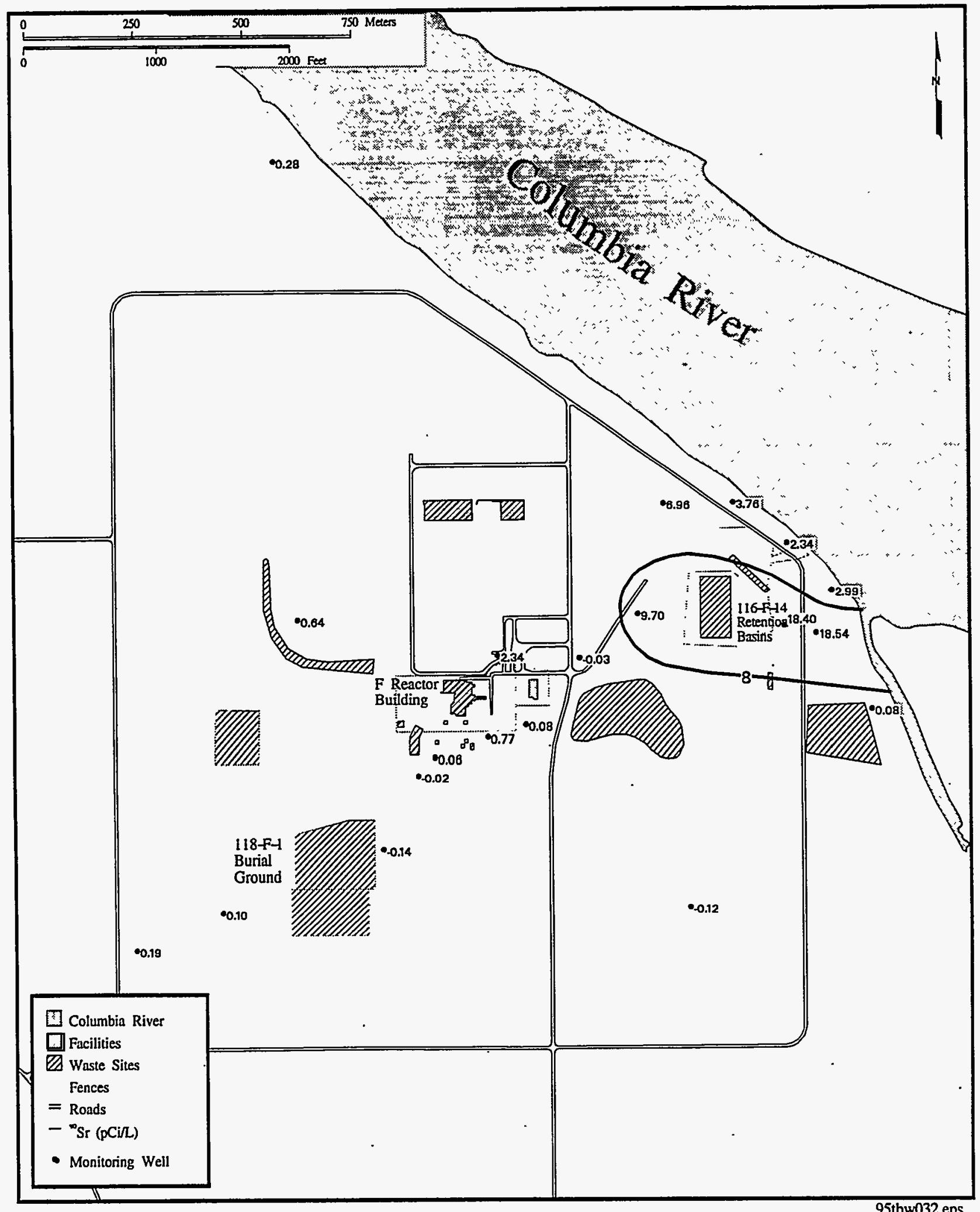

Figure 5.6. 1994 Average Strontium-90 in the 100-F Area 


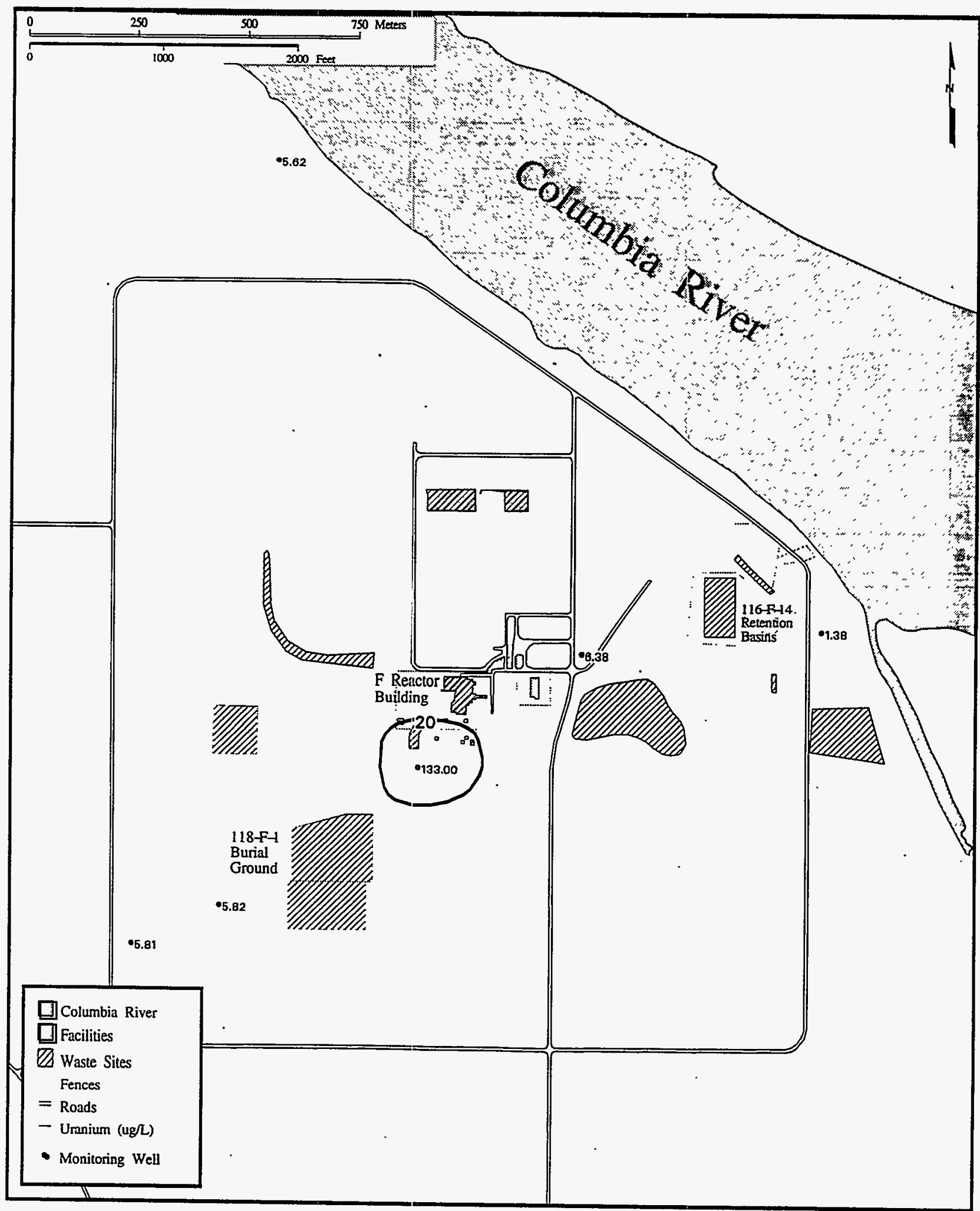

Figure 5.7. 1994 Average Uranium in the 100-F Area 


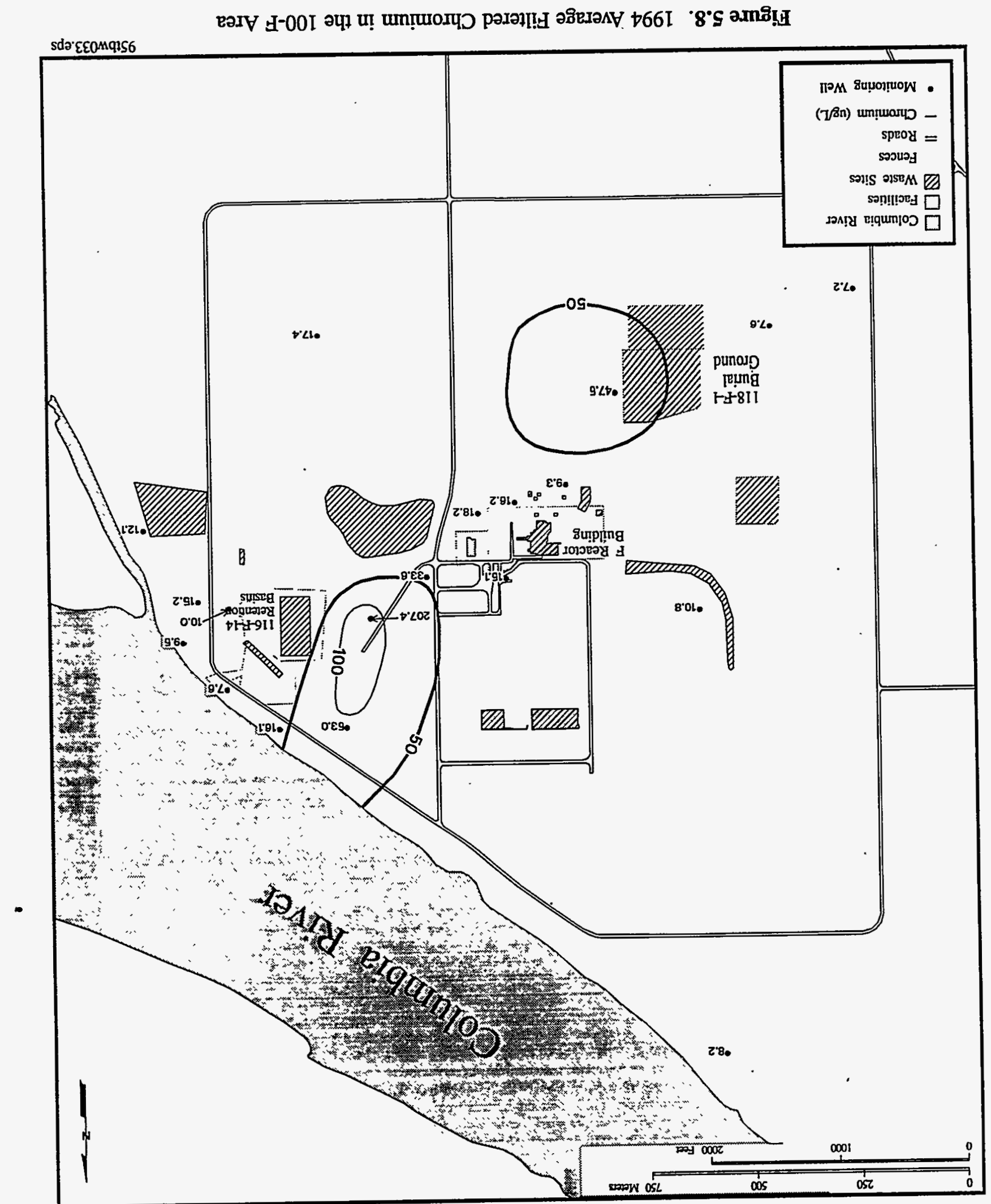


t

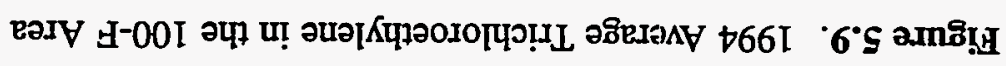

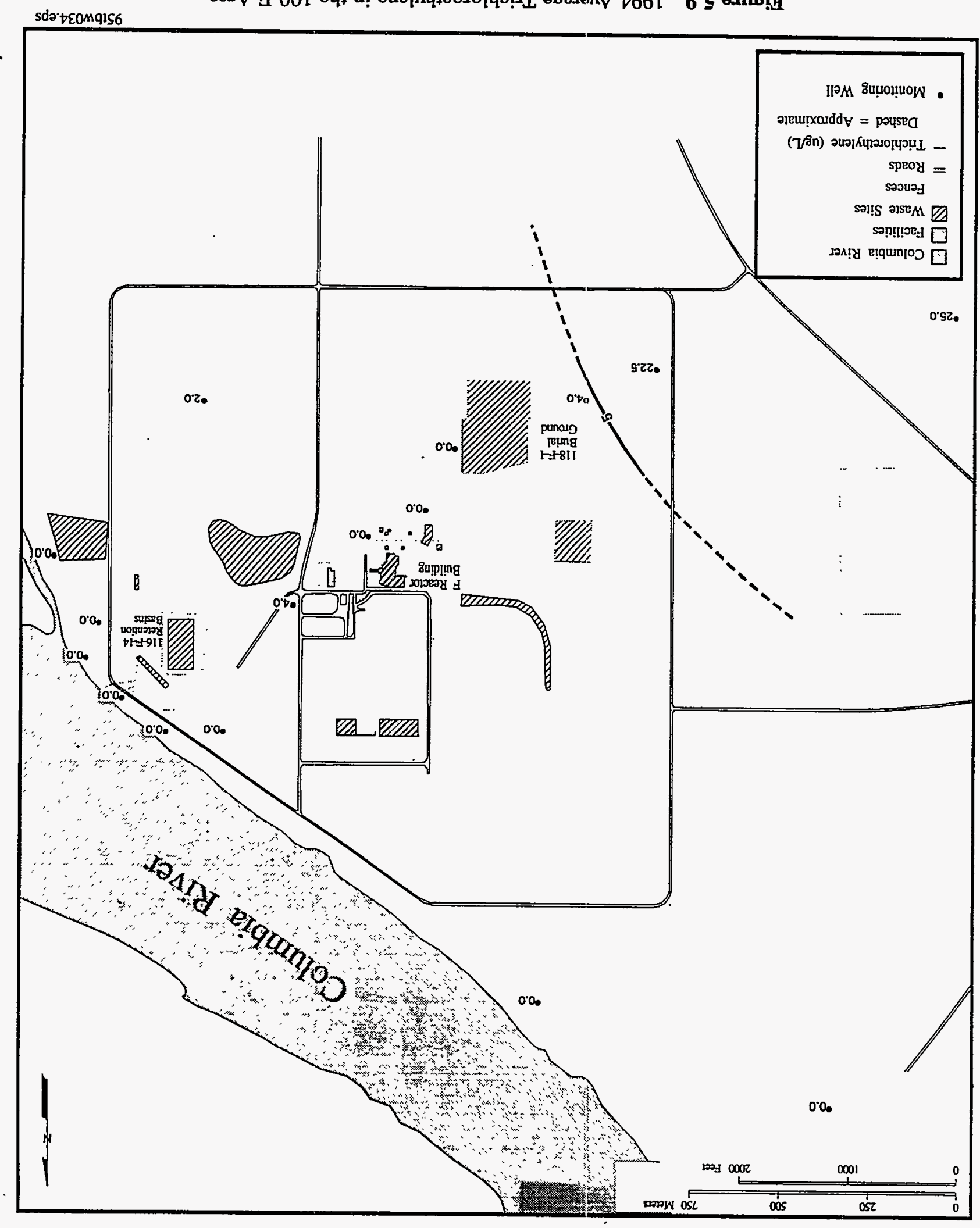




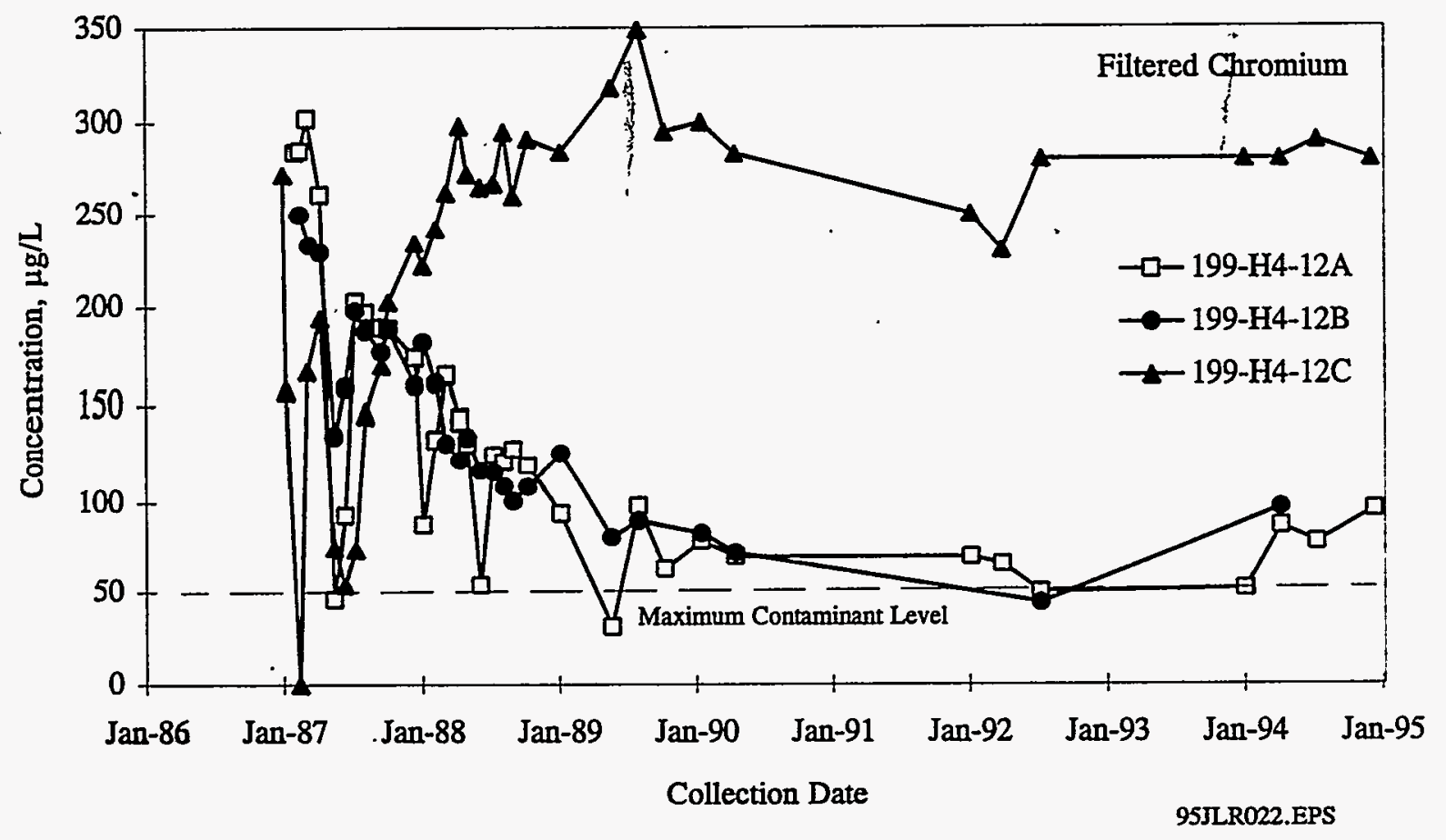

Figure 5.10. Filtered Chromium Concentration Trend in the 199-H4-12 Well Nest 


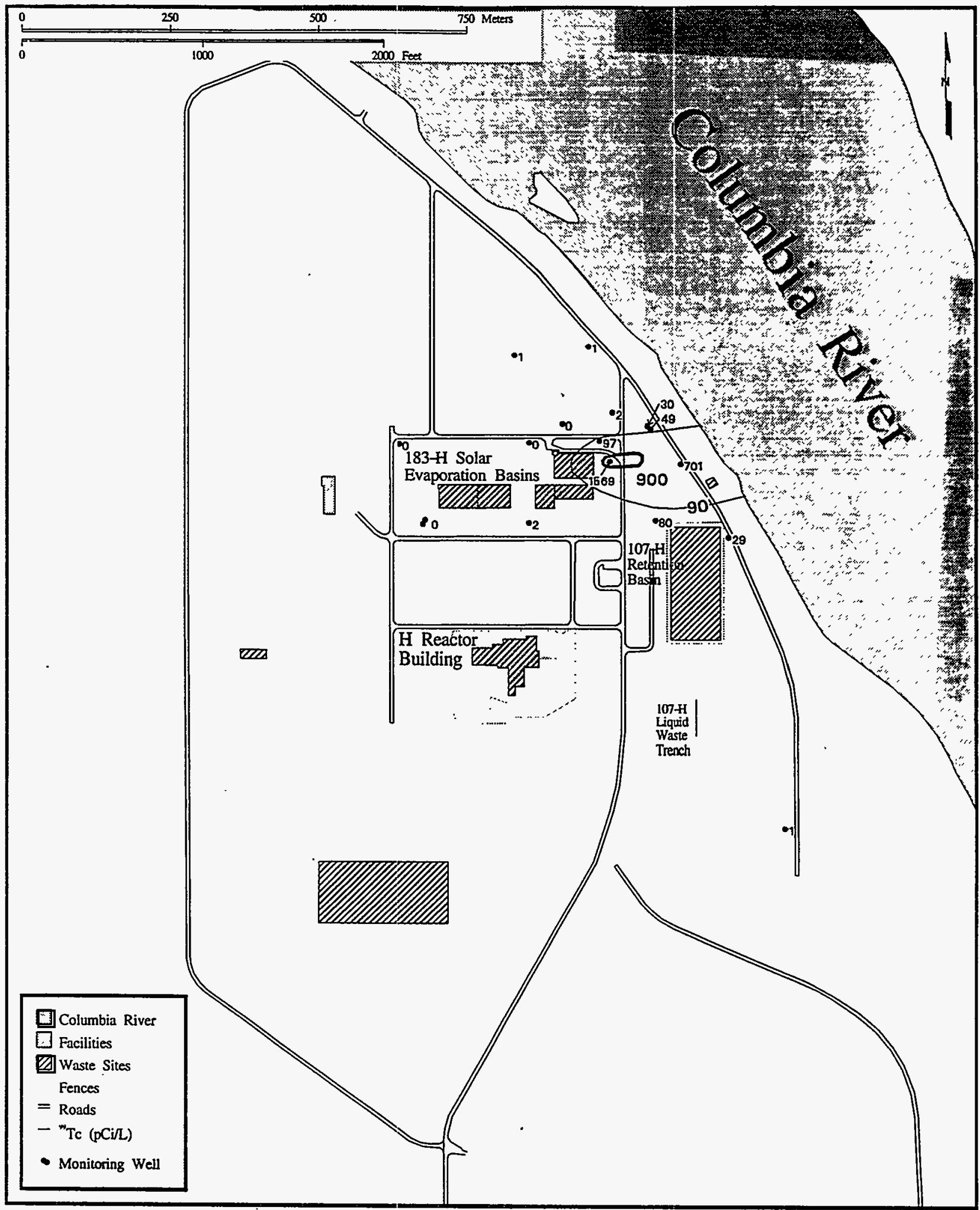

Figure 5.11. 1994 Average Technetium- 99 in the 100-H Area 


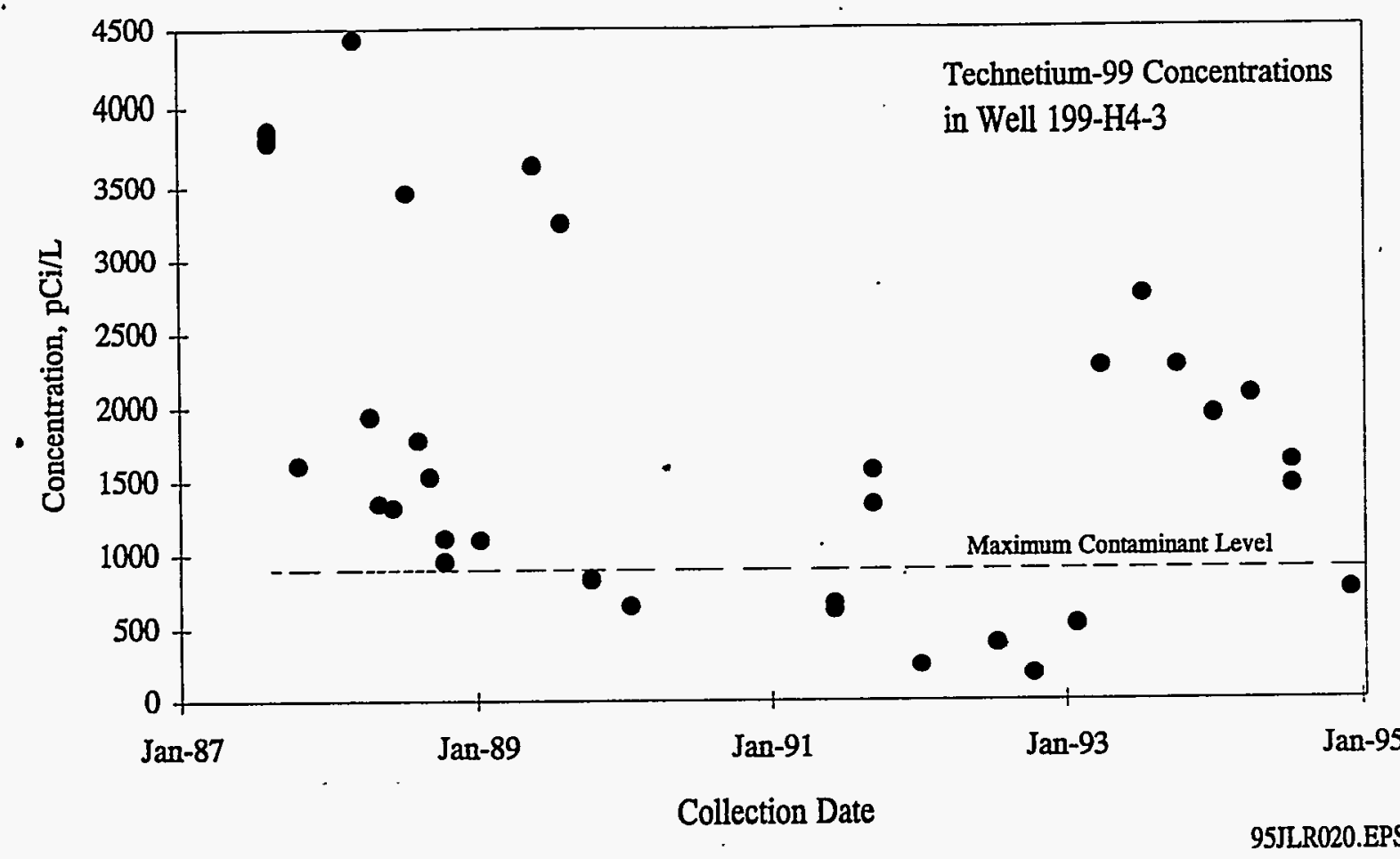

Figure 5.12. Technetium-99 Concentration Trend in Well 199-H4-3

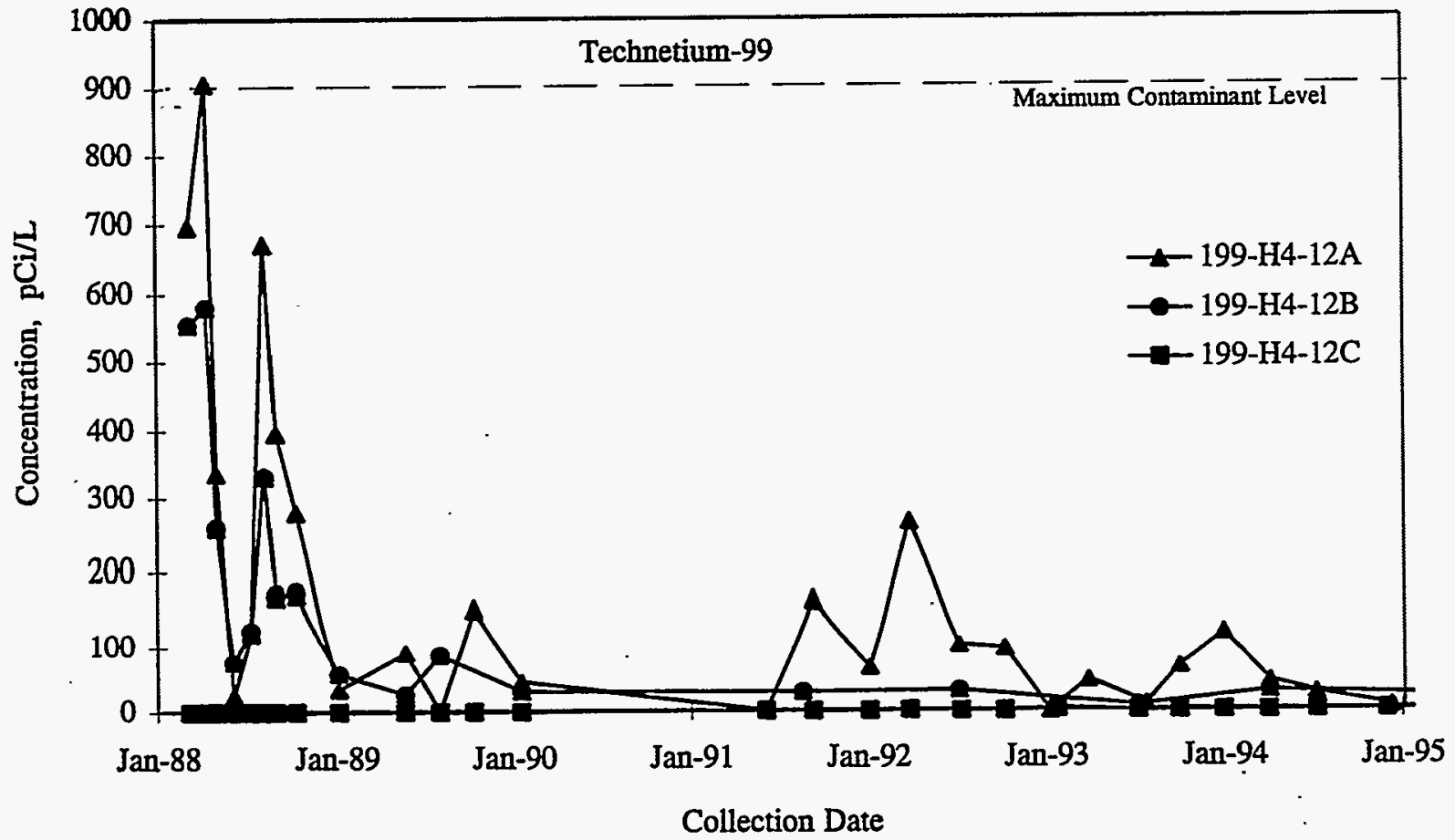

Figure 5.13. Technetium-99 Concentration Trend in the 199-H4-12 Well Nest 


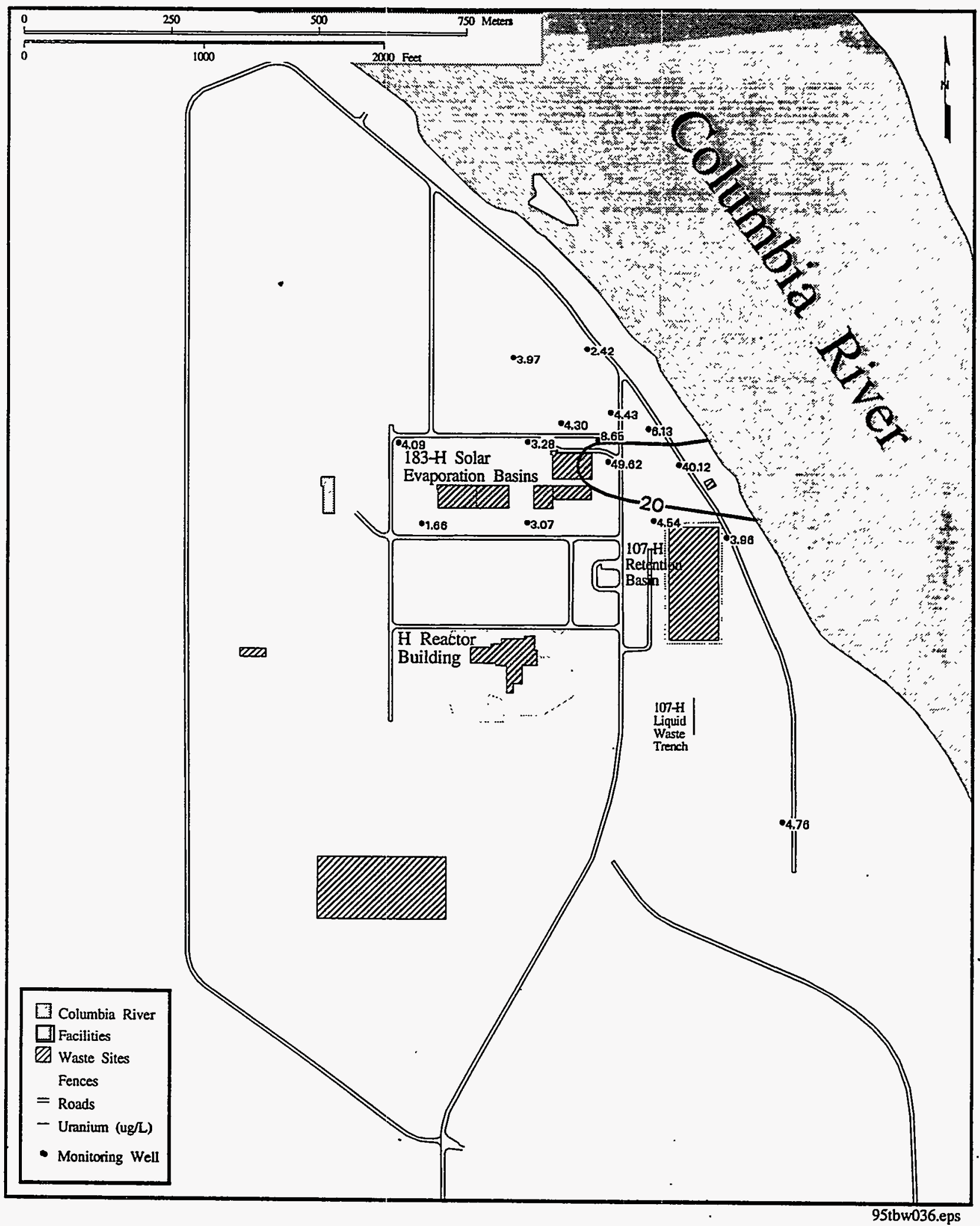

Figure 5.14. 1994 Average Uranium Concentration in the 100-H Area 


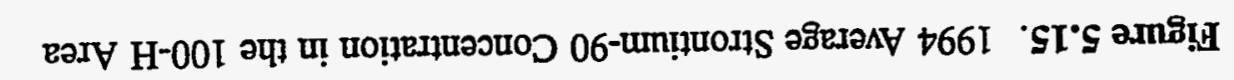

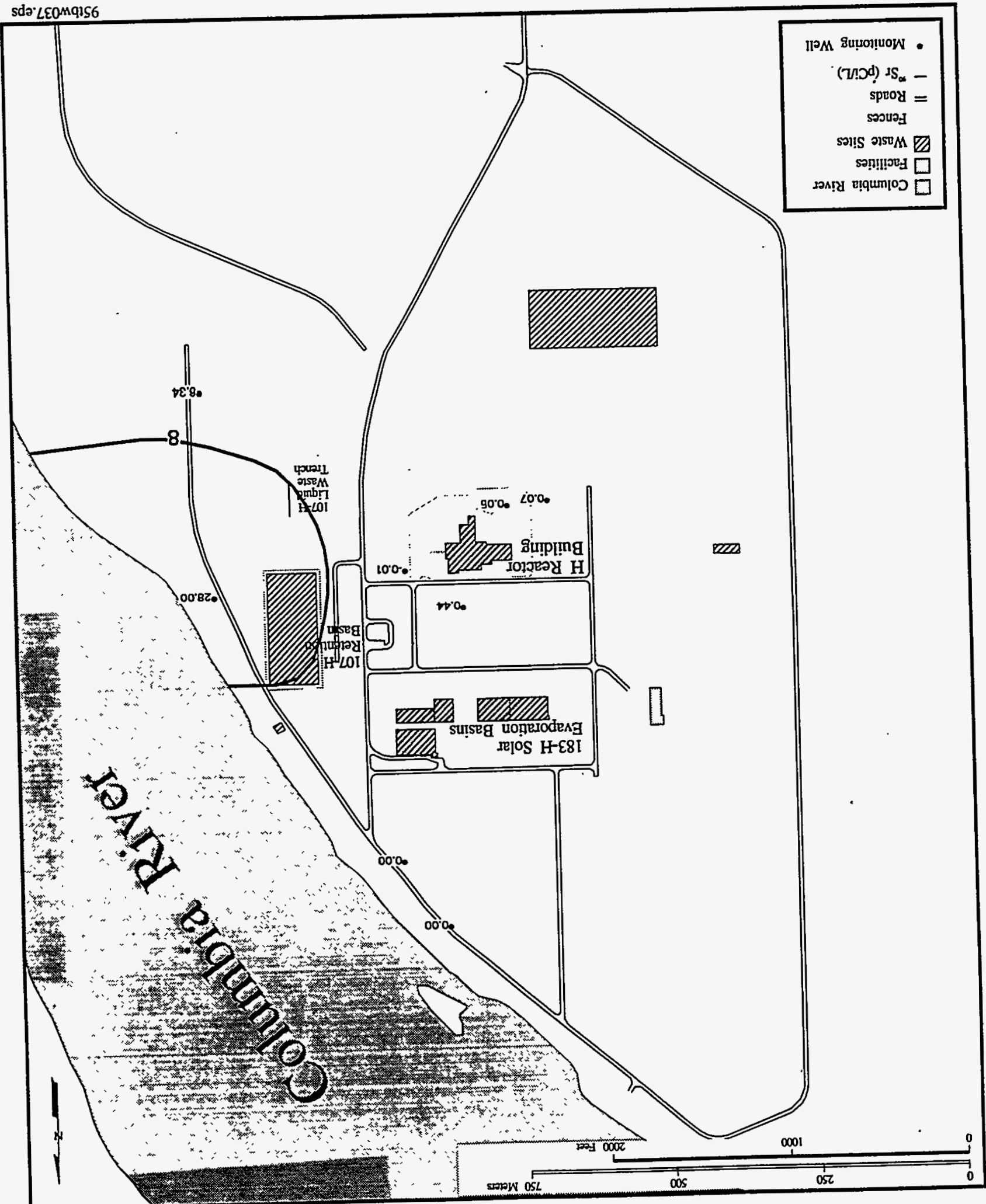




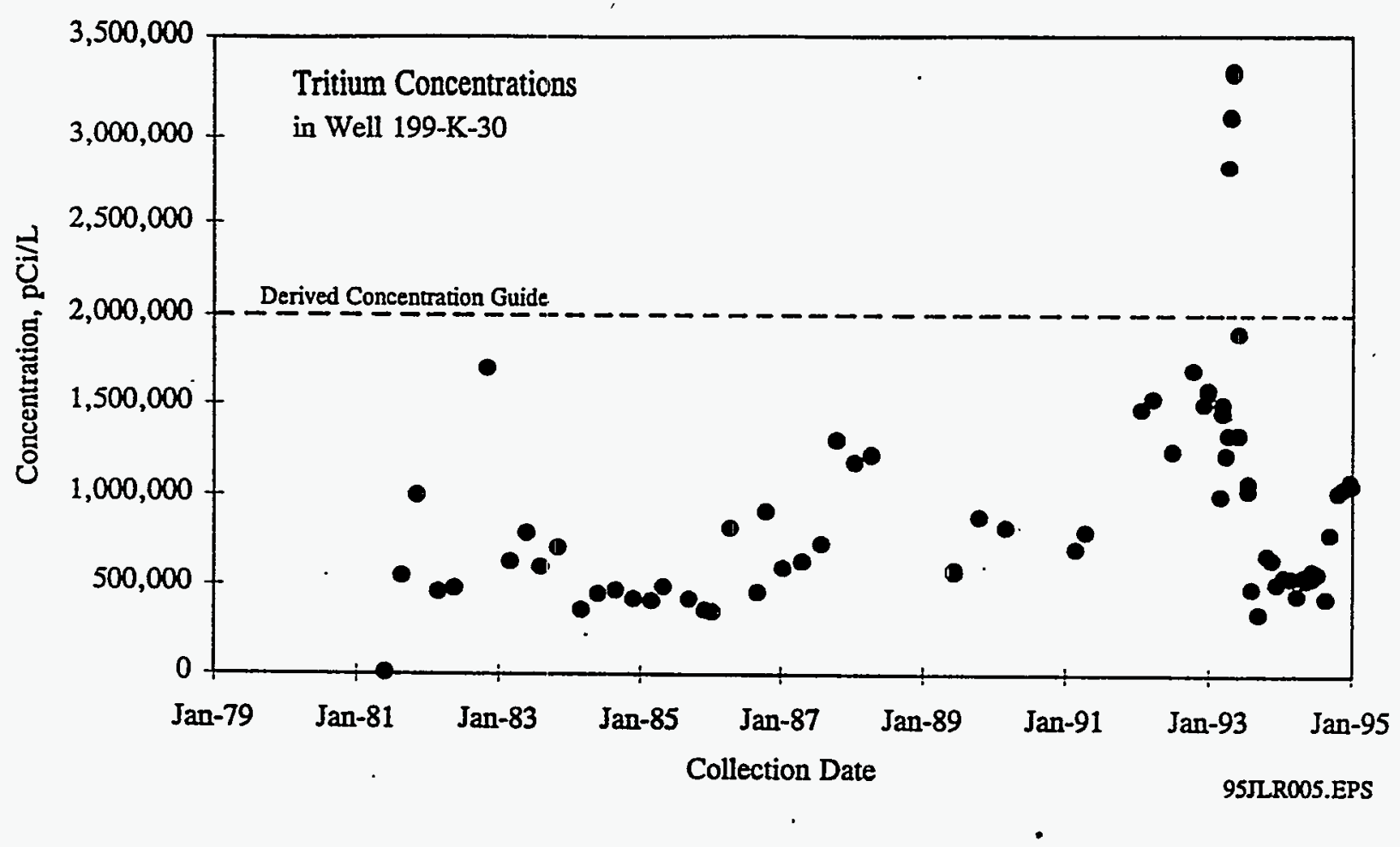

Figure 5.16. Tritium Concentration Trend for Well 199-K-30

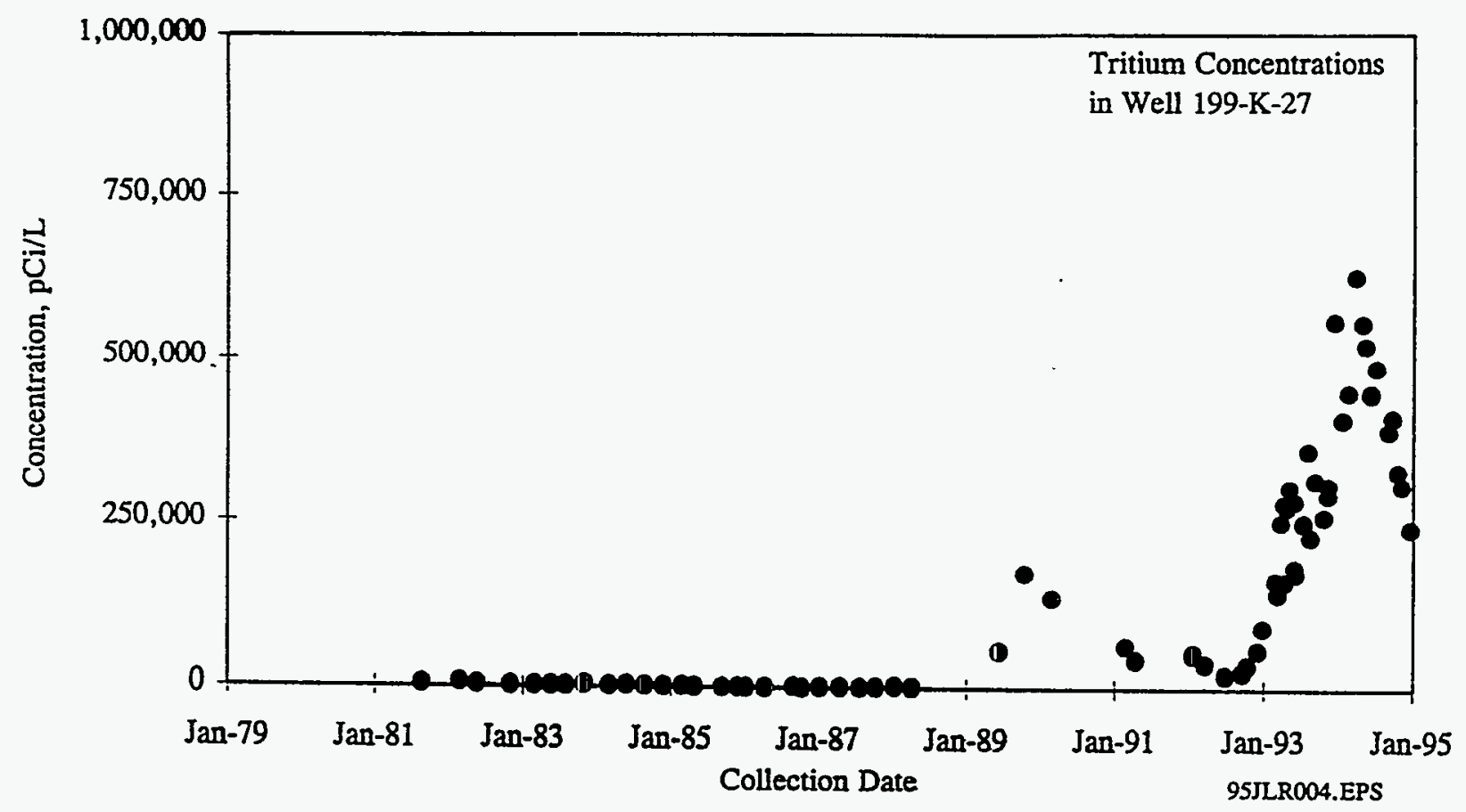

Figure 5.17. Tritium Concentration Trend for Well 199-K-27 


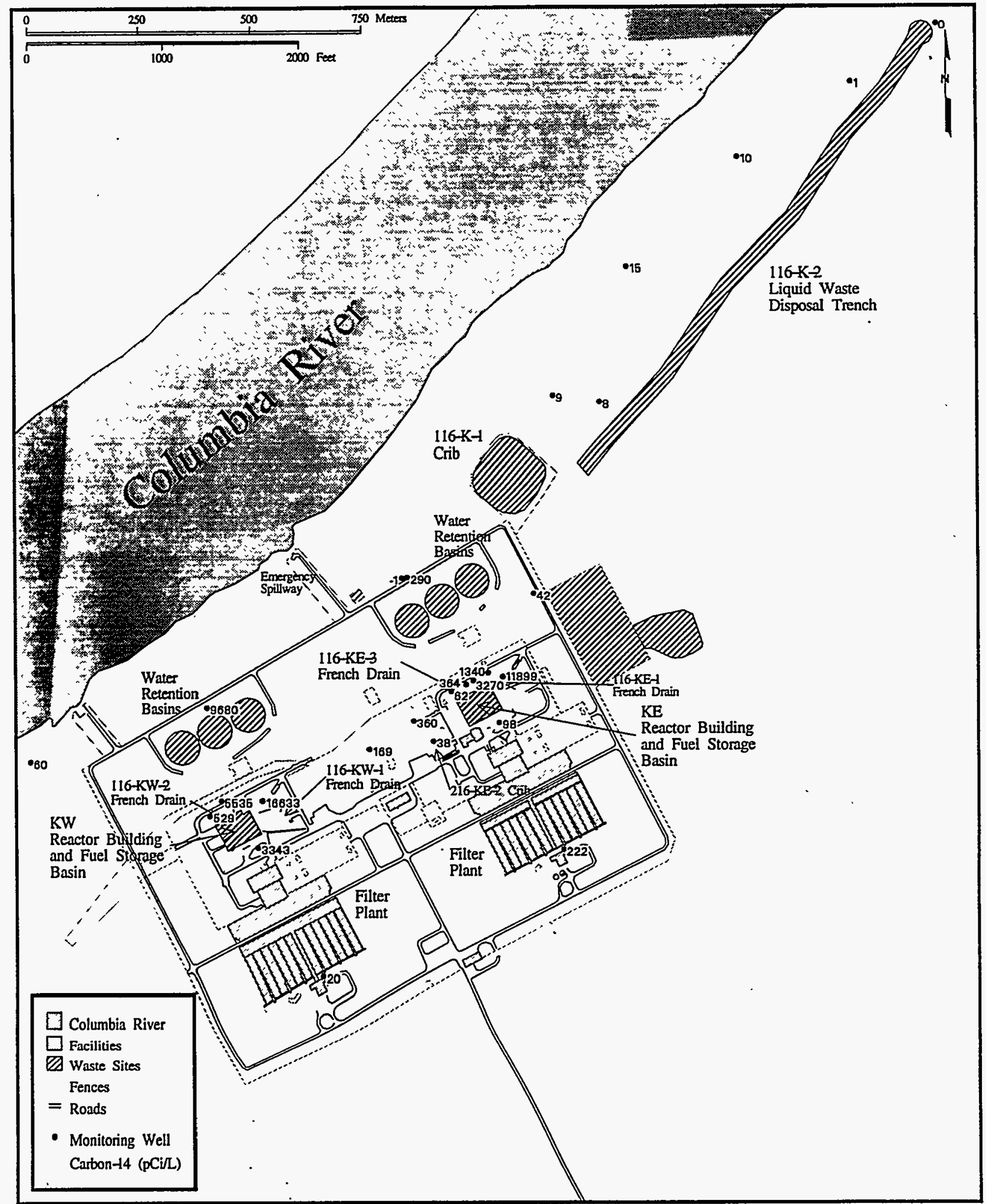

Figure 5.18. 1994 Average Carbon-14 Concentration in the 100-K Area 


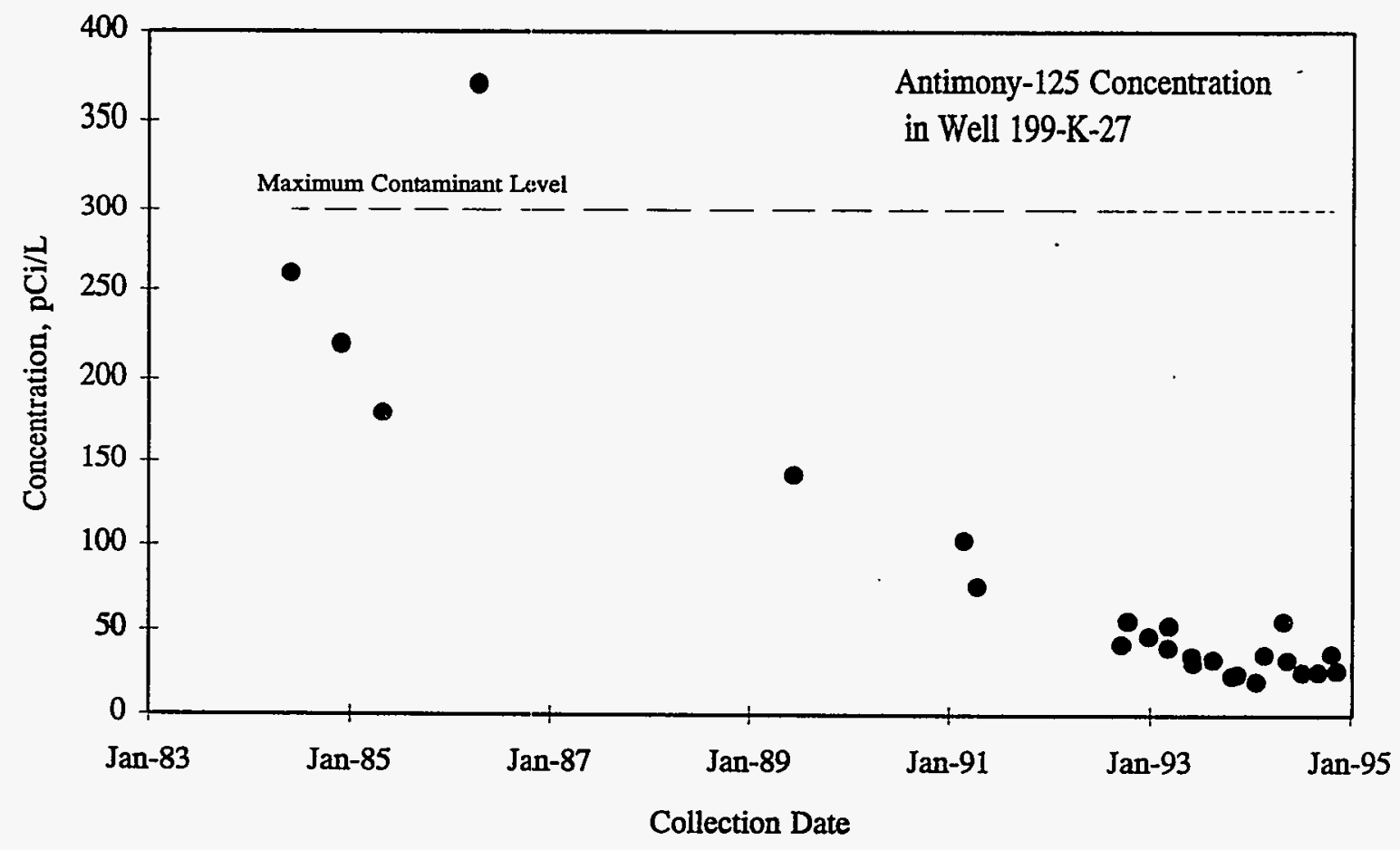

Figure 5.19. Antimony-125 Concentration Trend for Well 199-K-27

95JLR018.EPS 


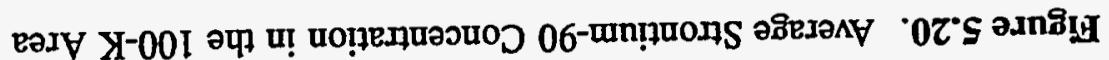

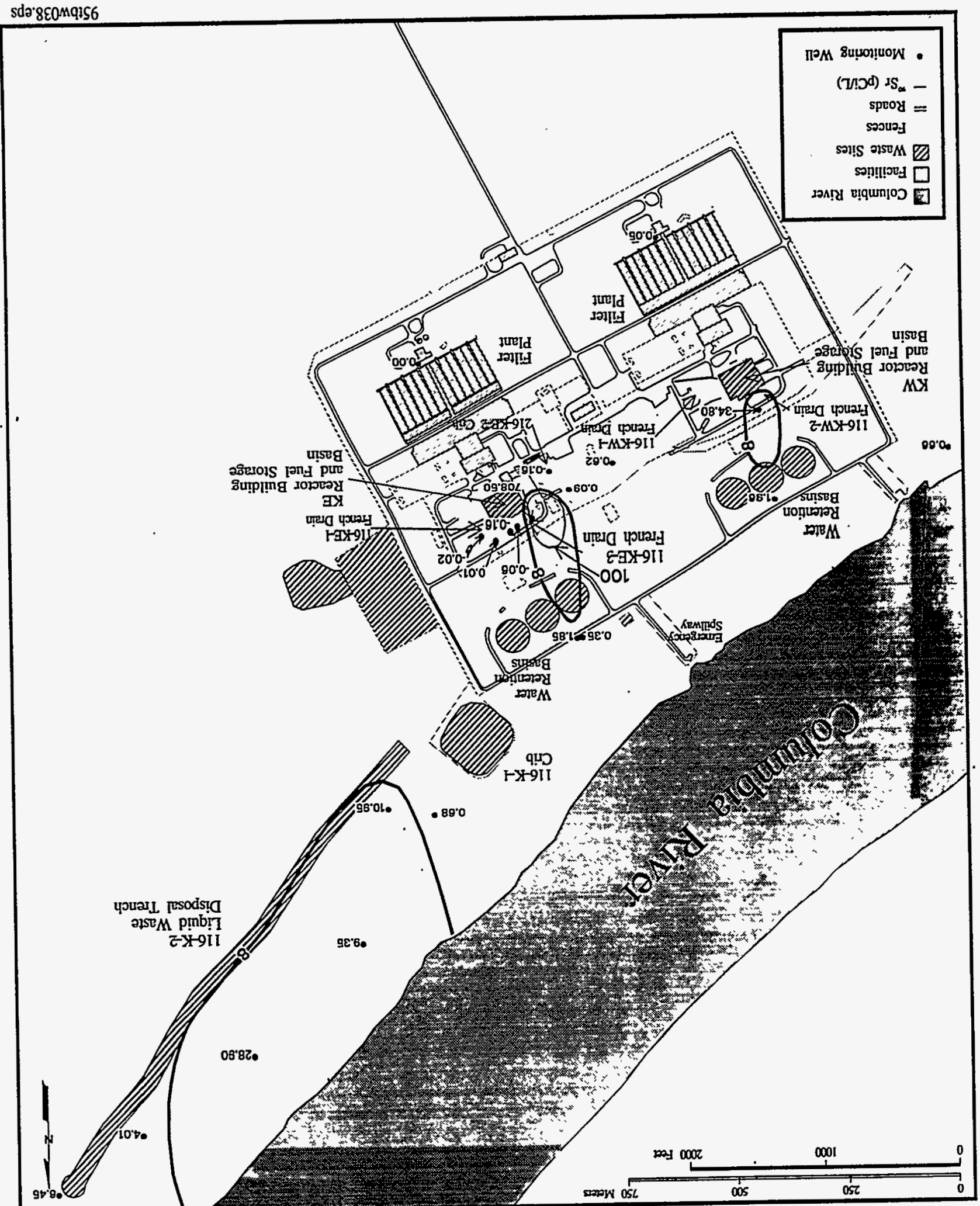




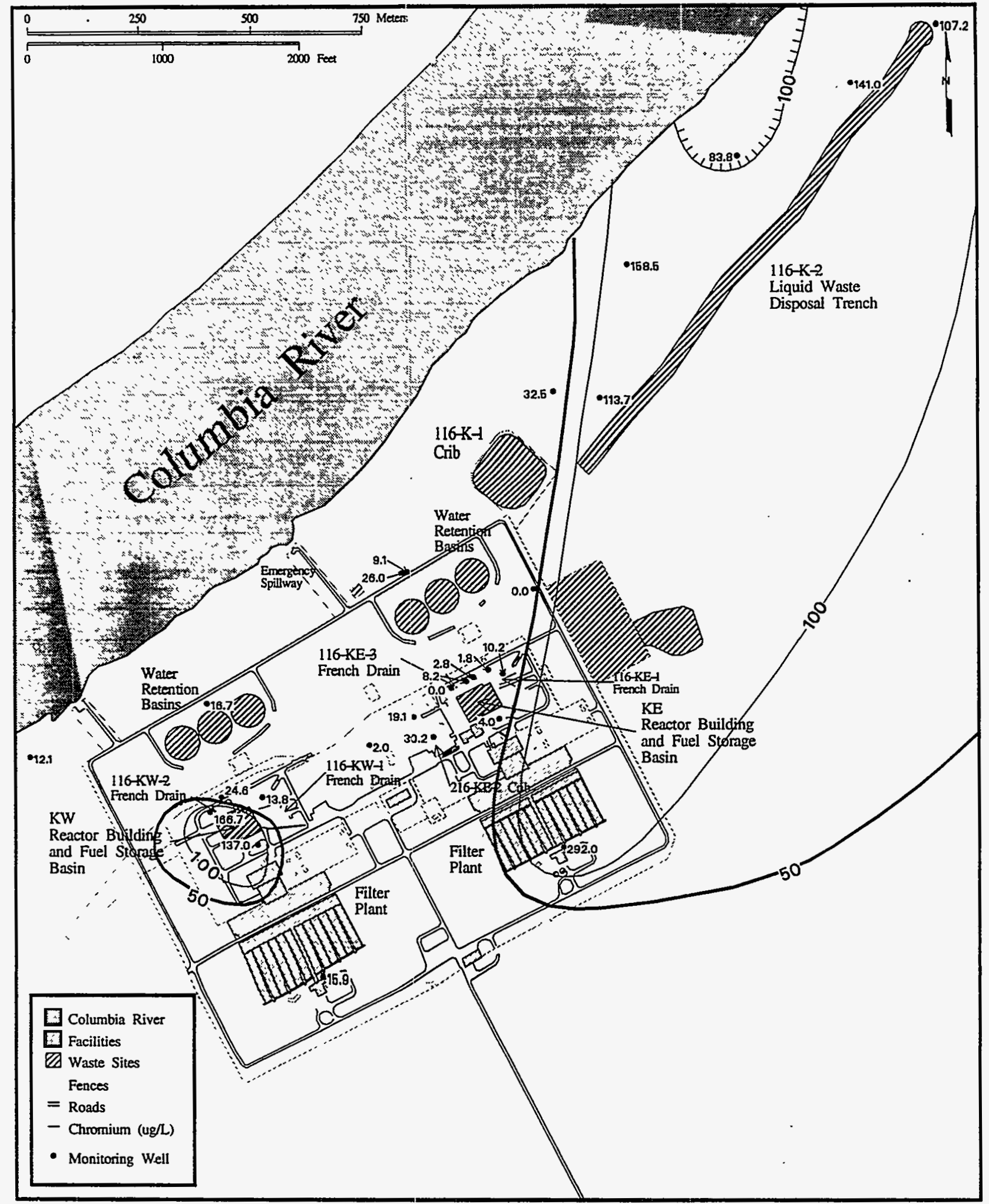

95tbw039.eps

Figure 5.21. 1994 Average Chromium Concentration in the 100-K Area 


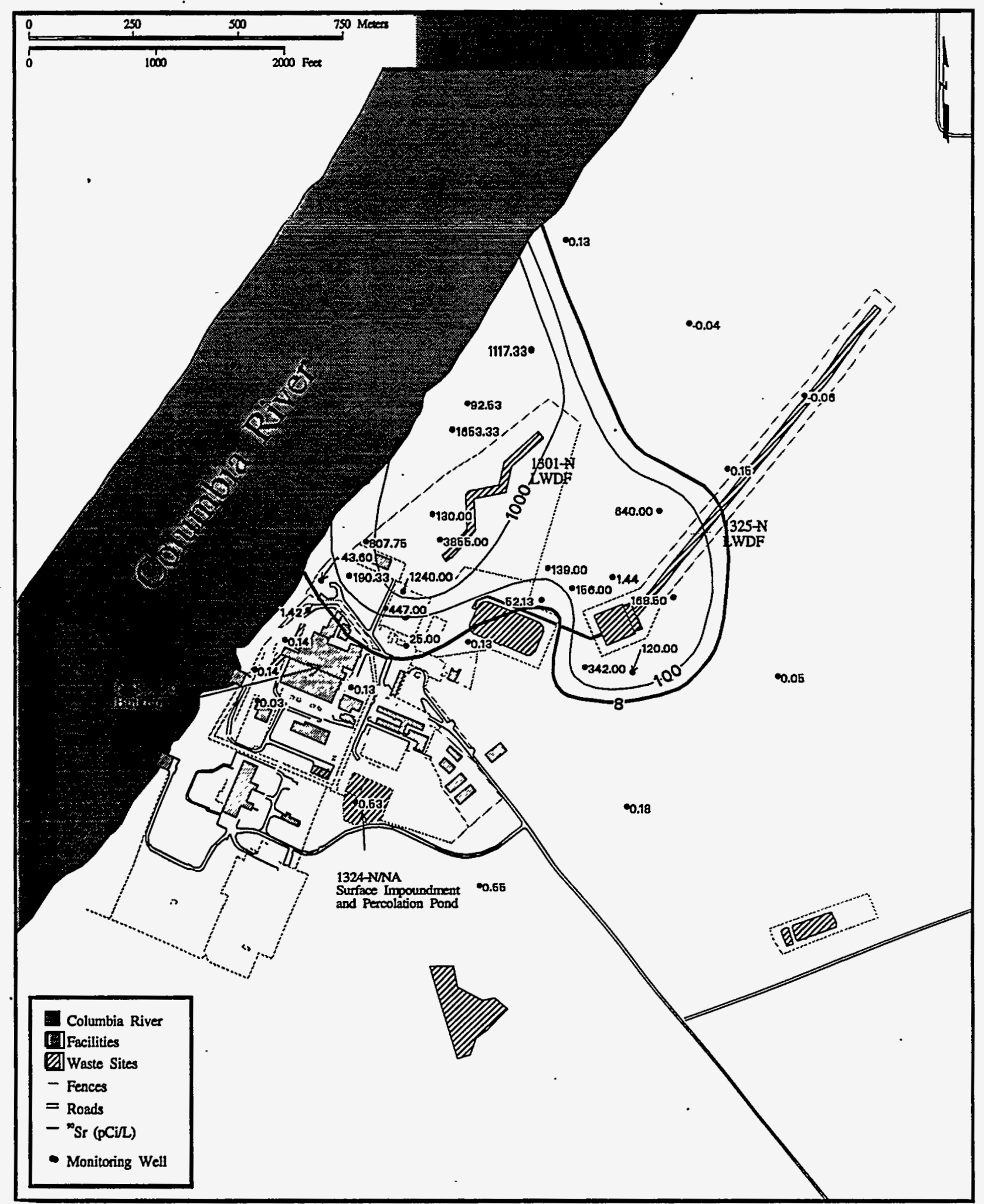

Figure 5.22. 1994 Average Strontium-90 Concentration for the 100-N Area 


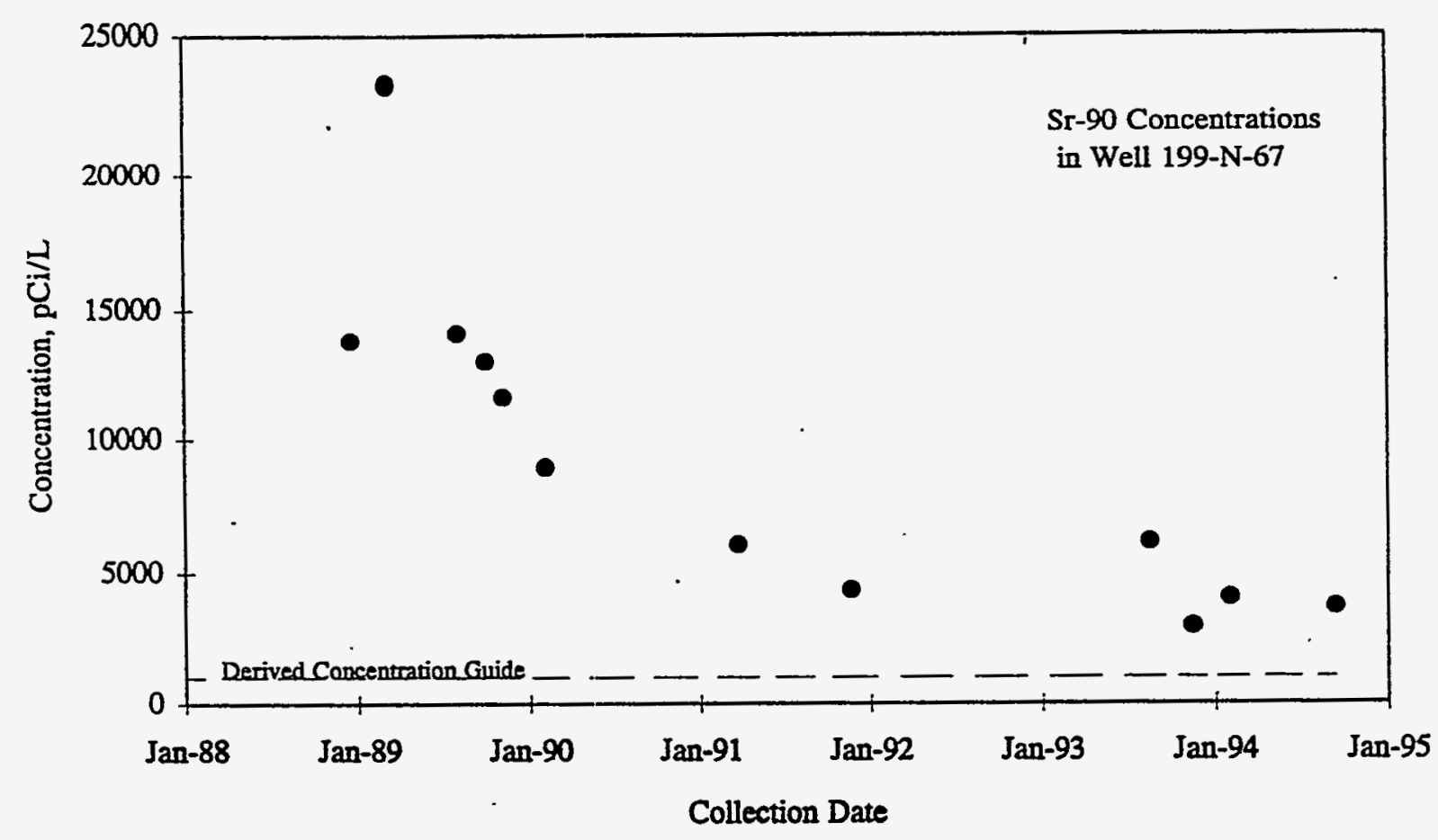

Figure 5.23. Strontium-90 Trend for Well $199-\mathrm{N}-67$

95JLR021.EPS

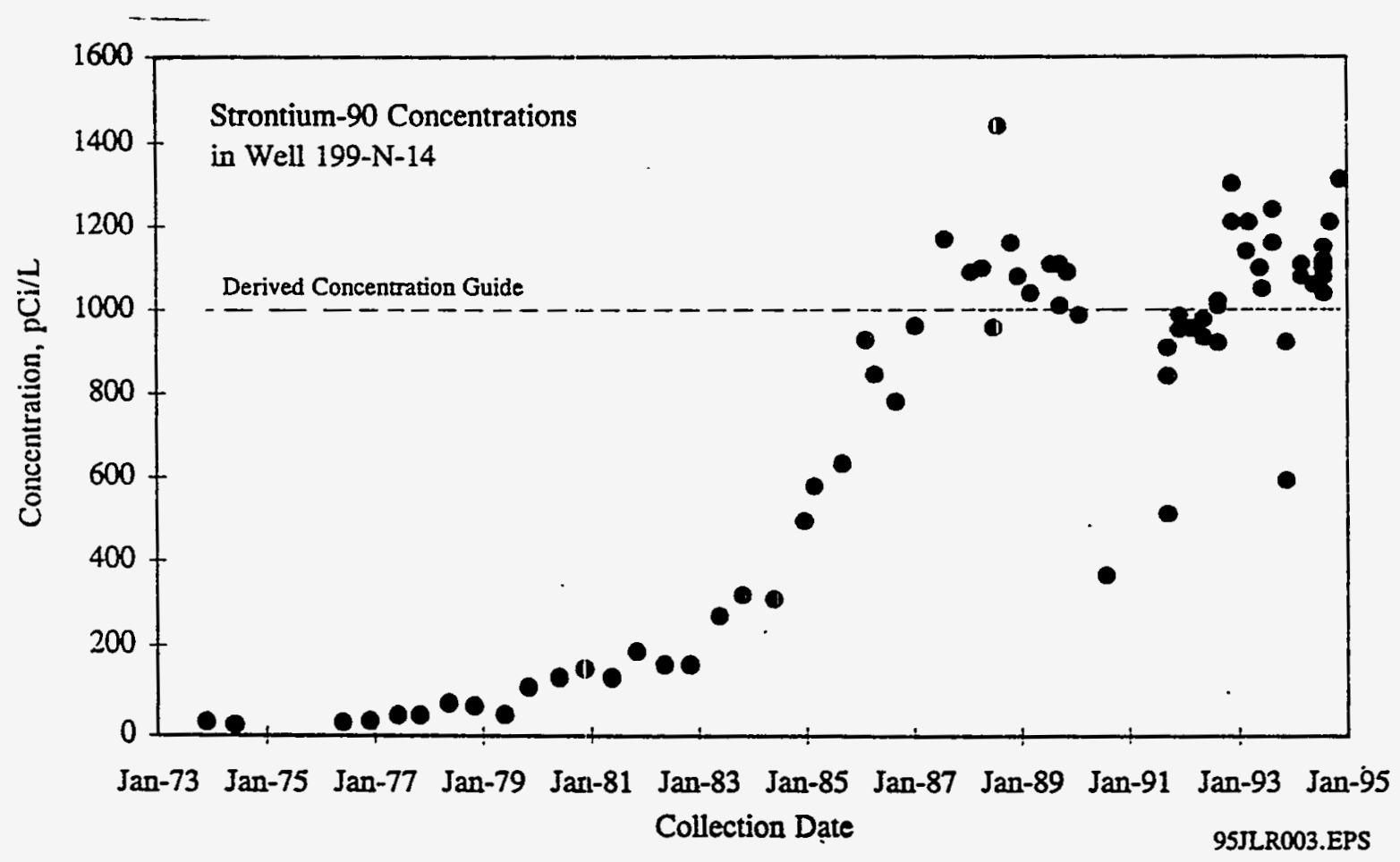

Figure 5.24. Strontium-90 Trend for Well $199-\mathrm{N}-14$ 


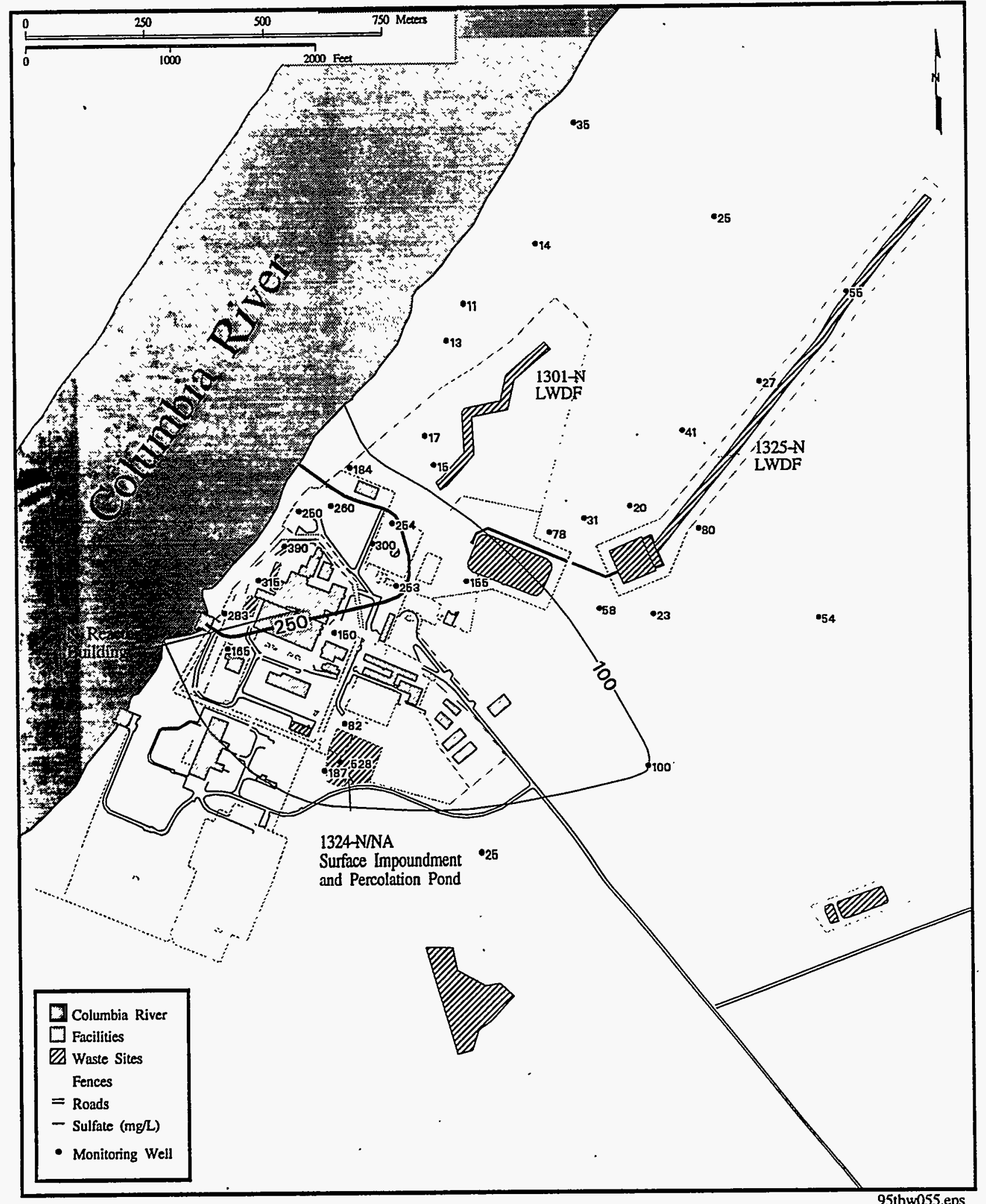

Figure 5.25. 1994 Average Sulfate Concentration for the $100-\mathrm{N}$ Area 


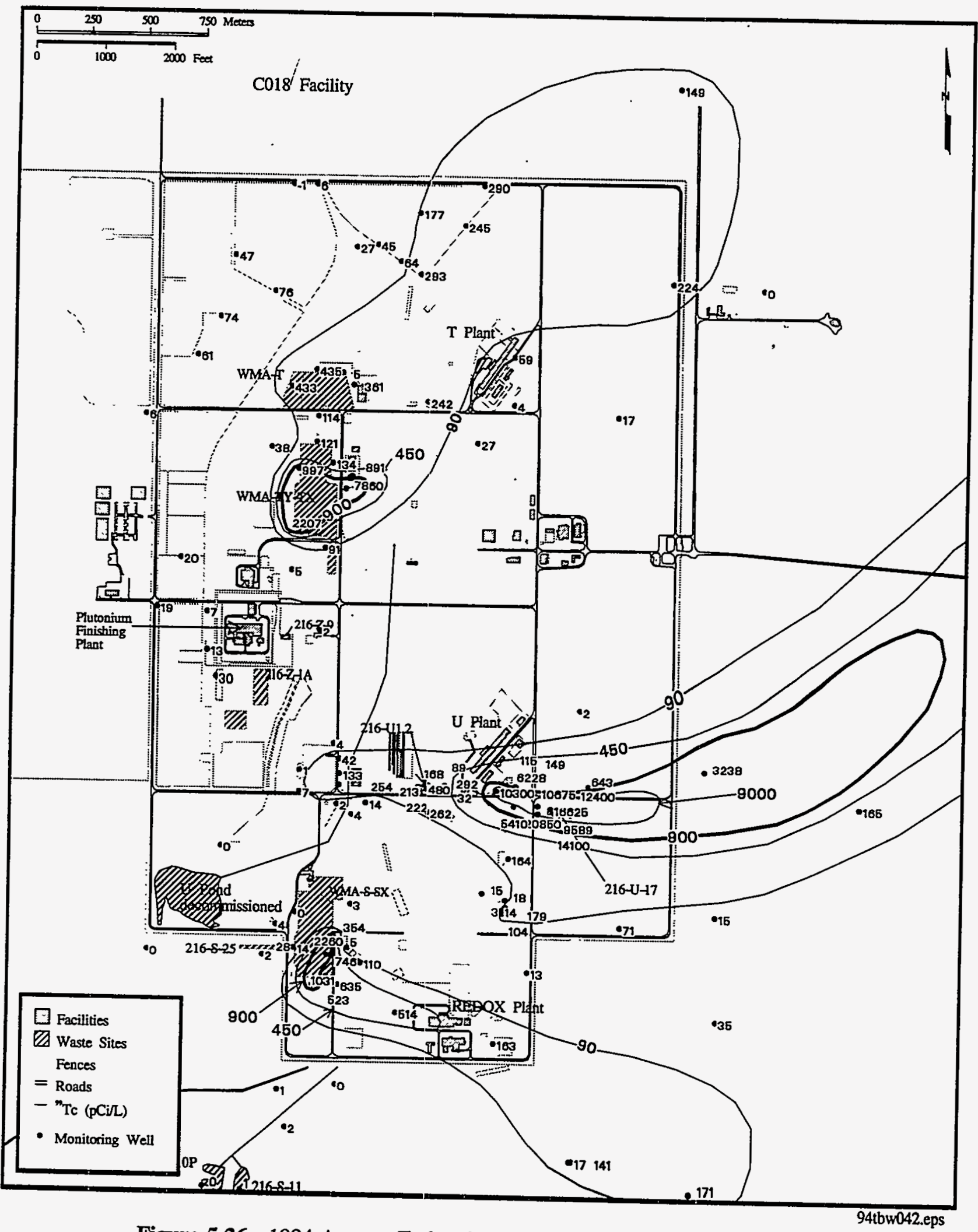

Figure 5.26. 1994 Average Terhnetium-99 Concentration in the 200-West Area 


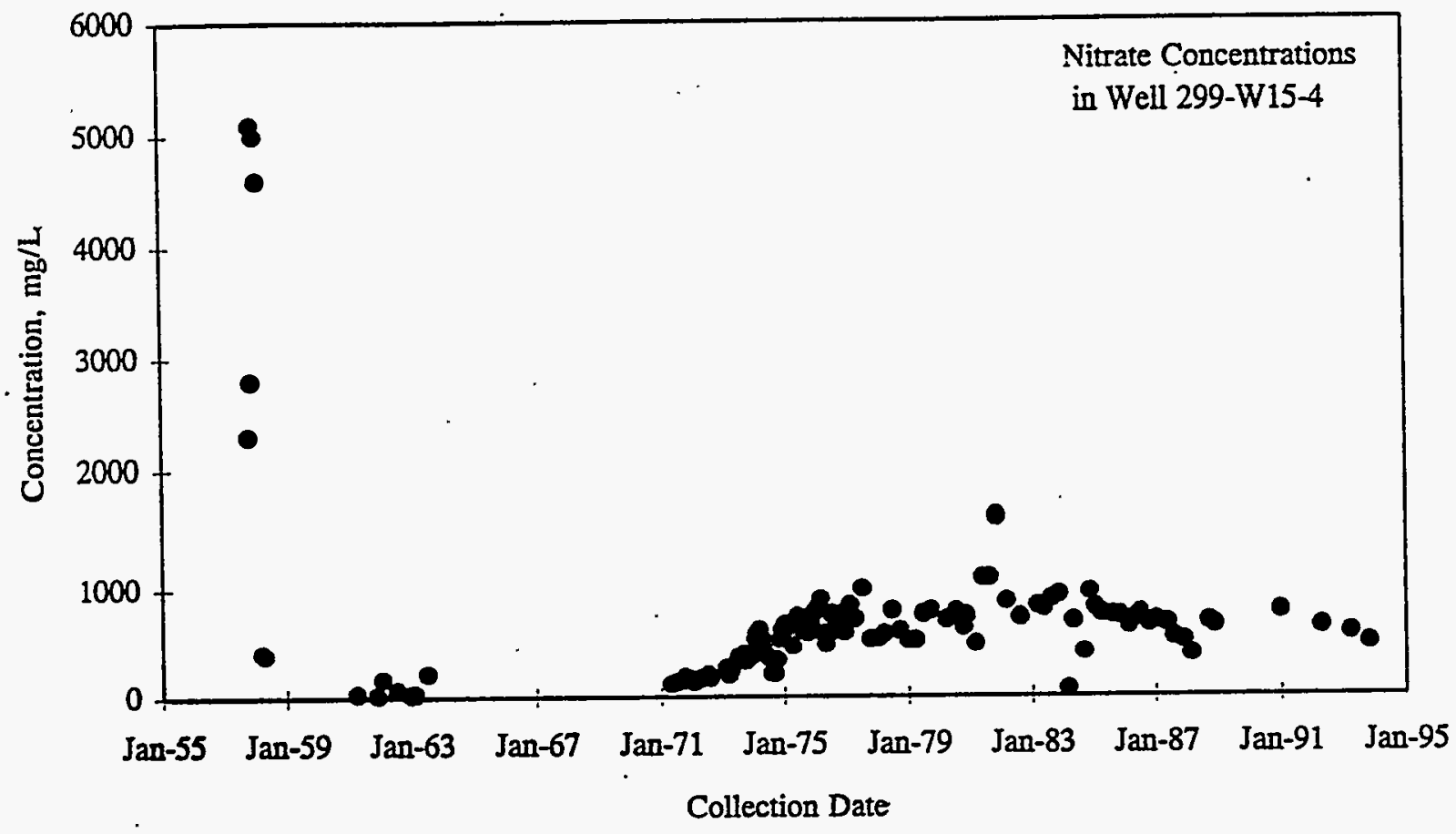

Figure 5.27. Nitrate Concentration Trend for Well 299-W15-4 95ЛR015.EPS 


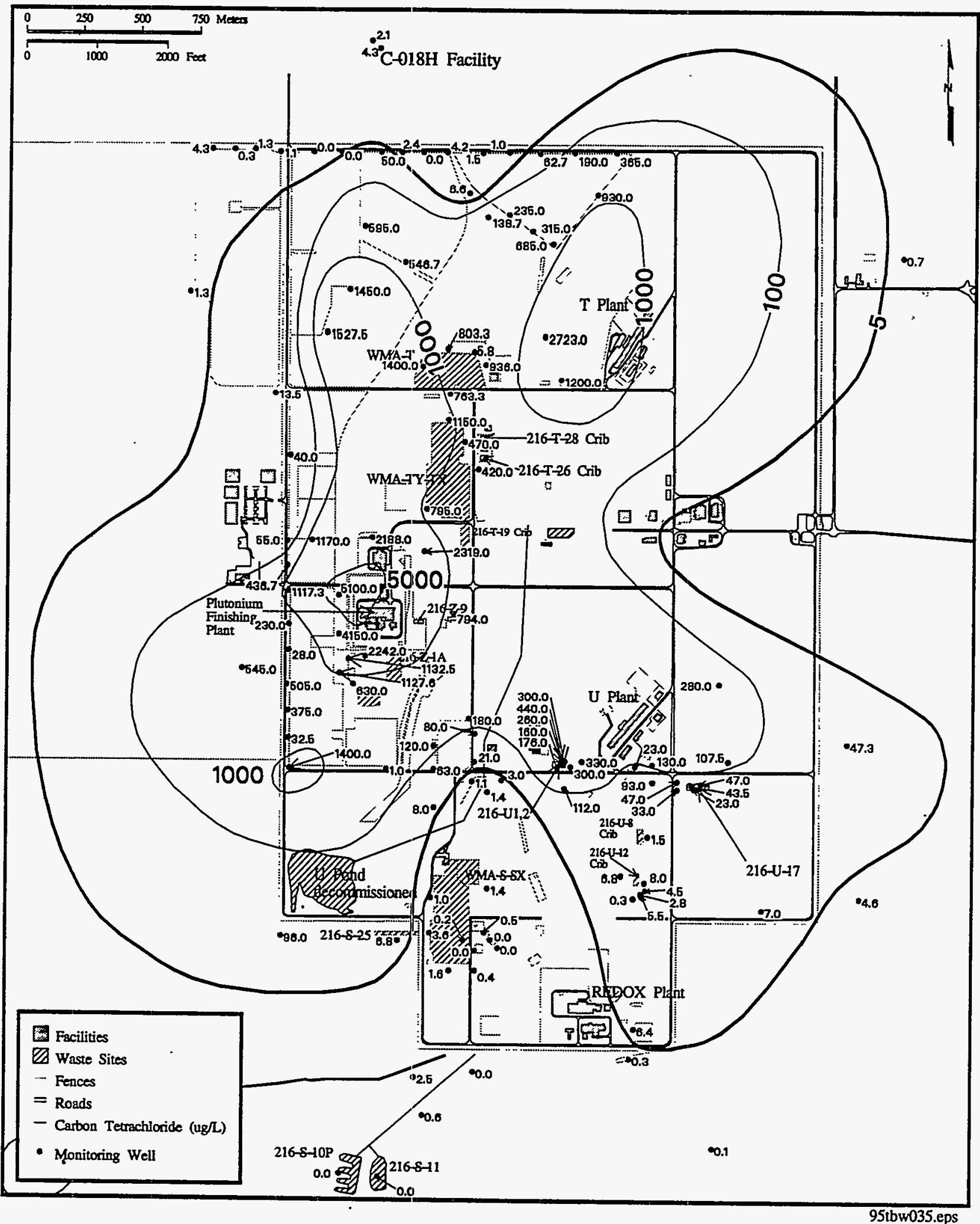

Figure 5.28. 1994 Average Carbon Tetrachloride Concentration in the 200-West Area 


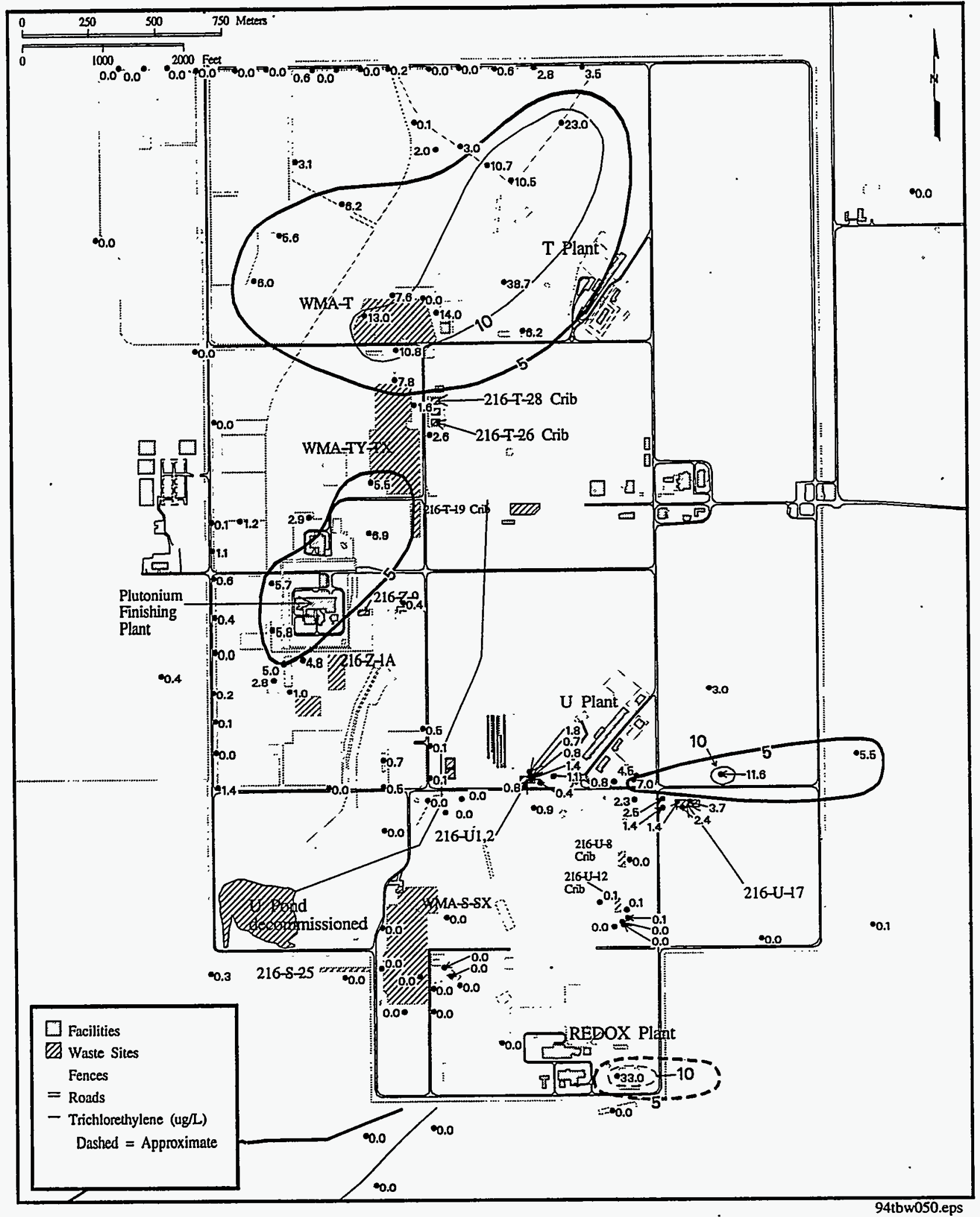

Figure 5.29. 1994 Average Trichlorethylene Concentration in the 200-West Area 


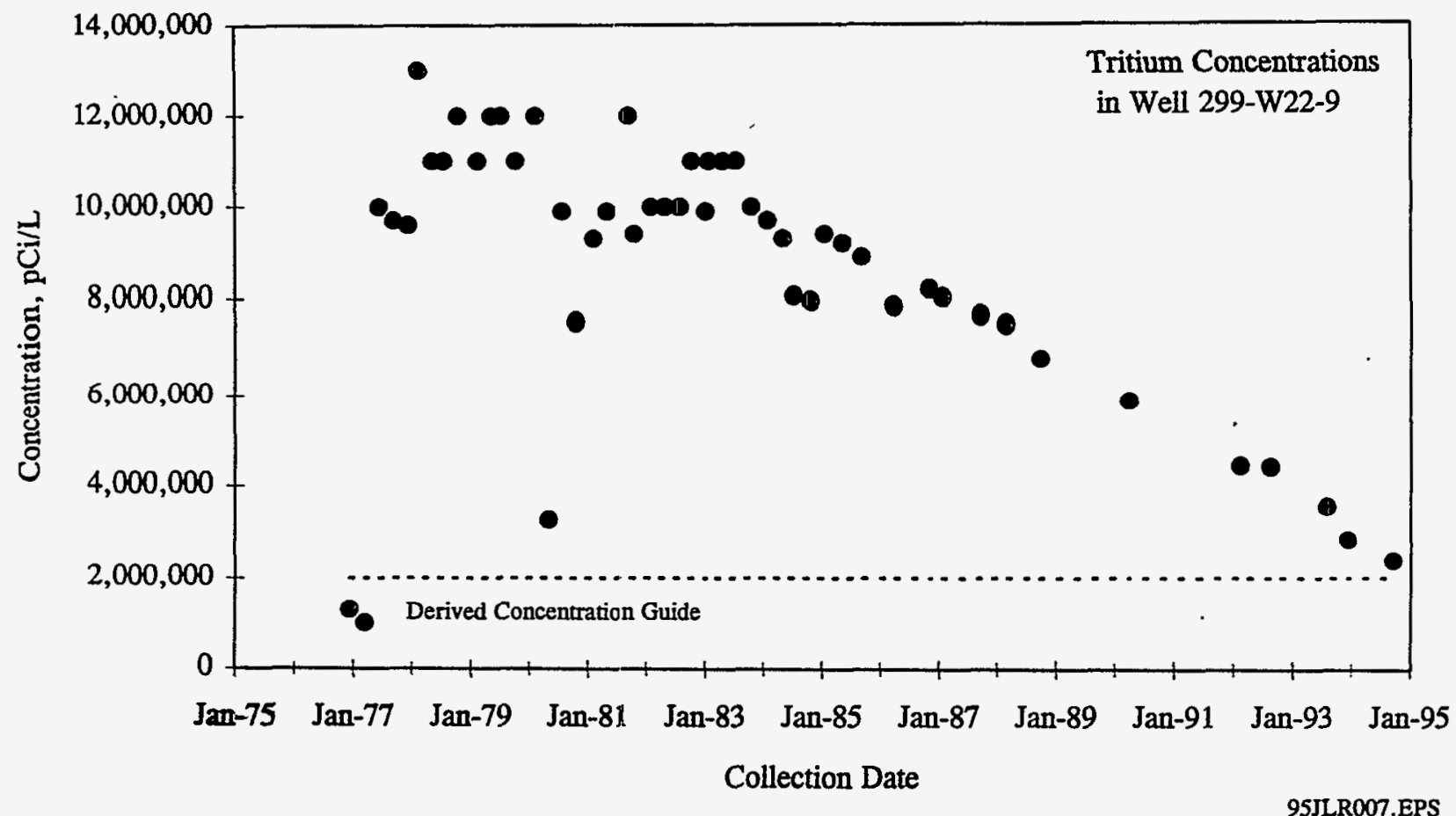

Figure 5.30. Tritium Concentration Trend for Well 299-W22-9 


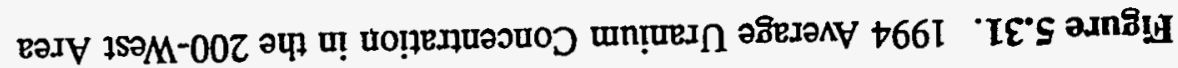

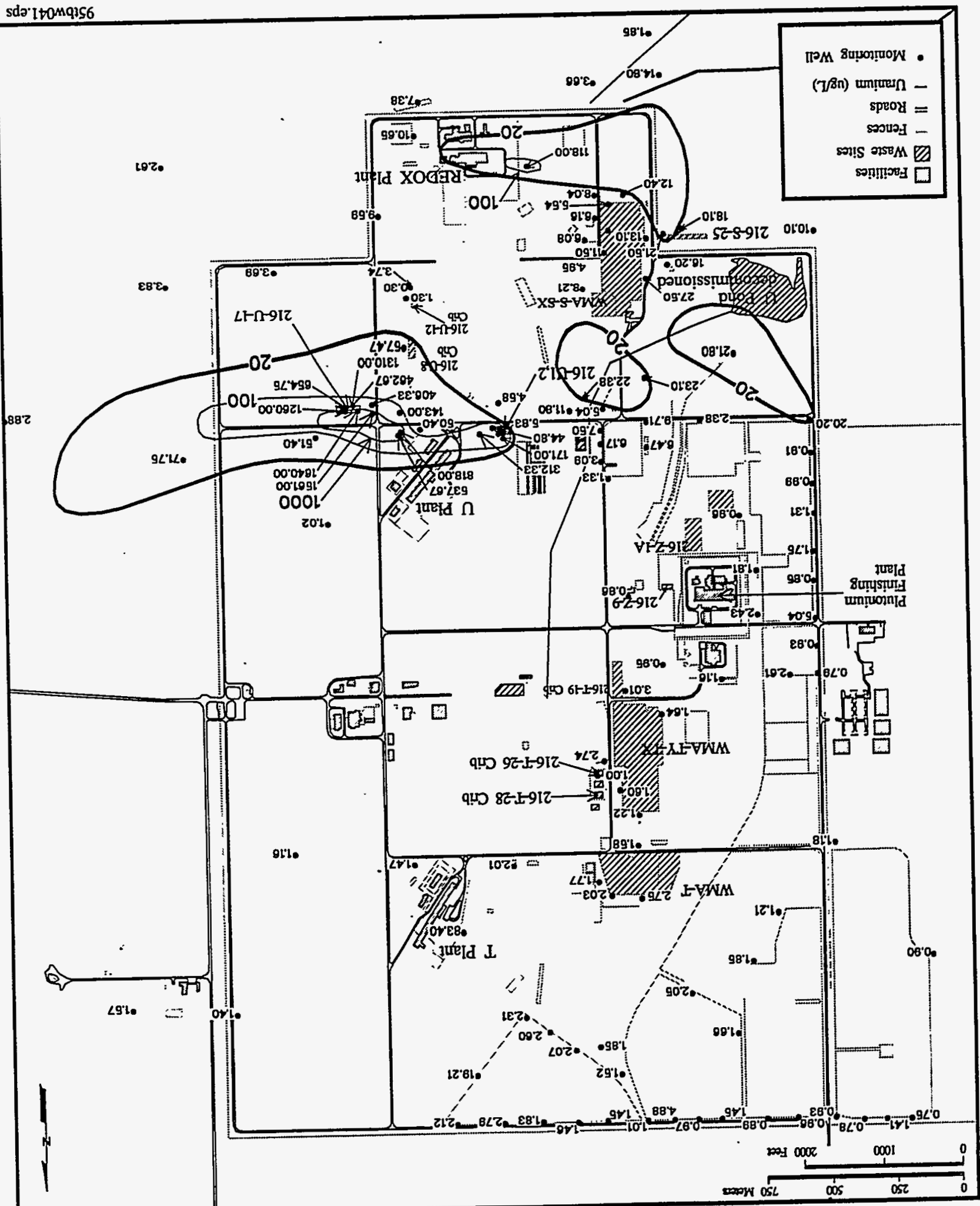




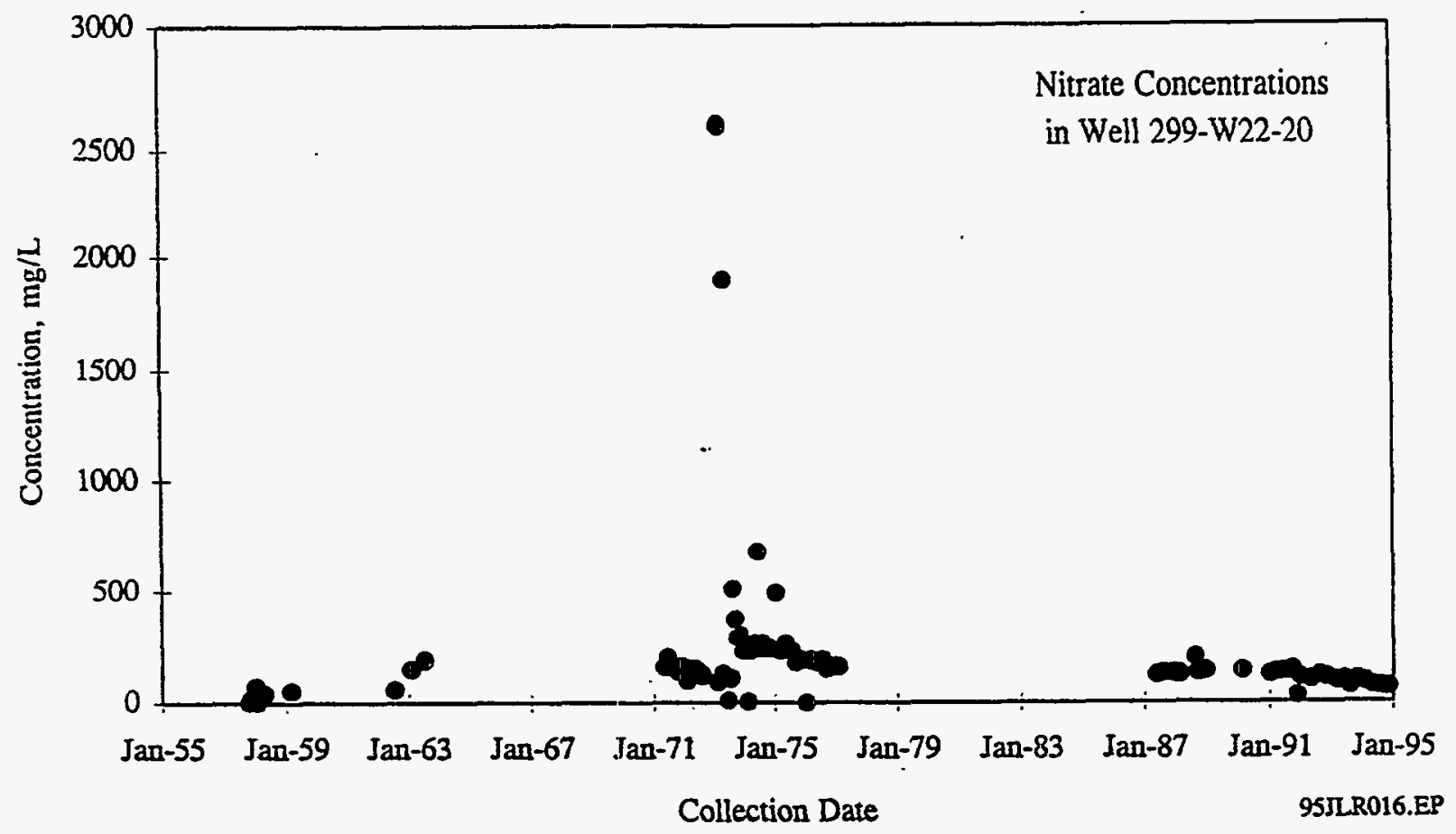

Figure 5.32. Nitrate Concentration Trend for Well 299-W22-20

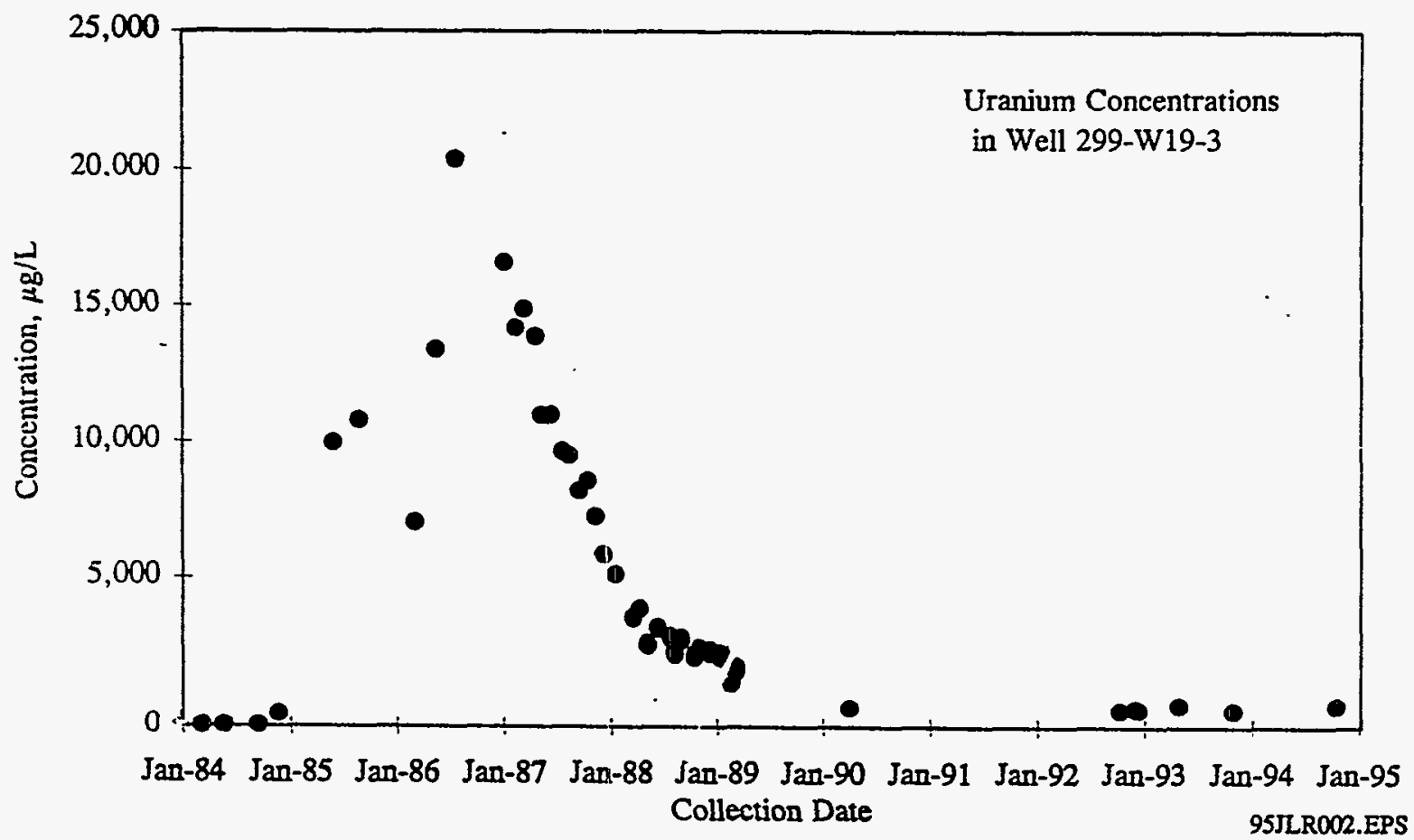

Figure 5.33. Uranium Concentration Trend for Well 299-W19-3 


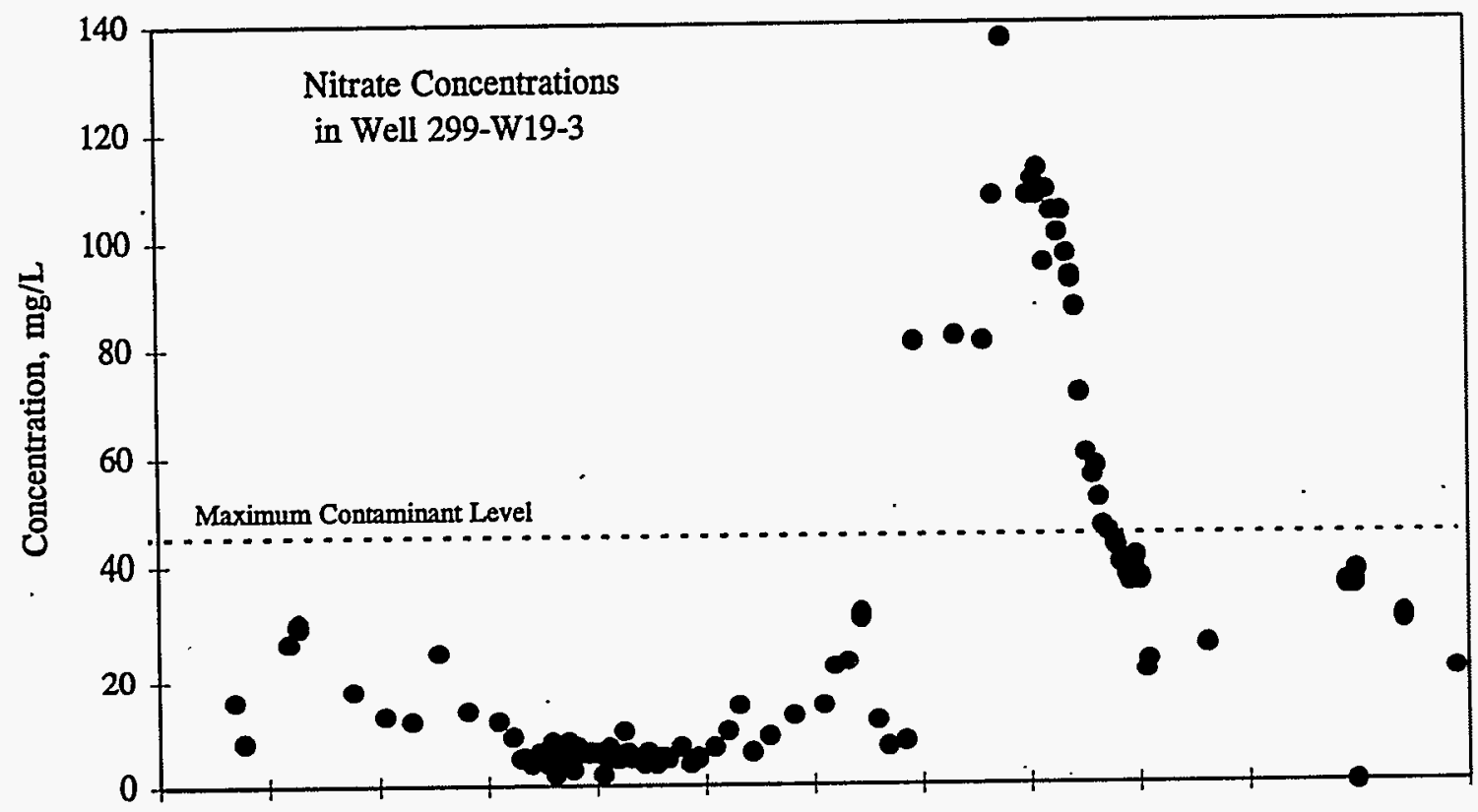

Jan-71 Jan-73 Jan-75 Jan-77 Jan-79 Jan-81 Jan-83 Jan-85 Jan-87 Jan-89 Jan-91 Jan-93 Jan-95

Collection Date

95JI R011.EPS

Figure 5.34. Nitrate Concentration Trend for Well 299-W19-3 


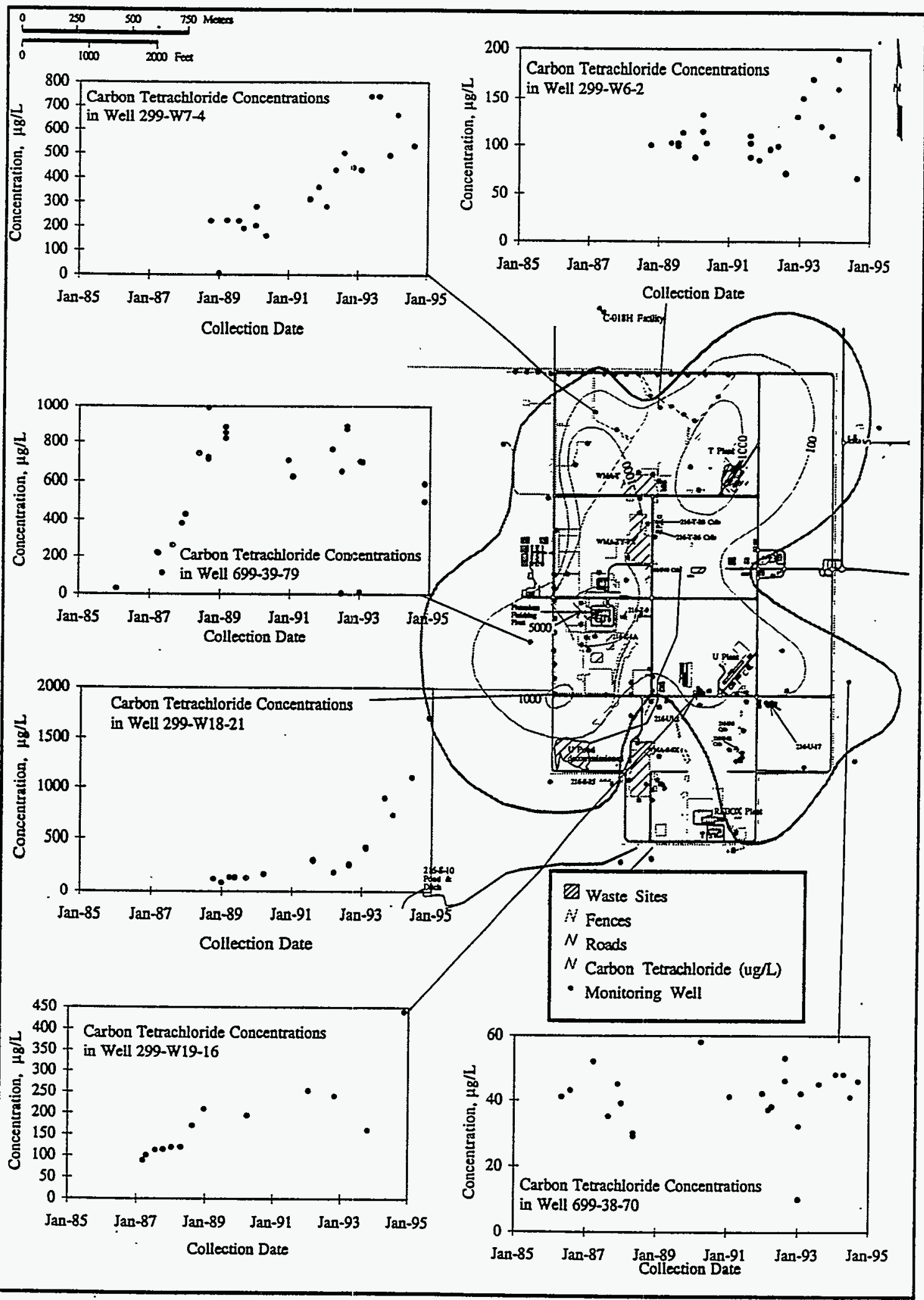

Figure 5.35. Carbon Tetrachloride Concentration Trends in Selected Wells 95ibw013.eps in the 200-West Area 


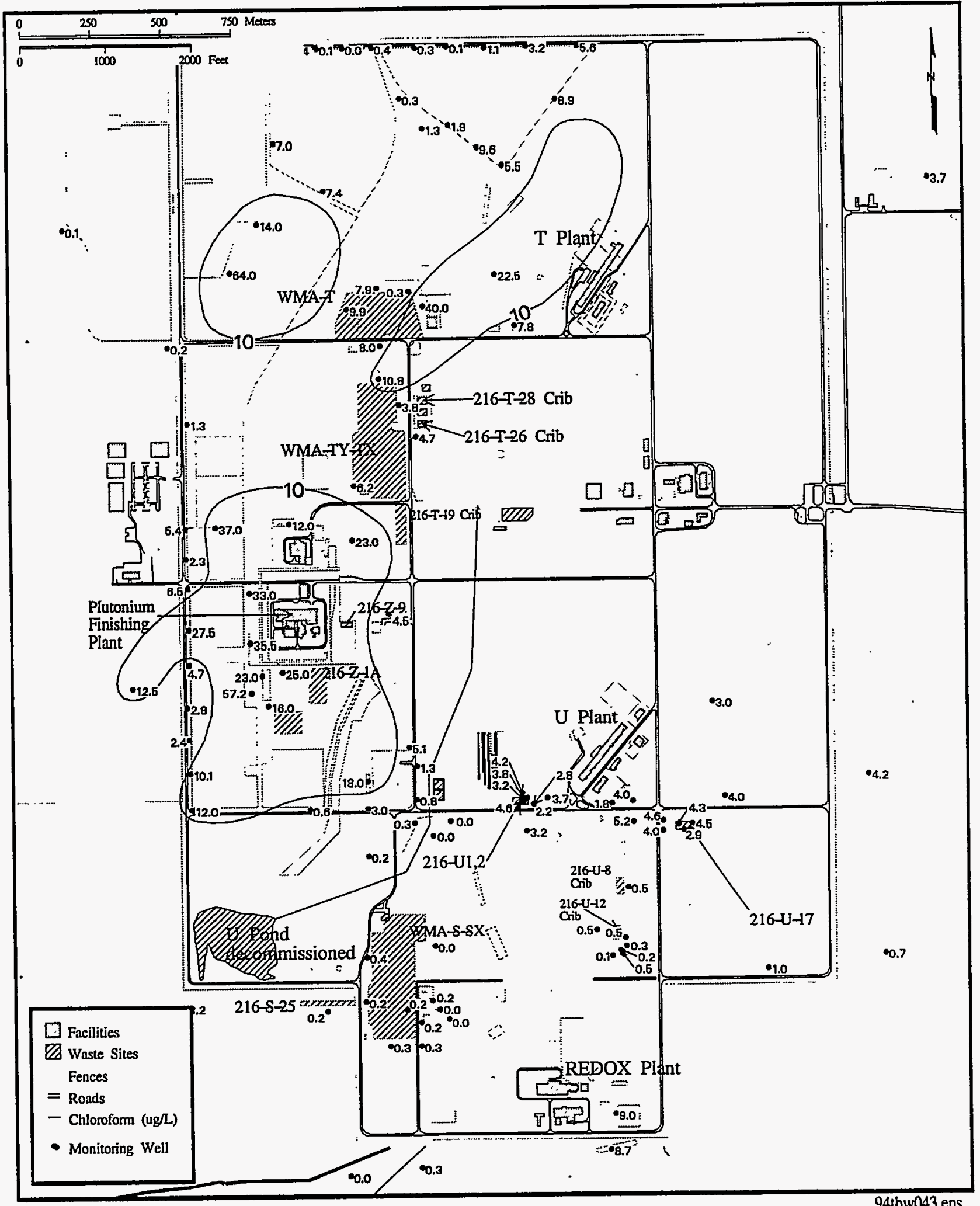

Figure 5.36. 1994 Average Chloroform Concentration for the 200-West Area 


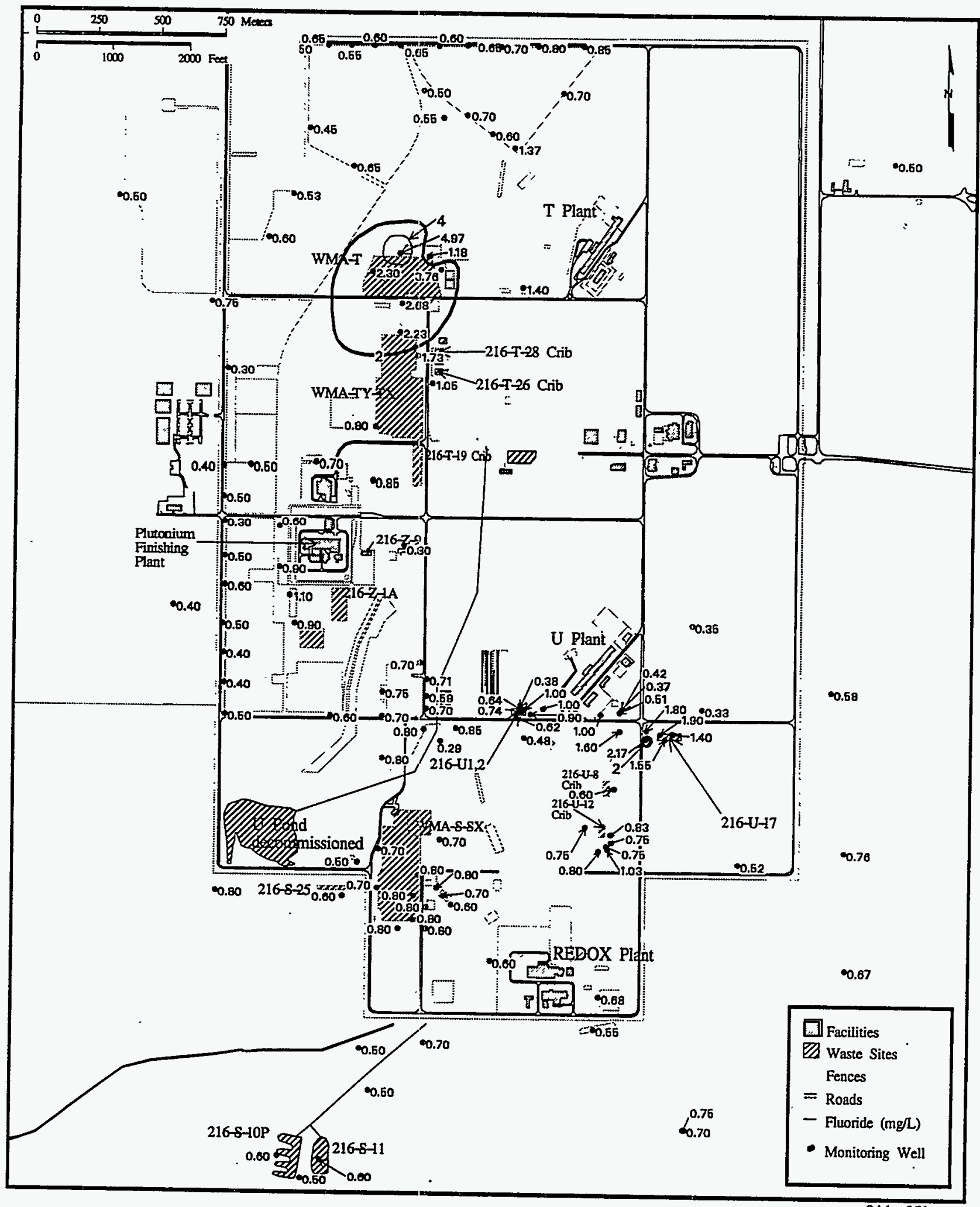

Figure 5.37. 1994 Average Fluoride Concentration for the 200-West Area 


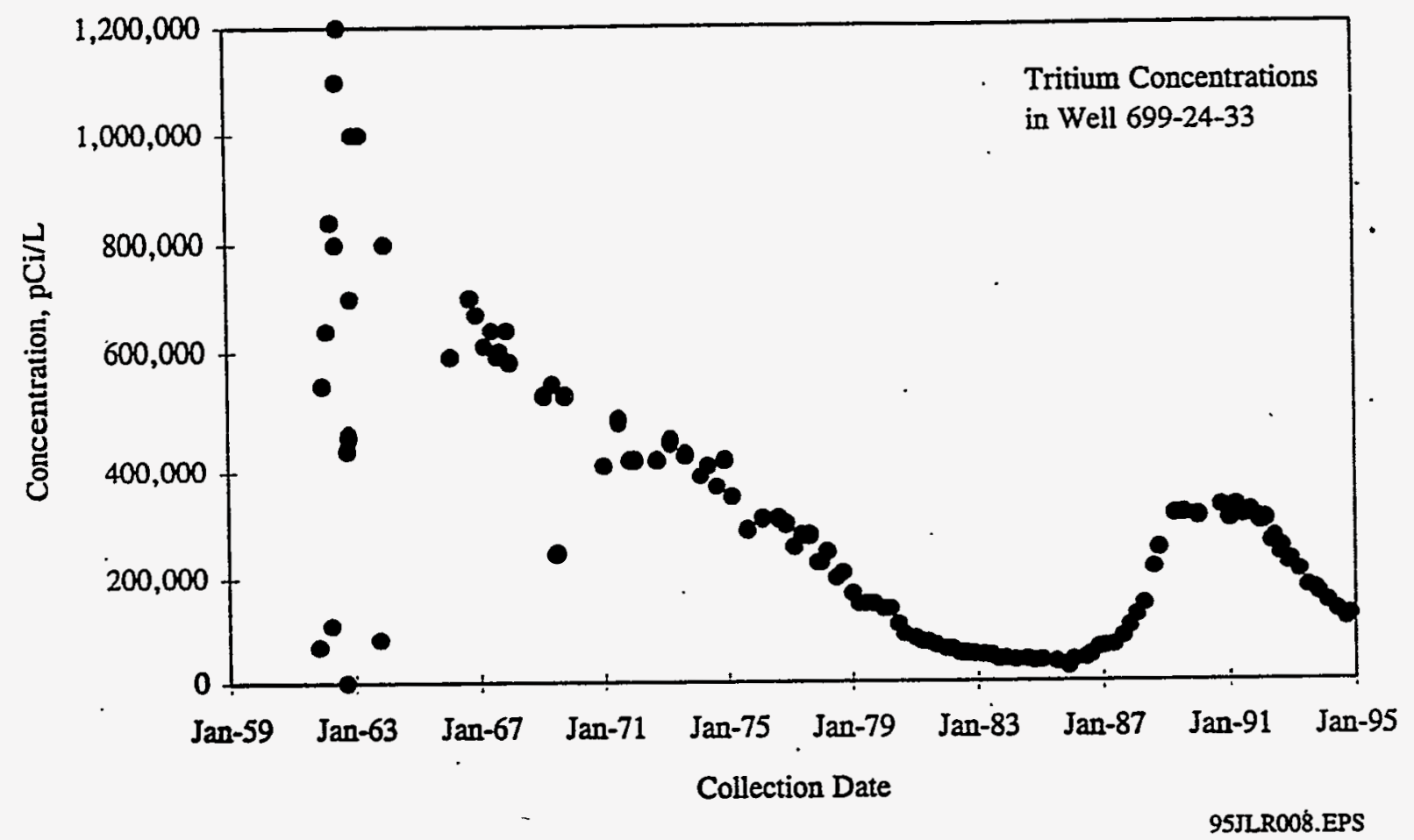

Figure 5.38. Tritium Concentration Trend for Well 699-24-33 


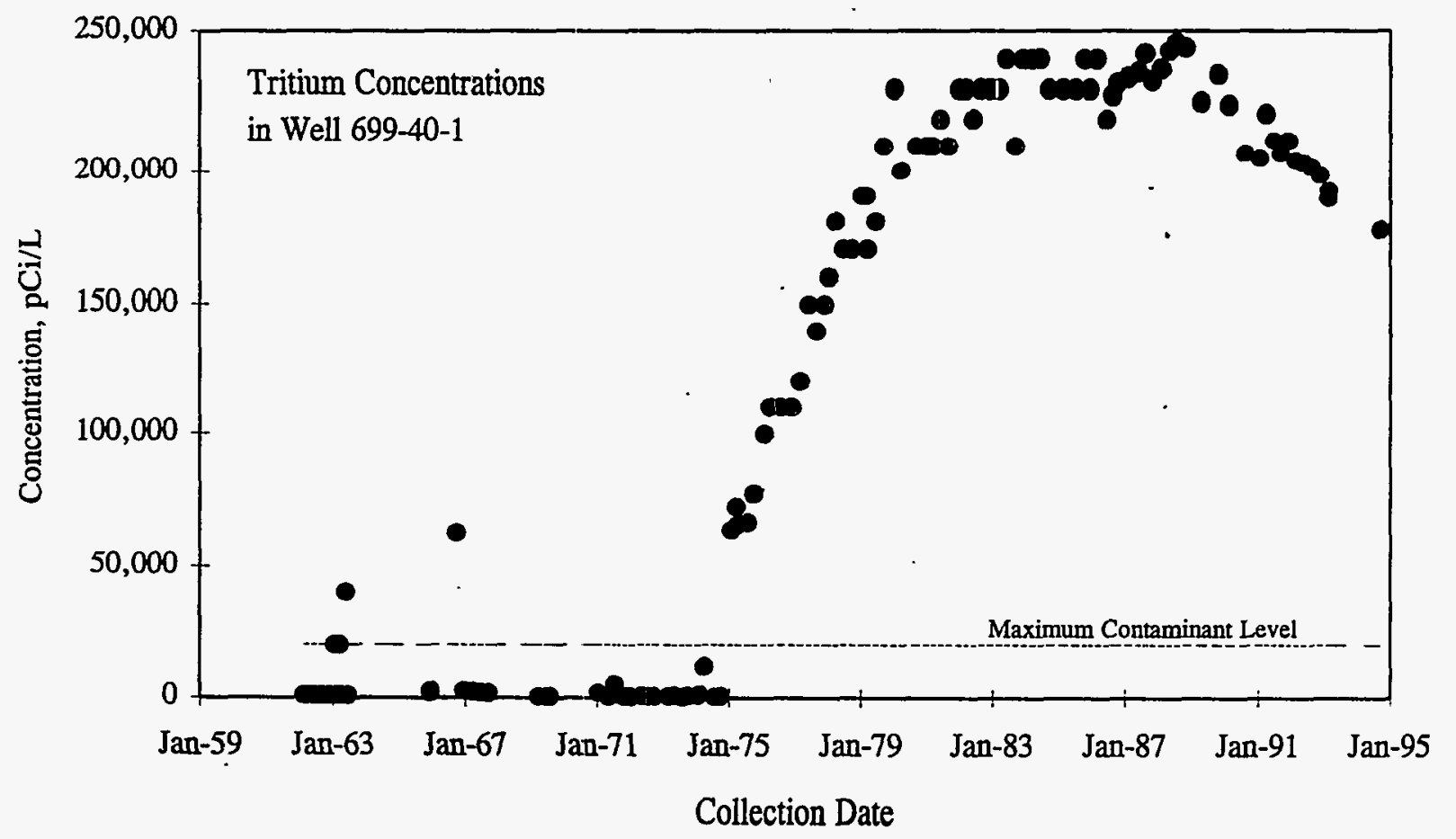

95JLR009.EPS

Figure 5.39. Tritium Concentration Trend for Well 699-40-1 


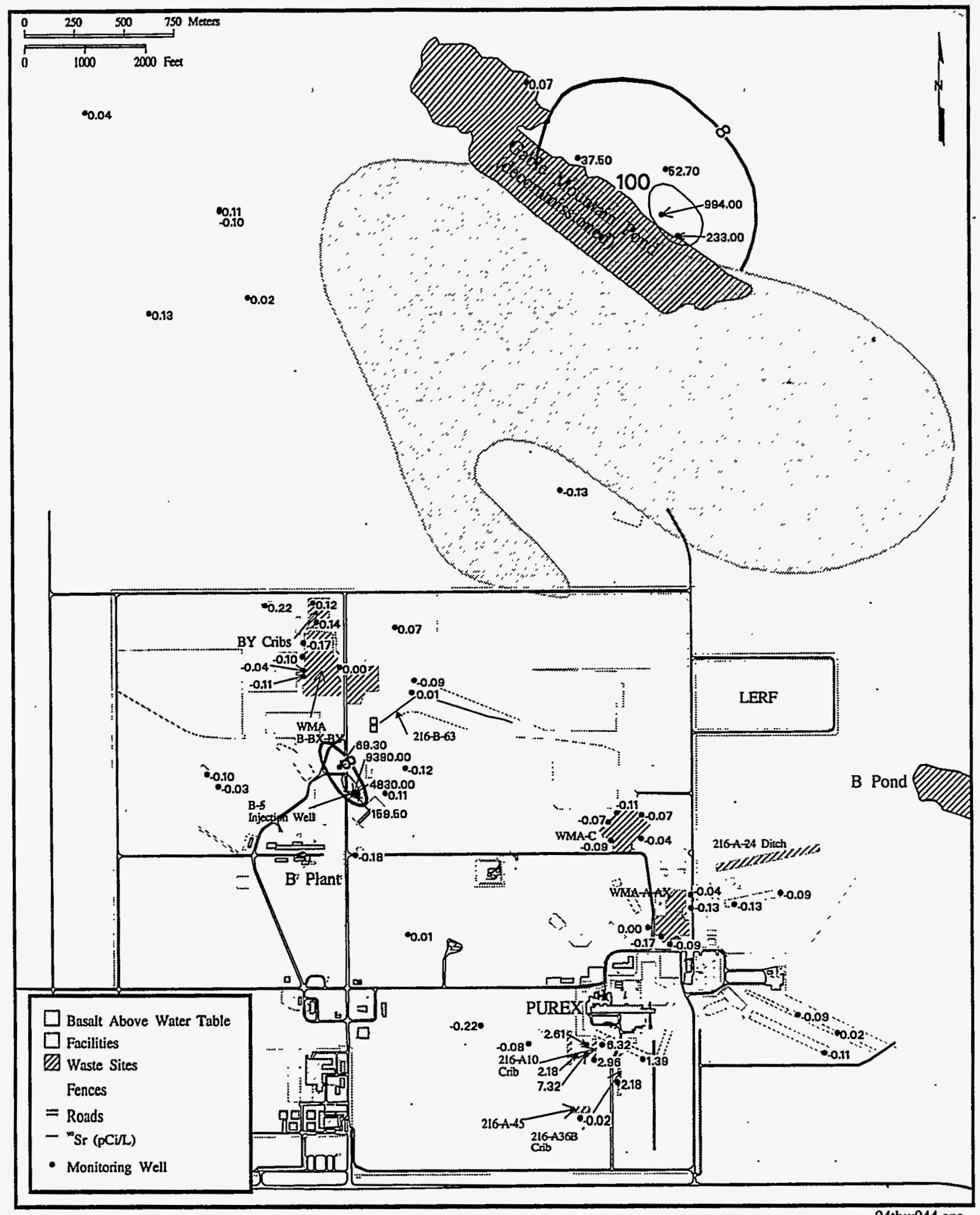

94tbw044.eps

Figure 5.40. 1994 Average Strontium-90 Concentration in the 200-East Area and Surrounding 600 Area 


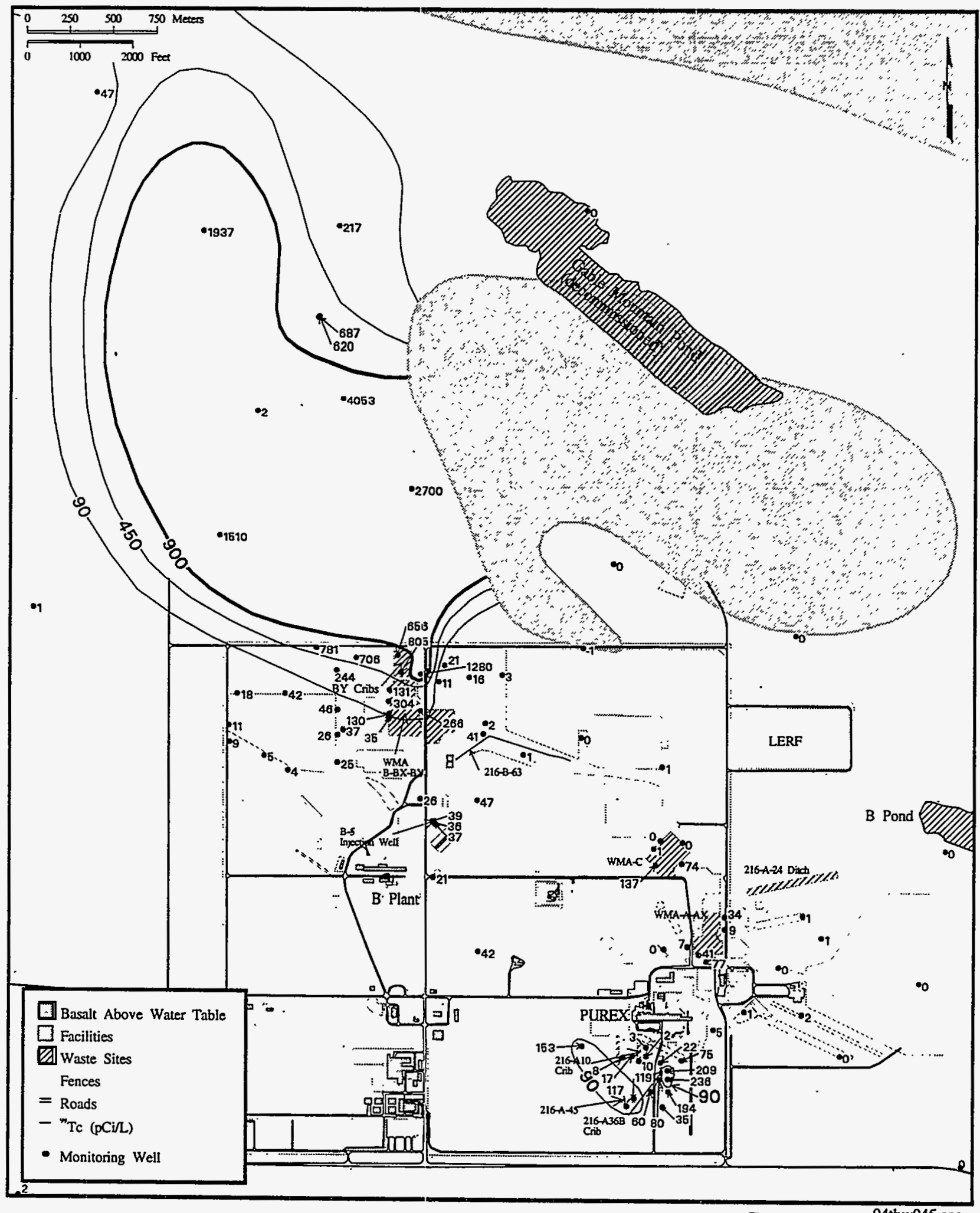

Figure 5.41. 1994 Average Technetium-99 Concentration in the 200-East Area and Surrounding 600 Area 


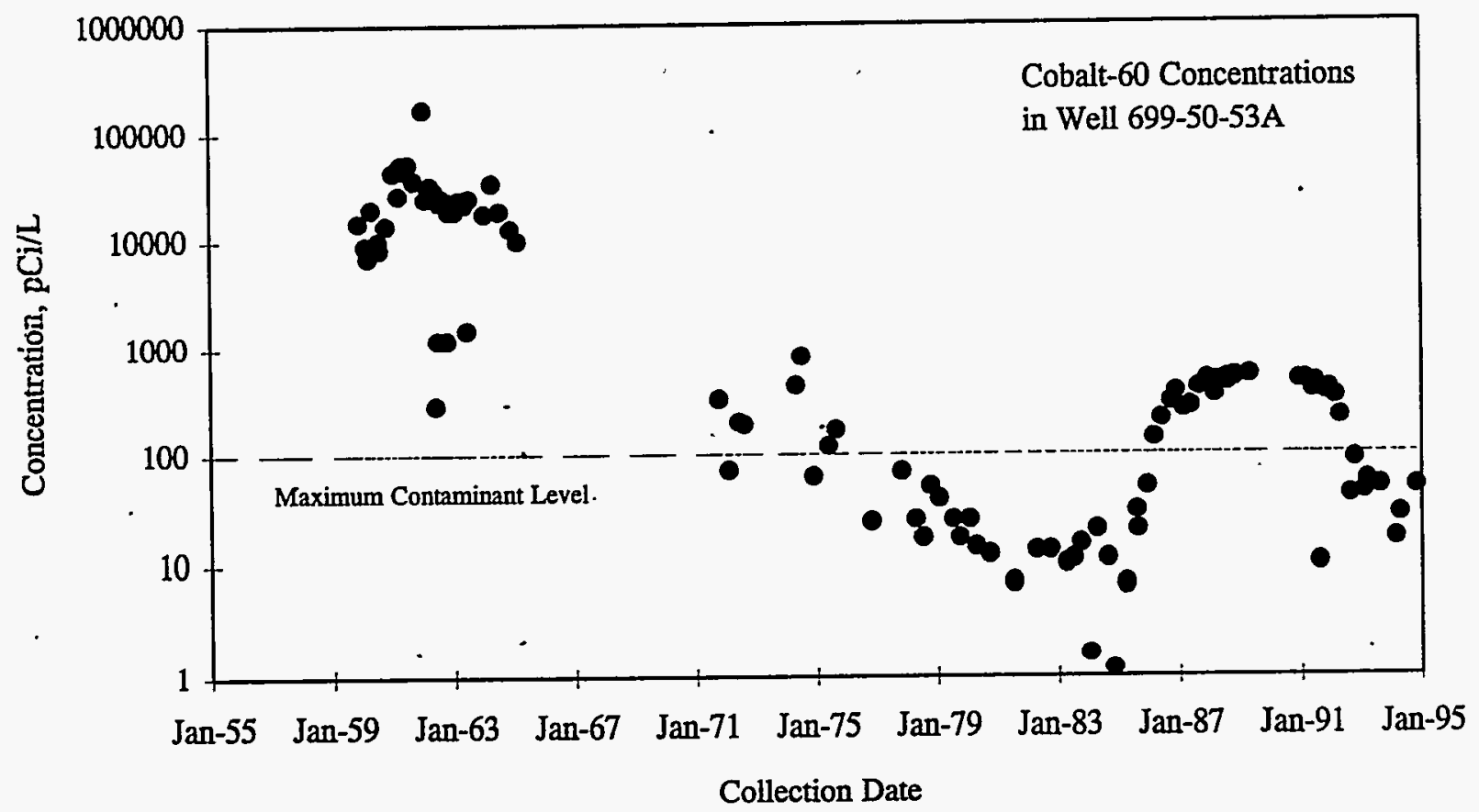

95JLR019.EPS

Figure 5.42. Cobalt-60 Concentration Trend for Well 699-50-53A

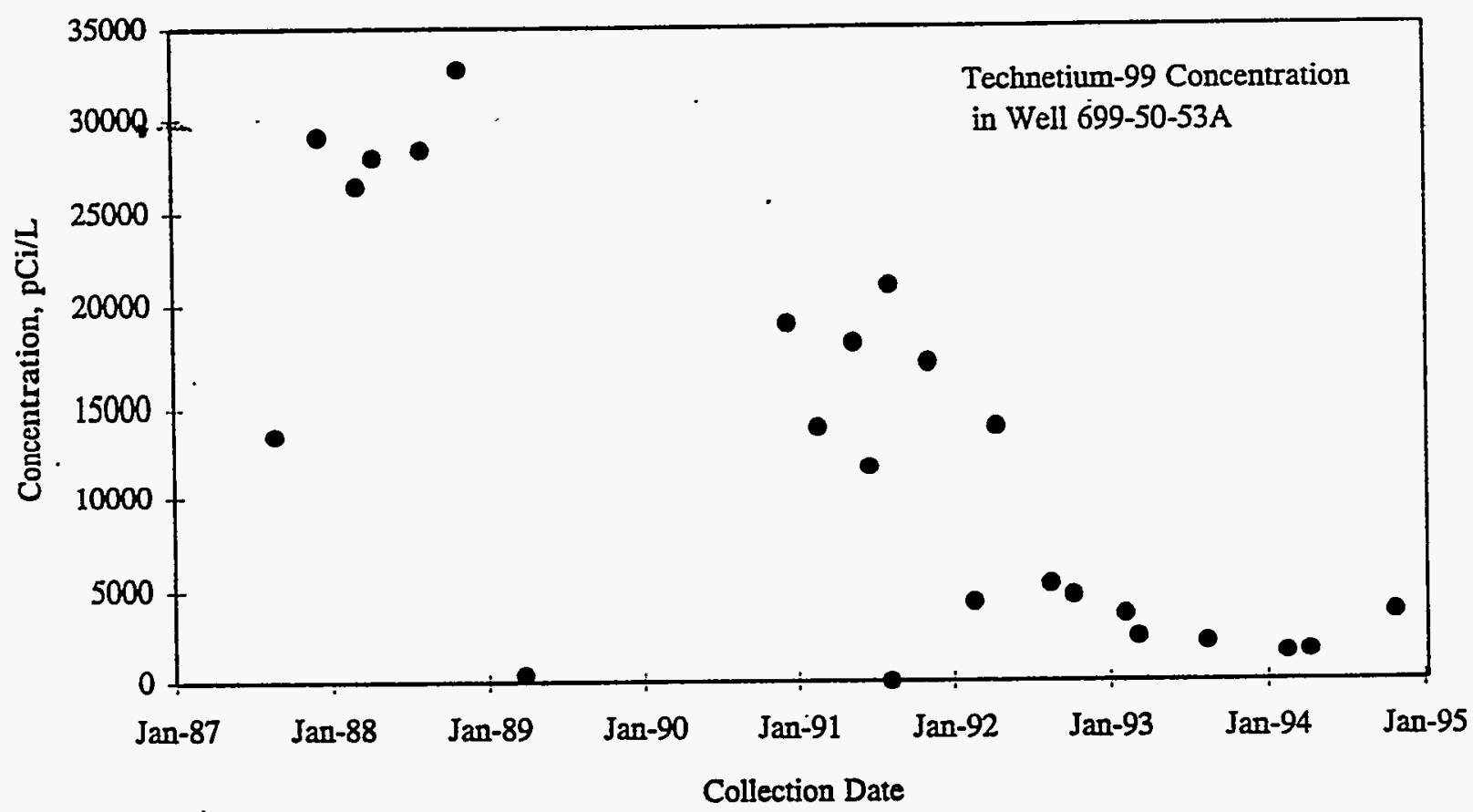

Figure 5.43. Technetium-99 Concentration Trend for Well 699-50-53A 95JLR017.EPS 


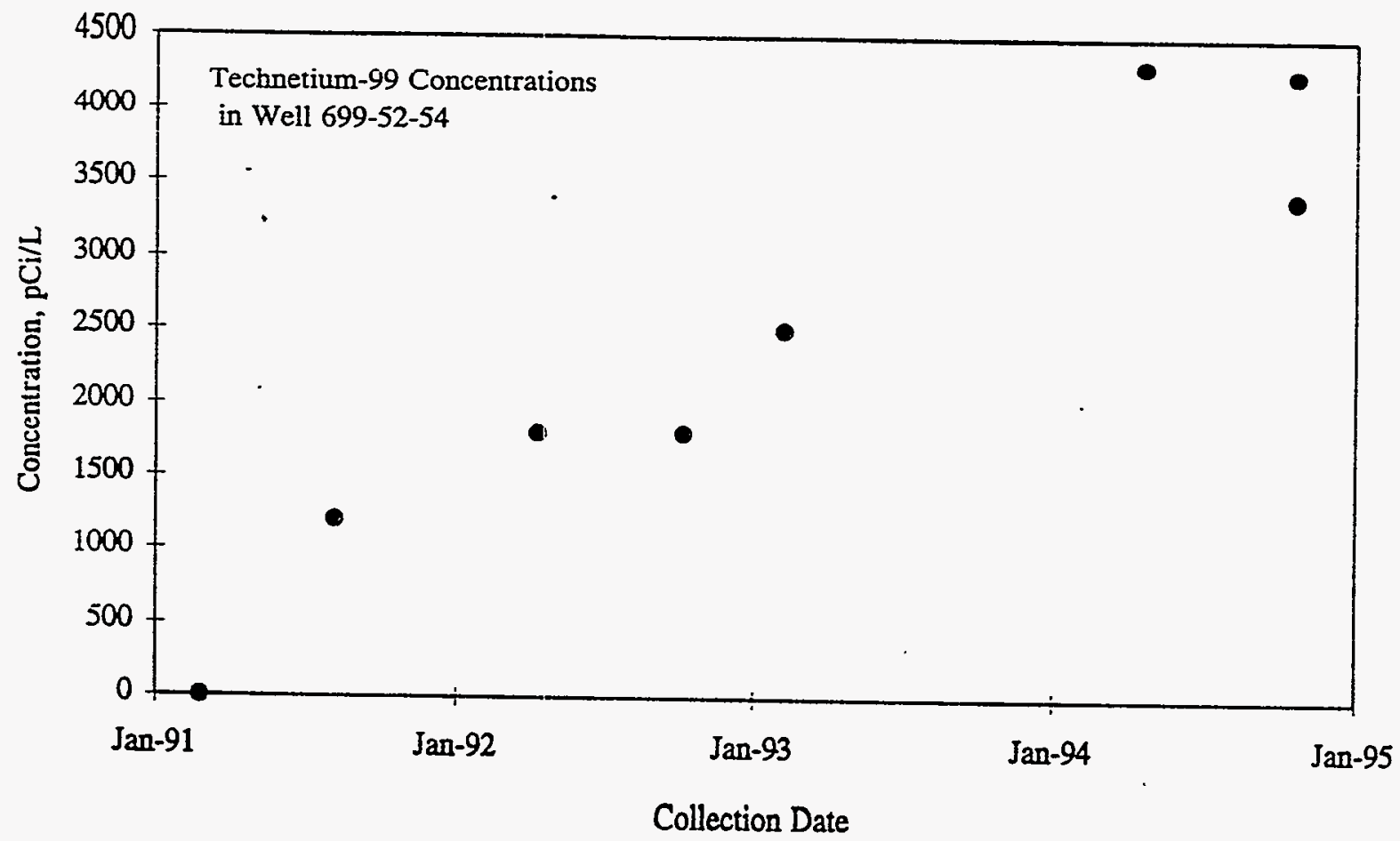

Figure 5.44. Technetium-99 Concentration Trend for Well 699-52-54

95JLR013.EPS 


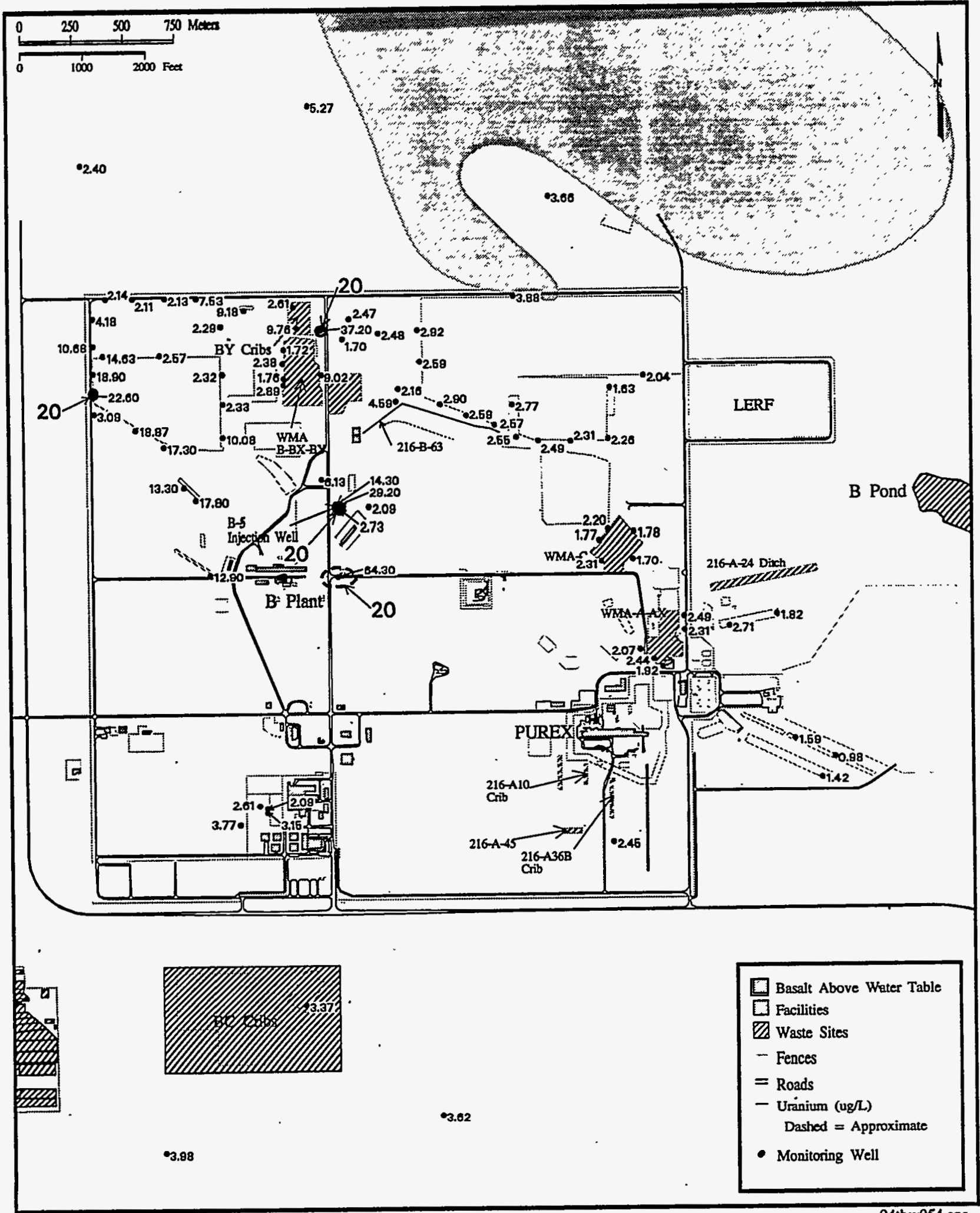

94tbw054.eps

Figure 5.45. 1994 Average Uranium Concentration in the 200-East Area 


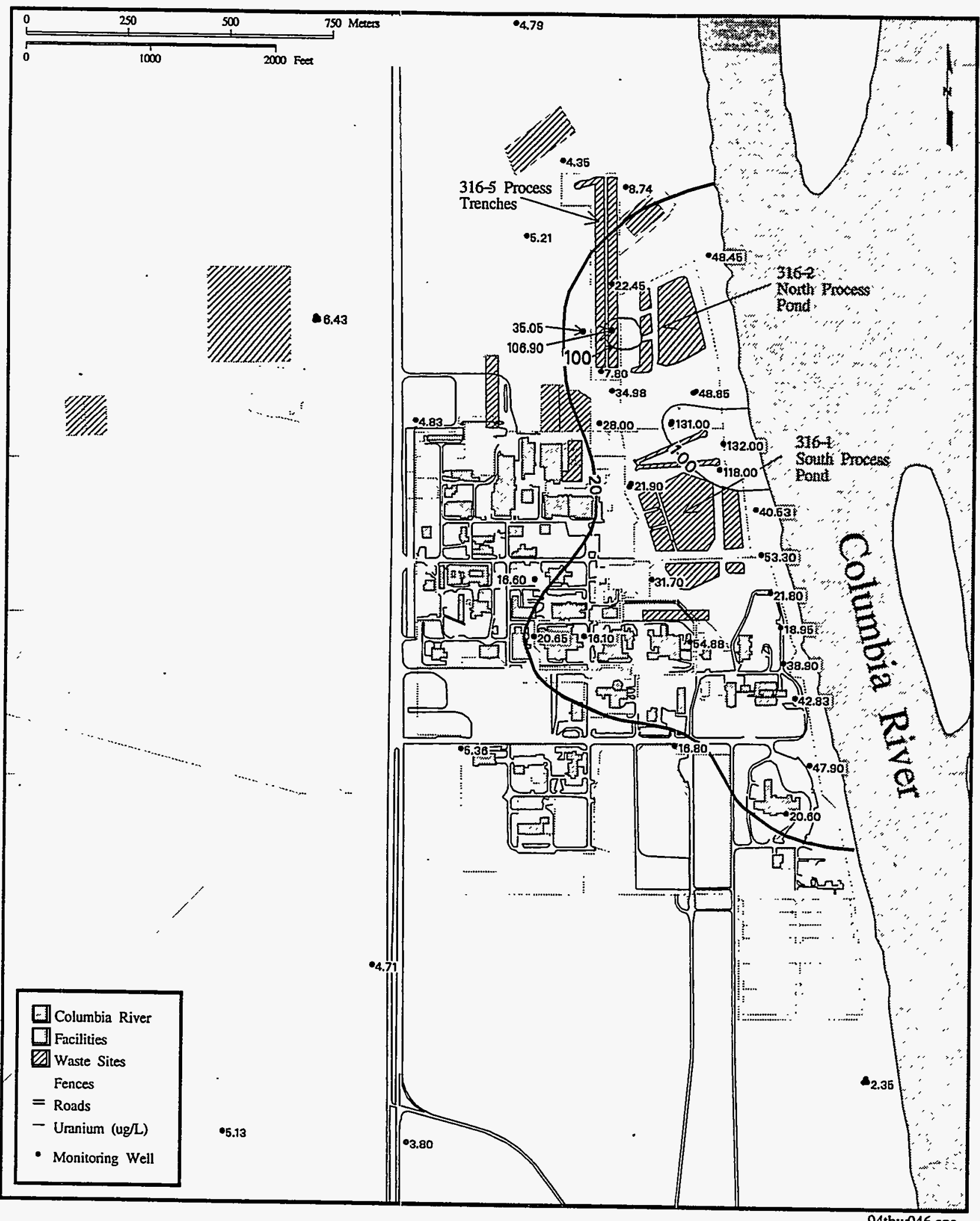

Figure 5.46. 1994 Average Uranium Concentration in the 300 Area 


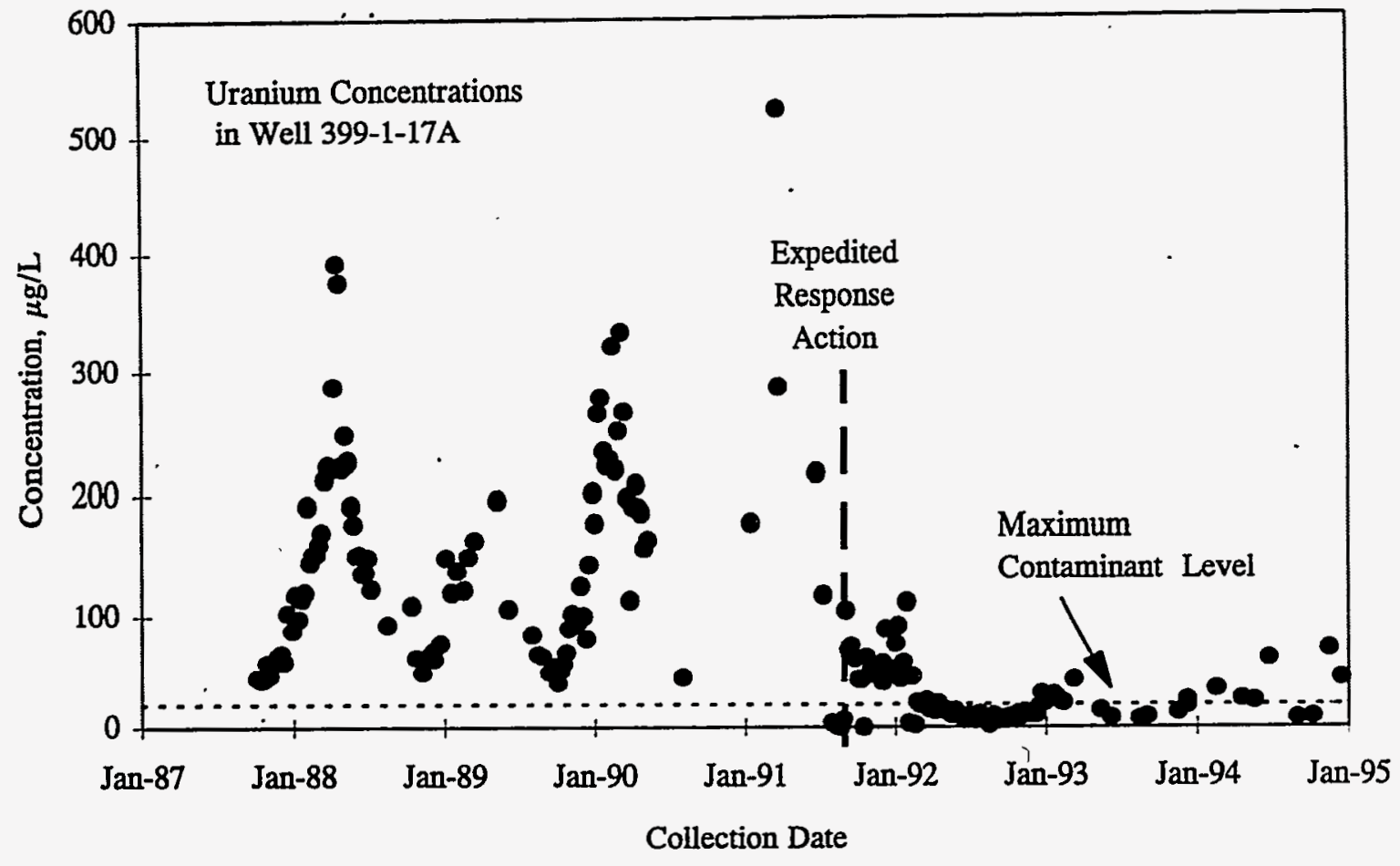

95JLR001.EPS

Figure 5.47. Uranium Concentration Trend for Well 399-1-17A 


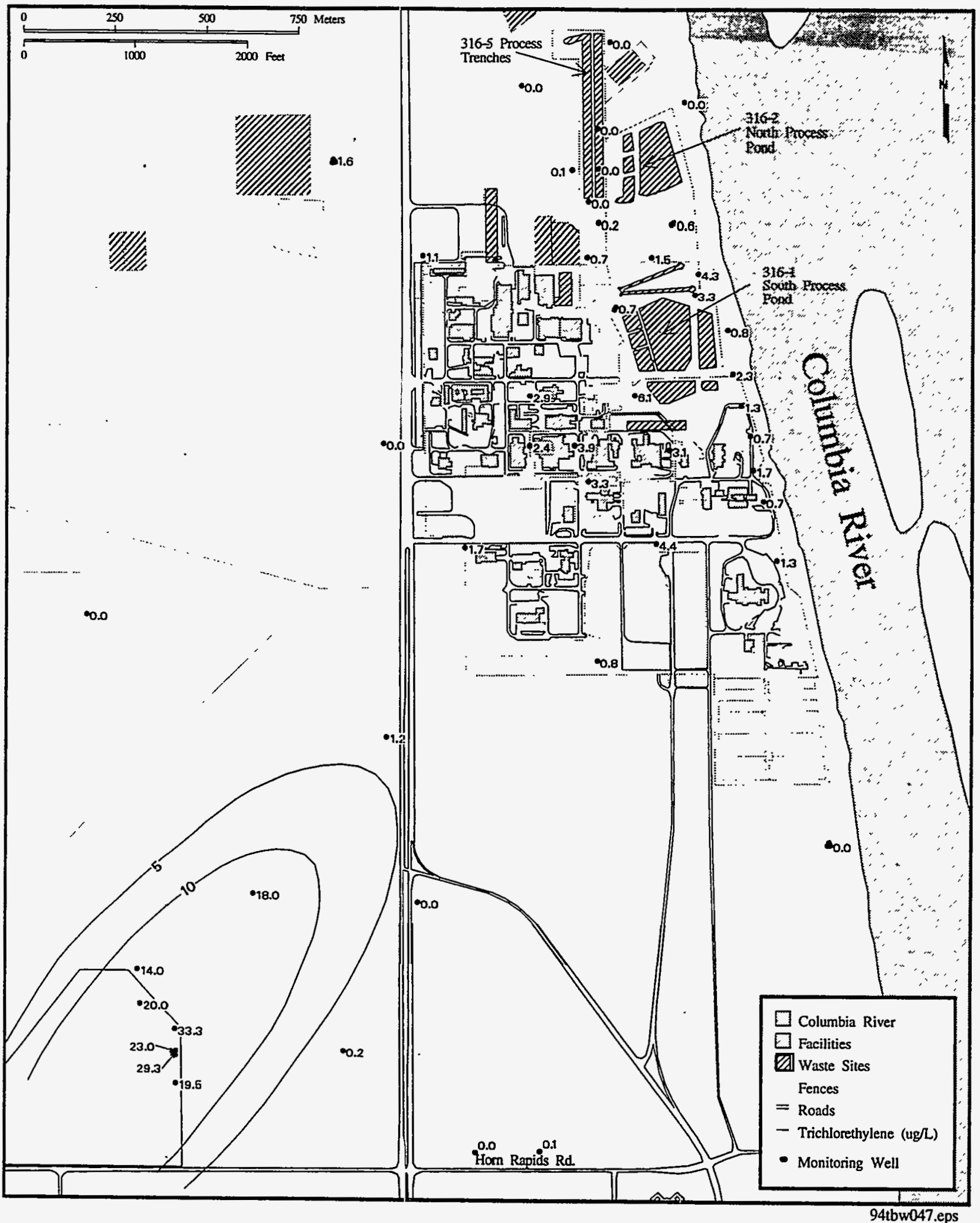

Figure 5.48. 1994 Average Trichloroethylene Concentration in the 300 Area 


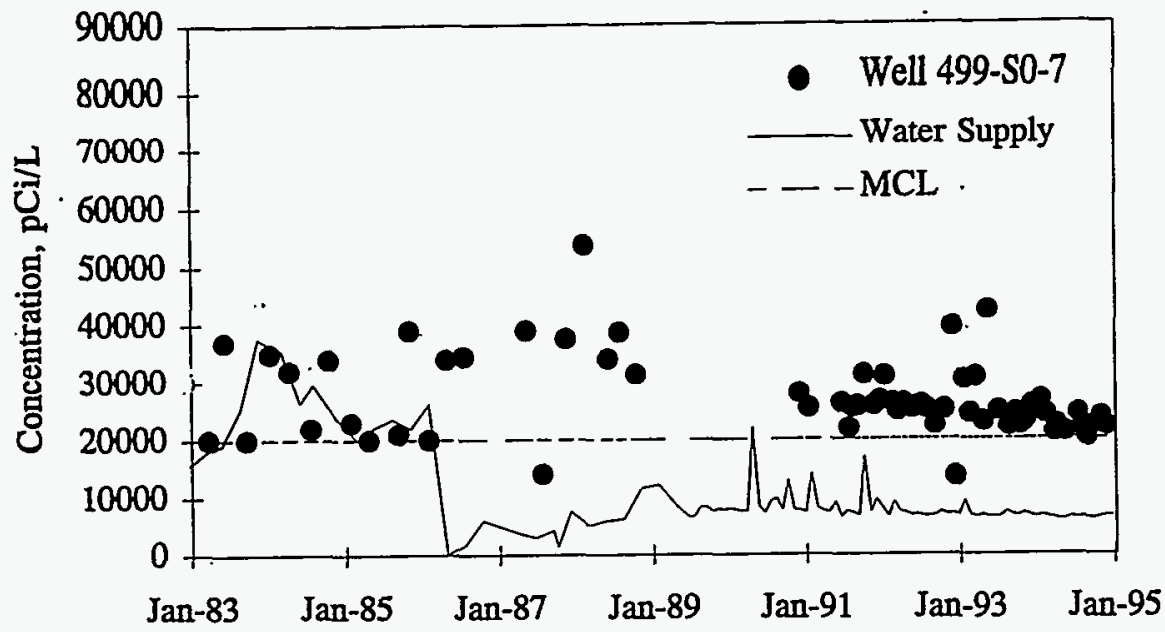

Collection Date
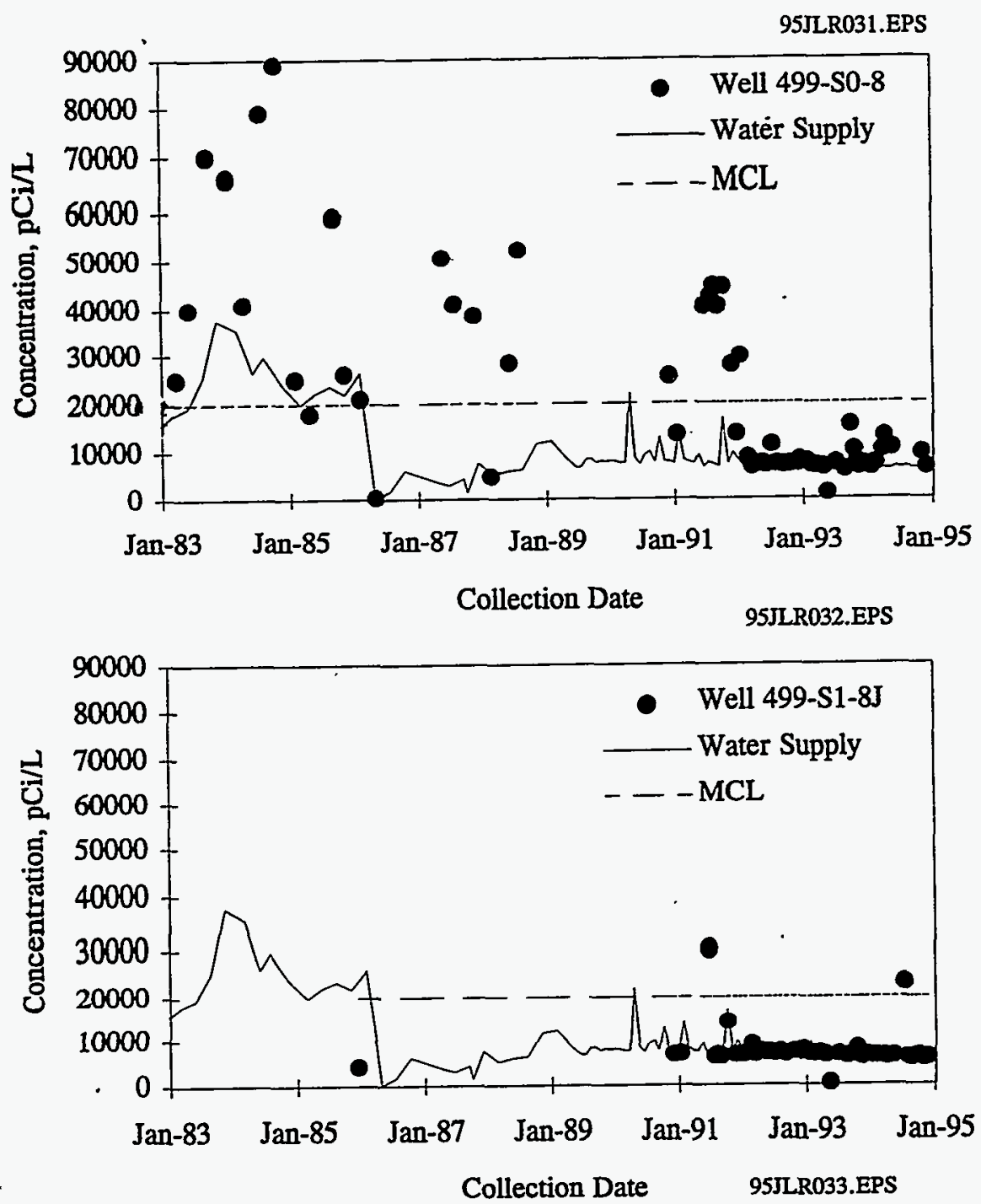

Figure 5.49. Comparison of Tritium Trends in the 400 Area Drinking Water System 


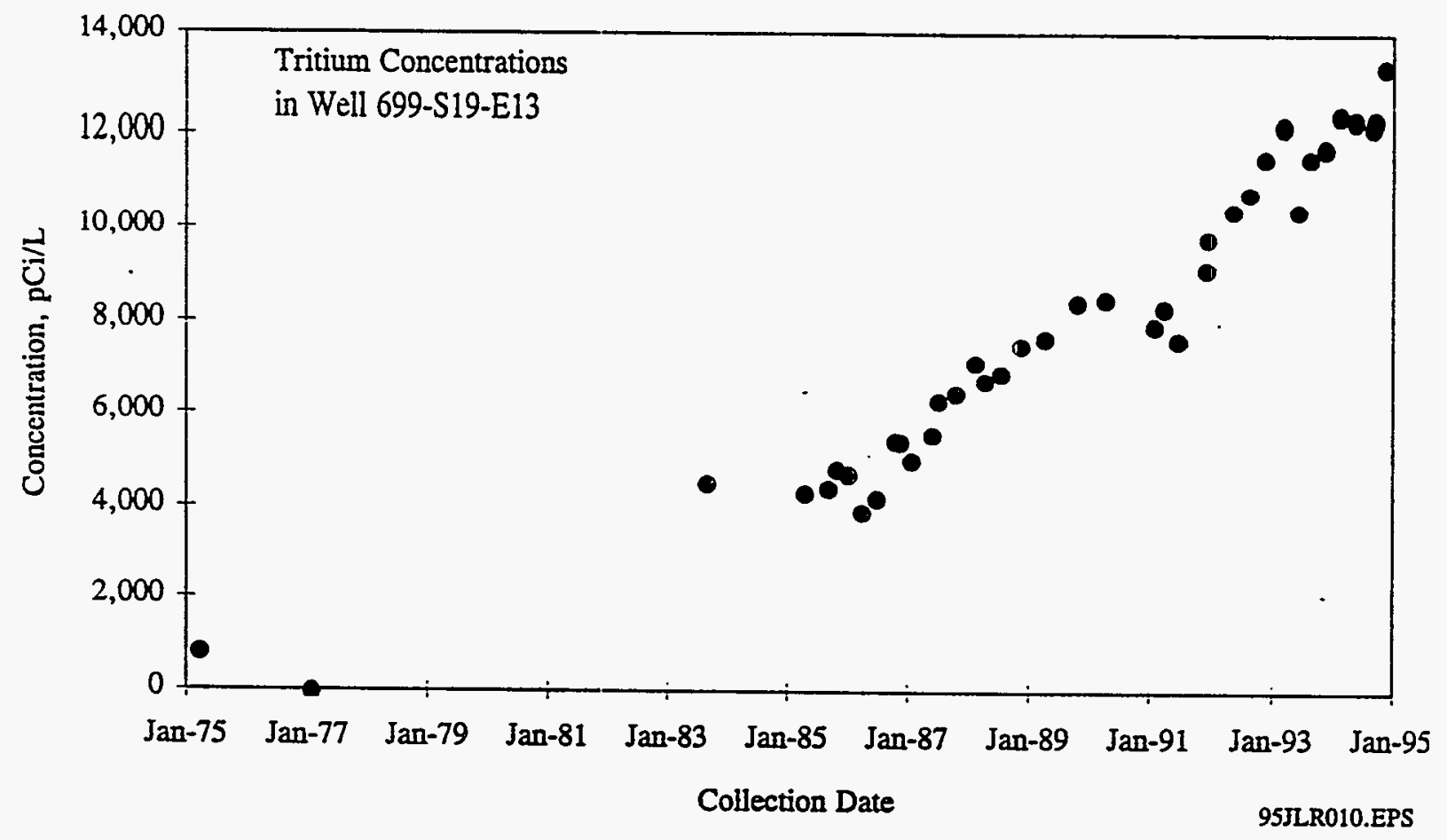

Figure 5.50. Tritium Concentration Trend for Well 699-S19-E13 


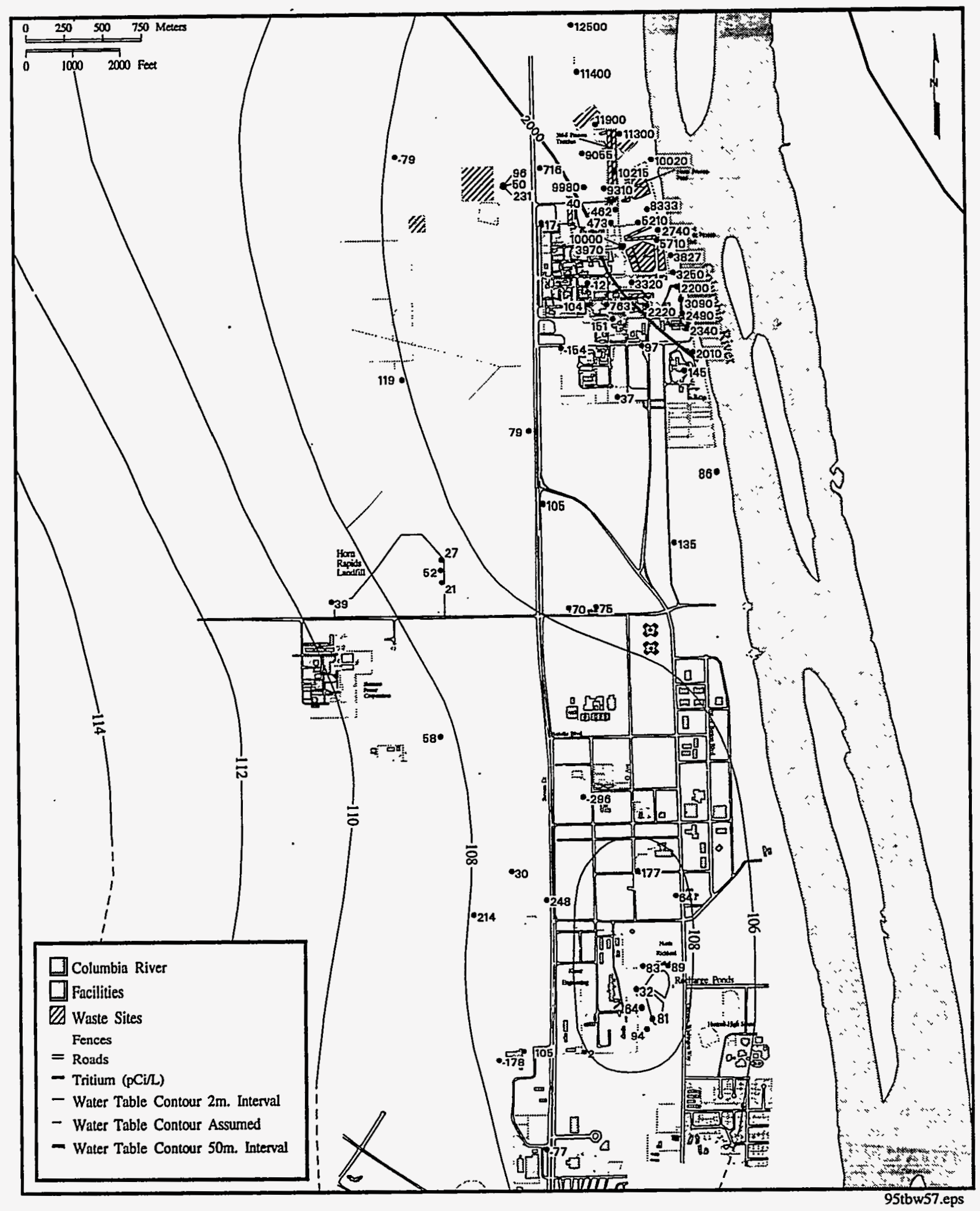

Figure 5.51. 1994 Average Tritium Concentrations and June Water Levels for the 300 Area and Richland North Area 


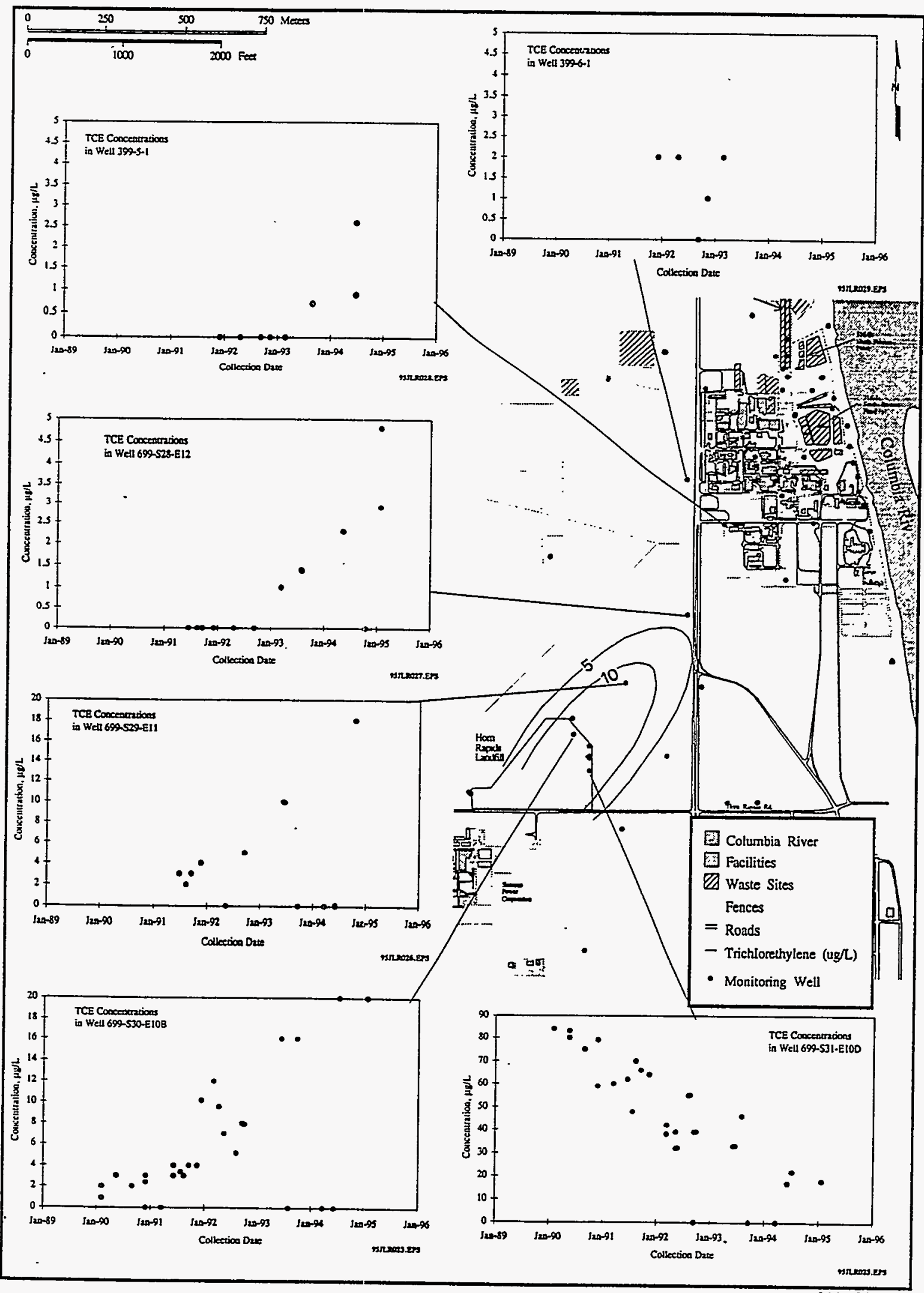

Figure 5.52. Trichloroethylene Concentration Trends for Selected Wells in the Richland North Area 


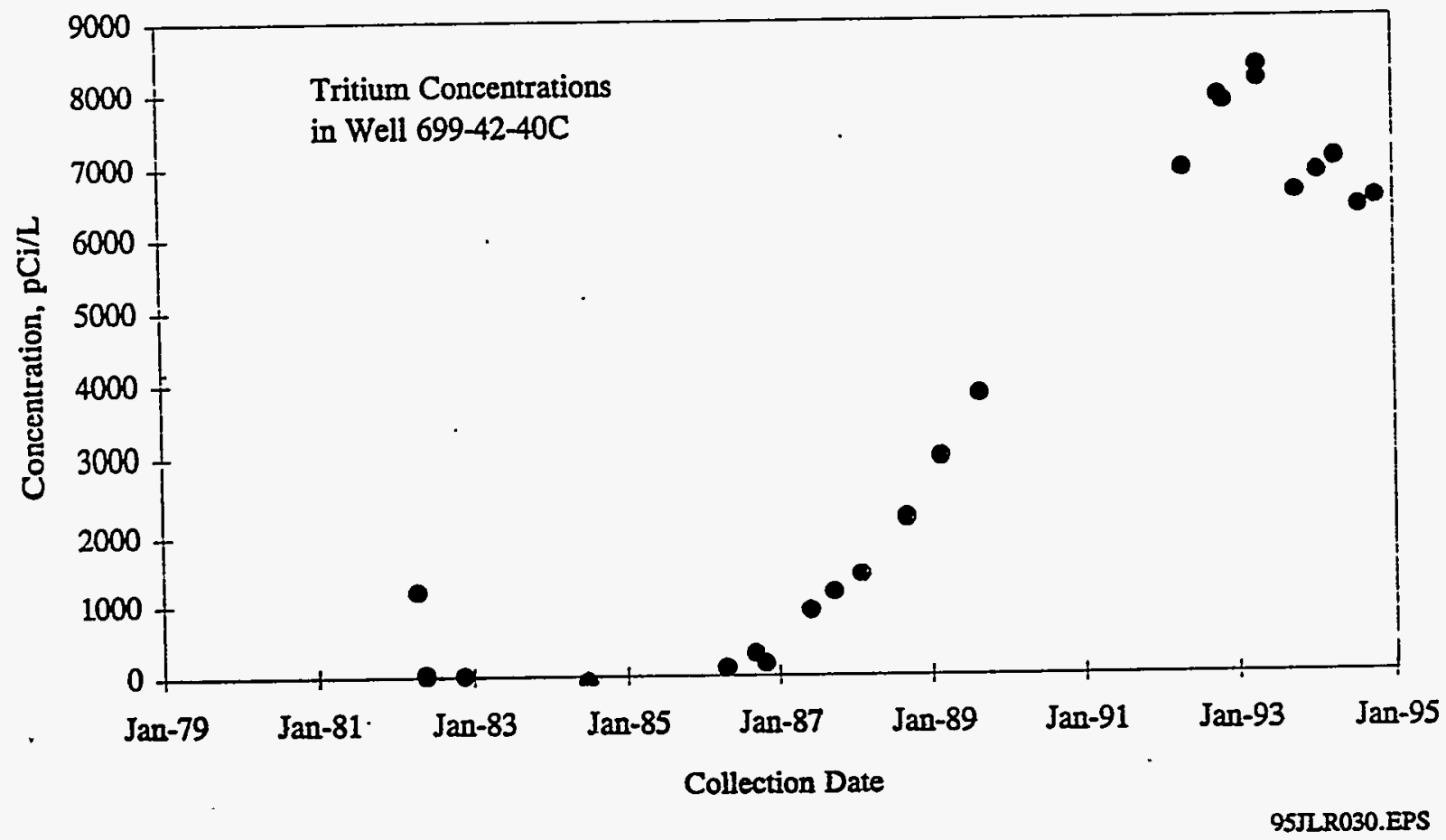

Figure 5.53. Tritium Concentration Trend for Well 699-42-40C 


\title{
6.0 Conclusions
}

\author{
P.E. Dresel
}

This report summarizes the results of 1994 ground-water monitoring performed by the GroundWater Surveillance Project at the Hanford Site. The Ground-Water Surveillance Project measured water-level elevations and sampled ground water for chemical and radiological analysis. Data collected by the project were integrated with results from other programs to produce a sitewide assessment of ground-water hydrology and contaminant chemistry. The 1994 monitoring results have improved the understanding of the sources and extent of ground-water contamination onsite and provide a basis for predicting future changes in the extent of contamination. This section discusses new activities and the major differences from the information presented in previous monitoring reports.

Geologic and hydrologic characterization activities include further refinement of the threedimensional geologic and hydrologic conceptual model to support the ongoing development of a multilayer three-dimensional numerical model of the unconfined aquifer system. The existing twodimensional ground-water flow model was refined and applied to predict impacts of declining water levels on the monitoring well network. The modeling indicated that many wells may go dry within the next 10 years. The ground-water flow model was also used to predict pathlines for contaminant transport from selected source areas.

Water levels in wells completed in the unconfined and confined aquifer system were measured to provide information on the direction and velocity of ground-water flow and contaminant transport. The measurements demonstrate the ongoing response of the unconfined aquifer to decreases in liquid waste disposal. Slow dissipation of ground-water mounding in the 100-N, 200-West, and 200-East Areas continues. Water-level declines are evident to a lesser degree over most of the site. However, water levels increased in the immediate vicinity of the eastern lobe of B Pond. Offsite, to the west and across the Columbia River to the north and east, water levels are strongly influenced by irrigation practices. Water levels near the Columbia River vary greatly in response to fluctuations in the river stage.

The Ground-Water Surveillance Project sampled approximately 500 wells in 1994, and a total of about 800 wells were sampled by the various ground-water projects onsite. Most samples were analyzed for tritium and common anions, including nitrate, because tritium and nitrate are the most widespread contaminants on the Hanford Site. Additional radiological analyses were completed for cobalt-60, strontium-90, technetium-99, antimony-125, iodine-129, cesium-137, uranium, and plutonium. Other chemical contaminants analyzed were fluoride, cyanide, chromium, carbon tetrachloride, chloroform, trichloroethylene, and tetrachloroethylene. In addition, soil-gas monitoring in the Richland North Area was carried out to further delineate the trichloroethylene plume near the Horn Rapids Landfill. 
Findings from the ground-water monitoring were generally in agreement with past years' information as discussed in the Summary and in Section 5.0. Significant changes or enhancements in the interpretation from previous years include:

- Chromium is found sporadically at levels above the MCL in the 100-F Area.

- Tritium was not found at levels above the DCG in the 100-K Area in 1994, although several samples from Well 199-K-30 had been above the DCG in 1993. Tritium concentrations remain high near the K-East reactor building and appear to be related predominantly to a source at the 199$\mathrm{KE}-1$ french drain although another source, such as leaks from the K-East fuel storage basin, may alsø contribute.

- The recent data for strontium-90 in the 100-N Area confirm that the plume is not spreading to the north at a discernable rate. Maximum concentrations in the central part of the plume appear to be leveling out in contrast to the decline between approximately 1989 and 1992.

- Sulfate contamination at levels above the secondary MCL in the 100-N Area appears to be related to disposal at the 1324-N/NA facility.

- The plume of tritium, technetium-99, and iodine-129 in the vicinity of waste management and disposal facilities related to T Plant operations (200-West Area) has not been explicitly identified in previous ground-water monitoring reports. It is likely that this plume results from $T$ Plant operations.

- The tritium plume extending from the southern 200-West Area appears to be expanding slowly and may be impacting wells at the U.S. Ecology facility south of the 200-East Area. Tritium concentrations at that facility appear to be increasing slowly. Only one well in the 200-West Area contained tritium at levels greater than the DCG in 1994.

- The iodine-129 plume extending from the southern 200-West Area into the 600 Area to the east appears to have a source in cribs south of U Plant and a source near the REDOX Plant.

- The technetium-99 plume near the REDOX plant is not coincident with the tritium and iodine-129 plumes and appears to have a separate source.

- Relatively minor nitrate contamination currently appears to be associated with REDOX Plant operations. High nitrate levels are associated with contamination in the vicinity of U Plant.

- Ground-water contamination in the vicinity of U Plant includes trichloroethylene at levels somewhat above the MCL. 
- Chloroform contamination was identified in the 200-West Area in 1994, but at lower levels than in past years. All levels detected were below the MCL.

- The iodine-129 plume extending from the vicinity of the PUREX Plant appears somewhat more extensive than previously recognized. The downgradient extent of the plume south of the old Hanford townsite is not well-established. Little long-term trend data are available for iodine-129 in this plume.

- Cobalt-60 contamination is still detected north of the BY Cribs, but the concentrations detected continue to decline.

- Technetium-99 concentrations in the 600-Area north of the BY Cribs reached nearly five times the MCL, and the plume appears to be expanding through the gap between Gable Mountain and Gable Butte to the north. Based on the 1994 and previous data, there does not appear to be a uranium plume associated with this technetium-99 contamination.

- The distribution of iodine-129 in the northwestern 200-East Area and adjacent 600 Area is distinct from the technetium-99 distribution, suggesting different sources.

- Extremely high concentrations of plutonium were detected in one sample from a well near the 216B-5 Injection well in the 200-East Area. This could result from the presence of particulate matter containing plutonium in the sample. Strontium-90 was found at levels above the DCG near the 216-B-5 Injection Well. Strontium-90 and plutonium were detected in a well approximately $150 \mathrm{~m}$ from the B-5 Injection Well. The presence of these constituents in that monitoring well have not yet been confirmed.

- Uranium distribution in the 300 Area in 1994 remained similar to that in 1993. Concentrations in Well 399-1-17A near the 316-5 Process Trenches were generally higher than in 1993 and generally greater than the MCL. However, concentrations remain well below levels present before the expedited response action.

- Concentrations of all volatile organic constituents in wells monitoring the Central Landfill Complex were below the MCL for all 1994 samples.

- High levels of strontium-90 remain in the unconfined aquifer and in the top of bedrock in the Gable Mountain Pond vicinity. Maximum levels were slightly below the DCG.

- Trichloroethylene present at levels above the MCL in the vicinity of the Horn Rapids Landfill is increasing in the northern monitoring well and decreasing in the southern wells. The plume extends northeast towards the 300 Area. The extent of this plume was further defined by soil-gas monitoring in 1994. 
- Strontium-90 contamination at levels above the MCL, associated with elevated tritium concentrations, was noted in one confined aquifer well in the 100-BC Area. This well had previously been open to both the unconfined and confined aquifers and may have provided a conduit downward for contamination. 


\subsection{References}

40 CFR 264. 1981 (as amended). U.S. Environmental Protection Agency, "Standards for Owners and Operators of Hazardous Waste Treatment, Storage, and Disposal Facilities." U.S. Code of Federal Regulations.

40 CFR 265. 1981 (as amended). U.S. Environmental Protection Agency, "Interim Status Standards for Owners and Operators of Hazardous Waste Treatment, Storage, and Disposal Facilities." U.S. Code of Federal Regulations.

Airhart, S. P. 1990. Borehole Completion Data Package for the 216-S-10 Ditch and Pond. WHCMR-0206, Westinghouse Hanford Company, Richland, Washington.

Alexander, D. G. 1993. Groundwater Impact Assessment Report for the 100-D Ponds. WHC-EP0666. Westinghouse Hanford Company, Richland, Washington.

Alexander, D. J., and V. G. Johnson. 1993. Groundwater Impact Assessment Report for the 1325-N Liquid Waste Disposal Facility. WHC-EP-0675, Westinghouse Hanford Company, Richland, Washington.

American Society for Testing and Materials (ASTM). 1986. Annual Book of ASTM Standards. American Society for Testing and Materials, Philadelphia, Pennsylvania.

American Society for Testing and Materials (ASTM). 1988. Standard Method for Determining Subsurface Liquid Levels in a Borehole or Monitoring Well (Observation Hell). D 4750-87, American Society for Testing and Materials, Philadelphia.

ASTM (see American Society for Testing and Materials)

Bauer, H. H., J. J. Vaccaro, and R. C. Lane. 1985. Maps Showing Ground-Water Levels in the Columbia River Basalt and Overlying Materials, Spring 1983, Southeastern Washington. WaterResources Investigations Report 84-4360, U.S. Geological Survey, Tacoma, Washington.

Bisping, L. E. 1994. Hanford Site Environmental Data 1993 - Surface and Columbia River. PNL9824, Pacific Northwest Laboratory, Richland, Washington.

Bjornstad, B. N. 1984. Suprabasalt Stratigraphy Within and Adjacent to the Reference Repository Location. SD-BWI-DP-039, Rockwell Hanford Operations, Richland, Washington.

Brown, R. E. 1979. A Review of Water-Well Data From the Unconfined Aquifer in the Eastern and Southern Parts of the Pasco Basin. RHO-BWI-C-56, Rockwell Hanford Operations, Richland, Washington. 
Campbell, M. D., W. J. McMahon, and K. R. Simpson. 1993. Water Level Measurements for Modeling Hydraulic Properties in the 300-FF-5 and 100 Aggregate Area Operable Units. PNL-8580, Pacific Northwest Laboratory, Richland, Washington.

Campbell, M. D. 1994. Monitoring Groundwater and River Interaction Along the Hanford Reach of the Columbia River. PNL-9437, Pacific Northwest Laboratory, Richland, Washington.

Carpenter, R. W., and S. L. Cote. 1994. 100-K Area Technical Baseline Report. WHC-SD-EN-TI239, Westinghouse Hanford Company, Richland, Washington.

Chamness, M. A., and J. K. Merz. 1993. Hanford Wells. PNL-8800. Pacific Northwest Laboratory, Richland, Washington.

Connelly, M. P. 1994. Capture Zone Analysis for the 200-ZP-1 and 200-UP-1, Pilot-Scale Pump-andTreat Tests. WHC-SD-EN-TI-252, Rev.0. Westinghouse Hanford Company, Richland, Washington.

Connelly, M. P, J. V. Borghese, C. D. Delaney, B. H. Ford, J. W. Lindberg, and S. J. Trent. 1992a. Hydrogeologic Model for the 200 East Groundwater Aggregate Area. WHC-SD-TI-019, Westinghouse Hanford Company, Richland, Washington.

Connelly, M. P, B. H. Ford, and J. V. Borghese. 1992b. Hydrogeologic Model for the 200 Hest Groundwater Aggregate Area. WHC-SD-TI-014, Westinghouse Hanford Company, Richland, Washington.

Dirkes, R. L., R. W. Hanf, R. K. Woodruff, and R. E. Lundgren. 1994. Hanford Site Environmental Report for Calendar Year 1993. PNL-9823. Pacific Northwest Laboratory, Richland, Washington.

DOE (see U.S. Department of Energy)

DOE-RL (see U.S. Department of Energy, Richland Operations Office)

Dresel, P. E., F. A. Spane, D. R. Newcomer, R. G. Raymond, J. C. Evans, B. E. Opitz, and W. D. Webber. 1993. Hanford Site Ground-Water Monitoring for 1992. PNL-8716, Pacific Northwest Laboratory, Richland, Washington.

Dresel, P. E., S. P. Luttrell, J. C. Evans, W. D. Webber, P. D. Thorne, M. A. Chamness, B. M. Gillespie, B. E. Opitz, J. T. Rieger, and J. K. Merz. 1994. Hanford Site Ground-Water Monitoring for 1993. PNL-10082, Pacific Northwest Laboratory, Richland, Washington.

Drost, B. W., K. M. Schurr, and W. E. Lurn II. 1989. Selected Ground-Water Information for the Pasco Basin and Adjacent Areas, Washington, 1986-1989. Open-File Report 89-228, U.S. Geological Survey, Tacoma, Washington.

Drost, B. W., J. C. Ebbert, and S. E. Cox. 1993. Long-Term Effects of Irrigation With Imported Water on Water Levels and Water Quality. Water-Resources Investigations Report 93-4060, U.S. Geological Survey, Tacoma, Washington. 
Ebbert, J. C., S. E. Cox, and B. W. Drost. 1991. The Effects of Lining Irrigation Canals on Nitrate Concentrations in Ground Water. Proceedings of the Conference on Nonpoint Source Pollution: The Unfinished Agenda for the Protection of Our Water Quality. Tacoma, Washington. March 1991.

Ecology, EPA, and DOE. 1992. Hanford Federal Facility Agreement and Consent Order, 2 vols., as amended, Washington State Department of Ecology, the U.S. Environmental Protection Agency, and the U.S. Department of Energy, Olympia, Washington.

Eddy, P. A., D. A. Myers, and J. R. Raymond. 1978. Vertical Contamination in the Unconfined Groundwater at the Hanford Site, Washington. PNL-2724, Pacific Northwest Laboratory, Richland, Washington.

EPA (see U.S. Environmental Protection Agency)

Evans, J. C., R. W. Bryce, D. R. Sherwood, M. L. Kemner, and D. R. Newcomer. 1989. Hanford Site Ground-Water Monitoring for July Through December 1988. PNL-7120, Pacific Northwest Laboratory, Richland, Washington.

Evans, J. C., R. W. Bryce, and D. J. Bates. 1992a. Hanford Site Ground-Water Monitoring for 1990. PNL-8073, Pacific Northwest Laboratory, Richland, Washington.

Evans, J. C., R. W. Bryce, and D. J. Bates. 1992b. Hanford Site Ground-Water Monitoring for 1991. PNL-8284, Pacific Northwest Laboratory, Richland, Washington.

Fayer, M. J., and T. B. Walters. 1995. Estimated Recharge Rates at the Hanford Site. PNL-10285, Pacific Northwest Laboratory, Richland, Washington.

Freshley, M. D., and P. D. Thorne. 1992. Ground-Water Contribution to Dose from Past Hanford Operations. Prepared by Hanford Environmental Dose Reconstruction Project, Battelle, Pacific Northwest Laboratories, Richland, Washington.

Fruland, R. M., and R. E. Lundgren, eds. 1989. RCRA Ground-Water Monitoring Projects for Hanford Facilities: Annual Progress Report for 1988. PNL-6852, Pacific Northwest Laboratory, Richland, Washington.

Garber, M. S., and F. C. Koopman. 1968. Methods of Measuring Water.Levels in Deep Wells: U.S. Geological Survey TRWI, Book 8, Chapter A-1. U.S. Government Printing Office, Washington, D.C.

Gee, G. W., M. J. Fayer, M. L. Rockhold, and M. D. Campbell. 1992. "Variations in Recharge at the Hanford Site." Northwest Science 66:237-250.

Gephart, R. E., R. C. Arnett, R. G. Baca, L. S. Leonhart, and F. A. Spane, Jr. 1979. Hydrologic Studies Within the Columbia Plateau, Washington: An Integration of Current Knowledge. RHO-BWIST-5, Rockwell Hanford Operations, Richland, Washington. 
Geraghty and Miller, Inc. 1995. Fourth Quarter 1994 Quarterly Groundwater Monitoring Report, Siemens Power Corporation, Richland, Washington. Geraghty and Miller, Inc. Environmental Services, Redmond, Washington.

Graham, M. J., G. V. Last, and K. R. Fecht. 1984. An Assessment of Aquifer Intercommunication in the B Pond-Gable Mountain Pond Area of the Hanford Site. RHO-RE-ST-12 P, Rockwell Hanford Operations, Richland, Washington.

Grolier, M. J., and J. W. Bingham. 1978. Geology of Parts of Grant, Adams, and Franklin Counties, East-Central Washington. Bulletin No. 71, Department of Natural Resources, State of Washington, Olympia, Washington.

Hall, S. H. 1989. Evaluation of the Ground-Hater Contaminant Plume Extending from the 183-H Solar Evaporation Basins. PNL-7130, Pacific Northwest Laboratory, Richland, Washington.

Haney, W. A. 1957. Disposal of High Cobalt-60 Scavenged Wastes. HW48862, Hanford Atomic Products Operation, Richland, Washington.

Hanf, R. W. and R. L. Dirkes. 1995. Hanford Site Environmental Report for Calendar Year 1994. PNL-10574, Pacific Northwest Laboratory, Richland, Washington.

Hartman, M. J. 1994. "100-N Area Resource Conservation and Recovery Act Site." In Annual Report for RCRA Groundwater Monitoring Projects at Hanford Site Facilities for 1993. DOE/RL-93-88, U.S. Department of Energy, Richland Operations Office, Richland, Washington.

Hartman, M. J. 1995a. "100-D Ponds." In Annual Report for RCRA Groundwater Monitoring Projects at Hanford Site Facilities for 1994. U.S. Department of Energy, Richland Operations Office, Richland, Washington.

Hartman, M. J. 1995b. "183-H Solar Evaporation Basins.". In Annual Report for RCRA Groundwater Monitoring Projects at Hanford Site Facilities for 1994. U.S. Department of Energy, Richland Operations Office, Richland, Washington.

Hartman, M. J., and K. A. Lindsey. 1993. Hydrogeology of the 100-N Area, Hanford Site, Washington. WHC-SD-EN-EV-027, Rev. 0, Westinghouse Hanford Company, Richland, Washington.

Hodges, F. N. 1995a. "Nonradioactive Dangerous Waste Landfill." In Annual Report for RCRA Groundwater Monitoring Projects at Hanford Site Facilities for 1994. U.S. Department of Energy, Richland Operations Office, Richland, Washington.

Hodges, F. N. 1995b. "Solid Waste Landfill." In Annual Report for RCRA Groundwater Monitoring Projects at Hanford Site Facilities for 1994. U.S. Department of Energy, Richland Operations Office, Richland, Washington.

ICF. 1987. Hydrogeologic Study of North Richland Well Field and Ground-Water Recharge Basins. Prepared by ICF Northwest for the City of Richland, Richland, Washington. 
Jacques, I. D. 1993. Nonradioactive Dangerous Waste Landfill Soil-Gas Survey: Final Data Report. WHC-SD-EN-TI-199, Rev. 0, Westinghouse Hanford Company, Richland, Washington.

Jacobson, E. A., and M. D. Freshley. 1990. An Initial Inversè Calibration of the Ground-Water Flow Model for the Hanford Unconfined Aquifer. PNL-7144, Pacific Northwest Laboratory, Richland, Washington.

Jarvis, A. B., and L. Siu. 1981. Environmental Radioactivity Laboratory Intercomparison Studies Program: Fiscal Year 1980-81. EPA-600/4-81-004, U.S. Environmental Protection Agency, Las Vegas, Nevada.

Jenkins, O. P. 1922. Underground Water Supply of the Region About White Bluffs and Hanford. Bulletin No. 26, State of Washington Department of Conservation and Development, Division of Geology, Olympia, Washington.

Jensen, E. J. 1987. Summary of Water-Level Measurements Around the 1325-N Crib During the Fall of 1985 and the Winter of 1986-1987. PNL-6374, Pacific Northwest Laboratory, Richland, Washington.

Kasza, G. L., M. J. Hartman, W. A. Jordan, and D. C. Weekes. 1994a. Groundwater Maps of the Hanford Site, June 1993. WHC-EP-0394-7, Westinghouse Hanford Company, Richland, Washington.

Kasza, G. L., M. J. Hartman, W. A. Jordan, and J. V. Borghese. 1994b. Groundwater Maps of the Hanford Site, December 1993. WHC-EP-0394-8, Westinghouse Hanford Company, Richland, Washington.

Kipp, K. L., A. E. Reisenauer, C. A. Cole, and L. A. Bryan. 1972. Variable Thickness Transient Groundwater Flow Model: Theory and Numerical Implementation. BNWL-1703, Pacific Northwest Laboratory, Richland, Washington.

Last, G. V., and V. H. Rohay. 1993. Refined Conceptual Model for the Volatile Organic Compounds - Arid Integrated Demonstration and 200 West Area Carbon Tetrachloride Expedited Response Action, PNL-8597, Pacific Northwest Laboratory, Richland, Washington.

Liikala, T. L., R. L. Aaberg, N. J. Aimo, D. J. Bates, T. J Gilmore, E. J. Jensen, G. V. Last, P. L. Oberlander, K. B. Olsen, K. R. Oster, L. R. Roome, J. C. Simpson, S. S. Teel, and E. J. Westergard. 1988. Geohydrologic Characterization of the Area Surrounding the 183-H Solar Evaporation Basins. PNL-6728, Pacific Northwest Laboratory, Richland, Washington.

Lindberg, J. W. 1993a. Geology of the 100-B/C Area, Hanford Site, South-Central Washington. WHC-SD-EN-TI-133, Westinghouse Hanford Company, Richland, Washington.

Lindberg, J. W. 1993b. Geology of the 100-K Area, Hanford Site, South-Central Washington. WHCSD-EN-TI-155, Westinghouse Hanford Company, Richland, Washington. 
Lindberg, J. W. 1995. "300 Area Process Trench." In Annual Report for RCRA Groundwater Monitoring Projects at Hanford Site Facilities for 1994. U.S. Department of Energy, Richland Operations Office, Richland, Washington.

Lindberg, J. W., and F. W. Bond. 1979. Geohydrology and Ground-Water Quality Beneath the 300 Area, Hanford Site, Washington. PNL-2949, Pacific Northwest Laboratory, Richland, Washington.

Lindsey, K. A. 1992. Geology of the Northern Part of the Hanford Site: An Outline of Data Sources and the Geologic Setting of the 100 Areas. WHC-SD-EN-TI-011, Rev. 0, Westinghouse Hanford Company, Richland, Washington.

Lindsey, K. A., B. N. Bjornstad, J. W. Lindberg, and K. M. Hoffman. 1992. Geologic Setting of the 200 East Area; An Update. WHC-SD-EN-TI-012, Westinghouse Hanford Company, Richland, Washington.

Luttrell, S. P., D. R. Newcomer, S. S. Teel, and V. R. Vermeul. 1992. Hydrogeologic Controls on Ground-Water and Contaminant Discharge to the Columbia River in the Hanford Townsite Vicinity. PNL-8167, Pacific Northwest Laboratory, Richland, Washington.

McMahon, W. J., and R. E. Peterson. 1992. Estimating Aquifer Hydraulic Properties Using the Ferris Method, Hanford Site, Washington. DOE/RL-92-64, U.S. Department of Energy, Richland, Washington.

Myers, C. W., S. M. Price, J. A. Caggiano, M. P. Cochran, W. J. Czimer, N. J. Davidson, R. C. Edwards, K. R. Fecht, G. E. Holmes, M. G. Jones, J. R. Kunk, R. D. Landon, R. K. Ledgerwood, J. T. Lillie, P. E. Long, T. H. Mitchell, E. H. Price, S. P. Riedel, and A. M. Tallman. 1979. Geologic Studies of the Columbia Plateau: A Status Report. RHO-BWI-ST-4, Rockwell Hanford Operations, Richland, Washington.

Newcomb, R. C., and S. G. Brown. 1961. Evaluation of Bank Storage Along the Columbia River Between Richland and China Bar, Washington. Water-Supply Paper 1539-I, U.S. Geological Survey, Washington, D.C.

Newcomb, R. C., J. R. Strand, and F. J. Frank. 1972. Geology and Ground-Water Characteristics of the Hanford Reservation of the U.S. Atomic Energy Commission, Washington. Professional Paper 717, U.S. Geological Survey, Washington, D.C.

Newcomer, D. R. 1990. Evaluation of Hanford Site Water-Table Changes-1980 to 1990. PNL-7498, Pacific Northwest Laboratory, Richland, Washington.

Newcomer, D. R., K. D. Pohlod; and J. P. McDonald. 1992. Water-Table Elevations on the Hanford Site, 1991. PNL-8122, Pacific Northwest Laboratory, Richland, Washington. 
O'Dell, J. W., J. D. Pfaff, M. E. Gales, and G. D. McKee. Text Method: The Determination of Inorganic Anions in Water by Ion Chromotography - Method 300.0. 1984. EPA-600/4-84-017, U.S. Environmental Protection Agency, Environmental Monitoring and Support Laboratory, Cincinnati, Ohio.

Peterson, R. E. 1992. Hydrologic and Geologic Data Available for the Region North of Gable Mountain, Hanford Site, Washington. WHC-SD-EN-TT-006, Westinghouse Hanford Company, Richland, Washington.

Peterson, R. E. 1994. "183-H Solar Evaporation Basins." In Annual Report for RCRA Groundwater Monitoring Projects at Hanford Site Facilities for 1993. DOE/RL-93-88, U.S. Department of Energy, Richland Operations Office, Richland, Washington.

Peterson, R. E., and M. P. Connelly. 1992. Characterization of a Chromium Plume in Groundwater Along the Columbia River Shoreline, Hanford Site, Washington. WHC-SA-1674-VA, Westinghouse Hanford Company, Richland, Washington.

PNL (Pacific Northwest Laboratory). 1993. Procedures for Ground-Water Investigations. PNL-6894, Rev. 1, Richland, Washington.

Reidel, S. P., K. A. Lindsey, and K. R. Fecht. 1992. Field Trip Guide to the Hanford Site. WHCMR-0391, Westinghouse Hanford Company, Richland, Washington.

RHO (see Rockwell Hanford Operations)

Rohay, V. J., K. J. Swett, and G. V. Last. 1994a. FY94 Conceptual Model of the Carbon Tetrachloride Contamination in the 200 West Area at the Hanford Site. WHC-SD-EN-TI-248, Westinghouse Hanford Company, Richland, Washington.

Rohay, V. J., K. J. Swett, and G. V. Last. 1994b. 1994 Conceptual Model of the Carbon Tetrachloride Contamination in the 200. Hest Area at the Hanford Site. WHC-SD-EN-TI-248, Rev. 0, prepared by V. J. Rohay and K. J. Swett, Westinghouse Hanford Company, and G. V. Last, Pacific Northwest Laboratory, for Westinghouse Hanford Company, Richland, Washington.

Sanderson, C. G. 1985. Semi-Annual Report of the Department of Energy, Operational Safety, Health and Environmental Division, Quality Assessment Program Data Report. EML-439, Environmental Measurements Laboratory, U.S. Department of Energy, New York.

Schalla, R., R. W. Wallace, R. L. Aaberg, S. P. Airhart, D. J. Bates, J. V. M. Carlile, C. S. Cline, D. I. Dennison, M. D. Freshley, P. R. Heller, E. J. Jensen, K. B. Olsen, R. G. Parkhurst, J. T. Rieger, and E. J. Westergard. 1988. Interim Characterization Report for the 300 Area Process Trenches. PNL-6716, Pacific Northwest Laboratory, Richland, Washington.

Serkowski, J. A., W. A. Jordan, and M. J. Hartman. 1994. Groundwater Maps of the Hanford Site, June 1994. WHC-EP-0394-9, Westinghouse Hanford Company, Richland, Washington. 
Smith, R. M. 1980. 216-B-5 Reverse Well Characterization Study. RHO-ST-37, Rockwell Hanford Operations, Richland, Washington.

Spane, F. A., Jr. 1987. Fresh-Water Potentiometric Map and Inferred Flow Direction of Ground Water Within the Mabton Interbed, Hanforl Site, Washington State-January 1987. SD-BWI-TI-335, Rockwell Hanford Operations, Richland, Washington.

Spane, F. A., and R. G. Raymond. 1993. Preliminary Potentiometric Map and Flow Dynamic Characteristics for the Upper-Basalt Confined Aquifer System. PNL-8869, Pacific Northwest Laboratory, Richland, Washington.

Stenner, R. D., K. H. Cramer, K. A. Higley, S. J. Jette, D. A. Lamar, T. J. McLaughlin, D. R. Sherwood, and N. C. VanHouten. 1988. Hazard Ranking System Evaluation of CERCLA Inactive Waste Sites at Hanford. Vlume 1, Evaluation Method and Results. PNL-6456, Pacific Northwest Laboratory, Richland, Washington.

Swanson, L. C. 1992. Phase I Hydrogeologic Summary of the 300-FF-5 Operable Unit, 300 Area. WHC-SD-EN-TI-052, Westinghouse Hanford Company, Richland, Washington.

Thorne, P. D., M. A. Chamness, F. A. Spane, V. R. Vermeul, and W. D. Webber. 1993. ThreeDimensional Conceptual Model for the Hanford Site Unconfined Aquifer System, FY93 Status Report. PNL-8971, Pacific Northwest Laboratory, Richland, Washington.

Tyler, D. K. 1992. Groundwater Impact Assessment Report for the 400 Area Ponds. WHC-EP-0587, Westinghouse Hanford Company, Richland, Washington.

U.S. Department of Energy (DOE). 1988b. Consultation Draft, Site Characterization Plan, Reference Repository Location, Hanford Site, Washington. DOE/RW-0164, Vol. 1, U.S. Department of Energy, Washington, D.C.

U.S. Department of Energy (DOE). 1988a. "General Environmental Protection Program." DOE Order 5400.1.

U.S. Department of Energy (DOE). 1990. "Radiation Protection of the Public and the Environment." DOE Order 5400.5 .

U.S. Department of Energy, Richland Operations Office (DOE-RL). 1992. Final Remedial Investigation Study-Environmental Assessment Report for the 1100-EM-1 Operable Unit, Hanford. DOE/RL-92-67 Draft B. U.S. Department of Energy, Richland Operations Office, Richland, Washington.

U.S. Department of Energy, Richland Operations Office (DOE-RL). 1993a. Limited Field Investigation Report for the 100-BC-5 Operable Unit. DOE/RL-93-37, U.S. Department of Energy, Richland Operations Office, Richland, Washington. 
U.S. Department of Energy, Richland Operations Office (DOE-RL). 1993c. Limited Field Investigation Report for the 100-HR-3 Operable Unit. DOE/RL-93-43, U.S. Department of Energy, Richland Operations Office, Richland, Washington.

U.S. Department of Energy, Richland Operations Office (DOE-RL). 1993d. Limited Field Investigation Report for the 100-KR-4 Operable Unit. DOE/RL-93-79, U.S..Department of Energy, Richland Operations Office, Richland, Washington

U.S. Department of Energy, Richland Operations Office (DOE-RL.) 1993a. Quarterly Report of RCRA Groundwater Monitoring Data for Period January 1, 1993 through March 31, 1993. DOE/RL93-56-1, U.S. Department of Energy, Richland Operations Office, Richland, Washington.

U.S. Department of Energy, Richland Operations Office (DOE-RL). 1993b. Quarterly Report of RCRA Groundwater Monitoring Data for Period April 1, 1993 through June 30, 1993. DOE/RL-9356-2, U.S. Department of Energy, Richland Operations Office, Richland, Washington.

U.S. Department of Energy, Richland Operations Office (DOE-RL). 1994a. Annual Report of RCRA Groundwater Monitoring Projects at Hanford Site Facilities for 1993. DOE/RL-93-88, U.S. Department of Energy, Richland Operations Office, Richland, Washington.

U.S. Department of Energy, Richland Operations Office (DOE-RL). 1994b. Quarterly Report of RCRA Groundwater Monitoring Data for Period July 1, 1993 through September 30, 1993. DOE/RL93-56-3, U.S. Department of Energy, Richland Operations Office, Richland, Washington.

U.S. Department of Energy, Richland Operations Office (DOE-RL). 1994c. Quarterly Report of RCRA Groundwater Monitoring Data for Period October 1, 1993 through December 31, 1993. DOE/RL-93-56-4, U.S. Department of Energy, Richland Operations Office, Richland, Washington.

U.S. Department of Energy, Richland Operations Office (DOE-RL). 1995a. Annual Report for RCRA Groundwater Monitoring Projects at Hanford Site Facilities for 1994. DOE/RL-94-36, Rev. 0, U.S. Department of Energy, Richland Operations Office, Richland, Washington.

U.S. Department of Energy, Richland Operations Office (DOE-RL). 1995b. Quarterly Report of RCRA Groundwater Monitoring Data for Period July 1, 1994 through September 30, 1994. DOE/RL94-36-3, U.S. Department of Energy, Richland Operations Office, Richland, Washington.

U.S. Department of Energy, Richland Operations Office (DOE-RL). 1995c. Quarterly Report of RCRA Groundwater Monitoring Data for Period October 1, 1994 through December 31, 1994. DOE/RL-94-36-4, U.S. Department of Energy, Richland Operations Office, Richland, Washington.

U.S. Department of Energy, Richland Operations Office (DOE-RL). 1995d. Remedial Investigation/Feasibility Study Report for the 300-FF5 Operable Unit. DOE/RL-94-85, U.S. Department of Energy, Richland Operations Office, Richland, Washington.

U.S. Environmental Protection Agency (EPA). 1982. Methods for Chemical Analysis of Water and Wastes. EPA-600/4-82-055, U.S. Environmental Protection Agency, Washington, D.C. 
U.S. Environmental Protection Agency (EPA). 1986b. Resource Conservation and Recovery Act (RCRA) Ground-Water Monitoring Technical Enforcement Guidance Document. OWSER-9950.1, U.S. Environmental Protection Agency, Washington, D.C.

U.S. Environmental Protection Agency (EPA). 1986a. Test Methods for Evaluation Solid Waste: Physical/Chemical Methods, 3rd ed. SW-846, Office of Solid Waste and Emergency Response, Washington, D.C.

\section{USGS (see U.S. Geological Survey)}

U.S. Geological Survey (USGS) 1977. National Handbook of Recommended Methods for Water Data Acquisition. U.S. Geological Survey, Office of Water Data Coordination, Reston, Virginia.

WAC (see Washington Administrative Code)

Waite, J. L. 1991. Tank Wastes Discharged Directly to the Soil at the Hanford Site. WHC-MR-0227, Westinghouse Hanford Company, Richland, Washington.

Walters, K. L., and M. J. Grolier. 1960. Geology and Ground Water Resources of the Columbia Basin Project Area, Washington Volume I. Division of Water Resources, State of Washington, Olympia, Washington.

Washington Administrative Code (WAC). 1986a. Washington State Department of Ecology, "Dangerous Waste Regulations." WAC 173-303, Olympia, Washington.

Washington Administrative Code (WAC). 1986b. Washington State Department of Ecology, "Minimum Functional Standards for Solid Waste Handling." WAC-173-304, Olympia, Washington.

Webber, W. D., and J. P. McDonald. 1994. Impact of Declining Water Levels on Ground-Water Monitoring Networks at the Hanford Site, Richland, Washington. Letter Report for Westinghouse Hanford Company by Pacific Northwest Laboratory, Richland, Washington.

Westinghouse Hanford Company (WHC). In press. Environmental Releases for Calendar Year 1994. WHC-EP-0527-4, Westinghouse Hanford Company, Richland, Washington.

Westinghouse Hanford Company (WHC). 1989. Environmental Investigations and Site Characterization Manual. WHC-CM-7-7, Vol. 1, Westinghouse Hanford Company, Richland, Washington.

Westinghouse Hanford Company (WHC). 1992a. Environmental Releases for Calendar Year 1990. WHC-EP-0527, Westinghouse Hanford Company, Richland, Washington.

Westinghouse Hanford Company (WHC). 1992b. Environmental Releases for Calendar Year 1991. WHC-EP-0527-1, Westinghouse Hanford Company, Richland, Washington. 
Westinghouse Hanford Company (WHC). 1993. Environmental Releases for Calendar Year 1992. WHC-EP-0527-2, Westinghouse Hanford Company, Richland, Washington.

Westinghouse Hanford Company (WHC). 1994.'Environmental Releases for Calendar Year 1993. WHC-EP-0527-3, Westinghouse Hanford Company, Richland, Washington.

WHC (see Westinghouse Hanford Company)

Wurstner, S. K., and J. L. Devary. 1993. Hanford Site Ground-Water Model: Geographic Information System Linkages and Model Enhancements, FY 1993. PNL-8991, Pacific Northwest Laboratory, Richland, Washington.

Wurstner, S. K., and M. D. Freshley. 1994. Predicted Impacts of Future Water Level Decline on Monitoring Wells Using a Ground-Water Model of the Hanford Site. PNL-10196, Pacific Northwest Laboratory, Richland, Washington.

Zimmerman, D. A., A. E. Reisenauer, G. D. Black, and M. A. Young. 1986. Hanford Site Water Table Changes 1950 Through 1980-Data Observations and Evaluation. PNL-5506, Pacific Northwest Laboratory, Richland, Washington. 


\subsection{Historical Bibliography}

Reports on ground water monitoring are listed in chronological order by type of report in this section.

\subsection{Environmental Monitoring Monthly and Quarterly Reports (1946 through 1957)}

Turner, L. D. 1947. Trend of Contamination in the Air, Columbia River, Rain, Sanitary Water, Vegetation and Wastes at Hanford Works and Vicinity - Quarterly, 1946. HW 3-5402, General Electric Company, Hanford Atomic Products Operation, Richland, Washington.

Turner, L. D. 1947. Trend of Contamination in the Air, Columbia River, Rain, Sanitary Water, Vegetation and Wastes at Hanford Works and Vicinity - Quarterly, 1/1/47 to 3/25/47. HW 3-5511, General Electric Company, Hanford Atomic Products Operation, Richland, Washington.

Healy, J. W. 1947. Trend of Contamination in the Air, Columbia River, Rain, Sanitary Water, Vegetation and Wastes at Hanford Works and Vicinity - Quarterly, 3/25/47 to 6/30/47. HW-7317, General Electric Company, Hanford Atomic Products Operation, Richland, Washington.

Singlevich, W. 1947. Trend of Contamination in the Air, Columbia River, Rain, Sanitary Water, Vegetation and Whastes at Hanford Works and Vicinity - Quarterly, 7/1/47 to 9/30/47. HW-8549 DEL, General Electric Company, Hanford Atomic Products Operation, Richland, Washington.

Singlevich, W. 1947. Trend of Contamination in the Air, Columbia River, Rain, Sanitary Water, Vegetation and Wastes at Hanford Works and Vicinity - Quarterly, 10/1/47 to 12/31/47. HW-9496 DEL, General Electric Company, Hanford Atomic Products Operation, Richland, Washington.

Singlovich, W. 1948. Radioactive Contamination in the Environs of the Hanford Works for the Period January-March 1948. HW-10242, General Electric Company, Hanford Works, Richland, Washington.

Singlovich, W. 1948. Radioactive Contamination in the Environs of the Hanford Works for the Period April-June 1948. HW-11333 DEL, General Electric Company, Hanford Works, Richland, Washington.

Singlovich, W. 1949. Radioactive Contamination in the Envinons of the Hanford Whrks for the Period July-September 1948. HW-12677 DEL, General Electric Company, Hanford Works, Richland, Washington.

Singlovich, W. 1949. Radioactive Contamination in the Environs of the Hanford Wbrks for the Period October-December 1948. HW-13743 DEL, General Electric Company, Hanford Works, Richland, Washington. 
Singlovich, W., and H. J. Paas. 1949. Radioactive Contamination in the Environs of the Hanford Wrrks for the Period January-March 1949. HW-14243 DEL, General Electric Company, Hanford Works, Richland, Washington.

Singlovich, W., and H. J. Paas. 1949. Radioactive Contamination in the Environs of the Hanford Wbrks for the Period April-June 1949. HW-17434 DEL, General Electric Company, Hanford Works, Richland, Washington.

Paas, H. J., and W. Singlovich. 1950. Radioactive Contamination in the Environs of the Hanford Works for the Period July-September 1949. HW-18615, General Electric Company, Hanford Works, Richland, Washington.

Paas, H. J., and W. Singlovich. 1950. Radioactive Contamination in the Environs of the Hanford Works for the Period October-December 1949. HW-17003 DEL, General Electric Company, Hanford Works, Richiand, Washington.

Paas, H. J., and W. Singlovich. 1950. Radioactive Contamination in the Environs of the Hanford Works for the Period January-March 1950. HW-18446, General Electric Company, Hanford Works, Richland, Washington.

Paas, H. J., and W. Singlovich. 1950. Radioactive Contamination in the Environs of the Hanford Wbrks for the Period April-June 1950. HW-19454, General Electric Company, Hanford Works, Richland, Washington.

Singlevich, W. 1950. H.I. Environs Report of the Month of September 1950. HW-19046, General Electric Company, Hanford Works, Richland, Washington.

Singlevich, W. 1950. H.I. Environs Report of the Month of October 1950. HW-19454, General Electric Company, Hanford Works, Richland, Washington.

Singlevich, W. 1950. H.l. Environs Report of the Month of November 1950. HW-19625, General Electric Company, Hanford Works, Richland, Washington.

Singlevich, W. 1950. H.I. Environs Report of the Month of December 1950. HW-19896, General Electric Company, Hanford Works, Richland, Washington.

Paas, H. J., and W. Singlovich. 1951. Radioactive Contamination in the Environs of the Hanford Wrrks for the Period July-September 1950. HW-20700, General Electric Company, Hanford Works, Richland, Washington.

Paas, H. J. 1951. Radioactive Contamination in the Environs of the Hanford Wbrks for the Period October-December 1950. HW-21566, General Electric Company, Hanford Works, Richland, Washington. 
Paas, H. J., and W. Singlovich. 1951. Radioactive Contamination in the Environs of the Hanford Works for the Period January-March 1951. HW-21214, General Electric Company, Hanford Works, Richland, Washington.

Paas, H. J. 1951. Radioactive Contamination in the Environs of the Hanford Works for the Period April-June 1951. HW-22313, General Electric Company, Hanford Works, Richland, Washington.

Paas, H. J. 1951. Radioactive Contamination in the Environs of the Hanford Works for the Period July-September 1951. 'HW-23133, General Electric Company, Hanford Works, Richland, Washington.

Paas, H. J. 1952. Radioactive Contamination in the Environs of the Hanford Wbrks for the Period October-December 1951. HW-24203, General Elẹctric Company, Hanford Works, Richland, Washington.

Paas, H. J. 1952. Radioactive Contamination in the Environs of the Hanford Works for the Period January-March 1952. HW-25866, General Electric Company, Hanford Works, Richland, Washington.

Paas, H. J. 1952. Radioactive Contamination in the Environs of the Hanford Works for the Period April-June 1952. HW-26493, General Electric Company, Hanford Works, Richland, Washington.

Paas, H. J. 1952. Radioactive Contamination in the Environs of the Hanford Works for the Period July-September 1952. HW-27510, General Electric Company, Hanford Works, Richland, Washington.

Paas, H. J. 1953. Radioactive Contamination in the Environs of the Hanford Works for the Period October-December 1952. HW-27641, General Electric Company, Hanford Atomic Products Operation, Richland, Washington.

Paas, H. J. 1953. Radioactive Contamination in the Environs of the Hanford Wbrks for the Period January-March 1953. HW-28009, General Electric Company, Hanford Atomic Products Operation, Richland, Washington.

Paas, H. J. 1953. Radioactive Contamination in the Environs of the Hanford Works for the Period April-June 1953. HW-29514, General Electric Company, Hanford Atomic Products Operation, Richland, Washington.

Paas, H. J. 1953. Radioactive Contamination in the Environs of the Hanford Wbrks for the Period July-September 1953. HW-30174, General Electric Company, Hanford Atomic Products Operation, Richland, Washington.

Paas, H. J. 1954. Radioactive Contamination in the Environs of the Hanford Works for the Period October-December 1953. HW-30744, General Electric Company, Hanford Atomic Products Operation, Richland, Washington.

Paas, H. J. 1954. Radioactive Contamination in the Environs of the Hanford Works for the Period January-March 1954. HW-31818, General Electric Company, Hanford Atomic Products Operation, Richland, Washington. 
Paas, H. J., and G. E. Pilcher. 1954. Radioactive Contamination in the Environs of the Hanford Wbrks for the Period April-June 1954. HW-33896, General Electric Company, Hanford Atomic Products Operation, Richland, Washington.

Pilcher, G. E., J. K. Soldat, and Z. E. Carey. 1955. Radioactive Contamination in the Environs of the Hanford Works for the Period July-September 1954. HW-36504, General Electric Company, Hanford Atomic Products Operation, Richland, Washington.

Pilcher, G. E. 1955. Radioactive Contamination in the Environs of the Hanford Wbrks for the Period October-December 1954. HW-36505, General Electric Company, Hanford Atomic Products Operation, Richland, Washington.

Pilcher, G. E. 1955. Radioactive Contamination in the Environs of the Hanford Works for the Period January-March 1955. HW-36506, General Electric Company, Hanford Atomic Products Operation, Richland, Washington.

Anderson, B. V. 1955. Radioactive Contamination in the Environs of the Hanford Wbrks for the Period April-June 1955. HW-38566, General Electric Company, Hanford Atomic Products Operation, Richland, Washington.

Anderson, B. V., and J. K. Soldat. 1955. Radioactive Contamination in the Environs of the Hanford Works for the Period July-September 1955. HW-39429, General Electric Company, Hanford Atomic Products Operation, Richland, Washington.

Anderson, B. V., and J. K. Soldat. 1956. Radioactive Contamination in the Environs of the Hanford Whrks for the Period October-December 1955. HW-40871, General Electric Company, Hanford Atomic Products Operation, Richland, Washington.

Anderson, B. V., and J. K. Soldat. 1956. Radioactive Contamination in the Environs of the Hanford Wrks for the Period January-March 1956. HW-43012, General Electric Company, Hanford Atomic Products Operation, Richland, Washington.

Anderson, B. V., and J. K. Soldat. 1956. Radioactive Contamination in the Environs of the Hanford Works for the Period April-June 1956. HW-44215, General Electric Company, Hanford Atomic Products Operation, Richland, Washington.

Anderson, B. V., J. K. Soldat, and M. W. McConiga. 1956. Radioactive Contamination in the Environs of the Hanford Works for the Period July-September 1956. HW-46726, General Electric Company, Hanford Atomic Products Operation, Richland, Washington.

Anderson, B. V., J. K. Soldat, and M. W. McConiga. 1957. Radioactive Contamination in the Environs of the Hanford Works for the Period October-December 1956. HW-48374, General Electric Company, Hanford Atomic Products Operation, Richland, Washington. 
McConiga, M. W., and J. K. Soldat. 1957. Radioactive Contamination in the Environs of the Hanford Works for the Period January-March 1957. HW-51009, General Electric Company, Hanford Atomic Products Operation, Richland, Washington.

McConiga, M. W., and J. K. Soldat. 1957. Radioactive Contamination in the Environs of the Hanford Works for the Period April-June 1957. HW-52803, General Electric Company, Hanford Atomic Products Operation, Richland, Washington.

McConiga, M. W., and J. K. Soldat. 1957. Radioactive Contamination in the Environs of the Hanford Works for the Period July-September 1957. HW-54841, General Electric Company, Hanford Atomic Products Operation, Richland, Washington.

McConiga, M. W., J. M. Selby, and J. K. Soldat. 1958. Radioactive Contamination in the Environs of the Hanford Works for the Period October-December 1957. HW-54842, General Electric Company, Hanford Atomic Products Operation, Richland, Washington.

\section{Vegetation Contamination Reports}

Healy, J. W. 1946. Vegetation Contamination Quarterly, lst Quarter 1946. HW 3-3495, General Electric Company, Hanford Works, Richland, Washington.

Turner, L. D. 1946. Vegetation Contamination Quarterly, 2nd Quarter 1946. HW 3-3603, General Electric Company, Hanford Atomic Products Operation, Richland, Washington.

Turner, L. D. 1946. Vegetation Contamination Quarterly, 3rd Quarter 1946. HW 3-3055, General Electric Company, Hanford Works, Richland, Washington.

Turner, L. D. 1947. Vegetation Contamination Quarterly, 3rd Quarter 1946. HW 3-5521, General Electric Company, Hanford Atomic Products Operation, Richland, Washington.

\subsection{Effluent and Waste Technology Quarterly and Semi-Annual Reports (1956 through 1966)}

Earth Sciences Personnel. 1956. Earth Sciences' Waste Disposal Monitoring Activities Summary, January 1956. HW-43149, General Electric Company, Hanford Atomic Products Operation, Richland, Washington.

Earth Sciences Personnel. 1956. Earth Sciences' Waste Disposal Monitoring Activities Summary, April 1956. HW-44354, General Electric Company, Hanford Atomic Products Operation, Richland, Washington.

Brown, D. J., ed. 1957. Chemical Effluents Technology Waste Disposal Investigations - JulySeptember 1956. HW-49465, General Electric Company, Hanford Atomic Products Operation, Richland, Washington. . 
Brown, D. J., ed. 1957. Chemical Effluents Technology Waste Disposal Investigations - OctoberDecember 1956. HW-50186, General Electric Company, Hanford Atomic Products Operation, Richland, Washington.

Brown, D. J., ed. 1957. Chemical Effluents Technology Waste Disposal Investigations - JanuaryMarch 1957. HW-51095, General Electric Company, Hanford Atomic Products Operation, Richland, Washington.

Brown, D. J., ed. 1957. Chemical Effluents Technology Waste Disposal Investigations - April-June 1957. HW-53225, General Electric Company, Hanford Atomic Products Operation, Richland, Washington.

Brown, D. J., ed. 1957. Chemical Effluents Technology Waste Disposal Investigations - JulySeptember 1957. HW-54655, General Electric Company, Hanford Atomic Products Operation, Richland, Washington.

Bierschenk, W. H., ed. 1958. Chemical Effluents Technology Waste Disposal Investigations October-December 1957. HW-54848, General Electric Company, Hanford Atomic Products Operation, Richland, Washington.

Bierschenk, W. H., ed. 1958. Chemical Effluents Technology Waste Disposal Investigations January-March 1958. HW-55841-RD, General Electric Company, Hanford Atomic Products Operation, Richland, Washington.

Bierschenk, W. H., ed. 1958. Chemical Effluents Technology Waste Disposal Investigations - AprilJune 1958. HW-57002-RD, General Electric Company, Hanford Atomic Products Operation, Richland, Washington.

Bierschenk, W. H., ed. 1958. Chemical Effluents Technology Waste Disposal Investigations - JulySeptember 1958. HW-58023-RD, General Electric Company, Hanford Atomic Products Operation, Richland, Washington.

Bierschenk, W. H., ed. 1959. Chemical Effluents Technology Whaste Disposal Investigations October-December 1958. HW-58811-RD, General Electric Company, Hanford Atomic Products Operation, Richland, Washington.

Bierschenk, W. H., ed. 1959. Chemical Effluents Technology Whaste Disposal Investigations January-March 1959. HW-60163-RD, General Electric Company, Hanford Atomic Products Operation, Richland, Washington.

Bierschenk, W. H., ed. 1959. Chemical Effluents Technology Waste Disposal Investigations - AprilJune 1959. HW-61197-RD, General Electric Company, Hanford Atomic Products Operation, Richland, Washington. 
Bierschenk, W. H., ed. 1959. Chemical Effluents Technology Waste Disposal Investigations - JulySeptember 1959. HW-62692-RD, General Electric Company, Hanford Atomic Products Operation, Richland, Washington.

Haney, W. A., ed. 1960. Chemical Effluents Technology Whaste Disposal Investigations - OctoberDecember 1959. HW-64094-RD, General Electric Company, Hanford Atomic Products Operation, Richland, Washington.

Haney, W. A., ed. 1960. Chemical Effluents Technology Waste Disposal Investigations - JanuaryMarch 1960. HW-65464-RD, General Electric Company, Hanford Atomic Products Operation, Richland, Washington.

Haney, W. A., ed. 1960. Chemical Effluents Technology Waste Disposal Investigations - April-June 1960. HW-66859-RD, General Electric Company, Hanford Atomic Products Operation, Richland, Washington.

Haney, W. A., ed. 1960. Chemical Effluents Technology Waste Disposal Investigations - JulySeptember 1960. HW-67753-RD, General Electric Company, Hanford Atomic Products Operation, Richland, Washington.

Haney, W. A., ed. 1961. Chemical Effuents Technology Waste Disposal Investigations - OctoberDecember 1960. HW-68953-RD, General Electric Company, Hanford Atomic Products Operation, Richland, Washington.

Haney, W. A., ed. 1961. Chemical Effluents Technology Waste Disposal Investigations - JanuaryJune 1961. HW-70806-RD, General Electric Company, Hanford Atomic Products Operation, Richland, Washington.

Brown, D. J., ed. 1962. Chemical Effluents Technology Waste Disposal Investigations - JulyDecember 1961. HW-72645-RD, General Electric Company, Hanford Atomic Products Operation, Richland, Washington.

Brown, D. J. 1962. Chemical Effuents Technology Waste Disposal Investigations - January-June 1962. HW-74915-RD, General Electric Company, Hanford Atomic Products Operation, Richland, Washington.

Brown, D. J. 1963. Chemical Effluents Technology Waste Disposal Investigations - July-December 1962. HW-76120-RD, General Electric Company, Hanford Atomic Products Operation, Richland, Washington.

Haney, W. A. 1963. Chemical Effuents Technology Waste Disposal Investigations - January-June 1963. HW-78951-RD, General Electric Company, Hanford Atomic Products Operation, Richland, Washington. 
Brown, D. J., and W. A. Haney. 1964. Chemical Effluents Technology Waste Disposal Investigations - July-December 1963. HW-80909, General Electric Company, Hanford Atomic Products Operation, Richland, Washington.

Brown, D. J. 1964. Chemical Effluents Technology Waste Disposal Investigations - JanuaryDecember 1964. HW-84549, General Electric Company, Hanford Atomic Products Operation, Richland, Washington.

Brown, D. J. 1965. Chemical Effluents Technology Waste Disposal Investigations - January-June 1965. BNWL-CC-285, Battelle Northwest Laboratory, Richland, Washington.

Eliason, J. R. 1966. Earth Sciences Waste Disposal Investigations - July-December 1965. BNWLCC-574, Battelle Northwest Laboratory, Richland, Washington.

Eliason, J. R. 1966. Earth Sciences Waste Disposal Investigations - January-June 1965. BNWL-CC887, Battelle Northwest Laboratory, Richland, Washington.

\subsection{Environmental Monitoring Annual Reports (1958 through 1993)}

Anderson, B. V. 1959. Hanford Envirommental Monitoring Annual Report 1958. HW-61676, General Electric Company, Hanford Atomic Products Operation, Richland, Washington.

Junkins, R. L., E. C. Watson, I. C. Nelson, and R. C. Henle. 1960. Evaluation of Radiological Conditions in the Vicinity of Hanford for 1959. HW-64371, General Electric Company, Hanford Atomic Products Operation, Richland, Washington.

Foster, R. F, and I. C. Nelson. 1961. Evaluation of Radiological Conditions in the Vicinity of Hanford for 1960. HW-68435, General Electric Company, Hanford Atomic Products Operation, Richland, Washington.

Foster, R. F., and I. C. Nelson. 1962. Evaluation of Radiological Conditions in the Vicinity of Hanford for 1961. HW-71999, General Electric Company, Hanford Atomic Products Operation, Richland, Washington.

Foster, R. F., and R. H. Wilson. 1963. Evaluation of Radiological Conditions in the Vicinity of Hanford for 1962. HW-76526, General Electric Company, Hanford Atomic Products Operation, Richland, Washington.

Foster, R. F., and R. H. Wilson. 1964. Evaluation of Radiological Conditions in the Vicinity of Hanford for 1963. HW-80991, General Electric Company, Hanford Atomic Products Operation, Richland, Washington.

Foster, R. F., and R. H. Wilson. 1965. Evaluation of Radiological Conditions in the Vicinity of Hanford for 1964. BNWL-90, Battelle Northwest Laboratory, Richland, Washington. 
Foster, R. F., J. K. Soldat, and T. H. Essig. 1966. Evaluation of Radiological Conditions in the Vicinity of Hanford for 1965. BNWL-316, Battelle Northwest Laboratory, Richland, Washington.

Foster, R. F., D. Moore, and T. H. Essig. 1966. Evaluation of Radiological Conditions in the Vicinity of Hanford for 1965 Appendices. BNWL-316 APP, Battelle Northwest Laboratory, Richland, Washington.

Honstead, J. F., T. H. Essig, and J. K. Soldat. 1967. Evaluation of Radiological Conditions in the Vicinity of Hanford for 1966. BNWL-439, Battelle Northwest Laboratory, Richland, Washington.

Honstead, J. F., and T. H. Essig. 1967. Evaluation of Radiological Conditions in the Vicinity of Hanford for 1966 Appendices. BNWL-439 APP, Battelle Northwest Laboratory, Richland, Washington.

Corley, J. P., and C. B. Wooldridge. 1969. Evaluation of Radiological Conditions in the Vicinity of Hanford for 1967. BNWL-983, Battelle Northwest Laboratory, Richland, Washington.

Corley, J. P., and C. B. Wooldridge. 1969. Evaluation of Radiological Conditions in the Vicinity of Hanford for 1967 Appendices. BNWL-983 APP, Battelle Northwest Laboratory, Richland, Washington.

W. L. Fisher, and C. B. Wilson. 1970. Evaluation of Radiological Conditions in the Vicinity of Hanford for 1968. BNWL-1341, Battelle Northwest Laboratory, Richland, Washington.

W. L. Fisher, and C. B. Wilson. 1970. Evaluation of Radiological Conditions in the Vicinity of Hanford for 1968 Appendices. BNWL-1341 APP, Battelle Northwest Laboratory, Richland, Washington.

Corley, J. P., C. B. Wilson, and T. H. Essig. 1970. Evaluation of Radiological Conditions in the Vicinity of Hanford for 1969. BNWL-1505, Battelle Northwest Laboratory, Richland, Washington.

Corley, J. P., and C. B. Wilson. 1970. Evaluation of Radiological Conditions in the Vicinity of Hanford for 1969 Appendices. BNWL-1505 APP, Battelle Northwest Laboratory, Richland, Washington.

Corley, J. P. 1973. Environmental Surveillance at Hanford for CY 1970. BNWL-1669, Battelle Northwest Laboratory, Richland, Washington.

Corley, J. P. 1973. Environmental Surveillance at Hanford for CY 1970 Data. BNWL-1669 ADD, Battelle Northwest Laboratory, Richland, Washington.

Bramson, P. E., and J. P. Corley. 1972. Environmental Surveillance at Hanford for CY 1971. BNWL-1683, Battelle Northwest Laboratory, Richland, Washington.

Bramson, P. E., and J. P. Corley. 1972. Environmental Surveillance at Hanford for CY 1971 (Addendum). BNWL-1683 ADD, Battelle Northwest Laboratory, Richland, Washington. 
Bramson, P. E., and J. P. Corley. 1973. Envimnmental Surveillance at Hanford for CY 1972. BNWL-1727, Battelle Northwest Laboratory, Richland, Washington.

Bramson, P. E., and J. P. Corley. 1973. Environmental Surveillance at Hanford for CY 1972 Data. BNWL-1727 ADD, Battelle Northwest Laboratory, Richland, Washington.

Nees, W. L., and J. P. Corley. 1974. Environmental Surveillance at Hanford for CY 1973. BNWL-1811, Battelle Northwest Laboratory, Richland, Washington.

Nees, W. L., and J. P. Corley. 1974. Environmental Surveillance at Hanford for CY 1973 Data.

BNWL-1811 ADD, Battelle Northwest Laboratory, Richland, Washington.

Fix, J. J. 1975. Environmental Surveillance at Hanford for CY 1974. BNWL-1910, Battelle Northwest Laboratory, Richland, Washington.

Fix, J. J., and P. J. Blumer. 1975. Environmental Surveillance at Hanford for CY 1974 Data. BNWL-1910 ADD, Battelle Northwest Laboratory, Richland, Washington.

Speer, D. R., J. J. Fix, and P. J. Blumer. 1976. Environmental Surveillance at Hanford for CY 1975. BNWL-1979 Rev., Battelle Northwest Laboratory, Richland, Washington.

Fix, J. J., P. J. Blumer, and D. R. Speer. 1976. Environmental Surveillance at Hanford for CY 1975 Data. BNWL-1980, Battelle Northwest Laboratory, Richland, Washington.

Fix, J. J., P. J. Blumer, G. R. Hoenes, and P. E. Bramson. 1977. Environmental Surveillance at Hanford for CY 1976. BNWL-2142, Battelle Northwest Laboratory, Richland, Washington.

Blumer, P. J., and J. J. Fix. 1977. Environmental Surveillance at Hanford for CY 1976 Data. BNWL-2142 ADD, Battelle Northwest Laboratory, Richland, Washington.

Houston, J. R., and P. J. Blumer. 1978. Environmental Surveillance at Hanford for CY 1977. PNL2614, Pacific Northwest Laboratory, Richland, Washington.

Houston, J. R., and P. J. Blumer. 1979. Environmental Surveillance at Hanford for CY 1978. PNL2932, Pacific Northwest Laboratory, Richland, Washington.

Houston, J. R., and P. J. Blumer. 1980. Environmental Surveillance at Hanford for CY 1979. PNL3283, Pacific Northwest Laboratory, Richland, Washington.

Sula, M. J., and P. J. Blumer. 1981. Environmental Surveillance at Hanford for CY 1980. PNL3728, Pacific Northwest Laboratory, Richland, Washington.

Sula, M. J., W. D. McCormack, R. L. Dirkes, K. R. Price, and P. A. Eddy. 1982. Environmental Surveillance at Hanford for. CY 1981. PNL-4211, Pacific Northwest Laboratory, Richland, Washington. 
Sula, M. J., J.M.V. Carlile, K. R. Price, and W. D. McCormack. 1983. Environmental Surveillance at Hanford for CY 1982. PNL-4657, Pacific Northwest Laboratory, Richland, Washington.

Price, K. R., J.M.V. Carlile, R. L. Dirkes, and M. S. Trevathan. 1984. Environmental Surveillance at Hanford for CY 1983. PNL-5038, Pacific Northwest Laboratory, Richland, Washington.

Price, K. R., J.M.V. Carlile, R. L. Dirkes, R. E. Jaquish, M. S. Trevathan, and R. K. Woodruff. 1985. Environmental Surveillance at Hanford for CY 1984. PNL-5407, Pacific Northwest Laboratory, Richland, Washington.

Price, K. R. 1986. Environmental Monitoring at Hanford for 1985. PNL-5817, Pacific Northwest Laboratory, Richland, Washington.

Pacific Northwest Laboratory (PNL). 1987. Environmental Monitoring at Hanford for 1986. PNL6120, Pacific Northwest Laboratory, Richland, Washington.

Jaquish, R. E., and P. J. Mitchell (eds.). 1988. Environmental Monitoring at Hanford for 1987. PNL-6464, Pacific Northwest Laboratory, Richland, Washington. NTIS, Springfield, VA.

Jaquish, R. E., and R. W. Bryce (eds.). 1989. Hanford Site Environmental Report for Calendar Year 1988. PNL-6825, Pacific Northwest Laboratory, Richland, Washington. NTIS, Springfield, VA.

Jaquish, R. E., and R. W. Bryce (eds.). 1990. Hanford Site Environmental Report for Calendar Year 1989. PNL-7346, Pacific Northwest Laboratory, Richland, Washington. NTIS, Springfield, VA.

Woodruff, R. K., R. W. Hanf, M. G. Hefty, and R. E. Lundgren, (eds.). 1991. Hanford Site Environmental Report for Calendar Year 1990. PNL-7930, Pacific Northwest Laboratory, Richland, Washington. NTIS, Springfield, VA.

Woodruff, R. K., R. W. Hanf, and R. E. Lundgren, (eds.). 1992. Hanford Site Environmental Report for Calendar Year 1991. PNL-8148, Pacific Northwest Laboratory, Richland, Washington. NTIS, Springfield, VA.

Woodruff, R. K., R. W. Hanf, and R. E. Lundgren, (eds.). 1993. Hanford Site Environmental Report for Calendar Year 1992. PNL-8682, Pacific Northwest Laboratory, Richland, Washington. NTIS, Springfield, VA.

Dirkes, R. L., R. W. Hanf, R. K. Woodruff, and R. E. Lundgren, (eds.). 1994. Hanford Site Environmental Report for Calendar Year 1993. PNL-9823, Pacific Northwest Laboratory, Richland, Washington. NTIS, Springfield, VA.

\section{Rockwell/WHC Environmental Surveillance Reports}

Wheeler, R. E. and A. G. Law. 1980. Rockwell Hanford Operations Environmental Surveillance Report for Calendar Year 1979. RHO-LD-132, Rockwell Hanford Operations, Richland, Washington. 
Conklin, A. W., R. E. Elder, W. L. Osborne, and J. M. Pisarcik. 1982. Rockwell Hanford Operations Environmental Surveillance Annual Report - Calendar Year 1981. RHO-HS-SR-82 4P, Rockwell Hanford Operations, Richland, Washington.

Conklin, A. W., R. E. Elder, and W. L. Osborne. 1982. Rockwell Hanford Operations Environmental Surveillance Annual Report - Calendar Year 1982. RHO-HS-SR-82-13 P, Rockwell Hanford Operations, Richland, Washington.

Conklin, A. W., R. E. Elder, V. G. Johnson, W. L. Osborne, and A. G. Law. 1984. Rockwell Hanford Operations Environmental Surveillance Annual Report - Calendar Year 1983. RHO-HS-SR83-13-REV 1P, Rockwell Hanford Operations, Richland, Washington.

Elder, R. E., A. W. Conklin, G. W. Egert, D. D. Brekke, and W. L. Osborne. 1986. Rockwell Hanford Operations Environmental Surveillance Annual Report - Calendar Year 1985. RHO-HS-SR85-13 P, Rockwell Hanford Operations, Richland, Washington.

Elder, R. E., G. W. Egert, A. R. Johnson, and W. L. Osborne. 1986. Rockwell Hanford Operations Environmental Surveillance Annual Report - Calendar Year 1986. RHO-HS-SR-86-13 P, Rockwell Hanford Operations, Richland, Washington.

Perkins, C. J. 1988. Hestinghouse Hanford Company Environmental Surveillance Annual Report 100 Areas, Calendar Year 1987. WHC-EP-0161, Westinghouse Hanford Company, Richland, Washington.

\section{UNC Environmental Surveillance Reports;}

Greager, E. M. 1980. Radiological Surveillance Report for the 100-N Area Environment - 1980. UNI-1581, UNC Nuclear Industries, Richland, Washington.

Greager, E. M. 1981. UNC Environmental Surveillance Report for the 100 Areas - FY 1981. UNI1849, UNC Nuclear Industries, Richland, Washington.

Greager, E. M. 1982. UNC Environmental Surveillance Report for the 100 Areas - FY 1982. UNI2226, UNC Nuclear Industries, Richland, Washington.

Greager, E. M. 1983. UNC Environmental Surveillance Report for the 100 Areas - FY 1983. UNI2640, UNC Nuclear Industries, Richland, Washington.

Greager, E. M. 1984. UNC Environmental Surveillance Report for the 100 Areas - FY 1984. UNI3069, UNC Nuclear Industries, Richland, Washington.

Jacques, I. D. 1986. UNC Environmental Surveillance Report for the 100 Areas - FY 1985 . UNI3760, UNC Nuclear Industries, Richland, Washington.

Jacques, I. D. 1987. UNC Environmental Surueillance Report for the 100 Areas - FY 1986. UNI- 


\subsection{Environmental Status Annual Reports (1965 through 1983)}

Essig, T. H., and R. B. Ball. 1966. Environmental Status of the Hanford Project - 1965 Annual Summary. BNWL-CC-913, Battelle Northwest Laboratory, Richlanḍ, Washington.

Essig, T. H., and R. B. Ball. 1967. Environmental Status of the Hanford Reservation from December 1966. BNWL-CC-637-12, Battelle Northwest Laboratory, Richland, Washington.

Wooldridge, C. B., ed. 1968. Environmental Status of the Hanford Resenvation for NovemberDecember 1967: BNWL-CC-1197-6, Battelle Northwest Laboratory, Richland, Washington.

Wooldridge, C. B., ed. 1968. Environmental Status of the Hanford Reservation for January-June 1968. BNWL-CC-1850, Battelle Northwest Laboratory, Richland, Washington.

Wooldridge, C. B., ed. 1969. Environmental Status of the Hanford Reservation for July-December 1968. BNWL-CC-2026, Battelle Northwest Laboratory, Richland, Washington.

Wilson, C. B., and T. H. Essig, eds. 1970. Envimnmental Status of the Hanford Reservation for January-June 1969. BNWL-CC-2478, Battelle Northwest Laboratory, Richland, Washington.

Wilson, C. B., and T. H. Essig, eds. 1971. Environmental Status of the Hanford Reservation for JulyDecember 1969. BNWL-CC-2583, Battelle Northwest Laboratory, Richland, Washington.

Bramson, P. E., ed. 1972. Envimnmental Status of the Hanford Reservation for 1970. BNWL-C-96, Battelle Northwest Laboratory, Richland, Washington.

Bramson, P. E., and J. P. Corley. 1972. Environmental Status of the Hanford Reservation for 1971. BNWL-B-228, Battelle Northwest Laboratory, Richland, Washington.

Bramson, P. E., J. P. Corley, and W. L. Nees. 1973. Environmental Status of the Hanford Reservation for CY 1972. BNWL-B-278, Battelle Northwest Laboratory, Richland, Washington.

Nees, W. L., and J. P. Corley. 1975. Environmental Status of the Hanford Reservation for CY 1973. BNWL-B-336, Battelle Northwest Laboratory, Richland, Washington.

Fix, J. J. 1975. Environmental Status of the Hanford Reservation for CY 1974. BNWL-B-429, Battelle Northwest Laboratory, Richland, Washington.

Fix, J. J., D. R. Speer, and P. J. Blumer. 1976. Environmental Status of the Hanford Site for CY 1975. BNWL-B-477, Battelle Northwest Laboratory, Richland, Washington.

Fix, J. J., P. J. Blumer, and P. E. Bramson. 1977. Environmental Status of the Hanford Site for CY 1976. BNWL-2246, Battelle Northwest Laboratory, Richland, Washington. 
Houston, J. R., and P. J. Blumer. 1978. Environmental Status of the Hanford Site for CY 1977. PNL-2677, Pacific Northwest Laboratory, Richland, Washington.

Houston, J. R., and P. J. Blumer. 1979. Environmental Status of the Hanford Site for CY 1978. PNL-2933, Pacific Northwest Laboratory, Richland, Washington.

Houston, J. R., and P. J. Blumer. 1980. Eivironmental Status of the Hanford Site for CY 1979. PNL-3284, Pacific Northwest Laboratory, Richland, Washington.

Sula, M. J., P. J. Blumer, and R. L. Dirkes. 1981. Environmental Status of the Hanford Site for CY 1980. PNL-3729, Pacific Northwest Laboratory, Richland, Washington.

Sula, M. J., P. J. Blumer, and R. L. Dirkes. 1982. Environmental Status of the Hanford Site for CY 1981. PNL-4212, Pacific Northwest Laboratory, Richland, Washington.

Sula, M. J., P. J. Blumer, R. L. Dirkes, and J.M.V. Carlile. 1983. Environmental Status of the Hanford Site for CY 1982. PNL-4658, Pacific Northwest Laboratory, Richland, Washington.

Price, K. R., P. J. Blumer, J.M.V. Carlile, R. L. Dirkes, and M. S. Trevathan. 1984. Environmental Status of the Hanford Site for CY 1983. PNL-5039, Pacific Northwest Laboratory, Richland, Washington.

\subsection{Ground-Water Monitoring Quarterly and Annual Reports}

Essig, T. H. 1968. Radiological Status of the Groundwater Beneath the Hanford Project, JulyDecember 1967. BNWL-835, Battelle Northwest Laboratory, Richland, Washington.

Essig, T. H. 1969. Radiological Status of the Groundwater Beneath the Hanford Project, JanuaryJune 1968. BNWL-984, Battelle Northwest Laboratory, Richland, Washington.

Denham, D. H. 1969. Radiological Status of the Groundwater Beneath the Hanford Project, JulyDecember 1968. . BNWL-1047, Battelle Northwest Laboratory, Richland, Washington.

Denham, D. H. 1969. Radiological Status of the Groundwater Beneath the Hanford Project, JanuaryJune 1969. BNWL-1233, Battelle Northwest Laboratory, Richland, Washington.

Denham, D. H. 1970. Radiological Status of the Groundwater Beneath the Hanford Project, JulyDecember 1969. BNWL-1392, Battelle Northwest Laboratory, Richland, Washington.

Essig, T. H. 1970. Radiological Status of the Groundwater Beneath the Hanford Project, JanuaryJune 1970. BNWL-1539, Battelle Northwest Laboratory, Richland, Washington.

Essig, T. H. 1971. Radiological Status of the Groundwater Beneath the Hanford Project, JulyDecember 1970. BNWL-1613, Battelle Northwest Labor atory, Richland, Washington. 
Kipp, K. L., Jr. 1972. Radiological Status of the Groundwater Beneath the Hanford Project, JanuaryJune 1971. BNWL-1649, Battelle Northwest Laboratory, Richland, Washington.

Kipp, K. L., Jr. 1973. Radiological Status of the Groundwater Beneath the Hanford Project, JulyDecember 1971. BNWL-1680, Battelle Northwest Laboratory, Richland, Washington.

Kipp, K. L., Jr. 1973. Radiological Status of the Groundwater Beneath the Hanford Project, JanuaryJune 1972. BNWL-1737, Battelle Northwest Laboratory, Richland, Washington.

Kipp, K. L., Jr. 1973. Radiological Status of the Groundwater Beneath the Hanford Project, JulyDecember 1972. BNWL-1752, Battelle Northwest Laboratory, Richland, Washington.

Kipp, K. L., Jr. 1975. Radiological Status of the Groundwater Beneath the Hanford Project, JanuaryDecember 1973. BNWL-1860, Battelle Northwest Laboratory, Richland, Washington.

Raymond, J. R., D. A. Myers, J. J. Fix, V. L. McGhan, and P. M. Schrotke. 1976. Environmental Monitoring Report on Radiological Status of the Groundwater Beneath the Hanford Site, JanuaryDecember 1974. BNWL-1970, Battelle Northwest Laboratory, Richland, Washington.

Myers, D. A., J. J. Fix, P. J. Blumer, J. R. Raymond, V. L. McGhan, and E. L. Hilty. 1976. Environmental Monitoring Report on Radiological Status of the Groundwater Beneath the Hanford Site, January-December 1975. BNWL-2034, Battelle Northwest Laboratory, Richland, Washington.

Myers, D. A., J. J. Fix, and J. R. Raymond. 1977. Environmental Monitoring Report on Radiological Status of the Groundwater Beneath the Hanford Site, January-December 1976. BNWL-2199, Battelle Northwest Laboratory, Richland, Washington.

Myers, D. A. 1978. Environmental Monitoring Report on Radiological Status of the Groundwater Beneath the Hanford Site, January-December.1977. PNL-2624, Pacific Northwest Laboratory, Richland, Washington.

Eddy, P. A. 1979. Environmental Monitoring Report on Radiological Status of the Groundwater Beneath the Hanford Site, January-December 1978. PNL-2899, Pacific Northwest Laboratory, Richland, Washington.

Eddy, P. A., and J. S. Wilbur. 1980. Environmental Monitoring Report on Radiological Status of the Groundwater Beneath the Hanford Site, January-December 1979. PNL-3346, Pacific Northwest Laboratory, Richland, Washington.

Eddy, P. A., and J. S. Wilbur. 1981. Environmental Monitoring Report on Radiological Status of the Groundwater Beneath the Hanford Site, January-December 1980. PNL-3768, Pacific Northwest Laboratory, Richland, Washington.

Eddy, P. A., C. S. Cline, and L. S. Prater. 1982. Environmental Monitoring Report on Radiological Status of the Groundwater Beneath the Hanford Site, January-December 1981.

PNL-4237, Pacific Northwest Laboratory, Richland, Washington. 
Eddy, P. A., L. S. Prater, and J. T. Rieger. 1983. Ground-Water Surveillance at the Hanford Site for CY 1982. PNL-4659, Pacific Northwest Laboratory, Richland, Washington.

Prater, L. S., J. T. Rieger, C. S. Cline, E. J. Jensen, T. L. Liikala, K. R. Oster, and P. A. Eddy. 1984. Ground-Water Surveillance at the Hanford Site for CY 1983. PNL-5041, Pacific Northwest Laboratory, Richland, Washington.

Cline, C. S., J. T. Rieger, J. R. Raymond, and P. A. Eddy. 1985. Ground-Water Monitoring at the Hanford Site, January-December 1984. PNL-5408, Pacific Northwest Laboratory, Richland, Washington.

Evans, J. C., P. J. Mitchell, and D. I. Dennison. 1988. Hanford Site Ground-Water Monitoring for April through June 1987. PNL-6315-1, Pacific Northwest Laboratory, Richland, Washington.

Evans, J. C., D. I. Dennison, R. W. Bryce, P. J. Mitchell, D. R. Sherwood, K. M. Krupka, N. W. Hinman, E. A. Jacobson, and M. D. Freshley. 1988. Hanford Site Ground-Water Monitoring for July Through December 1987. PNL-6315-2, Pacific Northwest Laboratory, Richland, Washington.

Evans, J. C., R. W. Bryce, and D. R. Sherwood. 1989. Hanford Site Ground-Water Monitoring for January through June 1988. PNL-6886, Pacific Northwest Laboratory, Richland, Washington. NTIS, Springfield, Virginia.

Evans, J. C., R. W. Bryce, D. R. Sherwood, M. L. Kemner, and D. R. Newcomer. 1989. Hanford Site Ground-Whter Monitoring for July through December 1988. PNL-7120, Pacific Northwest Laboratory, Richland, Washington. NTIS, Springfield, Virginia.

Evans, J. C., R. W. Bryce, and M. L. Kemner. 1990. Hanford Site Ground-Whater Surveillance for 1989. PNL-7396, Pacific Northwest Laboratory, Richland, Washington. NTIS, Springfield, Virginia.

Evans, J. C., R. W. Bryce, and D. J. Bates. 1992. Hanford Site Ground-Water Monitoring for 1990. PNL-8073, Pacific Northwest Laboratory, Richland, Washington. NTIS, Springfield, Virginia.

Dresel, P. E., D. J. Bates, and J. K. Merz. 1993. Hanford Site Environmental Data for Calendar Year 1990 - Ground Water. PNL-8582, Pacific Northwest Laboratory, Richland, Washington. NTIS, Springfield, Virginia.

Evans, J. C., R. W. Bryce, and D. J. Bates. 1992. Hanford Site Ground-Water Monitoring for 1991. PNL-8284, Pacific Northwest Laboratory, Richland, Washington. NTIS, Springfield, Virginia.

Dresel, P. E., D. J. Bates, and J. K. Merz. 1993. Hanford Site Environmental Data for Calendar Year 1991 - Ground Water. PNL-8581, Pacific Northwest Laboratory, Richland, Washington. NTIS, Springfield, Virginia.

Dresel, P. E., D. R. Newcomer, J. C. Evans, W. D. Webber, F. A. Spane, Jr., R. G. Raymond, and B. E. Opitz. 1993. Hanford Site Ground-Water Monitoring for 1992. PNL-8716, Pacific Northwest Laboratory, Richland, Washington. NTIS, Springfield, Virginia. 
Merz, J. K., and P. E. Dresel. 1993. Hanford Site Environmental Data for Calendar Year 1992 Ground Water. PNL-8884, Pacific Northwest Laboratory, Richland, Washington. NTIS, Springfield, Virginia.

Dresel, P. E., S. P. Luttrell, J. C. Evans, W. D. Webber, P. D. Thorne, M. A. Chamness, B. M. Gillespie, B. E. Opitz, J. T. Rieger, and J. K. Merz. 1994. Hanford Site Ground-Water Monitoring for 1993. PNL-10082, Pacific Northwest Laboratory, Richland, Washington. NTIS, Springfield, Virginia.

\section{Separations Area Annual Reports}

Graham, M. J., and W. R. Brown. 1981. Results of the Separations Area Ground-Water Monitoring Network for 1980. RHO-LD-165, Informal Report, Rockwell Hanford Operations, Richland, Washington.

Wilbur, J. S., M. J. Graham, and A. H. Lu. 1983. Results of the Separations Area Ground-Water Monitoring Network for 1982. RHO-RE-SR-83-24P, Rockwell Hanford Operations, Richland, Washington.

Law, A. G., and R. M. Allen. 1984. Results of the Separations Area Ground-Water Monitoring Network for 1983. RHO-RE-SR-84-24P, Rockwell Hanford Operations, Richland, Washington.

Law, A. G., A. L. Schatz, M. R. Fuchs, and K. L. Dillon. 1986. Results of the Separations Area Ground-Water Monitoring Network for 1984. RHO-RE-SR-85-24P, Rockwell Hanford Operations, Richland, Washington.

Law, A. G., and A. L. Schatz. 1986. Results of the Separations Area Ground-Water Monitoring Network for 1985. RHO-RE-SR-86-24P, Rockwell Hanford Operations, Richland, Washington.

Law, A. G., J. A. Serkowski, and A. L. Schatz. 1987. Results of the Separations Area Ground-Water Monitoring Network for 1986. RHO-RE-SR-87-24P, Rockwell Hanford Operations, Richland, Washington.

Serkowski, J. A., A. G. Law, J. J. Ammerman, and A. L. Schatz. 1988. Results of Ground-Water Monitoring for Radionuclides in the Separations Area - 1987. WHC-EP-0152, Westinghouse Hanford Company, Richland, Washington.

Serkowski, J. A., and W. A. Jordan. 1989. Operational Groundwater Monitoring at the Hanford Site-1988, WHC-EP-0260, Westinghouse Hanford Company, Richland, Washington. 


\subsection{Ground-Water Compliance (RCRA) Monitoring Reports}

PNL, 1986, Ground-Water Monitoring Compliance Projects for Hanford Site Facilities: Progress Report for the Period May 1 to September 30, 1986, PNL-6466, Pacific Northwest Laboratory, Richland, Washington.

PNL, 1987, Ground-Water Monitoring Compliance Projects for Hanford Site Facilities: Progress Report for the Period October I to December 31, 1986, 3 vols., PNL-6465, Pacific Northwest Laboratory, Richland, Washington.

PNL, 1987, Ground-Water Monitoring Compliance Projects for Hanford Site Facilities: Progress Report for the Period January 1 to March 31, 1987, 3 vols., PNL-6467, Pacific Northwest Laboratory, Richland, Washington.

PNL, 1987, Ground-Whater Monitoring Compliance Projects for Hanford Site Facilities: Progress Report for the Period April 1 to June 30, 1987, PNL-6468, Pacific Northwest Laboratory, Richland, Washington.

PNL, 1987, Ground-Water Monitoring Compliance Projects for Hanford Site Facilities: Progress Report for the Period July 1 to September 30, 1987, PNL-6469, Pacific Northwest Laboratory, Richland, Washington.

PNL, 1988, Ground-Water Monitoring Compliance Projects for Hanford Site Facilities: Progress Report for the Period October 1 to December 31, 1987, PNL-6536, Pacific Northwest Laboratory, Richland, Washington.

PNL, 1988, Ground-Water Monitoring Compliance Projects for Hanford Site Facilities: Progress Report for the Period January 1 to March 31, 1988, PNL-6581, Pacific Northwest Laboratory, Richland, Washington.

PNL, 1988, Ground-Water Monitoring Compliance Projects for Hanford Site Facilities; Progress Report for the Period April 1 to June 30, 1988, PNL-6675, Pacific Northwest Laboratory, Richland, Washington.

Fruland, R. M., D. J. Bates, and R. E. Lundgren, 1989, Resource Conservation and Recovery Act Ground-Water Monitoring Projects for Hanford Facilities: Progress Report for the Period July 1 to September 30, 1988, PNL-6789, Pacific Northwest Laboratory, Richland, Washington.

Fruland, R. M., D. J. Bates, and R. E. Lundgren, 1989, Resource Conservation and Recovery ACt Ground-Water Monitoring Projects for Hanford Facilities: Progress Report for the Period October 1 to December 31, 1988, PNL-6844, Pacific Northwest Laboratory, Richland, Washington.

Fruland, R. M., and R. E. Lundgren, eds., 1989, RCRA Ground-Water Monitoring Projects for Hanford Facilities: Annual Progress Report for 1988, PNL-6852, Pacific Northwest Laboratory, Richland, Washington. 
Smith, R. M., D. J. Bates, and R. E. Lundgren, 1989, Resource Conservation and Recovery Act Ground-Water Monitoring Projects for Hanford Facilities: Progress Report for the Period January 1 to March 31, 1989, PNL-6957, Pacific Northwest Laboratory, Richland, Washington.

Smith, R. M., D. J. Bates, and R. E. Lundgren, 1989, Resource Conservation and Recovery Act Ground-Water Monitoring Projects for Hanford Facilities: Progress Report for the Period April 1 to June 30, 1989, PNL-7134, Pacific Northwest Laboratory, Richland, Washington.

Smith, R. M., D. J. Bates, and R. E. Lundgren, 1989, Resource Conservation and Recovery Act Ground-Water Monitoring Projects for Hanford Facilities: Progress Report for the Period July 1 to September 30, 1989, PNL-7222, Pacific Northwest Laboratory, Richland, Washington.

Smith, R. M., D. J. Bates, and R. E. Lundgren, 1990, Resource Conservation and Recovery Act Ground-Whater Monitoring Projects for Hanford Facilities: Progress Report for the Period October 1 to December 31, 1989, PNL-7306, Pacific Northwest Laboratory, Richland, Washington.

Smith, R. M., and W. R. Gorst, eds., 1990, RCRA Ground-Water Monitoring Projects for Hanford Facilities; Annual Progress Report for 1989, PNL-6852, Pacific Northwest Laboratory, Richland, Washington.

Lerch, R. E., 1990, Quarterly Report of Resource Conservation and Recovery Act Ground-Water Monitoring Data for Period January 1, 1990 Through March 31, 1990, (internal letter \#9053781 to R. D. Izatt, May 25), Westinghouse Hanford Company, Richland, Washington.

DOE-RL, 1990, Quarterly Report of RCRA Groundwater Monitoring Data for Period April 1, 1990 - through June 30, 1990, DOE/RL-90-36, U.S. Department of Energy, Richland Operations Office, Richland, Washington.

DOE-RL, 1990, Quarterly Report of RCRA Groundwater Monitoring Data for Period July 1, 1990 through September 30, 1990, DOE/RL-90-46, U.S. Department of Energy, Richland Operations Office, Richland, Washington.

DOE-RL, 1991, Quarterly Report of RCRA Groundwater Monitoring Data for Period October 1, 1990 through December 31, 1990, DOE/RL-91-04, U.S. Department of Energy, Richland Field Office, Richland, Washington.

DOE-RL, 1991, Annual Report for RCRA Groundwater Monitoring Projects at Hanford Site Facilities for 1990, DOE/RL-91-03, U.S. Department of Energy, Richland Field Office, Richland, Washington.

DOE-RL, 1991, Quarterly Report of RCRA Groundwater Monitoring Data for Period January 1, 1991 through March 31, 1991, DOE/RL-91-26, U.S. Department of Energy, Richland Field Office, Richland, Washíngton.

DOE-RL, 1991, Quarterly Report of RCRA Groundwater Monitoring Data for Period April 1, 1991 through June 30, 1991, DOE/RL-91-47, U.S. Department of Energy, Richland, Field Office, Richland, Washington. 
DOE-RL, 1991, Quarterly Report of RCRA Groundwater Monitoring Data for Period July 1, 1991 through September 30, 1991, DOE/RL-91-57, U.S. Department of Energy, Richland Field Office, Richland, Washington.

DOE-RL, 1992, Quarterly Report of RCRA Groundwater Monitoring Data for Period October 1, 1991 through December 31, 1991, DOE/RL-92-26, U.S. Department of Energy, Richland Field Office, Richland, Washington.

DOE-RL, 1992, Annual Report for RCRA Groundwater Monitoring Projects at Hanford Site Facilities for 1991, DOE/RL-92-03, U.S. Department of Energy, Richland Field Office, Richland, Washington.

DOE-RL, 1991, Quarterly Report of RCRA Groundwater Monitoring Data for Period January 1, 1992 through March 31, 1992, DOE/RL-92-26-1, U.S. Department of Energy, Richland Field Office, Richland, Washington.

DOE-RL, 1992, Quarterly Report of RCRA Groundwater Monitoring Data for Period April 1, 1992 through June 30, 1992, DOE/RL-92-26-2, U.S. Department of Energy, Richland Field Office, Richland, Washington.

DOE-RL, 1992, Quarterly Report of RCRA Groundwater Monitoring Data for Period July 1, 1992 through September 30, 1992, DOE/RL-92-26-3, U.S. Department of Energy, Richland Field Office, Richland, Washington.

DOE-RI, 1993, Quarterly Report of RCRA Groundwater Monitoring Data for Period October 1, 1992, through December 31, 1992, DOE/RL-92-26-4, U.S. Department of Energy, Richland Operations Office, Richland, Washington.

DOE-RL, 1993, Annual Report for RCRA Groundwater Monitoring Projects at Hanford Site Facilities for 1992, DOE/RL-93-09, U.S. Department of Energy, Richland Operations Office, Richland, Washington.

DOE-RL, 1993, Quarterly Report of RCRA. Groundwater Monitoring Data for Period January 1, 1993 through March 31, 1993, DOE/RL-93-56-1, U.S. Department of Energy, Richland Operations Office, Richland, Washington.

DOE-RL, 1993, Quarterly Report of RCRA Groundwater Monitoring Data for Period April 1, 1993 through June 30, 1993, DOE/RL-93-56-2, U.S. Department of Energy, Richland Operations Office, Richland, Washington.

DOE-RL, 1994, Quarterly Report of RCRA Groundwater Monitoring Data for Period July 1, 1993 through September 30, 1993, DOE/RL-93-56-3, U.S. Department of Energy, Richland Operations Office, Richland, Washington.

DOE-RL, 1994, Quarterly Report of RCRA Groundwater Monitoring Data for Period October 1, 1993 through December 31, 1993, DOE/RL-93-56-4, U.S. Department of Energy, Richland Operations Office, Richland, Washington. 
DOE-RL, 1994, Annual Report for RCRA Groundwater Monitoring Projects at Hanford Site Facilities for 1993, DOE/RL-93-88, Rev. 0, U.S. Department of Energy, Richland Operations Office, Richland, Washington.

DOE-RL, 1994, Quarterly Report of RCRA Groundwater Monitoring Data for Period January 1, 1994 through March 31, 1994, DOE/RL-94-36-1, U.S. Department of Energy, Richland Operations Office, Richland, Washington.

DOE-RL, 1994, Quarterly Report of RCRA Groundwater Monitoring Data for Period April 1, 1994 through June 30, 1994, DOE/RL-94-36-2, U.S. Department of Energy, Richland Operations Office, Richland, Washington.

DOE-RL, 1995, Quarterly Report of RCRA Groundwater Monitoring Data for Period July 1, 1994 through September 30, 1994, DOE/RL-94-36-3, U.S. Department of Energy, Richland Operations Office, Richland, Washington.

DOE-RL, 1995, Quarterly Report of RCRA Groundwater Monitoring Data for Period October 1, 1994 through December 31, 1994, DOE/RL-94-36-4, U.S. Department of Energy, Richland Operations Office, Richland, Washington.

DOE-RL, 1995, Annual Report for RCRA Groundwater Monitoring Projects at Hanford Site Facilities for 1.994; DOE/RL-94-136, Rev. 0, U.S. Department of Energy, Richland Operations Office, Richland, Washington.

\subsection{Operable Unit Reports}

Swanson, L. C. 1992. Phase 1 Hydrogeologic Summary of the 300-FF-5 Operable Unit, 300 Area. WHC-SD-EN-TI-052, Westinghouse Hanford Company, Richland, Washington.

U.S. Department of Energy (DOE). 1989. RCRA Facility Investigation/Corrective Measures Study Work Plan for the 100-HR-3 Operable Unit, Hanford Site, Richland, Washington. DOE/RL-88-36 DRAFT, U.S. Department of Energy, Richland, Washington.

U.S. Department of Energy (DOE). 1990. Remedial Investigation/Feasibility Study Work Plan for the 100-BC-5 Operable Unit, Hanford Site, Richland, Washington. DOE/RL-90-08 DRAFT, U.S. Department of Energy, Richland, Washington.

U.S. Department of Energy (DOE). 1990. Remedial Investigation/Feasibility Study Work Plan for the 300-FF-5 Operable Unit, Hanford Site, Richland, Washington. DOE/RL-89-14, U.S. Department of Energy, Richland, Washington.

U.S. Department of Energy (DOE). 1991. Remedial Investigation/Feasibility Study Work Plan for the. 100-FR-3 Operable Unit, Hanford Site, Richland, Washington. DOE/RL-91-53 DRAFT A, U.S. Department of Energy, Richland, Washington. 
U.S. Department of Energy (DOE). 1991. Remedial Investigation/Feasibility Study Wbrk Plan for the 100-KR-4 Operable Unit, Hanford Site, Richland, Washington. DOE/RL-90-21, U.S. Department of Energy, Richland, Washington.

U.S. Department of Energy (DOE). 1992. RCRA Facility Investigation/Corrective Measures Study Wbrk Plan for the 100-HR-3 Operable Unit, Hanford Site, Richland, Washington. DOE/RL-88-36 DRAFT D, U.S. Department of Energy, Richland, Washington.

U.S. Department of Energy (DOE). 1992. Remedial Investigation/Feasibility Study Work Plan for the 100-BC-5 Operable Unit, Hanford Site, Richland, Washington. DOE/RL-90-08 DRAFT C, U.S. Department of Energy, Richland, Washington.

U.S. Department of Energy (DOE). 1992. Remedial Investigation/Feasibility Study Work Plan for the 100-FR-3 Operable Unit, Hanford Site, Richland, Washington. DOE/RL-91-53 DRAFT B, U.S. Department of Energy, Richland, Washington.

U.S. Department of Energy (DOE). 1992. Remedial Investigation/Feasibility Study Wbrk Plan for the 100-FR-3 Operable Unit, Hanford Site, Richland, Washington. DOE/RL-91-53, U.S. Department of Energy, Richland, Washington.

U.S. Department of Energy (DOE). 1992. Remedial Investigation/Feasibility Study Wbrk Plan for the 100-KR-4 Operable Unit, Hanford Site, Richland, Washington. DOE/RL-90-21, U.S. Department of Energy, Richland, Washington.

U.S. Department of Energy (DOE). 1993. Draft Remedial Investigation/Feasibility Study for the 100EM-1 Operable Unit, Hanford. DOE/RL-92,67 DRAFT C, U.S. Department of Energy, Richland, Washington.

U.S. Department of Energy (DOE). 1993. Interim Remedial Measures Proposed Plan for the 200-ZP1 Operable Unit, Hanford Site, Washington. DOE/RL-93-68, U.S. Department of Energy, Richland, Washington.

U.S. Department of Energy (DOE). 1993. RCRA Facility Investigation/Corrective Measures Study Wbrk Plan for the 100-HR-2 Operable Unit, Hanford Site, Richland, Washington. DOE/RL-93-20 DRAFT A, U.S. Department of Energy, Richland, Washington.

U.S. Department of Energy (DOE). 1994. Phase I Remedial Investigation Report for the 300-FF-5 Operable Unit. DOE/RL-93-21, U.S. Department of Energy, Richland, Washington.

U.S. Department of Energy (DOE). 1994. Phase I and II Feasibility Study Report for the 300-FF-5 Operable Unit. DOE/RL-93-22, U.S. Department of Energy, Richland, Washington.

U.S. Department of Energy (DOE). 1994. Remedial Investigation/Feasibility Study Work Plan for the 200-UP-1 Groundwater Operable Unit, Hanford Site, Richland, Washington. DOE/RL-92-76, U.S. Department of Energy, Richland, Washington. 
Note: The following references are in alphabetical rather than chronological order.

\subsection{Aggregate Area Report}

Connelly, M. P., B. H. Ford, and J. V. Borghese. 1992b. Hydrogeologic Model for the 200 West Groundwater Aggregate Area. WHC-SD-EN-TI-014, Westinghouse Hanford Company, Richland, Washington.

Connelly, M. P., B. H. Ford, J. W. Lindberg, S. J. Trent, and C. D. Delaney. 1992a.

Hydrogeologic Model for the 200 East Groundwater Aggregate Area. WHC-SD-EN-TI-019, Westinghouse Hanford Company, Richland, Washington.

Ford, B. H. 1993. Groundwater Field Characterization Report for the 200 Aggregate Area Management Study. WHC-SD-EN-TI-020, Westinghouse Hanford Company, Richland, Washington.

Newcomer, D. R., S. S. Teel, A. W. Pearson, K. R. O. Barton, B. N. Bjornstad, and T. J. Gilmore, 1992, Unconfined Aquifer Hydrologic Test Data Package for the 200 West Groundwater Aggregate Area Management Study, WHC-SD-EN-DP-029, Rev. 0, Westinghouse Hanford Company, Richland, Washington.

Newcomer, D. R., R. J. Brockman, M. A. Chamness, S. M. Goodwin, D. L. McAlister, A. W. Pearson, and S. S. Teel, 1992b, Confined Aquifer Hydrologic Test Data Package for the 200 West Groundwater Aggregate Area Management Study, WHC-SD-EN-DP-031, Rev. 0, Westinghouse Hanford Company, Richland, Washington.

U.S. Department of Energy (DOE). 1993. 200 West Groundwater Aggregate Area Management Study Report. DOE/RL-92-16, U.S. Department of Energy, Richland, Washington.

\subsection{Water-Table Reports and Maps}

Bauer, H. H., J. J. Vaccaro, and R. C. Lane. 1985. Maps Showing Ground-Water Levels in the Columbia River Basalt and Overlying.Materials, Spring 1983, Southeastern Washington. Water Resources Investigation Report 84-4360, U.S. Geological Survey, Tacoma, Washington.

Bierschenk, W. H., 1957, Fluctuations of Hanford Water Levels, HW-53599, General Electric Company, Richland, Washington.

Campbell, M. D., and D. R. Newcomer. 1992. Automatic Measurement of Whater Levels Within the 300-FF-5 Boundary. PNL-7874, Pacific Northwest Laboratory, Richland, WA. NTIS, Springfield, VA.

Jensen, E. J. 1987. Summary of Water-Level Measurements Around the 1325-N Crib During the Fall of 1985 and the Winter of 1986-1987. PNL-6374, Pacific Northwest Laboratory, Richland, Washington. 
Kasza, G. L. 1990. Ground-Water Maps of Hanford Site Separations Areas, December 1989. WHC-EP-0142-4, Westinghouse Hanford Company, Richland, Washington.

Kasza, G. L., S. F. Harris, and M. J. Hartman. 1990. Ground-Water Maps of the Hanford Site. WHC-EP-0394-1, Westinghouse Hanford Company, Richland, Washington.

Kasza, G. L., M. J. Hartman, F. N. Hodges, and D. C. Weekes. 1992. Groundwater Maps of the Hanford Site, June 1992. WHC-EP-0394-5, Westinghouse Hanford Company, Richland, Washington.

Kipp, K. L., and R. D. Mudd. 1974. Selected Water Table Contour Maps and Well Hydrographs for the Hanford Reserwation, 1944-1973. BNWL-B-360, Pacific Northwest Laboratory, Richland, Washington.

Newcomer, D. R. 1990. Evaluation of Hanford Site Water-Table Changes - 1980 to 1990.

PNL-7498, Pacific Northwest Laboratory, Richland, Washington.

Newcomer, D. R., and J. P. McDonald. 1990. Water-Table Elevations on the Hanford Site, December 1989. PNL-7374, Pacific Northwest Laboratory, Richland, Washington. NTIS, Springfield, VA.

Newcomer, D. R., J. P. McDonald, and S. M. Goodwin. 1990. Water-Table Elevations on the Hanford Site, June 1989. PNL-7282, Pacific Northwest Laboratory, Richland, Washington. NTIS, Springfield, VA.

Newcomer, D. R., K. D. Pohlod, and J. P. McDonald. 1991. Water-Table Elevations on the Hanford Site, 1990. PNL-7693, Pacific Northwest Laboratory, Richland, Washington.

Newcomer, D. R., K. D. Pohlod, and J. P. McDonald. 1992. Water-Table Elevations on the Hanford Site and Outlying Areas, 1991. PNL-8122, Pacific Northwest Laboratory, Richland, Washington. NTIS, Springfield, Virginia. $47 \mathrm{pp}$. plus appendices.

Rockwell Hanford Operations. 1984. Unconfined Aquifer Water-Table Map -June 1984. H-2-38396, Rev. 17, Rockwell Hanford Operations, Richland, Washington.

Rockwell Hanford Operations. 1979. Water Table Measurement Data Maps - December 1979. H-238396, Rev. 8, Rockwell Hanford Operations, Richland, Washington.

Rockwell Hanford Operations. 1980a. Water Table Measurement Data Maps - June 1980. H-238396, Rev. 9, Rockwell Hanford Operations, Richland, Washington.

Rockwell Hanford Operations. 1980b. Water Table Measurement Data Maps - December 1980. H-238396, Rev. 10, Rockwell Hanford Operations, Richland, Washington.

Rockwell Hanford Operations. 1981a. Water Table Measurement Data Maps - June 1981. H-238396, Rev. 11, Rockwell Hanford Operations, Richland, Washington. 
Rockwell Hanford Operations. 1981b. Whater Table Measurement Data Maps - December 1981. H-238396, Rev. 12, Rockwell Hanford Operations, Richland, Washington.

Rockwell Hanford Operations. 1982a. Water Table Measurement Data Maps - June 1982. H-238396, Rev. 13, Rockwell Hanford Operations, Richland, Washington.

Rockwell Hanford Operations. 1982b. Water Table Measurement Data Maps - December 1982. H-238396, Rev. 14, Rockwell Hanford Operations, Richland, Washington.

Rockwell Hanford Operations. 1983a. Water Table Measurement Data Maps - June 1983. H-238396, Rev. 15, Rockwell Hanford Operations, Richland, Washington.

Rockwell Hanford Operations. 1983b. Unconfined Aquifer and Rattlesnake Ridge Aquifer Water-Level Measurements Data Maps - December 1983. H-2-38396, Rev. 16, Rockwell Hanford Operations, Richland, Washington.

Rockwell Hanford Operations. 1984a. Unconfined Aquifer Water-Table Map - June 1984. H-238396, Rev. 17, Rockwell Hanford Operations, Richland, Washington.

Rockwell Hanford Operations. 1984b. Unconfined Aquifer and Rattlesnake Ridge Aquifer Water-Level Measurements Data Maps -December 1984. H-2-38396, Rev. 18, Rockwell Hanford Operations, Richland, Washington.

Rockwell Hanford Operations. 1985a. Unconfined Aquifer Water-Table Map - June 1985. H-238396, Rev. 19, Rockwell Hanford Operations, Richland, Washington.

Rockwell Hanford Operations. 1986b. Unconfined Aquifer and Rattlesnake Ridge Aquifer Water-Level Measurements Data Maps - December 1986. SD-WM-TI-273, Rev. 1, Rockwell Hanford Operations, Richland, Washington.

Schatz, A. L., J. J. Ammerman, J. A. Serkowski. 1987. Hanford Site Water Table Map June 1987. WHC-EP-0054, Westinghouse Hanford Company, Richland, Washington.

Spane, F.A., Jr. and R.B. Mercer, 1985, HEADCO: A Program for Converting Observed Water Levels and Pressure Measurements to Formation Pressure and Standard Hydraulic Head, RHO-BWST-71 P, Rockwell Hanford Operations, Richland, Washington.

Zimmerman, D. A., A. E. Reisenauer, G. D. Black, and M. A. Young. 1986. Hanford Site Water Table Changes 1950 Through 1980 - Data Observations and Evaluation. PNL-5506, Pacific Northwest Laboratory, Richland, Washington. 


\subsection{Drinking Water Reports}

Maas, L. J. 1977. Hanford Sanitary Water Quality Surveillance CY 1976. Hanford Environmental Health Foundation, Richland, Washington.

Maas, L. J. 1978. Hanford Sanitary Water Quality Surveillance CY 1977. Hanford Environmental Health Foundation, Richland, Washington.

Maas, L. J. 1979. Hanford Sanitary Water Quality Surveillance CY 1978. HEHF-29, Hanford Environmental Health Foundation, Richland, Washington.

Maas, L. J. 1980. Hanford Sanitary Water Quality Surveillance CY 1979. HEHF-31, Hanford Environmental Health Foundation, Richland, Washington.

Maas, L. J. 1981. Hanford Sanitary Hater Quality Surveillance CY 1980. HEHF-33, Hanford Environmental Health Foundation, Richland, Washington.

Maas, L. J. 1982. Hanford Sanitary Water Quality Surveillance CY 1981. HEHF-36, Hanford Environmental Health Foundation, Richland, Washington.

Maas, L. J. 1983. Hanford Sanitary Water Quality Surveillance CY 1982. HEHF-39, Hanford Environmental Health Foundation, Richland, Washington.

Maas, L. J. 1984. Hanford Sanitary Water Quality Surveillance CY 1983. HEHF-42, Hanford Environmental Health Foundation, Hanford, Washington.

Maas, L. J. 1985. Hanford Sanitary Water Quality Surveillance CY 1984. HEHF-45, Hanford Environmental Health Foundation, Richland, Washington.

Somers, S. R. 1986. Hanford Sanitary Water Quality Surveillance CY 1985. HEHF-55, Hanford Environmental Health Foundation, Richland, Washington.

Somers, S. R. 1987. Hanford Sanitary Water Quality Surveillance CY 1986. HEHF-59, Hanford Environmental Health Foundation, Richland, Washington.

Somers, S. R. 1988. Hanford Sanitary Water Quality Surveillance CY 1987. HEHF-71, Hanford Environmental Health Foundation, Richland, Washington.

Somers, S. R. 1989. Hanford Sanitary Hater Quality Surveillance CY 1988. HEHF-74, Hanford Environmental Health Foundation, Richland, Washington.

Thurman, P. A. 1990. Hanford Sanitary Hater Quality Surveillance CY 1989. HEHF-76, Hanford Environmental Health Foundation, Richland, Washington.

Thurman, P. A. 199.1. Hanford Sanitary Hater Quality Surveillance CY 1990. HEHF-82, Hanford Environmental Health Foundation, Richland, Washington. 
Clark, M. L., and P. A. Thurman. 1992. Hanford Sanitary Water Quality Surveillance for Calendar Year 1991. HEHF-88, Hanford Environmental Health Foundation, Richland, Washington.

Thurman, P. A. 1993. Hanford Sanitary Whater Quality Surveillance for Calendar Year 1992. HEHF90, Hanford Environmental Health Foundation, Richland, Washington.

4065, UNC Nuclear Industries, Richland, Washington.

\subsection{Miscellaneous Ground-Water Reports}

Albenesius, E. L. 1959. "Tritium as a Product of Fission." Phys. Rev. Letters 3:274.

Albenesius, E. L., and R. S. Ondrejin. 1960. "Nuclear Fission Produces Tritium." Nucleonics 100.

Aldrich, R. C. 1985. Radioactive Liquid Wastes Discharged to Ground in the 200 Areas During 1984. RHO-HS-SR-84-3-4Q LIQ P, Rockwell Hanford Operations, Richland, Washington.

Aldrich, R. C. 1986. Radioactive Liquid Wastes Discharged to Ground in the 200 Areas During 1985. RHO-HS-SR-85-3-4Q LIQ P, Rockwell Hanford Operations, Richland, Washington.

Ames, L. L., P. F. Salter, J. E. McGarrah, and B. A. Walker. 1984. Selenate-Selenium Sorption on a Columbia River Basalt (Umtanum Basalt, Washington, U.S.A.) Chem. Geol. 43:287-302.

Barney, G. S. 1981. Radionuclide Reactions with Groundwater and Basalts from Columbia River Basalts. RHO-SA-217, Rockwell Hanford Operations, Richland, Washington.

Barney, G. S. 1984. Radionuclide Sorption and Desorption Reactions with Interbed Materials from the Columbia River Basalt Formation. In: Geochemical Behavior of Disposed Radioactive Waste, eds. G. S. Barney, J. D. Navratil, and W. W. Schultz. ACS Symposium Series 246, American Chemical Society, Washington, D.C.

Bauer, H. H., and J. J. Vaccaro. 1990. Estimates of Ground-Water Recharge to the Columbia Plateau Regional Aquifer System, Washington, Oregon, and Idaho for Predevelopment and current Land Use Conditions. Water Resources Investigation Report 88-4108, U.S. Geological Survey, Tacoma, Washington.

Bierschenk, W. H., 1957, Fluctuations of Hanford Water Levels, HW-53599, General Electric Company, Richland, Washington.

Bierschenk, W. H. 1959. Aquifer Characteristics and Ground-Water Movement at Hanford. HW-60601, General Electric Company, Hanford Atomic Products Operation, Richland, Washington.

Bjornstad, B. N. 1990. Geohydrology of the 218-W-5 Burial Ground. PNL-7336, Pacific Northwest Laboratory, Richland, Washington. NTIS, Springfield, Virginia. 
Brown, D. J., and J. R. Raymond. 1962. Hanford Experience in the Radiological Monitoring of Ground Water. HW-SA-2566, General Electric Company, Hanford Atomic Products Operation, Richland, Washington.

Brown, D. J. 1963. Status of the Ground Vhater Beneath Hanford Reactor Areas, January 1962 to January 1963. HW-77170, General Electric: Company, Hanford Atomic Products Operation, Richland, Washington.

Brown, D. J. 1964. Ground Water Travel Time Calculations for the 1301-N Crib. HW-80558, General Electric Company, Hanford Atomic Products Operation, Richland, Washington.

Bryce, R. W., and S. M. Goodwin. 1989. Borehole Summary Report for Five Ground-Water Monitoring Wells Constructed in the 1100 Area. PNL-6824, Pacific Northwest Laboratory, Richland, Washington.

Buske, N., and L. Josephson, 1988, Water and Sediment Reconnaissance of the Hanford Shoreline, Hanford Reach Project, Data Report No. 4, Fall 1988, SEARCH Technical Services, Davenport, Washington.

Chamness, M. A., S. P. Luttrell, and S. Dudziak. 1989. 40 CFR 265. Interim-Status Ground-Water Monitoring Plans for the 2101-M Pond. PNL-6851, Pacific Northwest Laboratory, Richland, Washington. NTIS, Springfield, Virginia.

Chamness, M. A., and J. K. Merz. 1993. Hanford Wells. PNL-8800, Pacific Northwest Laboratory, Richland, Washington. NTIS, Springfield, Virginia.

Chamness, M. A., T. J. Gilmore, and S. S. Teel. 1993. Savage Island Project Borehole Completion Report. PNL-8485, Pacific Northwest Laboratory, Richland, Washington. NTIS, Springfield, Virginia.

Deju, R. A., and W. K. Summers. 1975. Transmissivity and Hydraulic Conductivity of Saturated Sedimentary Rocks in the Hanford Reservation. CA-168-RA-D5, Atlantic Richfield Hanford Company, Richland, Washington.

Delaney, C. D., K. A. Lindsey, and S. P. Reidel, 1991, Geology and Hydrology of the Hanford Site: A Standardize Text for Use in Westinghouse Hanford Company Documents and Reports, WHC-SD-ER-TI-003, Rev. 0, Westinghouse Hanford Company, Richland, Washington.

Delegard, C. H., R. L. Weiss, R. T. Kimura, A. G. Law, and R. C. Routson. 1986. Characterization and Anion Exchange Removal of Uranium from Hanford Ground Water. In: Waste Management '86, Proceedings of the Symposium on Waste Management, Vol. 1 General Interest, ED. R. G. Post. University of Arizona Press, Tucson, Arizona. (RHO-RE-SA-116P)

Dirkes, R. L., 1990, 1988 Hanford Riverbank Springs Characterization Report, PNL-7500, Pacific Northwest Laboratory, Richland, Washington. 
DOE-RL, 1990, Hanford Site Solid Waste Landfill Permit Application, DOE/RL-90-38, U.S. Department of Energy, Richland Operations Office, Richland, Washington.

Drost, B. W., K. M. Schurr, and W. E. Lum II. 1989. Selected Ground-Water Information for the Pasco Basin and Adjacent Areas, Washington, 1986-1989. Open-File Report 89-228, U.S. Geological Survey, Tacoma, Washington.

Ecology and EPA, 1986, Consent Agreement and Compliance Order, DE86-133, PCHB No. 86-44, Washington State Department of Ecology, and the U.S. Environmental Protection Agency, Olympia, Washington.

Ecology, EPA, and DOE, 1992, Hanford Federal Facility Agreement and Consent Order, 2 vols., as amended, Washington State Department of Ecology, U.S. Environmental Protection Agency, and U.S. Department of Energy, Olympia, Washington.

Eddy, P. A., D. A. Myers, and J. R. Raymond. 1978. Vertical Contamination in the Unconfined Ground Water at the Hanford Site, Washington. PNL-2724, Pacific Northwest Laboratory, Richland, Washington.

Eddy, P. A., S. S. Teel, J. R. Raymond, and W. H. Bierschenk. 1988. Water Quality: Historic Values and Impact of Drilling Activities During FY 1988 at the Reference Repository Location in Southeastern Washington. PNL-6497, Pacific Northwest Laboratory, Richland, Washington.

Fancher, J. D. 1993. 200 Hest Carbon Tetrachloride Expedited Response Action Baseline Monitoring Data Package. WHC-SD-EN-DP-063, Rev. 0, Westinghouse Hanford Company, Richland, Washington.

Fayer, M. J., and T. B. Walters. 1995. Estimated Recharge Rates at the Hanford Site. PNL-10285, Pacific Northwest Laboratory, Richland, WA. NTIS, Springfield, VA.

Freshley, M. D. 1989. "Estimation of Ground-Water Travel Time at the Hanford Site, Washington." In: Abstracts, Fall Meeting, American Geophysical Union, December 4-8, San Francisco, California. American Geophysical Union 70(43):1098.

Freshley, M. D., and M. J. Graham. 1988. Estimation of Ground-Water Travel Time at the Hanford Site: Description, Past Wbrk, and Future Needs. PNL-6328, Pacific Northwest Laboratory, Richland, Washington.

Freshley, M. D., and P. D. Thorne. 1991. Reconstruction of Radionuclide Movement in Groundwater at the Hanford Site. Trans. Am. Nuc. Soc. 63:47-49.

Freshley, M. D., and P. D. Thorne. 1992. Ground-Water Contribution to Dose from Past Hanford Operations. PNWD-1974 HEDR, Battelle Pacific Northwest Laboratories, Richland, Washington. NTIS, Springfield, Virginia. 
Fruland, R. M., R. A. Hagen, C. S. Cline, D. J. Bates, J. C. Evans, and R. L. Aaberg. 1989.

Interim Site Characterization Report and Ground Water Monitoring Program for the Hanford Site Solid Whaste Landfill. PNL-6823, Pacific Northwest Laboratory, Richland, Washington. NTIS, Springfield, Virginia.

Gee, G. W., and R. R. Kirkham. 1984. Arid Site Water Balance: Evapotranspiration Modeling and Measurements. PNL-5177, Pacific Northwest Laboratory, Richland, Washington.

Gee, G. W. 1987. Recharge at the Hanfond Site: Status Report. PNL-6403, Pacific Northwest Laboratory, Richland, Washington.

Gee, G. W. 1991. Tracking the Movement of Contaminants into Groundwater. Geophysics News, pp. 14-15. American Geophysical Union. Washington, D.C.

Gee, G. W., M. J. Fayer, M. L. Rockhold, and M. D. Campbell. 1992. Variations in Recharge at the Hanford Site. Northwest Sci: 66:237-250.

Gephart, R. E., F. A. Spane, L. S. Leonhart, D. A. Palombo, and S. R. Strait, 1979, "Pasco Basin Hydrology," In: Hydrologic Studies Within the Columbia Plateau, Washington: An Integration of Current Knowledge, RHO-BWI-DT-5, Rockwell Hanford Operations, Richland, Washington.

Gephart, R. E., R. C. Arnett, R. G. Bacq, L. S. Leonhart, and F. A. Spane, Jr. 1979. Hydrologic Studies within the Columbia Plateau, Washington: An Integration of Current Knowledge.

RHO-BWI-ST-5, Rockwell Hanford Operations, Richland, Washington.

Gilmore, T. J. 1989. The Installation of the Multiport Ground-Water Sampling System in the 3000 Area. PNL-6910, Pacific Northwest Laboratory, Richland, Washington. NTIS, Springfield, Virginia.

Gilmore, T. J., J. V. Borghese, J. P. McDonald, and D. R. Newcomer. 1990. Effects of River Stage Fluctuations on an Unconfined Aquifer Beneath Waste-Water Disposal Facilities. Ground-Water 28(5):793-794.

Gilmore, T. J., D. R. Newcomer, S. K. Wurstner, and F. A. Spane, 1992, Calculation of Groundwater Discharge to the Columbia River in the 100-N Area, PNL-8057, Pacific Northwest Laboratory, Richland, Washington.

Graham, M. J., M. D. Hall, S. R. Strait, and W. R. Brown. 1981. Hydrology of the Separations Area. RHO-ST-42, Rockwell Hanford Operations, Richland, Washington.

Graham, M. J., G. V. Last, and K. R. Fecht. 1984. An Assessment of Aquifer Intercommunication in the B Pond, Gable Mountain Pond Area. RHO-RE-ST-12P, Rockwell Hanford Operations, Richland, Washington. 
Gutknecht, P. J., W. A. Rice, C. R. Cole, and M. D. Freshley. 1980. Pasco Basin Hydrometeorological Study. PNL-3855, prepared for Rockwell Hanford Operations (RHO-BWI-C-98) by Pacific Northwest Laboratory, Richland, Washington.

Hall, S. H. 1989. Evaluations of the Ground-Water Contaminant Plume Extending from the 183-H Solar Evaporation Basins. PNL-7130, Pacific Northwest Laboratory, Richland, Washington. NTIS, Springfield, Virginia.

Hall, S. H. 1990. "Resolving Superimposed Ground-Water Contaminant Plumes Characterized by Chromium, Nitrate, Uranium, and Technetium-99". In: Proceedings, Ground-Water Geochemistry, February 20-22, 1990, Kansas, Missouri. National Well Water Association, Dublin, Ohio.

Haney, W. A., D. J. Brown, and A. E. Reisenauer. 1962. Fission Product Tritium in Separations Whastes and in the Ground Water. HW-74536, General Electric Company, Hanford Atomic Products Operation, Richland, Washington.

Hartman, M. J., 1991, Groundwater Monitoring Plan for the 1301-N, 1324-N/NA, and 1325-N Facilities, WHC-SD-EN-AP-038, Rev. 0, Westinghouse Hanford Company, Richland, Washington.

Hartman, M. J., and K. A. Lindsey. 1993. Hydrogeology of the 100-N Area, Hanford Site, Washington. WHC-SD-EN-EV-027, Rev. 0, Westinghouse Hanford Company, Richland, Washington.

Hartman, M. J., and R. E. Peterson, 1992, Hydrologic Information Summary for the Northern Hanford Site, WHC-SD-EN-TI-023, Rev. 0, Westinghouse Hanford Company, Richland, Washington.

Honstead, J. F., M. W. McConiga, and J. R. Raymond, 1955. Gable Mountain Groundwater Tests, HW-34532, General Electric Company, Richland, Washington.

Hoover, J. D., and T. LeGore. 1991. Characterization and Use of Soil and Groundwater Background for the Hanford Site. WHC-MR-0246, Westinghouse Hanford Company, Richland, Washington.

Jacobson, E. A., and M. D. Freshley. 1990. An Initial Inverse Calibration of the Ground-Water Flow Model for the Hanford Unconfined Aquifer. PNL-7144, Pacific Northwest Laboratory, Richland, Washington. NTIS, Springfield, Virginia. 45 p.

Jensen, E. J. 1987. An Evaluation of Aquifer Intercommunication Between the Unconfined and Rattlesnake Ridge Aquifers on the Hanford Site. PNL-6313, Pacific Northwest Laboratory, Richland, Washington.

Kipp, K. L., and R. D. Mudd. 1973. Collection and Analysis of Pump Test Data for Transmissivity Values. BNWL-1709, Pacific Northwest Laboratory, Richland, Washington.

Last, G. V., B. N. Bjornstad, M. P. Bergeron, D. W. Wallace, D. R. Newcomer, J. A. Schramke, M. A. Chamness, C. S. Cline, S. P. Airhart, and J. S. Wilbur. 1989. Hydrogeology of the 200 Areas Low-Level Burial Grounds - An Interim Report. PNL-6820, 2 Volumes, Pacific Northwest Laboratory, Richland, Washington. 
Last, G. V., and V. J. Rohay. 1991. Carbon Tetrachloride Contamination, 200 West Area, Hainford Site. PNL-SA-19564, Pacific Northwest Laboratory, Richland, Washington.

Last, G. V., and V. J. Rohay. 1993. Refined Conceptual Model for the Vlatile Organic CompoundsArid Integrated Demonstration and 200 West Area Carbon Tetrachloride Expedited Response Action. PNL-8597, Pacific Northwest Laboratory, Richland, Washington.

Laul, J. C., M. R. Smith, V. G. Johnson, and R. M. Smith. 1985. Disequilibrium of Natural Radionuclides in Hanford Site Groundwater. In High-Level Nuclear Waste Disposal, ed. H. C. Burkholder, pp. 401-410. Battelle Press, Richland, Washington.

Liikala, T. L. 1993. Hydrogeology Along the Southern Boundary of the Hanford Site Between the Yakima and Columbia Rivers, Washington. Unpublished M.S. Thesis, Washington State University, Pullman, Washington.

Liikala, T. L., R. L., Aaberg, N. J. Aimo, D. J. Bates, T. J. Gilmore, E. J. Jensen, G. V. Last, P. L. Oberlander, K. B. Olsen, K. R. Oster, L. R. Roome, J. C. Simpson, S. S. Teel, and E. J. Westergard, 1988, Geohydrologic Characterization of the Area Surrounding the 183-H Solar Evaporation Basins, PNL-6728, December 1988, Pacific Northwest Laboratory, Richland, Washington.

Liikala, T. L., D. S. Daly, and A. P. Toste. 1988. An Evaluation of the Effects of Well Construction Materials and Ground-Water Sampling Equipment on Concentrations of Volatile Organic Compounds. PNL-6585, Pacific Northwest Laboratory, Richland, Washington.

Lindberg J. W. 1993a. Geology of the 100-B/C Area, Hanford Site, South-Central Washington. WHC-SD-EN-TI-133, Rev. 0, Westinghouse Hanford Company, Richland, Washington.

Lindberg J. W. 1993b. Geology of the 100-K Area, Hanford Site, South-Central Washington. WHCSD-EN-TI-155, Rev. 0, Westinghouse Hanford Company, Richland, Washington.

Lindsey, K. A., and G. K. Jaeger. 1993. Geologic Setting of the 100-HR-3 Operable Unit, Hanford Site, South-Central Washington. WHC-SD-EN-TI-132, Rev. 0, Westinghouse Hanford Company, Richland, Washington.

Luttrell, S. P., D. R. Newcomer, S. S. Teel, and V. R. Vermeul. 1992. Hydrogeologic Controls on Ground-Water and Contaminant Discharge to the Columbia River in the Hanford Townsite Vicinity. PNL-8167, Pacific Northwest Laboratory, Richland, Washington.

McCormack, W. D., and J. M. V. Carlile. 1984. Investigation of Ground-Water Seepage from the Hanford Shoreline of the Columbia River. PNL-5289, Pacific Northwest Laboratory, Richland, Washington.

McGhan, V. L. 1989. Hanford Wells. PNL-6907, Pacific Northwest Laboratory, Richland, Washington. NTIS, Springfield, VA. 
Meyer, P. D. 1993. A Quantitative Method for Ground-Water Surveillance Monitoring Network Design at the Hanford Site. PNL-8868, Pacific Northwest Laboratory, Richland, Washington. NTIS, Springfield, VA.

Mitchell, P. J., R. S. Argo, S. L. Bradymire, and C. A. Newbill. 1985. Hanford Ground-Water Data Base Management Guide and User's Manual. PNL-5486, Pacific Northwest Laboratory, Richland, Washington.

Newcomb, R. C., and J. R. Strand. 1953. Geology and Ground-Water Characteristics of the Hanford Reservation of the Atomic Energy Commission, Washington: U.S. Geological Survey, Working Paper 8, U.S. Geological Survey, Washington, D.C.

Newcomb, R. C., J. R. Strand, and F. J. Frank. .1972. Geology and Ground-Water Characteristics of the Hanford Reservation of the U.S. Atomic Energy Commission, Washington, Professional Paper 717, U.S. Geological Survey, Washington, D.C.

Nielsen, J. M., and R. W. Perkins. 1957. The Depletion of Radioisotopes from the Columbia River by Natural Causes. HW-52908, General Electric Company, Hanford Atomic Products Operation, Richland, Washington.

Parker, H. M. 1959. Hearings Before the Special Subcommittee on Radiation of the Joint Committee on Atomic Energy Congress of the United States Eighty-Sixth Congress First Session on industrial Radioactive Waste Disposal. January 28-February 3, 1959, Vol. 1, pp. 202-235, 330-391.

Peterson, R. E., 1992, Hydrologic and Geologic Data Available for the Region North of Gable Mountain, Hanford Site, Washington, WHC-SD-EN-TI-006, Rev. 0, Westinghouse Hanford Company, Richland, Washington.

PNL. 1986. Environmental Monitoring Procedures. PNL-MA-580, Pacific Northwest Laboratory, Richland, Washington.

PNL. 1989. Procedures for Ground-Water Investigations, PNL-6894, Pacific Northwest Laboratory, Richland, Washington.

PNL. 1990. Hanford Ground-Water Data Base Management Guide. PNL-7003, Pacific Northwest Laboratory, Richland, Washington.

Poeter, E., and D. R. Gaylord. 1990. "Influence of Aquifer Heterogeneity on Contaminant Transport at the Hanford Site." Ground Water 28:900-909.

Raymond, J. R., and D. J. Brown. 1963. Ground Water Exchange with Fluctuating Rivers, Hanford Laboratories. HW-SA-3198, General Electric Company, Hanford Atomic Products Operation, Richland, Washington.

Resource Conservation and Recovery Act of 1976, 42 USC 6901 et seq. 
Rhoads, K., B. N. Bjornstad, R. E. Lewis, S. S. Teel K. J. Cantrell, R. J. Serne, J. L. Smoot, C. T. Kincaid, and S. K. Wurstner. 1993. Estimation of the Release and Migration of Lead through Soils and Groundwater at the Hanford Site 218-E-12B Burial Ground. PNL-8356, Vol. 1, Pacific Northwest Laboratory, Richland, Washington. NTIS, Springfield, VA.

Rickard, W. H., and K. R. Price. 1989. Uptake of Tritiated Groundwater by Black Locust Trees. Northwest Sci. 63(3):87-89.

Rieger, J. T., and R. W. Bryce. 1990. Effective Sample Labeling, pp. 327-329. In: R. H. Gray (ed.), Environmental Monitoring, Restoration and Assessment: What Have We Learned? Proceedings, 28th Hanford Symposium on Health and the Environment, October 16-19, 1989, Richland, Washington. Battelle Press, Columbus, $\mathrm{OH}$.

Rockhold, M. L., M. J. Fayer, G. W. Gee, and M. J. Kanyid. 1989. Natural Groundwater Recharge and Soil-Water Balance at the Hanford Site. PNL-7215, Pacific Northwest Laboratory, Richland, Washington. NTIS, Springfield, Virginia.

Rockhold, M. L., M. J. Fayer, C. T. Kincaid, and G. W. Gee. 1995. Estimation of Natural Ground Water Recharge for the Performance Assessment of a Low-Level Waste Disposal Facility at the Hanford Site. PNL-10508, Pacific Northwest Laboratory, Richland, WA. NTIS, Springfield, VA.

Rohay, V. J., G. V. Last, V. L. King, and L. A. Doremus. 1992a. FY92 Site Characterization Status Report and Data Package for the Carbon Tetrachloride Site. WHC-SD-EN-EI-063, Rev. 0, prepared by V. J. Rohay and V. L. King, Westinghouse Hanford Company, and G. V. Last and L. A. Doremus, Pacific Northwest Laboratory, for Westinghouse Hanford Company, Richland, Washington.

Schalla, R., R. W. Wallace, R. L. Aaberg, S. P. Airhart, D. J. Bates, J. V. M. Carlile, C. S. Cline, D. I. Dennison, M. D. Freshley, P. R. Heller, E. J. Jensen, K. B. Olsen, R. G. Parkhurst, J. T. Rieger, and E. J. Westergard. 1988. Interim Characterization Report for the 300 Area Process Trenches. PNL-6716, Pacific Northwest Laboratory, Richland, Washington.

Sherwood, D. R., J. R. Evans, and R. W. Bryce. 1990. "Identification of Contaminants of Concern in Hanford Ground Waters," pp. 51-59. In: R. H. Gray (ed.), Environmental Monitoring, Restoration and Assessment: What Have He Learned? Proceedings, 28th Hanford Symposium on Health and the Environment, October 16-19, 1989, Richland, Washington. Battelle Press, Columbus, Ohio. 
Smith, M. R., J. C. Laul, and V. G. Johnson. 1987. Natural Radionuclides in Hanford Site Ground Waters. Mater, Res. Soc. Symp. Proc. 112:249-257.

Spane, Jr., F. A. 1987. Fresh-Water Potentiometric Map and Interred Flow Direction of Ground Water Within the Mabton Interbed, Hanford Site, Washington State - January 1987. SD-BWI-TI-335, Rockwell Hanford Operations, Richland, Washington.

Spane, Jr., F. A. 1992. Applicability of Slug Interference Tests under Hanford Site Test Conditions: Analytical Assessment and Field Test Evaluation. PNL-8070, Pacific Northwest Laboratory, Richland, Washington.

Spane, Jr., F. A. 1992. Hydraulic Test Results for Savage Island Wells: 699-32-22B, 699-42-E9A, and 699-42-E9B. PNL-8173, Pacific Northwest Laboratory, Richland, Washington. NTIS, Springfield, Virginia.

Spane, Jr., F. A., D. L. Graham, and R. W. Bryce. 1982. Hydrochemical and Isotopic Content of Basalt Groundwaters Beneath the Hanford Site, Washington. RHO-BW-SA-190, Rockwell Hanford Operations, Richland, Washington.

Spane, Jr., F. A., and R. G. Raymond. 1993. Preliminary Potentiometric Map and Flow Dynamic Characteristics for the Upper-Basalt Confined Aquifer System. PNL-8869, Pacific Northwest Laboratory, Richland, Washington. NTIS, Springfield, VA.

Spane, Jr., F. A., and P. D. Thorne. 1992. An Evaluation of Slug Interference Tests for Aquifer Characterization at the Hanford Site, pp. 387-392. In: Proceedings, Nuclear and Hazardous Waste Management, Spectrum 92, Vol. 1, August 23-27, Boise, ID. American Nuclear Society, La Grange Park, IL.

Strait, S. R., and B. A. Moore. 1982. Geohydrology of the Rattlesnake Ridge Interbed in the Gable Mountain Pond Area. RHO-ST-38, Rockwell Hanford Operations, Richland, Washington.

Summers, W. K., and G. Schwab. 1980. Hydrology and Isotopic Analyses of Whater in a Recharge Area, Eastern Washington. (Abstract) RHO-BWI-SA-71 A, Rockwell Hanford Operations, Richland, Washington.

Thomas, C. W., D. L. Reid, and H. A. Treibe. 1956. Cobalt-60 in Ground Water and Separations Plant Waste Streams. HW-42612, General Electric Company, Hanford Atomic Products Operation, Richland, Washington.

Thorne, P. D., and M. A. Chamness. 1992. Status Report on the Development of a ThreeDimensional Conceptual Model for the Hanford Site Unconfined Aquifer System. PNL-8332, Pacific Northwest Laboratory, Richland, Washington.

Thorne, P. D., M. A. Chamness, F. A. Spane, V. R. Vermeul, and W. B. Webber. 1993. ThreeDimensional Conceptual Model for the Hanford Site Unconfined Aquifer System, FY 1993. PNL-8971, Pacific Northwest Laboratory, Richland, Washington. NTIS, Springfield, VA. 
Thorne, P. D., and D. R. Newcomer. 1992. Summary and Evaluation of Available Hydraulic Property Data for the Hanford Site Unconfined Aquifer System. PNL-8337, Pacific Northwest Laboratory, Richland, Washington.

U.S. Department of Energy (DOE). 1993. Columbia River Impact Evaluation Plan. DOE/RL-92-28, U.S. Department of Energy, Richland, Washington.

U.S. Department of Energy (DOE). 1994. Limited Field Investigation Report for the 100-HR-3 Operable Unit. DOE/RL-93-43, U.S. Department of Energy, Richland, Washington.

U.S. Geological Survey (USGS). 1987. Subsurface Transport of Radionuclides in Shallow Deposits of the Hanford Nuclear Reservation, Washington - Review of Selected Previous Work and Suggestions for Further Study. Open File Report 87-222, U.S. Geological Survey, Tacoma, Washington.

Van Luik, A. R., R. M. Mitchell, G. V. Last, R. C. Routson, D. S. Landeen, and K. R. Fecht. 1980. Characterization of the W-5 Burial Ground Expansion Site. RHO-CD-941, Rockwell Hanford Operations, Richland, Washington.

WAC 173-303, "Dangerous Waste Regulations", Washington Administrative Code, as amended.

WAC 173-304, "Minimum Functional Standards for Solid Waste Handling", Washington Administrative Code, as amended.

Waiters, K. L., and M. J. Grolier. 1960. Geology and Ground-Water Resources of the Columbia Basin Project Area, Washington Volume I, Division of Water Resources, State of Washington, Olympia, Washington.

Weekes, D. C., S. P. Luttrell, and M. R. Fuchs. 1987. Interim Hydrogeologic Characterization Report and Groundwater Monitoring System for the Nonradioactive Dangerous Waste Landfill, Hanford Site, Washington. WHC-EP-0021, Westinghouse Hanford Company, Richland, Washington.

Westinghouse Hanford Company. 1987. Llata Compilation: Iodine-129 in Hanford Groundwater. WHC-EP-0037, Westinghouse Hanford Company, Richland, WA..

\section{Computer Models/Codes}

Fayer, M. J., G. W. Gee, and T. L. Jones. 1986. UNSAT-H Version 1.0: Unsaturated Flow Code Documentation and Applications for the Hanford Site. PNL-5899, Pacific Northwest Laboratory, Richland, Washington.

Gee, G. W. 1987. Recharge at the Hanford Site: Status Report. PNL-6403, Pacific Northwest Laboratory, Richland, Washington.

Kincaid, C. T., and P. J. Mitchell. 1986. Review of Multiphase Flow and Pollutant Transport Models for the Hanford Site. PNL-6048, Pacific Northwest Laboratory, Richland; Washington. 
Mitchell, P. J., and M. D. Freshley. 1987. Ground-Water Monitoring and Modeling at the Hanford Site. In: Waste Management '87, Proceedings of the Symposium on Waste Management 1987, Vol. 1 General Interest, ed. R. G. Post. University of Arizona Press, Tucson, Arizona.

Schalla, R., and L. A. Leonhart. 1982. Dealing with Regional Hydrologic Data Base Limitations and Uncertainties, Case Example: the Columbia River Basalts. In: Proceedings of the Symposium on the Effectiveness of Geologic Isolation of High Level Radioactive Waste, ed. D. C. Kocher. NTIS, Springfield, Virginia.

Simmons, C. S., C. T. Kincaid, and A. E. Reisenauer. 1986. A Simplified Model for Radioactive Waste Transport: The TRANSS Code. PNL-6029, Pacific Northwest Laboratory, Richland, Washington.

Wurstner, S. K., and J. L. Devary. 1993. Hanford Site Ground-Water Model: Geographic Information System Linkages and Model Enhancements, FY 1993. PNL-8991, Pacific Northwest Laboratory, Richland, Washington. NTIS, Springfield, VA. 
Appendix A

Selected Water-Level Measurements from Unconfined Aquifer Wells on the Hanford Site and Outlying Areas, June 1994 


\section{Appendix A}

Table A.1. Selected Water-Level Measurements from Unconfined Aquifer Wells on the Hanford Site and Outlying Areas, June 1994

\begin{tabular}{|c|c|c|c|c|c|}
\hline Well Name & Measure Date & $\begin{array}{c}\text { Reference } \\
\text { Elevation } \\
\text { (meters } \\
\text { above } \\
\text { NGVD29) }\end{array}$ & $\begin{array}{l}\text { Depth to } \\
\text { Water } \\
\text { (meters) }\end{array}$ & $\begin{array}{l}\text { Water-Table } \\
\text { Elevation } \\
\text { (meters } \\
\text { above } \\
\text { NGVD29) }\end{array}$ & $\begin{array}{c}\text { Depth } \\
\text { Measured } \\
\text { By }\end{array}$ \\
\hline 08N30E03A01 & 08-Jun-94 & 118.87 & 15.70 & 103.18 & PNLGW \\
\hline 09N29E09C01 & 07-Jun-94 & 156.67 & 45.99 & 110.68 & PNLGW \\
\hline O9N29E15N01 & 07-Jun-94 & 122.53 & 17.68 & 104.85 & PNLGW \\
\hline O9N30E02B01 & 08-Jun-94 & 155.14 & 33.23 & 121.91 & PNLGW \\
\hline O9N30E06D01 & 07-Jun-94 & 134.42 & 23.75 & 110.67 & PNLGW \\
\hline O9N30E16F01 & 08-Jun-94 & 123.75 & 18.49 & 105.26 & PNLGW \\
\hline O9N30E23NO1 & 08-Jun-94 & 134.11 & 27.57 & 106.54 & PNLGW \\
\hline 10N29E01A01 & 07-Jun-94 & 202.08 & 8.53 & 193.55 & PNLGW \\
\hline 10N29E08R01 & 07-Jun-94 & 189.28 & 5.29 & 183.99 & PNLGW \\
\hline 10N29E11NO1 & 07-Jun-94 & 199.34 & 2.22 & 197.12 & PNLGW \\
\hline 10N29E15D01 & 07-Jun-94 & 187.45 & 3.69 & 183.76 & PNLGW \\
\hline 10N29E25A01 & 07-Jun-94 & 151.79 & 9.78 & 142.01 & PNLGW \\
\hline 10N29E26A01 & 07-Jun-94 & 151.18 & 14.00 & 137.19 & PNLGW \\
\hline 10N29E27C01 & 07-Jun-94 & 147.52 & 39.66 & 107.87. & PNLGW \\
\hline 10N29E28B01 & 07-Jun-94 & 153.62 & 44.92 & 108.70 & PNLGW \\
\hline $10 \mathrm{~N} 29 \mathrm{E} 34 \mathrm{CO}$ & 07-Jun-94 & 138.38 & 7.79 & 130.59 & PNLGW \\
\hline 10N30E04EO1 & 08-Jun-94 & 169.47 & 5.26 & 164.21 & PNLGW \\
\hline 10N30E05BO1' & 07-Jun-94 & 179.83 & 3.75 & 176.08 & PNLGW \\
\hline 10N30E05NO1 & 07-Jun-94 & 168.56 & 9.09 & 159.47 & PNLGW \\
\hline 10N30E08F01 & 08-Jun-94 & 163.98 & 6.57 & 157.41 & PNLGW \\
\hline 1ON30E14NO1 & 08-Jun-94 & 217.63 & 8.60 & 209.03 & PNLGW \\
\hline 10N30E $18 Q 02$ & 07-Jun-94 & 152.40 & 2.79 & 149.61 & PNLGW \\
\hline 10N30E21R01 & 08-Jun-94 & 184.40 & 2.76 & 181.64 & PNLGW \\
\hline IIN28E25R02 & 07-Jun-94 & 262.13 & 3.78 & 258.35 & PNLGW \\
\hline IIN29E05D01 & 07-Jun-94 & 279.50 & 4.42 & 275.08 & PNLGW \\
\hline
\end{tabular}


Table A.1. Selected Water-Level Measurements from Unconfined Aquifer Wells on the Hanford Site and Outlying Areas, June 1994

\begin{tabular}{|c|c|c|c|c|c|}
\hline Well Name & Measure Date & $\begin{array}{l}\text { Reference } \\
\text { Elevation } \\
\text { (meters } \\
\text { above } \\
\text { NGVD29) }\end{array}$ & $\begin{array}{l}\text { Depth to } \\
\text { Water } \\
\text { (meters) }\end{array}$ & $\begin{array}{l}\text { Water-Table } \\
\text { Elevation } \\
\text { (meters } \\
\text { above } \\
\text { NGVD29) }\end{array}$ & $\begin{array}{c}\text { Depth } \\
\text { Measured } \\
\text { By }\end{array}$ \\
\hline 11N29E14R01 & 07-Jun-94 & 238.05 & 7.43 & 230.62 & PNLGW \\
\hline IIN29E16N01 & 07-Jun-94 & 277.98 & 9.91 & 268.07 & PNLGW \\
\hline 11N29E19R01 & 07-Jun-94 & 266.70 & 3.17 & 263.53 & PNLGW \\
\hline 11N29E24R01 & 07-Jun-94 & 209.09 & 9.44 & 199.65 & PNLGW \\
\hline 11N29E26D01 & 07-Jun-94 & 253.29 & 10.99 & 242.30 & PNLGW \\
\hline $11 \mathrm{~N} 30 \mathrm{E} 06 \mathrm{NO} 1$ & 07-Jun-94 & 259.69 & 4.97 & 254.72 & PNLGW \\
\hline 11N30E08N01 & 07-Jun-94 & 227.69 & 11.70 & 215.98 & PNLGW \\
\hline 11N30E32D01 & 07-Jun-94 & 203.61 & 2.02 & 201.58 & PNLGW \\
\hline 12N28E11J01 & 08-Jun-94 & 203.61 & 10.55 & 193.06 & PNLGW \\
\hline 12N29E01M01 & 07-Juñ-94 & 223.42 & 1.77 & 221.65 & PNLGW \\
\hline 12N29E03R01 & 07-Jun-94 & 225.55 & 7.68 & 217.87 & PNLGW \\
\hline 12N29E25D01 & 07-Jun-94 & 282.55 & 7.49 & 275.06 & PNLGW \\
\hline 12N29E33D01 & 07-Jun-94 & 278.28 & 2.57 & 275.72 & PNLGW \\
\hline 12N30E18D01 & 07-Jun-94 & 293.52 & 8.03 & 285.49 & PNLGW \\
\hline 12N30E30R01 & 07-Jun-94 & 221.29 & 2.40 & 218.88 & PNLGW \\
\hline 13N28E03A01 & 08-Jun-94 & 302.67 & 3.11 & 299.56 & PNLGW \\
\hline 13N28E03NO1 & 08-Jun-94 & 294.74 & 3.92 & 290.83 & PNLGW \\
\hline 13N28E14B01 & 08-Jun-94 & 296.88 & 2.10 & 294.78 & PNLGW \\
\hline 13N28E16J01 & 08-Jun-94 & 286.21 & 1.97 & 284.24 & PNLGW \\
\hline 13N28E22B01 & 08-Jun-94 & 293.52 & 3.48 & 290.05 & PNLGW \\
\hline 13N28E24D01 & 08-Jun-94 & 289.87 & 2.27 & 287.60 & PNLGW \\
\hline 13N28E26R01 & 08-Jun-94 & 286.82 & 3.40 & 283.42 & PNLGW \\
\hline 13N28E27Q01 & 08-Jun-94 & 282.86 & 4.03 & 278.82 & PNLGW \\
\hline 13N29E04A01 & 08-Jun-94 & 288.04 & 8.76 & 279.28 & PNLGW \\
\hline 13N29E20D01 & 08-Jun-94 & 302.36 & 2.37 & 300.00 & PNLGW \\
\hline 13N29E32D01 & 08-Jun-94 & 289.87 & 5.97 & 283.89 & PNLGW \\
\hline 13N29E36D01 & 07-Jun-94 & 235.00 & 10.45 & 224.55 & PNLGW \\
\hline 13N30E30H01 & 07-Jun-94 & 261.21 & 4.21 & 257.00 & PNLGW \\
\hline
\end{tabular}


Table A.1. Selected Water-Level Measurements from Unconfined Aquifer Wells on the Hanford Site and Outlying Areas, June 1994

\begin{tabular}{|c|c|c|c|c|c|}
\hline Well Name & Measure Date & $\begin{array}{c}\text { Reference } \\
\text { Elevation } \\
\text { (meters } \\
\text { above } \\
\text { NGVD29) }\end{array}$ & $\begin{array}{l}\text { Depth to } \\
\text { Water } \\
\text { (meters) }\end{array}$ & $\begin{array}{l}\text { Water-Table } \\
\text { Elevation } \\
\text { (meters } \\
\text { above } \\
\text { NGVD29) }\end{array}$ & $\begin{array}{c}\text { Depth } \\
\text { Measured } \\
\text { By }\end{array}$ \\
\hline 13N30E32A01 & 07-Jun-94 & 274.02 & 10.60 & 263.42 & PNLGW \\
\hline 14N25E01D02 & 09-Jun-94 & 205.44 & 5.74 & 199.70 & PNLGW \\
\hline 14N25E03E01 & 09-Jun-94 & 205.74 & 3.72 & 202.02 & PNLGW \\
\hline 14N2SE05NO1 & 09-Jun-94 & 222.81 & 9.87 & 212.94 & PNLGW \\
\hline 14N25E10J01 & 07-Jun-94 & 195.07 & 16.97 & 178.10 & PNLGW \\
\hline 14N25E17A01 & 09-Jun-94 & 209.40 & 11.45 & 197.95 & PNLGW \\
\hline 14N27E03PA & 17-Jun-94 & 205.44 & 37.42 & 168.02 & PNLGW \\
\hline 14N27E03PB & 17-Jun-94 & 205.44 & 16.03 & 189.41 & PNLGW \\
\hline 14N27E03PC & 17-Jun-94 & 205.44 & 7.86 & 197.57 & PNLGW \\
\hline 14N27E16C01 & 17-Jun-94 & 202.69 & 14.46 & 188.24 & PNLGW \\
\hline $14 \mathrm{~N} 27 \mathrm{E} 16 \mathrm{C} 02 \mathrm{~B}$ & 17-Jun-94 & 202.39 & 36.90 & 165.49 & PNLGW \\
\hline $14 \mathrm{~N} 27 \mathrm{E} 16 \mathrm{CO} \mathrm{C}$ & 17-Jun-94 & 202.39 & 14.74 & 187.65 & PNLGW \\
\hline 14N27E26E01 & 17-Jun-94 & 207.27 & 5.32 & 201.94 & PNLGW \\
\hline 14N27E26J01 & 17-Jun-94 & 220.07 & 8.97 & 211.10 & PNLGW \\
\hline 14N27E26M01 & 17-Jun-94 & 205.74 & 3.57 & 202.17 & PNLGW \\
\hline 14N27E27A01 & 17-Jun-94 & 208.18 & 4.96 & 203.22 & PNLGW \\
\hline 14N28E30D01 & 17-Jun-94 & 224.64 & 2.88 & 221.76 & PNLGW \\
\hline 14N28E30M01 & 17-Jun-94 & 223.42 & 3.41 & 220.01 & PNLGW \\
\hline 14N28E30N01 & 17-Jun-94 & 224.33 & 3.17 & 221.17 & PNLGW \\
\hline 14N29E21A01 & 08-Jun-94 & 308.76 & 9.61 & 299.15 & PNLGW \\
\hline 14N29E28A01 & 08-Jun-94 & 282.25 & 3.64 & 278.60 & PNLGW \\
\hline 15N24E34Q01 & 09-Jun-94 & 242.32 & 9.37 & 232.94 & PNLGW \\
\hline 15N24E35J01 & 09-Jun-94 & 258.78 & 3.21 & 255.56 & PNLGW \\
\hline 15N25E25E01 & 09-Jun-94 & 263.35 & 5.58 & 257.76 & PNLGW \\
\hline 15N25E30H01 & 09-Jun-94 & 263.96 & 12.74 & 251.22 & PNLGW \\
\hline I5N25E30R01 & 09-Jun-94 & 247.19 & 7.57 & 239.63 & PNLGW \\
\hline 15N25E32N01 & 09-Jun-94 & 231.95 & 11.22 & 220.73 & PNLGW \\
\hline 15N25E34D01 & 09-Jun-94 & 240.49 & 11.80 & 228.69 & PNLGW \\
\hline
\end{tabular}


Table A.1. Selected Water-Level Measurements from Unconfined Aquifer Wells on the Hanford Site and Outlying Areas, June 1994

\begin{tabular}{|c|c|c|c|c|c|}
\hline Well Name & Measure Date & $\begin{array}{c}\text { Reference } \\
\text { Elevation } \\
\text { (meters } \\
\text { above } \\
\text { NGVD29) }\end{array}$ & $\begin{array}{l}\text { Depth to } \\
\text { Water } \\
\text { (meters) }\end{array}$ & $\begin{array}{l}\text { Water-Table } \\
\text { Elevation } \\
\text { (meters } \\
\text { above } \\
\text { NGVD29) }\end{array}$ & $\begin{array}{c}\text { Depth } \\
\text { Measured } \\
\text { By }\end{array}$ \\
\hline $15 \mathrm{~N} 26 \mathrm{E} 30 \mathrm{HO}$ & 09-Jun-94 & 260.30 & 7.27 & 253.03 & PNLGW \\
\hline 199-B3-2 & 30-Jun-94 & 134.88 & 11.57 & 123.31 & PNLGW \\
\hline 199-D2-5 & 29-Jun-94 & 140.30 & 22.92 & 117.38 & PNLGW \\
\hline 199-D5-13 & 09-Aug-94 & 143.71 & 26.82 & 116.89 & WHCRCRA \\
\hline 199-D8-4 & 13-Jun-94 & 142.87 & 25.65 & 117.21 & WHCRCRA \\
\hline 199-D8-5 & 08-Jun-94 & 137.92 & 20.76 & 117.16 & WHCRCRA \\
\hline 199-D8-6 & 08-Jun-94 & $145.24^{\circ}$ & 27.86 & 117.37 & WHCRCRA \\
\hline 199-F7-1 & 29-Jun-94 & 118.79 & 5.36 & 113.43 & PNLGW \\
\hline 199-H3-1 & 29-Jun-94 & 128.63 & 13.84 & 114.79 & PNLGW \\
\hline 199-H4-3 & 13-Jun-94 & 128.11 & 13.11 & 114.99 & WHCRCRA \\
\hline 199-H4-4 & 13-Jun-94 & 126.10 & 11.14 & 114.95 & WHCRCRA \\
\hline 199-H4-6 & 12-Jul-94 & 127.89 & 13.26 & 114.63 & WHCRCRA \\
\hline $199-\mathrm{K}-111 \mathrm{~A}$ & 08-Jun-94 & 141.86 & 20.48 & 121.38 & WHCRCRA \\
\hline 199-K-13 & 31-May-94 & 141.43 & 22.42 & 119.01 & WHCRCRA \\
\hline $199-\mathrm{K}-18$ & 21-Jun-94 & 124.66 & 6.46 & 118.20 & WHCRCRA \\
\hline $199-\mathrm{K}-28$ & 31-May-94 & 143.06 & 22.33 & 120.74 & WHCRCRA \\
\hline 199-K-30 & 31-May-94 & 143.13 & 22.33 & 120.80 & WHCRCRA \\
\hline $199-\mathrm{K}-32 \mathrm{~A}$ & 01-Jun-94 & 135.34 & 16.64 & 118.70 & WHCRCRA \\
\hline 199-K-34 & 31-May-94 & 142.67 & $23.40^{\circ}$ & 119.27 & WHCRCRA \\
\hline $199-\mathrm{N}-14$ & 24-May-94 & 138.12 & 20.96 & 117.16 & WHCRCRA \\
\hline 199-N-27 & 29-Jun-94 & 136.88 & 18.82 & 118.06 & PNLGW \\
\hline $199-\mathrm{N}-3$ & 13-Jun-94 & 140.04 & 21.95 & 118.09 & WHCRCRA \\
\hline $199-N-57$ & 14-Jun-94 & 139.53 & 21.37 & 118.15 & WHCRCRA \\
\hline $199-\mathrm{N}-59$ & 13-Jun-94 & 140.07 & 21.97 & 118.09 & WHCRCRA \\
\hline $199-N-74$ & 14-Jun-94 & 139.50 & 20.53 & 118.96 & WHCRCRA \\
\hline 199-N-75 & 15-Jun-94 & 139.23 & 21.21 & 118.02 & WHCRCRA \\
\hline 299-E17-14 & 15-Jun-94 & 220.12 & 97.71 & 122.41 & WHCRCRA \\
\hline 299-E17-15 & 15-Jun-94 & 220.00 & 97.93 & 122.06 & WHCRCRA \\
\hline
\end{tabular}


Table A.1. Selected Water-Level Measurements from Unconfined Aquifer Wells on the Hanford Site and Outlying Areas, June 1994

\begin{tabular}{|c|c|c|c|c|c|}
\hline Well Name & Measure Date & $\begin{array}{c}\text { Reference } \\
\text { Elevation } \\
\text { (meters } \\
\text { above } \\
\text { NGVD29) }\end{array}$ & $\begin{array}{l}\text { Depth to } \\
\text { Water } \\
\text { (meters) }\end{array}$ & $\begin{array}{l}\text { Water-Table } \\
\text { Elevation } \\
\text { (meters } \\
\text { above } \\
\text { NGVD29) }\end{array}$ & $\begin{array}{c}\text { Depth } \\
\text { Measured } \\
\text { By }\end{array}$ \\
\hline 299-E17-16 & 15-Jun-94 & 219.63 & 97.48 & 122.15 & WHCRCRA \\
\hline 299-E17-17 & 14-Jun-94 & 219.43 & 97.25 & 122.18 & WHCRCRA \\
\hline 299-E17-18 & 17-Jun-94 & 219.66 & 97.54 & 122.11 & WHCRCRA \\
\hline 299-E17-5 & 17-Jun-94 & 219.06 & 96.87 & 122.19 & WHCRCRA \\
\hline 299-E17-9 & 17-Jun-94 & 218.74 & 96.47 & 122.26 & WHCRCRA \\
\hline 299-E18-1 & 14-Jun-94 & 219.53 & 97.23 & 122.29 & WHCRCRA \\
\hline 299-E18-2 & 14-Jun-94 & 219.83 & 97.71 & 122.12 & WHCRCRA \\
\hline 299-E18-3 & 21-Jun-94 & 220.08 & 97.60 & 122.48 & WHCRCRA \\
\hline $299-E 18-4$ & 03-Jun-94 & 219.94 & 100.05 & 119.89 & WHCRCRA \\
\hline 299-E23-2Q & 29-Jun-94 & 219.84 & 97.23 & 122.61 & PNLGW \\
\hline 299-E25-11, & 2!-Jul-94 & 207.66 & 85.28 & 122.37 & WHCRCRA \\
\hline 299-E25-18 & $21-J u l-94$ & 206.98 & 84.72 & 122.26 & WHCRCRA \\
\hline 299-E25-19 & 21-Jul-94 & 206.41 & 84.10 & 122.32 & WHCRCRA \\
\hline 299-E25-20 & 21-Jul-94 & 206.14 & 83.80 & 122.33 & WHCRCRA \\
\hline 299-E25-21 & 22-Jul-94 & 206.43 & 83.91 & 122.52 & WHCRCRA \\
\hline 299-E25-26 & 29-Jul-94 & 203.77 & 81.47 & 122.30 & WHCRCRA \\
\hline 299-E25-28 & 22-Jul-94 & 201.91 & 79.47 & 122.44 & WHCRCRA \\
\hline 299-E25-31 & 20-Jul-94 & 204.99 & 83.08 & 121.91 & WHCRCRA \\
\hline 299-E25-32P & 19-Jul-94 & 203.97 & 81.68 & 122.29 & WHCRCRA \\
\hline 299-E25-42 & 19-Jul-94 & 208.27 & 85.77 & 122.50 & WHCRCRA \\
\hline 299-E25-43 & 20-Jul-94 & 198.09 & 75.48 & 122.60 & WHCRCRA \\
\hline 299-E25-47 & 21-JuI-94 & 205.37 & 82.78 & 122.58 & WHCRCRA \\
\hline 299-E25-48 & 19-Jul-94 & 207.97 & 85.43 & 122.54 & WHCRCRA \\
\hline 299-E26-12 & 20-Jul-94 & 192.25 & 69.59 & 122.66 & WHCRCRA \\
\hline 299-E26-13 & 20-JuJ-94 & 184.41 & 62.36 & 122.05 & WHCRCRA \\
\hline 299-E26-4 & 10-May-94 & 197.44 & 74.87 & 122.57 & PNLGW \\
\hline 299-E27-10 & 02-Jun-94 & 190.34 & 67.95 & 122.39 & PNLGW \\
\hline 299-E27-10 & 02-Jun-94 & 190.34 & 67.95 & 122.39 & PNLGW \\
\hline
\end{tabular}


Table A.1. Selected Water-Level Measurements from Unconfined Aquifer Wells on the Hanford Site and Outlying Areas, June 1994

\begin{tabular}{|c|c|c|c|c|c|}
\hline Well Name & Measure Date & $\begin{array}{c}\text { Reference } \\
\text { Elevation } \\
\text { (meters } \\
\text { above } \\
\text { NGVD29) }\end{array}$ & $\begin{array}{l}\text { Depth to } \\
\text { Water } \\
\text { (meters) }\end{array}$ & $\begin{array}{l}\text { Water-Table } \\
\text { Elevation } \\
\text { (meters } \\
\text { above } \\
\text { NGVD29) }\end{array}$ & $\begin{array}{c}\text { Depth } \\
\text { Measured } \\
\text { By }\end{array}$ \\
\hline 299-E27-11 & 16-May-94 & 196.08 & 73.72 & 122.35 & WHCRCRA \\
\hline 299-E32-2 & 29-Jun-94 & 204.24 & 81.86 & 122.37 & PNLGW \\
\hline 299-E33-36 & 17-Мay-94 & 197.11 & 75.59 & 121.51 & WHCRCRA \\
\hline 299-E34-12 & 24-May-94 & 194.72 & 72.29 & 122.42 & WHCRCRA \\
\hline 299-E34-2 & 17-May-94 & 192.27 & 69.92 & 122.34 & WHCRCRA \\
\hline 299-E34-3 & 17-May-94 & 186.39 & 63.84 & 122.55 & WHCRCRA \\
\hline 299-E34-5 & 17-May-94 & 180.07 & 57.42 & 122.65 & WHCRCRA \\
\hline 299-E34-8 & 17-May-94 & 195.23 & 73.32 & 121.91 & WHCRCRA \\
\hline 299-W10-13 & 01-Jul-94 & 213.07 & 72.40 & 140.67 & PNLGW \\
\hline 299-W10-14 & 01-Jul-94 & 213.19 & 72.64 & 140.54 & PNLGW \\
\hline $299-W 10-15$ & 01-Jul-94 & 205.94 & 64.80 & 141.13 & WHCRCRA \\
\hline $299-W 10-16$ & 01-Jul-94 & 205.06 & 63.81 & 141.25 & WHCRCRA \\
\hline $299-W 10-19$ & 25-May-94 & 208.18 & 67.92 & 140.26 & WHCRCRA \\
\hline $299-W 10-20$ & 25-May-94 & 209.56 & 69.12 & 140.45 & WHCRCRA \\
\hline $299-W 10-21$ & 26-May-94 & 205.45 & 65.68 & 139.77 & WHCRCRA \\
\hline 299-W11-10 & 01-Jul-94 & 222.17 & 84.06 & 138.11 & PNLGW \\
\hline $299-W 15-15$ & 27-May-94 & 212.74 & 71.75 & 140.98 & WHCRCRA \\
\hline 299-W15-16 & 01-Jul-94 & 208.76 & 67.44 & 141.31 & WHCRCRA \\
\hline $299-W 15-17$ & 27-May-94 & 208.68 & 67.62 & 141.05 & WHCRCRA \\
\hline $299-W 15-18$ & 26-May-94 & 209.01 & 67.80 & 141.20 & WHCRCRA \\
\hline 299-W15-19 & 27-May-94 & 210.80 & 69.83 & 140.96 & WHCRCRA \\
\hline 299-W15-20 & 27-May-94 & 212.86 & 71.91 & 140.95 & WHCRCRA \\
\hline $299-W 15-22$ & 01-Jul-94 & $204.45^{\circ}$ & 62.96 & 141.49 & WHCRCRA \\
\hline 299-W15-23 & 27-May-94 & 213.21 & 72.23 & 140.97 & WHCRCRA \\
\hline 299-W15-24 & 27-May-94 & 213.17 & 72.18 & 140.99 & WHCRCRA \\
\hline 299-W18-21 & 01-Jul-94 & 203.80 & 62.78 & $141.01^{\circ}$ & PNLGW \\
\hline $299-W 18-22$ & 01-Jul-94 & 203.76 & 62.88 & 140.87 & PNLGW \\
\hline $299-W 18-23$ & 02-Jun-94 & 212.39 & 71.32 & 141.06 & WHCRCRA \\
\hline
\end{tabular}


Table A.1. Selected Water-Level Measurements from Unconfined Aquifer Wells on the Hanford Site and Outlying Areas, June 1994

\begin{tabular}{|c|c|c|c|c|c|}
\hline Well Name & Measure Date & $\begin{array}{c}\text { Reference } \\
\text { Elevation } \\
\text { (meters } \\
\text { above } \\
\text { NGVD29) }\end{array}$ & $\begin{array}{l}\text { Depth to } \\
\text { Water } \\
\text { (meters) }\end{array}$ & $\begin{array}{c}\text { Water-Table } \\
\text { Elevation } \\
\text { (meters } \\
\text { above } \\
\text { NGVD29) }\end{array}$ & $\begin{array}{c}\text { Depth } \\
\text { Measured } \\
\text { By }\end{array}$ \\
\hline 299-W18-25 & 28-Jun-94 & 203.01 & 61.75 & 141.26 & WHCRCRA \\
\hline 299-W18-26 & 03-Jun-94 & 213.07 & 71.98 & 141.08 & WHCRCRA \\
\hline 299-W18-27 & 02-Jun-94 & 210.39 & 69.28 & 141.10 & WHCRCRA \\
\hline 299-W18-28 & O2-Jun-94 & 207.26 & 66.22 & 141.04 & WHCRCRA \\
\hline 299-W18-30 & 28-Jun-94 & 205.08 & 63.90 & 141.18 & WHCRCRA \\
\hline 299-W18-31 & 28-Jun-94 & 202.44 & 61.71 & 140.72 & WHCRCRA \\
\hline 299-W18-32 & 26-May-94 & 206.24 & 42.11 & 164.13 & WHCRCRA \\
\hline 299-W18-33 & 07-Jun-94 & 204.91 & 63.05 & 141.86 & WHCRCRA \\
\hline 299-W18-5 & 01-Jul-94 & 208.18 & 67.32 & 140.86 & PNLGW \\
\hline 299-W19-1 & 03-Jun-94 & 205.37 & 63.70 & 141.66 & WHCRCRA \\
\hline 299-W19-21 & 07-Jun-94 & 206.82 & 65.54 & 141.27 & WHCRCRA \\
\hline 299-W19-27 & 07-Jun-94 & 208.38 & 67.71 & 140.66 & WHCRCRA \\
\hline 299-W19-31 & 28-Jun-94 & 205.49 & 64.15 & 141.35 & WHCRCRA \\
\hline 299-W22-20 & 01-Jul-94 & 206.09 & 67.89 & 138.19 & PNLGW \\
\hline 299-W22-22 & 02-Jun-94 & 210.33 & 71.92 & 138.40 & WHCRCRA \\
\hline 299-Ẃ22-23 & 27-Jun-944 & 210.53 & 71.92 & 138.61 & WHCRCRA \\
\hline $299-W 22-40$ & 27-Jun-94 & 210.99 & 72.45 & 138.55 & WHCRCRA \\
\hline 299-W22-4! & 27-Jun-94 & 210.84 & 72.30 & 138.54 & WHCRCRA \\
\hline 299-W22-43 & 27-Jun-94 & 210.72 & 71.94 & 138.78 & WHCRCRA \\
\hline $299-W 23-11$ & 01-Jul-94 & 202.43 & 62.29 & 140.14 & PNLGW \\
\hline 299-W26-10 & 21-Jun-94 & 204.48 & 65.57 & 138.91 & WHCRCRA \\
\hline $299-W 26-12$ & 21-Jun-94 & 205.95 & 66.92 & 139.02 & WHCRCRA \\
\hline 299-W26-7 & 16-Jun-94 & 198.73 & 59.37 & 139.35 & WHCRCRA \\
\hline 299-W26-8 & 16-Jun-94 & 203.09 & 63.99 & 139.09 & WHCRCRA \\
\hline 299-W26-9 & 16-Jun-94 & 199.39 & 60.40 & 138.98 & WHCRCRA \\
\hline 299-W9-1 & 25-May-94 & 224.86 & 84.40 & 140.46 & WHCRCRA \\
\hline $399-1-10 \mathrm{~A}$ & 23-Jun-94 & 113.89 & 8.93 & 104.96 & WHCRCRA \\
\hline $399-1-11$ & 22-Jun-94 & 115.15 & 10.22 & 104.93 & WHCRCRA \\
\hline
\end{tabular}


Table A.1. Selected Water-Level Measurements from Unconfined Aquifer Wells on the Hanford Site and Outlying Areas, June 1994

\begin{tabular}{|c|c|c|c|c|c|}
\hline Well Name & Measure Date & $\begin{array}{c}\text { Reference } \\
\text { Elevation } \\
\text { (meters } \\
\text { above } \\
\text { NGVD29) }\end{array}$ & $\begin{array}{l}\text { Depth to } \\
\text { Water } \\
\text { (meters) }\end{array}$ & $\begin{array}{l}\text { Water-Table } \\
\text { Elevation } \\
\text { (meters } \\
\text { above } \\
\text { NGVD29) }\end{array}$ & $\begin{array}{c}\text { Depth } \\
\text { Measured } \\
\text { By }\end{array}$ \\
\hline $399-1-12$ & 22-Jun-94 & 117.18 & 12.43 & 104.74 & WHCRCRA \\
\hline $399-1-14 A$ & 22-Jun-94 & 116.81 & 11.88 & 104.92 & WHCRCRA \\
\hline $399-1-16 A$ & 23-Jun-94 & 116.29 & 11.49 & 104.79 & WHCRCRA \\
\hline $399-1-17 A$ & 22-Jun-94 & 115.05 & 10.17 & 104.88 & WHCRCRA \\
\hline $399-1-17 B$ & 22-Jun-94 & 115.18 & 10.12 & 105.05 & WHCRCRA \\
\hline $399-1-18 \mathrm{~A}$ & 30-Jun-94 & 119.13 & 14.01 & 105.11 & PNLGW \\
\hline $399-1-18 B$ & 30-Jun-94 & 118.85 & 13.65 & 105.21 & PNLGW \\
\hline $399-2-1$ & 23-Jun-94 & 114.39 & 9.74 & 104.65 & WHCRCRA \\
\hline $399-3-10$ & 23-Jun-94 & 117.47 & 12.80 & 104.66 & WHCRCRA \\
\hline $399-4-1$ & 10-Mar-94 & 120.60 & 16.63 & 103.98 & PNLGW \\
\hline $399-8-1$ & 28-Jun-94 & 120.76 & 15.91 & 104.85 & PNLGW \\
\hline $399-8-2$ & 28-Jun-94 & 121.34 & 16.32 & 105.02 & PNLGW \\
\hline 699-S11-E12A & 01-Jul-94 & 111.51 & 4.88 & 106.63 & PNLGW \\
\hline $699-\$ 12-29$ & 29-Jun-94 & 148.65 & 25.48 & 123.16 & PNLGW \\
\hline $699-\$ 12-3$ & 01-Jul-94 & 132.75 & 16.62 & 116.13 & PNLGW \\
\hline 699-S18-E2A & 01-Jul-94 & 132.54 & 22.99 & 109.55 & PNLGW \\
\hline 699-S18-E2B & 01-Jul-94 & 133.38 & 22.81 & 110.57 & PNLGW \\
\hline 699-S19-E13 & 30-Jun-94 & 120.25 & 15.00 & 105.24 & PNLGW \\
\hline 699-\$19-11 & 01-Jul-94 & 147.44 & 28.54 & 118.91 & PNLGW \\
\hline 699-S22-E9A & 28-Jun-94 & 114.05 & 8.71 & 105.35 & PNLGW \\
\hline 699-S22-E9B & 28-Jun-94 & 113.91 & 8.36 & 105.55 & PNLGW \\
\hline 699-S27-E 14 & 28-Jun-94 & 121.85 & 17.27 & 104.58 & PNLGW \\
\hline 699-S27-E9A & 28-Jun-94 & 118.95 & 12.73 & 106.22 & PNLGW \\
\hline 699-S28-E0 & 27-Jun-94 & 136.69 & 21.98 & 114.71 & PNLGW \\
\hline 699-S29-E12 & 28-Jun-94 & 118.25 & 12.88 & 105.37 & PNLGW \\
\hline 699-S31-E10B & 28-Mar-94 & 116.96 & 9.95 & 107.00 & PNLGW \\
\hline 699-S31-E10E & 28-Mar-94 & 116.86 & 10.02 & 106.85 & PNLGW \\
\hline $699-\$ 31-1$ & 27-Jun-94 & 140.21 & 25.04 & 115.17 & PNLGW \\
\hline
\end{tabular}


Table A.1. Selected Water-Level Measurements from Unconfined Aquifer Wells on the Hanford Site and Outlying Areas, June 1994

\begin{tabular}{|c|c|c|c|c|c|}
\hline Well Name & Measure Date & $\begin{array}{l}\text { Reference } \\
\text { Elevation } \\
\text { (meters } \\
\text { above } \\
\text { NGVD29) }\end{array}$ & $\begin{array}{l}\text { Depth to } \\
\text { Water } \\
\text { (meters) }\end{array}$ & $\begin{array}{l}\text { Water-Table } \\
\text { Elevation } \\
\text { (meters } \\
\text { above } \\
\text { NGVD29) }\end{array}$ & $\begin{array}{c}\text { Depth } \\
\text { Measured } \\
\text { By }\end{array}$ \\
\hline 699-S32-E13B & 27-Jun-94 & 120.31 & 14.37 & 105.94 & PNLGW \\
\hline 699-S32-E8 & 07-Mar-94 & 114.54 & 4.37 & 110.17 & PNLGW \\
\hline 699-S34-E10 & 29-Jun-94 & 116.55 & 8.38 & 108.16 & PNLGW \\
\hline 699-S34-E15 & 30-Jun-94 & 124.37 & 16.79 & 107.58 & PNLGW \\
\hline 699-S3-E12 & 30-Jun-94 & 121.28 & 13.36 & 107.92 & PNLGW \\
\hline $699-\$ 3-25$ & 01-Jul-94 & 159.56 & 38.08 & 121.48 & PNLGW \\
\hline 699-S40-E14 & 30-Jun-94 & 122.79 & 14.18 & 108.61 & PNLGW \\
\hline 699-S42-E8A & 27-May-94 & 109.66 & 1.04 & 108.62 & PNLGW \\
\hline 699-S42-E8B & 27-May-94 & 109.39 & 0.73 & 108.66 & PNLGW \\
\hline 699-S43-E12 & 30-Jun-94 & 123.63 & 15.63 & 107.99 & PNLGW \\
\hline 699-S43-E7A & 27-May-94 & 110.48 & 1.62 & 108.86 & PNLGW \\
\hline 699-S6-EAB & 29-Jun-94 & 128.43 & 15.42 & 113.01 & PNLGW \\
\hline 699-S6-E4D & 29-Jun-94 & 131.21 & 17.72 & 113.48 & PNLGW \\
\hline 699-\$7-34 & 29-Jun-94 & 160.67 & 36.16 & 124.51 & PNLGW \\
\hline $699-\$ 8-19$ & 29-Jun-94 & 153.56 & 32.71 & 120.85 & PNLGW \\
\hline $699-10-\mathrm{E} 12 \mathrm{Q}$ & 24-Jun-94 & 131.33 & 22.45 & 108.88 & PNLGW \\
\hline $699-10-54 A$ & 29-Jun-94 & 157.40 & 31.33 & 126.07 & PNLGW \\
\hline $699-11-45 A$ & 29-Jun-94 & 176.35 & 50.72 & 125.64 & PNLGW \\
\hline $699-14-38$ & 29-Jun-94 & 156.94 & 33.59 & 123.35 & PNLGW \\
\hline $699-14-47$ & 29-Jun-94 & 178.99 & 53.35 & 125.64 & PNLGW \\
\hline $699-15-26$ & 01-Jul-94 & 159.66 & 37.84 & 121.82 & PNLGW \\
\hline $699-17-5$ & $01-J u l-94$ & 132.04 & 13.96 & 118.08 & PNLGW \\
\hline $699-17-70$ & 27-Jun-94 & 171.66 & 27.03 & 144.63 & PNLGW \\
\hline $699-19-58$ & 29-Jun-94 & 174.67 & 47.08 & 127.58 & PNLGW \\
\hline $699-19-88$ & 27-Jun-94 & 196.43 & 39.79 & 156.64 & PNLGW \\
\hline $699-1-18$ & 29-Jun-94 & 163.88 & 42.79 & 121.08 & PNLGW \\
\hline 699-20-E12 & 02-Mar-94 & 133.27 & 24.38 & 108.90 & PNLGW \\
\hline $699-20-\mathrm{E} 120$ & 29-Mar-94 & 133.35 & 24.37 & 108.98 & PNLGW \\
\hline
\end{tabular}


Table A.1. Selected Water-Level Measurements from Unconfined Aquifer Wells on the Hanford Site and Outlying Areas, June 1994

\begin{tabular}{|c|c|c|c|c|c|}
\hline Well Name & Measure Date & $\begin{array}{c}\text { Reference } \\
\text { Elevation } \\
\text { (meters } \\
\text { above } \\
\text { NGVD29) }\end{array}$ & $\begin{array}{l}\text { Depth to } \\
\text { Water } \\
\text { (meters) }\end{array}$ & $\begin{array}{l}\text { Water-Table } \\
\text { Elevation } \\
\text { (meters } \\
\text { above } \\
\text { NGVD29) }\end{array}$ & $\begin{array}{c}\text { Depth } \\
\text { Measured } \\
\text { By }\end{array}$ \\
\hline 699-20-E12Q & 29-Mar-94 & 133.34 & 24.52 & 108.82 & PNLGW \\
\hline $699-20-20$ & 27-Jun-94 & 154.10 & 32.30 & 121.80 & PNLGW \\
\hline 699-20-39 & 29-Jun-94 & 164.59 & 42.17 & 122.42 & PNLGW \\
\hline $699-20-41 P$ & 23-Jun-94 & 163.46 & 41.51 & 121.95 & PNLGW \\
\hline $699-20-41 Q$ & 23-Jun-94 & 163.46 & 42.07 & 121.39 & PNLGW \\
\hline $699-20-41 \mathrm{R}$ & 23-Jun-94 & 163.46 & 42.15 & 121.31 & PNLGW \\
\hline $699-21-17$ & 27-Jun-94 & 160.72 & 40.09 & 120.63 & PNLGW \\
\hline $699-22-35$ & 07-Jun-94 & 162.75 & 40.54 & 122.21 & WHCRCRA \\
\hline $699-23-34 \mathrm{~A}$ & 06-Jun-94 & 162.42 & 40.14 & 122.27 & WHCRCRA \\
\hline 699-23-34B & 02-Jun-94 & 162.61 & 40.33 & 122.28 & WHCRCRA \\
\hline $699-24-33$ & 06-Jun-94 & 159.78 & 37.57 & 122.21 & WHCRCRA \\
\hline $699-24-34 A$ & 06-Jun-94 & 162.73 & 40.45 & 122.27 & WHCRCRA \\
\hline $699-24-34 \mathrm{~B}$ & 06-Jun-94 & 162.61 & 40.31 & 122.29 & WHCRCRA \\
\hline $699-24-34 \mathrm{C}$ & 01-Jun-94 & 162.33 & 40.06 & 122.27 & WHCRCRA \\
\hline $699-24-35$ & 01-Jun-94 & 164.23 & 41.95 & 122.27 & WHCRCRA \\
\hline $699-24-46$ & 03-Mar-94 & 180.28 & 57.29 & 122.99 & PNLGW \\
\hline $699-25-34 C$ & 21-Jun-94 & .163 .21 & 40.99 & 122.21 & WHCRCRA \\
\hline $699-25-55$ & 29-Jun-94 & 206.21 & 80.56 & 125.66 & PNLGW \\
\hline $699-25-70$ & 27-Jan-94 & 191.96 & 56.14 & 135.82 & PNLGW \\
\hline $699-26-15 A$ & 28-Jun-94 & 134.92 & 13.91 & 121.01 & PNLGW \\
\hline $699-26-35 A$ & 01-Jun-94 & 162.36 & 40.07 & 122.28 & WHCRCRA \\
\hline $699-27-8$ & 01-Jul-94 & 141.94 & 22.25 & 119.69 & PNLGW \\
\hline $699-28-40$ & 27-Jun-94 & 170.52 & 48.10 & 122.42 & PNLGW \\
\hline $699-29-78$ & 01-Jul-94 & 197.22 & 57.28 & 139.94 & PNLGW \\
\hline $699-2-3$ & 01-Jun-94 & 145.43 & 26.63 & 118.79 & WHCRCRA \\
\hline $699-2-33 B$ & 29-Jun-94 & 163.37 & 39.72 & 123.66 & PNLGW \\
\hline $699-2-7$ & 01-Jun-94 & 156.12 & 36.50 & 119.61 & WHCRCRA \\
\hline $699-31-31$ & 27-Jun-94 & 161.34 & 39.05 & 122.29 & PNLGW \\
\hline
\end{tabular}


Table A.1. Selected Water-Level Measurements from Unconfined Aquifer Wells on the Hanford Site and Outlying Areas, June 1994

\begin{tabular}{|c|c|c|c|c|c|}
\hline Well Name & Measure Date & $\begin{array}{c}\text { Reference } \\
\text { Elevation } \\
\text { (meters } \\
\text { above } \\
\text { NGVD29) }\end{array}$ & $\begin{array}{l}\text { Depth to } \\
\text { Water } \\
\text { (meters) }\end{array}$ & $\begin{array}{c}\text { Water-Table } \\
\text { Elevation } \\
\text { (meters } \\
\text { above } \\
\text { NGVD29) }\end{array}$ & $\begin{array}{c}\text { Depth } \\
\text { Measured } \\
\text { By }\end{array}$ \\
\hline $699-32-43$ & 27-Jun-94 & 157.47 & 35.01 & 122.46 & PNLGW \\
\hline $699-32-62$ & 19-Aug-94 & 215.52 & 85.18 & 130.34 & PNLGW \\
\hline 699-32-70B & 03-Mar-94 & 203.21 & 66.63 & 136.57 & PNLGW \\
\hline $699-32-72 B$ & 03-Aug-94 & 204.06 & 66.98 & 137.08 & WHCRCRA \\
\hline $699-34-61$ & 06-May-94 & 220.77 & 93.57 & 127.20 & WHCRCRA \\
\hline $699-34-88$ & 01-Jul-94 & 192.88 & 50.41 & 142.48 & PNLGW \\
\hline $699-35-66 \mathrm{~A}$ & 01-Jul-94 & 221.18 & 87.87 & 133.31 & PNLGW \\
\hline $699-35-70$ & 01-Jul-94 & 211.45 & 74.79 & 136.66 & PNLGW \\
\hline 699-35-9 & 29-Jun-94 & 152.35 & 35.21 & 117.14 & PNLGW \\
\hline $699-36-93$ & 14-Feb-94 & 196.53 & 53.27 & 143.26 & PNLGW \\
\hline $699-37-\mathrm{E} 4$ & 06-May-94 & 117.99 & 8.63 & 109.35 & PNLGW \\
\hline $699-37-43$ & 16-Dec-94 & 210.36 & 87.74 & 122.62 & WHCRCRA \\
\hline $699-38-61$ & 06-May-94 & 227.13 & 103.93 & 123.20 & WHCRCRA \\
\hline $699-38-65$ & $16-F e b-94$ & 229.62 & 98.86 & 130.76 & PNLGW \\
\hline $699-3-45$ & 27-Jun-94 & 153.78 & 28.15 & 125.64 & PNLGW \\
\hline $699-40-1$ & 29-Jun-94 & 133.72 & 23.01 & 110.71 & PNLGW \\
\hline $699-40-33 \mathrm{~A}$ & 16-Feb-94 & 157.90 & 32.69 & 125.21 & PNLGW \\
\hline $699-40-36$ & 01-Aug-94 & 161.22 & 36.01 & 125.21 & WHCRCRA \\
\hline $699-41-35$ & 03-Aug-94 & 158.61 & 33.06 & 125.55 & WHCRCRA \\
\hline $699-41-42$ & 01-Aug-94 & 196.26 & 70.90 & 125.36 & WHCRCRA \\
\hline 699-42-E9A & 21-Aug-94 & 117.96 & 9.33 & 108.63 & PNLGW \\
\hline $699-42-12 \mathrm{~A}$ & 29-Jun-94 & 156.75 & 42.49 & 114.26 & PNLGW \\
\hline 699.42 .37 & 29-Jul-94 & 158.32 & 32.37 & 125.95 & WHCRCRA \\
\hline $699-42-40 \mathrm{~B}$ & 27-Jun-94 & 166.56 & 37.91 & 128.65 & PNLGW \\
\hline $699-42-41$ & 25-Jul-94 & 172.91 & 44.75 & 128.17 & WHCRCRA \\
\hline $699-42-42 B$ & 29-Jul-94 & 177.77 & 50.89 & 126.88 & WHCRCRA \\
\hline $699-43-104$ & 19-Aug-94 & 233.50 & 83.25 & 150.25 & PNLGW \\
\hline 699-43-104P & 02-Dec-94 & 233.50 & 83.38 & 150.12 & PNLGW \\
\hline
\end{tabular}


Table A.1. Selected Water-Level Measurements from Unconfined Aquifer Wells on the Hanford Site and Outlying Areas, June 1994

\begin{tabular}{|c|c|c|c|c|c|}
\hline Well Name & Measure Date & $\begin{array}{c}\text { Reference } \\
\text { Elevation } \\
\text { (meters } \\
\text { above } \\
\text { NGVD29) }\end{array}$ & $\begin{array}{l}\text { Depth to } \\
\text { Water } \\
\text { (meters) }\end{array}$ & $\begin{array}{l}\text { Water-Table } \\
\text { Elevation } \\
\text { (meters } \\
\text { above } \\
\text { NGVD29) }\end{array}$ & $\begin{array}{c}\text { Depth } \\
\text { Measured } \\
\text { By }\end{array}$ \\
\hline $699-43-40$ & 29-Jul-94 & 165.26 & 37.14 & 128.12 & WHCRCRA \\
\hline $699-43-42 \mathrm{~J}$ & 28-Jul-94 & 177.30 & 49.93 & 127.36 & WHCRCRA \\
\hline $699-43-43$ & 27-Jun-94 & 176.59 & 50.29 & 126.30 & PNLGW \\
\hline $699-43-45$ & 19-Jul-94 & 182.17 & 59.45 & 122.72 & WHCRCRA \\
\hline $699-43-89$ & 01-Jul-94 & 196.34 & 54.72 & 141.62 & PNLGW \\
\hline $699-44-39 B$ & 28-Jul-94 & 156.49 & 28.34 & 128.14 & WHCRCRA \\
\hline $699-44-42$ & 28-Jul-94 & 176.55 & 48.58 & 127.97 & WHCRCRA \\
\hline $699-44-64$ & 10-May-94 & 221.16 & 97.34 & 123.83 & PNLGW \\
\hline $699-45-2$ & 10-May-94 & 115.79 & 6.83 & 108.96 & PNLGW \\
\hline $699-45-42$ & 27-Jun-94 & 175.97 & 49.10 & 126.87 & PNLGW \\
\hline $699-45-69 A$ & 15-Nov-94 & 221.12 & 85.58 & 135.54 & WHCRCRA \\
\hline $699-46-21 B$ & 28-Jun-94 & 159.11 & 40.15 & 118.96 & PNLGW \\
\hline $699-47-46 A$ & 27-Jun-94 & 176.83 & 53.99 & 122.84 & PNLGW \\
\hline $699-47-60$ & 01-Jul-94 & 198.58 & 76.18 & 122.40 & PNLGW \\
\hline $699-48-50$ & 27-Jun-94 & 174.97 & 52.09 & 122.88 & PNLGW \\
\hline $699-48-71$ & 01-Jul-94 & 209.75 & 74.45 & 135.30 & PNLGW \\
\hline $699-48-77 \mathrm{C}$ & 23-May-94 & 205.52 & 67.73 & 137.79 & WHCRCRA \\
\hline 699-48-77D & 23-May-94 & 205.40 & 67.11 & 138.28 & WHCRCRA \\
\hline 699-49-13E & 28-Jun-94 & 125.80 & 15.72 & 110.08 & PNLGW \\
\hline $699-50-30$ & 28-Jun-94 & 161.19 & 41.20 & 119.99 & PNLGW \\
\hline $699-50-42$ & 28-Jun- 94 & 142.29 & 17.31 & 124.99 & PNLGW \\
\hline $699-51-63$ & 01-Jul-94 & 174.30 & 51.20 & 123.10 & PNLGW \\
\hline $699-52-19$ & 29-Jun-94 & 125.30 & 15.17 & 110.12 & PNLGW \\
\hline $699-52-54$ & 28-Jun-94 & 173.26 & 50.96 & 122.30 & PNLGW \\
\hline $699-53-35$ & 28-Jun-94 & 161.85 & 39.69 & 122.16 & PNLGW \\
\hline $699-53-47 \mathrm{~A}$ & 27-Jun-94 & 133.59 & 10.08 & 123.51 & PNLGW \\
\hline $699-54-42$ & 28-Jun-94 & 155.90 & 35.10 & 120.80 & PNLGW \\
\hline $699-54-45 \mathrm{~A}$ & 28-Jun-94 & 150.66 & 29.38 & 121.28 & PNLGW \\
\hline
\end{tabular}


Table A.1. Selected Water-Level Measurements from Unconfined Aquifer Wells on the Hanford Site and Outlying Areas, June 1994

\begin{tabular}{|c|c|c|c|c|c|}
\hline Well Name & Measure Date & $\begin{array}{c}\text { Reference } \\
\text { Elevation } \\
\text { (meters } \\
\text { above } \\
\text { NGVD29) }\end{array}$ & $\begin{array}{c}\text { Depth to } \\
\text { Water } \\
\text { (meters) }\end{array}$ & $\begin{array}{l}\text { Water-Table } \\
\text { Elevation } \\
\text { (meters } \\
\text { above } \\
\text { NGVD29) }\end{array}$ & $\begin{array}{c}\text { Depth } \\
\text { Measured } \\
\text { By }\end{array}$ \\
\hline $699-54-48$ & 27-Jun-94 & 139.30 & 17.11 & 122.19 & PNLGW \\
\hline $699-55-44$ & 28-Jun-94 & 158.40 & 37.70 & 120.69 & PNLGW \\
\hline $699-55-50 \mathrm{C}$ & 28-Jun-94 & 135.46 & 13.28 & 122.19 & PNLGW \\
\hline $699-55-70$ & 15-Dec-94 & 173.44 & 42.07 & 131.38 & PNLGW \\
\hline $699-55-76$ & 01-Jul-94 & 177.77 & 42.70 & 135.08 & PNLGW \\
\hline $699-55-89$ & 30-Jun-94 & 188.19 & 49.89 . & 138.31 & PNLGW \\
\hline $699-57-83 A$ & 15-Dec-94 & 176.16 & 44.48 & 131.68 & PNLGW \\
\hline $699-59-58$ & 28-Jun-94 & 151.80 & 29.58 & 122.22 & PNLGW \\
\hline $699-59-80 \mathrm{~B}$ & 30-Jun-94 & 177.78 & 46.86 & 130.91 & PNLGW \\
\hline $699-60-57$ & 28-Jun-94 & 143.13 & 20.90 & 122.22 & PNLGW \\
\hline $699-60-60$ & $30-J u n-94$ & 156.07 & 33.90 & 122.17 & PNLGW \\
\hline $699-61-37$ & 28-Jun-94 & 135.01 & 18.83 & 116.17 & PNLGW \\
\hline $699-61-41$ & 28-Juin-94 & 130.74 & 10.22 & 120.51 & PNLGW \\
\hline $699-61-62$ & 30-Jun-94 & 151.64 & 29.49 & 122.15 & PNLGW \\
\hline $699-61-66$ & 20-Jan-94 & 159.16 & 37.22 & 121.94 & PNLGW \\
\hline $699-62-43 A$ & 28-Jun-94 & 131.77 & 11.19 & 120.58 & PNLGW \\
\hline $699-63-25 A$ & 19-Jan-94 & 120.44 & $\cdot 10.45$ & 109.99 & PNLGW \\
\hline $699-63-51$ & 28-Jun-94 & 129.40 & 7.93 & 121.47 & PNLGW \\
\hline $699-63-58$ & 08-Mar-94 & 149.93 & 28.18 & 121.75 & PNLGW \\
\hline $699-63-90$ & 30-Jun-94 & 155.37 & 33.46 & 121.90 & PNLGW \\
\hline $699-64-62$ & 04-Mar-94 & 152.48 & 30.78 & 121.69 & PNLGW \\
\hline $699-65-50$ & 28-Jun-94 & 142.36 & 20.90 & 121.46 & PNLGW \\
\hline $699-66-23$ & 29-Jun-94 & 118.57 & 7.72 & 110.85 & PNLGW \\
\hline $699-66-39$. & 28-3un-94 & 138.31 & 14.39 & 123.92 & PNLGW \\
\hline $699-66-58$ & 04-Mar-94 & 153.42 & 31.77 & 121.64 & PNLGW \\
\hline $699-66-91$ & 30-Jun-94 & 142.57 & 20.53 & 122.04 & PNLGW \\
\hline $699-67-98$ & $30-J u n-94$ & 138.83 & 16.63 & 122.19 & PNLGW \\
\hline $699-68-105$ & 30-Jun-94 & 137.72 & 16.19 & 121.54 & PNLGW \\
\hline
\end{tabular}


Table A.1. Selected Water-Level Measurements from Unconfined Aquifer Wells on the Hanford Site and Outlying Areas, June 1994

\begin{tabular}{|c|c|c|c|c|c|}
\hline Well Name & Measure Date & $\begin{array}{c}\text { Reference } \\
\text { Elevation } \\
\text { (meters } \\
\text { above } \\
\text { NGVD29) }\end{array}$ & $\begin{array}{l}\text { Depth to } \\
\text { Water } \\
\text { (meters) }\end{array}$ & $\begin{array}{l}\text { Water-Table } \\
\text { Elevation } \\
\text { (meters } \\
\text { above } \\
\text { NGVD29) }\end{array}$ & $\begin{array}{c}\text { Depth } \\
\text { Measured } \\
\text { By }\end{array}$ \\
\hline $699-69-38$ & 29-Jun-94 & 129.27 & 6.49 & 122.77 & PNLGW \\
\hline $699-70-68$ & 01-Jul-94 & 160.39 & 39.03 & 121.36 & PNLGW \\
\hline $699-72-92$ & 30-Jun-94 & 137.84 & 15.46 & 122.38 & PNLGW \\
\hline $699-77-54$ & 29-Jun-94 & 146.48 & 25.79 & 120.69 & PNLGW \\
\hline $699-81-38$ & 29-Jun-94 & 123.89 & 8.41 & 115.48 & PNLGW \\
\hline $699-83-47$ & 29-Jun-94 & 132.67 & 14.35 & 118.32 & PNLGW \\
\hline $699-87-55$ & 08-Mar-94 & 139.79 & 22.21 & 117.58 & PNLGW \\
\hline $699-88-41$ & 29-Jun-94 & 126.81 & 10.39 & 116.42 & PNLGW \\
\hline 699-8-17 & 29-Jun-94 & 159.24 & 38.13 & 121.11 & PNLGW \\
\hline $699-8-25$ & 29-Jun-94 & 155.24 & 33.75 & 121.48 & PNLGW \\
\hline 699-8-32 & 29-Jun-94 & 168.98 & 47.29 & 121.69 & PNLGW \\
\hline $699-90-45$ & 04-Mar-94 & 128.50 & 11.52 & 116.99 & PNLGW \\
\hline $699-97-43$ & 30-Apr-94 & 128.58 & 13.27 & 115.31 & PNLGW \\
\hline 699-9-E2 & 01-Jul-94 & 127.43 & 13.96 & 113.48 & PNLGW \\
\hline
\end{tabular}




\section{Appendix B}

Water-Level Measurements from Unconfined Aquifer Wells on the Hanford Site, December 1994 


\section{Appendix B}

Table B.1. Water-Level Measurements from Unconfined Aquifer Wells on the Hanford Site, December 1994

Well Name

$1199-41-15$

199-H3-1 ·

199-H3-2A

199-H4-12C

199-H4-12C

199-H4-13

199-H4-14

199-H4-15A

199-H4-18

199-H4-3

199-H4-4

199-H4-45

199-H4-46

199.H4-47

199-H4-49

199-H4-5

199-H4-6

199-H4-7

199-H4-8

199-H6-1

199-K-109A

199-K-110A

199-K-18

199-K-19

199-K-20

Measure
Date
.

20-Dec-94
16-Dec-94
02-Dec-94
05-Dec-94
05-Dec-94
21-Dec-94
05-Dec-94
21-Dec-94
05-Dec-94
05-Dec-94
05-Dec-94
21-Dec-94
20-Dec-94
20-Dec-94
20-Dec-94
05-Dec-94
02-Dec-94
05-Dec-94
02-Dec-94
21-Dec-94
28-Dec-94
01-Dec-94
01-Dec-94 94
01-Dec-

Reference

Elevation

(meters

above

NGVD29)

$$
121.60
$$

128.63

127.52

126.04

126.04

127.47

128.20

124.12

128.57

128.10

126.10

126.99

129.29

129.51

129.49

126.86

127.89

128.20

128.02

127.44

143.74

143.67

124.66

128.68

128.80

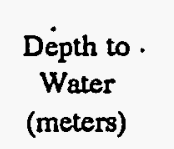

Water-Table
Elevation
(meters
above

NGVD29)

13.69

14.17

13.19

12.36

12.36

14.27

13.76

10.39

14.77

14.77

12:47

13.11

15.08

15.24

15.04

12.88

13.72

14.25

14.19

13.53

23.47

22.99

7.21

10.90

11.13
107.90

114.46

114.33

113.68

113.68

113.20

114.43

113.72

113.80

113.34

113.62

113.88

114.21

114.28

114.45

113.98

114.17

113.95

113.83

113.90

120.27

120.68

117.45

117.77

117.67
Depth

Measured By

PNLGW
PNLGW

WHCRCRA

PNLGW

WHCRCRA

HEISPROD

WHCRCRA

HEISPROD

WHCRCRA

WHCRCRA

WHCRCRA

HEISPROD

HEISPROD

HEISPROD

HEISPROD

WHCRCRA

WHCRCRA

WHCRCRA

WHCRCRA

HEISPROD

WHCRCRA

WHCRCRA

WHCRCRA

PNLGW

PNLGW 
Table B.1. Water-Level Measurements from Unconfined Aquifer Wells on the Hanford Site, December 1994

\begin{tabular}{|c|c|c|c|c|c|}
\hline Well Name & $\begin{array}{l}\text { Measure } \\
\text { Date }\end{array}$ & $\begin{array}{c}\text { Reference } \\
\text { Elevation } \\
\text { (mneters } \\
\text { above } \\
\text { NGVD29) }\end{array}$ & $\begin{array}{c}\text { Depth to } \\
\text { Water } \\
\text { (meters) } \\
.\end{array}$ & $\begin{array}{c}\text { Water-Table } \\
\text { Elevation } \\
\text { (meters } \\
\text { above } \\
\text { NGVD29) }\end{array}$ & $\begin{array}{c}\text { Depth } \\
\text { Measured } \\
\text { By }\end{array}$ \\
\hline $199-\mathrm{K}-32 \mathrm{~A}$ & 20-Dec-94 & 135.34 & 17.15 & 118.19 & WHCRCRA \\
\hline $199-\mathrm{K}-34$ & 19-Dec-94 & 142.67 & 23.79 & 118.88 & WHCRCRA \\
\hline $199-\mathrm{N}-17$ & 01-Dec-94 & 140.57 & 23.55 & 117.03 & PNLGW \\
\hline $199-\mathrm{N}-27$ & 16-Dec-94 & 136.88 & 19.10 & 117.78 & PNLGW \\
\hline $199-N-51$ & 15-Dec-94 & 140.87 & 24.03 & 116.84 & PNLGW \\
\hline $199-\mathrm{N}-64$ & 28-Dec-94 & 1.38 .57 & 20.89 & 117.68 & PNLGW \\
\hline 299-E17-14 & 06-Dec-94 & 220.12 & 97.80 & 122.32 & WHCRCRA \\
\hline 299-E17-15 & 06-Dec-94 & 220.00 & 98.04 & 121.96 & WHCRCRA \\
\hline 299-E17-16 & 06-Dec-94 & 219.63 & 97.38 & 122.26 & WHCRCRA \\
\hline 299-E17-17 & 06-Dec-94 & 219.43 & 97.58 & 121.86 & WHCRCRA \\
\hline 299-E17-18 & 07-Dec-94 & 219.65 & 97.77 & 121.89 & WHCRCRA \\
\hline 299-E17-9 & 07-Dec-94 & 218.74 & 96.58 & 122.15 & WHCRCRA \\
\hline 299-E18-1 & 01-Dec-94 & 219.53 & 97.23 & 122.30 & WHCRCRA \\
\hline 299-E 18-2 & 01-Dec-94 & 219.83 & 97.55 & 122.27 & WHCRCRA \\
\hline 299-E18-3 & 01-Dec-94 & 220.08 & 97.78 & 122.30 & WHCRCRA \\
\hline 299-E18-4 & 01-Dec-94 & 219.94 & 97.54 & 122.40 & WHCRCRA \\
\hline 299-E23-1 & 20-Dec-94 & 217.35 & 94.99 & 122.37 & PNLGW \\
\hline 299-E23-2 & 20-Dec-94 & 219.65 & 97.25 & 122.40 & PNLGW \\
\hline 299-E24-1 & 28-Dec-94 & 218.30 & 96.88 & 121.42 & PNLGW \\
\hline 299-E24-12 & 02-Dec-94 & 218.32 & 95.98 & 122.34 & PNLGW \\
\hline 299-E24-4 & 15-Dec-94 & 212.35 & 89.95 & 122.40 & PNLGW \\
\hline 299-E27-10 & 13-Dec-94 & 190.34 & 67.97 & 122.37 & WHCRCRA \\
\hline 299-E28-2 & 13-Dec-94 & 207.54 & 85.14 & 122.40 & WHCRCRA \\
\hline 299-E28-2 & 13-Dec-94 & 208.55 & 85.14 & 122.40 & WHCRCRA \\
\hline 299-E28-2 & 13-Dec-94 & 207.52 & 85.14 & 122.40 & WHCRCRA \\
\hline 299-E28-26 & 12-Dec-94 & 209.48 & 87.16 & 122.32 & WHCRCRA \\
\hline 299-E28-27 & 12-Dec-94 & 207.38 & 85.06 & 122.31 & WHCRCRA \\
\hline 299-E28-28 & 12-Dec-94 & 209.26 & 87.02 & 122.24 & WHCRCRA \\
\hline
\end{tabular}


Table B.1. Water-Level Measurements from Unconfined Aquifer Wells on the Hanford Site, December 1994

\begin{tabular}{|c|c|c|c|c|c|}
\hline Well Name & $\begin{array}{l}\text { Measure } \\
\text { Date }\end{array}$ & $\begin{array}{c}\text { Reference } \\
\text { Elevation } \\
\text { (meters } \\
\text { above } \\
\text { NGVD29) }\end{array}$ & $\begin{array}{l}\text { Depth to } \\
\text { Water } \\
\text { (meters) }\end{array}$ & $\begin{array}{l}\text { Water-Table } \\
\text { Elevation } \\
\text { (meters } \\
\text { above } \\
\text { NGVD29) }\end{array}$ & $\begin{array}{l}\text { Depth } \\
\text { Measured } \\
\text { By }\end{array}$ \\
\hline 299-E28-5 & 12-Dec-94 & 204.85 & 82.54 & 122.30 & WHCRCRA \\
\hline 299-E28-6 & 09-Dec-94 & 213.39 & 91.00 & 122.39 & WHCRCRA \\
\hline 299-E32-10 & 13-Dec-94 & 194.44 & 72.15 & 122.30 & WHCRCRA \\
\hline 299-E32-2 & 15-Dec-94 & 204.23 & 81.93 & 122.30 & PNLGW \\
\hline 299-E32-2 & 13-Dec-94 & 204.23 & 82.04 & 122.20 & WHCRCRA \\
\hline 299-E32-3 & 13-Dec-94 & 206.26 & 83.91 & 122.29 & WHCRCRA \\
\hline 299-E32-3 & 13-Dec-94 & 206.20 & 83.91 & 122.29 & WHCRCRA \\
\hline 299-E32-3 & 13-Dec-94 & 207.30 & 83.91 & 122.29 & WHCRCRA \\
\hline 299-E32-4 & 13-Dec-94 & 209.13 & 86.85 & 122.21 & WHCRCRA \\
\hline 299-E32-4 & 13-Dec-94 & 209.06 & 86.85 & 122.21 & WHCRCRA \\
\hline 299-E32-4 & 13-Dec-94 & 210.16 & 86.85 & 122.21 & WHCRCRA \\
\hline 299-E32-5 & 13-Dec-94 & 207.92 & 85.72 & 122.20 & WHCRCRA \\
\hline 299-E32-6 & 12-Dec-94 & 203.44 & 81.06 & 122.38 & WHCRCRA \\
\hline 299-E32-7 & 12-Dec-94 & 200.69 & 78.33 & 122.36 & WHCRCRA \\
\hline 299-E32-8 & 12-Dec-94 & 196.78 & 74.43 & 122.35 & WHCRCRA \\
\hline 299-E32-9 & 13-Dec-94 & 196.09 & 73.75 & 122.34 & WHCRCRA \\
\hline 299-E33-28 & 12-Dec-94 & 202.46 & 80.16 & 122.30 & WHCRCRA \\
\hline 299-E33-29 & 12-Dec-94 & 205.37 & 83.05 & 122.32 & WHCRCRA \\
\hline 299-E33-30 & 14-Dec-94 & 202.30 & 79.96 & 122.33 & WHCRCRA \\
\hline 299-E33-34 & 14-Dec-94 & 193.04 & 70.65 & 122.39 & WHCRCRA \\
\hline 299-E33-35 & 12-Dec-94 & 195.99 & 73.76 & 122.23 & WHCRCRA \\
\hline 299-E34-2 & 15-Dec-94 & 192.27 & 69.85 & 122.41 & PNLGW \\
\hline 299-W10-13 & 20-Dec-94 & 213.07 & 78.58 & 134.49 & PNLGW \\
\hline 299-W10-13 & 16-Dec-94 & 213.07 & 72.58 & 140.49 & PNLGW \\
\hline 299-W10-13 & 14-Dec-94 & 213.07 & 72.47 & 140.60 & WHCRCRA \\
\hline 299-W10-19 & 14-Dec-94 & 208.18 & 68.11 & 140.07 & WHCRCRA \\
\hline 299-W10-20 & 15-Dec-94 & 209.56 & 67.80 & 141.77 & WHCRCRA \\
\hline $299-W 10-21$ & 14-Dec-94 & 205.45 & 65.74 & 139.71 & WHCRCRA \\
\hline
\end{tabular}


Table B.1. Water-Level Measurements from Unconfined Aquifer Wells on the Hanford Site, December 1994

Well Name

299-W11-10

299-W18-21

299-W18-5

299-W19-1

299-W19-12

299-W19-16

299-W19-19

299-W19-2

299-W19-20

299-W19-20

299-W19-23

299-W19-26

299-W19-30

299-W19-32

299-W19-4

299-W22-20

299-W22-21

299-W22-23

299-W22-40

299-W22-41

299-W22-42

299-W22-43

299-W23-11

299-W26-10

299-W26-12

299-W26-7

299-W26-8

Measure
Date

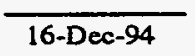

14-Dec-94

16-Dec-94

16-Dec-94

19-Dec-94

16-Dec-94

13-Dẹc-94

30-Dec-94

22-Dec-94

30-Dec-94

13-Dec-94

29-Dec-94

29-Dec-94

29-Dec-94

16-Dec-94

19-Dec-94

16-Dec-94

19-Dec-94

15-Dec-94

15-Dec-94

15-Dec-94

15-Dec-94

15-Dec-94

16-Dec-94

07-Dec-94

07-Dec-94

07-Dec-94

07-Dec-94

Reference
Elevation
(meters
above

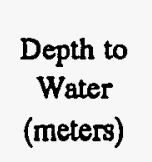

NGVD29)

222.17

215.45

203.80

208.18

205.37

205.21

211.82

211.81

211.54

210.63

210.63

212.88

211.41

213.17

205.71

218.01

206.08

204.22

210.53

210.99

210.84

210.67

210.72

202.43

204.48

205.95

198.73

203.09
Water-Table
Elevation
(meters
above

NGVD29)

137.92

139.22

140.76

140.56

141.06

140.95

140.23

138.37

138.43

138.29

138.45

139.42

141.58

137.09

140.95

139.04

145.80

138.46

138.51

138.53

138.56

138.46

138.71

139.88

138.39

138.75

139.21

138.86
Depth
Measured
By

PNLGW

WHCRCRA

PNLGW

PNLGW

PNLGW

PNLGW

PNLGW

HEISPROD

PNLGW

HEISPROD

PNLGW

HEISPROD

HEISPROD

HEISPROD

PNLGW

PNLGW

PNLGW

PNLGW

WHCRCRA

WHCRCRA

WHCRCRA

WHCRCRA

WHCRCRA

PNLGW

WHCRCRA

WHCRCRA

WHCRCRA

WHCRCRA 
Table B.1. Water-Level Measurements from Unconfined Aquifer Wells on the Hanford Site, December 1994

\begin{tabular}{|c|c|c|c|c|c|}
\hline Well Name & Date & $\begin{array}{c}\text { (meters } \\
\text { above } \\
\text { NGVD29) }\end{array}$ & $\begin{array}{c}\text { Water } \\
\text { (meters) }\end{array}$ & $\begin{array}{c}\text { (meters } \\
\text { above } \\
\text { NGVD29) }\end{array}$ & $\begin{array}{l}\text { Measured } \\
\text { By }\end{array}$ \\
\hline 299-W26-9 & 07-Dec-94 & 199.39 & 60.66 & 138.73 & WHCRCRA \\
\hline 299-W6-10 & 14-Dec-94 & 217.16 & 78.92 & 138.25 & WHCRCRA \\
\hline 299-W6-2 & 14-Dec-94 & 211.06 & 71.86 & 139.20 & WHCRCRA \\
\hline 299-W6-4 & 14-Dec-94 & 213.74 & 74.72 & 139.02 & WHCRCRA \\
\hline 299-W6-9 & 13-Dec-94 & 212.17 & 73.41 & 138.76 & WHCRCRA \\
\hline 299-W9-1 & 14-Dec-94 & 224.86 & 84.55 & 140.31 & WHCRCRA \\
\hline $399-1-14 A$ & 07-Dec-94 & 116.81 & 12.34 & 104.46 & PNLGW \\
\hline $399-1-17 \mathrm{~A}$ & 15-Dec-94 & 115.05 & 10.58 & 104.47 & WHCRCRA \\
\hline $399-1-17 A$ & 07-Dec-94 & 115.05 & 10.72 & 104.33 & PNLGW \\
\hline $399-6-1$ & 08-Dec-94 & 117.94 & 14.12 & 103.81 & PNLGW \\
\hline $399-8-1$ & 07-Dec-94 & 120.76 & 16.40 & 104.36 & PNLGW \\
\hline $399-8-2$ & 08-Dec-94 & 121.34 & 16.88 & 104.46 & PNLGW \\
\hline $399-8-3$ & 07-Dec-94 & 120.34 & 16.93 & 103.41 & PNLGW \\
\hline $399-8-4$ & 20-Dec-94 & 120.10 & 15.14 & 104.96 & PNLGW \\
\hline $399-8-5 \mathrm{~A}$ & 07-Dec-94 & 122.01 & 17.58 & 104.43 & PNLGW \\
\hline $399-8-5 B$ & 07-Dec-94 & 121.87 & 17.28 & 104.60 & PNLGW \\
\hline $399-8-5 \mathrm{C}$ & 20-Dec-94 & 121.89 & 9.30 & 112.60 & PNLGW \\
\hline $699-\$ 12-29$ & 08-Dec-94 & 148.65 & $25.57^{\circ}$ & 123.07 & PNLGW \\
\hline 699-\$14-20A & 08-Dec-94 & 150.19 & 28.08 & 122.11 & PNLGW \\
\hline 699-S19-E13 & 05-Dec-94 & 120.25 & 15.21 & 105.03 & PNLGW \\
\hline 699-\$19-11 & 08-Dec-94 & 147.44 & 28.65 & 118.79 & PNLGW \\
\hline 699-S22-E9A & 08-Dec-94 & 114.05 & 9.07 & i04.98 & PNLGW \\
\hline 699-S27-E14 & 07-Dec-94 & 121.85 & 17.57 & 104.28 & PNLGW \\
\hline 699-S27-E9A & 07-Dec-94 & 118.95 & 12.81 & 106.14 & PNLGW \\
\hline 699-S27-E9B & 07-Dec-94 & 119.00 & 12.47 & 106.53 & PNLGW \\
\hline 699-S28-E12 & 06-Dec-94 & 118.80 & 13.81 & 104.99 & PNLGW \\
\hline 699-S29-E11 & 06-Dec-94 & 117.56 & 11.66 & 105.90 & PNLGW \\
\hline 699-S29-E12 & 06-Dec-94 & 118.25 & 13.82 & 104.43 & PNLGW \\
\hline
\end{tabular}


Table B.1. Water-Level Measurements from Unconfined Aquifer Wells on the Hanford Site, December 1994

\begin{tabular}{|c|c|c|c|c|c|}
\hline Well Name & $\begin{array}{l}\text { Measure } \\
\text { Date }\end{array}$ & $\begin{array}{c}\text { Reference } \\
\text { Elevation } \\
\text { (meters } \\
\text { above } \\
\text { NGVD29) }\end{array}$ & $\begin{array}{l}\text { Depth to } \\
\text { Water } \\
\text { (meters) }\end{array}$ & $\begin{array}{l}\text { Water-Table } \\
\text { Elevation } \\
\text { (meters } \\
\text { above } \\
\text { NGVD29) }\end{array}$ & $\begin{array}{c}\text { Depth } \\
\text { Measured } \\
\text { By }\end{array}$ \\
\hline 699-S29-E16A & 20-Dec-94 & 115.74 & 11.61 & 104.14 & PNLGW \\
\hline $699-\$ 31-1$ & 07-Dec-94 & 140.21 & 25.00 & 115.21 & PNLGW \\
\hline 699-\$31-1 & 21-Dec-94 & 140.21 & 25.15 & 115.06 & PNLGW \\
\hline $699-\$ 31-1$ & 16-Dec-94 & 140.21 & 25.03 & 115.18 & PNLGW \\
\hline 699-S32-E13A & 06-Dec-94 & 119.01 & 13.43 & 105.59 & PNLGW \\
\hline 699-S34-E10 & 06-Dec-94 & 116.55 & 8.49 & 108.05 & PNLGW \\
\hline 699-\$34-E15 & 20-Dec-94 & 124.37 & 17.10 & 107.27 & PNLGW \\
\hline 699-S37-E11A & 06-Dec-94 & 121.71 & 13.91 & 107.80 & PNLGW \\
\hline 699-S37-E14 & 06-Dec-94 & 124.44 & 16.93 & 107.52 & PNLGW \\
\hline 699-S38-E11 & 06-Dec-94 & 121.49 & 13.40 & 108.09 & PNLGW \\
\hline 699-S38-E12A & 06-Dec-94 & 123.43 & 15.68 & 107.75 & PNLGW \\
\hline 699-\$38-E12B & 06-Deç-94 & 123.44 & 15.69 & 107.76 & PNLGW \\
\hline 699-S3-E12 & 05-Dec-94 & 121.28 & 13.39 & 107.89 & PNLGW \\
\hline $699-\$ 3-25$ & 08-Dec-94 & 159.56 & 38.15 & 121.42 & PNLGW \\
\hline 699-S40-E13A & 06-Dec-94 & 124.50 & 16.71 & 107.79 & PNLGW \\
\hline 699-S40-E13B & 06-Dec-94 & 124.70 & 16.65 & 108.04 & PNLGW \\
\hline 699-S40-E13C & 06-Dec-94 & 124.59 & 16.76 & 107.83 & PNLGW \\
\hline 699-S40-E14 & 06-Dec-94 & 122.79 & 14.73 & 108.06 & PNLGW \\
\hline 699-S41-E11A & 06-Dec-94 & 122.33 & 14.18 & 108.16 & PNLGW \\
\hline 699-S41-E13A & 06-Dec-94 & 125.14 & $17.17^{\circ}$ & 107.97 & PNLGW \\
\hline 699-S41-E13B & 06-Dec-94 & 125.00 & 17.02 & 107.98 & PNLGW \\
\hline 699-S41-E13C & 06-Dec-94 & 125.17 & 17.25 & 107.92 & PNLGW \\
\hline 699-S43-E12 & 06-Dec-94 & 123.63 & 15.78 & 107.85 & PNLGW \\
\hline 699-S6-E14A & 05-Dec-94 & 115.30 & 8.64 & 106.66 & PNLGW \\
\hline 699-S6-EAB & 06-Dec-94 & 128.43 & 15.44 & 112.99 & PNLGW \\
\hline 699-\$7-34 & 08-Dec-94 & 160.67 & 36.17 & 124.50 & PNLGW \\
\hline 699-S7-34P & 08-Dec-94 & 160.67 & 36.72 & 123.94 & PNLGW \\
\hline 699-S7-34Q & 08-Dec-94 & 160.67 & 36.19 & 124.48 & PNLGW \\
\hline
\end{tabular}


Table B.1. Water-Level Measurements from Unconfined Aquifer Wells on the Hanford Site, December 1994

\begin{tabular}{|c|c|c|c|c|c|}
\hline Well Name & $\begin{array}{c}\text { Measure } \\
\text { Date }\end{array}$ & $\begin{array}{c}\text { Reference } \\
\text { Elevation } \\
\text { (meters } \\
\text { above } \\
\text { NGVD29) }\end{array}$ & $\begin{array}{l}\text { Depth to } \\
\text { Water } \\
\text { (meters) }\end{array}$ & $\begin{array}{l}\text { Water-Table } \\
\text { Elevation } \\
\text { (meters } \\
\text { above } \\
\text { NGVD29) }\end{array}$ & $\begin{array}{c}\text { Depth } \\
\text { Measured } \\
\text { By }\end{array}$ \\
\hline 699-S8-19 & 08-Dec-94 & 153.56 & 32.75 & 120.81 & PNLGW \\
\hline 699-10-E12 & 06-Dec-94 & 131.33 & 22.53 & 108.80 & PNLGW \\
\hline 699-10-E12Q & 06-Dec-94 & 131.33 & 22.47 & 108.86 & PNLGW \\
\hline $699-10-54 A$ & 12-Dec-94 & 157.40 & 31.35 & 126.05 & PNLGW \\
\hline $699-11-45 \mathrm{~A}$ & 09-Dec-94 & 176.35 & 50.77 & 125.58 & PNLGW \\
\hline $699-13-64$ & 12-Dec-94 & 168.27 & 36.56 & 131.71 & PNLGW \\
\hline $699-14-38$ & 09-Dec-94 & 156.94 & 33.64 & 123.30 & PNLGW \\
\hline $699-14-47$ & 09-Dec-94 & 178.99 & 53.40 & 125.59 & PNLGW \\
\hline $699-15-26$ & 08-Dec-94 & 159.66 & 37.87 & 121.80 & PNLGW \\
\hline $699-17-5$ & 06-Dec-94 & 132.04 & 14.01 & 118.02 & PNLGW \\
\hline $699-17-70$ & 12-Dec-94 & 171.66 & 27.03 & 144.63 & PNLGW \\
\hline 699-19:58 & 09-Dec-94 & 174.67 & 47.15 & 127.51 & PNLGW \\
\hline $699-19-88$ & 12-Dec-94 & 196.43 & $39.80^{\circ}$ & 156.63 & PNLGW \\
\hline $699-1-18$ & 14-Dec-94 & 163.88 & 42.89 & 120.98 & WHCRCRA \\
\hline 699-20-E12 & 06-Dec-94 & 133.27 & 24.40 & 108.87 & PNLGW \\
\hline 699-20-E12Q & 06-Dec-94 & 133.34 & 24.48 & 108.85 & PNLGW \\
\hline 699-20-E12R & 06-Dec-94 & 133.34 & 24.57 & 108.76 & PNLGW \\
\hline 699-20-E12S & 06-Dec-94 & 133.34 & 24.47 & 108.87 & PNLGW \\
\hline $699-20-20$ & 08-Dec-94 & 154.10 & 32.32 & 121.78 & PNLGW \\
\hline $699-20-39$ & 09-Dec-94 & 164.59 & 42.27 & 122.32 & PNLGW \\
\hline $699-20-39 P$ & 09-Dec-94 & 164.66 & 39.73 & 124.93 & PNLGW \\
\hline $699-21-17$ & 09-Dec-94 & 160.72 & 40.13 & 120.59 & PNLGW \\
\hline $699-22-70$ & 09-Dec-94 & 187.44 & 56.53 & 130.91 & PNLGW \\
\hline $699-23-34 \mathrm{~A}$ & 16-Dec-94 & 162.42 & 40.15 & 122.26 & PNLGW \\
\hline 699-23-34B & 16-Dec-94 & 162.61 & 40.37 & 122.24 & PNLGW \\
\hline $699-25-34 \mathrm{~B}$ & 02-Dec-94 & 161.36 & 38.81 & 122.55 & PNLGW \\
\hline $699-25-55$ & 09-Dec-94 & 206.21 & 80.64 & 125.57 & PNLGW \\
\hline $699-25-70$ & 09-Dec-94 & 191.96 & 56.30 & 135.66 & PNLGW \\
\hline
\end{tabular}


Table B.1. Water-Level Measurements from Unconfined Aquifer Wells on the Hanford Site, December 1994

\begin{tabular}{|c|c|c|c|c|c|}
\hline Well Name & $\begin{array}{c}\text { Measure } \\
\text { Date }\end{array}$ & $\begin{array}{c}\text { Reference } \\
\text { Elevation } \\
\text { (meters } \\
\text { above } \\
\text { NGVD29) }\end{array}$ & $\begin{array}{l}\text { Depth to } \\
\text { Water } \\
\text { (meters) }\end{array}$ & $\begin{array}{l}\text { Water-Table } \\
\text { Elevation } \\
\text { (meters } \\
\text { above } \\
\text { NGVD29) }\end{array}$ & $\begin{array}{l}\text { Depth } \\
\text { Measured } \\
\text { By }\end{array}$ \\
\hline 699-26-15A & 09-Dec-94 & 134.92 & 13.94 & 120.97 & PNLGW \\
\hline $699-26-89$ & 12-Dec-94 & 199.06 & 55.68 & 143.38 & PNLGW \\
\hline $699-27-8$ & 08-Dec-94 & 14.1 .94 & 22.31 & 119.63 & PNLGW \\
\hline $699-28-40$ & 09-Dec-94 & 170.52 & 48.17 & 122.35 & PNLGW \\
\hline $699-29-78$ & 09-Dec-94 & 197.22 & 57.53 & 139.69 & PNLGW \\
\hline $699-29-83$ & 12-Dec-94 & 190.13 & 27.71 & 162.42 & PNLGW \\
\hline $699-2-3$ & 12-Dec-94 & 145.43 & 26.69 & 118.74 & WHCRCRA \\
\hline $699-2-3$ & 06-Dec-94 & 145.43 & 26.67 & 118.77 & PNLGW \\
\hline $699-2-33 A$ & 08-Dec-94 & 163.49 & 40.30 & 123.19 & PNLGW \\
\hline $699-2-7$ & 06-Dec-94 & 156.12 & 36.55 & 119.57 & PNLGW \\
\hline $699-31-31$ & 09-Dec-94 & 161.34 & 39.08 & 122.25 & PNLGW \\
\hline $699-31-53 \mathrm{~B}$ & 15-Dec-94 & 215.66 & 92.34 & 123.32 & PNLGW \\
\hline $699-32-22 \mathrm{~A}$ & 09-Dec-94 & $157.7 \dot{j}$ & 36.09 & 121.66 & PNLGW \\
\hline $699-32-43$ & 09-Dec-94 & 157.47 & 35.08 & 122.39 & PNLGW \\
\hline $699-32-62$ & 13-Dec-94 & 215.52 & 85.22 & 130.30 & PNLGW \\
\hline 699-32-70B & 13-Dec-94 & 203.20 & 66.83 & 136.37 & PNLGW \\
\hline $699-34-42$ & 09-Dec-94 & 164.65 & 42.24 & 122.42 & PNLGW \\
\hline $699-34-88$ & 13-Dec-94 & 192.88 & 50.55 & 142.34 & PNLGW \\
\hline $699-35-66 \mathrm{~A}$ & 16-Dec-94 & 221.18 & 87.85 & 133.33 & PNLGW \\
\hline $699-35-66 \mathrm{~A}$ & 13-Dec-94 & 221.18 & 88.11 & 133.06 & PNLGW \\
\hline $699-35-70$ & 13-Dec-94 & 211.45 & 75.07 & 136.38 & PNLGW \\
\hline 699-35-78A & 13-Dec-94 & 201.37 & 60.94 & 140.43 & PNLGW \\
\hline 699-35-9 & 07-Dec-94 & 152.35 & 35.30 & 117.05 & PNLGW \\
\hline $699-37-43$ & 16-Dec-94 & 210.36 & 87.74 & 122.62 & WHCRCRA \\
\hline $699-37-82 \mathrm{~A}$ & 16-Dec-94 & 194.08 & 52.87 & 141.21 & PNLGW \\
\hline $699-37-84$ & 13-Dec-94 & 193.47 & 2.25 & 191.22 & PNLGW \\
\hline $699-38-65$ & 16-Dec-94 & 229.62 & 99.02 & 130.59 & PNLGW \\
\hline $699-38-70$ & 13-Dec-94 & 216.61 & 79.76 & 136.85 & PNLGW \\
\hline
\end{tabular}


Table B.1. Water-Level Measurements from Unconfined Aquifer Wells on the Hanford Site, December 1994

\begin{tabular}{|c|c|c|c|c|c|}
\hline Well Name & $\begin{array}{l}\text { Measure } \\
\text { Date }\end{array}$ & $\begin{array}{c}\text { Reference } \\
\text { Elevation } \\
\text { (meters } \\
\text { above } \\
\text { NGVD29) }\end{array}$ & $\begin{array}{l}\text { Depth to } \\
\text { Water } \\
\text { (meters) }\end{array}$ & $\begin{array}{l}\text { Water-Table } \\
\text { Elevation } \\
\text { (meters } \\
\text { above } \\
\text { NGVD29) }\end{array}$ & $\begin{array}{c}\text { Depth } \\
\text { Measured } \\
\text { By }\end{array}$ \\
\hline $699-38-70$ & 16-Dec-94 & 216.61 & 79.54 & 137.07 & PNLGW \\
\hline 699-39-0 & 08-Dec-94 & 137.02 & 26.37 & 110.65 & PNLGW \\
\hline $699-3-45$ & 12-Dec-94 & 153.78 & 28.15 & 125.64 & PNLGW \\
\hline $699-40-1$ & 08-Dec-94 & 133.72 & 23.27 & 110.44 & PNLGW \\
\hline $699-40-12 \mathrm{C}$ & 08-Dec-94 & 156.76 & 39.80 & 116.96 & PNLGW \\
\hline $699-40-20$ & 09-Dec-94 & 145.25 & 25.42 & 119.82 & PNLGW \\
\hline $699-41-11$ & 08-Dec-94 & 156.30 & 43.77 & 112.53 & PNLGW \\
\hline $699-42-12 \mathrm{~A}$ & 08-Dec-94 & 156.75 & 42.56 & 114.19 & PNLGW \\
\hline $699-42-2$ & 08-Dec-94 & 132.13 & 23.41 & 108.72 & PNLGW \\
\hline $699-42-40 B$ & 13-Dec-94 & 166.56 & 38.06 & 128.50 & PNLGW \\
\hline $699-43-104 \mathrm{P}$ & 02-Dec-94 & 233.50 & 83.38 & 150.12 & PNLGW \\
\hline $699-43-18$ & 09-Dec-94 & 157.88 & 38.79 & 119.09 & PNLGW \\
\hline $699-43-43$ & 13-Dec-94 & 176.59 & 50.55 . & 126.04 & PNLGW \\
\hline $699-43-89$ & 15-Dec-94 & 196.34 & 54.83 & 141.50 & PNLGW \\
\hline 699-43-9 & 08-Dec-94 & 149.58 & 39.64 & 109.94 & PNLGW \\
\hline $699-44-16$ & 09-Dec-94 & 136.40 & 18.09 & 118.30 & PNLGW \\
\hline $699-44-64$ & 16-Dec-94 & 221.16 & 97.62 & 123.54 & PNLGW \\
\hline $699-45-42$ & 13-Dec-94 & 175.97 & 49.19 & 126.78 & PNLGW \\
\hline $699-46-21 \mathrm{~B}$ & 09-Dec-94 & 159.11 & 40.23 & 118.88 & PNLGW \\
\hline $699-47-46 \mathrm{~A}$ & 13-Dec-94 & 176.83 & 54.04 & 122.79 & PNLGW \\
\hline $699-47-60$ & 15-Dec-94 & 198.58 & 76.33 & 122.26 & PNLGW \\
\hline $699-48-18$ & 09-Dec-94 & 129.53 & 19.41 & 110.12 & PNLGW \\
\hline $699-48-50$ & 13-Dec-94 & 174.97 & 52.12 & 122.85 & PNLGW \\
\hline $699-48-71$ & 13-Dec-94 & 209.75 & 74.59 & 135.16 & PNLGW \\
\hline $699-49-13 E$ & 07-Dec-94 & 125.80 & 15.89 & 109.91 & PNLGW \\
\hline $699-49-28$ & 09-Dec-94 & 163.19 & 43.41 & 119.78 & PNLGW \\
\hline $699-49-57 \mathrm{~A}$ & 14-Dec-94 & 168.71 & 46.34 & 122.37 & PNLGW \\
\hline $699-50-30$ & 09-Dec-94 & 161.19 & 41.27 & 119.92 & PNLGW \\
\hline
\end{tabular}


Table B.1. Water-Level Measurements from Unconfined Aquifer Wells on the Hanford Site, December 1994

\begin{tabular}{|c|c|c|c|c|c|}
\hline Well Name & $\begin{array}{c}\text { Measure } \\
\text { Date }\end{array}$ & $\begin{array}{c}\text { Reference } \\
\text { Elevation } \\
\text { (meters } \\
\text { above } \\
\text { NGVD29) }\end{array}$ & $\begin{array}{l}\text { Depth to } \\
\text { Water } \\
\text { (meters) }\end{array}$ & $\begin{array}{l}\text { Water-Table } \\
\text { Elevation } \\
\text { (meters } \\
\text { above } \\
\text { NGVD29) }\end{array}$ & $\begin{array}{c}\text { Depth } \\
\text { Measured } \\
\text { By }\end{array}$ \\
\hline $699-50-42$ & 09-Dec-94 & 142.29 & 17.36 & 124.93 & PNLGW \\
\hline $699-51-19$ & 09-Dec-94 & 129.55 & 20.03 & 109.52 & PNLGW \\
\hline $699-51-63$ & 15-Dec-94 & 174.30 & 51.23 & 123.07 & PNLGW \\
\hline $699-52-19$ & 09-Dec-94 & 125.30 & 15.33 & 109.97 & PNLGW \\
\hline $699-52-54$ & 13-Dec-94 & 173.26 & 50.99 & 122.27 & PNLGW \\
\hline $699-53-35$ & 12-Dec-94 & 161.85 & 43.93 & 117.92 & PNLGW \\
\hline $699-53-35$ & 12-Dec-94 & 161.85 & 39.66 & 122.19 & PNLGW \\
\hline $699-53-47 \mathrm{~A}$ & 13-Dec-94 & 133.59 & 10.10 & 123.49 & PNLGW \\
\hline $699-54-42$ & 12-Dec-94 & 155.90 & 35.10 & 120.80 & PNLGW \\
\hline $699-54-45 A$ & 12-Dec-94 & 150.66 & 29.35 & 121.31 & PNLGW \\
\hline $699-54-48$ & 12-Dec-94 & 139.30 & 17.17 & 122.13 & PNLGW \\
\hline $699-55-44$ & 12-Dec-94 & 158.40 & 37.69 & 120.71 & PNLGW \\
\hline $699-55-50 \mathrm{C}$ & 12-Dec-94 & 135.46 & 13.30 & 122.16 & PNLGW \\
\hline $699-55-70$ & 15-Dec-94 & 173.44 & 42.07 & 131.38 & PNLGW \\
\hline $699-55-76$ & 15-Dec-94 & 177.77 & 42.78 & 134.99 & PNLGW \\
\hline 699-55-89 & 15-Dec-94 & 188.19 & 49.94 & 138.26 & PNLGW \\
\hline $699-57-59$ & 15-Dec-94 & 175.64 & 53.45 & 122.19 & PNLGW \\
\hline $699-57-83 \mathrm{~A}$ & 15-Dec-94 & 175.16 & 44.48 & 131.68 & PNLGW \\
\hline $699-59-55$ & 15-Dec-94 & 131.64 & 9.47 & 122.17 & PNLGW \\
\hline $699-59-58$ & 15-Dec-94 & 151.80 & 29.62 & 122.17 & PNLGW \\
\hline 699-59-80B & 15-Dec-94 & 177.78 & 46.89 & 130.89 & PNLGW \\
\hline $699-60-57$ & 15-Dec-94 & 143.13 & 20.96 & 122.17 & PNLGW \\
\hline $699-60-60$ & 15-Dec-94 & 155.07 & 33.95 & 122.12 & PNLGW \\
\hline $699-61-37$ & 15-Dec-94 & 135.01 & 18.86 & 116.15 & PNLGW \\
\hline $699-61-41$ & 15-Dec-94 & 130.74 & 10.23 & 120.50 & PNLGW \\
\hline $699-61-62$ & 15-Dec-94 & 151.64 & 29.53 & 122.11 & PNLGW \\
\hline $699-62-31$ & 15-Dec-94 & 132.32 & 22.30 & 110.02 & PNLGW \\
\hline $699-62-43 F$ & 15-Dec-94 & 129.03 & 9.77 & 119.26 & PNLGW \\
\hline
\end{tabular}


Table B.1. Water-Level Measurements from Unconfined Aquifer Wells on the Hanford Site, December 1994

\begin{tabular}{|c|c|c|c|c|c|}
\hline Well Name & $\begin{array}{c}\text { Measure } \\
\text { Date }\end{array}$ & $\begin{array}{c}\text { Reference } \\
\text { Elevation } \\
\text { (meters } \\
\text { above } \\
\text { NGVD29) }\end{array}$ & $\begin{array}{l}\text { Depth to } \\
\text { Water } \\
\text { (meters) }\end{array}$ & $\begin{array}{l}\text { Water-Table } \\
\text { Elevation } \\
\text { (meters } \\
\text { above } \\
\text { NGVD29) }\end{array}$ & $\begin{array}{c}\text { Depth } \\
\text { Measured } \\
\text { By }\end{array}$ \\
\hline $699-63-51$ & 15-Dec-94 & 129.40 & 7.96 & 121.44 & PNLGW \\
\hline $699-63-90$ & 16-Dec-94 & 155.37 & 34.55 & 120.81 & PNLGW \\
\hline $699-65-50$ & 16-Dec-94 & 142.36 & 20.94 & 121.42 & PNLGW \\
\hline $699-66-23$ & 16-Dec-94 & 118.57 & 8.85 & 109.73 & PNLGW \\
\hline $699-66-38$ & 16-Dec-94 & 132.97 & 10.41 & 122.55 & PNLGW \\
\hline 699-66-39. & 16-Dec-94 & 138.31 & 14.40 & 123.91 & PNLGW \\
\hline $699-66-91$ & 16-Dec-94 & 142.57 & 21.40 & 121.17 & PNLGW \\
\hline $699-67-98$ & 16-Dec-94 & 138.83 & 17.63 & 121.20 & PNLGW \\
\hline $699-68-105$ & 20-Dec-94 & 137.72 & 17.86 & 119.87 & PNLGW \\
\hline $699-69-38$ & 16-Dec-94 & 129.27 & 6.36 & 122.90 & PNLGW \\
\hline $699-69-450$ & 16-Dec-94 & 148.49 & 27.27 & 121.22 & PNLGW \\
\hline $699-70-68$ & 16-Dec-94 & 160.39 & 39.21 & 121.18 & PNLGW \\
\hline $699-71-77$ & 19-Dec-94 & 143.95 & 23.63 & 120.32 & PNLGW \\
\hline $699-72-73$ & 19-Dec-94 & 147.09 & 26.62 & 120.47 & PNLGW \\
\hline $699-72-92$ & 16-Dec-94 & 137.84 & 16.62 & 121.21 & PNLGW \\
\hline $699-74-48$ & 16-Dec-94 & 148.49 & 27.64 & 120.85 & PNLGW \\
\hline $699-77-54$ & 16-Dec-94 & 146.48 & 25.87 & 120.62 & PNLGW \\
\hline $699-81-62$ & 16-Dec-94 & 134.56 & 9.33 & 125.22 & PNLGW \\
\hline $699-83-47$ & 16-Dec-94 & 132.67 & 14.40 & 118.27 & PNLGW \\
\hline $699-8-17$ & 08-Dec-94 & 159.24 & 38.19 & 121.05 & PNLGW \\
\hline $699-8-25$ & 08-Dec-94 & 155.23 & 33.80 & 121.43 & PNLGW \\
\hline 699-8-32 & 08-Dec-94 & 168.98 & 47.35 & 121.63 & PNLGW \\
\hline $699-93-48 \mathrm{~A}$ & 16-Dec-94 & 133.44 & 16.90 & 116.54 & PNLGW \\
\hline $699.96-43$ & 27-Dec-94 & 128.58 & 13.13 & 115.45 & HEISPROD \\
\hline $699-97-43$ & 27-Dec-94 & 128.58 & 13.29 & 115.29 & HEISPROD \\
\hline 699-9-E2 & 06-Dec-94 & 127.43 & 13.99 & 113.44 & PNLGW \\
\hline
\end{tabular}


Appendix C

Listing of Chemical and Radiological Data for Calendar Year 1994 


\section{Appendix C}

\section{Listing of Chemical and Radiological Data for Calendar Year, 1994}

This appendix describes the electronic listing of ground-water radiological and chemical monitoring data obtained on the Hanford Site during the period January through December 1994. Data is provided on an IBM PC compatible $31 / 2$ inch diskette. Ground-water sampling was performed for DOE by PNL's Ground-Water Surveillance and other projects, by WHC's RCRA project, and by the ERC team and the U.S. Army Corps of Engineers CERCLA projects. .

Well coordinate locations for wells sampled in 1994 are included on the data diskette in a delimited text file, WELL_LOC.TXT. The file lists well names and coordinates, expressed in Lambert NAD83 State Plane coordinates, in meters. The list of well locations encompasses most wells on the Hanford Site, including abandoned and nongroundwater wells.

The data listings were generated in June, 1995 from the HEIS database, which is designated as the central repository for Hanford ground-water data. Most of the sample analyses for calendar year 1994 are included; however, some data may not yet have been loaded into HEIS. Validation of the 1994 data is not yet complete, particularly CERCLA data loaded by the ERC team, and is subject to change in HEIS. Users of data on the enclosed disk should keep in mind that current data can always be obtained from HEIS. Effort has been made to provide the best analytical data possible. However, it cannot be guaranteed that the data are error-free.

The data were divided into seven groups: anions, radionuclides, metals, pesticides, semivolatile organics, volatile organics, and miscellaneous. Data within each group are listed in semicolon-delimited ASCII text files, arranged alphabetically by the short constituent name. The metals, miscellaneous, and volatile organic groups were divided into multiple files, so the number of - records in each file would not exceed 16,000 records.

Table C. 1 lists the disk file names and general contents. Data files for each group have been compressed, using the PKWARE zip utility. A copy of UNZIP.EXE is included on the diskette; UNZIP.EXE is a freely available utility that will inflate the seven zipped group files into their 12 text file components.

To unzip the files, copy the contents of the diskette onto your hard disk and run UNZIP.EXE. For example, to inflate the zipped VOA.ZIP into the two voa text files, at the c: > prompt, enter UNZIP VOA. This will inflate VOA.ZIP into VOA1.TXT and VOA2.TXT files. Repeat for each group. It is NOT recommended that the text files be printed out, as they are quite large. To read the text files into EXCEL, select the TEXT option for a semicolon-delimited file.

Table C. 2 explains the fields included in the data listing. Additional information regarding a particular sample or well may be available in the HEIS database. 
Table C.3 lists the full constituent name and the constituent ID for each of the short constituent names in the data listings. The constituent ID is the Chemical Abstract Services (CAS) number when one is available. The constituent name information is also available on the diskette in a semicolon-delimited text file, CONSTIT.TXT.

Tables C. 4, C.5, C.6, and C.7 translate/define the data qualifiers for each form type. Although the use of the Qualifier and Cflag fields has varied between the data owners, effort has been made to correctly define the appropriate set of qualifiers used for each type of data. However, no. assurance can be given that the definitions are accurate in all cases. For further clarification of Qualifier information, the individual data owner(s) should be consulted.

Table C. 8 defines the review codes. 


\section{Table C.1. Diskette Contents}

\begin{tabular}{|c|c|c|c|}
\hline File Name & $\begin{array}{l}\text { Inflated Text } \\
\text { File Name }\end{array}$ & $\begin{array}{l}\text { Number of } \\
\text { Records }\end{array}$ & Contents \\
\hline ANION.ZIP & ANION.TXT & 11823 & All anion data \\
\hline RAD.ZIP & RAD.TXT & 12504 & All radiological data \\
\hline \multirow[t]{4}{*}{ METALS.ZIP } & METALS1.TXT & 10241 & $\begin{array}{l}\text { Aluminum, Antimony, Arsenic, Barium, } \\
\text { Beryllium, Bismuth }\end{array}$ \\
\hline & METALS2.TXT & 11390 & Cadmium, Calcium,Chromium, Cobalt, Copper \\
\hline & METALS3.TXT & 11677 & $\begin{array}{l}\text { Iron, Lead; Magnesium, Manganese, Mercury, } \\
\text { Nickel }\end{array}$ \\
\hline & METALS4.TXT & 14790 & $\begin{array}{l}\text { Potassium, Selenium, Silver, Sodium, Thallium, } \\
\text { Tin, Vanadium, Zinc }\end{array}$ \\
\hline PEST.ZIP & PEST1.TXT & 5754 & All Pesticides data \\
\hline SEMI.ZIP & SVOA.TXT & 12900 & All Semivolatile data \\
\hline \multirow[t]{2}{*}{ VOA.ZIP } & VOAl.TXT & 10420 & Volatiles; 1,1,1-Trichloroethane to Hexone \\
\hline & VOA2.TXT & 6736 & Volatiles; Iodomethane to Vinylac \\
\hline \multirow[t]{2}{*}{ MISC.ZIP } & MISC1.TXT & 10181 & $\mathrm{COD}$ to $\mathrm{pH}$ \\
\hline & MISC2.TXT & 10018 & TDS to Turbidity \\
\hline UNZIP.EXE & . & & $\begin{array}{l}\text { Freely available utility to expand the } \\
\text { compressed files. }\end{array}$ \\
\hline CONSTIT.TXT & & & $\begin{array}{l}\text { Semicolon-delimited text file with constituent } \\
\text { short names, con-id, and constituent long name. } \\
\text { Same text as Table C. } 3 \text {. }\end{array}$ \\
\hline WELLLOC.TXT & & & $\begin{array}{l}\text { Comma-delimited text file listing well locations. } \\
\text { The values are expressed in meters, using } \\
\text { Lambert NAD83 State Plan coordinates. }\end{array}$ \\
\hline
\end{tabular}


Table C.2. Explanation of Fields Included in Data Listing

Field

Well Name

Constituent

Filtered

Date

Qualifier

CFlag

Concentration or Activity

Units

Counting Error

Review

Form
Explanation

The well identification. The first part of the number identifies the area, as follows:

$\begin{array}{ll}199 & -100 \text { Area wells } \\ 299-E & -200-\text { East Area wells } \\ 299-W & -200-\text { West Area wells } \\ 399 & -300 \text { Area wells } \\ 499 & -400 \text { Area wells } \\ 699 & -600 \text { Area wells } \\ 1199 & -1100 \text { Area wells } \\ 3099 & -3000 \text { Area wells } \\ \text { Others } & - \text { Offsite wells }\end{array}$

Short name for the specific chemical or radiological compound or physical property. See Table C.3 for full constituent names.

A "Y" is placed in this field for filtered samples. Used primarily for metals analyses.

Date that the sample was collected.

Data qualifiers associated with the sample results. See Tables C.4, C.5, C.6, and C.7 for an explanation of data qualifiers.

Additional qualifier information available for certain sample results. Use definition on translations in Table C.5, Inorganic CLP qualifiers.

Result of the analyses.

Reporting units for the analysis. May not be reported in consistent units for a given constituent.

Measurement error in radionuclide analyses. Analytical results may be negative values as the result of counting error.

Indicator code that the quality of the results is or has been questioned. See Table C. 8 for list of Review codes.

Form type for the result. Determines which Qualifier translation to use from Tables C.4, C.5, C.6, and C.7. The six form types are:

CLPO = CLP analysis, Organic (Use Table C.4)

CLPI = CLP analysis, Inorganic (Use Table C.5)

NCLP $=$ Non-CLP analysis (Use Table C.6)

NCLP* = Non-CLP analysis using CLPI qualifiers (Use Table C.5)

LAS = Laboratory Analytic Services analysis (Use Table C.6)

FEAD = Format for Electronic Analytical Data (Use Table C.7) 
Table C.3. Constituent Table

\begin{tabular}{|c|c|c|}
\hline Short name & $\underline{\text { ID }}$ & Long Name \\
\hline $1,1,1-\mathrm{T}$ & $71-55-6$ & 1,1,1-Trichloroethane \\
\hline $1,1,2-\mathrm{T}$ & $79-00-5$ & 1,1,2-Trichloroethane \\
\hline 1,1-DCL & $75-34-3$ & 1,1-Dichloroethane \\
\hline 1,1DCLPENE & $563-58-6$ & 1,1-Dichloropropene \\
\hline 1,2-DCL & $107-06-2$ & 1,2-Dichloroethane \\
\hline $1,3 D C L P A N E$ & $142-28-9$ & 1,3-Dichloropropane \\
\hline 1-NAPHTHAM & $134-32-7$ & 1-Naphthylamine \\
\hline 1112-TCE & $630-20-6$ & 1,1,1,2-Tetrachloroethane \\
\hline 1122-TCE & $79-34-5$ & $1,1,2,2$-Tetrachloroethane \\
\hline 123-TRCLPR & $96-18-4$ & 1,2,3-Trichloropropane \\
\hline 123TRCL & $87-61-6$ & 1,2,3-Trichlorobenzene \\
\hline 124TRMEBEN & $95-63-6$ & 1,2,4-Trimethylbenzene \\
\hline 12DICHL & $540-59-0$ & 1,2-Dichloroethylene \\
\hline 12DICLBENZ & $95-50-1$ & 1,2-Dichlorobenzene \\
\hline 135TRMEBEN & $108-67-8$ & 1,3,5-Trimethylbenzene \\
\hline 13DICLBENZ & $541-73-1$ & 1,3-Dichlorobenzene \\
\hline 14DICLBENZ & $106-46-7$ & 1,4-Dichlorobenzene \\
\hline 1BUTANOL & $71-36-3$ & 1-Butanol \\
\hline 2,2DCLPANE & $594-20-7$ & 2,2-Dichloropropane \\
\hline $2,4,5-\mathrm{T}$ & $93-76-5$ & $2,4,5-\mathrm{T}$ \\
\hline $2,4,5 \mathrm{TP}$ & $93-72-1$ & $2,4,5-\mathrm{TP}$ \\
\hline $2,4-D$ & $94-75-7$ & 2,4-Dichlorophenoxyacetic acid \\
\hline 2-NAPHTHAM & $91-59-8$ & 2-Naphthylamine \\
\hline 2-PICOLINE & $109-06-8$ & 2-Picoline \\
\hline 2378TCD & $1746-01-6$ & $2,3,7,8-$ Tetrachlorodibenzo-p-dioxin \\
\hline 245TRCLPHN & $95-95-4$ & 2,4,5-Trichlorophenol \\
\hline 246TRCLPHN & $88-06-2$ & 2,4,6-Trichlorophenol \\
\hline 24DICLPHEN & $120-83-2$ & 2,4-Dichlorophenol \\
\hline 24DIMET & $105-67-9$ & 2,4-Dimethylphenol \\
\hline 24DINITOLU & $121-14-2$ & 2,4-Dinitrotoluene \\
\hline 26DICLPHEN & $87-65-0$ & 2;6-Dichlorophenol \\
\hline 26DINITOLU & $606-20-2$ & 2,6-Dinitrotoluene \\
\hline 2HEXANONE & $591-78-6$ & 2-Hexanone \\
\hline 2MENAPH & $91-57-6$ & 2-Methylnaphthalene \\
\hline 2METHPH & $95-48-7$ & 2-Methylphenol \\
\hline 2NITRAN & $88-74-4$ & 2-Nitroaniline \\
\hline 2NITRPH & $88-75-5$ & 2-Nitrophenol \\
\hline 33DIMBE & $119-93-7$ & 3,3'-Dimethylbenzidine \\
\hline 3NITRAN & $99-09-2$ & 3-Nitroaniline \\
\hline 4-CLTUENE & $106-43-4$ & 4-Chlorotoluene \\
\hline 46DINIT & $534-52-1$ & 4,6-Dinitro-o-cresol \\
\hline 4CHLOET & $7005-72-3$ & 4-Chlorophenylphenyl ether \\
\hline
\end{tabular}


Table C.3. Constituent Table (Cont'd)

ShOIt name
4METHPH
4NITQUI
9H-CARB
A-BHC
ACEFENE
ACENAPH
ACENATL
ACETILE
ACETONE
ACETOPH
ACROLEIN
ACRYILE
ALDRIN
ALKALINITY
ALLYLCL
ALPHA
ALPHA
ALPHCHL
ALUMINUM
AM-241
AMINOYL
AMM-ABS
AMMONIA
ANILINE
ANTHRACENE
ANTIMONY
AR1016
AR1221
AR1232
AR1242
AR1248
AR1254
AR1260
ARAMITE
ARSENIC
B-BHC
BARIUM
BCM
BDCM
BE-7
BENZAAN
BENZALC

\section{$\underline{\text { ID }}$}

$106-44-5$

56-57-5

86-74-8

319-84-6

53-96-3

83-32-9

208-96-8

$75-05-8$

67-64-1

98-86-2

107-02-8

107-13-1

309-00-2

ALKALINITY

107-05-1

12587-46-1.

ALPHA

5103-71-9

7429-90-5

$14596-10-2$

92-67-1

7664-41-7

14798-03-9

62-53-3

120-12-7

7440-36-0

12674-11-2

11104-28-2

11141-16-5

53469-21-9

12672-29-6

11097-69-1

11096-82-5

140-57-8

7440-38-2

$319-85-7$

7440-39-3

$74-97-5$

75-27-4

$13966-02-4$

56-55-3

$100-51-6$
Long Name

4-Methylphenol

4-Nitroquinoline-1-oxide

9H-carbazole

Alpha-BHC

2-Acetylaminofluorene

Acenaphthene

Acenaphthylene

Acetonitrile

Acetone

Acetophenone

Acrolein

Acrylonitrile

Aldrin

Alkalinity

Allyl chloride

Gross Alpha

Gross alpha

alpha-Chlordane

Aluminum

Americium-241

4-Aminobiphenyl

Ammonia

Ammonia

Aniline

Anthracene

Antimony

Arocior-1016

Aroclor-1221

Aroclor- 1232

Aroclor-1242

Aroclor-1248

Aroclor-1254

Aroclor-1260

Aramite

Arsenic

Beta-BHC

Barium

Bromochloromethane

Bromodichloromethane

Beryllium-7

Benzo(a)anthracene

Benzyl alcohol 
Table C.3. Constituent Table (Cont'd)

\begin{tabular}{|c|c|c|}
\hline Short name & $\underline{\mathrm{ID}}$ & Long Name \\
\hline BENZBFL & $205-99-2$ & Benzo(b)fluoranthene \\
\hline BENZENE & $71-43-2$ & Benzene \\
\hline BENZOPE & $191-24-2$ & Benzo(ghi)perylene \\
\hline BENZOPY & $50-32-8$ & Benzo(a)pyrene \\
\hline BERYLLIUM & $7440-41-7$ & Beryllium \\
\hline BETA & $12587-47-2$ & Gross Beta \\
\hline BETA & BETA & Gross beta \\
\hline BIS2CHE & $111-44-4$ & Bis(2-chloroethyl) ether \\
\hline BIS2CHM & $111-91-1$ & Bis (2-Chloroethoxy)methane \\
\hline BIS2EPH & $117-81-7$ & Bis(2-ethylhexyl) phthalate \\
\hline BIS2ETH & $108-60-1$ & Bis(2-Chloroisopropyl) ether \\
\hline BISMUTH & $7440-69-9$ & Bismuth \\
\hline BNZKFLU & $207-08-9$ & Benzo(k)fluoranthene \\
\hline BNZOTHZ & $95-16-9$ & Benzothiazole \\
\hline BROBENZ & $108-86-1$ & Bromobenzene \\
\hline BROMACI & $314-40-9$ & Bromacil (ACN) \\
\hline BROMIDE & $24959-67-9$ & Bromide \\
\hline BROMOFORM & $75-25-2$ & Bromoform \\
\hline BROPHEN & $101-55-3$ & 4-Bromophenylphenyl ether \\
\hline BUTBENP & $85-68-7$ & Butylbenzylphthalate \\
\hline BUTDINP & $88-85-7$ & 2-secButyl-4,6-dinitrophenol(DNBP) \\
\hline C-14 & $14762-75-5$ & Carbon-14 \\
\hline CADMIUM & $7440-43-9$ & Cadmium \\
\hline CALCIUM & $7440-70-2$ & Calcium \\
\hline CARBIDE & $75-15-0$ & Carbon disulfide \\
\hline CARBTET & $56-23-5$ & Carbon tetrachloride \\
\hline CDBM & $124-48-1$ & Dibromochloromethane \\
\hline CE-144 & $14762-78-8$ & Cerium-144 \\
\hline CEPR144 & CE/PR-144 & Cerium/Praseodymium-144 \\
\hline CHLANIL & $106-47-8$ & 4-Chloroaniline \\
\hline CHLCRES & $59-50-7$ & 4-Chloro-3-methylphenol \\
\hline CHLLATE & $510-15-6$ & Chlorobenzilate \\
\hline CHLNAPH & $91-58-7$ & 2-Chloronaphthalene \\
\hline CHLORDANE & $57-74-9$ & Chlordane \\
\hline CHLORIDE & $12595-89-0$ & Chloride \\
\hline CHLORIDE & $16887-00-6$ & Chloride \\
\hline CHLOROBENZ & $108-90-7$ & Chlorobenzene \\
\hline CHLOROFORM & $67-66-3$ & Chloroform \\
\hline CHLOTOL & $95-49-8$ & 2-Chlorotoluene \\
\hline CHLPHEN & $95-57-8$ & 2-Chlorophenol \\
\hline CHLTHER & $110-75-8$ & 2-Chloroethyl vinyl ether \\
\hline CHROMIUM & $7440-47-3$ & Chromium \\
\hline
\end{tabular}


Table C.3. Constituent Table (Cont'd.)

Short name

CHRYSENE

CIS13DI

CISDCE

CLETHAN

CLOPREN

CO-58

CO-60

COBALT

COD

COLIFORM

CONDUCT

COPPER

CR-51

CRESOLS

CS-134

CS-137

CYANIDE

CYANIDE

D-BHC

DDD

DDE

DDT

DECANE

DIALLATE

DIBAHAN

DIBENFR

DIBPHTH

DIBRCHL

DIBRETH

DIBRMET

DICDIFM

DICETHY

DICHBEN

DICPANE

DIELDRIN

DIEPHTH

DIMBENZ

DIMEAMB

DIMETHOATE

DIMPHAM

DIMPHTH

DINPHEN
ID

218-01-9

10061-01-5

156-59-2

75-00-3

126-99-8

13981-38-9

10198-40-0

$7440-48-4$

COD

COLIFORM

CONDUCT

7440-50-8

14392-02-0

$1319-77-3$

13967-70-9

10045-97-3

57-12-5

$\mathrm{CN}$

319-86-8

$72-54-8$

$72-55-9$

50-29-3

124-18-5

2303-16-4

53-70-3

132-64-9

84-74-2

96-12-8

$106-93-4$

74-95-3

$75-71-8$

$75-35-4$

91-94-1

78-87-5

$60-57-1$

84-66-2.

$57-97-6$

$60-11-7$

60-51-5

122-09-8

$131-11-3$

51-28-5
Long Name

Chrysene

cis-1;3-Dichloropropene

cis-1,2-Dichloroethylene

Chloroethane

Chloroprene

Cobalt-58

Cobalt-60

Cobalt

Chemical Oxygen Demand

Coliform Bacteria

Conductivity

Copper

Chromium-51

Total cresols

Cesium-134

Cesium-137

Cyanide

Cyanide

Delta-BHC

4,4'-DDD

4,4'-DDE

4,4'-DDT

Decane

Diallate

Dibenz[a,h]anthracene

Dibenzofuran

Di-n-butylphthalate

1,2-Dibromo-3-chloropropane

1,2-Dibromoethane

Dibromomethane

Dichlorodifluoromethane

1,1-Dichloroethene

3,3'-Dichlorobenzidine

1,2-Dichloropropane

Dieldrin

Diethylphthalate

7,12-Dimethylbenz[a]anthracene

p-Dimethylaminoazobenzene

Dimethoate

alpha,alpha-Dimethylphenethylamine

Dimethyl phthalate

2,4-Dinitrophenol 
Table C.3. Constituent Table (Cont'd)

Short name
DIOPHTH
DIOXANE
DIPHAMINE
DIPRNIT
DIPYRPH
DISULFOTON
DMTHLDSLFD
DODECANE
ENDHYDE
ENDO1
ENDOS2
ENDRIN
ENDRKETONE
ENDSFAN
ETHBENZENE
ETHCYANIDE
ETHMETH
ETHMETS
EU-152
EU-154
EU-155
FAMPHUR
FE-59
FLUORAN
FLUORENE
FLUORIDE
GAM-BHC
GAMMCHL
HEPTACHLOR
HEPTIDE
HEXACHL
HEXAENE
HEXCBEN
HEXCBUT
HEXCCYC
HEXCETH
HEXONE
HYDRAZINE
I-129
I-129
I-129LO
INDENOP

\begin{tabular}{ll} 
ID & Long Name \\
\hline & \\
$117-84-0$ & Di-n-octylphthalate \\
$123-91-1$ & 1,4-Dioxane \\
$122-39-4$ & Diphenylamine \\
$621-64-7$ & N-Nitroso-di-n-dipropylamine \\
$297-97-2$ & 0,0-Diethyl 0-2-pyrazinyl phosphorothioa \\
$298-04-4$ & Disulfoton \\
$624-92-0$ & Dimethyldisulfide \\
$112-40-3$ & Dodecane \\
$7421-93-4$ & Endrin aldehyde \\
$959-98-8$ & Endosulfan I \\
$33213-65-9$ & Endosulfan II \\
$72-20-8$ & Endrin \\
$53494-70-5$ & Endrin ketone \\
$1031-07-8$ & Endosulfan sulfate \\
$100-41-4$ & Ethylbenzene \\
$107-12-0$ & Ethyl cyanide \\
$97-63-2$ & Ethyl methacrylate \\
$62-50-0$ & Ethyl methanesulfonate \\
$14683-23-9$ & Europium-152 \\
$15585-10-1$ & Europium-154 \\
$14391-16-3$ & Europium-155 \\
$52-85-7$ & Famphur \\
$14596-12-4$ & Iron-59 \\
$206-44-0$ & Fluoranthene \\
$86-73-7$ & Fluorene \\
$16984-48-8$ & Fluoride \\
$58-89-9$ & Gamma-BHC (Lindane) \\
$5103-74-2$ & gamma-Chlordane \\
$76-44-8$ & Heptachlor \\
$1024-57-3$ & Heptachlor epoxide \\
$70-30-4$ & Hexachlorophene \\
$1888-71-7$ & Hexachloropropene \\
$118-74-1$ & Hexachlorobenzene \\
$87-68-3$ & Hexachlorobutadiene \\
$77-47-4$ & Hexachlorocyciopentadiene \\
$67-72-1$ & Hexachloroethane \\
$108-10-1$ & Hexone \\
$302-01-2$ & Hydrazine \\
$15046-84-1$ & Iodine-129 \\
I-129 & Iodine-129 \\
I-129L & Iodine-129, Low level \\
$193-39-5$ & Indeno(1,2,3-cd)pyrene \\
& \\
& \\
& \\
&
\end{tabular}


Table C.3. Constituent Table (Cont'd)

ShOI name
IODINE
IODOMETHAN
IRON
ISOBUTY
ISODRIN
ISOPHORONE
ISOPROBENZ
ISOSAFROLE
K-40
KEPONE
KEROSENE
LEAD
LPHENOL
M-XYLE
MAGNESIUM
MANGANESE
MCRESOL
MDINBEN
MERCURY
METACRY
METCHAN
METHACR
METHBRO
METHCHL
METHLOR
METHONE
METHPAR
METHYCH
METMSUL
METPYRL
MN-54
MONOPOTASS
MPXYLENE
MXYLENE
N-BUTYL
N-PROBENZ
NA-22
NAPHQUI
NAPHTHA
NB-94
NICKEL
NITBENZ

ID

7553-56-2

74-88-4

$7439-89-6$

78-83-1

$465-73-6$

$78-59-1$

98-82-8

120-5\&-1

13966-00-2

143-50-0

8008-20-6

$7439-92-1$

108-95-2

1330-20-7

7439-95-4

7439-96-5

108-39-4

99-65-0

$7439-97-6$

$80-62-5$

56-49-5

126-98-7

74-83-9

74-87-3

$72-43-5$

78-93-3

298-00-0

75-09-2

$66-27-3$

91-80-5

13966-31-9

7778-77-0

136777-61-2

108-38-3

$104-51-8$

103-65-1

13966-32-0

$130-15-4$

91-20-3

14681-63-1

7440-02-0

98-95-3
Long Name

Iodine

Iodomethane

Iron

Isobutyl alcohol

Isodrin

Isophorone

Isopropylbenzene

Isosafrole

Potassium-40

Kepone

Kerosene

Lead

Phenol

Xylenes (total)

Magnesium

Manganese

$\mathrm{m}$-Cresol

$\mathrm{m}$-Dinitrobenzene

Mercury

Methyl methacrylate

3-Methylcholanthrene

Mẹthacrylonitrile

Bromomethane

Chloromethane

Methoxychlor

2-Butanone

Methyl parathion

Methylenechloride

Methyl methanesulfonate

Methapyrilene

Manganese-54

monopotassium phosphate

$M+P-X y l e n e$

1,3-Dimethylbenzene

n-Butylbenzene

n-Propylbenzene

Sodium-22

1,4-Naphthoquinone

Naphthalene

Niobium-94

Nickel

Nitrobenzene 
Table C.3. Constituent Table (Cont'd)

\begin{tabular}{|c|c|c|c|}
\hline Short name & & $\underline{\mathrm{ID}}$ & Long Name \\
\hline NITPHENOL & & $100-02-7$ & 4-Nitrophenol \\
\hline NITRANILIN & & $100-01-6$ & 4-Nitroaniline \\
\hline NITRATE & & $14797-55-8$ & Nitrate \\
\hline NITRITE & & $14797-65-0$ & Nitrite \\
\hline NITRPYR & & $930-55-2$ & Nitrosopyrrolidine \\
\hline NITRTOL & & $99-55-8$ & 5-Nitro-o-toluidine \\
\hline NNDIPHA & & $86-30-6$ & N-Nitrosodiphenylamine \\
\hline NNIBUTY & & $924-16-3$ & N-Nitrosodi-n-butylamine \\
\hline NNIDIEY & & $55-18-5$ & N-Nitrosodiethylamine \\
\hline NNIDIME & & $62-75-9$ & N-Nitrosodimethylamine \\
\hline NNIMETH & & $10595-95-6$ & $\mathrm{~N}$-Nitrosomethylethylamine \\
\hline NNIMORP & & $59-89-2$ & N-Nitrosomorpholine \\
\hline NNIPIPE & & $100-75-4$ & N-Nitrosopiperidine \\
\hline $\mathrm{NO} 2+\mathrm{NO} 3$ & & $\mathrm{NO} 2+\mathrm{NO} 3-\mathrm{N}$ & Nitrite Nitrate \\
\hline NO2-N & & $\mathrm{NO} 2-\mathrm{N}$ & Nitrogen in Nitrite \\
\hline NO3-N & & NO3-N & Nitrogen in Nitrate \\
\hline OIL/GRS & & OIL/GREASE & Oil and grease \\
\hline OTOLDIN & & $95-53-4$ & o-Toluidine \\
\hline OXYLENE & & $95-47-6$ & 1,2-Dimethylbenzene \\
\hline PARATHION & & $56-38-2$ & Parathion \\
\hline PCDDS & & PCDDS & Polychlorodibenzodioxin \\
\hline PCDFS & & PCDFS & Polychlorodibenzofuran \\
\hline PCYMENE & & $99-87-6$ & p-Cymene \\
\hline PENTACH & & $76-01-7$ & Pentachloroethane \\
\hline PENTCHB & & $608-93-5$ & Pentachlorobenzene \\
\hline PENTCHN & & $82-68-8$ & Pentachloronitrobenzene (PCNB) \\
\hline PENTCHP & & $87-86-5$ & Pentachlorophenol \\
\hline PERCENE & & $127-18-4$ & Tetrachloroethene \\
\hline PH & & PH & $\mathrm{pH}$ Measurement \\
\hline PHENACETIN & & $62-44-2$ & Phenacetin \\
\hline PHENANT & & $85-01-8$ & Phenanthrene \\
\hline PHENDIA & - & $106-50-3$ & p-Phenylenediamine \\
\hline PHORATE & & $298-02-2$ & Phorate \\
\hline PHOSPHATE & & $14265-44-2$ & Phosphate \\
\hline PHOSPHORUS & & $7723-14-0$ & Phosphorus \\
\hline POTASSIUM & & $7440-09-7$ & Potassium \\
\hline PRONAMIDE & & $23950-58-5$ & Pronamide \\
\hline PROPANOL & . & $67-63-0$ & 2-Propanol \\
\hline PU-238 & & $13981-16-3$ & Plutonium-238 \\
\hline PU-241 & & $14119-32-5$ & Plutonium-241 \\
\hline PU39-40 & & PU-239/240 & Plutonium-239/40 \\
\hline PYRENE & & $129-00-0$ & Pyrene \\
\hline
\end{tabular}


Table C.3. Constituent Table (Cont'd)

\begin{tabular}{ll} 
Short name & ID \\
\hline PYRIDINE & $110-86-1$ \\
RA-226 & $13982-63-3$ \\
RA-228 & $15262-20-1$ \\
RADIOSR & RAD_SR \\
RADIUM & $7440-14-4$ \\
RU-103 & $13968-53-1$ \\
RU-106 & $13967-48-1$ \\
SAFROL & $94-59-7$ \\
SB-125 & $14234-35-6$ \\
SEC-BUTYL & $135-98-8$ \\
SELENIUM & $7782-49-2$ \\
SILICON & $7440-21-3$ \\
SILVER & $7440-22-4$ \\
SN-113 & $13966-06-8$ \\
SODIUM & $7440-23-5$ \\
SODMNITRIT & $7632-00-0$ \\
SR & $7440-24-6$ \\
SR-90 & $10098-97-2$ \\
STYRENE & $100-42-5$ \\
SULFATE & $14808-79-8$ \\
SULFIDE & $18496-25-8$ \\
SYMTRIN & $99-35-4$ \\
T14DC2B & $110-57-6$ \\
TC-99 & $14133-76-7$ \\
TDS & TDS \\
TEMPERATUR & TEMPERATURE \\
TERT-BUTYL & $98-06-6$ \\
TETCHPH & $25167-83-3$ \\
TETDITH & $3689-24-5$ \\
TETHYDF & $109-99-9$ \\
TETRADECAN & $629-59-4$ \\
TETRCHB & $95-94-3$ \\
TETRCHP & $58-90-2$ \\
TH-228 & $14274-82-9$ \\
TH-232 & TH-232. \\
THALLIUM & $7440-28-0$ \\
THORIUM & $7440-29-1$ \\
TIN & $7440-31-5$ \\
TITANIUM & $7440-32-6$ \\
TOC & TOC \\
TOLUENE & $108-88-3$ \\
TOTCARB & TC \\
\hline &
\end{tabular}

Long Name

Pyridine

Radium-226

Radium-228

Radiostrontium, total

Radium

Ruthenium-103

Ruthenium-106

Safrol

Antimony-125

sec-Butylbenzene

Selenium

Silicon

Silver

Tin-113

Sodium

Sodium nitrite

Strontium

Strontium-90

Styrene

Sulfate

Sulfides

sym-Trinitrobenzene

trans-1,4-dichloro-2-butene

Technetium-99

Total dissolved solids

Temperature

tert-Butylbenzene

Tetrachlorophenol

Tetraethyl dithiopyrophosphate

Tetrahydrofuran

Tetradecane

1,2,4,5-Tetrachlorobenzene

2,3,4,6-Tetrachlorophenol

Thorium-228

Thorium-232

Thallium

Thorium

Tin

Titanium

Total organic carbon

Toluene

Total carbon 
Table C.3. Conștituent Table (Cont'd)

Short name
TOX
TOXAPHENE
TPH-D
TRANDCE
TRANS13
TRCMFLM
TRIBUPH
TRICELN
TRICHLB
TRICHPH
TRIPHOS
TRIS2CH
TRITIUM
TURBIDITY
U-233/4
U-234
U-235
U-238
URANIUM
VANADIUM
VINYIDE
VINYLAC
ZINC
ZN-65
ZRNB-95

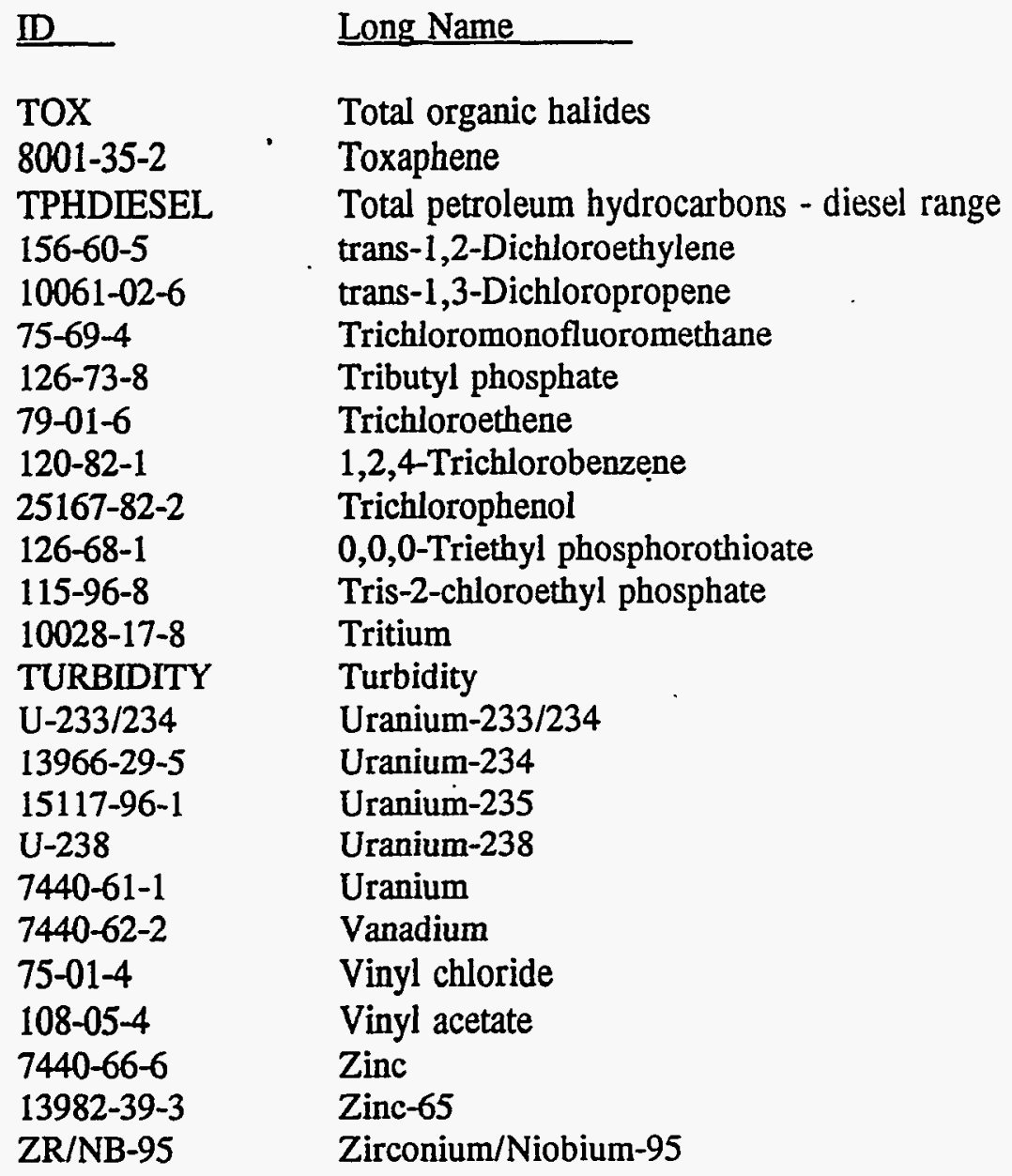


Table C.4. WP Data Qualifiers - Organics (Form = CLPO)

Qualifier

B

D

E

$\mathrm{J}$

JN

$\mathbf{R}$

U

UJ

\section{Definition}

The analyte is found in the associated blank as well as in the sample. Indicates possible contamination of the blank and warns the data user to take appropriate action. Should be replaced by "J" during validation.

Analysis was performed at a secondary dilution factor.

Identifies compounds whose concentrations exceed the calibration range of the GC/MS for that specific analysis.

The associated numerical value is an estimated quantity. The mass spectral data indicate the presence of a compound that meets the identification criteria, but the result is less than the contract-required quantitation limit and greater than zero.

Presumptive evidence of the presence of the material at an estimated quantity.

The data are unusable.

Undetected - analysis did not detect the material. The associated numerical value is the contract-required quantitation limit corrected for dilution and percent moisture.

The material was analyzed for but was not detected. The contract-required quantitation limit is estimated.

$\mathrm{GC} / \mathrm{MS}=$ gas chromatograph/mass spectrometer. 
Table C.5. Data Qualifiers - Inorganics (Form = CLPI and NCLP* or Field = CFlag)

Qualifier

*

$+$

B

BJ

E

J

M

$\mathbf{N}$

$\mathbf{R}$

$S$

$\mathrm{U}$

UJ

W

Definition

Duplicate analysis not within control limits.

Correlation coefficient for MSA is $<0.995$.

Reported value is less than the contract-required quantitation limit but is greater than the instrument detection limit. Should be replaced by "J" during data validation.

Reported value is less than the instrument standardization but is greater than the instrument detection limit. Should be replaced by "J" during data validation.

Serial dilution \%D out of control limits.

The analyte was analyzed for and detected. The associated numerical value is an estimated quantity usable for decision-making processes.

Duplicate injection precision not met.

Spike sample recovery is outside control limits. Presumptive evidence of the presence of the analyte.

The data are unusable.

Reported value determined by the MSA.

Undetected - analyte is below the detection limits of the methods and instruments used. The associated numerical value is the calculated contract-required quantitation limit based on wet weight of the soil sample. The contract-required quantitation limit based on dry weight (stated in the work plan) is higher.

The material was analyzed for but was not detected. The contract-required quantitation limit is estimated.

Post-digestion spike recovery for GFAA out of control limit.

Sample absorbance $<50 \%$ of spike.

GFAA = graphite furnace atomic adsorption

MSA = method of standard addition 
Table C.6. LAS Data Qualifiers (Form = LAS or NCLP)

\begin{tabular}{|c|c|}
\hline Qualifier & Definition \\
\hline $\bar{A}$ & Identifies a TIC as a suspected aldol-condensation product. \\
\hline B & $\begin{array}{l}\text { Used when the analyte is found in the associated blank as well as in the } \\
\text { sample. It indicates possible/probable blank contamination and warns the } \\
\text { data user to take appropriate action. This flag must be used for a TIC as } \\
\text { well as for a TCL compound. }\end{array}$ \\
\hline $\mathrm{C}$ & $\begin{array}{l}\text { Applies to pesticide results where the identification has been confirmed by } \\
\text { GC/MS. . Single component pesticides } \geq 10 \mathrm{ng} / \mathrm{ul} \text { in the final extract shall be } \\
\text { confirmed by GC/MS. }\end{array}$ \\
\hline $\mathrm{D}$ & $\begin{array}{l}\text { Identifies all compounds identified in an analysis at a secondary dilution } \\
\text { factor. }\end{array}$ \\
\hline $\mathrm{E}$ & $\begin{array}{l}\text { Identifies compounds whose concentration exceed the calibration range of the } \\
\text { GC/MS for that specific analysis. This flag does not apply to } \\
\text { pesticides/PCBs analyzed by GC/EC methods. If one or more compounds } \\
\text { have a response greater than full scale, the sample or extract must be diluted } \\
\text { and reanalyzed. If the dilution of the extract causes any compounds } \\
\text { identified in the first analysis to be below the calibration range in the second } \\
\text { analysis, then the results of both analyses shall be reported. }\end{array}$ \\
\hline $\mathrm{J}$ & $\begin{array}{l}\text { Indicates an estimated value. This flag is used either when estimating a } \\
\text { concentration for tentatively identified compounds where a } 1: 1 \text { response is } \\
\text { assumed, or when the mass spectral data indicate the presence of a compound } \\
\text { that meets the identification criteria but the result is less than the sample } \\
\text { quantitation limit and greater than zero. The sample quantitation limit is } \\
\text { corrected for dilution and for percent moisture as in the "U" flag. }\end{array}$ \\
\hline $\mathrm{L}$ & $\begin{array}{l}\text { Used when an analytical result below a CRQL and at or above an MDL is } \\
\text { reported. }\end{array}$ \\
\hline $\mathrm{U}$ & $\begin{array}{l}\text { Indicates compound was analyzed for but not detected. The sample } \\
\text { quantitation limit is corrected for dilution and for percent moisture. }\end{array}$ \\
\hline$X, Y$, or $Z$ & $\begin{array}{l}\text { Other specific flags and footnotes may be required to properly define the } \\
\text { results. If used, they must be fully described and such description attached to } \\
\text { the Sample Data Summary Package and Case Narrative. Begin by using } \\
\text { "X." If more than one flag is required, use "Y" and "Z" as needed. }\end{array}$ \\
\hline $\begin{aligned} \mathrm{CRQL} & = \\
\mathrm{GC} / \mathrm{EC} & = \\
\mathrm{GC} / \mathrm{MS} & = \\
\mathrm{MDL} & = \\
\mathrm{PCBS} & = \\
\mathrm{TCL} & = \\
\mathrm{TIC} & =\end{aligned}$ & $\begin{array}{l}\text { l required quantitation limit } \\
\text { aromatography/eddy current } \\
\text { aromatography/mass spectrometer } \\
\text { d detection limit } \\
\text { hlorinated biphenyls } \\
\text { compound list } \\
\text { ively identified compound }\end{array}$ \\
\hline
\end{tabular}




\section{Table C.7. FEAD Lab Qualifiers}

\section{Applicable for ANION Group}

B The detected amount of the analyte being tested is less than the RDL, but greater than or equal to the MDL/IDL.

U The analyte was analyzed for, but not detected at or above the statistically adjusted MDL/IDL. Report the MDL/IDL corrected for perfect solids, aliquot size and dilution factor as appropriate for the sample media.

\section{Applicable for METAL Group}

B The result value was less than the RDL, but was greater than or equal to the IDL.

E The reported value is estimated because of the presence of interference. An explanatory note must be included with the hard copy case narrative (defined in the applicable Statement of Work [SOW]) and must specify the sample number, Form number $\mathbf{I}$, and $C A S$ number.

U The analyte was analyzed for but not detected at or above the statistically adjusted IDL. Report the IDL corrected for perfect solids, aliquot size and dilution factor as appropriate for the sample media.

\section{Applicable for VOA Group}

B The analyte was found in the associated laboratory blank as well as in the sample. It indicates possible contamination of the sample and warns the data user to take appropriate action.

E The concentration of the compound exceeded the calibration range of the GC/MS.

J The result value is an estimate. The mass spectral data indicates the presence of a compound that meets the identification criteria, but the result is less than the RDL and is greater than zero.

U The analyte was analyzed for but not detected at or above the statistically adjusted MDL or IDL. Report the MDL corrected for perfect solids, aliquot size and dilution factor as appropriate for the sample media.

\section{Applicable for RAD Group}

$J$ The result value is an estimate. No $\mathbf{U}$ qualifier has been assigned and the result is below the RDL.

U The analyte was analyzed for, but the result is less than the MDA. This includes the gamma-scan case when the radionuclide was analyzed for and not detected. 
Table C.8. Data Review Codes

\begin{tabular}{cl} 
Review Code & Translation \\
\cline { 1 - 1 } D & $\begin{array}{l}\text { Result is associated with a documented laboratory } \\
\text { nonconformance. }\end{array}$ \\
F & $\begin{array}{l}\text { Result is undergoing further review. } \\
\text { G }\end{array}$ \\
H & Result is valid according to further review. \\
P & Potential problem. Collection/analysis circumstances makes value \\
Q & questionable. . \\
R & Associated quality control sample is out of limits. \\
Y & Result is not valid according to further review. \\
$\mathrm{Z}$ & Result is suspect. Review had insufficient evidence to show result valid or \\
& invalid.
\end{tabular}




\section{DISTRIBUTION}

No. of

Copies

\section{OFFSITE}

A. Aldrich

U.S. Bureau of Land Management Spokane District Office 1103 North Fancher Spokane, WA 99212-1275

M. Ault

U.S. Ecology, Inc.

P.O. Box 638

Richland, WA 99352

3 J. S. Bachmaier Office of Environmental Policy and Assistance

U.S. Department of Energy 1000 Independence Avenue SW Washington, D.C. 20585

J. Blanchard

U.S. Bureau of Reclamation

P.O. Box 815

Ephrata, WA 98823

L. Block

U.S. Fish and Wildlife Service

P.O. Box 1157

Moses Lake, WA 98837

J. O. Boda

U.S. Department of Energy 1000 Independence Avenue SW Washington, D.C. 20585

R. Buck, Jr.

Wanapum Indian Band

P.O. Box 878

Ephrata, WA 98823
No. of

Copies

C. Caprio

Jason, Associates

3250 Port of Benton Boulevard

Richland, WA 99352

J. Chasse

Washington Public Power Supply

System

P.O. Box 968

Richland, WA 99352

2 R.A. Danielson

Washington State Department of

Health

2 South 45th Avenue

Yakima, WA 98908

G. De Bruler

Columbia River United

P.O. Box 912

Bingen, WA 98605

B. Drost

U.S. Geologic Survey

1201 Pacific Avenue, Suite 600

Tacoma, WA 98402

2 M. Dunkleman

J. Erickson

Washington State Department of Health

Division of Radiation

Protection

P.O. Box 47827

Olympia, WA 98504-7827

A. J. K. Fyall

Benton County Planning

P.O. Box 910

Prosser, WA 99350 . 
No. of

Copies

T. Gilmore

Environmental Planning/

Rights Protection

Confederated Tribes of the

Umatilla Indian Reservation

P.O. Box 638

Pendleton, OR 97801

M. W. Grainey

Assistant to the Director

Oregon Department of Energy

625 Marion Street, NE

Salem, OR 973103

H. Gucinski, Chair

Pacific Northwest Natural Area

Committee

3200 Jefferson Way

Corvalis, OR 97331

\section{J. Hansen}

Mayor

City of Richland

505 Swift Boulevard

Richland, WA 99352

3 M. Harmon

U.S. Department of Energy

656 Quin Orchard Road

Building QO

Gaithersburg, MD 20585

S. Harris

Environmental Restoration/

Waste Management

Nez Perce Tribe

P.O. Box 365

Lapwai, ID 83540-0365
No. of

Copies

R. Jim

Yakama Indian Nation

Environmental Restoration/Waste Management

P.O. Box 151

Toppenish, WA 98948

P. Knight

Northwest Environmental Advocates/

Hanford Watch

133 Southwest Second Avenue,

Suite 302

Portland, OR 97204-3526

R. Leaumont

Lower Columbia Basin Audubon

Society

9016 Sunset Terrace

Pasco, WA 99301

J. Leier

U.S. Army Corps of Engineers

Walla Walla District

Building 602, City-County Airport

Walla Walla, WA 99632-9265

R. Patt

Oregon State Department of

Water Resources

3850 Portland Road

Salem, OR 97310

G. M. Pollet

Executive Director

Heart of America, NW

1305 Fourth Avenue

Cobb Building, Suite 208

Seattle, WA 98101 
No. of

Copies

D. Powaukee

Environmental Restoration/

Waste Management

Nez Perce Tribe

P.O. Box 365

Lapwai, ID 83540-0365

M. Reeves

Oregon League of Women Voters

22250 Boulder Crest Lane

Amity, OR 97101

P. Rodgers

Environmental Science and

Technology

2 Inverness Drive E. Suite 201

Englewood, CO 80111

South Columbia Basin Irrigation

District

402 W. Lewis Street

Pasco, WA 99301

L. Stembridge

Executive Director

Hanford Education Action League

(HEAL)

$1408 \mathrm{~W}$. Broadway Avenue

Spokane, WA 99205-1902

3 J. Stohr

C. Cline

J. Witczak

Washington State Department of

Ecology

P.O. Box 47600

M.S. 7600

Olympia, WA $98504-7600$

S. Strawn

Benton County Commission. 7014 West Fourth Street

Kennewick, WA 99336
No. of

Copies

T. Walker

Kennewick City Council

210 West Sixth Avenue

Kennewick, WA 99336

J. R. Wilkerson

Environmental Planning/

Rights Protection

Confederated Tribes of the

Umatilla Indian Reservation

P.O. Box 638

Pendleton, OR 97801

10 M. A. Wilson

Washington State Department of

Ecology

1315 4th Avenue

Kennewick, WA 99336

\section{ONSITE}

53 DOE Richland Operations Office

R. F. Brich

H4-83

E. M. Bowers

S7-55

C. E. Clark

A5-15

T. D. Cress

S7:51

J. K. Erickson

$\mathrm{H} 4-83$

M. J. Furman

S7-55

C. H. Gunion

H4-83

J. B. Hall

A5-55

R. D. Hildebrand (30)

H4-83

R. A. Holten

H4-83

L. K. McClain

H4-83

R. G. McLeod

H4-83

D. E. Olson

H4-83

D. J. Ortiz

G3-18

P. M. Pak

H4-83

R. A. Quintero

S7-55

W. B. Scott

A5-55

R. K. Stewart

H4-83

T. K. Teynor

S7-55

K. M. Thompson

A5- 15

A. C. Tortoso

H4-83

D. M. Wanek 
No. of

Copies

D. C. Ward

J. F. Young

15 Bechtel Hanford, Inc.

W. W. Ballard

J. V. Borghese

D. B. Erb

K. R. Fecht

B. H. Ford

R. L. Jackson

G. L. Kasza

A. J. Knepp

D. A. Myers

D. L. Parker

S. D. Liedle

L. C. Swanson

J. S. Treadwell

S. J. Trent

D. C. Weekes

\section{U.S. Army Corps of Engineers}

M. P. Blancq

$4 \quad$ U.S. Environmental Protection

Agency

P. R. Beaver (2)

D. A. Faulk

L. E. Gadbois

15 Westinghouse Hanford Company

W. L. Allen

D. B. Barnett

J. D. Davis

L. P. Diediker

M. G. Gardner

M. J. Hartman

F. N. Hodges

D. G. Horton

V. G. Johnson

M. J. Minette

P. C. Mohondro
A5-55

H4-83

H4-79

H4-90

H6-01

H6-04

H4-85

H4-90

H6-04

H4-85

H6-07

1H6-02

H4-81

H6-04

1H6-01

H6-02

H4-82

IH4-83

B5-01

B5-01

B5-01

146-28

H6-06

H5-61

S3-95

S3-24

H6-06

H6-06

H6-06

H6-06

B5-32

S6-71
No. of

Copies

J. S. Schmid H6-06

J. A. Serkowski H6-06

R. R. Thompson

H6-32
$\mathrm{K} 5-12$

K9-33

K9-08

K9-34

$\begin{array}{ll}\text { D. A. Carrothers } & \text { K9-41 } \\ \text { M. A. Chamness } & \text { K9-48 }\end{array}$

M. A. Chamness K9-48

S. F. Conley

R. L. Dirkes

P. G. Doctor

P. E. Dresel (20)

J. C. Evans

M. J. Fayer

M. D. Freshley

R. M. Fruland

D. R. Geist

R. E. Gephart

B. M. Gillespie

T. J. Gilmore

S. H. Hall

R. W. Hanf

B. L. Harper

C. T. Kincaid

G. V. Last

P. E. Long

S. P. Luttrell (73)

K6-75

K6-75

K8-37

K6-96

K6-96

K9-33

K9-36

K6-96

K6-85

K9-70

K6-75

K9-48

K6-96

K6-75

P7-82

K9-33

K9-48

K9-48

$\mathrm{K} 6-96$

J. P. McDonald

K6-96

J. K. Merz

K6-96

D. R. Newcomer K6-96

K. B. Olsen K6-96

B. E. Opitz

J. T. Rieger

K6-79

K6-96

K6-96

R. Schalla

T. D. Scheibe

R. E. Schrempt

K9-36

K6-86

R. M. Smith

K6-96

K8-31

K6-96

F. A. Spane, Jr. (3)

D. L. Stewart

K6-96 
No. of

Copies

G. P. Streile

K9-33

S. S. Teel

K9-48

P. D. Thorne

K6-96

V. R. Vermeul

K6-96

T. B. Walters

K6-96

W. D. Webber (3)

K6-96

H. E. Westerdahl

K6-75

M. S. Witkowski

K6-96

S. K. Wurstner

K9-36

Information Release

Office (7)

K1-11

Distr.5 


\section{Plate 1. Hanford Site and Outlying Al}

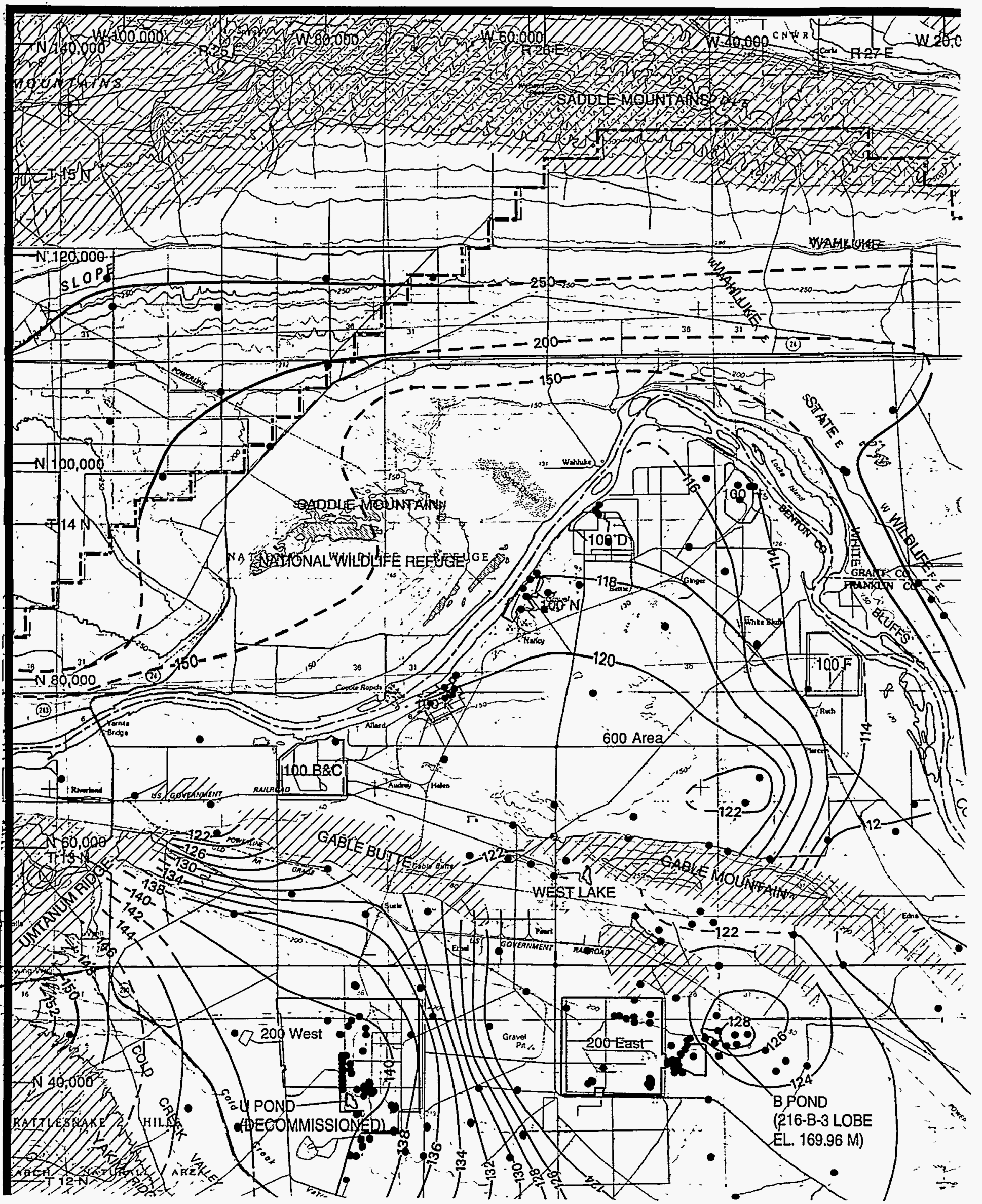




\section{reas Water-Table Map}

\section{June 1994}

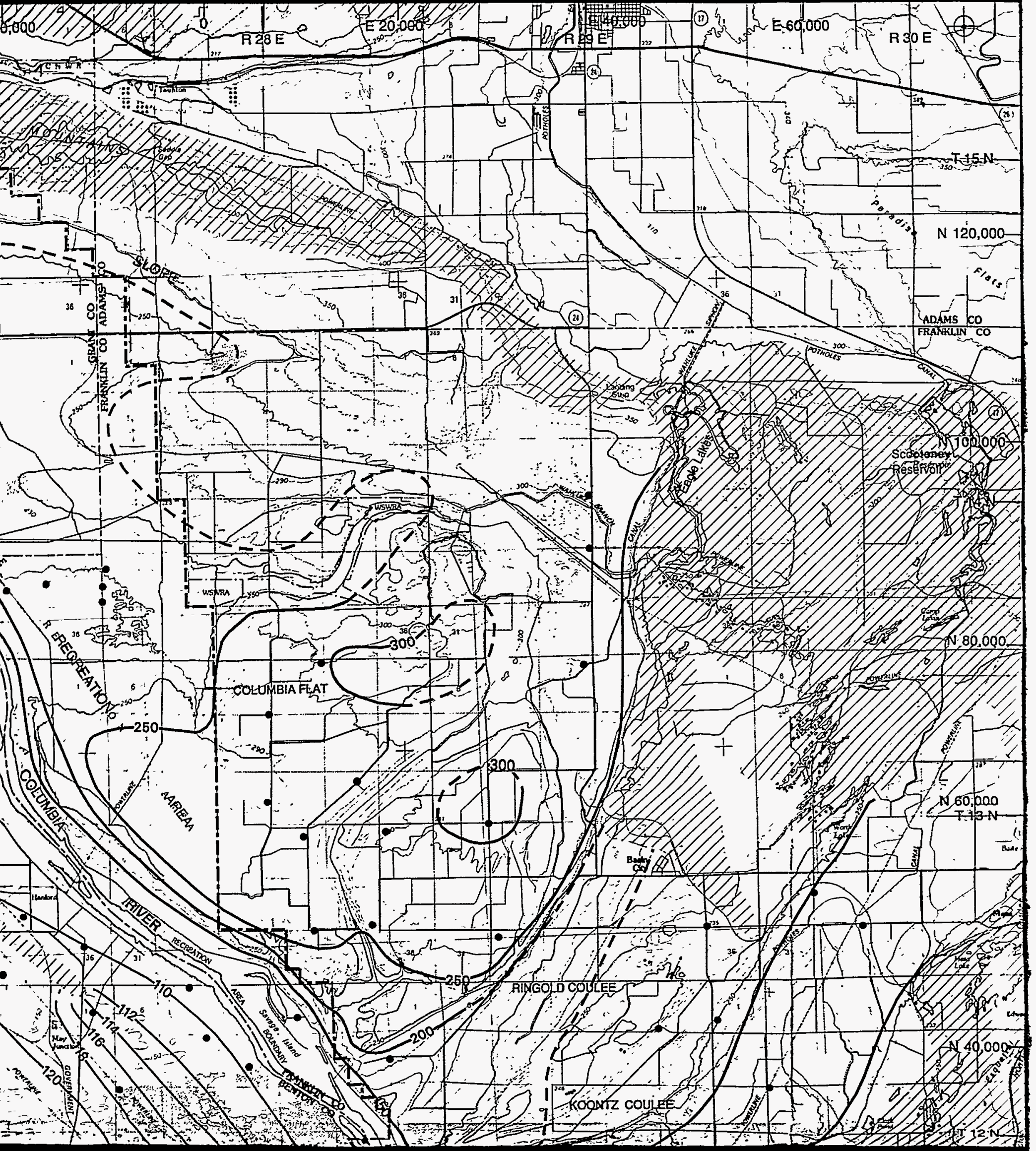




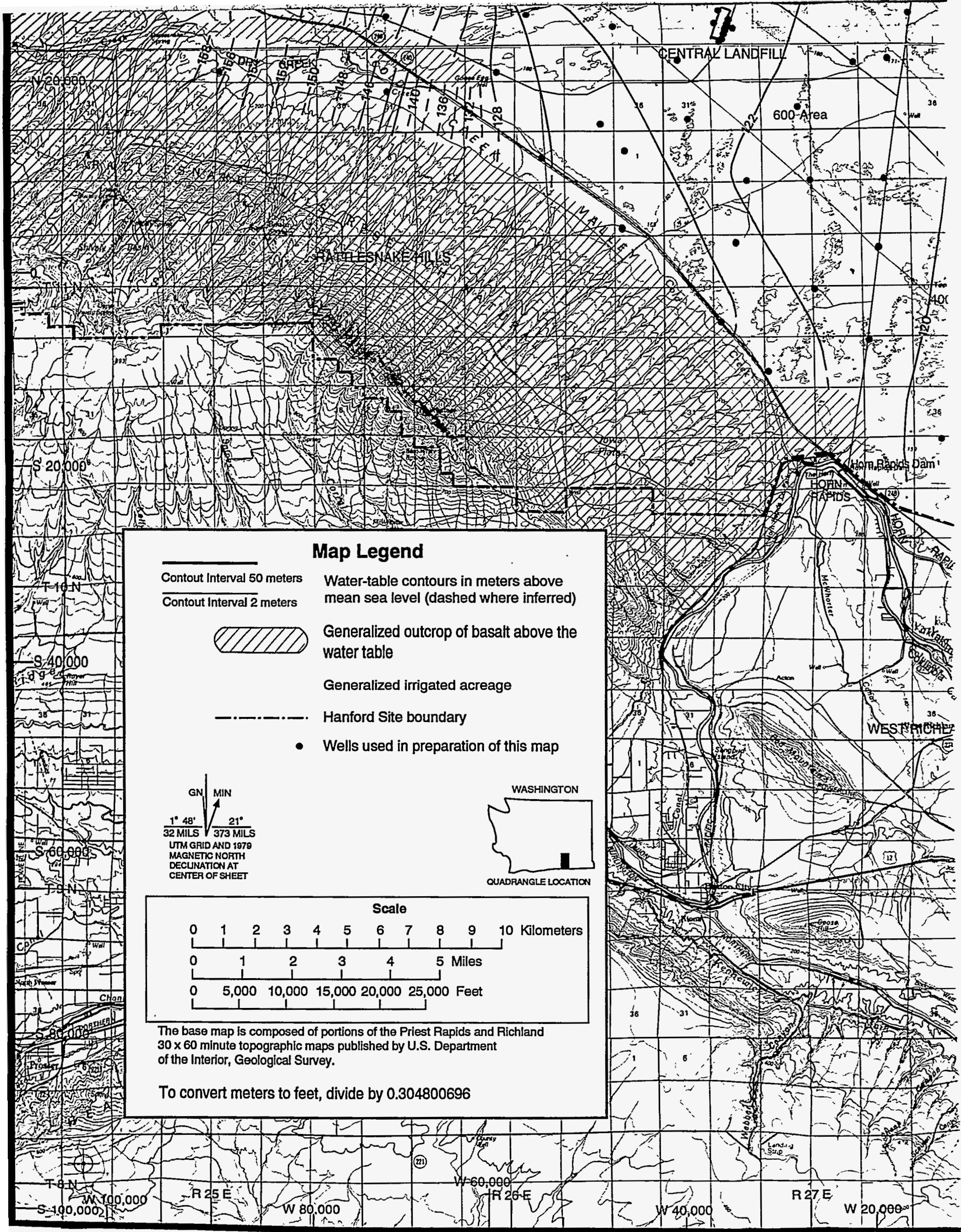




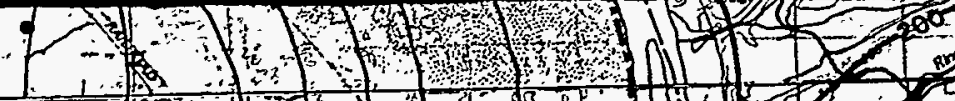

(x) $+4 \cdot 4$ - $1=x$
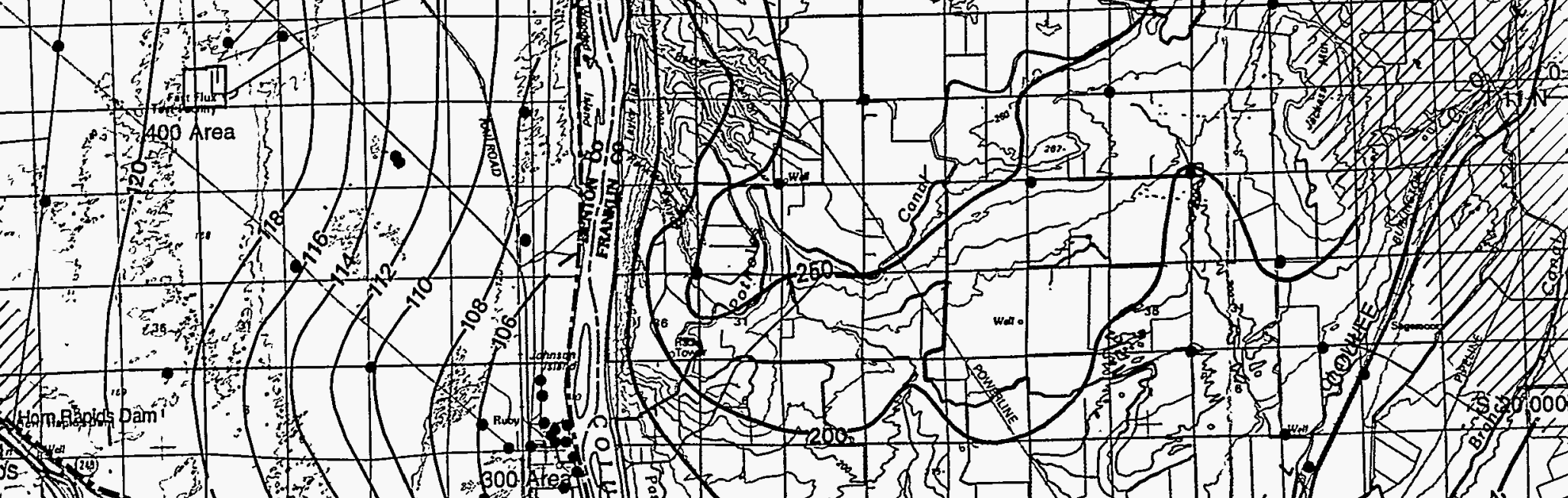

17100 ,

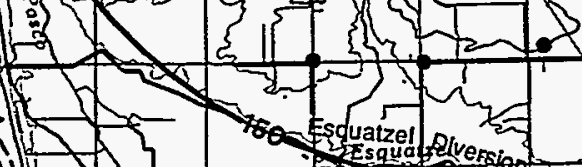

(1) Z WESTME
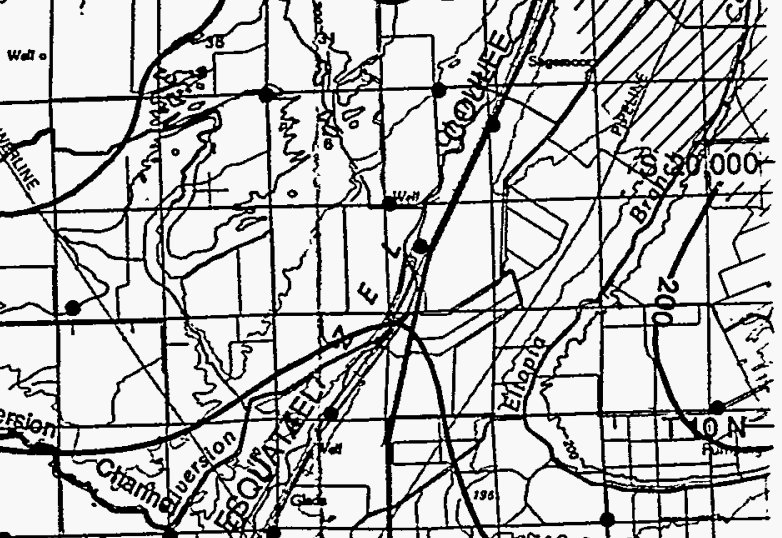
1.2010

(10)

(4)
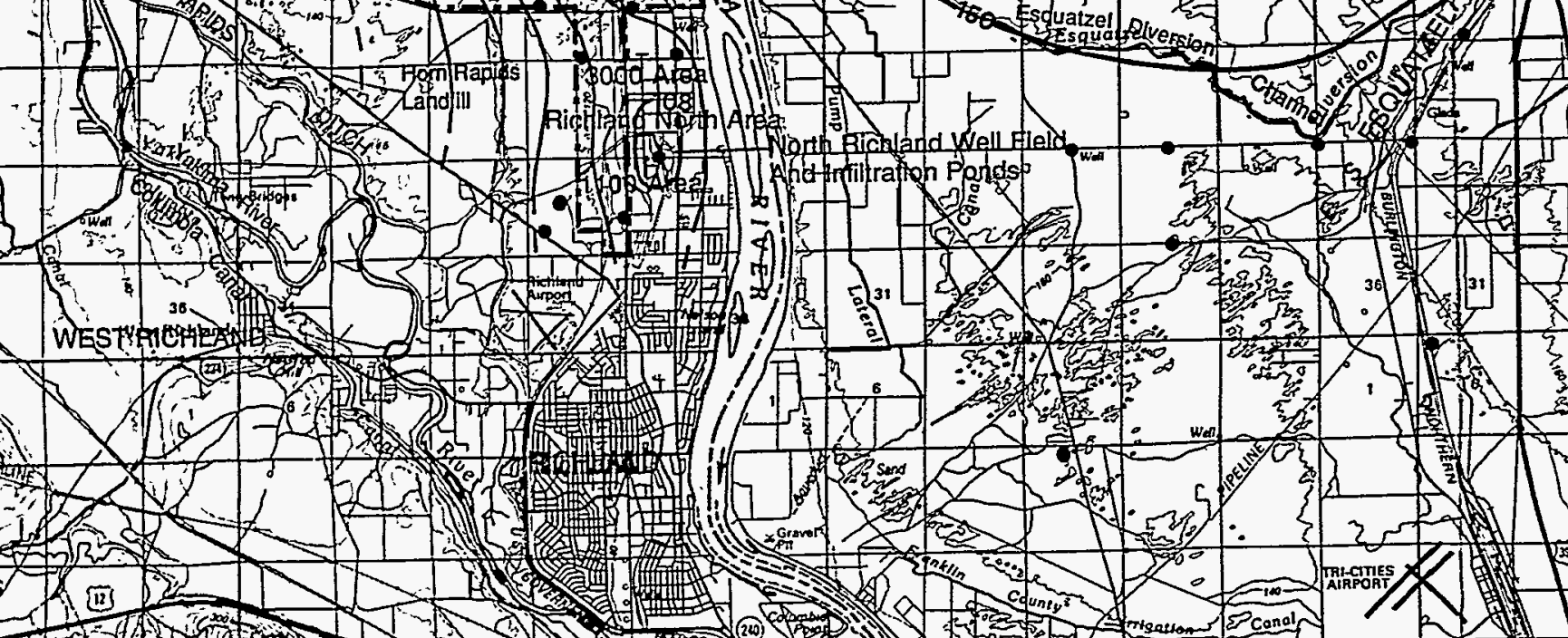

in

(1)
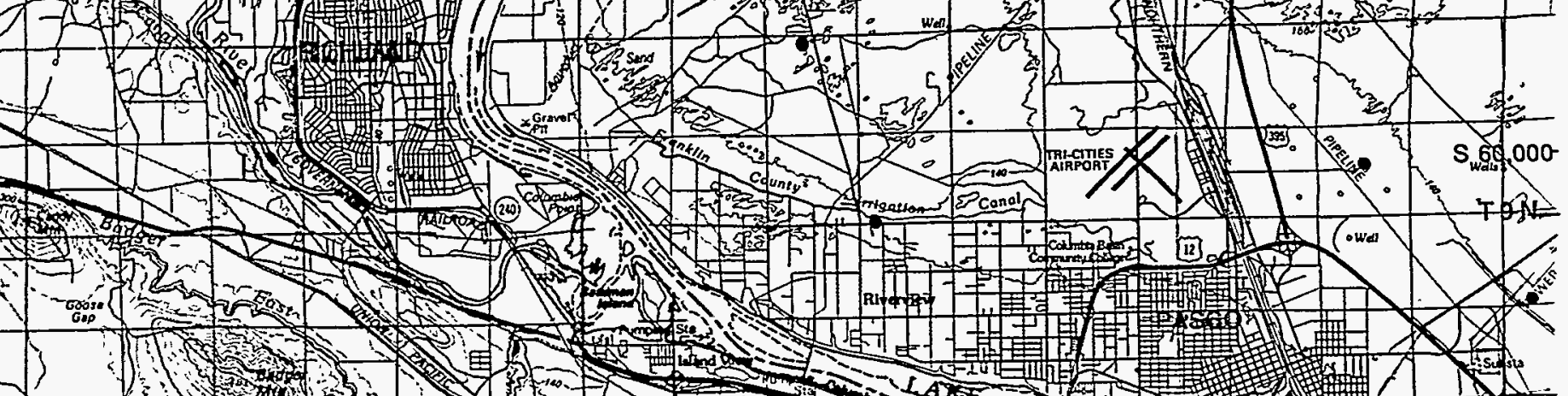

-2.

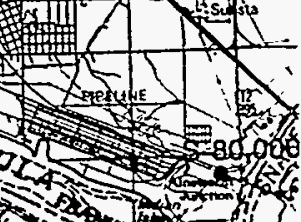

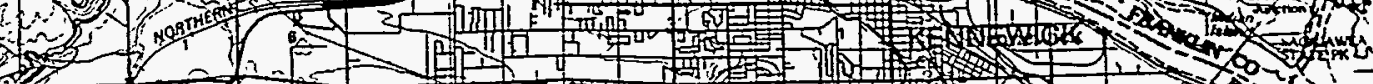

60 (1) 


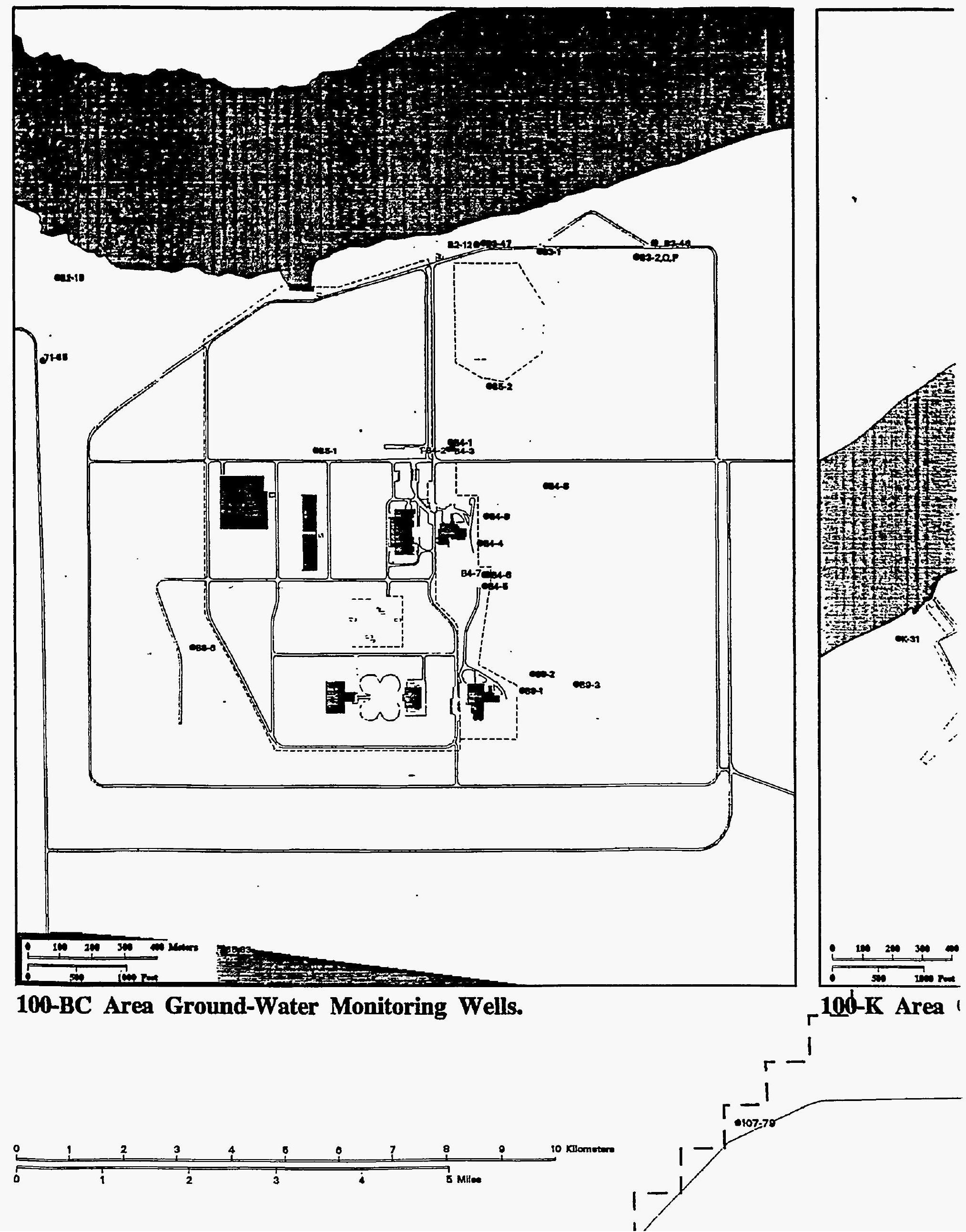


aquA-punoxग вary N-00I

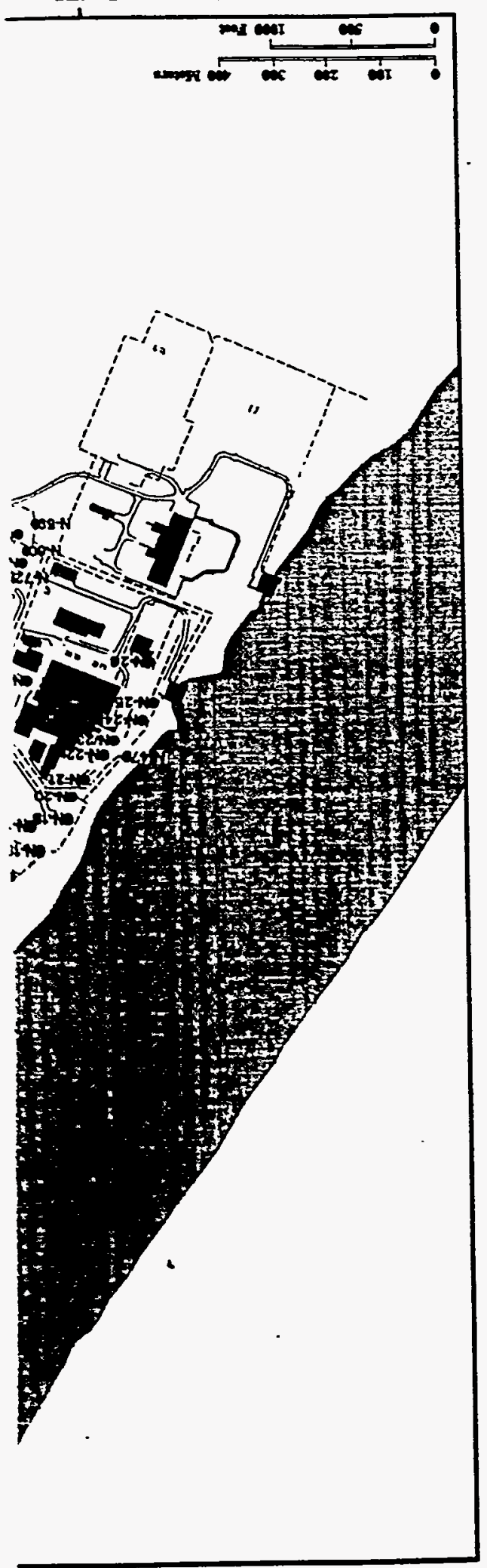

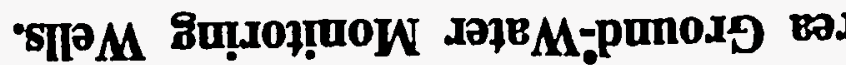

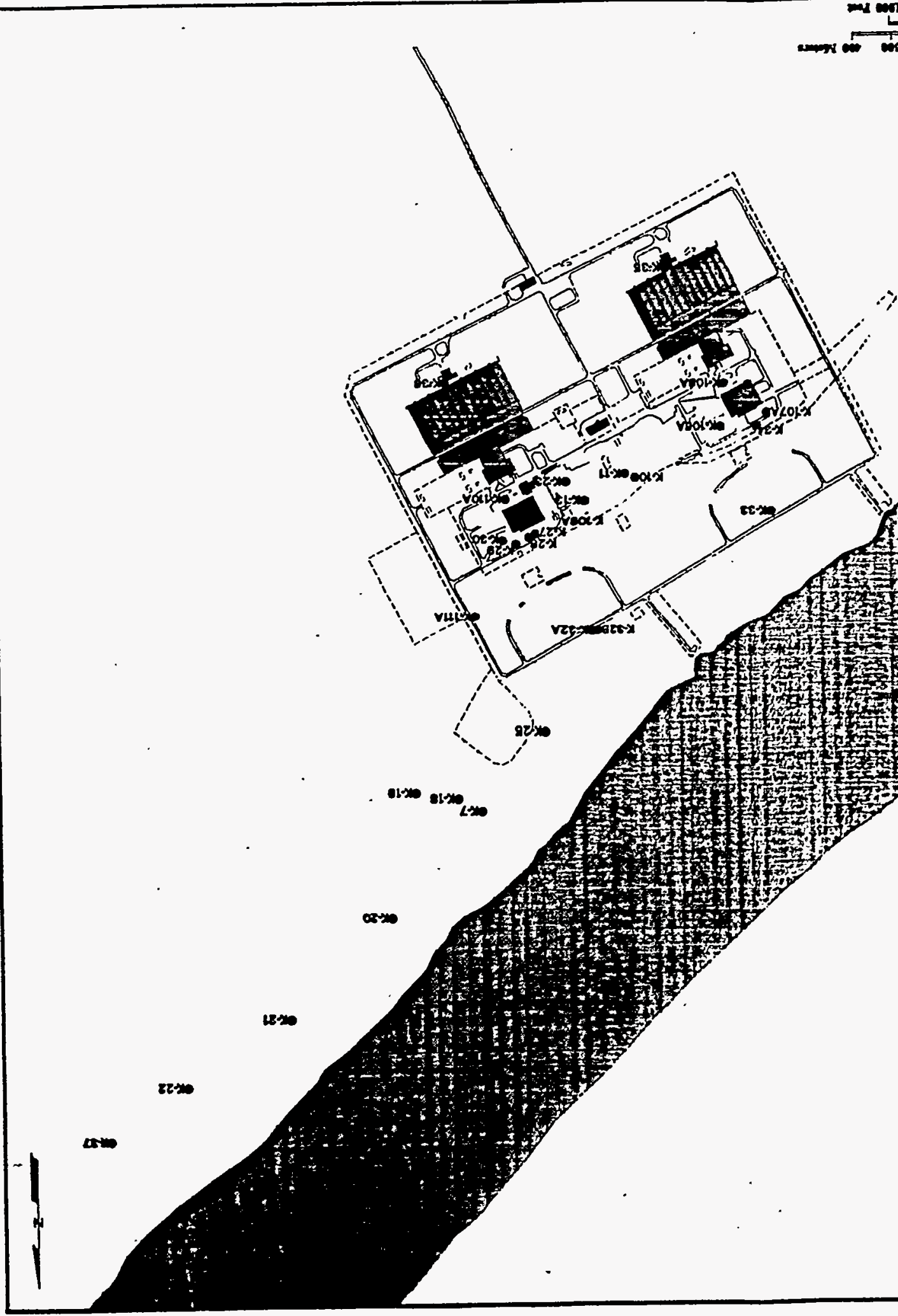


atsonst

Highnस8s 243

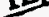

dits

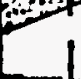
3.

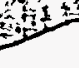




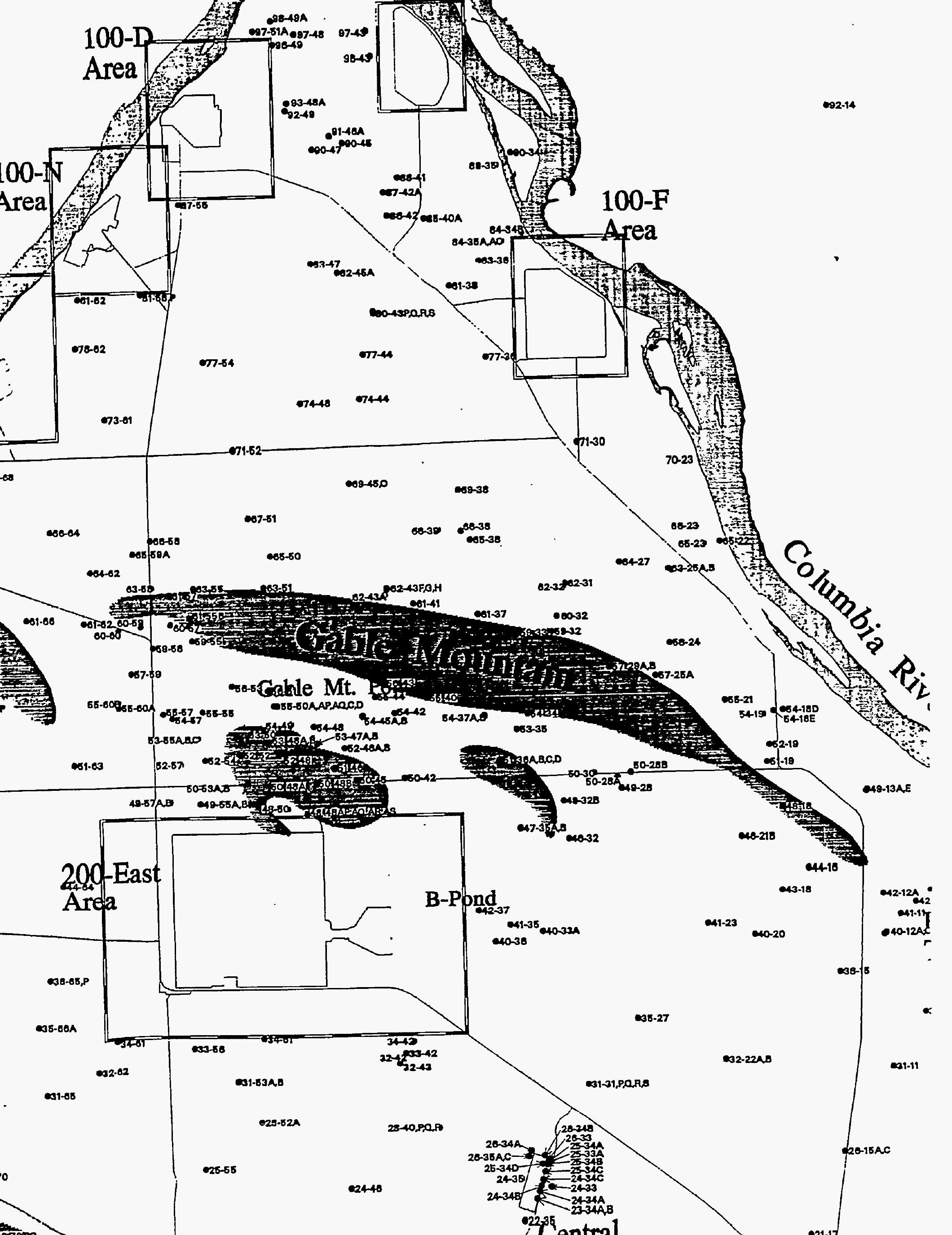




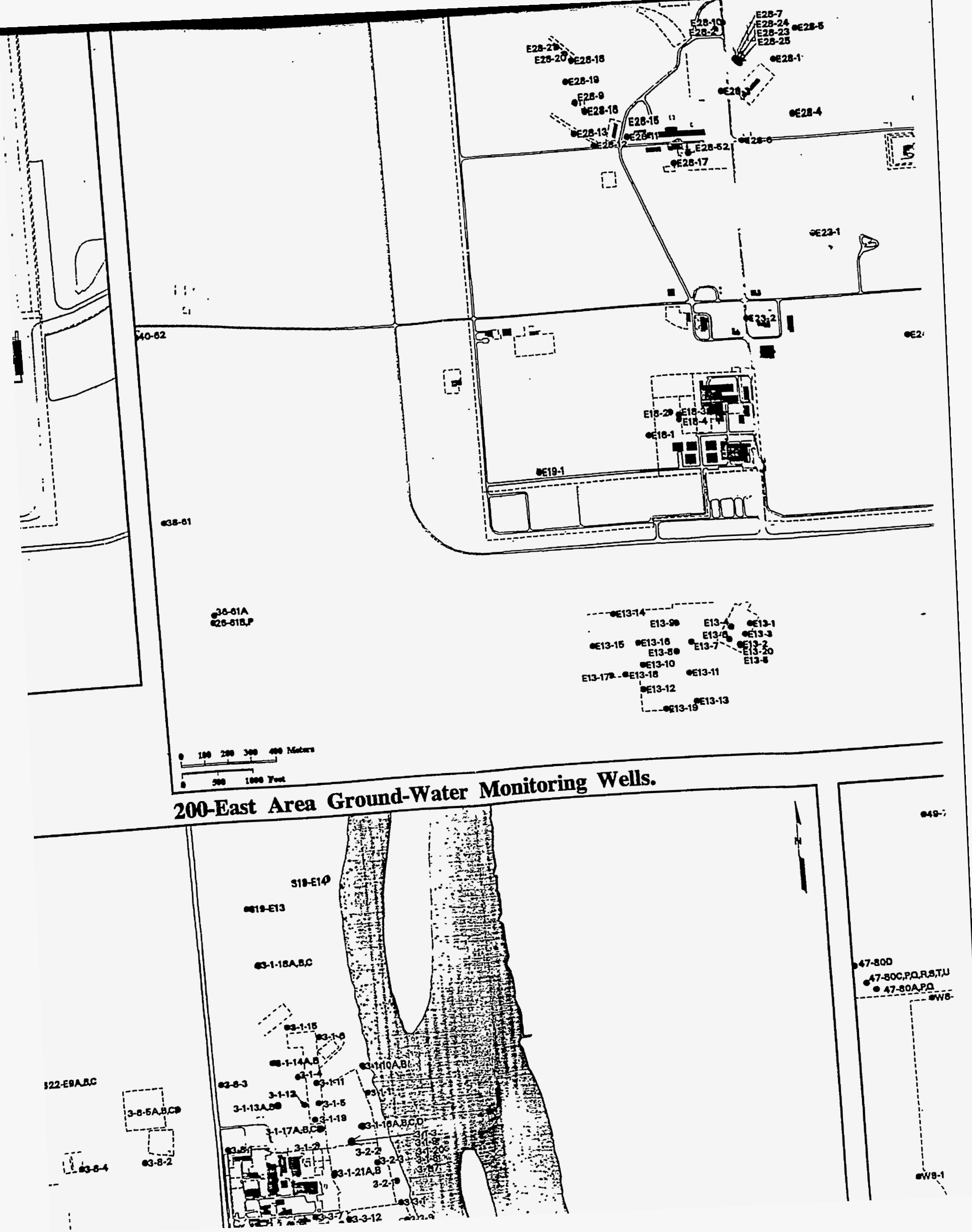




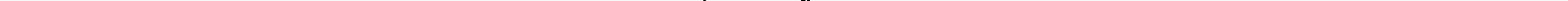





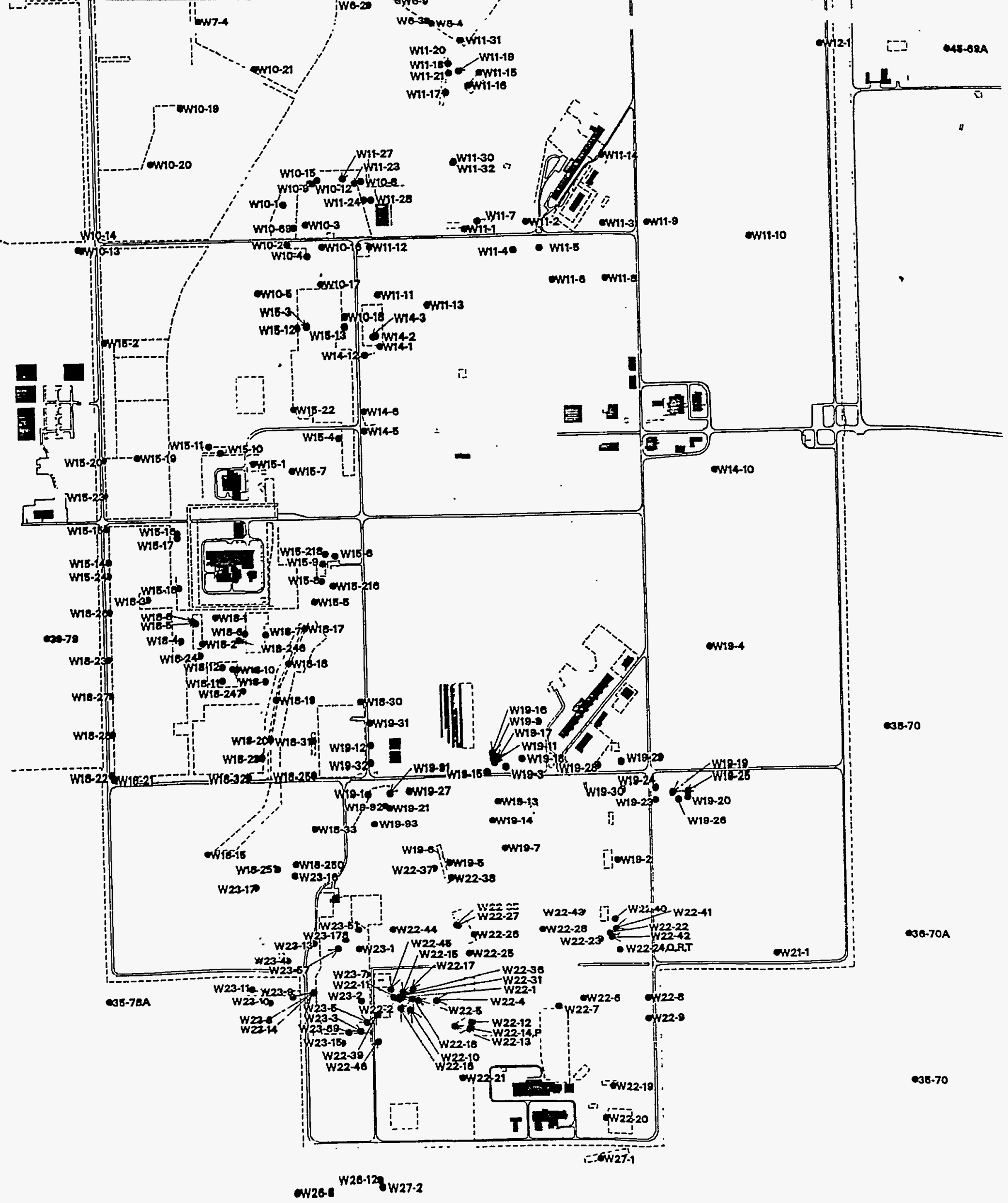

aw2e-2

W26-39 ow26-4

-W2e-10

w20-620-1 
Plate 2: Monitoring Wells At The 


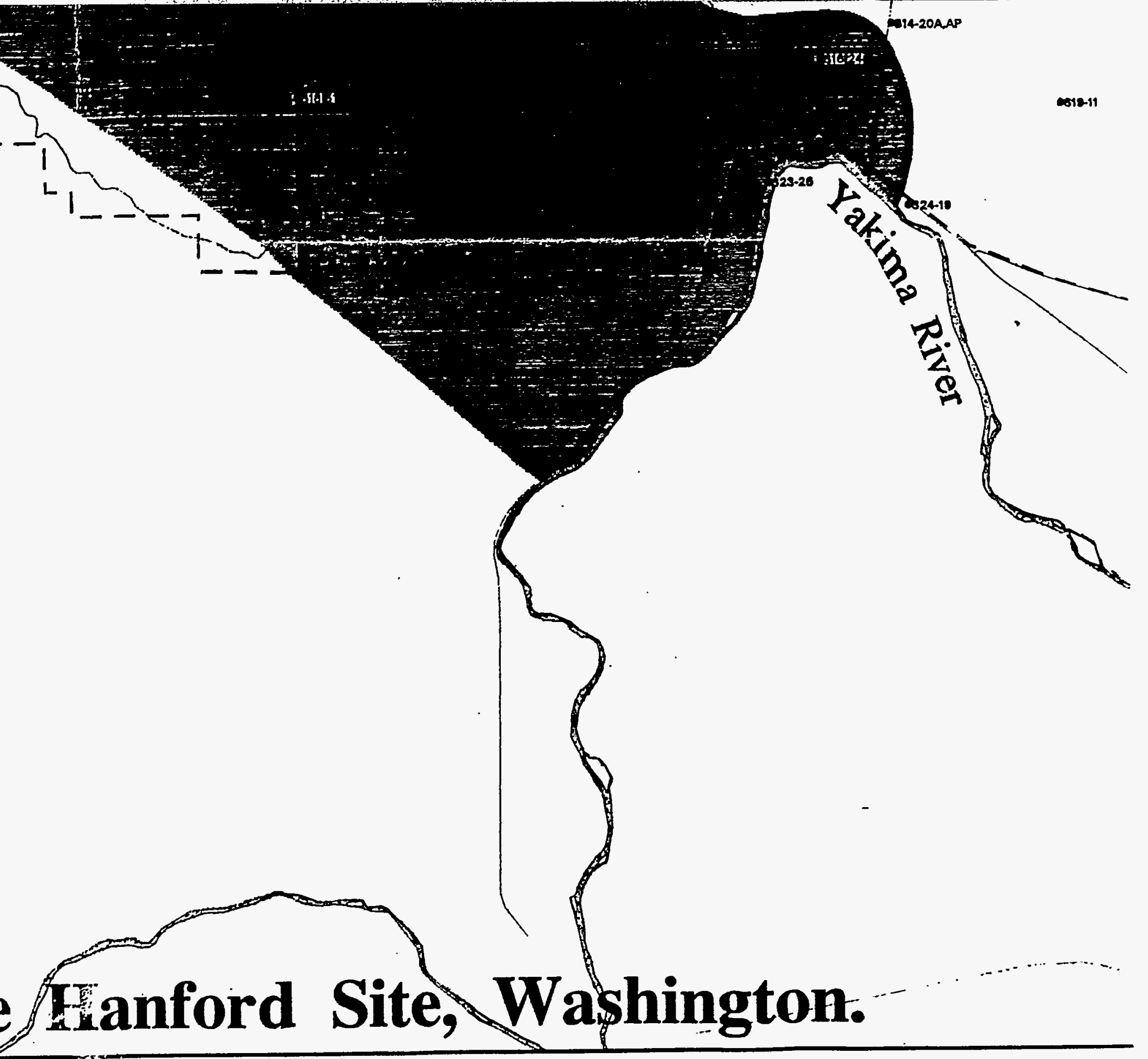




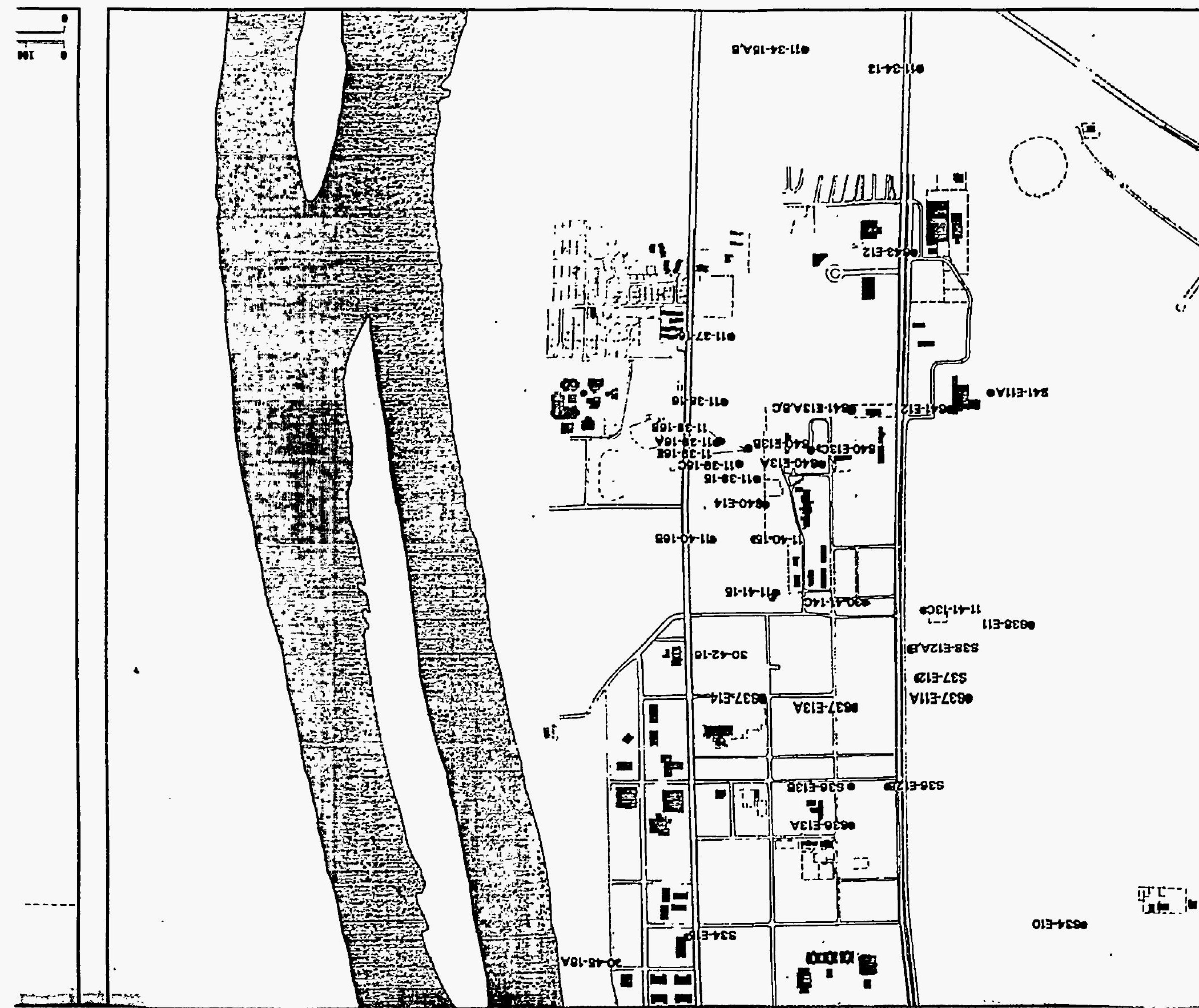




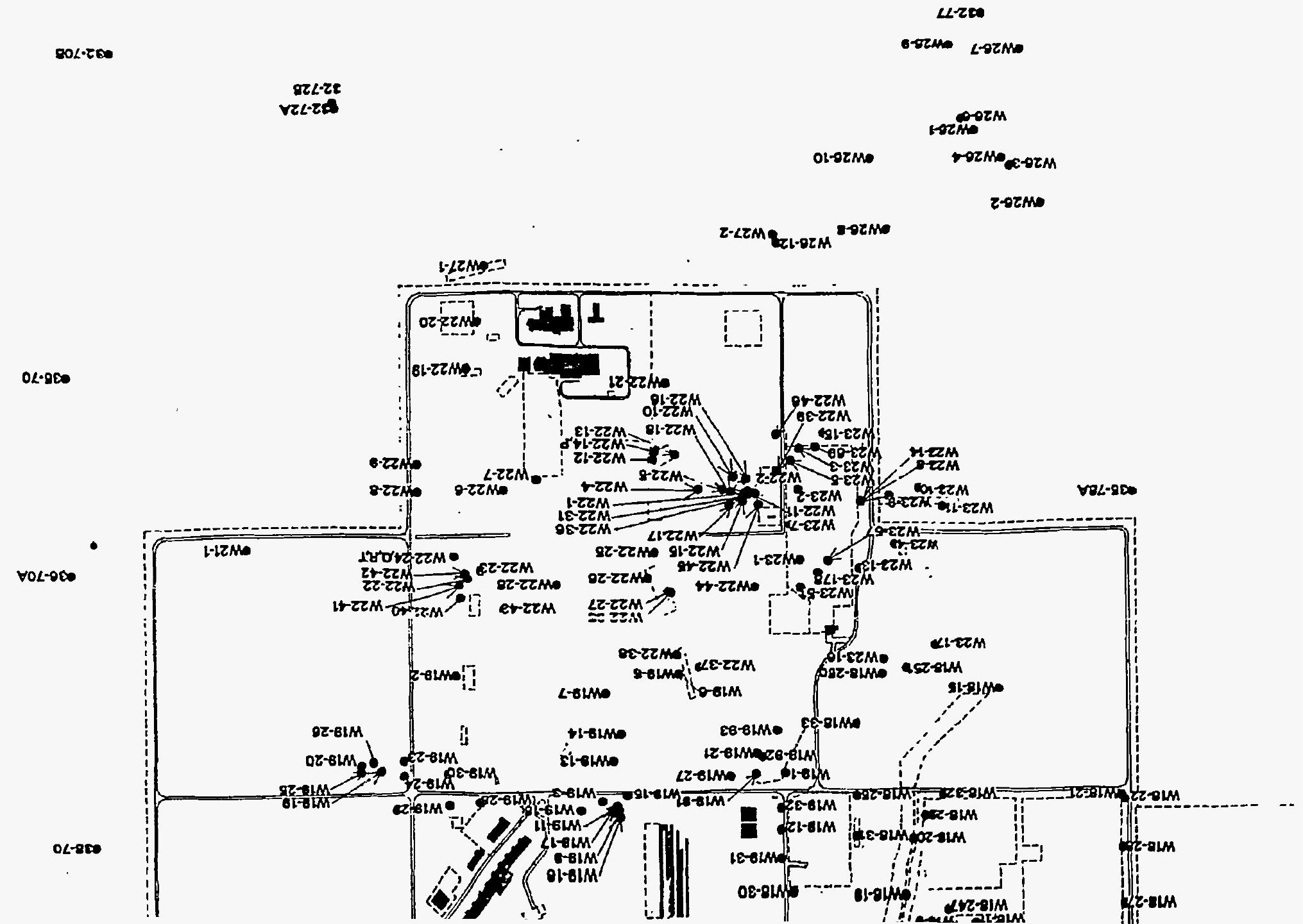




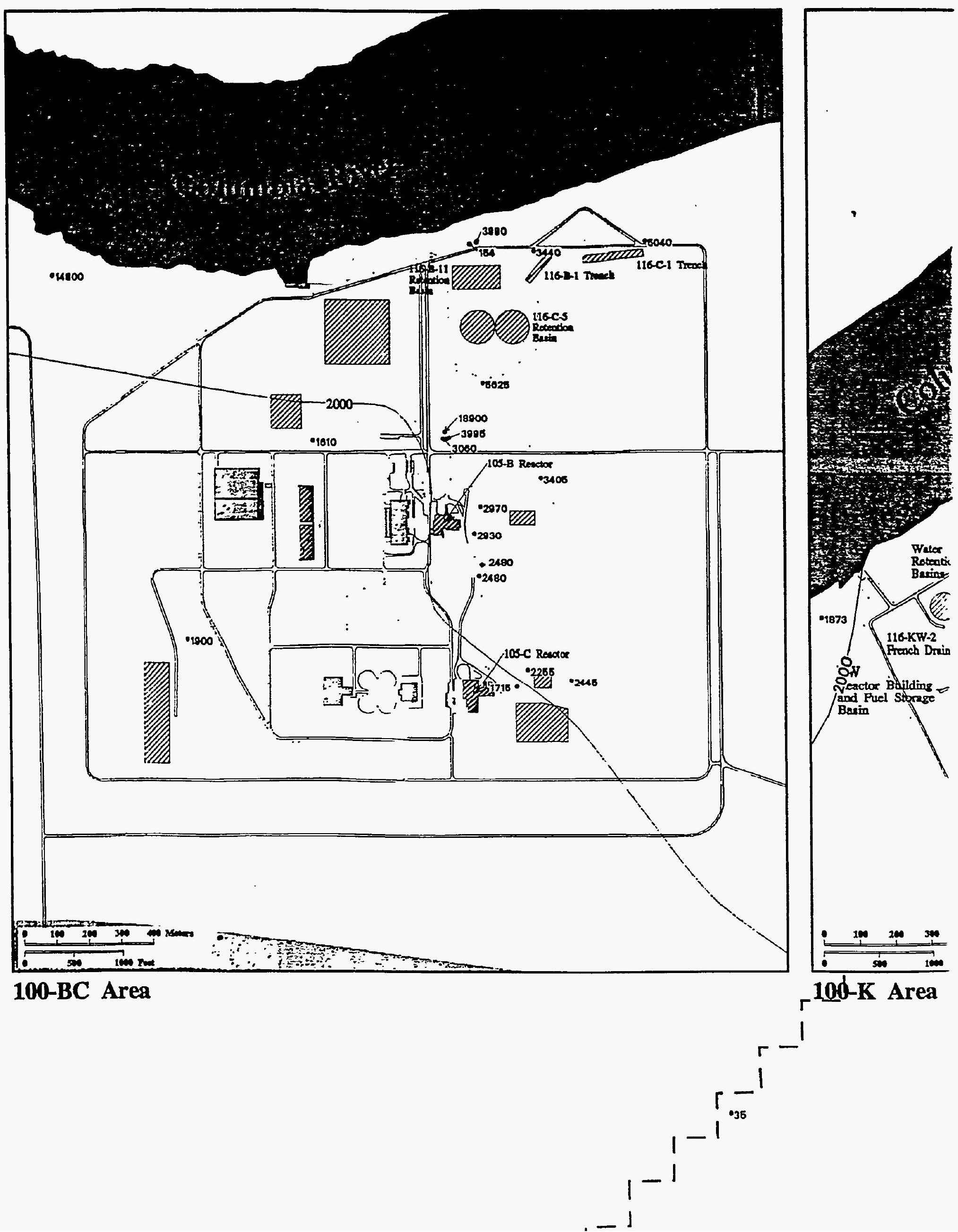




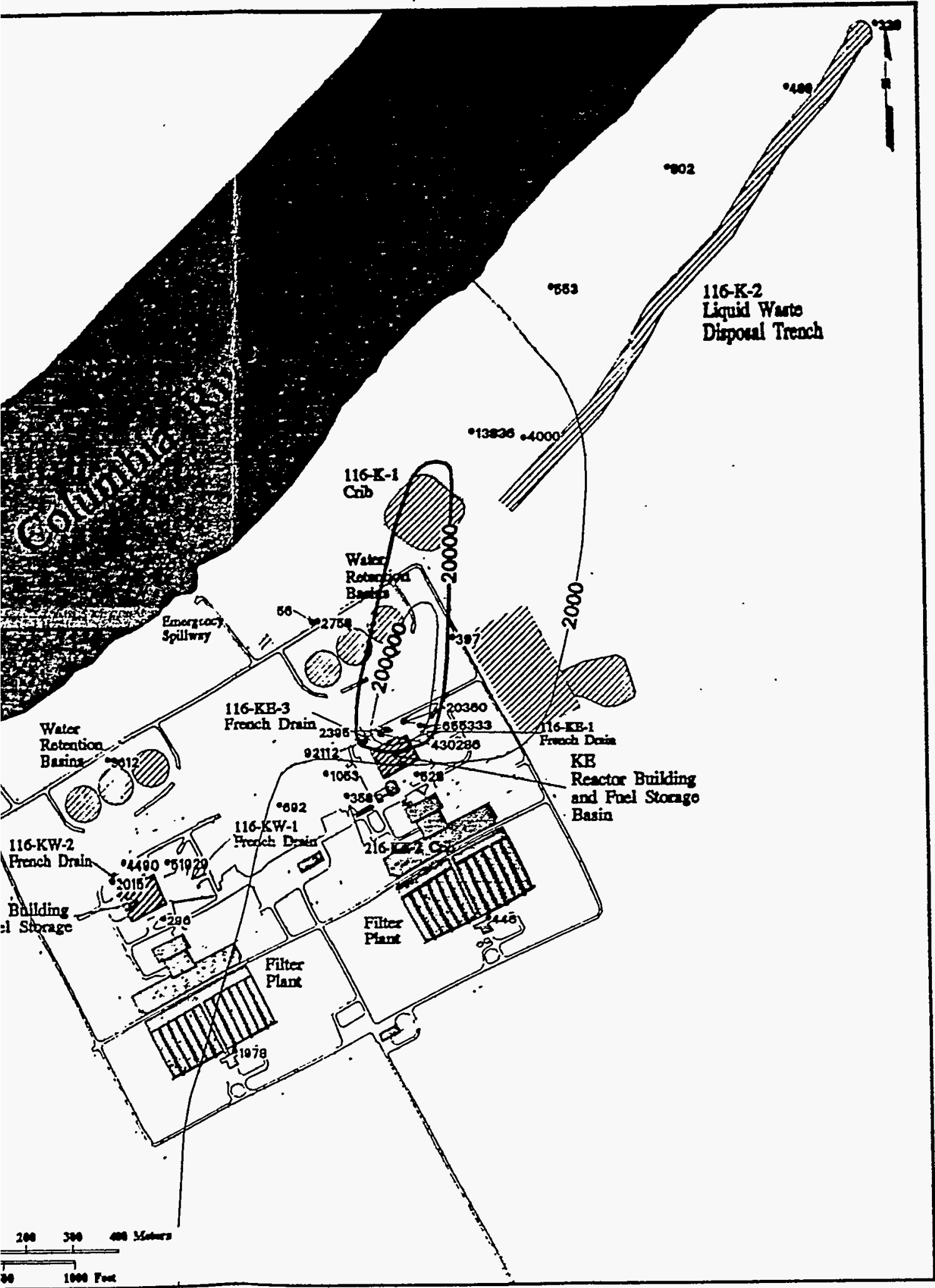

Area

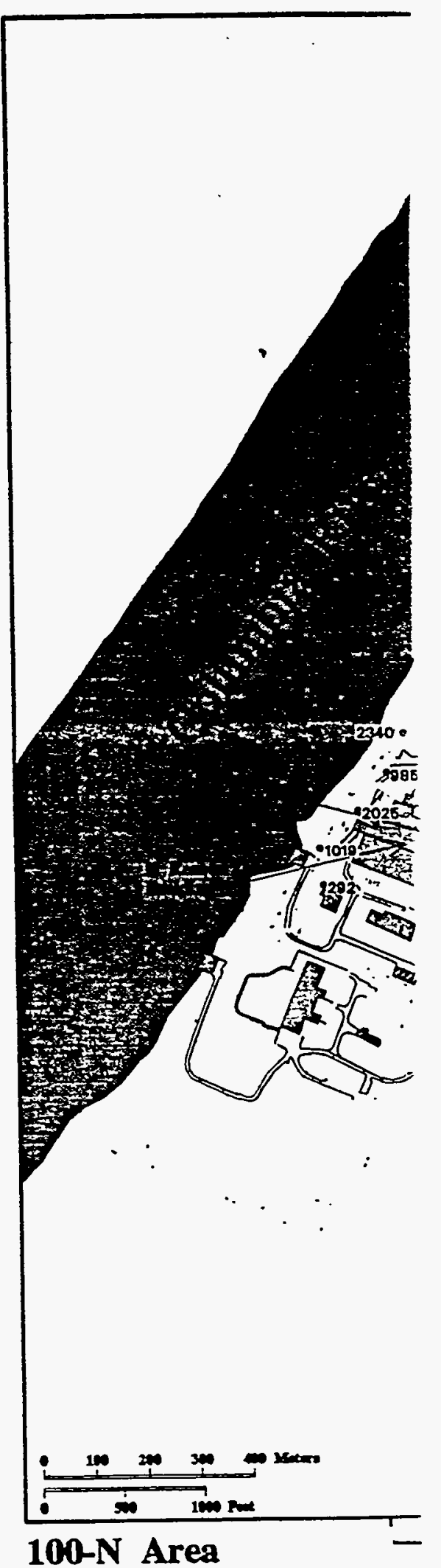

100-N Area

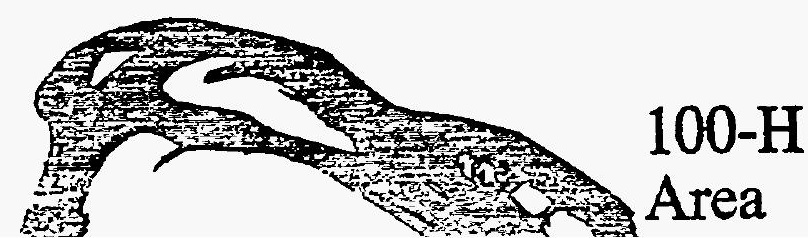



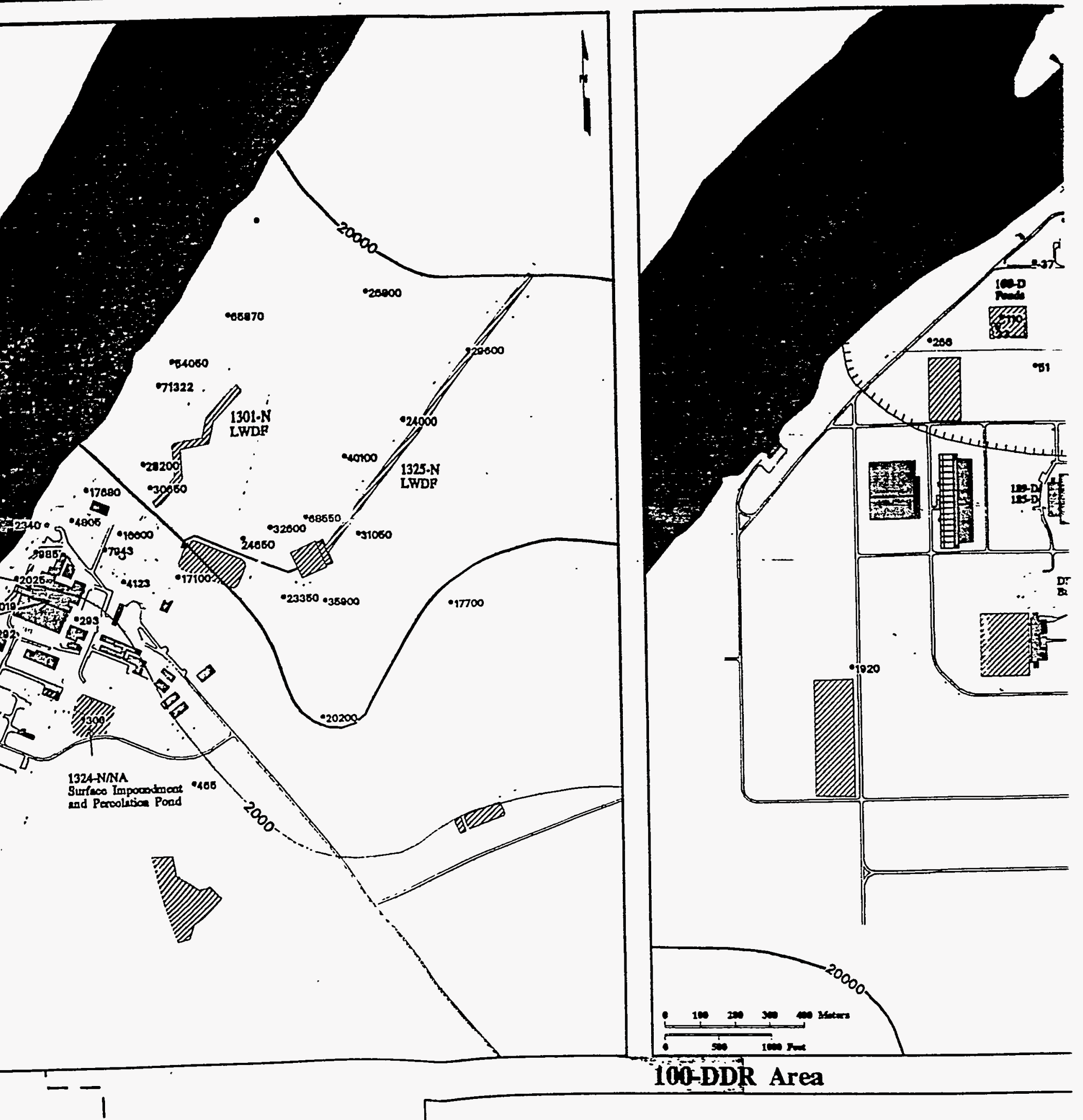

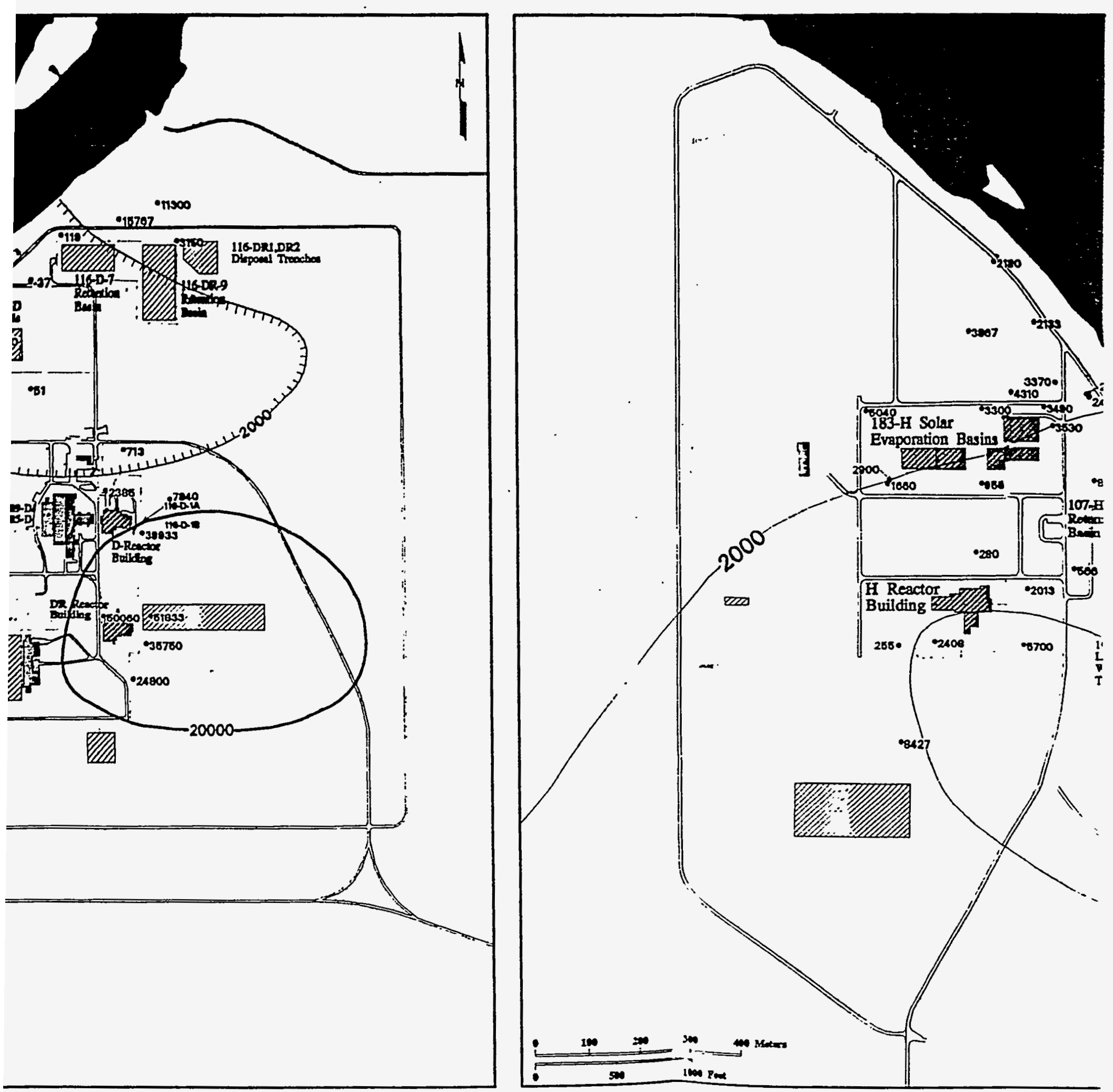

\section{0-H Area}



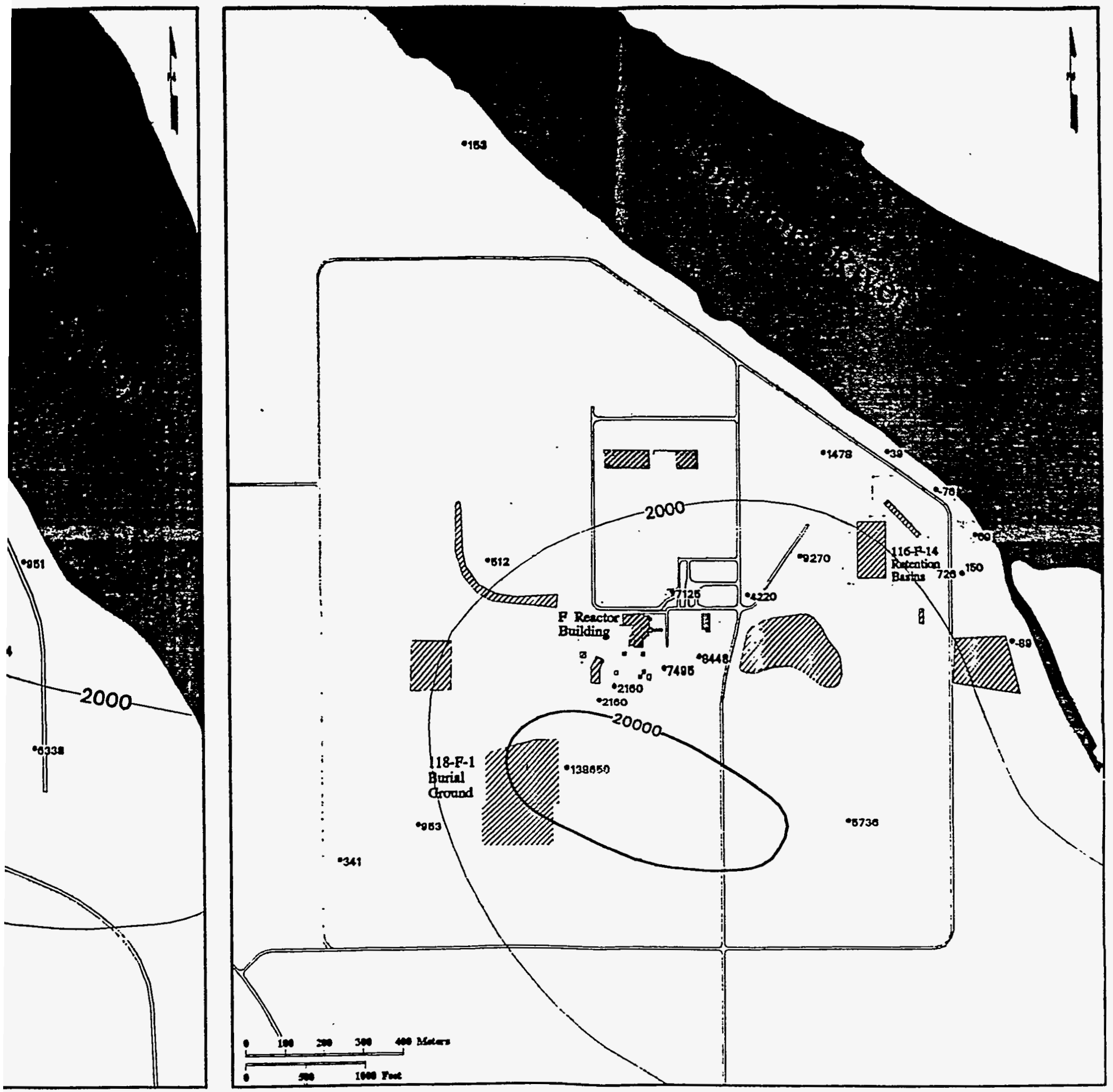

\section{0-F Area}

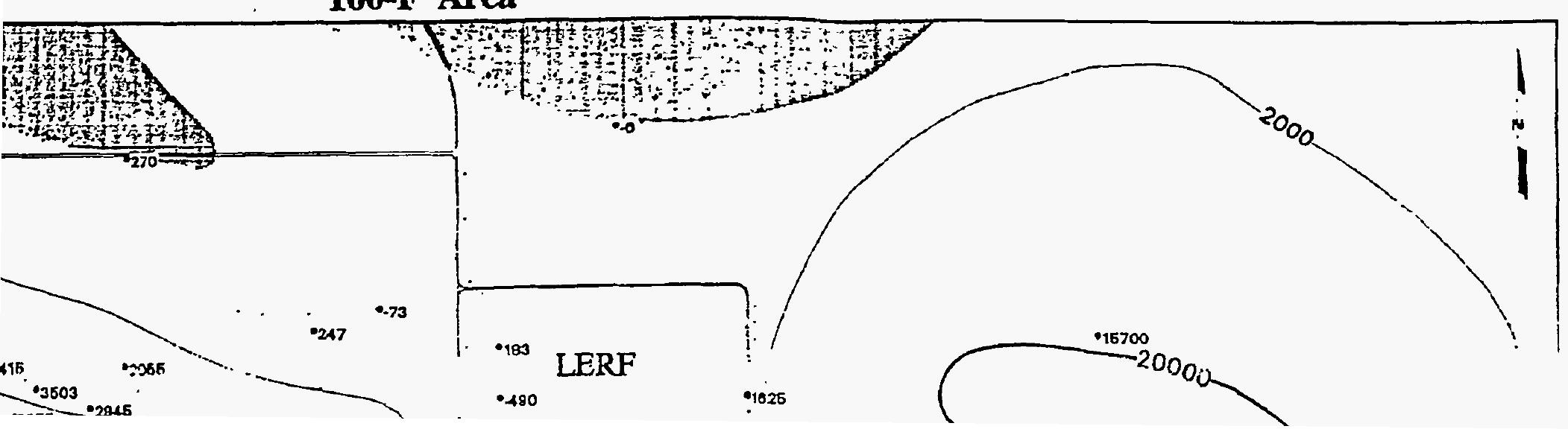




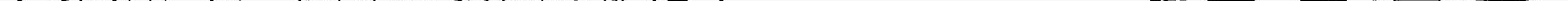




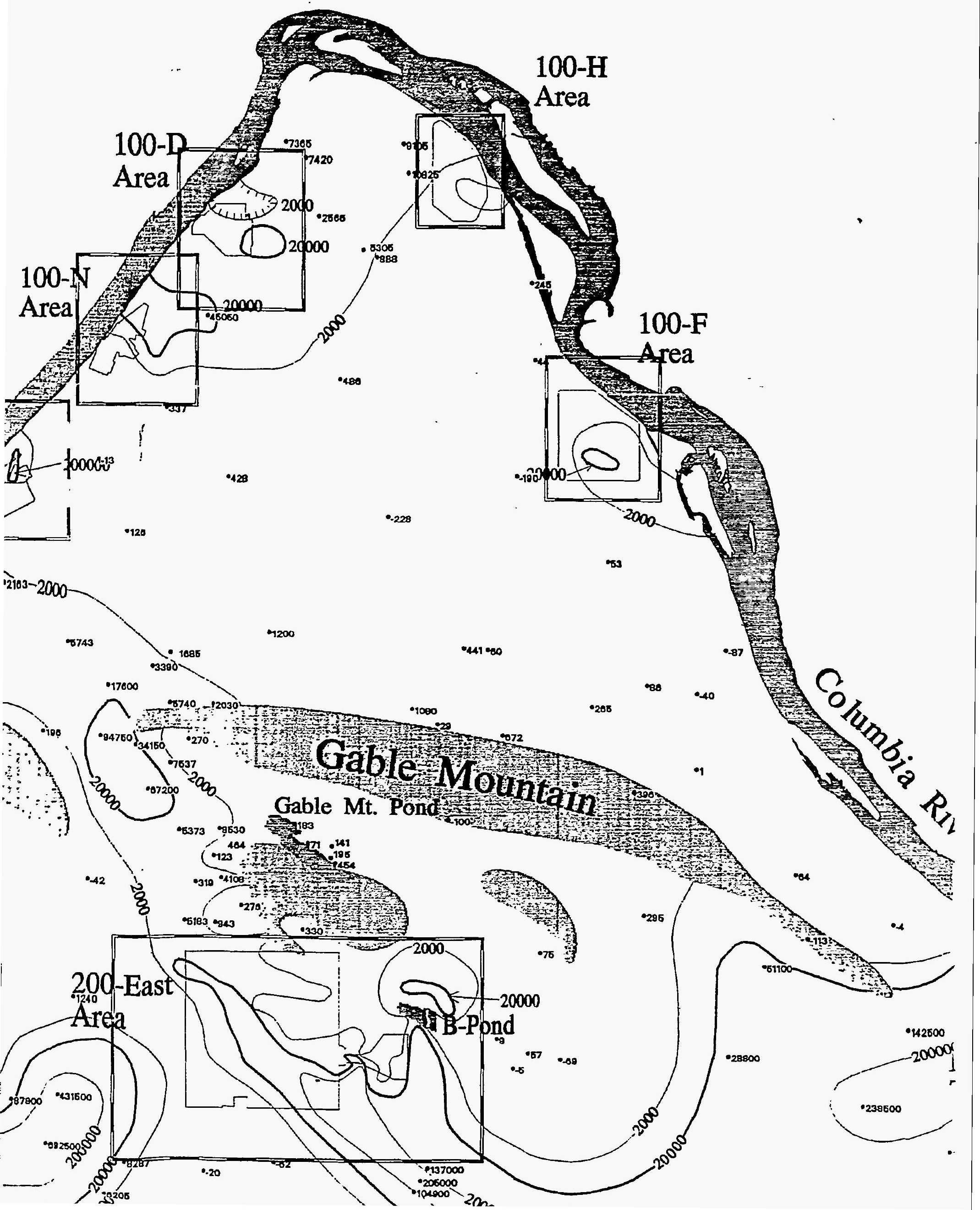




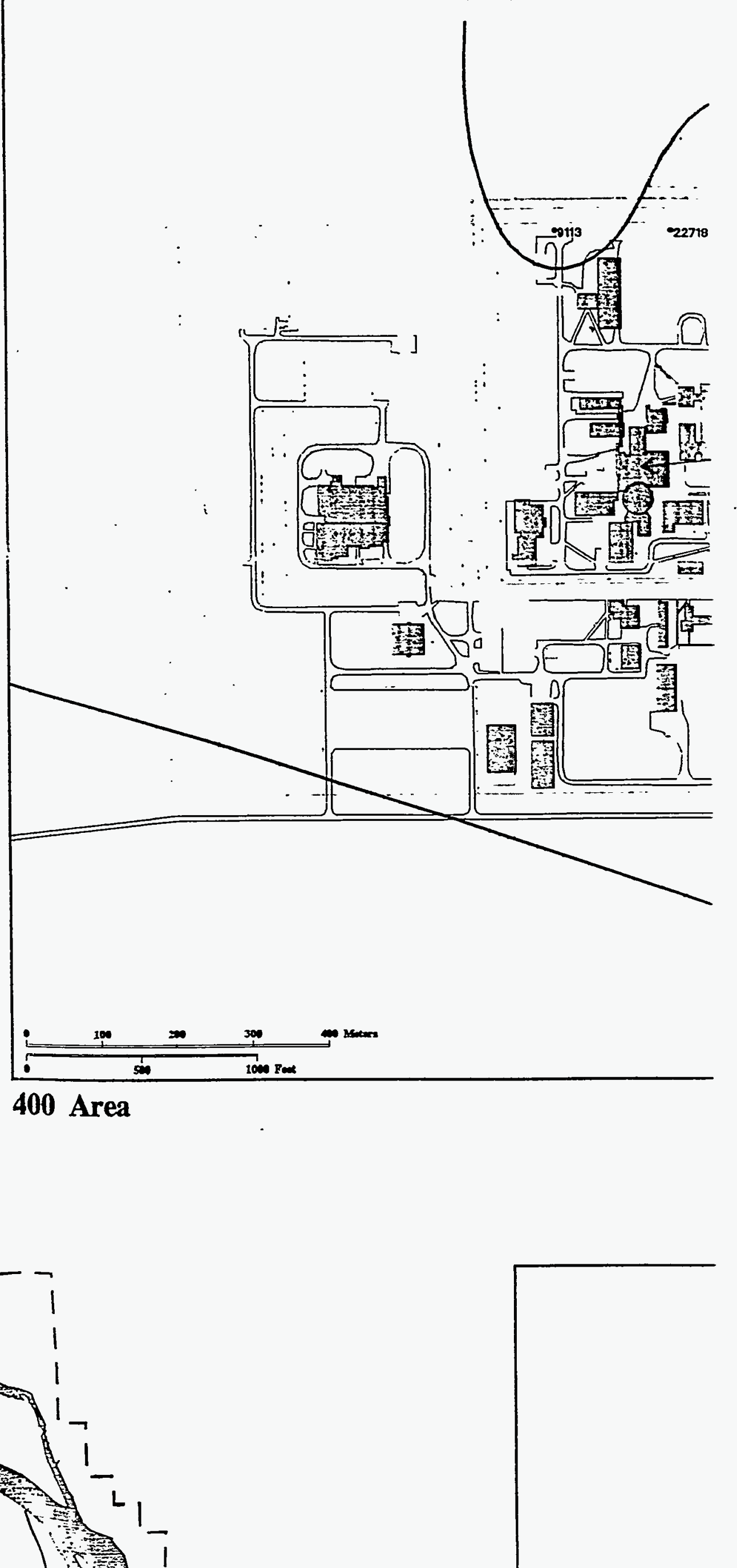




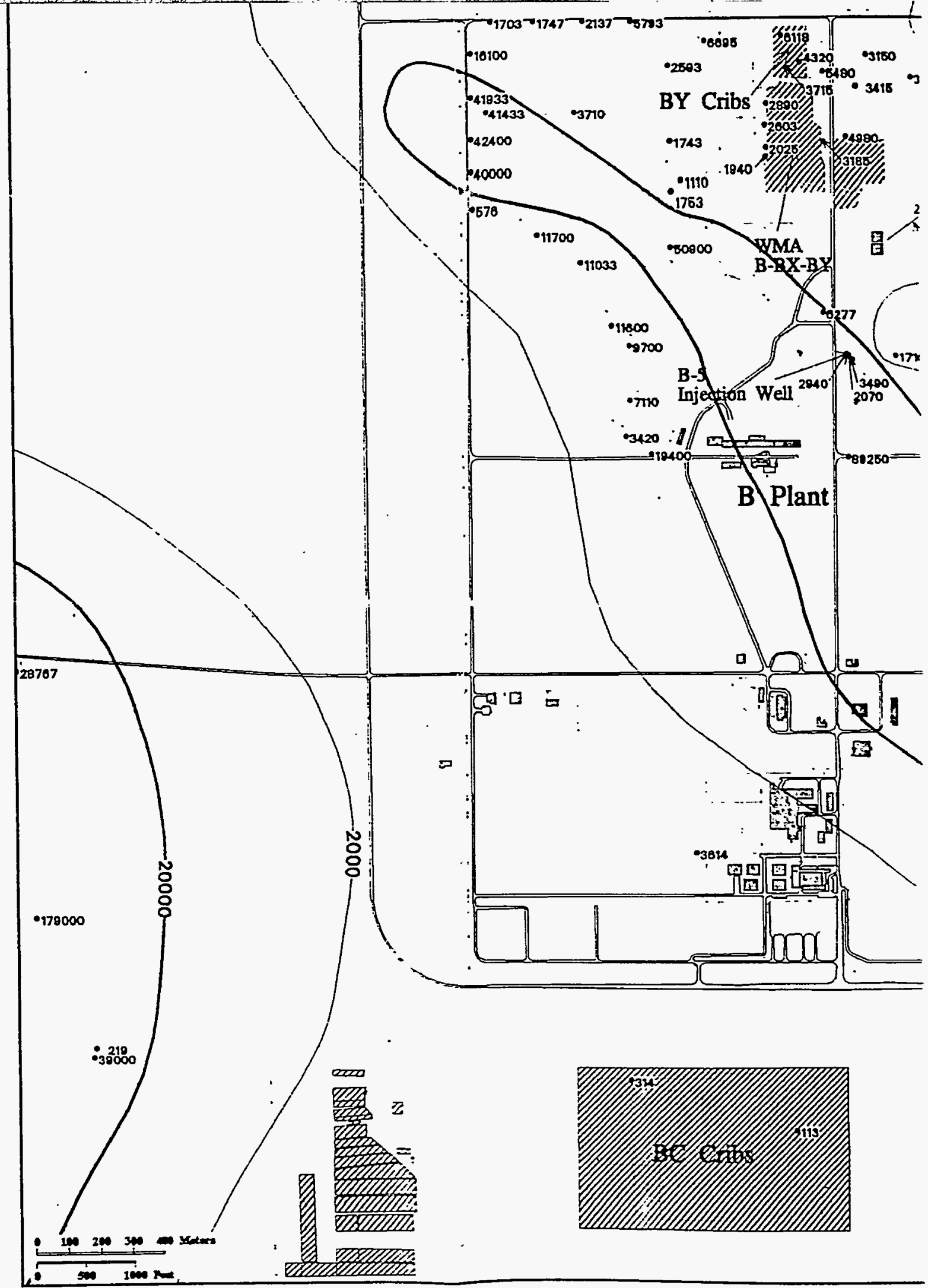

\section{0-East Area}

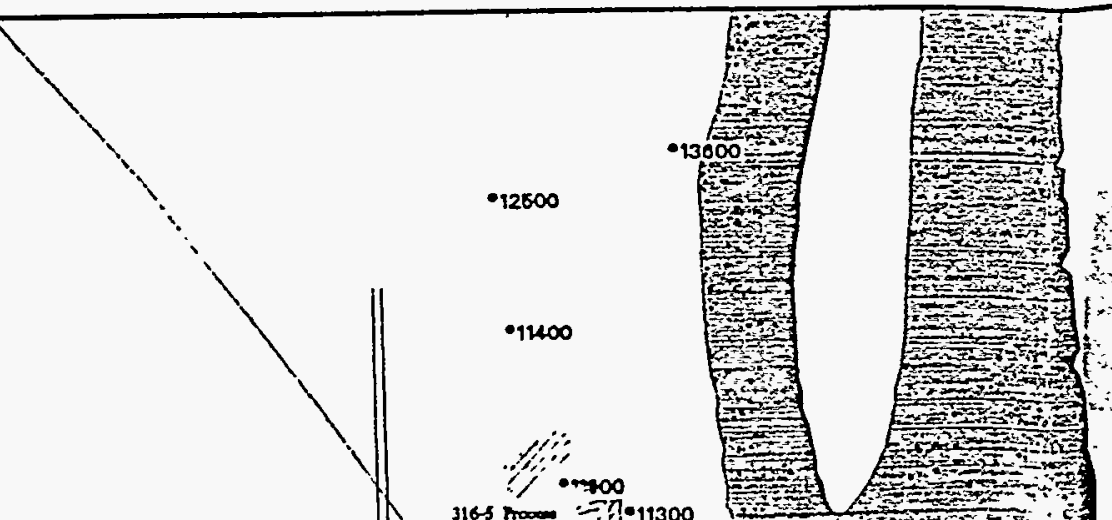



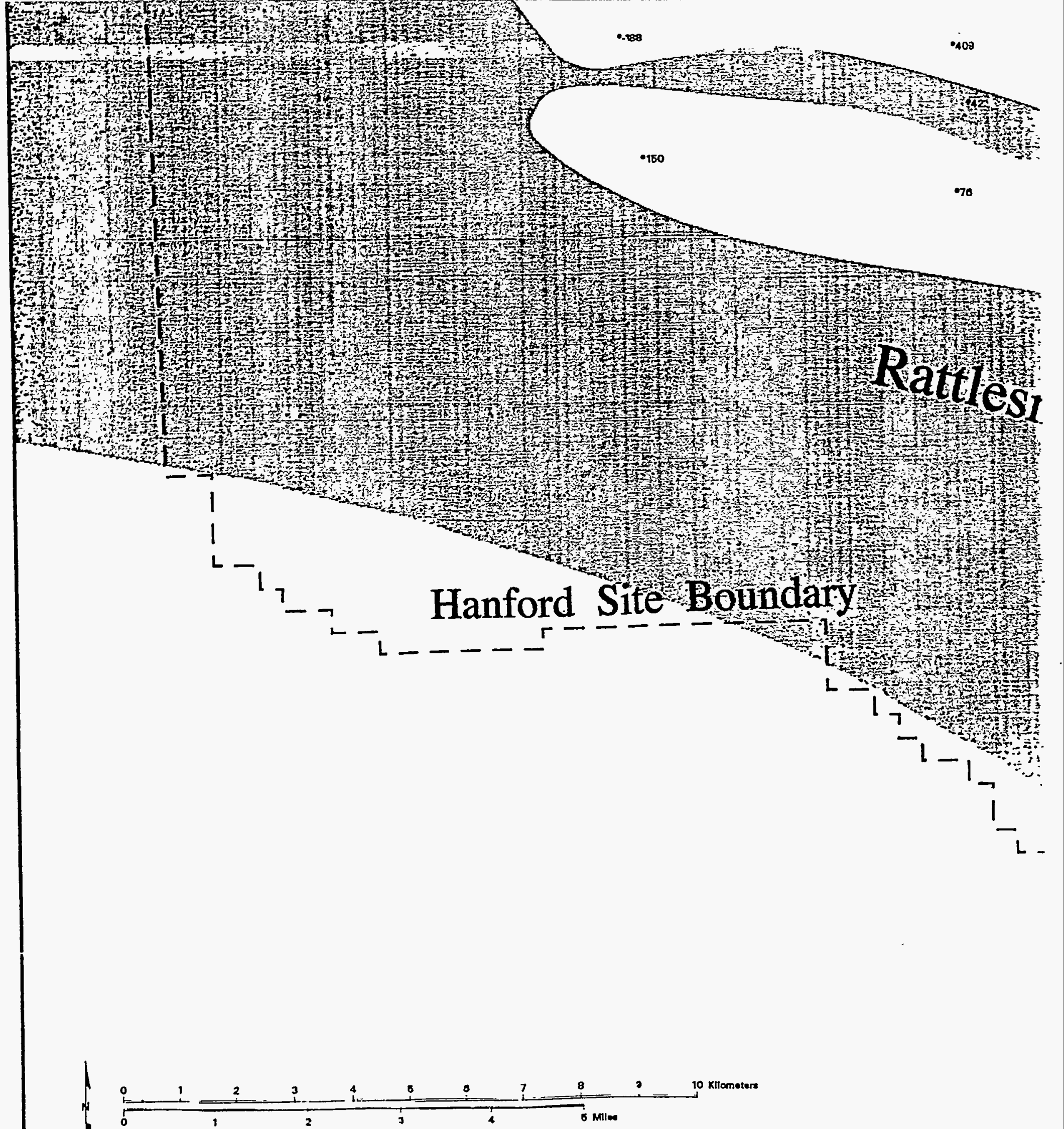

Facilities

Basalt Above the Water Table

Waste Sites

Roads

Fences 

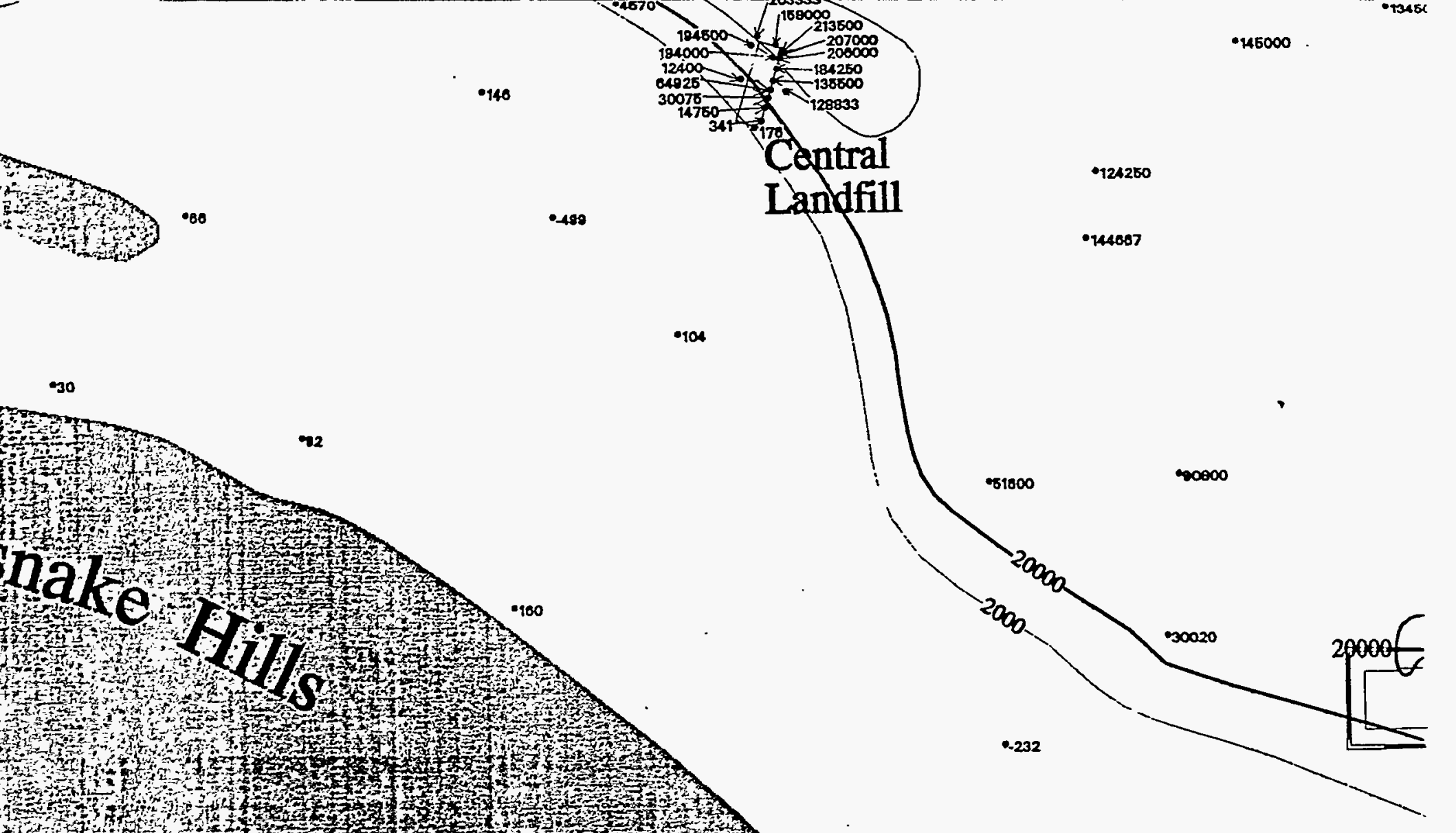

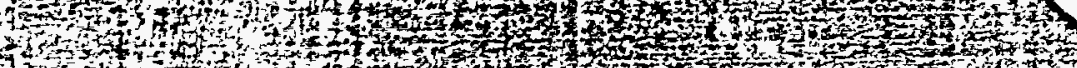

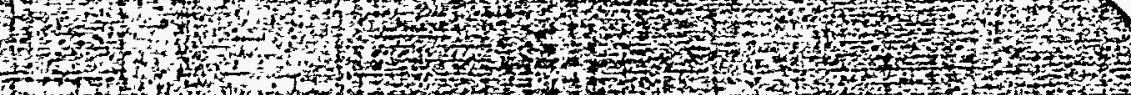

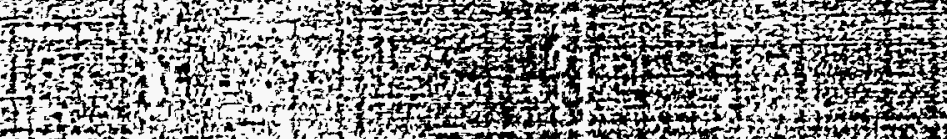

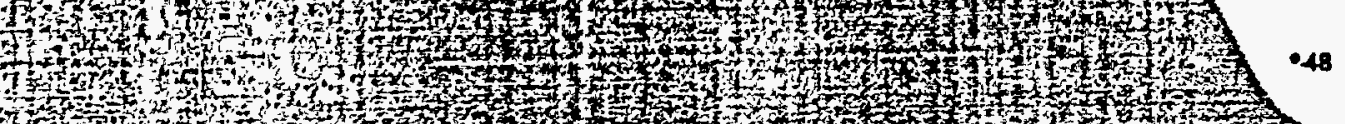

F

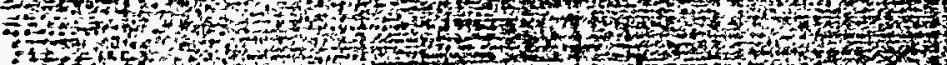

- 1 (1)

ᄂ

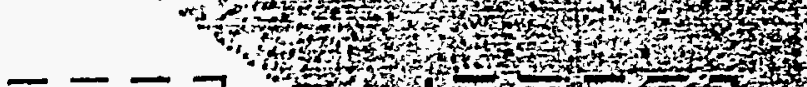

(1) H.

,

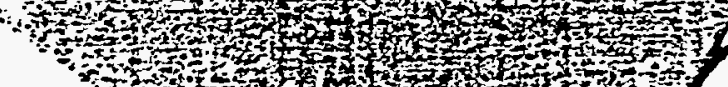

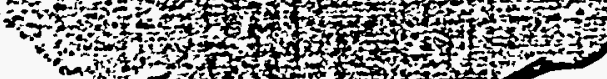

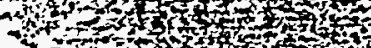

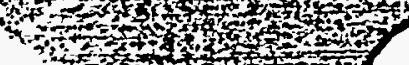

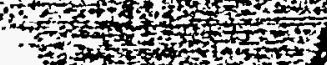

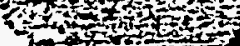

tof

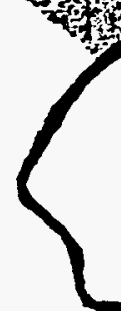




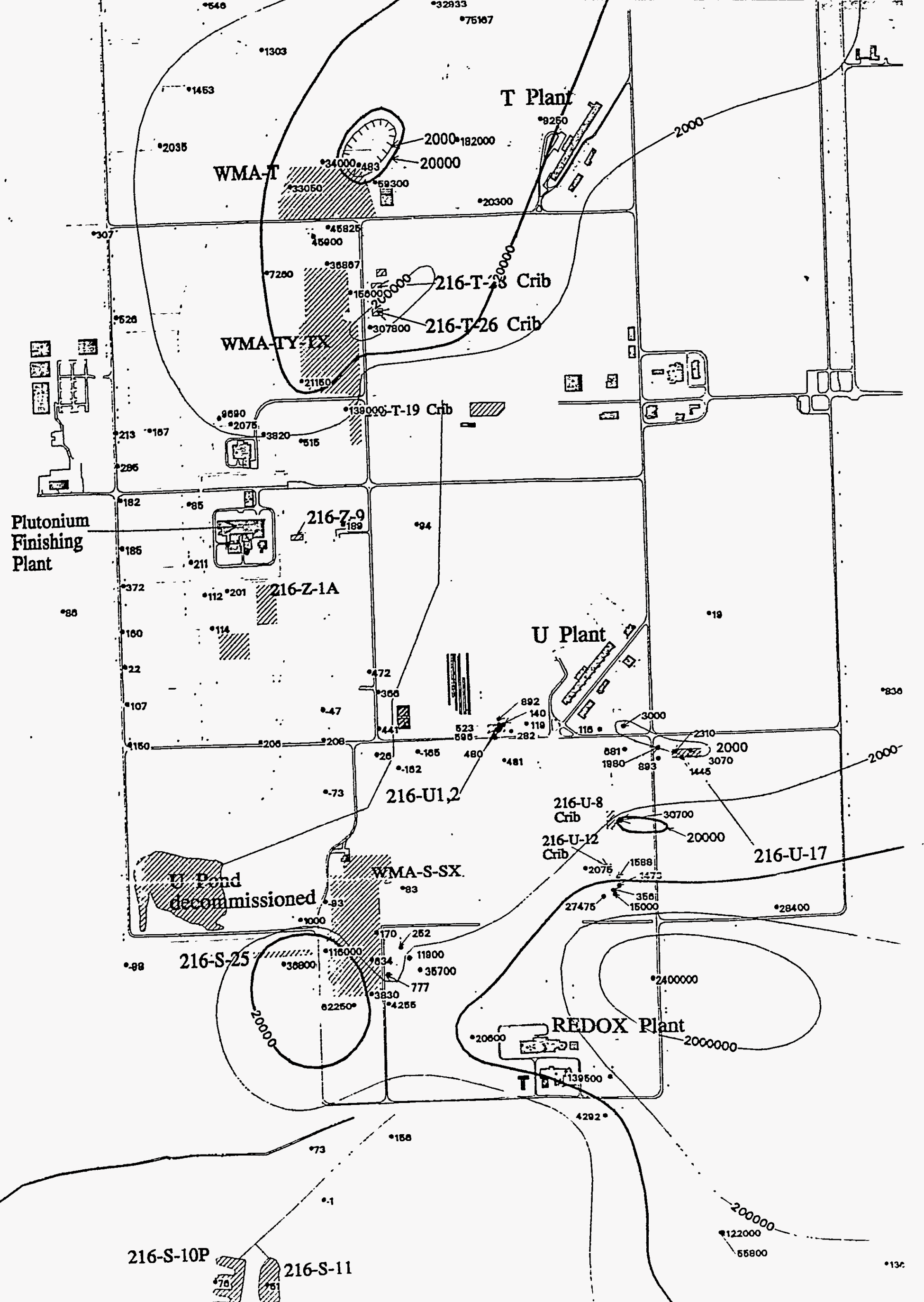




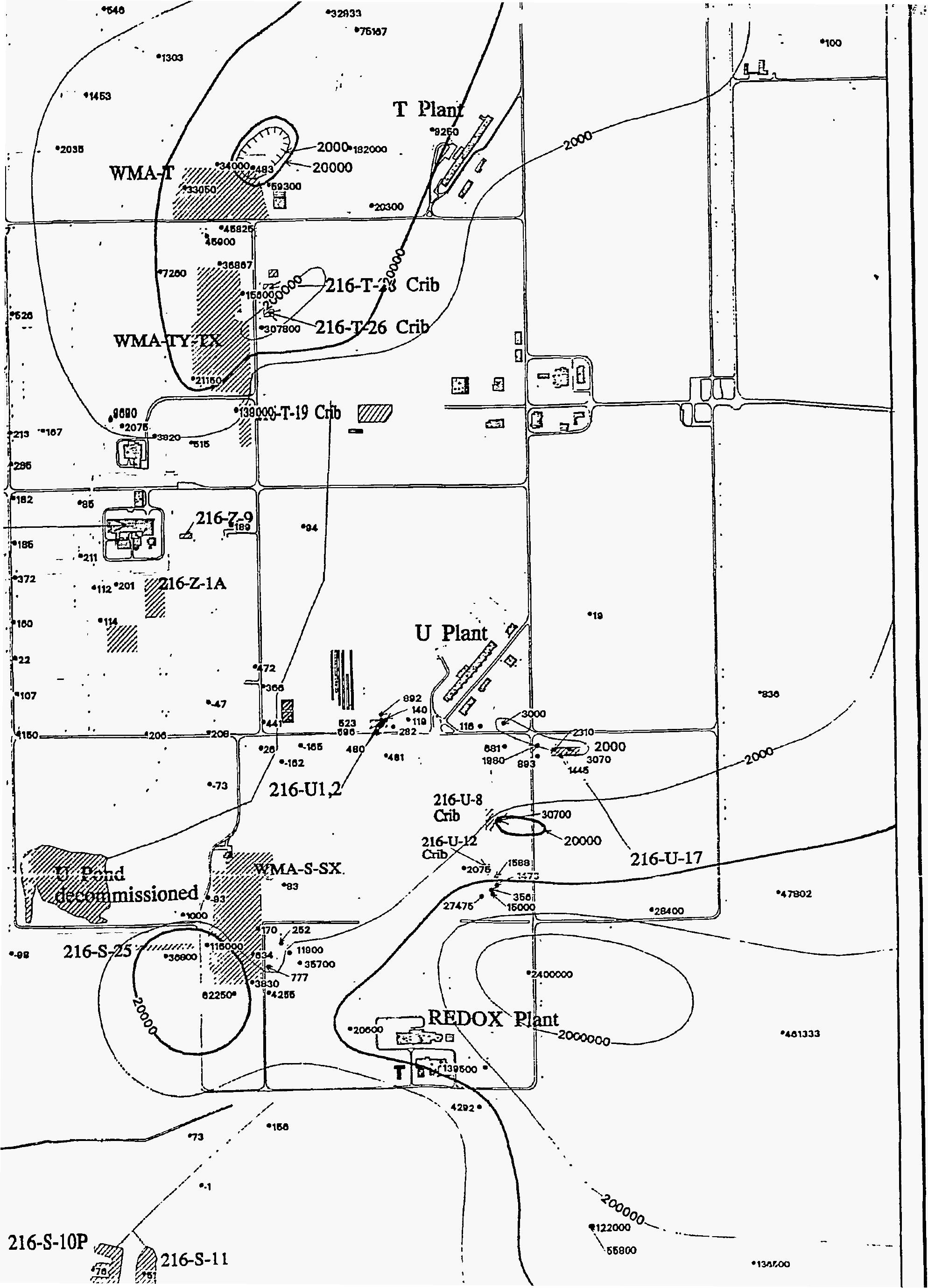




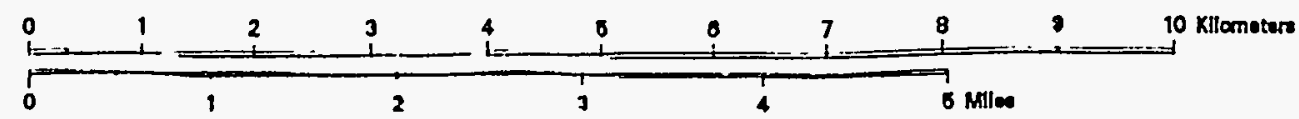

Facilities

Basalt Above the Water Table

Waste Sites

- Roads

Fences

- Tritium Contour pCi/L Dashed $=$ Approximate

$\mathrm{MCL}=20,000 \mathrm{pCi} / \mathrm{L}$

- Monitoring Well With Concentration

Plate 3: 1994 Average Tritium Con 



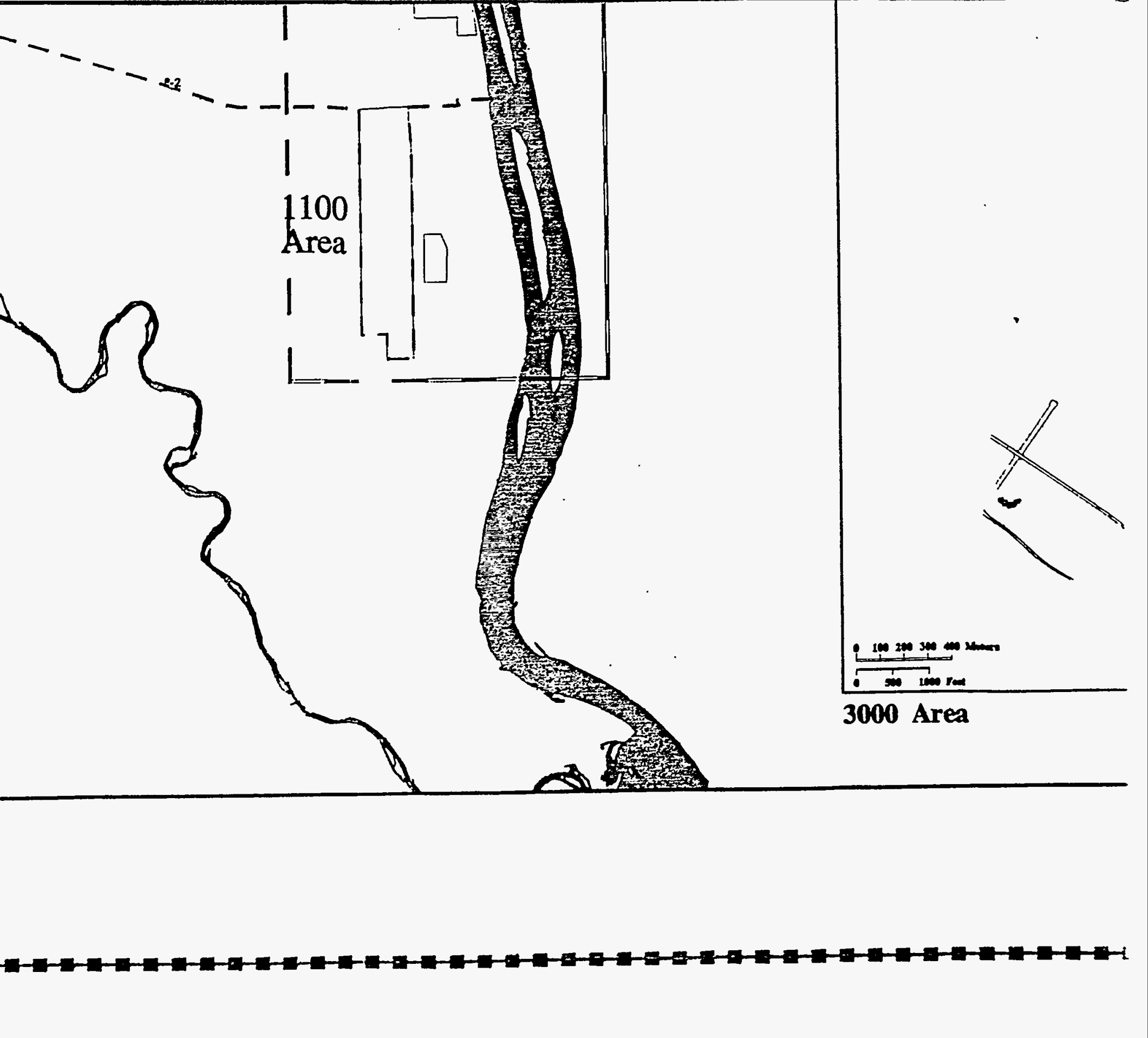




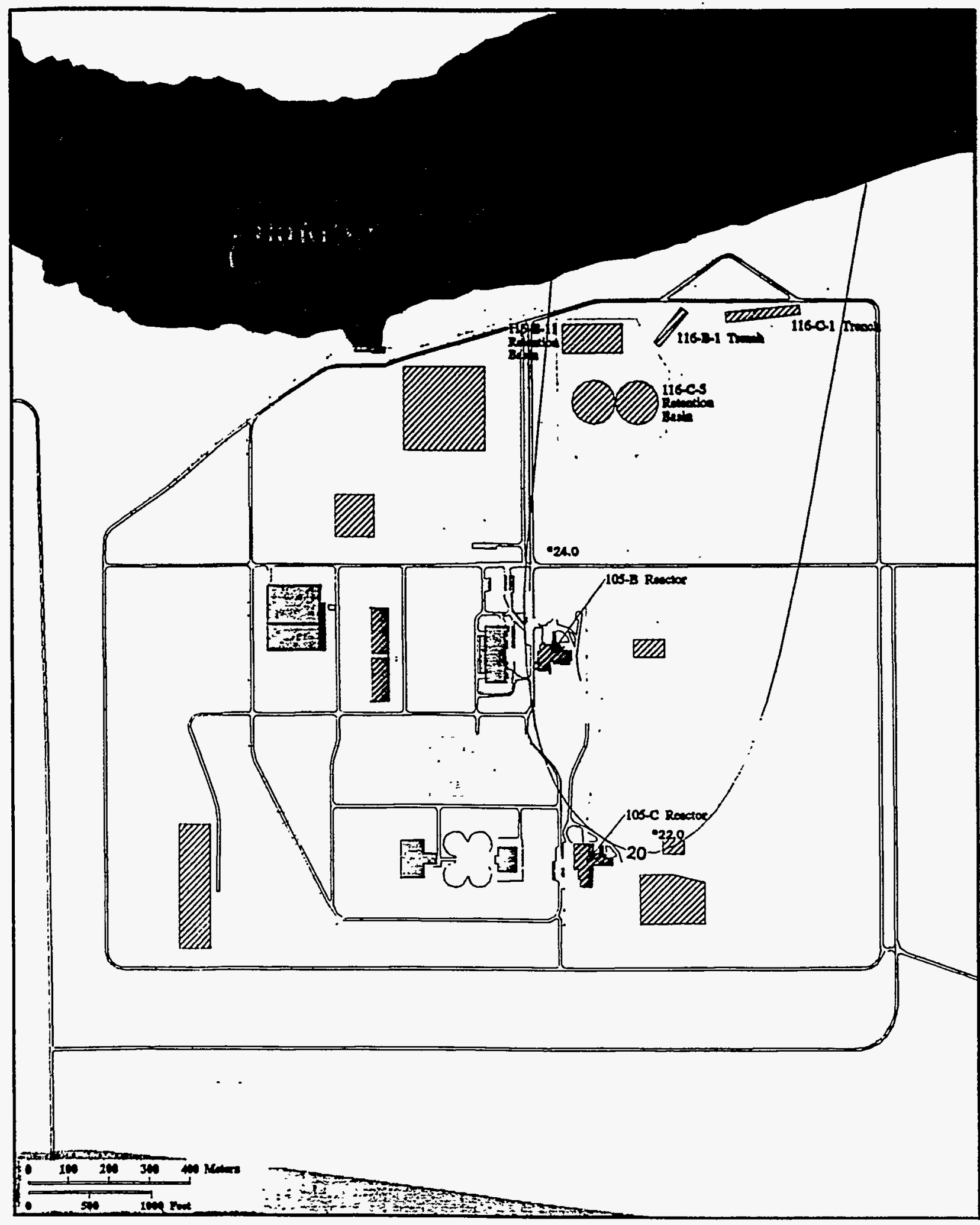

100-BC Area
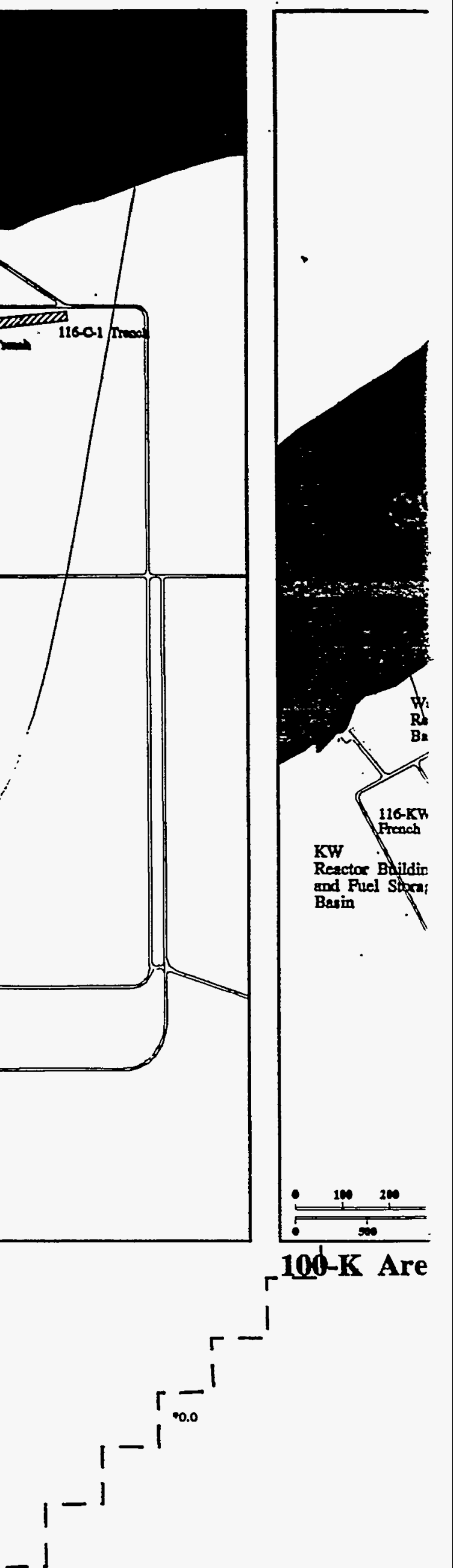


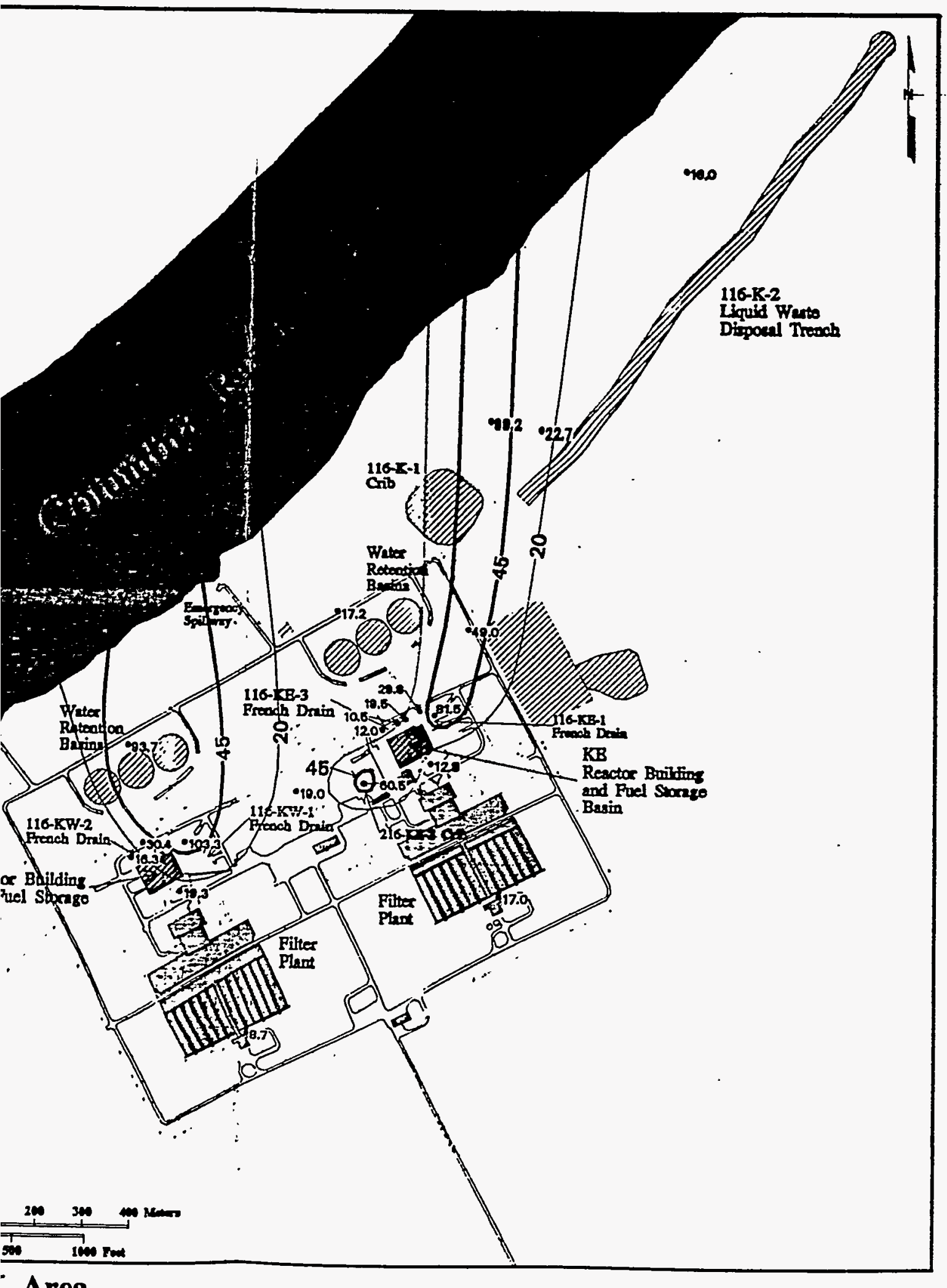

\section{Area}

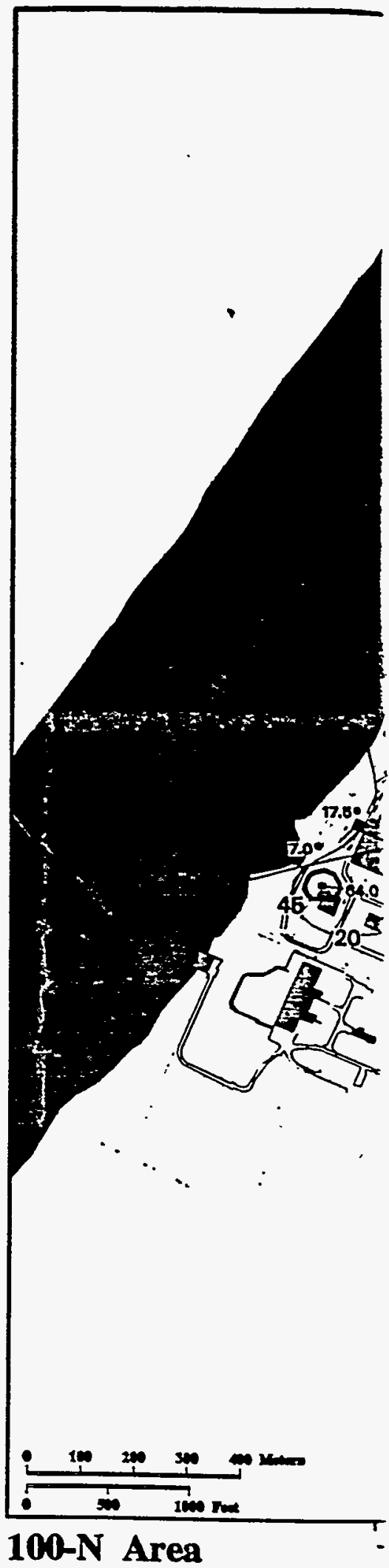




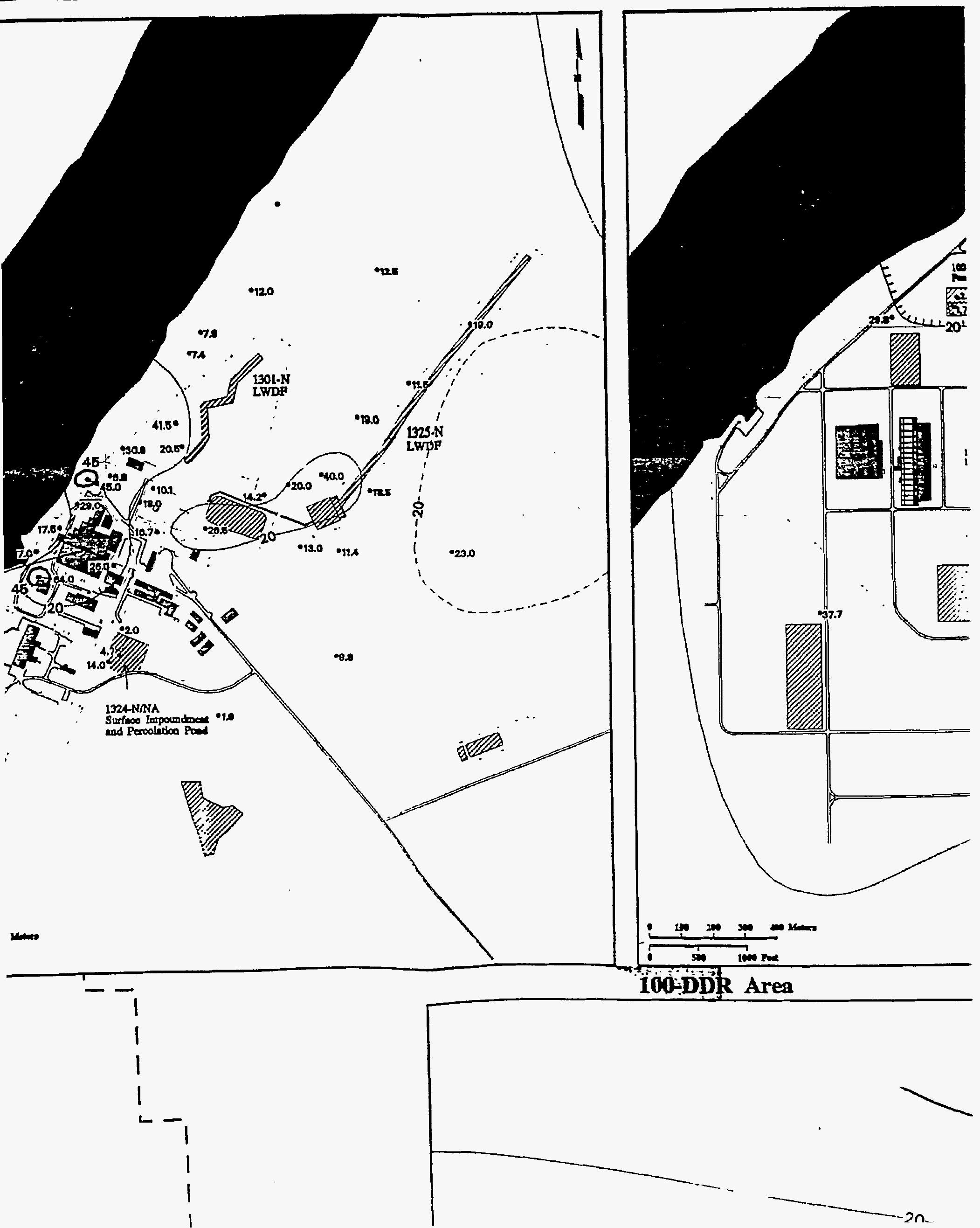



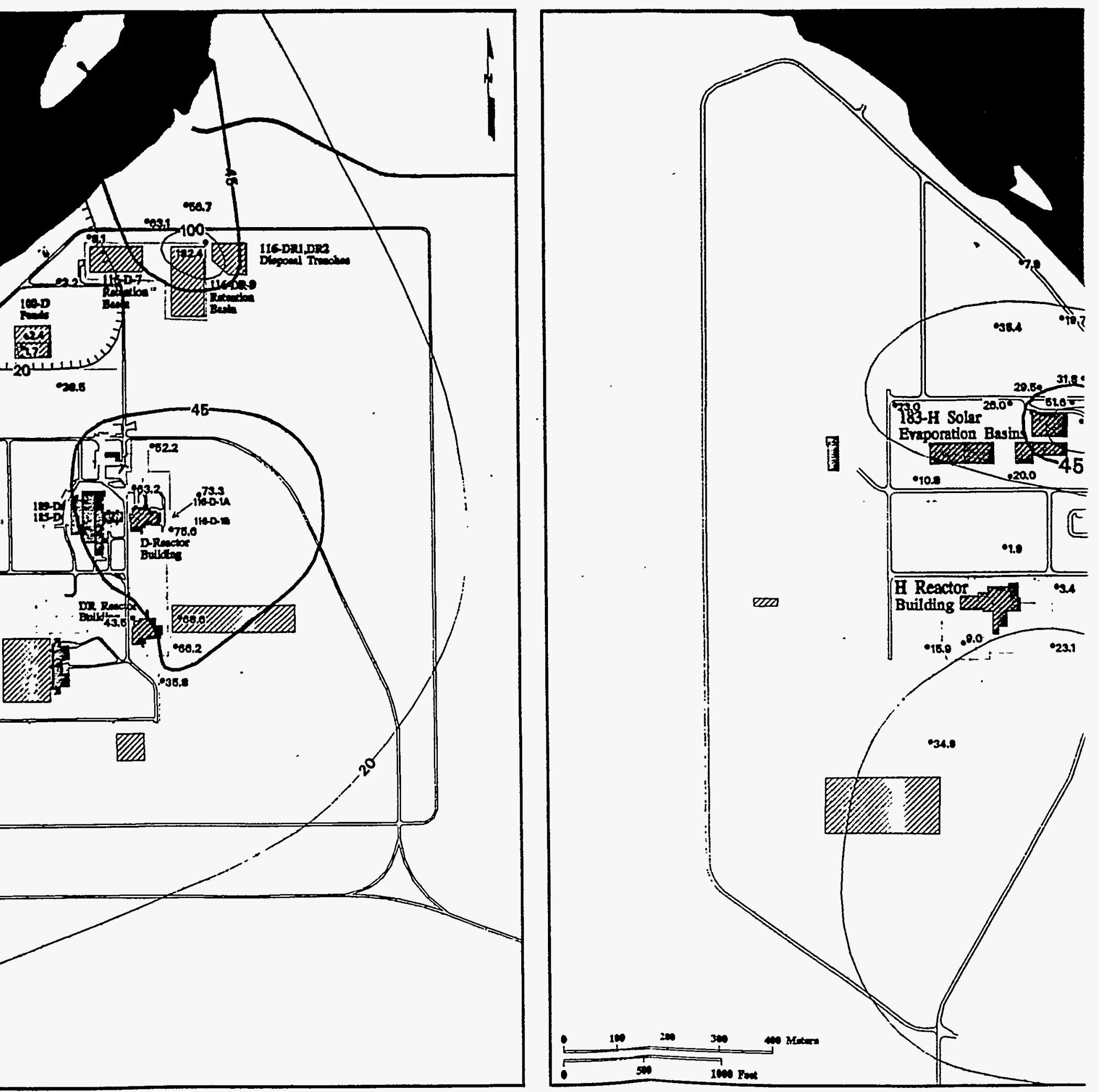

\section{0-H Area}

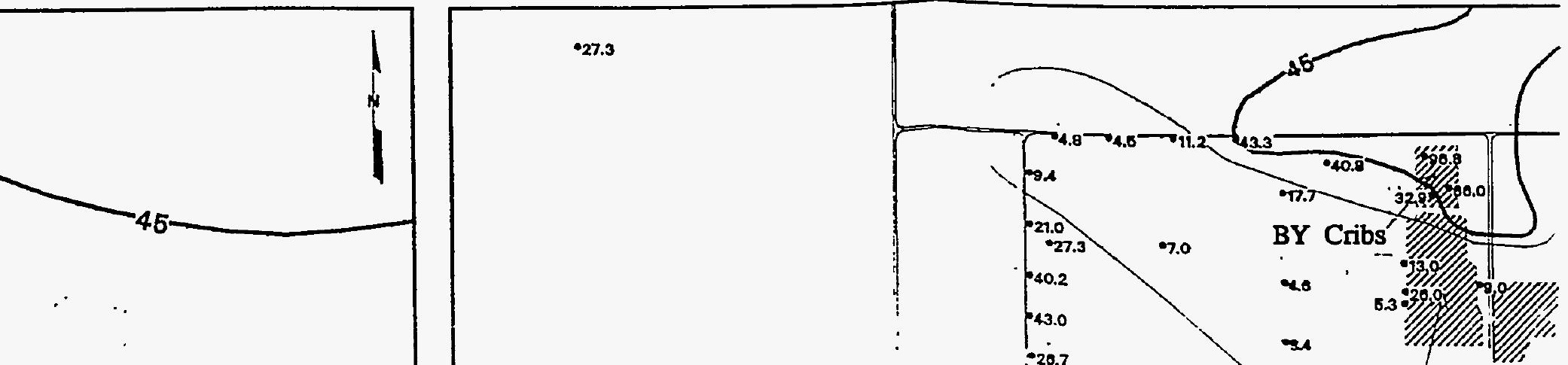




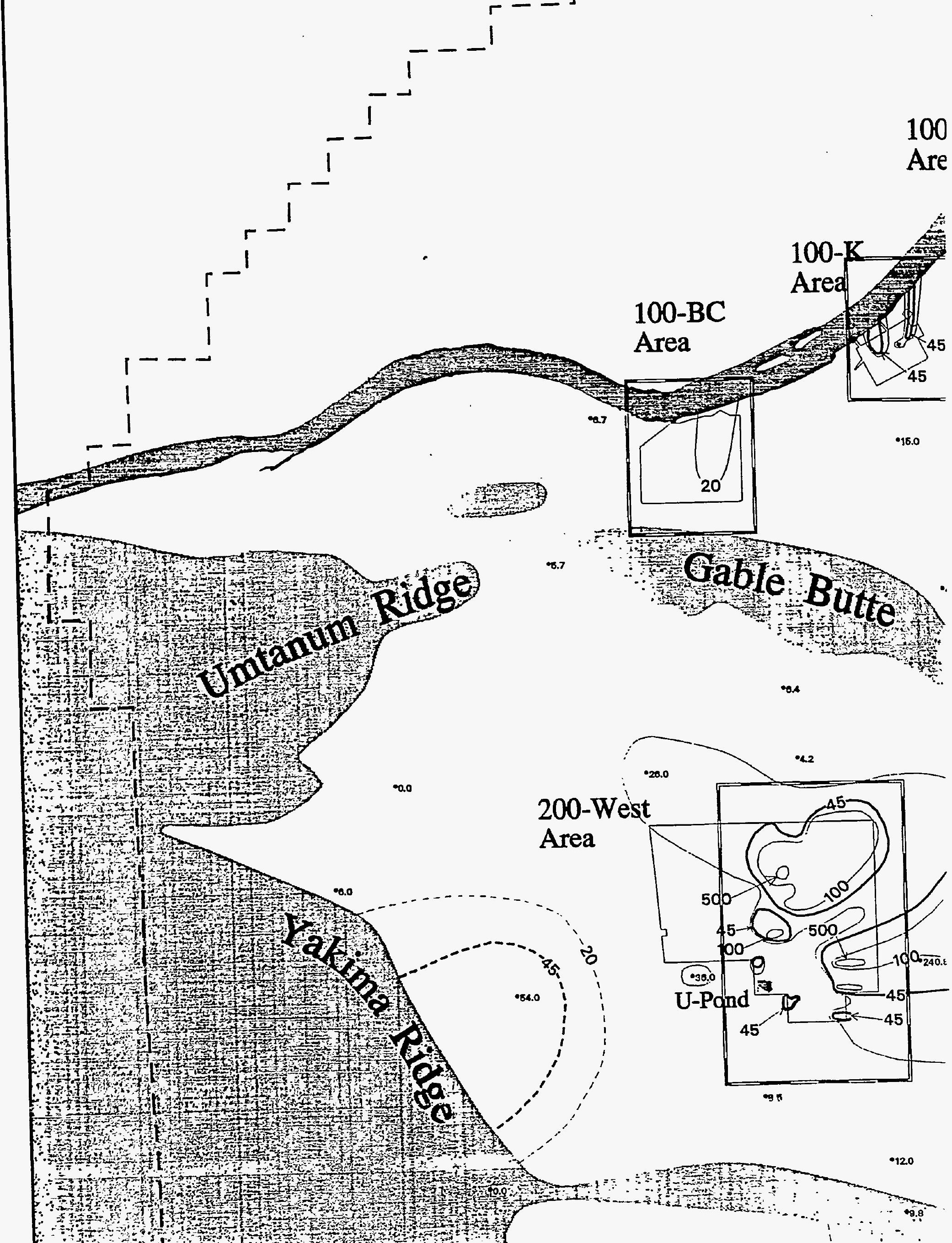




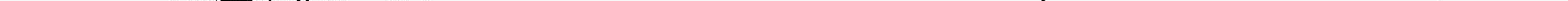


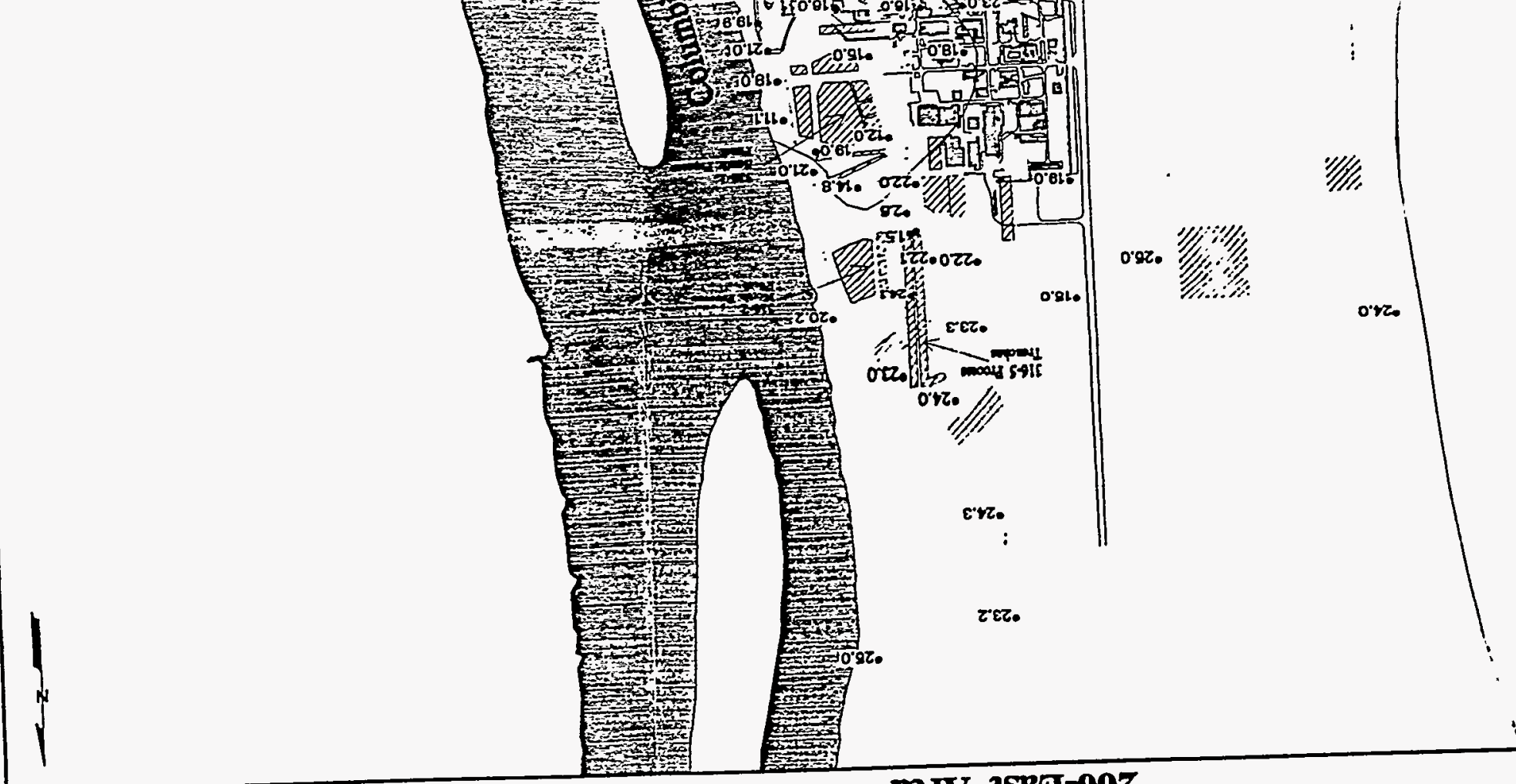

Bary 7S8G-00Z
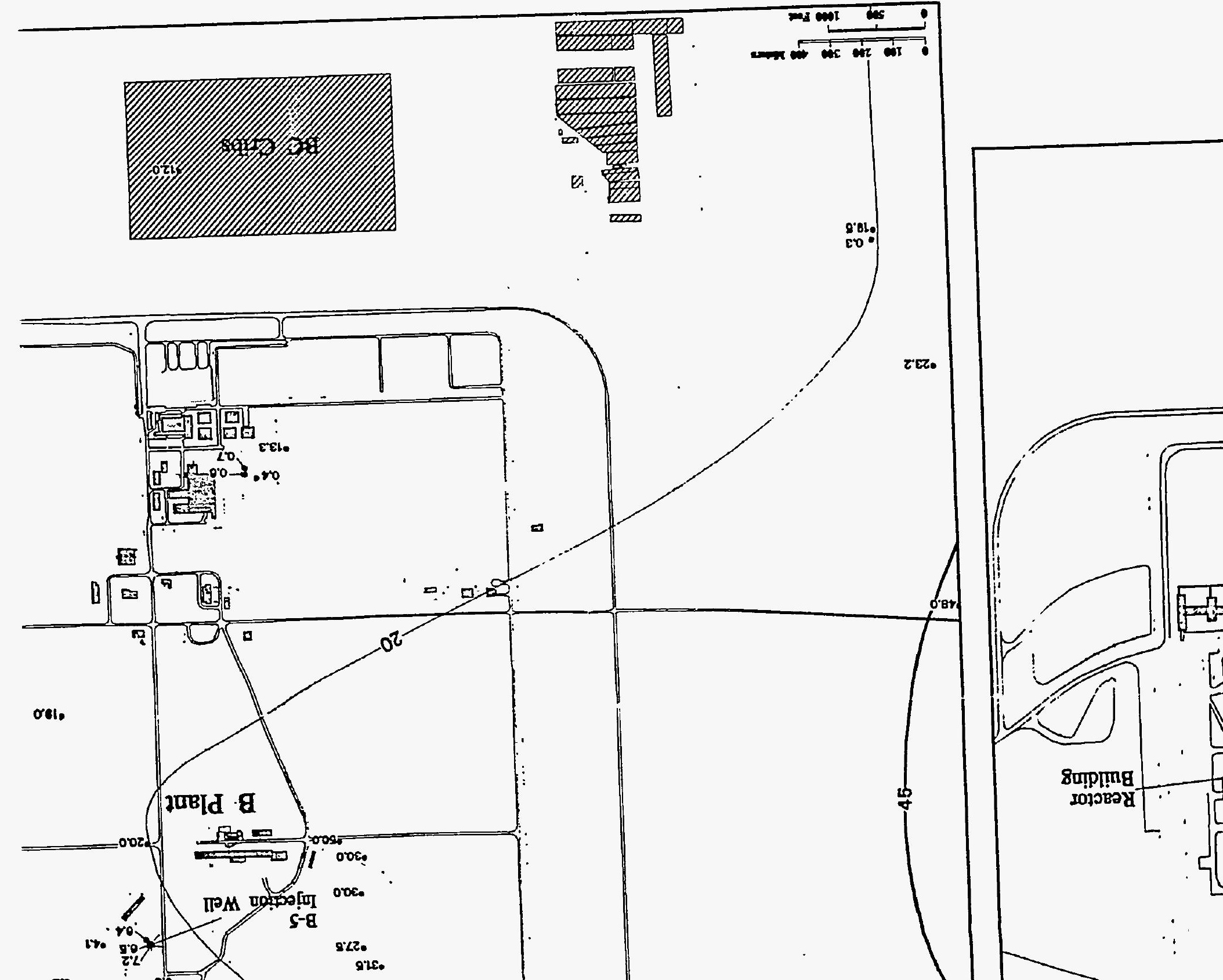

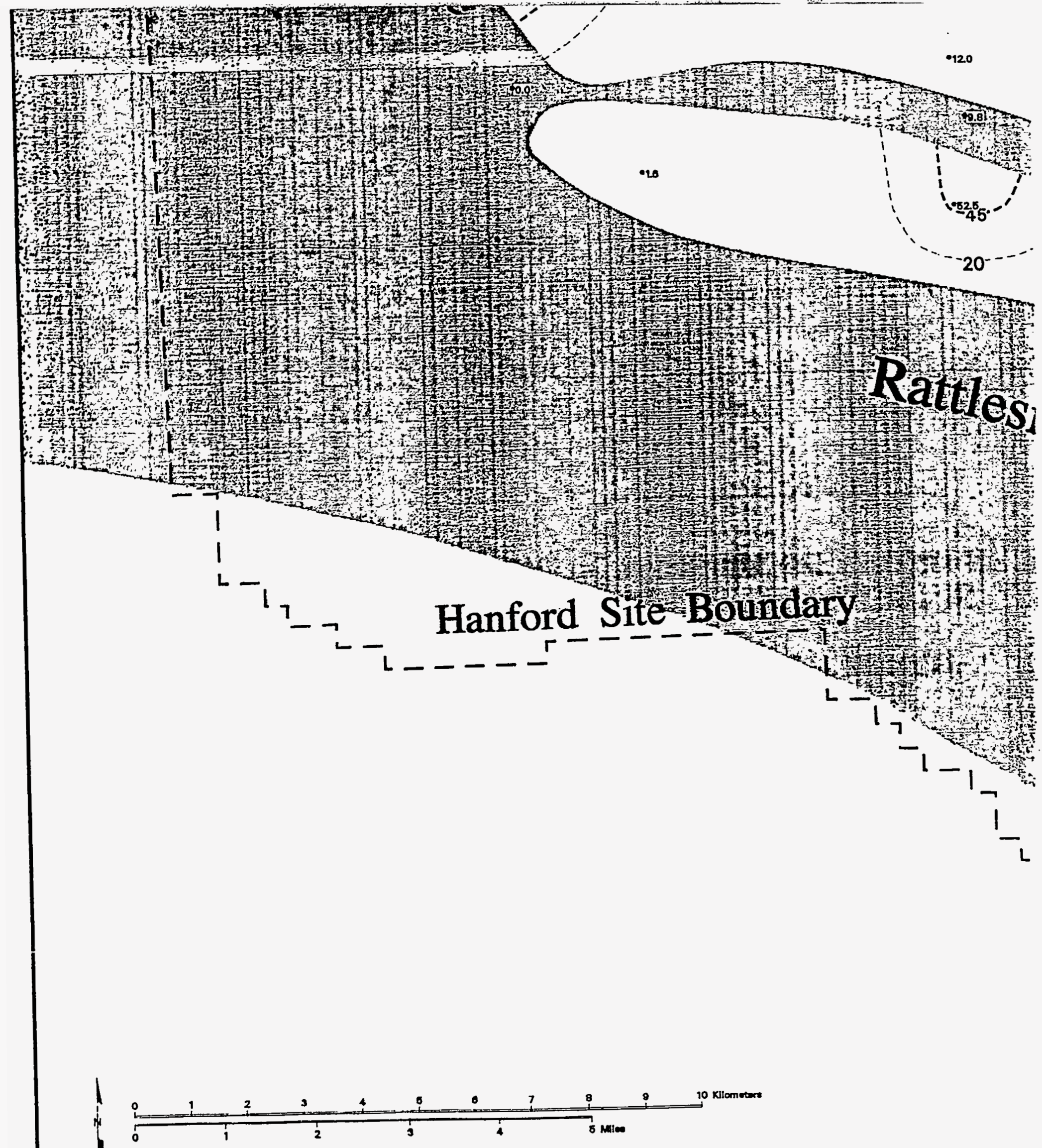

Facilities

Basalt Above the Water Table

. Waste Sites

Roads

Fences 


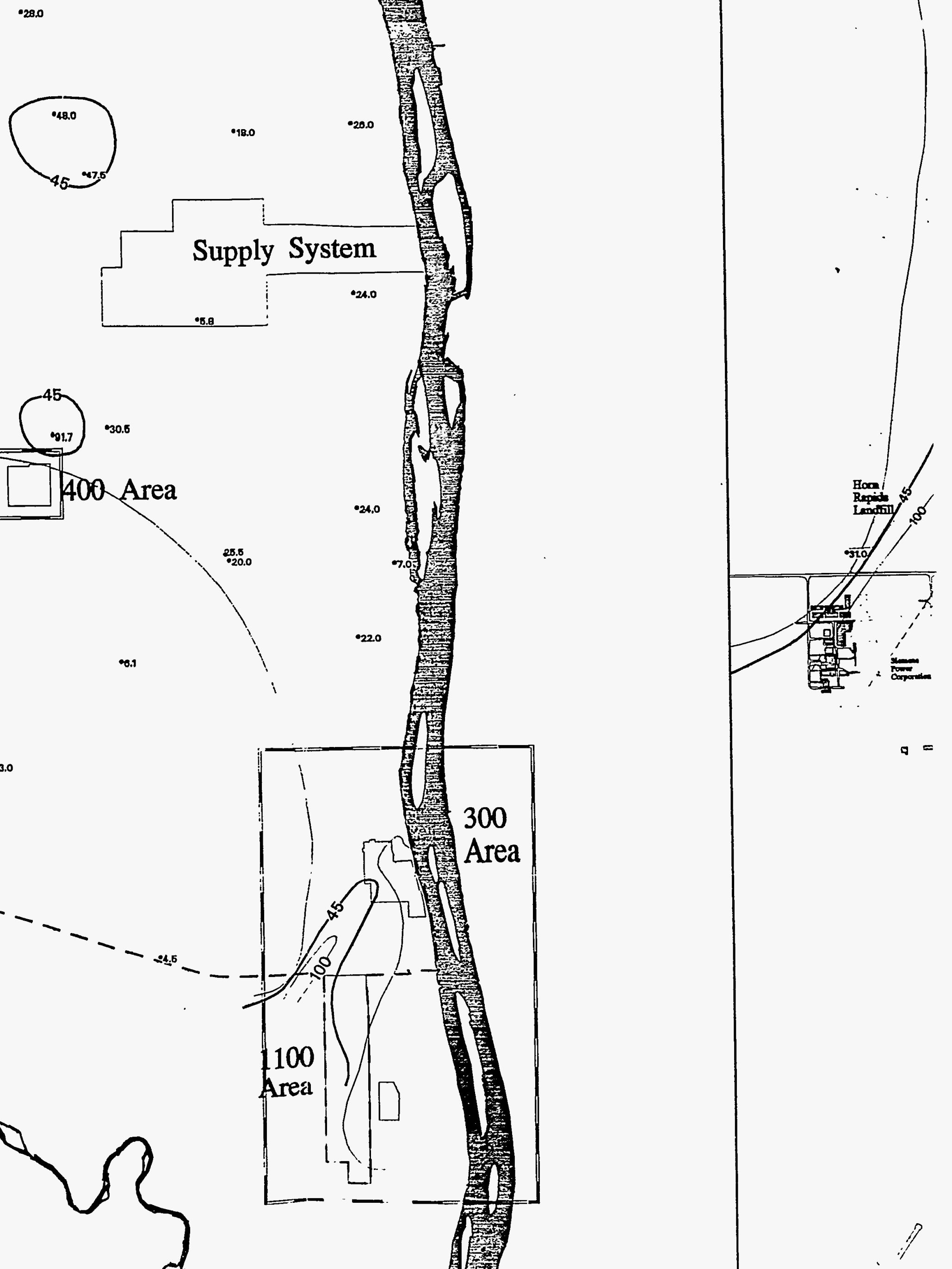




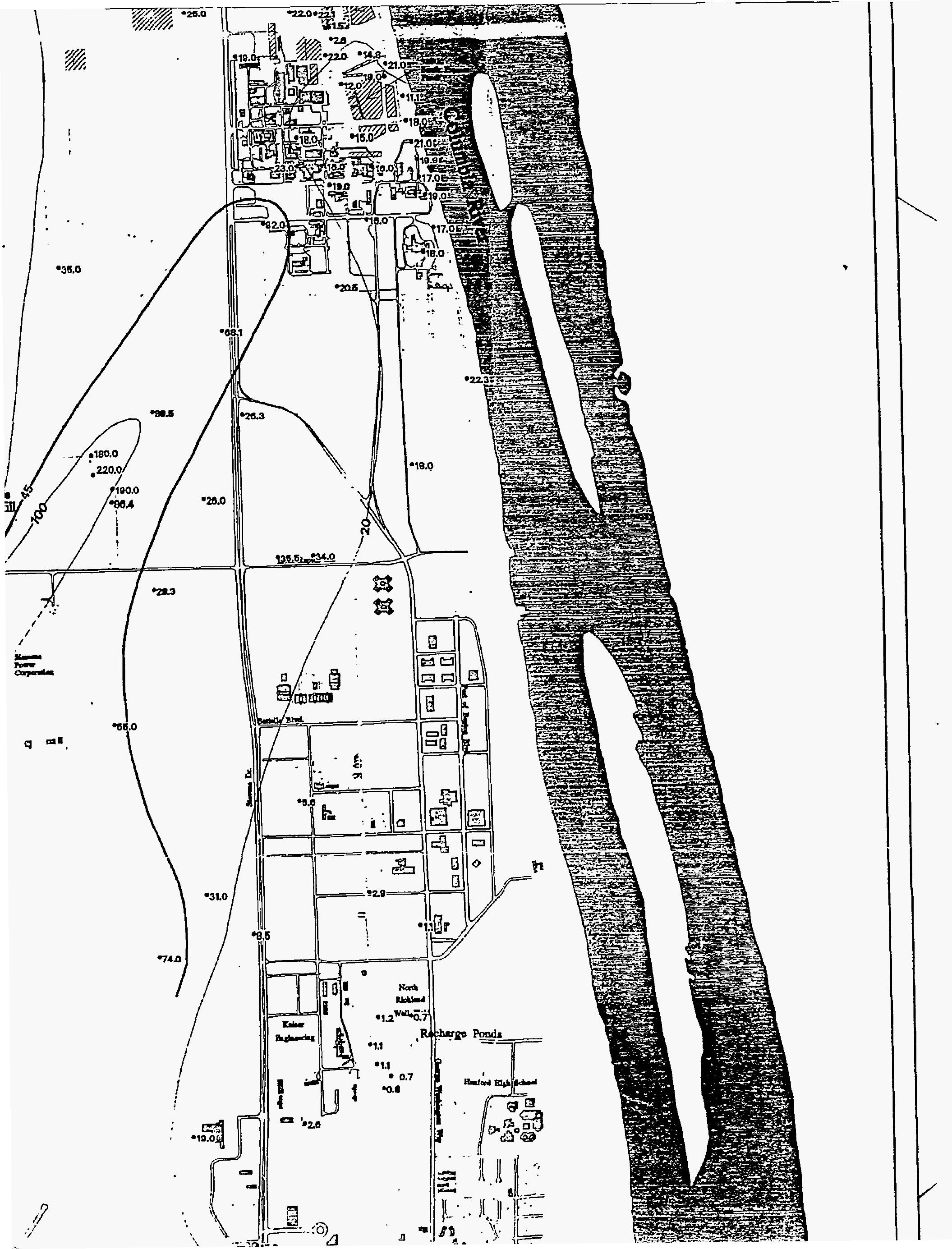




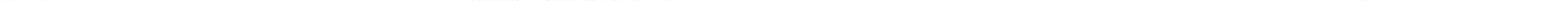




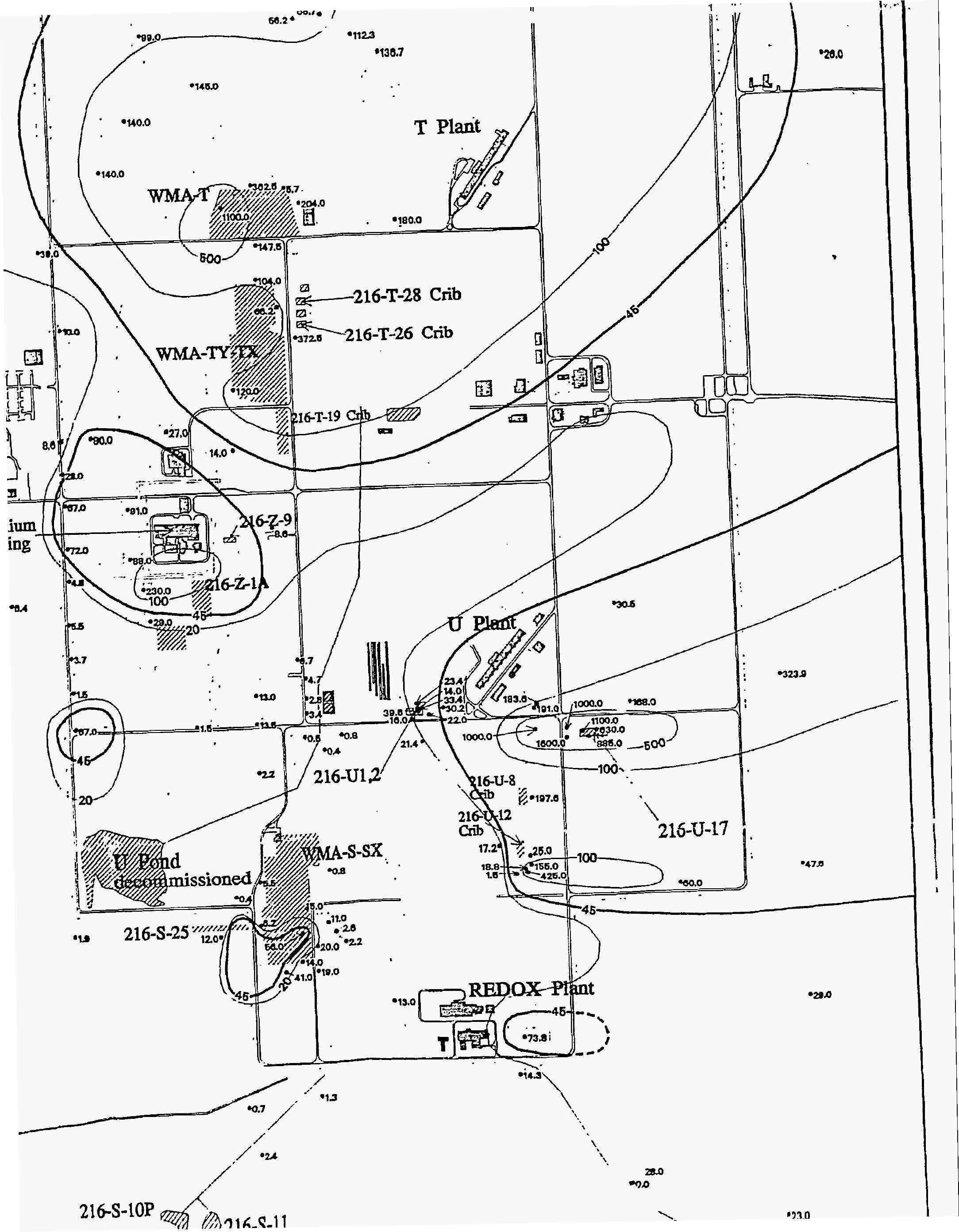




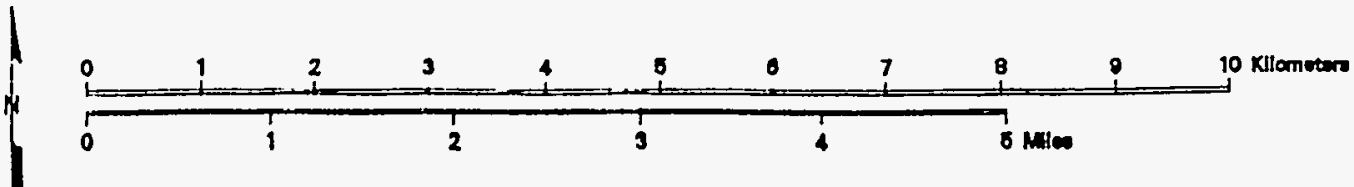

Facilities

Basalt Above the Water Table

Waste Sites

Roads

Fences

- Nitrate Contour mg/L Dashed $=$ Approximate $\mathrm{MCL}=45 \mathrm{mg} / \mathrm{L}$

- Monitoring Well With Concentration

Plate 4: 1994 Average Nitrate Cons 


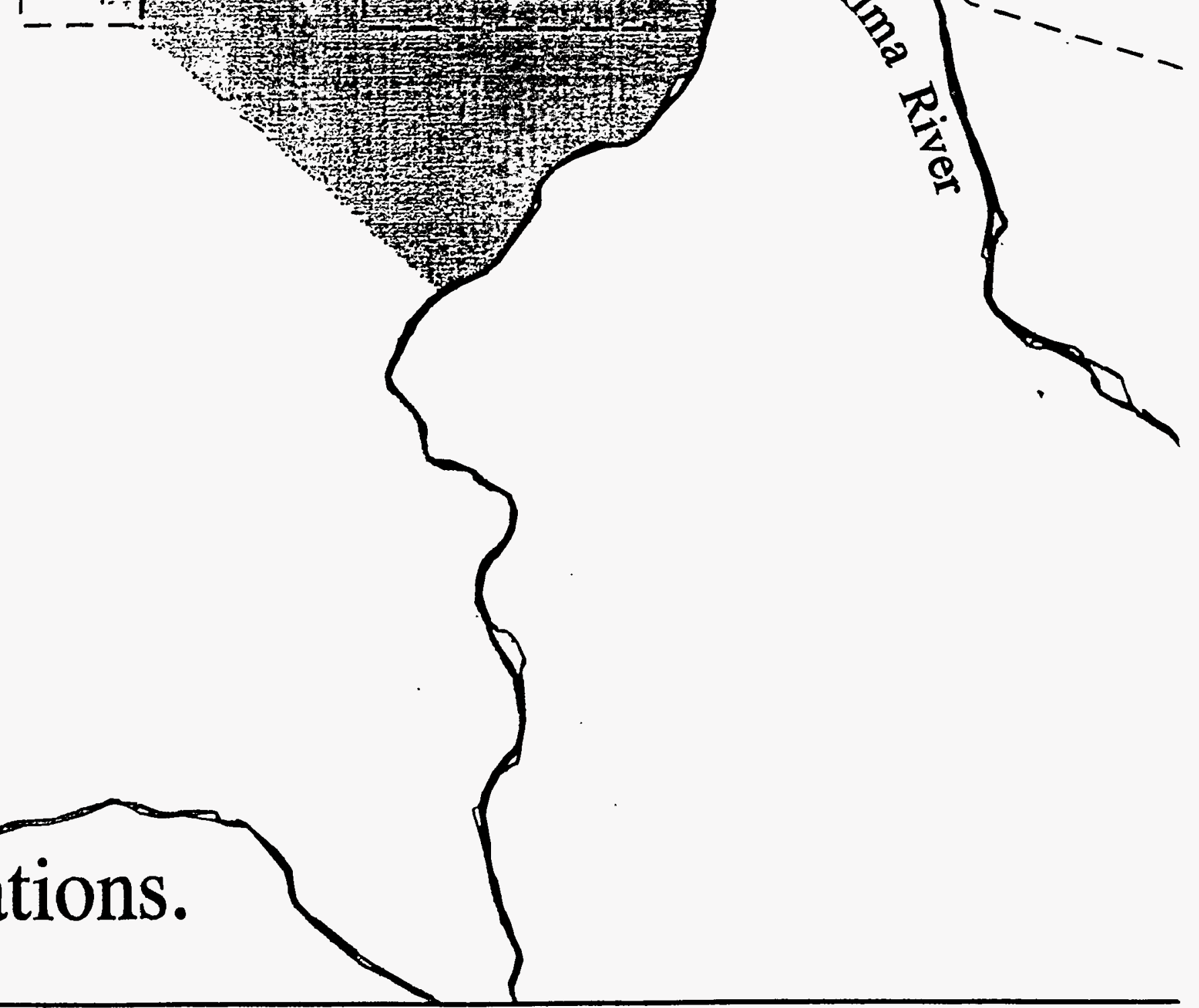




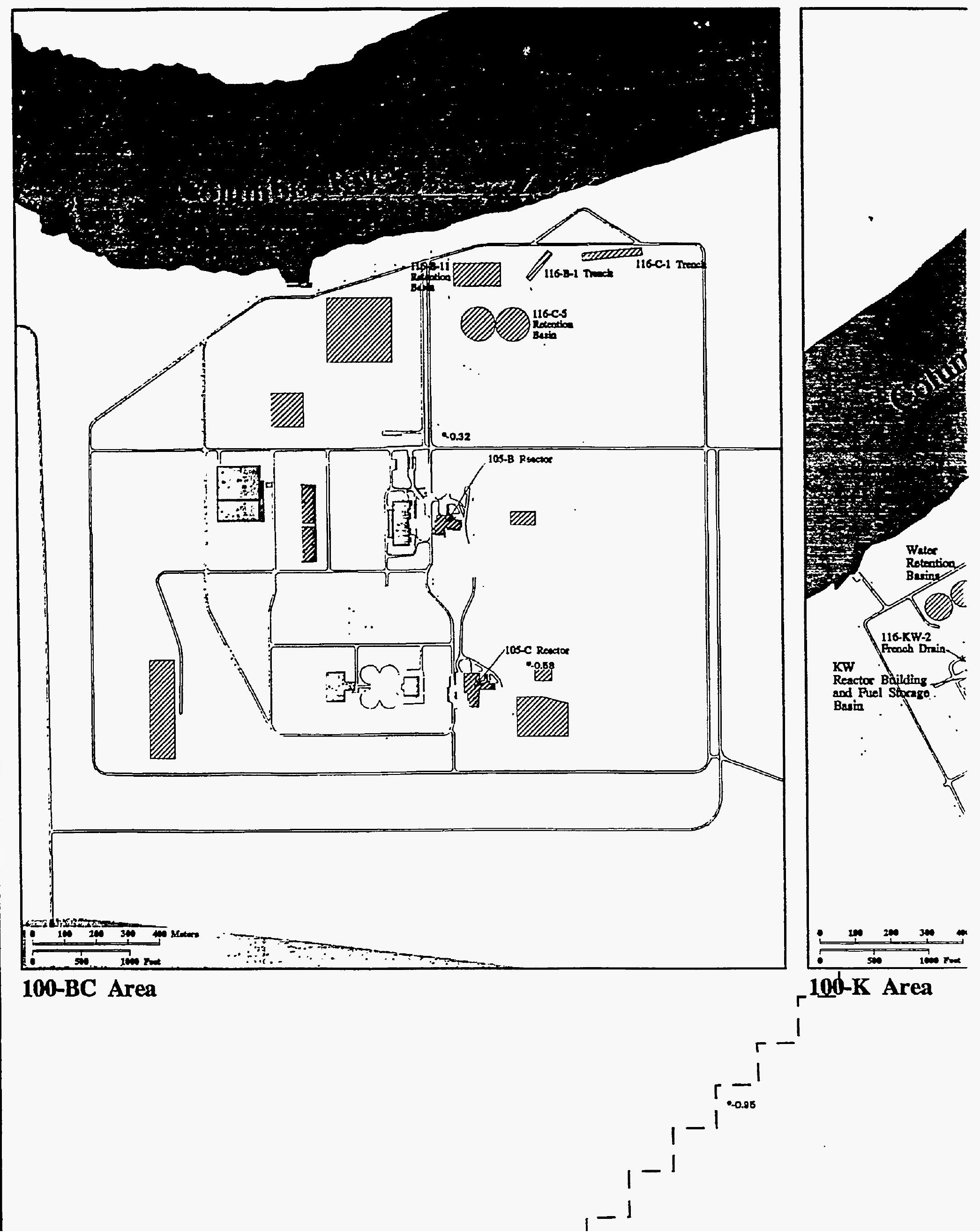



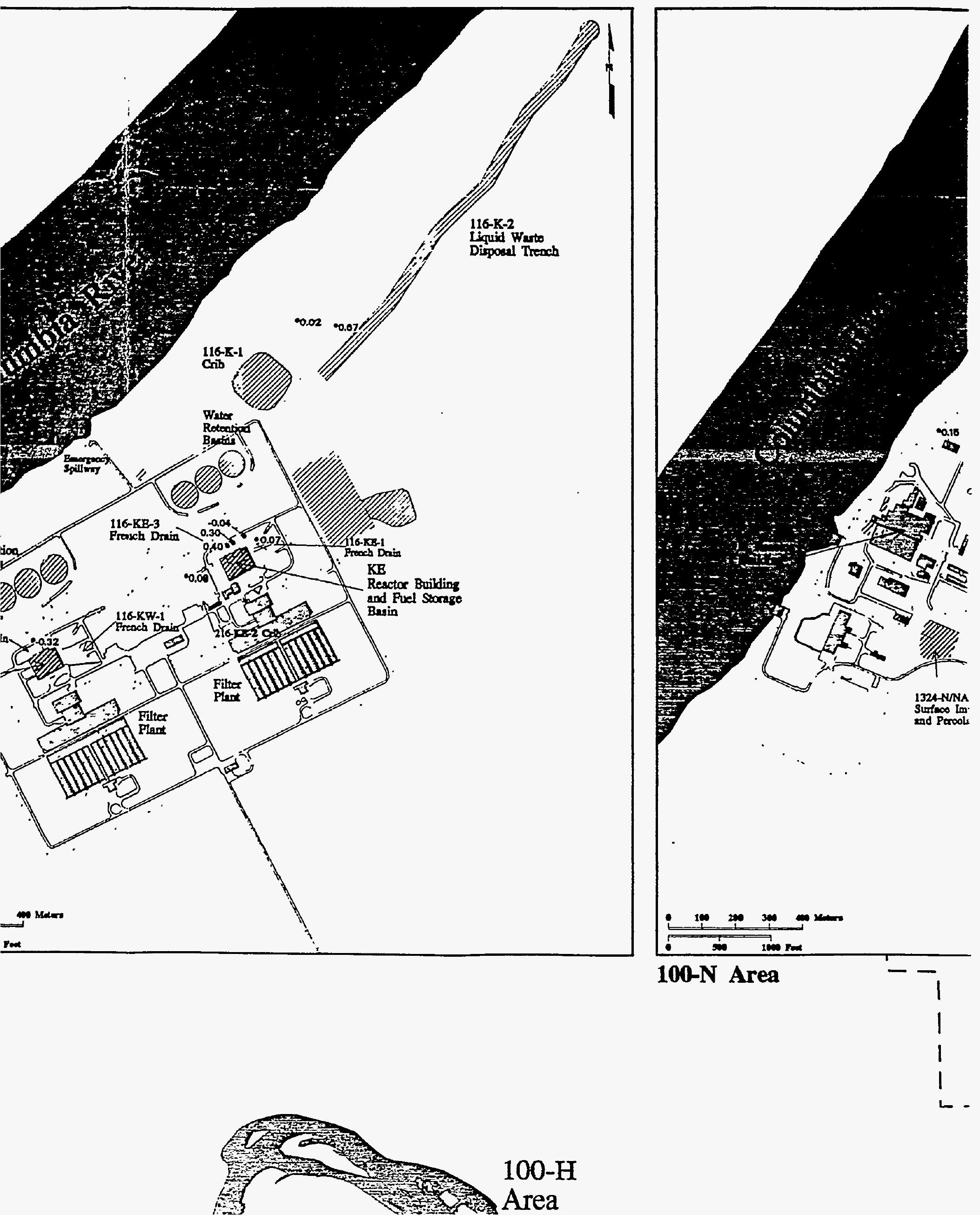

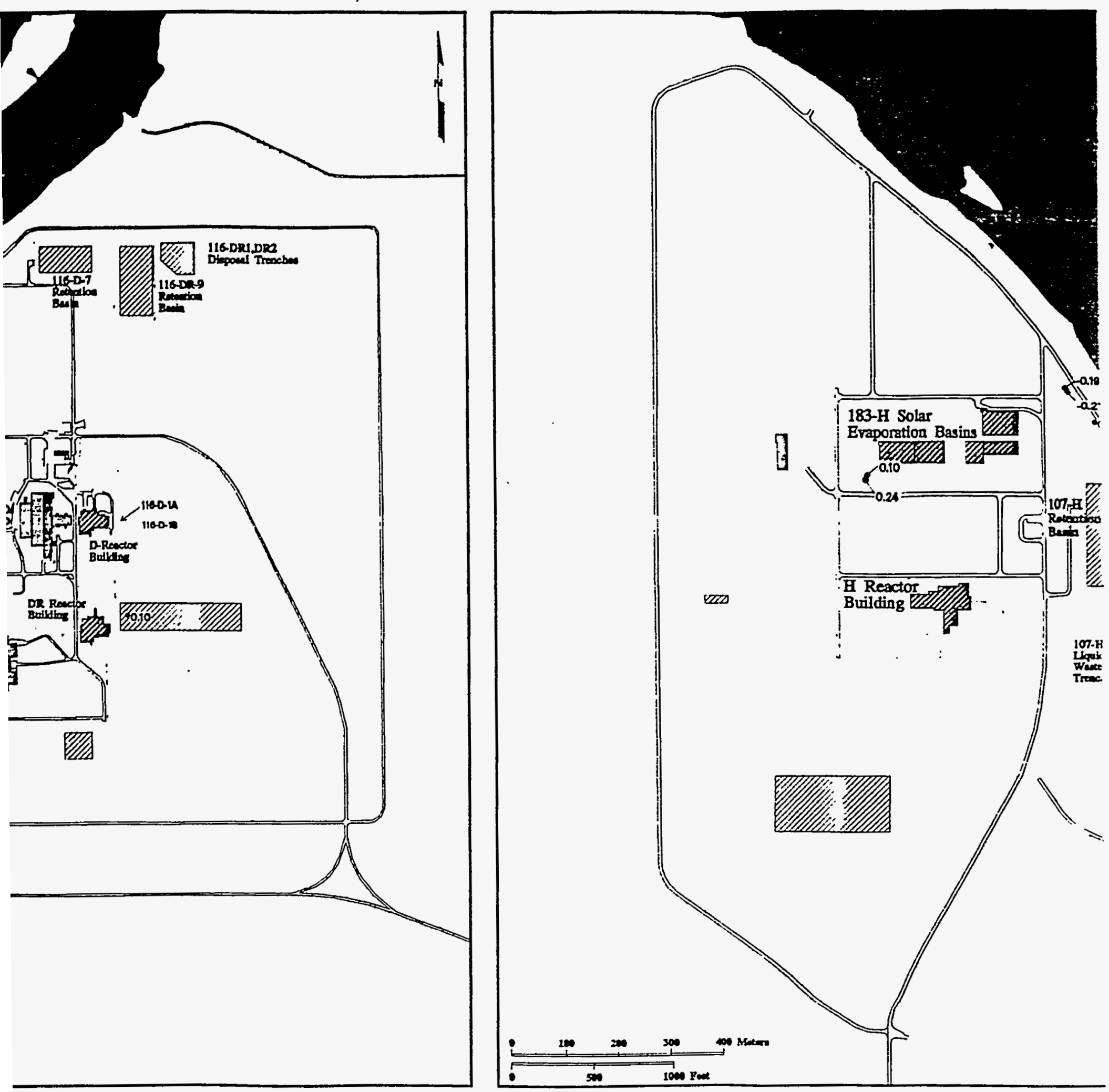

\section{0-H Area}

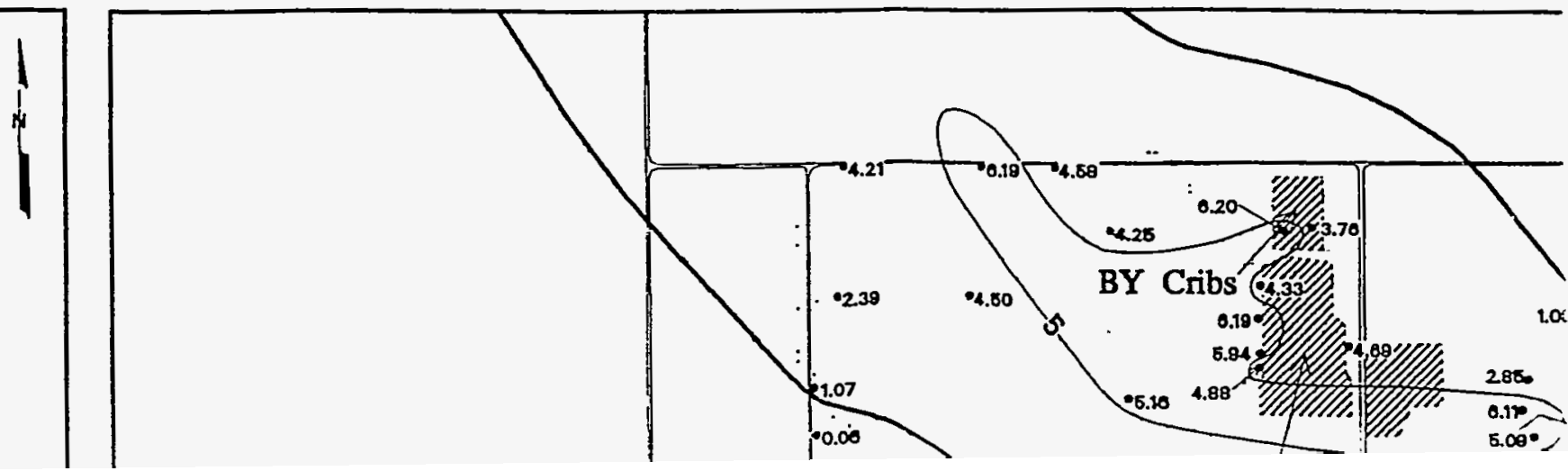



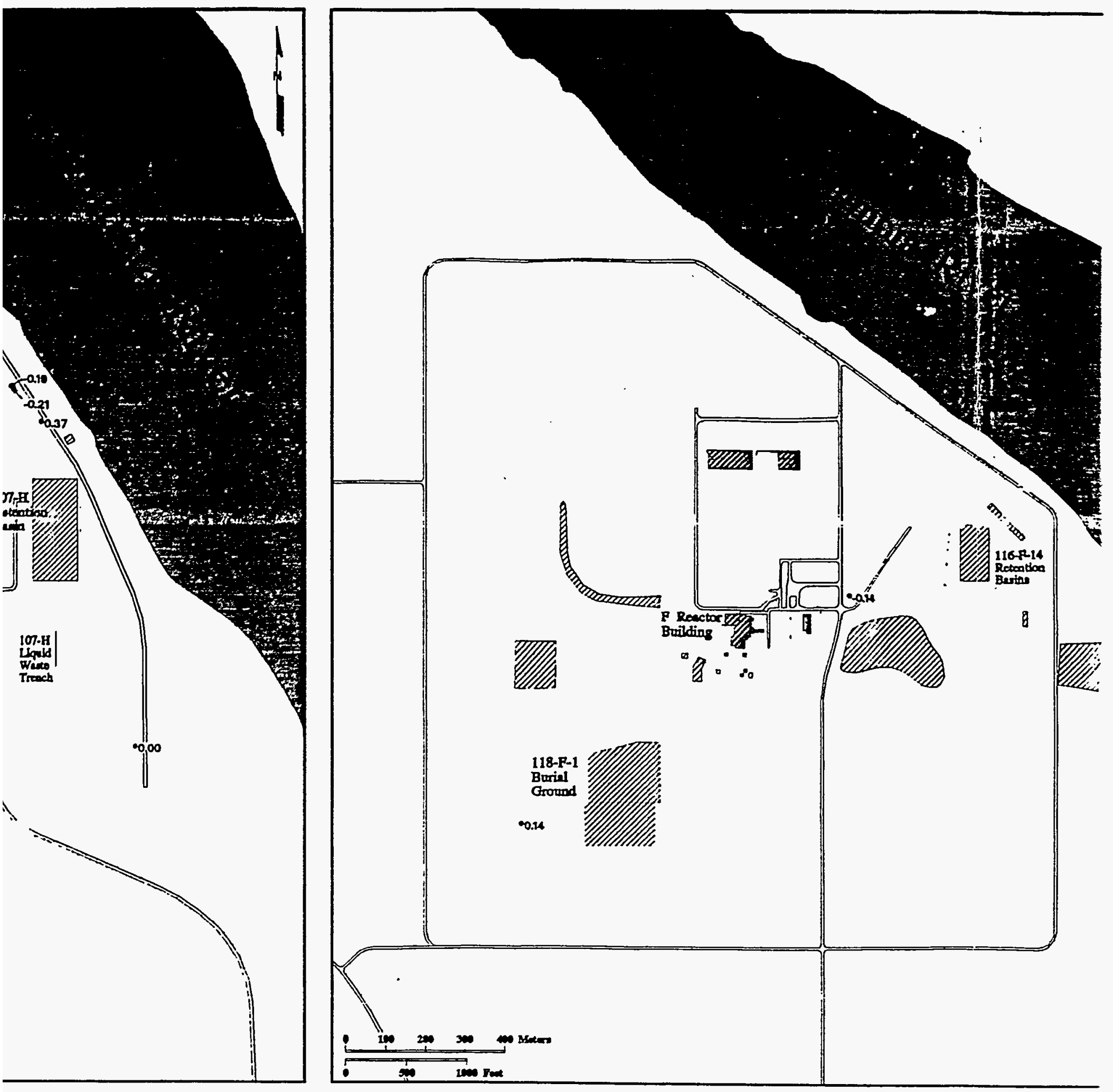

\section{0-F Area}

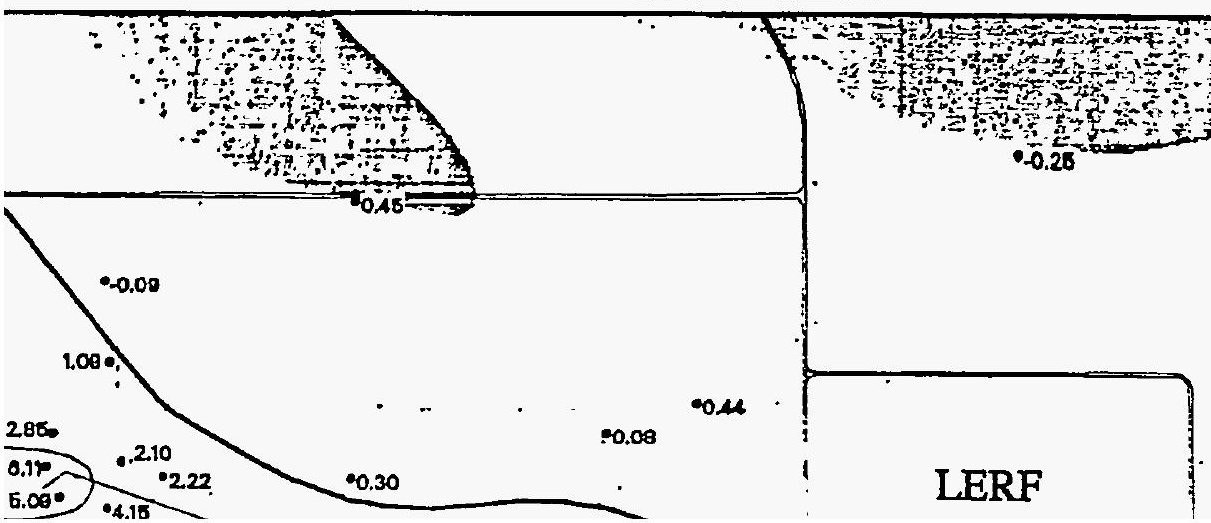



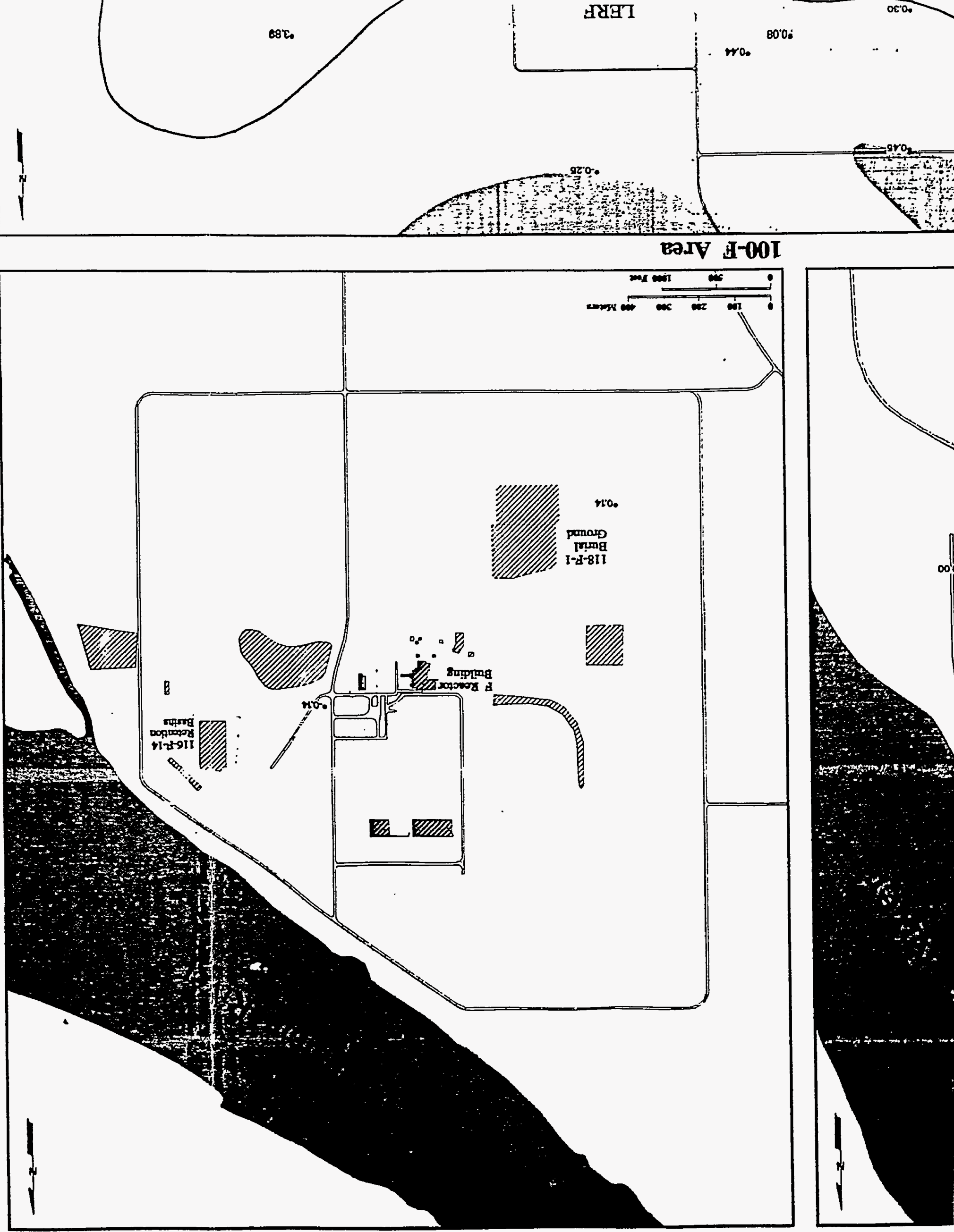


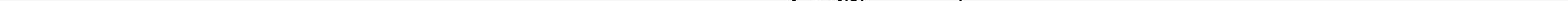




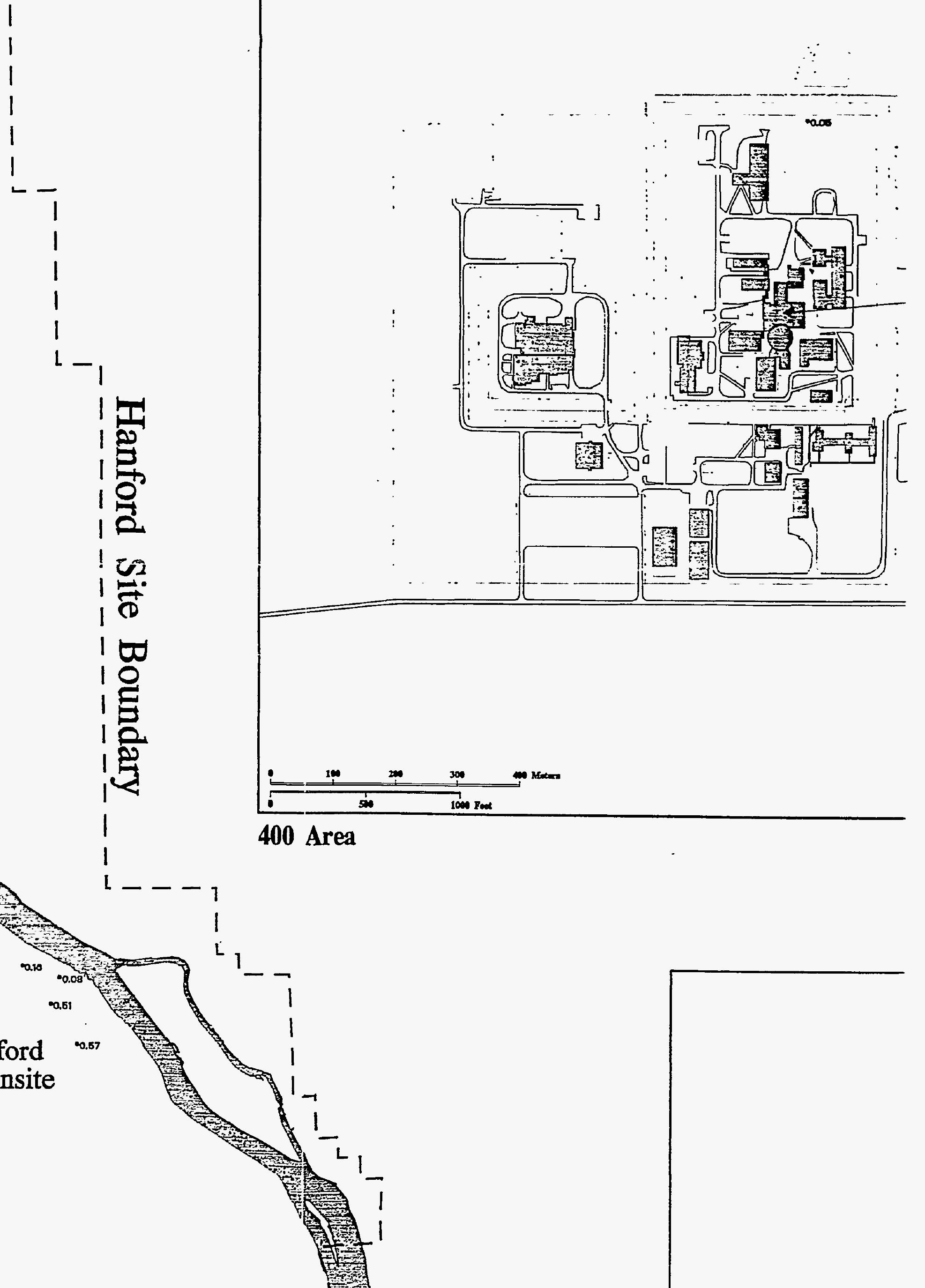




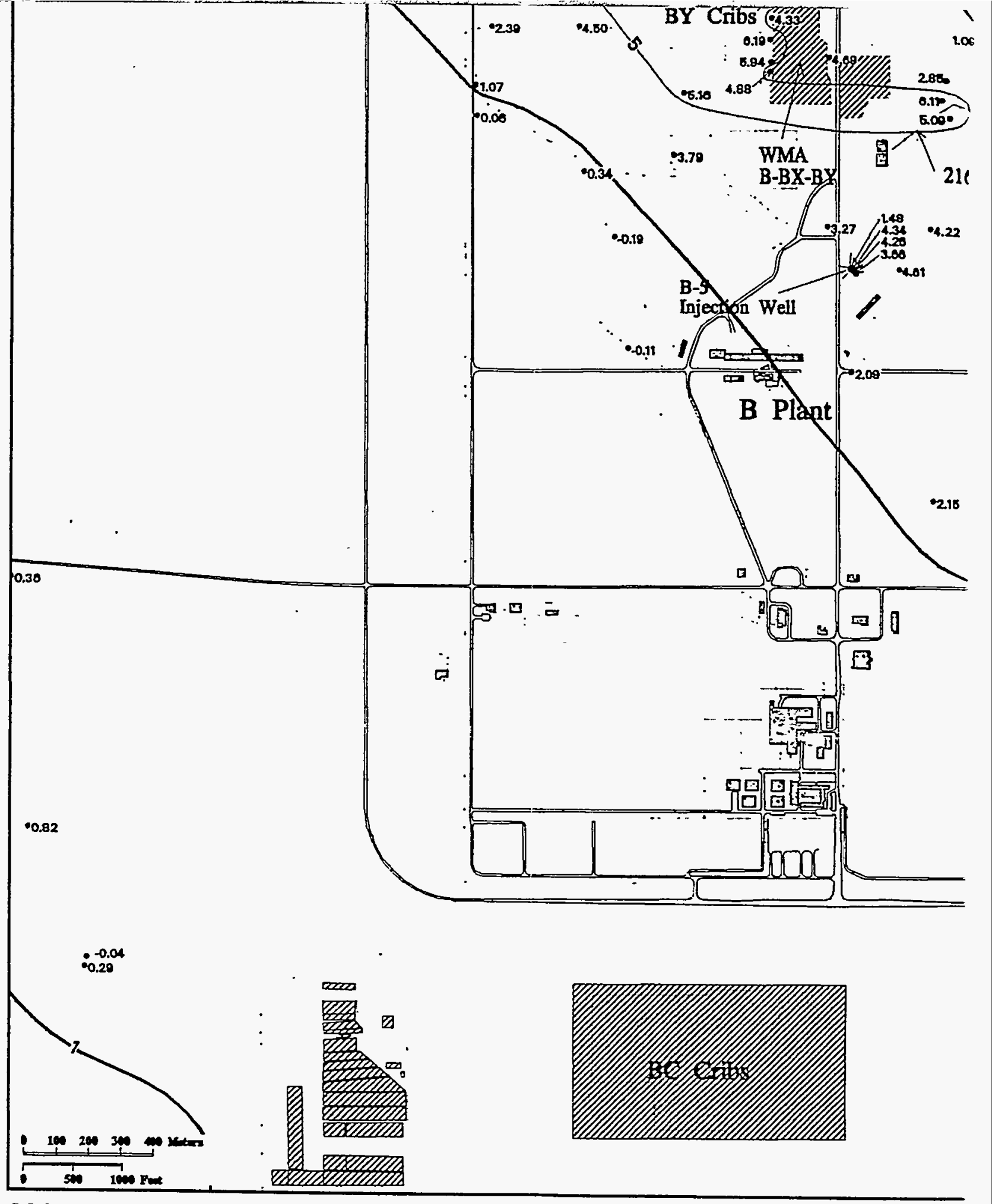

200-East Area
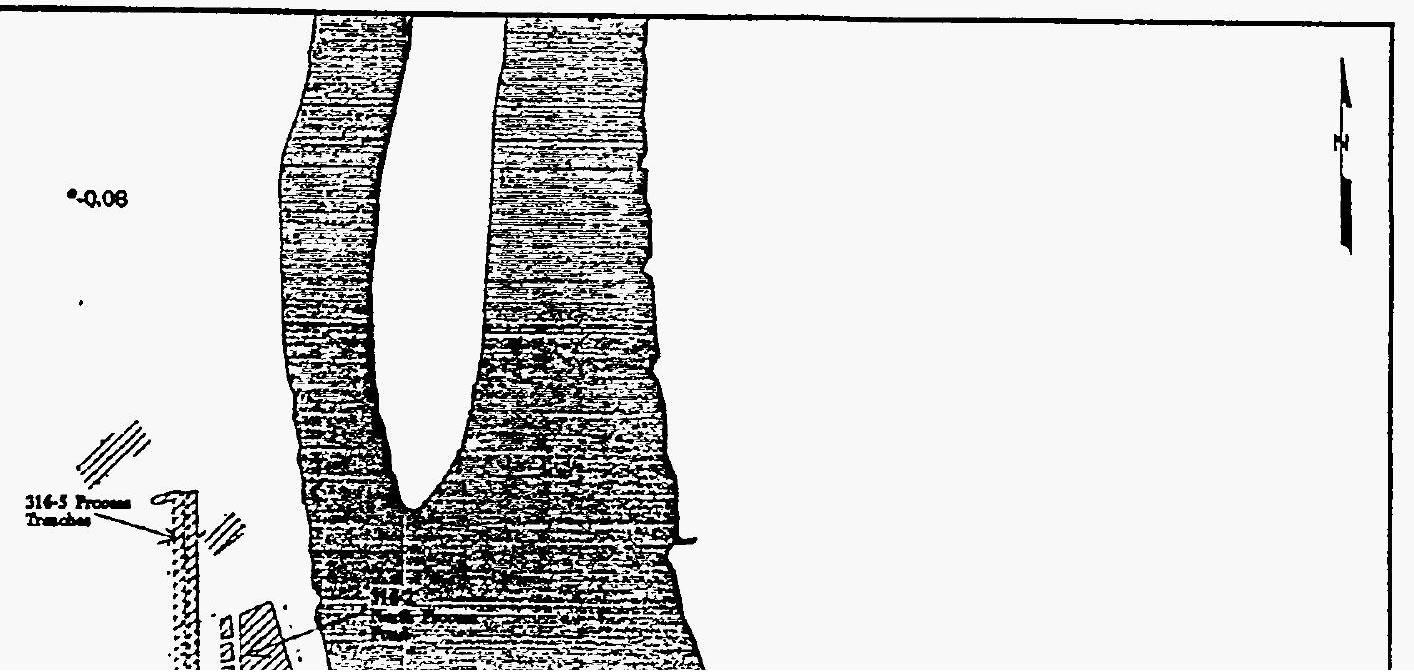


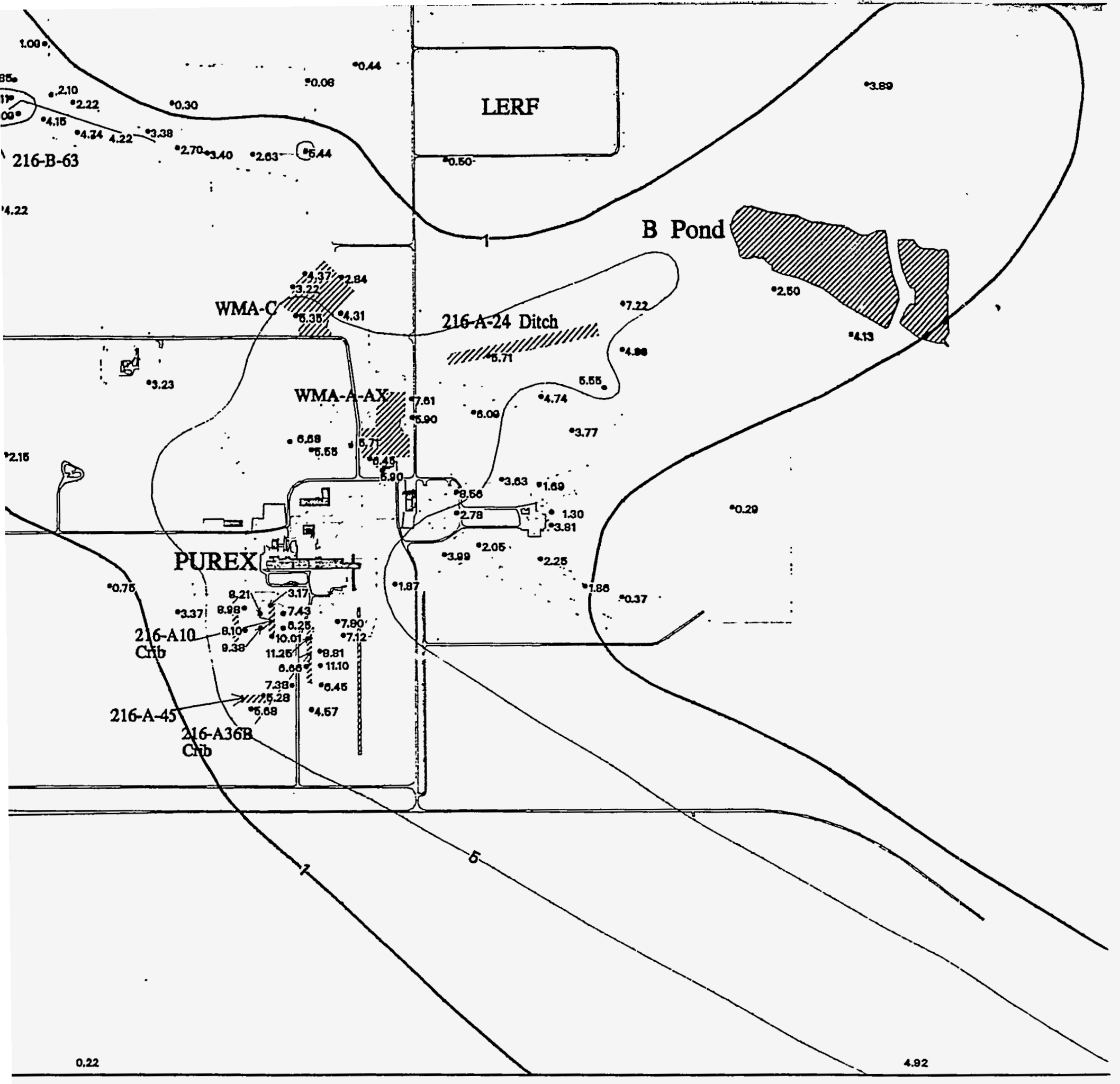

C018 Facility

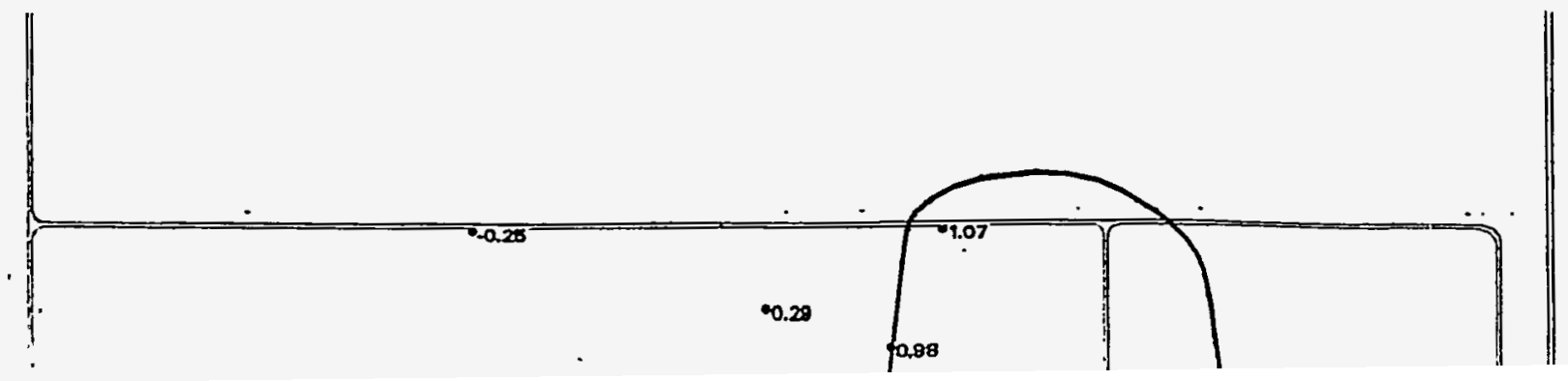




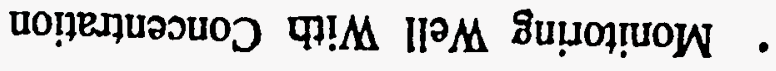

$$
\begin{aligned}
& \text { T/:Td } 1=\text { TOW } \\
& \text { ejeurxoudd }=\text { poysed } \\
& \text { T/.jd anoluo au!poI } \\
& \text { SPOUวम } \\
& \text { speoy - }
\end{aligned}
$$

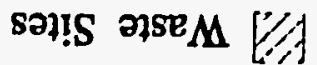

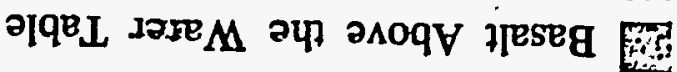

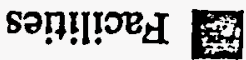
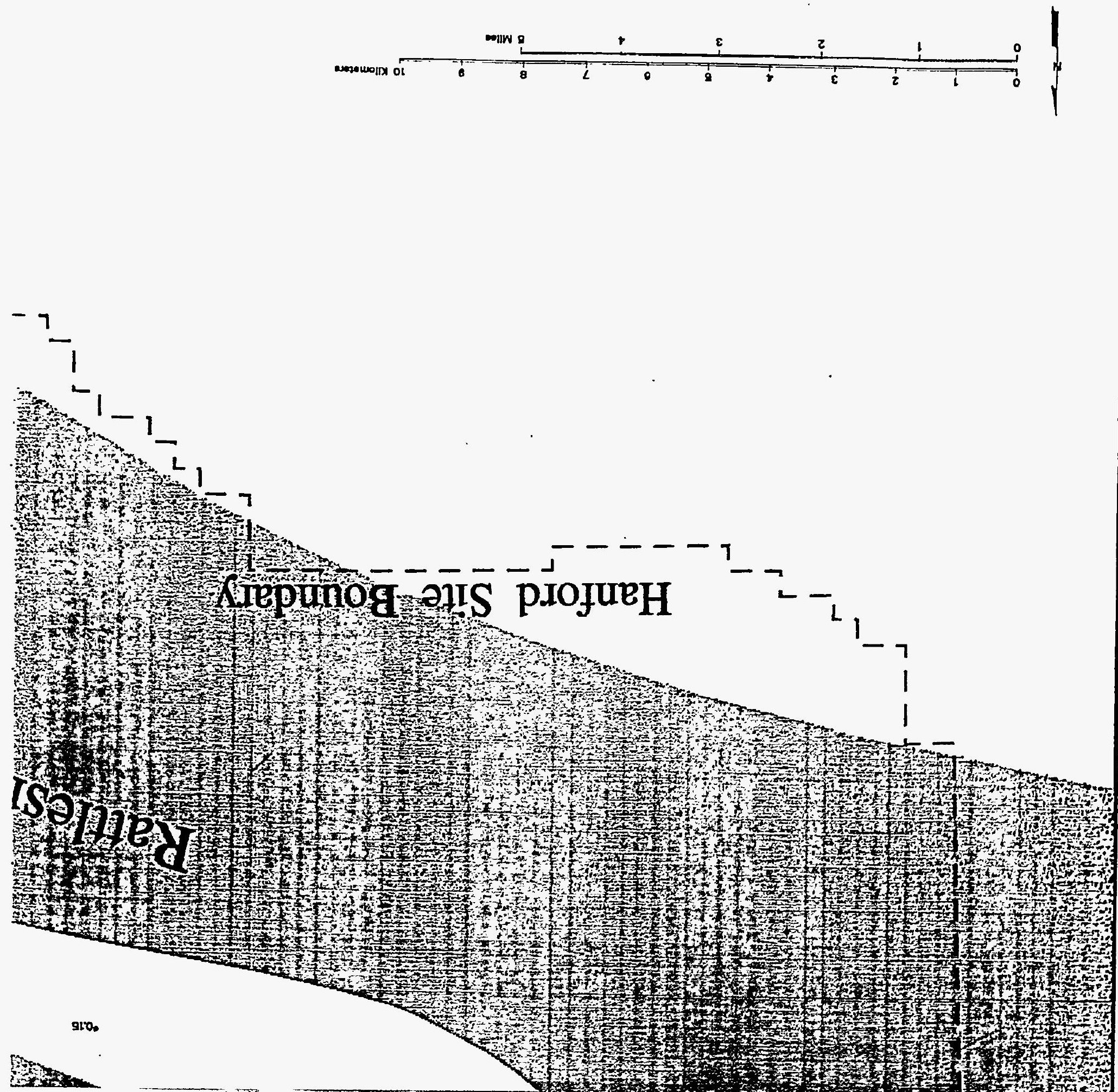


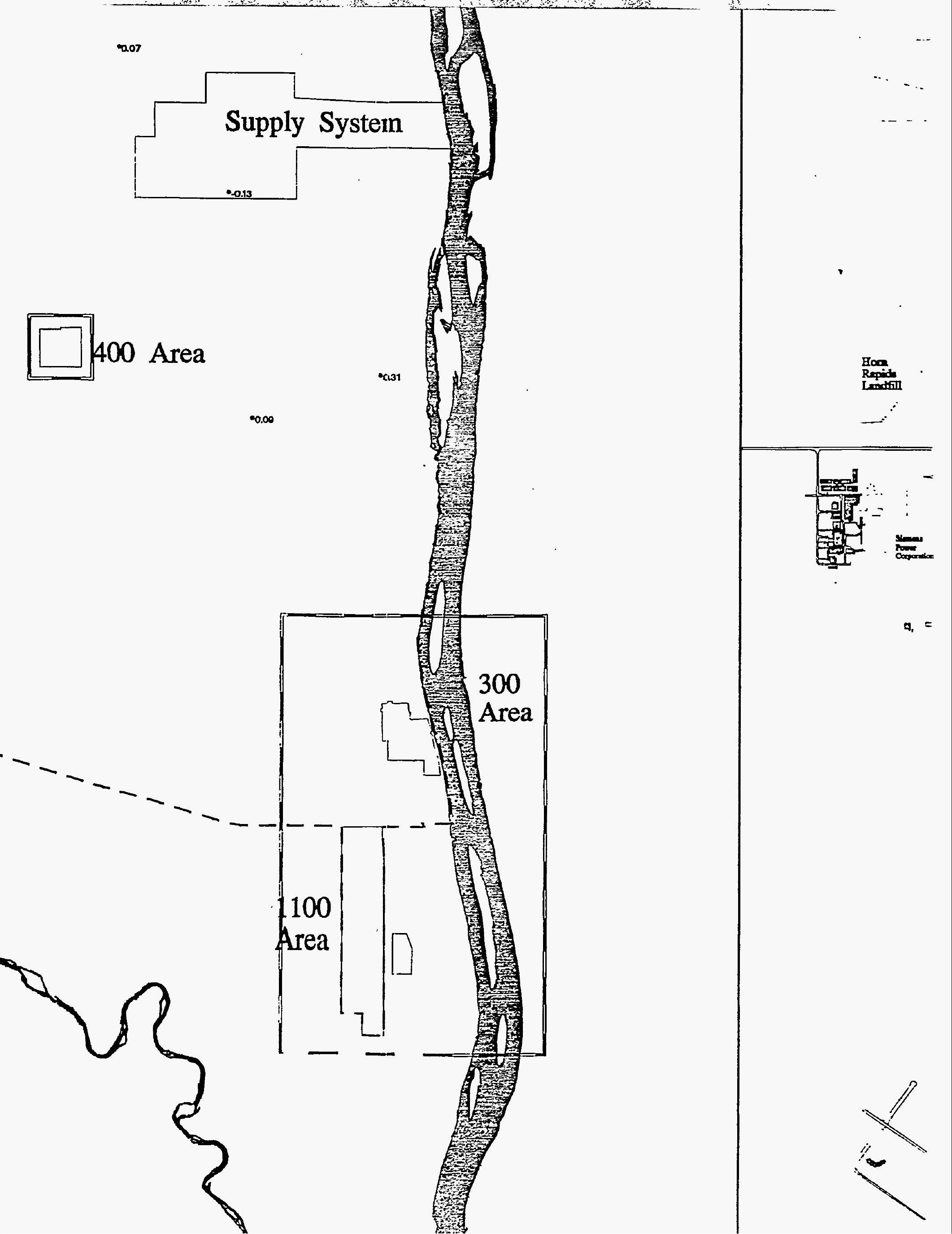





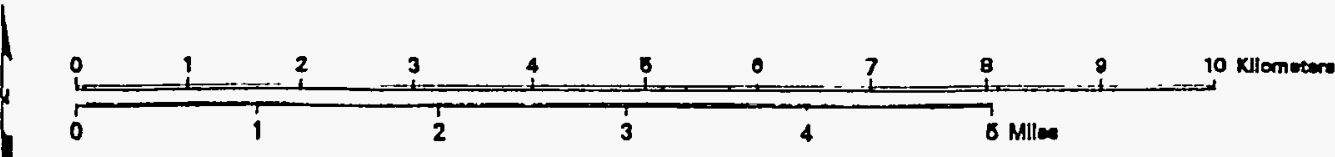

Facilities

Basalt Above the Warer Table

Waste Sites

- Roads

Fences

Iodine Contour $\mathrm{pCi} / \mathrm{L}$

Dashed = Approximare

$\mathrm{MCL}=\mathrm{L} \mathrm{pCi} / \mathrm{L}$

- Monitoring Well With Concentration

Plate 5: 1994 Average Iodine Conc 

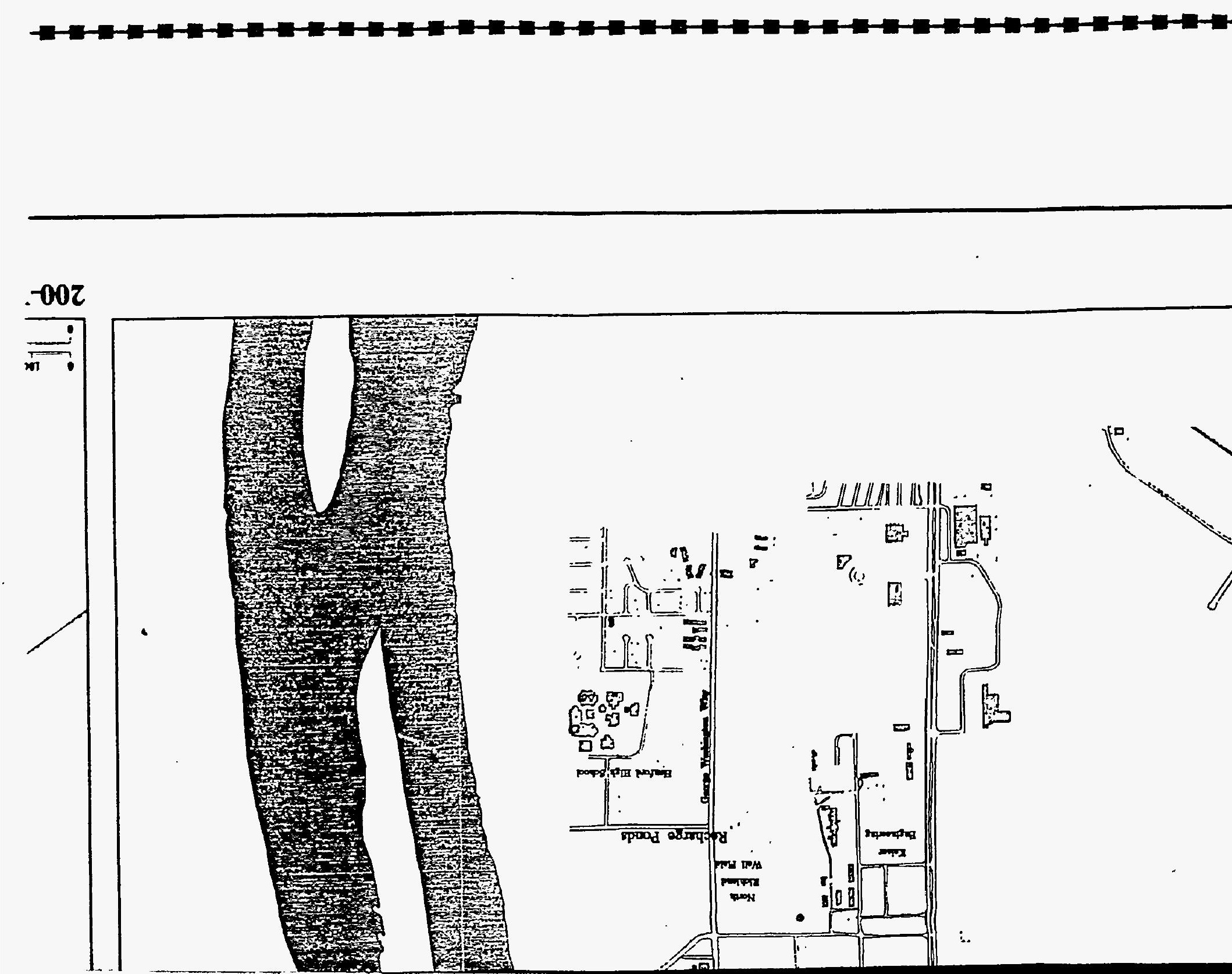


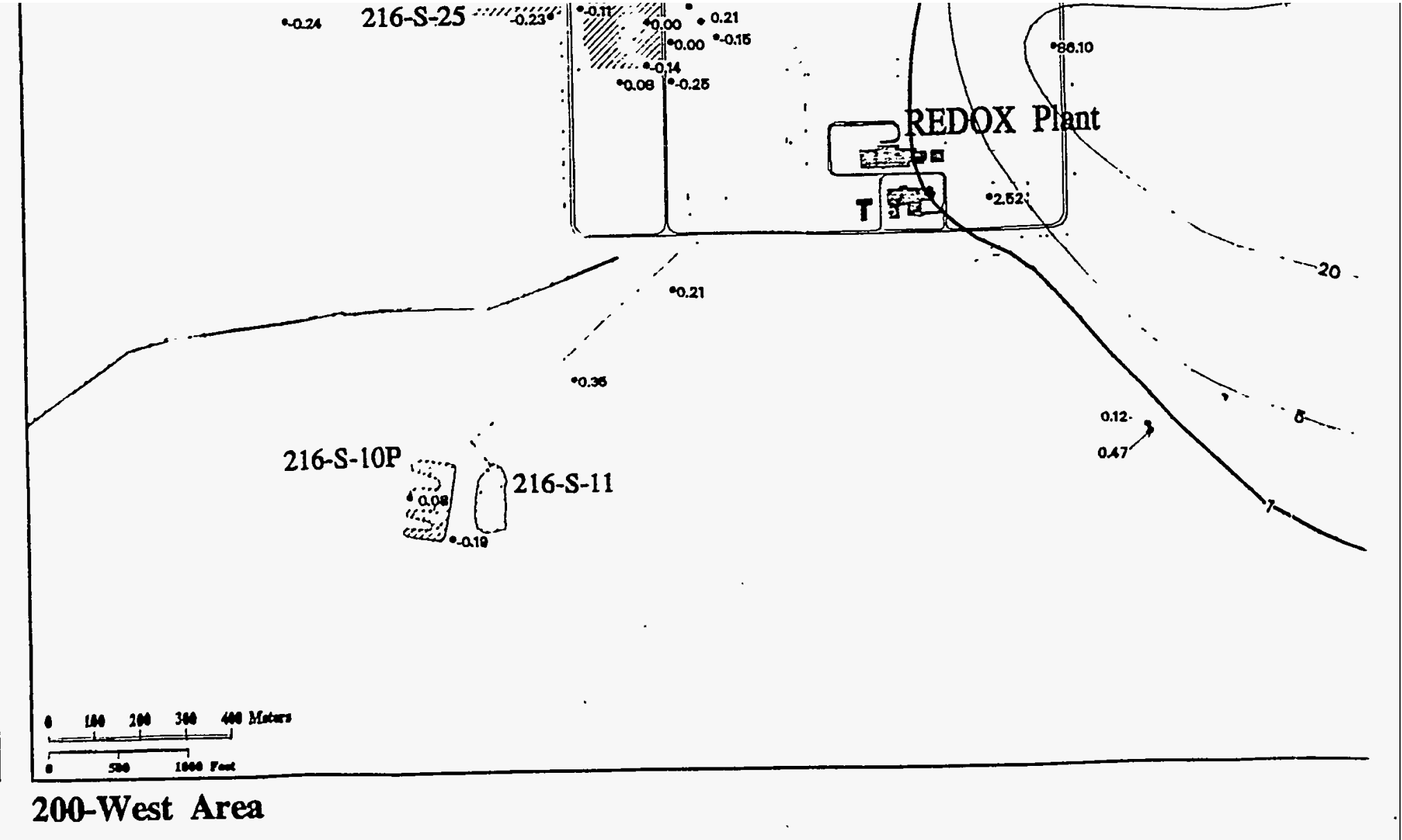




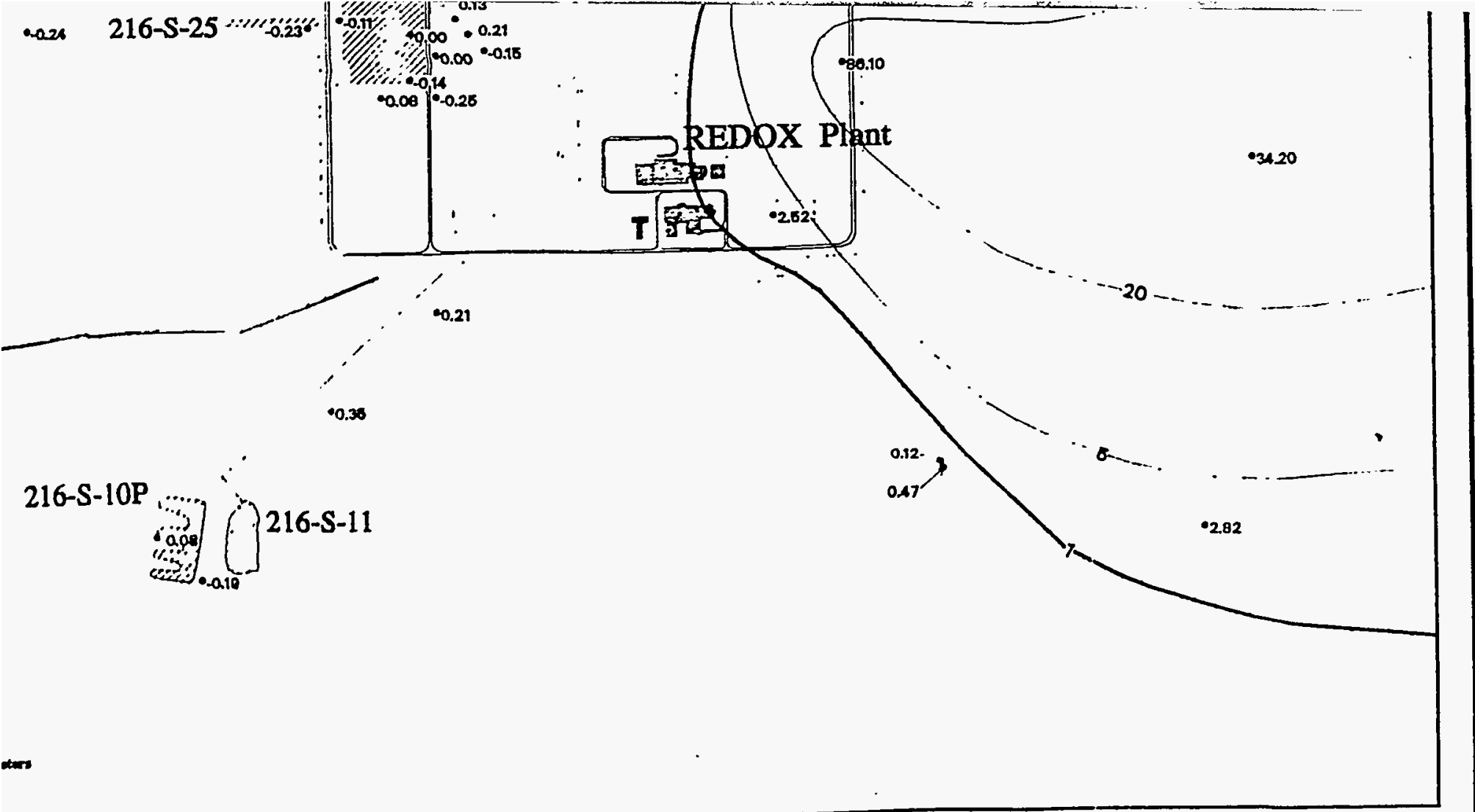

